UNIVERSIDADE DE BRASÍLIA

FACULDADE DE TECNOLOGIA

DEPARTAMENTO DE ENGENHARIA CIVIL E AMBIENTAL

\title{
ASPECTOS GEOTÉCNICOS E AMBIENTAIS PARA A DISPOSIÇÃO ADEQUADA DE LODO DE ESGOTO
}

\section{LEONARDO RAMOS DA SILVEIRA}

\author{
ORIENTADOR: NEWTON MOREIRA DE SOUZA, DSC. \\ CO-ORIENTADOR: ANDRÉ LUÍS BRASIL CAVALCANTE, DSC.
}

TESE DE DOUTORADO EM GEOTECNIA PUBLICAÇÃO: G.TD - 103/14

BRASÍLIA - DF, DEZEMBRO/2014 
UNIVERSIDADE DE BRASÍLIA

FACULDADE DE TECNOLOGIA

DEPARTAMENTO DE ENGENHARIA CIVIL E AMBIENTAL

\section{ASPECTOS GEOTÉCNICOS E AMBIENTAIS PARA A DISPOSIÇÃO ADEQUADA DE LODO DE ESGOTO}

\section{LEONARDO RAMOS DA SILVEIRA}

TESE DE DOUTORADO SUBMETIDA AO DEPARTAMENTO DE ENGENHARIA CIVIL DA UNIVERSIDADE DE BRASÍLIA COMO PARTE DOS REQUISITOS NECESSÁRIOS PARA A OBTENÇÃO DO GRAU DE DOUTOR

APROVADO POR:

NEWTON MOREIRA DE SOUZA, D.Sc (ENC-UNB) (ORIENTADOR)

ENNIO MARQUES PALMEIRA, D.Sc (ENC-UNB) (EXAMINADOR INTERNO 1)

LUIS FERNANDO MANTINS RIBEIRO, D.Sc (ENC-UNB) (EXAMINADOR INTERNO 2)

MARIA EUGÊNIA GIMENEZ BOSCOV, D.Sc (USP-SP) (EXAMIDANORA EXTERNA 1)

RAFAEL GERARD DE ALMEIDA DEMUELENAERE, D.Sc (DNIT) (EXAMINADOR EXTERNO 2)

DATA: BRASÍLIA, DF, 22 DE DEZEMBRO DE 2014 


\section{FICHA CATALOGRÁFICA}

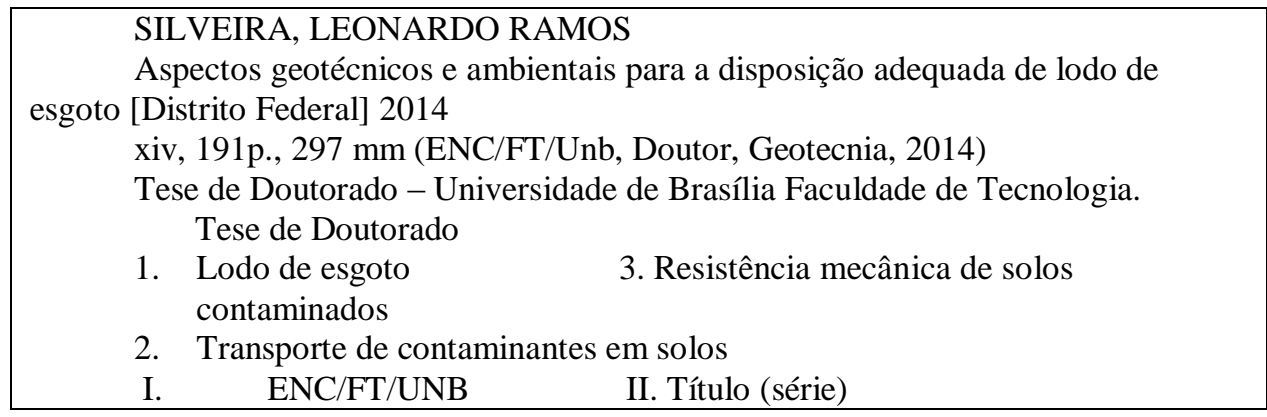

\section{REFERÊNCIA BIBLIOGRAFICA}

SILVEIRA, L. R. (2014). Aspectos geotécnicos e ambientais para a disposição adequada de lodo de esgoto. Tese de Doutorado em Geotecnia. Departamento de Engenharia Civil e Ambiental, Universidade de Brasília, Brasília, DF, 193p.

\section{CESSÃO DE DIREITOS}

NOME DO AUTOR: Leonardo Ramos da Silveira

Título da Tese de Doutorado: Aspectos geotécnicos e ambientais para a disposição adequada de lodo de esgoto.

GRAU / ANO: Doutor / 2014.

É concedida à Universidade de Brasília a permissão para reproduzir cópias desta Tese de Doutorado e para emprestar ou vender tais cópias somente para propósitos acadêmicos e científicos. $\mathrm{O}$ autor reserva outros direitos de publicação e nenhuma parte desta Tese de Doutorado pode ser reproduzida sem a autorização por escrito do autor.

Leonardo Ramos da Silveira

CLN 207 norte bloco A, kit 203

Asa Norte, Brasília - DF

Cep: 70852510

email: leonardoengambiental@yahoo.com.br 


\section{DEDICATÓRIA}

$\mathrm{Na}$ vida de todos nós, existem pessoas especiais que aplaudem nossas alegrias, e nos ajudam nos momentos de tristezas, essas pessoas quando nascemos chamamos de PAIS, e a nossa família temos irmãos. Dedico esse trabalho aos meus queridos pais Washington e Márcia, sem eles esse sonho não seria possível. Agradeço também as minhas irmãs que sempre me apoiaram. Papai e Mamãe, sem vocês esse trabalho não teria sido desenvolvido e realizado. 


\section{AGRADECIMENTOS}

A Deus, que me deu discernimento e inteligência para terminar mais essa caminhada

Aos meus pais (Washington e Márcia), pelo apoio, compreensão, conselhos nos momentos de desanimo, e apoio total para mais este sonho. Papai e Mamãe sem vocês isso não seria possível

As minhas irmãs (Maristhela e Caroline), pela confiança e apoio depositados em mim em mais esta conquista pessoal.

Ao meu professor e orientador Newton, que aceitou o desafio de trabalhar com lodo de esgoto e geotecnia ambiental. Suas contribuições e paciência foram à base para meu trabalho sair do papel e ser realizado. Muito obrigado pela compreensão e apoio, o senhor além de orientador é um ser humano incrível.

Ao meu co-orientador professor André Brasil que aceitou o desafio dessa jornada, obrigado pelos conselhos, pelo apoio, e por se fazer presente nos momentos em que precisei. Muito obrigado, algumas partes da Tese não seriam realizadas sem o seu apoio.

Aos professores Luis Fernando e Cláudia Gurjão pelas valiosas orientações durante os ensaios em laboratório. E a todos os professores da Geotecnia da UnB.

Aos técnicos do laboratório de geotecnia da UnB, Jonas e Thiago. Em especial ao Thiago, por ter sido primordial às idas a campo, e a execução do trabalho.

Ao laboratório de saneamento da UnB. Em especial a professora Yovanka que oportunizou a realização das análises geoambientais. As técnicas e amigas Marcilene, Sara e Carla.

A Companhia de Saneamento do Distrito Federal (CAESB), por ter sido uma parceira essencial para a realização do trabalho. Agradeço ao senhor Carlos Eduardo, as engenheiras Maria Goreth e Leiliane Oliveira que sempre me atenderam quando precisei. A CAESB, muito obrigado, sem essa parceria o trabalho não seria realizado.

Ao laboratório Quinosan pelo apoio e ajuda nas análises dos metais pesados.

Aos amigos do Doutorado, Camilla Borges, Janaina Tatto, Oisy Menendes e em especial ao Marlon (velhinho), o início disso tudo não seria possível sem sua ajuda.

Ao Conselho Nacional de Desenvolvimento Científico e Tecnológico (CNPq) a Capes e ao departamento de Geotecnia pelo apoio na realização desta pesquisa por meio da bolsa de Doutorado e ajuda de custos. 


\title{
ASPECTOS GEOTÉCNICOS E AMBIENTAIS PARA A DISPOSIÇÃO ADEQUADA DE LODO DE ESGOTO.
}

\begin{abstract}
RESUMO
Apesar dos sistemas de esgotamento sanitário serem altamente eficientes na remoção de matéria orgânica, organismos patogênicos e nutrientes, as estações de tratamento de esgoto tem sofrido com a gestão dos resíduos sólidos gerados. A grande preocupação com o lodo de esgoto gerado (biossólido), é que o mesmo apresenta em sua composição elementos que ao entrarem em contato com o solo e os lençóis de águas subterrâneas podem comprometer a sua qualidade, contaminando-os. Neste contexto, têm surgido pesquisas que visam à verificação do potencial de contaminante do lodo de esgoto, bem como o estudo de comportamento mecânico do solo sob a ação desse processo de disposição. O objetivo desta pesquisa foi verificar o transporte de contaminantes de lodo de esgoto no estado in natura, e o transporte monoespécie de soluções de níquel e cromo, além disso, verificar como os constituintes do lodo podem alterar as características de resistência do solo. A pesquisa foi realizada com ensaios de caracterização geotécnica de solos, ensaios geoambientais (difusão e sorção) em laboratório, e difusão em campo, além de ensaios de resistência de solos (adensamento e cisalhamento direto e compressão simples). Os resultados indicam que o solo em estudo trata-se de um típico solo laterítico do DF, e que o mesmo possui coeficiente de permeabilidade que o faz apresentar condições para ser usado como um liner compactado. Os resultados de transporte de contaminantes demonstraram que o contaminante no estado in natura, sofre dispersão em função da intensa atividade biológica e aumento de valores de capacidade de troca catiônica do solo. Já os resultados com as soluções sintéticas monoespécie, indicam a tendência para este tipo de ensaio, concentração diminuindo em função do tempo. Os resultados de resistência demonstraram que os contaminantes de lodo de esgoto possuem características que podem mudar as ligações de cimentação. Os resultados em que simularam sucessivas aplicações de lodo de esgoto no solo (cinco aplicações), foram os que obtiveram os menores valores de coesão, e maiores deformações na curva de adensamento de resistência. Já o solo contaminado com lodo de esgoto com a cal, foi o que obteve os menores valores para coesão. Sendo assim, pode-se observar que os constituintes do lodo de esgoto, podem migrar para o solo contaminando-o, e que os seus constituintes podem diminuir a resistência.
\end{abstract}

Palavras-chaves: lodo de esgoto, transporte de contaminantes em solos, resistência mecânica de solos contaminados. 


\title{
GEOTECHNICAL AND ENVIRONMENTAL ASPECTS FOR THE ADEQUATE DISPOSAL OF SEWAGE SLUDGE.
}

\begin{abstract}
Despite the fact that sewage systems are highly efficient in removing organic matter, pathogens and nutrients, sewage treatment plants have experienced challenges related to the management of the generation of solid waste. The major concern with the generated sewage sludge (biosolids) is that it presents in its composition elements that on contact with the ground and groundwater may compromise their quality, contaminating them. In this context, there have been studies aimed at verifying the potential contamination of sewage sludge, as well as studies on the mechanical behaviour of the soil under the action of this disposal process. The objective of this research was to investigate the transport of sewage sludge contaminants in nature state, and the monospecies transport of nickel and chromium solutions and further to verify how the sludge constituents can change the soil strength characteristics. This survey conducted geotechnical soil characterization tests, geo-environmental tests (diffusion and sorption) in the laboratory, and diffusion in the field, and also soil strength tests (consolidation and direct shear and simple compression). Results indicate that the soil under consideration is a typical laterite soil from the DF, and its coefficient of permeability allows the soil to be used as a compacted liner. Contaminant transport results showed that the contaminant in nature state suffers from dispersion, due to the intense biological activity and increased capacity of the soil cation exchange. However, results of the synthetic monospecies solutions indicate the tendency for this type of test, the concentration decreases as a function of time. The strength results demonstrated that the sewage sludge contaminants have characteristics that may change the cementation connections. The results in simulating successive applications of sewage sludge on the soil (five applications), were the ones the showed lower cohesion values and higher strains in the consolidation curve. On the other hand, the soil contaminated with sewage sludge and lime, was the one that showed the lowest cohesion values. Thus, it can be seen that the constituents of the sewage sludge, can migrate to the soil contaminating it, and that its constituents may decrease its strength.
\end{abstract}

Keywords: sewage sludge, transport of contaminants in soils, mechanical strength of contaminated soil. 


\section{LISTA DE FIGURAS}

Figura 2.1 - ETE SAMAMBAIA (Fonte: CAESB, 2014) 7

Figura 2.2 - Estação de tratamento de esgoto ETE MELCHIOR (Fonte: CAESB, 8 2014).

Figura 2.3 - Destinação atual do lodo de esgoto de ETE na bacia Piracicaba, Capivari e Jundiaí (Fonte: Biociclo (2012) apud Godoy (2013).

Figura 2.4 - Composição mineralógica do lodo por DRX. (Fonte: Medeiros et al. 18 2006).

Figura 2.5 - Mecanismos de advecção.

Figura 2.6 - Mecanismos de mistura mecânica em escala microscópica (Bedient, 40 1994) citados por Paula (2006).

Figura 2.7 - Mecanismos de difusão. Fonte: Costa (2002).

Figura 2.8 - Esquema da difusão de cátions e ânios de uma região de alta 42 concentração para outra de baixa concentração em um solo argiloso saturado. Fonte: Rowe et al. (1995).

Figura 2.9 - Conceito de comprimento efetivo no transporte em solo. Fonte: 43 Shackeldor \& Daniel (1999) citados por Jesus (2004).

Figura 2.10 - Efeito da dispersão 44

Figura 2.11 - Mecanismo de dispersão em fluxo uniforme bidimensional em areia isotrópica. (a) fonte contínua; (b) fonte instantânea. Fonte: Nascentes (2006).

Figura 2.12 - Fenômeno de expansão/contração da camada dupla (a) contração; (b) normal - referência acima; (c) expansão (Rowe et al. (1995).

Figura 2.13 - Isoterma linear. Fonte: Gurjão (2005).

Figura 2.14 - Isoterma de Freundlich: (a) curva mostrando a sorção em função da 50 concentração e (b) log usando os parâmetros determinados. Fonte: Gurjão (2005).

Figura 2.15 - Isoterma de Langmuir: (a) curva mostrando a sorção em função da concentração e (b) valores plotados usando os parâmetros determinados. Fonte: Gurjão (2005).

Figura 3.1 - Locação dos perfis de sondagens e classes de solos da ETE Melchior.

Figura 3.2 e 3.3 - (a) Sondagem a trado; (b) coleta de solos para caracterização 54 preliminar em laboratório.

Figura 3.4 - (a) Amostras de solos Perfil P33; (b) Amostras de solos Perfil P22. 
Figura 3.5 - Pastilhas sobre pedra porosa para posterior penetração da agulha.

Figuras 3.6 (a), (b) - (a) Coleta do extrato centrifugado; (b) armazenamento do extrato 60 de lodo centrifugado.

Figura 3.7 - Compactação do liner na célula de difusão 66

Figura 3.8 - Células de difusão para o ensaio com o liner não saturado 66

$\begin{array}{ll}\text { Figura 3.9 - Células saturando } & 67\end{array}$

Figura 3.10 - Contaminante. (a) solução contaminante coletada; (b) preenchimento da 67 célula.

Figura 3.11 - célula preenchida; (d) células para execução do ensaio. 68

Figura 3.12 - Concentrações de $\mathrm{Cr}^{3+} \quad 69$

Figura 3.13 - Diferentes concentrações da solução contaminante. $\quad 70$

Figura 3.14 - Concentrações de $\mathrm{Ni}^{+2} \quad 71$

Figura 3.15 - Coleta do contaminante de lodo de esgoto. 72

Figura 3.16 - Reservatório com o contaminante. (a) CP1 e CP2 4 dias; (b) CP2 e CP4 72 8 dias.

Figura 3.17 - Preparação das amostras $\quad 73$

Figura 3.18 - Espectrofotômetro para leitura de $\mathrm{NO}^{3-} \quad 74$

Figura 3.19 - Amostras em mesa agitadora. $\quad 74$

Figura 3.20 - Locação dos perfis com o local das células de difusão em campo $\quad 75$

Figura 3.21 - Escavação das células em campo. (a) início da escavação; (b) célula 76 sendo escavada; (c) abertura de novas células; (d) células já escavadas

Figura 3.22 - Compactação do liner 77

Figura 3.23 - Preenchimento das células com lodo de esgoto. (a) basculamento do 78 lodo na área. (b) pá carregadeira preenchendo a célula com lodo; (c) célula preenchida com lodo de esgoto.

Figura 3.24 - Abertura e coleta de solo. (a) limpeza da célula; (b), (c) e (d) retirada material; (e) e (f) coleta de solo no tubo de PVC.

Figura 3.25 - Teste de Expansão livre com água, 100\%, 80\%, 60\%, 40\%, 20\% 10\%, 80 $2 \%$ e $1 \%$ do contaminante.

Figura 3.26 - Montagem do ensaio de sucção. $\quad 82$

Figura 3.27 - Moldagem corpos de prova. (a) corpo de prova compactado; (b) corpo 84 de prova do bloco indeformado. 
Figura 4.1 - Diferentes umidades para o perfil P1 (natural, seca ao ar, moldagem de bola).

Figura 4.2 - Diferentes umidades para o perfil P2 (natural, seca ao ar, moldagem de 88 bola).

Figura 4.3 - Diferentes umidades para o perfil P3 (natural, seca ao ar, moldagem de 88 bola).

Figura 4.4 - Diferentes umidades para o perfil P4 (natural, seca ao ar, moldagem de 89 bola).

Figura 4.5 - Diferentes umidades para o perfil P5 (natural, seca ao ar, moldagem de 89 bola).

Figura 4.6 - Perfil P41 (a) cor úmida; (b) cor seca.

Figura 4.7 - Perfil P51 (a) cor úmida; (b) cor seca. 91

Figura 4.8 - Curva Granulométrica. 92

Figura 4.9 - Carta de Plasticidade para a classificação SUCS. 94

Figura 4.10 - Carta de classificação pelo método das pastilhas. 95

Figura 4.11 - Curva de deformabilidade. 95

Figura 4.12 - Família das curvas de compactação. 96

Figura 4.13 - Carta para classificação MCT, com resultados do solo. 96

Figura 4.14 - Curva de compactação proctor normal. 97

Figura 4.15 - Concentração de cobre no contaminante de lodo de esgoto. 101

Figura 4.16 - Concentração de cobre no corpo de prova. 102

Figura 4.17 - Concentração de manganês no contaminante de lodo de esgoto. 102

Figura 4.18 - Concentração de manganês no corpo de prova. 102

Figura 4.19 - Concentração de zinco no contaminante de lodo de esgoto. 103

Figura 4.20 - Concentração de zinco no corpo de prova. 103

Figura 4.21 - Concentração de cádmio no contaminante de lodo de esgoto. 103

Figura 4.22 - Concentração de cádmio no corpo de prova. 104

Figura 4.23 - Concentração de cromo no contaminante de lodo de esgoto. 104

Figura 4.24 - Concentração de cromo no corpo de prova. 104

Figura 4.25 - Concentração de cromo no contaminante de lodo de esgoto. 105

Figura 4.26 - Concentração de cromo no corpo de prova. 105

Figura 4.27 - Concentração multiespécie no contaminante de lodo de esgoto. 105 
Figura 4.28 - Concentração multiespécie primeira camada no corpo de prova.

Figura 4.29 - Concentração multiespécie segunda camada de solo.

Figura 4.30 - Concentração multiespécie terceira camada de solo.

Figura 4.31 - Concentração de cobre no contaminante de lodo de esgoto (liner 110 saturado).

Figura 4.32 - Concentração de cobre no corpo de prova (liner saturado).

Figura 4.33 - Concentração de manganês no contaminante de lodo de esgoto (liner 110 saturado).

Figura 4.34 - Concentração de manganês no corpo de prova (liner saturado).

Figura 4.35 - Concentração de zinco no contaminante de lodo de esgoto (liner 111 saturado).

Figura 4.36 - Concentração de zinco no corpo de prova (liner saturado).

Figura 4.37 - Concentração de níquel no contaminante de lodo de esgoto (liner 112 saturado).

Figura 4.38 - Concentração de níquel no corpo de prova (liner saturado).

Figura 4.39 - Concentração de cromo no contaminante de lodo de esgoto (liner saturado).

Figura 4.40 - Concentração de cromo no corpo de prova (liner saturado).

Figura 4.41 - Concentração de cádmio no contaminante de lodo de esgoto (liner 113 saturado).

Figura 4.42 - Concentração de cromo no corpo de prova (liner saturado).

Figura 4.43 - Concentração multiespécie no contaminante de lodo de esgoto (liner saturado).

Figura 4.44 - Concentração multiespécie primeira camada de solo (liner saturado).

Figura 4.45 - Concentração multiespécie segunda camada de solo (liner saturado).

Figura 4.46 - Concentração multiespécie terceira camada de solo (liner saturado).

Figura 4.47 - Concentração de cromo no reservatório.

Figura 4.48 - Concentração de cromo nas camadas de solo no $36^{\circ}$ dia.

Figura 4.49 - Coeficientes de difusão para as diferentes concentrações.

Figura 4.50 - Concentração de níquel no reservatório.

Figura 4.51 - Concentração de níquel nas camadas de solo.

Figura 4.52 - Coeficiente de difusão para as diferentes concentrações. 
Figura 4.54 - Concentração de nitrato no reservatório (8 dias).

Figura 4.55 - Concentração de nitrato no reservatório (32 dias).

Figura 4.56 - Concentração de nitrato no solo (4 e 8 dias).

Figura 4.57 - Concentração de nitrato na camada de solo (32 dias).

Figura 4.58 - Isotermar de Lagmuir de Ni (in natura).

Figura 4.59 - Isoterma de Freundlich de Ni (in natura).

Figura 4.60 - Isoterma de Freundlich de $\mathrm{Cr}^{3+}$ (in natura).

Figura 4.61 - Isoterma de Freundlich de $\mathrm{Cr}^{3+}$ (sintético).

Figura 4.62 - Isoterma de Langmuir de $\mathrm{Cr}^{3+}$ (sintético).

Figura 4.63 - Isotermas de Langmuir e Freundlich para o cromo (sintético). 128

Figura 4.64 - Isotermas de Freundlich para o níquel (sintético).

Figura 4.65 - Isotermas de Langmuir para o níquel (sintético).

Figura 4.66 - Isotermas de Freundlich e Langmuir (sintético).

Figura 4.67 - Isoterma de Langmuir para o $\mathrm{NO}_{3}{ }^{-}$

Figura 4.68 - Isotermas de Freundlich para $\mathrm{O} \mathrm{NO}_{3}{ }^{-}$

Figura 4.69 - Isotermas de Freundlich e Langmuir para o $\mathrm{NO}_{3}{ }^{-}$

Figura 4.70 - Curva característica de retenção de água e contaminantes.

Figura 4.71 - Relação umidade e resistência a tração sem cal.

Figura 4.72 - Relação umidade e resistência a tração com cal.

Figura 4.73 - Relação saturação e resistência a tração sem cal.

Figura 4.74 - Relação saturação e resistência a tração com cal.

Figura 4.75 - Relação sucção e resistência a tração sem cal.

Figura 4.76 - Relação sucção e resistência a tração com cal.

Figura 4.77 - Limites de Atterberg contaminante sem cal.

Figura 4.78 - Limites de Atterberg contaminante com cal.

Figura 4.79 - Curva granulométrica solo $(<\# 10)$ contaminado com extrato de lodo sem cal.

Figura 4.80 - Curva Granulometrica solo $(<\# 10)$ contaminado com extrato de lodo com cal.

Figura 4.81 - Curva granulométrica solos limite Atterberg sem cal.

Figura 4.82 - Curva granulométrica limite Atterberg com cal.

Figura 4.83 - Curva granulométrica com contaminante. 
Figura 4.84 - Curva granulométrica com contaminante e cal.

Figura 4.85 - Alturas finais de sedimentação dos solos.

Figura 4.86 - Determinações de pH contaminante sem cal.

Figura 4.87 - Determinações de pH contaminante com cal.

Figura 4.88 - Massa especifica dos grãos após contaminação.

Figura 4.89 - Tensão vertical de consolidação contaminante.

Figura 4.90 - Tensão vertical de consolidação solo natural.

Figura 4.91 - Tensão vertical de consolidação contaminante solo natural.

Figura 4.92 - Tensão vertical de consolidação com 5x aplicações.

Figura 4.93 - Tensão de consolidação com 5 aplicações de contaminantes com e sem cal.

Figura 4.94 - Tensão vertical de consolidação contaminante com cal.

Figura 4.95 - Tensão vertical de consolidação contaminante $100 \%$.

Figura 4.96 - Tensão vertical de consolidação contaminante com cal sem cal e 146 soluções alcalinas.

Figura 4.97 - Curva tensão cisalhante x deslocamento horizontal (solo natural).

Figura 4.98 - Curva tensão cisalhante x deslocamento horizontal água (solo 147 compactado).

Figura 4.99 - Curva tensão cisalhante x deslocamento horizontal 100\% (solo 148 compactado).

Figura 4.100 - Curva tensão cisalhante x deslocamento horizontal 80\% (solo 148 compactado).

Figura 4.101 - Curva tensão cisalhante x deslocamento horizontal 60\% (solo 148 compactado).

Figura 4.102 - Curva tensão cisalhante x deslocamento horizontal 40\% (solo 148 compactado).

Figura 4.103 - Curva tensão cisalhante x deslocamento horizontal lateral 20\% (solo 148 compactado).

Figura 4.104 - Curva tensão cisalhante x deslocamento horizontal lateral $100 \% \quad 148$ difusão (solo compactado).

Figura 4.105 - Curva tensão cisalhante x deslocamento horizontal $100 \%$ cal (solo 149 compactado).

Figura 4.106 - Curva tensão cisalhante x deslocamento horizontal água 5x (solo 149 compactado).

Figura 4.107 - Curva tensão cisalhante x deslocamento horizontal 100\% 5x (solo 149 compactado).

Figura 4.108 - Curva tensão cisalhante $\mathrm{x}$ deslocamento horizontal $80 \%$ 5x (solo 149 compactado). 
Figura 4.109 - Curva tensão cisalhante x deslocamento horizontal 60\% 5x (solo 149 compactado).

Figura 4.110 Curva tensão cisalhante x deslocamento horizontal $40 \%$ 5x (solo 149 compactado).

Figura 4.111 - Curva tensão cisalhante x deslocamento horizontal 20\% 5x (solo 150 compactado).

Figura 4.112 - Curva tensão cisalhante x deslocamento horizontal $100 \%$ cal 5x (solo 150 compactado).

Figura 4.113 - Relação resistência umidade sem cal (15 dias de cura).

Figura 4.114 - Relação resistência umidade sem cal (45 dias de cura).

Figura 4.115 - Relação resistência umidade sem cal (75 dias de cura).

Figura 4.116 - Relação resistência umidade sem cal.

Figura 4.117 - Relação resistência umidade com cal (15 dias de cura).

Figura 4.118 - Relação resistência umidade com cal (45 dias de cura).

Figura 4.119 - Relação resistência umidade com cal (75 dias de cura).

Figura 4.120 - Relação resistência umidade com cal.

Figura A1 - Cores Perfil 11. (a) úmido; (b) seco.

Figura A2 - Cores Perfil 12. (a) úmido; (b) seco.

Figura A3 - Cores Perfil 13. (a) úmido; (b) seco.

Figura A4 - Cores Perfil 21. (a) úmido; (b) seco.

Figura A5 - Cores Perfil 22. (a) úmido; (b) seco.

Figura A6 - Cores Perfil 23. (a) úmido; (b) seco.

Figura A7 - Cores Perfil 31. (a) úmido; (b) seco.

Figura A8 - Cores Perfil 32. (a) úmido; (b) seco.

Figura A9 - Cores Perfil 33. (a) úmido; (b) seco.

Figura A10 - Cores Perfil 42. (a) úmido; (b) seco.

Figura A11 - Cores Perfil 43. (a) úmido; (b) seco.

Figura A12 - Cores Perfil 52. (a) úmido; (b) seco.

Figura A13 - Cores Perfil 1. (a) úmido; (b) seco.

Figura B1 - Comportamento do cobre no corpo de prova (não sauturado).

Figura B2 - Comportamento do manganês no corpo de prova (não saturado).

Figura B3 - Comportamento do zinco no corpo de prova (não saturado).

Figura B4 - Comportamento do cádmio no corpo de prova (não saturado). 
Figura B6 - Comportamento do cromo no corpo de prova (não saturado).

Figura B7 - Comportamento do cobre no corpo de prova (saturado).

Figura B8 - Comportamento do manganês no corpo de prova (saturado).

Figura B9 - Comportamento do zinco no corpo de prova (saturado).

Figura B10 - Comportamento do níquel no corpo de prova (saturado).

Figura B11 - Comportamento do cromo no corpo de prova (saturado).

Figura C1 - Curvas características contaminante sem cal.

Figura C2 - Curvas características contaminante com cal. 


\section{LISTA DE TABELAS E QUADROS}

Tabela 2.1 - Valores típicos da produção de lodo em unidades de tratamento. $\quad 10$

Tabela 2.2 - apresenta meios de destinação de lodo de esgoto em diversos países. 11

Tabela 2.3 - Diferenças entre estruturas, área especifica e CTC para as diferentes 15 partículas ou minerais.

Tabela 2.4 - Metais pesados em diversas ETES (mg/kg) (Modificado de Jordão \& 17 Pessoa).

Tabela 2.5 - Concentração média de metais em rochas e solos $(\mathrm{mg} / \mathrm{Kg})$.

Tabela 2.6 - Valores orientadores para o cobre.

Tabela 2.7 - Valores norteadores para o manganês.

Tabela 2.8 - Valores norteadores para o zinco.

Tabela 2.9 - Valores orientadores para o cádmio.

Tabela 2.10 - Valores de referência para o cromo.

Tabela 2.11 - Valores de referência para o níquel.

Tabela 2.12 - Série de preferência em função do argilomineral para cátions 48 bivalentes.

Tabela 3.1 - Localização das sondagens e nomenclatura utilizada.

Tabela 3.2 - Valores de $\mathrm{Cr}^{3+}$ para a produção da solução sintética.

Tabela 3.2 - Valores de Ni para a produção da solução sintética.

Quadro 4.1 - Cores, matizes para o perfil P41.

Quadro 4.2 - Cores e matizes para o perfil P51.

Tabela 4.3 - Resultado da análise granulométrica.

Tabela 4.4 - Limites de Atterberg de massa especifica.

Tabela 4.5 - Valores de permeabilidade solo natural/compactado.

Tabela 4.6 - Caracterização do solo no local do experimento da ETE 98

Samambaia/Melchior Atributos analisados para o extrato de lodo centrifugado.

Tabela 4.7 - Atributos analisados para o extrato de lodo centrifugado.

Tabela 4.8 - Caracterização do lodo de esgoto.

Tabela 4.9 - Valores máximos de metais no solo após o ensaio de difusão (liner não 109 saturado).

Tabela 4.10 - Valores máximos de metais no solo após o ensaio de difusão (liner 117 saturado).

Tabela 4.11 - Dados de sorção para o zinco.

Tabela 4.12 - Dados sorção para o manganês.

Tabela 4.13 - Dados sorção para o cobre. 
Tabela 4.14 - Dados sorção para o níquel.

Tabela 4.15 - Dados sorção para o cromo.

Tabela 4.16 - Valores de isotermas, kd, E, kf, Sm, b.

Tabela 4.17 - Potencial de colapso (cp), coeficiente de compressibilidade (cc), 144 tensão de pré- adensamento e índices de vazios iniciais e finais dos corpos de prova. Tabela 4.18 - C Potencial de colapso (cp), coeficiente de compressibilidade (cc), tensão de pré- adensamento e índices de vazios iniciais e finais dos corpos de prova, (solo natural, indeformado).

Tabela 4.19 - Potencial de colapso (cp), coeficiente de compressibilidade (cc), 144 tensão de pré- adensamento e índices de vazios iniciais e finais dos corpos de prova, (cinco aplicações e soluções alcalinas).

Tabela 4.20 - Valores de ângulo de atrito e coesão.

Tabela A1 - Classificação MCT Perfil 1.

Tabela A2 - Classificação MCT Perfil 2.

Tabela A3 - Classificação MCT Perfil 3.

Tabela A4 - Classificação MCT Perfil 4.

Tabela A5 - Classificação MCT Perfil 5.

Tabela A6 - Matiz, valores de croma, e cor perfil P11.

Tabela A7 - Matiz, valores de croma, e cor perfil P12.

Tabela A8 - Matiz, valores de croma, e cor perfil P13.

Tabela A9 - Matiz, valores de croma, e cor perfil P21.

Tabela A10 - Matiz, valores de croma, e cor perfil P22.

Tabela A11 - Matiz, valores de croma, e cor perfil P23.

Tabela A12 - Matiz, valores de croma, e cor perfil P31.

Tabela A13 - Matiz, valores de croma, e cor perfil P32.

Tabela A14 - Matiz, valores de croma, e cor perfil P33.

Tabela A15 - Matiz, valores de croma, e cor perfil P41.

Tabela A16 - Matiz, valores de croma, e cor perfil P42.

Tabela A17 - Matiz, valores de croma, e cor perfil P43.

Tabela A18 - Matiz, valores de croma, e cor perfil P51.

Tabela A19 - Matiz, valores de croma, e cor perfil P52. 


\section{LISTA DE ABREVIATURAS E SIGLAS}

ABNT Associação Brasileira de Normas Técnicas

$\mathrm{Ag}-$ prata

$\mathrm{Al}$ - alumínio

As - arsênio

BET (batch equilíbrium test)

C concentração de equilíbrio

CAESB - Companhia de Saneamento do Distrito Federal

$\mathrm{Ca}^{+2}-$ Cálcio

$\mathrm{Cl}$ - cloro

Cd - cádmio

$\mathrm{Cr}$ - cromo

Cd 3 cambissolo álico

Cd 9 associação de cambissolo

$\mathrm{C}_{0}=$ concentração inicial da solução, colocada em contanto com o solo em mg/L

$\mathrm{C}=$ concentração final obtida após o equilíbrio em $\mathrm{mg} / \mathrm{L}$

$\mathrm{cm}^{2} / \mathrm{s}$ - centimetro ao quadrado por segundo

CTC - capacidade de troca catiônica

$\mathrm{CO}^{2-}{ }_{3}$ - carbonato

$\mathrm{cmol} / \mathrm{kg}$ - mol por quilograma

$\mathrm{CP}$ - corpo de prova

$\mathrm{CP}(\%)$ - é o potencial de colapso

$D^{*}$ - difusão efetiva

$\mathrm{D}_{\mathrm{e}}$ coeficiente de difusão em solução livre

$\mathrm{D}_{\mathrm{h}}$ - dispersão hidrodinâmica

DRX - difração de raio $\mathrm{x}$

e - índice de vazios

ETE - Estação de Tratamento de Esgoto

DNER Departamento Nacional de Estradas e Rodagem

F - fluor

$\mathrm{Fe}$ - ferro 
Fv fator de vermelho

$\mathrm{g} / \mathrm{cm}^{3}$ - grama por centímetro cubico

$\mathrm{g} / \mathrm{l}$ - grama por litro

GCL - geocomposto bentonítico

hab - habitante

$\mathrm{H}^{+}$- hidrogênio

$\mathrm{HF}$ - ácido fluorídrico

$\mathrm{Hg}^{+}$- mercúrio

Hi é a altura do corpo de prova, antes da inundação e carga

$\mathrm{HNO}_{3}$ - ácido nítrico

$\mathrm{HCl}$ - ácido cloridrico

$\Psi_{\mathrm{z}}$ potencial gravitacional

$\Psi_{p}$ potencial de pressão

IP - índice de plasticidade

$\mathrm{K}$ - condudividade

$\mathrm{K}^{+}$- potássio

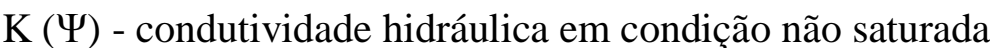

$\mathrm{K}_{\mathrm{f}}$ e $\varepsilon$-coeficientes empíricos da isoterma de Freundlich

$\mathrm{K}_{\mathrm{d}}-$ coeficiente de distribuição

$\mathrm{kg}$ - quilograma

$\mathrm{KCl}$ - cloreto de potássio

1/s - litros por segundo

LEd1 latossolo vermelho-escuro álico

LVd1 latossolo vermelho álico

LA' arenoso

LA areia

LG' argiloso

NS' siltoso

$\mathrm{m}=$ massa de solo em $\mathrm{g}$

$\mathrm{m}^{3}$ metro cúbico

$\mathrm{mE} / 100 \mathrm{~mL}$ - miliequivalente por cem mililitros

$\mathrm{mg} / \mathrm{L}$ miligrama por litro 
$\mathrm{m}^{2} \mathrm{~g}^{-1}-$ metro ao quadrado por grama

$\mathrm{mg} / \mathrm{kg}$ - miligrama por quilograma

$\mathrm{mL}$ - mililitros

$\mathrm{Mg}^{+2}$ - magnésio

Mn - manganês

$\mathrm{n}$ - porosidade

$\mathrm{Ni}$ - níquel

$\mathrm{NO}^{-3}$ - nitrato

$\mathrm{O}^{+}$- oxigênio

$\mathrm{OH}$ - íons hidroxila

$\mathrm{Pb}$ - chumbo

$\mathrm{pH}$ - potencial hidrogeniônico

$\mathrm{PO}_{4}^{3-}$ - fosfato

ppm - parte por milhão

$\mathrm{R}$ - coeficiente de retardo

RAFA - Reator anaeróbio de fluxo ascendente

$\mathrm{R}_{\mathrm{d}}$ - fator de retardamento

$\mathrm{S}$ grau de adsorção

$\mathrm{S}=$ adsorção, $\mathrm{mg} / \mathrm{g}$

$\mathrm{SO}_{3}^{2-}$ - sulfito

$\mathrm{V}=$ volume da solução utilizada em L

VI - valor máximo de investigação

VMP - valor máximo permitido

VM - valor máximo

VP - valor permitido

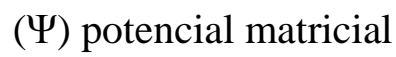

w - constante empírica

$\mathrm{w}_{0}$ umidade higroscópica

wL - limite de liquidez

wP - limite de plasticidade

$\mathrm{Zn}$ - zinco

$\rho g$ - massa específica real dos grãos 
pd - massa específica aparente seca

$\mathrm{S}_{\mathrm{m}}$ é o número de moles do soluto adsorvido por unidade de peso do adsorvente $\Delta \mathrm{pH}$ - diferença de $\mathrm{pH}$ em água e $\mathrm{KCl}$

$\Delta \mathrm{H}$ é a variação da altura do corpo de prova, devido a inundação e carga

$\mathrm{CrCl} 3.6 \mathrm{H} 2 \mathrm{O}$ - cloreto de cromo hexaidratado

$\mathrm{NiCl}_{2} 6 \mathrm{H}_{2} \mathrm{O}$ - cloreto de níquel hexaidratado 


\section{SUMÁRIO}

1 INTRODUÇÃO

1.1 RELEVÂNCIA DA PESQUISA........................................................................... 3

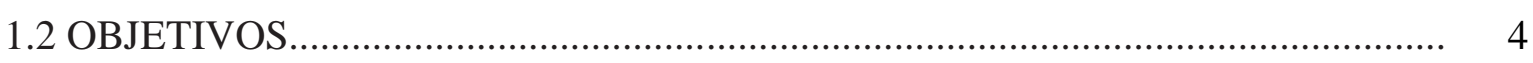

1.3 ESCOPO DA TESE................................................................................................... 5

2 REVISÃO DE LITERATURA.......................................................................

2.1 TRATAMENTO DE ESGOTO......................................................................... 6

2.1.1 TRATAMENTO DE ESGOTO NA ETE SAMAMBAIA/MELCHIOR................. 7

2.2 PROCESSOS DE GERAÇÃO DE LODO EM UMA ESTAÇÃO DE 8 TRATAMENTO DE ESGOTO.

2.3 ALTERNATIVAS DE DISPOSIÇÃO DE LODO DE ESGOTO............................... 11

2.4 ASPECTOS LEGAIS DA CONTAMINAÇÃO DE SOLOS E 12 ÁGUA...

$\begin{array}{lllllll}2.5 & \text { SOLO } & \mathrm{E} & \text { INTERAÇÕES } & \text { COM } & \text { OS } & 13\end{array}$

CONTAMINANTES.

2.5.1 METODOS DE EXTRAÇÃO DE METAIS DE SOLOS....................................... 15

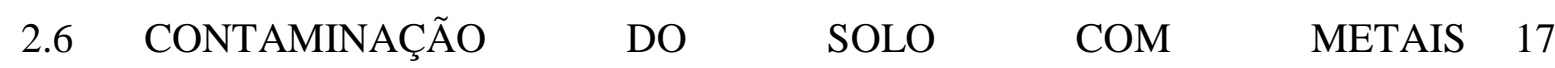

PESADOS.

2.6.1 AVALIAÇÃO DA CONTAMINAÇÃO DE SOLOS.......................................... 19

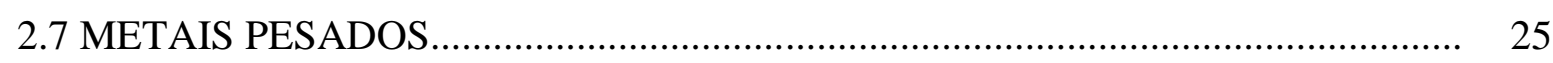

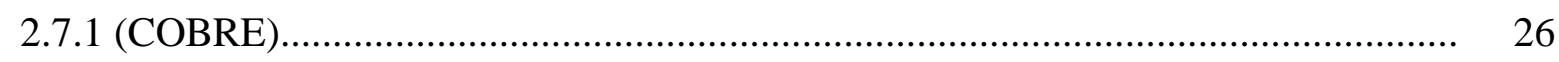

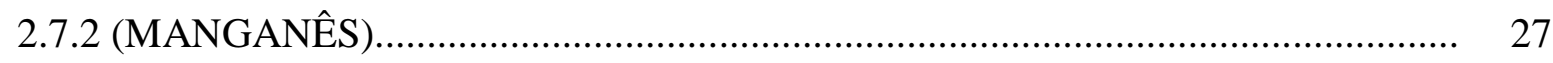

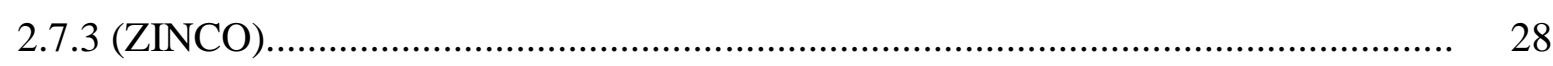

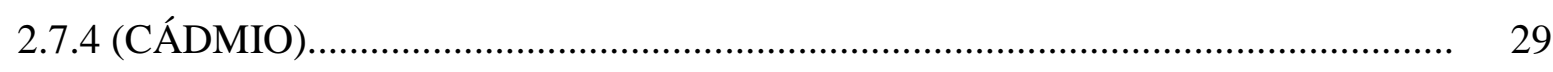

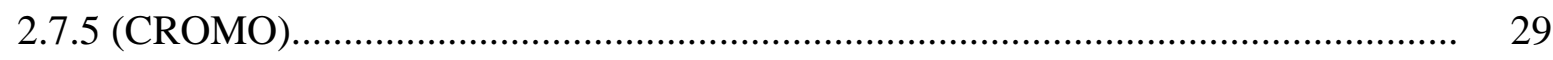

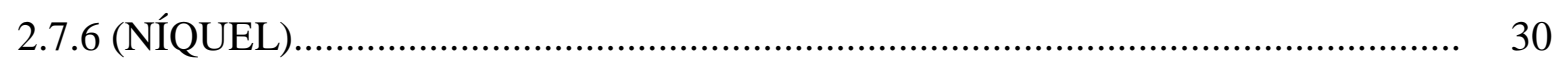

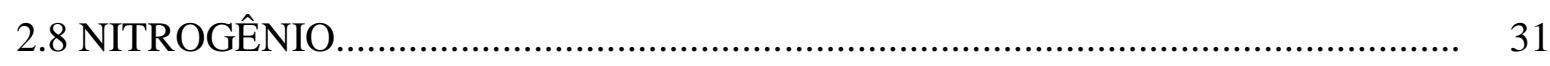

2.9 CURVA CARACTERISTICA DE SOLOS CONTAMINADOS......................... 32

2.10 CONTITUINTES DO ESGOTO E MUDANÇA DAS CARACTERISTICAS 33 DOS SOLOS.

2.11 CONSIDERAÇÕES SOBRE O FLUXO EM MEIOS POROSOS...................... 36 


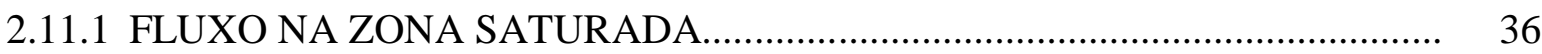

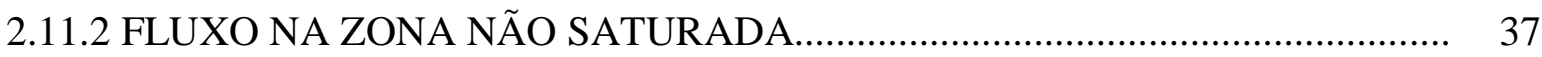

2.12 FLUXO DE CONTAMINANTES EM SOLOS................................................... 38

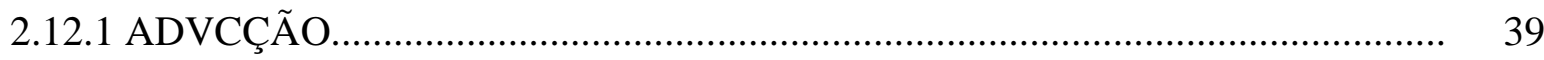

2.12.2 DISPERSÃO MECÂNICA OU HIDRÁULICA............................................... 39

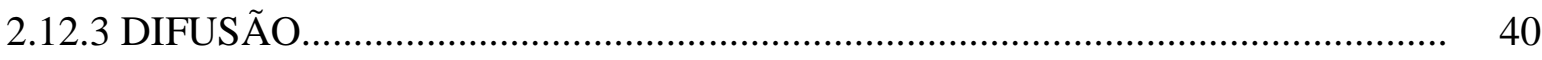

2.12.4 DISPERSÃO HIDRODINÂMICA................................................................. 43

2.12.5 REAÇÕES QUÍMICAS...............................................................................

2.12.5.1 ADSORÇÃO-DESSORÇÃO.................................................................... 46

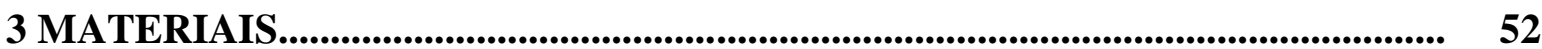

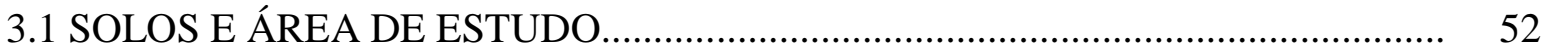

3.2 CARACTERIZAÇÃO FÍSICA DOS PERFIS...................................................... 55

3.2.1 Determinação do Teor de Umidade Natural de Cada Camada.............................. 55

3.2.2 Ensaio das pastilhas MCT........................................................................... 56

3.2.3 Limite de Plasticidade..................................................................................... 57

3.2.4 Carta Munssel para a determinação da cor dos solos.............................................. 57

3.3 CARACTERIZAÇÃO DO SOLO PARA A ÁREA DE EXECUAÇÃO DAS 58 CÉLULAS DE DIFUSÃO EM CAMPO

3.4 CARACTERIZAÇÃO DO EXTRATO DE LODO CENTRIFUGADO.................. 59

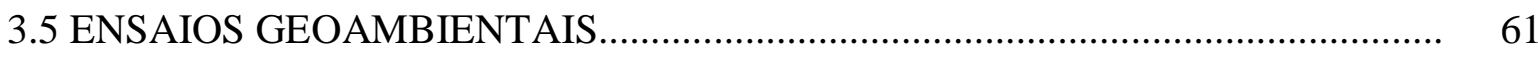

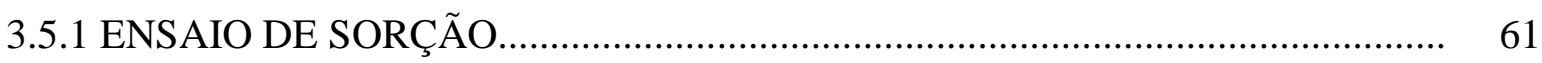

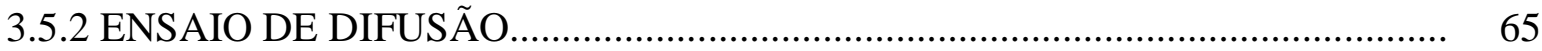

3.5.3 ENSAIOS DE DIFUSÃO MULTIESPÉCIE NÃO SATURADO E SATURADO 65

3.5.4 ENSAIO DE DIFUSÃO COM A SOLUÇÃO SINTÉTICA DE CLORETO DE 69 CROMO $3 \mathrm{Cr}_{3}{ }^{+}$.

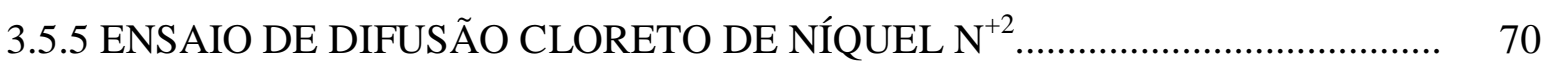

3.5.6 ENSAIO DE DIFUSÃOCOM NITRATO........................................................ 71

3.5.7 ENSAIOS DE DIFUSÃO EM CAMPO_.......................................................... 75

3.5.8 COMPATIBILIDADE (Shackelford, 1994).................................................... 79

3.5.9 DETERMINAÇÃO DO pH...................................................................... 81

3.5.10 MASSA ESPECIFICA DOS GRÃOS ........................................................

3.5.11 DETERMINAÇÃO DA CURVA CARACTERISTICA DE RETENÇÃO ........ 81 
3.6 ENSAIOS DE COMPRESSÃO DIAMETRAL ............................................. 83

3.7 ENSAIO DE CISALHAMENTO .............................................................. 83

3.8 ENSAIO EDOMÉTRICO........................................................................... 85

3.9 RESISTÊNCIA A COMPRESSÃO SIMPLES ................................................. 86

4.0 RESULTADOS E DISCUSSÕES...................................................................... 87

4.1 CARACTERIZAÇÃO FÍSICA DA ÁREA DE ESTUDO INSTALAÇÃO DOS 87 EXPERIMENTOS EM CAMPO.

4.2 CARACTERIZAÇÃO DO SOLO PARA A CONSTRUÇÃO DAS CÉLULAS DE 92 DIFUSÃO EM CAMPO.

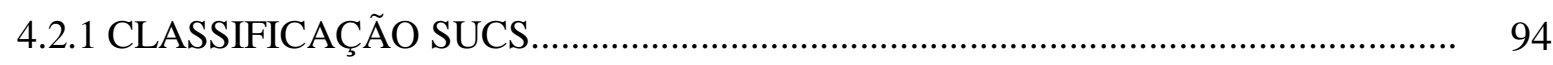

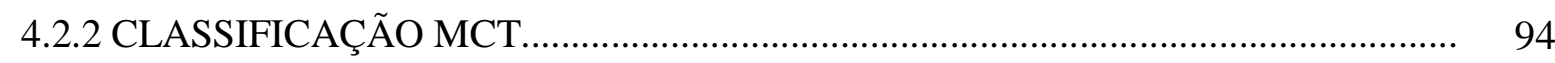

4.2.2.1 Classificação MCT Expedita.............................................................................. 94

4.2.2.2 Classificação MCT Tradicional.................................................................... 95

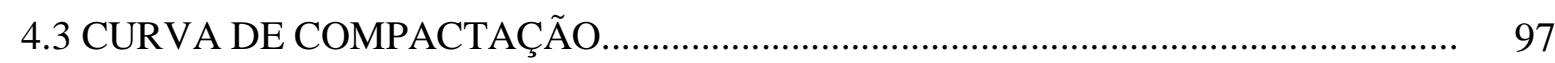

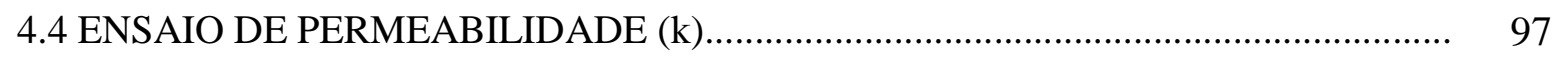

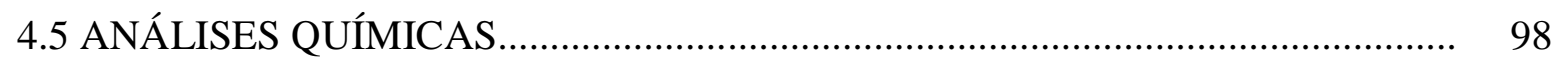

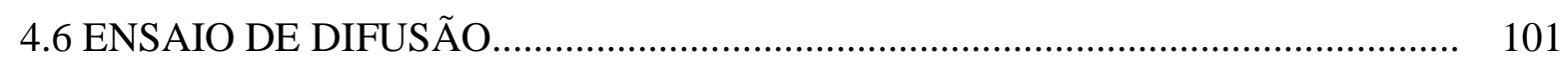

4.6.1 ENSAIO DE DIFUSÃO MULTIESPÉCIE LINER NÃO SATURADO.............. 101

4.6.2 ENSAIO DE DIFUSÃO MULTIESPÉCIE LINER SATURADO........................ 109

4.6.3 ENSAIO DE DIFUSÃO SOLUÇÃO SINTÉTICA DE $\mathrm{Cr}^{+3} \ldots \ldots \ldots \ldots \ldots \ldots \ldots \ldots \ldots \ldots . . . . . . . . . . . . . . . . . . . .117$

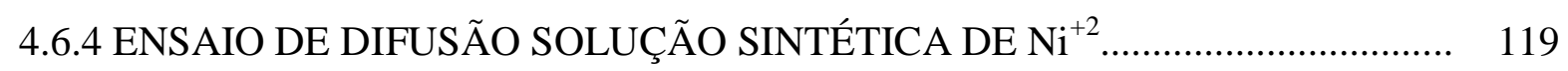

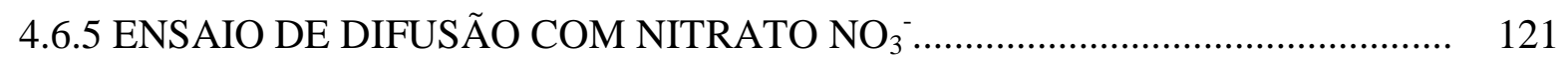

4.7 ENSAIO DE SORÇÃO.................................................................................. 123

$\begin{array}{llllllll}4.8 & \text { CURVA } & \text { CARACTERISTICA DE RETENÇÃO DE ÁGUA } & \text { E } & 132\end{array}$ CONTAMINANTE..

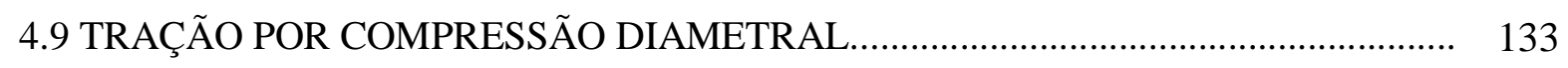

4.10 ENSAIOS DE COMPATIBILIDADE................................................................. 137

4.11 DETERMINAÇÃO DE pH e MASSA ESPECIFICA DOS GRÃOS.......................... 142

4.12 ENSAIO DE ADENSAMENTO......................................................................... 143

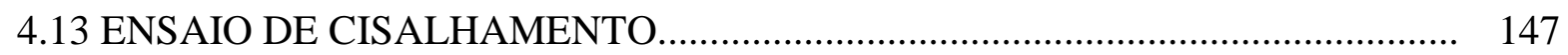

4.14 ENSAIO DE COMPRESSÃO SIMPLES........................................................ 151

5. CONSIDERAÇÕES FINAIS....................................................................... 156 
5.1 CONCLUSÕES

156

5.2 SUGESTÕES A TRABALHOS FUTUROS

159

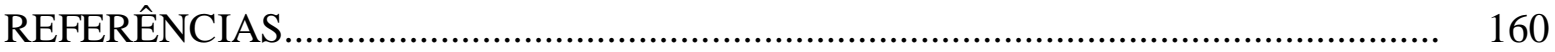

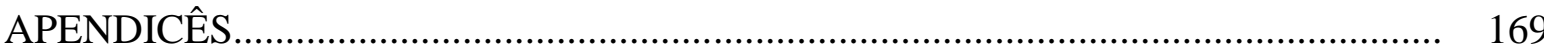




\section{INTRODUÇÃO}

Desde a antiguidade o homem aprendeu, experimentalmente, que a água poluída e os resíduos gerados podiam transmitir doenças, o que o fez pensar em adotar medidas para obter água de qualidade para o abastecimento, e dispor de forma correta os seus resíduos. Ações como estas permitiram o surgimento do saneamento do meio ambiente alterado. A partir daí os mecanismos de comando e controle tornaram-se mais evidentes no âmbito nacional nas matérias concernentes ao saneamento ambiental, permitindo que leis específicas fossem criadas para norteamento das questões ambientais.

No Brasil foi publicada a Lei $\mathrm{n}^{\circ} 11.445$ de 5 de janeiro de 2007, que estabelece diretrizes nacionais para o saneamento básico, definindo-o como o conjunto de serviços, infra-estruturas, instalações e operações de: abastecimento de água potável, esgotamento sanitário, limpeza urbana e manejo de resíduos sólidos, drenagem e manejo de águas pluviais urbanas. Para complementar a matéria de Saneamento em âmbito nacional foi publicada a Lei $\mathrm{n}^{\mathrm{o}} 12.305$ de 2 de agosto de 2010 a qual instituiu a Política Nacional de Resíduos Sólidos, dispondo sobre seus princípios, objetivos e instrumentos, bem como sobre as diretrizes relativas à gestão integrada e ao gerenciamento de resíduos sólidos, incluídos os perigosos, às responsabilidades dos geradores e do poder público e aos instrumentos econômicos aplicáveis.

Como parte integrante do saneamento básico, o tratamento de esgoto visa diminuir a capacidade poluidora e contaminante, principalmente reduzindo a carga de matéria orgânica e nutrientes. Diversas configurações de tratamento podem ser estabelecidas em função: do impacto ambiental do lançamento no corpo receptor, objetivos do tratamento (principais constituintes a serem removidos), nível de tratamento e eficiências de remoção desejada. Mesmo apresentando uma composição predominante de parte líquida, a pequena composição da parte sólida (lodo de esgoto) apresenta potencial poluidor e contaminante do meio ambiente, em função das suas características físico-químicas e biológicas.

De acordo com Sperling (2005), o termo lodo de esgoto tem sido utilizado para designar os subprodutos sólidos do tratamento de esgotos, também pode ser denominado de biossólido, sendo que esta é uma forma de ressaltar os seus aspectos benéficos, valorizando a 
utilização produtiva, em comparação com a mera disposição final improdutiva, por meio de aterros de disposição superficial no solo ou incineração.

O lodo de esgoto apresenta, em sua composição, metais pesados como cádmio $(\mathrm{Cd})$, cromo $(\mathrm{Cr})$, níquel $(\mathrm{Ni})$, zinco $(\mathrm{Zn})$, cobre $(\mathrm{Cu})$, manganês $(\mathrm{Mn})$, entre outros elementos, cujos teores variam principalmente em função da procedência do resíduo. Assim, se aplicado ao solo, o resíduo pode provocar aumento dos teores desses metais no solo, e poderá migrar para as zonas de água subterrânea e contaminá-las, comprometendo seus usos futuros.

As alternativas mais usuais para o aproveitamento ou disposição final do lodo de esgoto ou biossólidos são: disposição em aterro sanitário (aterro exclusivo e co-disposição com resíduos sólidos urbanos); reuso industrial (produção de agregado leve, fabricação de tijolos e cerâmica e produção de cimento); incineração (incineração exclusiva e coincineração com resíduos sólidos urbanos); conversão em óleo combustível; disposição oceânica; recuperação de solos (recuperação de áreas degradadas e de mineração); "landfarming" (tratamento no solo com ou sem vegetação) e uso agrícola e florestal (aplicação direta no solo, compostagem, fertilizante e solo sintético).

A quantidade gerada de lodo de esgoto cresce proporcionalmente ao aumento dos serviços de coleta e tratamento de esgoto, que, por sua vez, deve acompanhar o crescimento populacional. Em 2010, estimativas apontavam uma produção nacional de 150 a 220 mil toneladas de matéria seca por ano, considerando que o tratamento de esgoto atingia apenas $30 \%$ da população urbana (Pedroza et al., 2010).

Em média, estima-se que cada ser humano produza cerca de $120 \mathrm{~g}$ de sólidos secos diários lançados nas redes de esgoto (METCALF E EDDY, 1991, apud NUVOLARI et al. 2011). O esgoto, quando não contém resíduos industriais, é basicamente composto por 99,87\% de água, 0,04\% de sólidos sedimentáveis, 0,02\% de sólidos não sedimentáveis e 0,07\% de substâncias dissolvidas (NUVOLARI et al. 2011).

Conforme mencionado, existem diversas técnicas para a disposição do lodo de esgoto, sendo que grande parte das vezes o processo não utiliza técnicas corretas de engenharia, o que pode acarretar sérias consequências para o meio ambiente em função da migração dos contaminantes contidos no lodo para o solo e os lençóis de água subterrânea, além de poder mudar as características físicas do solo local. Sendo, assim, torna-se necessário o desenvolvimento de pesquisas que visem buscar a melhor alternativa ambientalmente correta para a disposição de lodo de esgoto sobre o solo. A implantação de estudos geotécnicos e 
ambientais configura-se como medida para o entendimento da dinâmica de disposição desse resíduo sólido altamente impactante para o meio ambiente.

\subsection{RELEVÂNCIA DA PESQUISA}

Apesar dos sistemas de tratamento de esgotos serem altamente eficientes no que diz respeito ao tratamento da carga orgânica, biológica e de nutrientes, o tratamento e a disposição final de lodo de estação de tratamento de esgoto (ETE), torna-se um grande problema no contexto mundial, uma vez que estes resíduos apresentam gestão com certo grau de complexidade. A lei ${ }^{\circ} 12.305$ de 2 de agosto de 2010, ao instituir a Política Nacional de Resíduos Sólidos, diz que a gestão de resíduos será desenvolvida por um conjunto de ações voltadas para a busca de soluções para os resíduos sólidos, de forma a considerar as dimensões política, econômica, ambiental, cultural e social, com controle social e sob a premissa do desenvolvimento sustentável.

Atualmente os sistemas mais utilizados para a disposição final, sejam eles em consórcio com os aterros sanitários, ou em recuperação de áreas degradadas, apresentam riscos ao meio ambiente em função da constituição físico-química e biológica do lodo. De maneira geral, a contaminação de uma área é um grave problema geoambiental, uma vez que afeta o solo, as águas subterrâneas e a vegetação. Quando ocorre o contato entre o contaminante e o solo, inicialmente o contaminante se infiltra na zona não saturada do solo, onde é parcialmente retido. Entretanto, as interações entre o solo, fluido intersticial, ar e contaminantes que ocorrem nesta região ainda são pouco conhecidas, devido às poucas pesquisas realizadas sobre o aspecto geotécnico ambiental da disposição de lodo de esgoto.

Em Brasília a Companhia de Saneamento do Distrito Federal utiliza locais de transbordo para armazenar temporariamente o lodo de esgoto antes que o mesmo seja direcionado para a recuperação de áreas degradadas, essas áreas de transbordo recebe diariamente a produção do Distrito Federal de 320 toneladas/dia (massa úmida - 18 a 20\% de teor de sólidos). A estação de tratamento de esgoto ETE Samambaia/Melchior produz cerca de 48 toneladas/dia (massa úmida - 15 a $16 \%$ de teor de sólidos), mais um motivo para se estudar esse mecanismo de disposição temporária uma vez que a quantidade diária é muito grande. A motivação para essa pesquisa se deu em função da necessidade de estudar o grau de contaminação, bem como possíveis alterações das características geotécnicas dos solos dessas áreas de armazenamento temporário, uma vez que os mesmos ao serem submetidos a 
repetitivas concentrações de lodo ao longo do tempo podem propiciar o acúmulo de substâncias no perfil de solo. Além disso, torna-se necessário o desenvolvimento de estudos complementares, cujo foco seja as alterações em camadas de solos compactados, uma vez que, essas áreas de transbordo não apresentando contenções do ponto de vista de engenharia, necessitariam de camadas de solos compactas como barreira de contaminantes.

\subsection{OBJETIVOS}

Esta pesquisa tem, como objetivo geral, verificar a influência da disposição de lodo de esgoto no solo, no que diz respeito à contaminação com metais pesados, e possíveis mudanças nas características hidromecânicas de um perfil de solo da Estação de Tratamento de Esgoto Samambaia/Melchior.

Como objetivos específicos têm-se:

- determinar os atributos ambientais e geotécnicos para entendimento do fluxo de contaminantes, pelos mecanismos de advecção, dispersão mecânica, difusão molecular, sorção, e com isso avaliar o retardo e atenuação natural;

- caracterizar o lodo sob seus aspectos físicos e químicos;

- verificar como os constituintes do lodo poderão alterar as características físicas do solo;

- construir células em campo simulando o ensaio de difusão em escala de campo;

- classificar o solo após os ensaios para verificação do fluxo de contaminantes de acordo com as propostas estabelecidas pela Resolução Conama n 420 de 2009; 


\subsection{ESCOPO DA TESE}

Este item apresenta como a Tese está organizada mostrando sua estrutura em capítulos e os assuntos mencionados em cada um deles.

O primeiro capítulo apresenta uma introdução sobre os aspectos gerais do lodo de esgoto e a importância para o estudo em que conciliem os aspectos geotécnicos e ambientais para a sua disposição. Ainda é feita uma abordagem sobre a relevância da pesquisa e os objetivos apresentados.

No capítulo dois é apresentada a revisão bibliográfica pertinente, mostrando como é gerado lodo de esgoto em uma estação de tratamento de esgoto e os diferentes tipos de disposições. Além disso, é apresentado estudo de contaminação de solos incluindo mecanismos de transporte de contaminantes e alterações das características hidromecânicas devido a interação com contaminantes. Nesse capítulo ainda são apresentados os principais mecanismos de transporte de contaminantes para solos.

No capítulo três são discutidas as principais metodologias para o desenvolvimento desta pesquisa. Nesse capítulo são apresentados os materiais, solo e contaminantes e formas de preparação das amostras para a realização dos ensaios. Ainda são apresentados os procedimentos de campo, laboratorial e numérico.

No capítulo quatro são apresentados os principais resultados, iniciando pelos dados referentes à caracterização dos solos proveniente das sondagens de campo. Posteriormente são apresentados os dados de caracterização do solo utilizado para a realização dos ensaios de fluxo de contaminantes, caracterização mecânica e resistência, além da simulação numérica.

No capítulo cinco são apresentadas as principais conclusões sobre a disposição ambientalmente adequada de lodo de esgoto, posteriormente é apresentada as sugestões para pesquisas futuras.

As referências bibliográficas e os anexos são apresentados ao final da tese. Nos anexos são apresentados os dados complementares dos ensaios. 


\section{REVISÃO DE LITERATURA}

Neste item da revisão de literatura, serão abordados de forma simplificada os processos de tratamento de esgoto, em especial o processo de geração de lodo de esgoto, bem como as principais formas de disposição final, além de mostrar os principais mecanismos de fluxo de contaminantes pelo solo.

\subsection{TRATAMENTO DE ESGOTO}

O esgoto deve passar por processos de tratamento de forma a adequá-lo ao poder de diluição específico de cada corpo receptor. Estes tratamentos concentram e removem a matéria orgânica e os demais poluentes, que constituirão o lodo de esgoto. Os sistemas de tratamento de esgotos normalmente utilizam de forma otimizada os fenômenos de biodegradação que já ocorrem na natureza. Os métodos mais comuns de tratamento são os biológicos, que utilizam os microrganismos presentes no esgoto para degradar a matéria orgânica e purificar a água (Sanepar, 1999).

O tratamento de efluentes, tanto domésticos quanto industriais, pode envolver diversos tipos de unidades de tratamento combinadas, que variam em função do tipo de efluente a ser tratado, das exigências da legislação vigente quanto às características do efluente tratado, das características do corpo receptor, dos custos dessas unidades de tratamento, do espaço disponível para a construção da estação. Nessas unidades de tratamento podem ocorrer processos químicos, físicos e biológicos que, na maioria das vezes, acontecem de forma interdependente e proporcionam a remoção de boa parte das impurezas contidas nos efluentes, como materiais inertes, matéria orgânica, macro e micro nutrientes, micropoluentes orgânicos, microorganismos patogênicos, metais potencialmente tóxicos, entre outros (Silva, 2005).

De acordo com Castro et al.(1997), os processos de tratamento de esgotos podem ser divididos entre sistemas simplificados (sem mecanização), caracterizados por lagoas de estabilização, disposição no solo e reatores anaeróbios, e sistemas mecanizados, caracterizados por lagoas de estabilização com aeração, filtros biológicos e lodos ativados. 
De acordo com Sperling (2005), os requisitos a serem atingidos para o efluente estão em função de legislação específica que prevê padrões de qualidade para o efluente e para o corpo receptor. O tratamento de esgoto é usualmente classificado nos seguintes níveis:

1 - Preliminar: objetiva apenas a remoção dos sólidos grosseiros; 2 - Primário: visa à remoção de sólidos sedimentáveis e, em decorrência, parte da matéria orgânica. Em ambos predominam os mecanismos físicos de remoção de poluentes; 3 - Secundário: predominam mecanismos biológicos, o objetivo é principalmente a remoção de matéria orgânica e eventualmente nutrientes (nitrogênio e fósforo); 4 - Terciário: objetiva remoção de poluentes específicos (usualmente tóxicos ou compostos não biodegradáveis), ou ainda, a remoção complementar de poluentes não suficientemente removidos no tratamento secundário.

\subsubsection{TRATAMENTO DE ESGOTO NA ETE SAMAMBAIA/MELCHIOR}

A estação de tratamento de esgoto ETE SAMAMBAIA apresenta como configuração básica de tratamento: Reator anaeróbico de fluxo ascendente (RAFA), lagoa facultativa, lagoa de alta taxa, lagoa de polimento e polimento final. Atualmente apresenta uma vazão média de 261 1/s atendendo a área da cidade satélite de Samambaia. Após tratamento todo o efluente tratado é lançado no corpo receptor: Córrego Gatume/Rio Melchior. A Figura 2.1 apresenta uma imagem da ETE SAMAMBAIA.

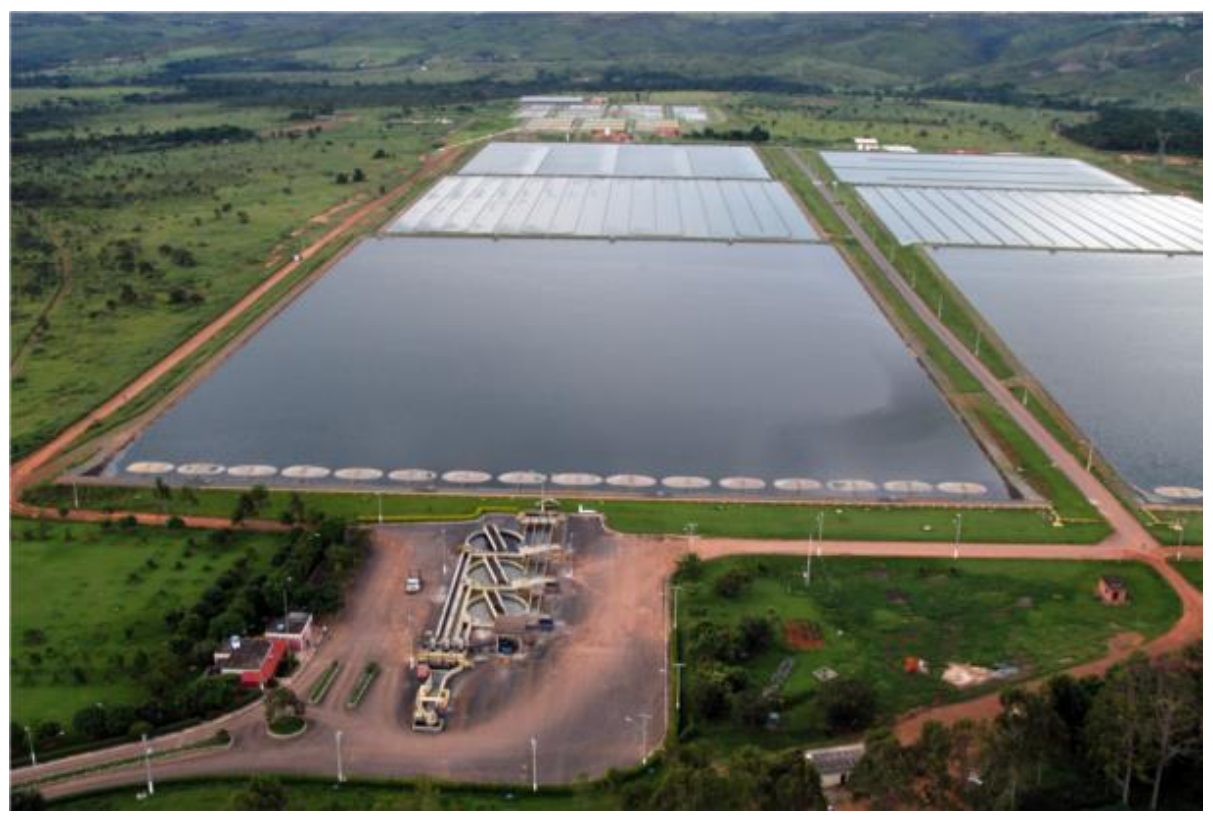

Figura 2.1 - ETE SAMAMBAIA (Fonte: CAESB, 2014). 
Já a estação de tratamento de esgoto ETE MELCHIOR, apresenta sua configuração de projeto de tratamento: Reator anaeróbico de fluxo ascendente seguido de unitank (conjunto de tanques de aeração e clarificação com polimento final. Apresenta uma vazão média atual de 889 1/s, atendendo as cidades satélites de Ceilândia, Taquatinga pequena e parte de Samambaia. Após tratamento o efluente é lançado no corpo receptor Rio Melchior. A Figura 2.2 apresenta uma imagem da estação de tratamento de esgoto ETE MELCHIOR.

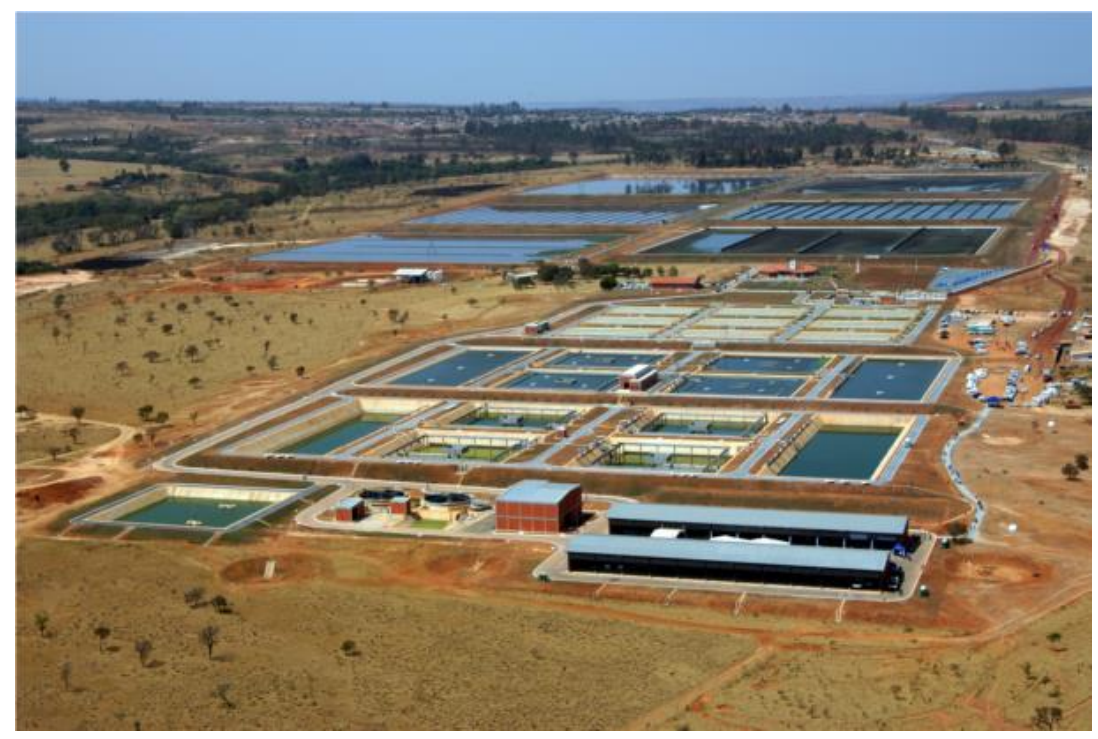

Figura 2.2 - Estação de tratamento de esgoto ETE MELCHIOR (Fonte: CAESB, 2014).

\subsection{PROCESSOS DE GERAÇÃO DE LODO EM UMA ESTAÇÃO DE TRATAMENTO DE ESGOTO}

O tratamento dos esgotos gera alguns subprodutos, na forma sólida, semi-sólida, ou líquida, que devem receber um tratamento específico antes de sua disposição final. Esses subprodutos do tratamento da fase líquida são: sólidos grosseiros, areia, escuma, e lodo. Desses, o lodo é o que apresenta a maior parcela de importância, devendo receber atenção particular em relação a seu tratamento, uma vez que apresenta metais pesados em sua composição e uma carga patogênica elevada (Jordão \& Pessôa, 2009).

A produção de lodo a ser gerado é função exclusiva do sistema de tratamento utilizado para a fase líquida. Em princípio, todos os processos de tratamento biológico geram lodo. Os processos que recebem o esgoto bruto em decantadores primários geram o lodo primário, composto pelos sólidos sedimentáveis do esgoto bruto. Na etapa biológica de tratamento, temse o lodo secundário, lodo biológico ou lodo excedente, dependendo do tipo de sistema. $\mathrm{O}$ 
lodo primário pode ser enviado para o tratamento juntamente com o lodo secundário, nesse caso, o lodo resultante da mistura passa ser chamado de lodo misto. Em sistemas de tratamento que incorporam uma etapa físico-química, tem-se o lodo químico (Sperling, 2005).

De acordo com Jordão \& Pessoa (2009), o tratamento e a disposição final do lodo constituem muitas vezes problemas particularmente difíceis ou complexos, face às grandes quantidades que podem ser geradas, à dificuldade em se encontrar locais adequados ou seguros para o destino final. No caso de esgotos sanitários, o lodo gerado na fase líquida do tratamento se apresenta como um líquido com concentração de sólidos bastante baixa, da ordem de $1 \%$ a $5 \%$ em peso. Este lodo, seja o removido nas fases de tratamento preliminar e primário, ou seja o gerado na fase de tratamento biológico, vai requerer um conjunto de operações específicas, que podem incluir a sequência seguinte no todo ou em parte:

- preparação: gradeamento, trituração, desarenação, mistura, reservação;

- adensamento: por gravidade, flotação, centrifugação, filtros de esteira;

- estabilização: biológica (digestão aeróbica e anaeróbica), estabilização química, tratamento térmico, compostagem;

- condicionamento: físico e químico;

- remoção de umidade: leitos de secagem, lagoas de lodo, filtros prensa, filtros a vácuo, filtros de esteira, centrífugas, secagem térmica;

- redução térmica: incineração (incineradores tipo "multiple hearth" e de leito fluidizado), co-incineração com resíduos sólidos (lixo), oxidação úmida;

- disposição final: aterros controlados, aplicação no solo para fins agrícolas, recuperação de áreas, lançamento submarino, reuso na indústria da construção civil.

Os processos de tratamento de lodo visam reduzir o teor de material orgânico biodegradável, a concentração de organismos patogênicos e o teor de água para que se obtenha um material sólido e estável, que não constitua perigo para a saúde e possa ser manipulado e transportado com facilidade e baixo custo. Aplicam-se quase exclusivamente métodos biológicos para estabilizar o lodo gerado nas ETES: digestão anaeróbia ou em poucos casos, a digestão aeróbia. A redução do teor de água é efetuada por processos físicos (adensamento, filtração, flotação, evaporação) e, eventualmente, precedidos por processos preparatórios e condicionamento que visam facilitar e/ou acelerar o processo de separação da água (Andreoli, 2006).

Segundo Godoy (2013), o aproveitamento do lodo já é feito em outros países há bastante tempo, sendo o reuso agrícola o método mais empregado. No Brasil as alternativas 
de reuso ainda são pouco utilizadas e a destinação mais comum é o aterro sanitário. A Figura 2.3 ilustra a atual distribuição da destinação do lodo na região da bacia dos rios Piracicaba, Capivari e Jundiaí.

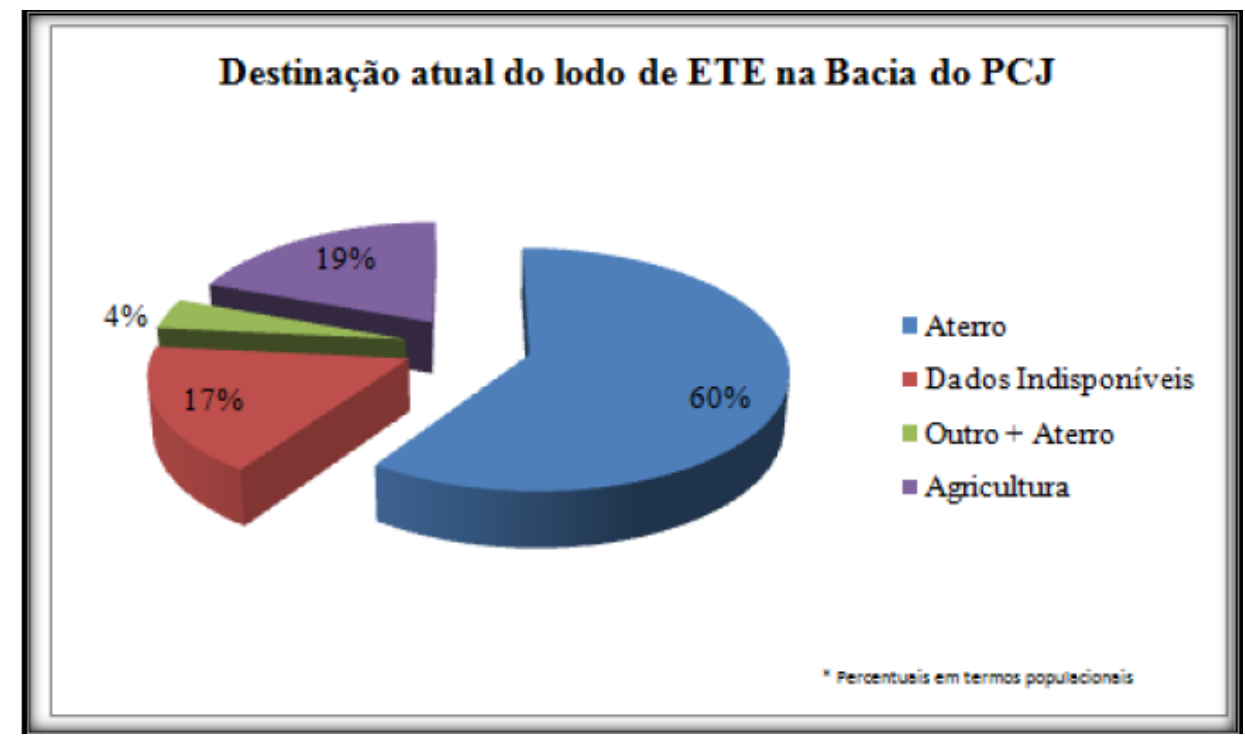

Figura 2.3 - Destinação atual do lodo de esgoto de ETE na bacia Piracicaba, Capivari e Jundiaí (Fonte: Biociclo (2012) apud Godoy (2013).

A quantidade e a qualidade do lodo produzido por um sistema de tratamento dependem da vazão e das características do esgoto tratado, do tipo de tratamento e da operação do sistema. A Tabela 2.1 apresenta os valores típicos da produção de lodo em várias modalidades de tratamento.

Tabela 2.1 - Valores típicos da produção de lodo em unidades de tratamento.

\begin{tabular}{c|c}
\hline Tipo de tratamento & $\begin{array}{c}\text { Quantidade de lodo produzido } \\
\left(\mathbf{m}^{\mathbf{3}} \mathbf{. h a b} \mathbf{a n o}^{\mathbf{- 1}} \mathbf{\text { and }}\right)\end{array}$ \\
\hline Lagoa anaeróbica - lagoa facultativa & 0,01 a 0,04 \\
\hline Lagoa aerada facultativa & 0,03 a 0,08 \\
\hline Lodos ativados convencionais & 1,1 a 1,5 \\
\hline Filtro biológico (baixa carga) & 0,4 a 0,6 \\
\hline Filtro biológico (alta carga) & 1,1 a 1,5 \\
\hline Reator anaeróbico de manta de lodo & 0,07 a 0,1 \\
\hline Fossa séptica - filtro anaeróbico & 0,07 a 0,1 \\
\hline
\end{tabular}

Fonte: Ferreira et al. (1999). 


\subsection{ALTERNATIVAS DE DISPOSIÇÃO DE LODO DE ESGOTO}

Existe uma preocupação crescente com relação à disposição do lodo de esgoto, em decorrência da ampliação dos sistemas de tratamento e das leis ambientais, que a cada dia tornam-se mais exigentes. Por apresentar em sua composição metais pesados, microrganismos patogênicos e outros compostos tóxicos, mesmo apos o processo de tratamento, o lodo quando disposto de maneira inadequada, pode trazer danos ao meio ambiente e a saúde humana (Kelm, 2014).

Segundo Jordão \& Pessoa (2011), entre as soluções possíveis para disposição final do lodo de esgoto pode-se relacionar: a disposição em aterros sanitários, incineração, usos agrícolas, reuso industrial e lançamento em oceano. O lançamento no mar já foi proibido em vários países, por causar um grande impacto ambiental, alterando a vida aquática e trazendo danos futuros a saúde humana através da ingestão de peixes contaminados. A Tabela 2.2 apresenta os diversos meios de destinação de lodo de esgoto.

A Tabela 2.2 - Formas de destinação de lodo de esgoto em diversos países.

\begin{tabular}{c|c|c|c|c}
\hline \multirow{2}{*}{ País } & \multicolumn{4}{|c}{ Método de disposição (como \% do total produzido) } \\
\cline { 2 - 5 } & Aterros & Agricultura & Incineração & Outros \\
\hline França $^{(1)}$ & 50 & 50 & 0 & 0 \\
\hline Alemanha $^{(1)}$ & 25 & 63 & 12 & 0 \\
\hline Itália(1) $^{1}$ & 34 & 55 & 11 & 0 \\
\hline Portugal(1) $^{(1)}$ & 80 & 13 & 0 & 7 \\
\hline Espanha $^{(1)}$ & 10 & 50 & 10 & 30 \\
\hline Japão(2) $^{2}$ & 6 & 14 & 80 & 0 \\
\hline EUA $^{(2)}$ & 30 & 20 & 30 & 20 \\
\hline Brasil( $^{(2)}$ & 80 & 5 & 0 & 15 \\
\hline
\end{tabular}

Fonte: Chang et al (2001); Geyer (2001) citados por Duarte (2008).

A principal limitação do uso do lodo de esgoto na agricultura tem sido em geral, a presença de metais pesados potencialmente tóxicos. A concentração de metais pesados no lodo depende da atividade, do desenvolvimento urbano e industrial da área que abastece a estação de tratamento. A adição de grandes quantidades de lodo de esgoto em aterros sanitários e na reciclagem agrícola pode levar à situação de solos altamente contaminados com metais pesados (Oliveira et al., 2007). 
A disposição em aterro sanitário é uma alternativa para o lodo cujas características físico-químicas sejam inadequadas aos usos praticados, podendo ser viabilizada em duas modalidades, segundo Luduvice \& Fernandes (2001):

- Aterros sanitários exclusivos - onde somente o lodo é disposto. Neste caso, o lodo deve possuir alto teor de sólidos (>30\%) ou ser seco termicamente;

- Co-disposição com resíduos sólidos urbanos - onde o lodo é disposto junto aos resíduos sólidos domiciliares, desde que o aterro seja construído com adaptações para o recebimento do mesmo.

No Brasil algumas pesquisas foram desenvolvidas no âmbito do aproveitamento do lodo para disposição final no solo, seja para produção agrícola ou na recuperação de áreas degradadas, como as realizadas por: Bezerra et al. (2006), Andreoli (2006) e Campos e Alves (2008).

Bezerra et al. (2006) estudaram e verificaram a viabilidade da aplicação do lodo, produzido pela Estação de Tratamento de Esgoto do Aeroporto Internacional do Rio de Janeiro, à revegetação de uma área degradada do próprio aeroporto;

Andreoli (2006), em trabalho com a Rede Prosab, apresenta diversas pesquisas sobre usos alternativos de lodo de estações de tratamento de água e estações de tratamento de esgoto; uso de lodo de esgoto na recuperação de áreas degradadas; uso de lodo de esgoto em plantações florestais; uso de lodo na produção vegetal; uso de lodo como matéria-prima na fabricação de cerâmica vermelha.

Campos \& Alves (2008) estudaram a influência do lodo de esgoto na recuperação de propriedades físicas de um latossolo vermelho degradado, cultivado com eucalipto e braquiária no município de Selvíria, MS;

\subsection{ASPECTOS LEGAIS DA CONTAMINAÇÃO DE SOLOS E ÁGUA}

Visto a toxicidade e natureza não biodegradável dos metais pesados, a disseminação dos mesmos nas águas superficiais e subterrâneas tem se tornado uma séria preocupação ambiental e de saúde pública. Inúmeras tecnologias têm sido desenvolvidas para a remoção de metais pesados de lixiviados e resíduos sólidos, responsáveis pela contaminação não somente da água, mas também do solo (Arab, 2011). 
O destino final do lodo é, portanto, uma atividade de grande importância e complexidade, pois frequentemente extrapola os limites das estações de tratamento e exige a integração com outros setores da sociedade. Segundo a legislação de diversos países, incluindo a brasileira, a responsabilidade pelos problemas que podem ser causados pelo destino inadequado é sempre dos produtores do resíduo, que podem ser enquadrados na própria lei de crimes ambientais (Lei n 9.605 de 12/02/98).

No Brasil, inúmeras normatizações ou portarias definem os aspectos legais concernente a solo e água, sendo elas:

- Resolução Conama no 357 de 17 de março de 2005, que dispõe sobre a classificação dos corpos de água e diretrizes ambientais para o seu enquadramento, bem como estabelece as condições e padrões de lançamento de efluentes, e dá outras providências;

- Resolução Conama n 375 de 29 de agosto de 2006, que define critérios e procedimentos, para o uso agrícola de lodos de esgoto gerados em estações de tratamento de esgoto sanitário e seus produtos derivados, e dá outras providências;

- Resolução Conama no 396 de 3 de abril de 2008 que dispõe sobre a classificação e diretrizes ambientais para o enquadramento das águas subterrâneas e dá outras providências;

- Resolução Conama n 420 de 28 de dezembro de 2009 que dispõe sobre critérios e valores orientadores de qualidade do solo quanto à presença de substâncias químicas e estabelece diretrizes para o gerenciamento ambiental de áreas contaminadas por essas substâncias em decorrência de atividades antrópicas;

- Portaria no 2914 do Ministério da Saúde de 12 de dezembro de 2011 que dispõe sobre os procedimentos de controle e de vigilância da qualidade da água para consumo humano e seu padrão de potabilidade.

\subsection{SOLO E INTERAÇÕES COM OS CONTAMINANTES}

Os processos de acumulação e transporte de contaminantes através do solo dependem da natureza do contaminante e do tipo do solo em questão. A composição e as propriedades dos resíduos são fatores significativos no desenvolvimento da interação com o substrato do solo. Se, contudo, for possível estimar as propriedades físicas e químicas mais importantes dos contaminantes e conhecer bem as características do solo, poderemos compreender melhor o seu transporte e, assim, dimensionar melhores barreiras naturais ou artificiais para áreas contaminadas ou para futuras áreas de disposição do resíduo (Demuelenaere, 2004). 
As trocas iônicas representam as principais interações entre o solo e as substâncias nele adicionadas e estão diretamente relacionadas com a fração argila e silte do solo. Os solos são em sua grande maioria eletronegativos, sendo capazes de adsorver as cargas opostas, os cátions, como o $\mathrm{Ca}^{+2}, \mathrm{Mg}^{+2}, \mathrm{H}^{+}$e os metais pesados como $\mathrm{Cd}^{+2}, \mathrm{Hg}^{+}, \mathrm{Pb}^{+2}$. Essa capacidade dos solos é chamada de capacidade de troca de cátions (CTC), que é a quantidade de cátions que um solo é capaz de reter por unidade de peso (Picarelli, 2003).

Atributos do solo, tais como $\mathrm{pH}$, teor de matéria orgânica, textura e composição das argilas, potencial redox, competição entre metais pelos sítios de adsorção, reações de complexação, temperatura e atividade microbiana são responsáveis pelo controle dos processos de degradação do conteúdo orgânico do resíduo e consequente solubilidade e mobilidade dos metais. Estudos de fracionamento de metais pesados realizados por Amaral Sobrinho et al. (1997) e Gomes et al. (1997) indicaram a importância dos óxidos de Fe e Al na retenção de metais, por meio de mecanismos de adsorção específica e/ou co-precipitação.

Os argilominerais juntamente com a matéria orgânica são os principais responsáveis pela troca de cátions no solo. A origem das cargas negativas na superfície das partículas minerais e orgânicas tem duas formas principais: substituição isomórfica na estrutura cristalina e por dissociação de íons $\mathrm{H}^{+}$. Assim um dos fatores que interferem diretamente na CTC é o pH, pois as cargas superficiais originadas da dissociação de íons $\mathrm{H}^{+}$formam-se quando há um aumento da concentração de íons $\mathrm{OH}^{-}$na solução, provocando a saída de íons de $\mathrm{H}^{+}$da superfície dos óxidos, argilominerais e matéria orgânica. Ou seja, a CTC aumenta com o aumento do $\mathrm{pH}$.

Quando se realiza a calagem, altera-se o $\mathrm{pH}$ do solo, alteram-se as reações nos sítios ativos do solo, tornando-o mais eletronegativo, há um consequente aumento na CTC, e tornase maior a capacidade do solo de reter cátions. Os solos tropicais têm em geral, o pH ácido e necessitam de calagem para aumentarem a sua CTC (Picarelli, 2003).

As argilas diferem quanto ao tamanho das áreas específicas de adsorção, nem toda fração argila tem a mesma origem nem a mesma CTC, a Tabela 2.3 apresenta essa diferenciação. 
Tabela 2.3 - Diferenças entre estruturas, área especifica e CTC para as diferentes partículas ou minerais.

\begin{tabular}{c|c|c|c|c}
\hline $\begin{array}{c}\text { Mineral ou } \\
\text { Partícula }\end{array}$ & Estrutura & $\begin{array}{c}\text { Área especifica } \\
\left(\mathrm{m}^{2} \mathrm{~g}^{-1}\right)\end{array}$ & $\begin{array}{c}\text { Capacidade de } \\
\text { Troca Catiônica } \\
(\mathrm{cmol} / \mathrm{kg})\end{array}$ & $\begin{array}{c}\text { Massa } \\
\text { específica } \\
\left(\mathrm{g} / \mathrm{cm}^{3}\right)\end{array}$ \\
\hline Caulinita & $1: 1$ & $10-20$ & $3-15$ & $2,61-2,66$ \\
\hline Haloisita & $1: 1$ & $21-43$ & $5-50$ & - \\
\hline Ilita & $2: 1$ & $70-120$ & $10-40$ & $2,60-286$ \\
\hline Hematita & $1: 1$ & - & - & $4,9-5,3$ \\
\hline Gibsita & $1: 1$ & - & - & $2,30-2,40$ \\
\hline Clorita & $2: 1$ & $79-150$ & $100-150$ & $2,60-2,90$ \\
\hline Vermiculita & $2: 1$ & $300-500$ & $60-150$ & 0,3 \\
\hline Esmectita & $2: 1$ & $700-800$ & $25-70$ & - \\
\hline Alofana & amorfa & $70-300$ & Muito pequena & - \\
\hline Silte & & $<0,1$ & Muito pequena & $2,66-2,70$ \\
\hline Areia fina & & $<0,1$ & Muito pequena & 2,65 \\
\hline Areia grossa & & $<0,01$ & & 2,65 \\
\hline
\end{tabular}

Grim (1953) citados por Laespiga (2008); Yong et al (1992) citados por Leite (2001); Russel (1973) \& Bohn et al (1979) citados por Resende et al (2002).

Nas relações entre o solo e as substâncias nele adicionadas, é importante considerar o teor e o tipo de matéria orgânica presente. A matéria orgânica desempenha um papel crucial na adsorção dos compostos apolares e pouco polares. O teor e o tipo de matéria orgânica presente nos solos devem ser considerados quando são feitas avaliações de sítios contaminados (Gaboriau \& Saada, 2001).

\subsubsection{METODOS DE EXTRAÇÃO DE METAIS DE SOLOS}

O impacto da contaminação e/ou poluição por metais pesados não deve ser avaliado somente pelo seu teor total em solos, mas pela sua biodisponibilidade, que é uma propriedade relacionada com sua mobilidade no solo e absorção pelas plantas (Costa et al., 2007). Uma das ferramentas para se avaliar o comportamento dos metais traços no solo é a utilização dos chamados métodos de extração sequencial. Conceitualmente, os metais (ou elementos) contidos em um material sólido podem ser fracionados em formas geoquímicas específicas, e podem ser seletivamente extraídos pelo uso de reagentes apropriados. Cada método apresenta um conjunto de reagentes que deve atacar especificamente a forma geoquímica para o qual foi escolhido (Conciani, 2011). 
A escolha do método mais eficiente passa primeiramente pela comparação dos teores de metais pesados obtidos por diferentes métodos de extração (Teodulo et al., 2003). A importância da escolha do método de extração reside na possibilidade de determinar não somente o teor do ponto de vista quantitativo, mas também a disponibilidade, a mobilidade e por fim a possibilidade de transferência do metal pesado do solo para a planta e por consequência a entrada desse na cadeia alimentar (Raurete, 1998).

Segundo Pelozato (2011) o conhecimento da concentração de base é fundamental para o estabelecimento do valor máximo permitido de um determinado metal pesado para os solos de uma região. A concentração de base está diretamente relacionada à interação do material de origem e o grau de intemperismo. Para a determinação da concentração de base ou valor de referência é necessária uma padronização do método de extração utilizado, pois cada método de análise possui particularidades, como diferentes soluções solubilizadoras, temperatura, granulometria do solo, relação solo:solução, entre outros, que resultam em diferentes capacidades de solubilizar a fração orgânica e mineral do solo e, por consequência, diferentes teores extraídos.

Segundo Diaz-Barrientos et al. (1991) citados por Saldanha et al. (1997) a maioria dos métodos de digestão não dissolve o conteúdo total dos metais nos solos e que as aberturas envolvendo HF (ácido fluorídrico) são mais efetivas na dissolução de silicatos, liberando para a solução os metais ligados ao retículo cristalino. Porém, os perigos decorrentes da manipulação de HF levam muitos analistas envolvidos em análises de rotina a testar outras técnicas que, apesar de menos efetivas, são mais fáceis e menos perigosas quando se está trabalhando com um grande número de amostras. Em relação a isso, assume-se que as frações não dissolvidas são irrelevantes em termos de biodisponibilidade.

A determinação do teor total de metais pesados (MP) em solos tem por objetivo a obtenção de dados sobre o acúmulo desses elementos ao longo do tempo. Para a determinação do teor de MP em solos é realizada a abertura das amostras com ácido fluorídrico (HF) juntamente com outros ácidos fortes. Cabe informar que, a água régia $\left(\mathrm{HNO}_{3}+\mathrm{HCl}\right)$ é o extrator recomendado para determinação de metais pesados em solos contaminados na Europa. 


\subsection{CONTAMINAÇÃO DO SOLO COM METAIS PESADOS}

O risco associado aos metais pesados do lodo está principalmente ligado ao fato do solo ser capaz de armazenar estes metais. Embora os metais pesados sejam cumulativos no solo, diversos fatores interferem na dinâmica da sua disponibilidade tais como o $\mathrm{pH}$, a capacidade de troca catiônica (CTC), a textura e o teor de matéria orgânica. Desta forma, dependendo das condições ambientais, os metais podem estar presentes no solo em formas não disponíveis para as plantas. Neste caso, a transferência de metais, para a cadeia alimentar, dependerá das características de cada solo e do tipo de planta, visto que as espécies vegetais têm capacidades variáveis de absorção de metais (Sanepar, 1999). A medição da presença dos metais no solo é normalmente feita com a indicação de massa por massa seca $(\mathrm{mg} / \mathrm{kg})$. A Tabela 2.4 apresenta determinações de metais pesados em lodos de diversas ETE’s no país, conforme apresentado por Jordão \& Pessoa (2009).

Tabela 2.4 - Metais pesados no lodo em diversas ETES (mg/kg) (Modificado de Jordão \& Pessoa).

\begin{tabular}{|c|c|c|c|c|c|c|c|c|c|c|c|}
\hline 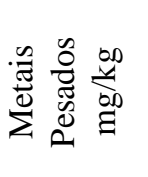 & 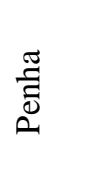 & 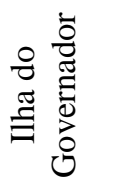 & 离 & 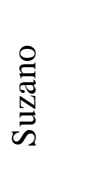 & 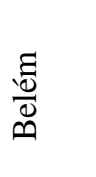 & 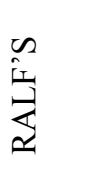 & 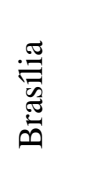 & 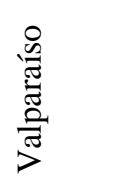 & Uृ & 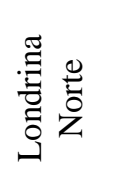 & 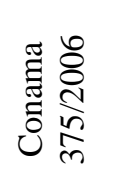 \\
\hline Cádmio & 3,0 & 2,0 & 18,0 & 5,9 & ND & ND & $<0,4$ & 2,0 & 6,0 & 54,0 & 39,0 \\
\hline Chumbo & 294,0 & 168,0 & 214 & 345,0 & 12,0 & 64,0 & 71,6 & 95,0 & 70,0 & 449,0 & 300,0 \\
\hline Cobre & 506,0 & 310,0 & 851 & 733,0 & 439,0 & 89,0 & 233,0 & 190,0 & 220,0 & 372,0 & 1500,0 \\
\hline Mercúrio & 7,1 & 6,9 & 2,1 & 23,7 & 1,0 & 0,5 & ND & 2,5 & ND & ND & 17,0 \\
\hline Níquel & 143,0 & 38,5 & 349 & 227,0 & 73,0 & 40,0 & $<0,6$ & 30,0 & 62,0 & 66,0 & 420,0 \\
\hline Zinco & 1204,0 & 1031,0 & 1870 & 1873,0 & 824,0 & 456,0 & 587,0 & 1512,0 & 701,0 & 1154,0 & 2800 \\
\hline
\end{tabular}

ND: dado não disponível

De acordo com a Sanepar (1999), os metais pesados presentes no lodo podem ter três origens:

a) Rejeitos domésticos: canalizações, fezes e águas residuárias de lavagem que contenham alguns metais.

b) Águas pluviais: as águas de escoamento de superfícies metálicas ou das ruas carregam resíduos de metais dispersos na fumaça de veículos.

c) Efluentes industriais: principal fonte de metais no esgoto, contribuindo com certos tipos específicos de cátions de acordo com a atividade da indústria. 
A identificação dos argilominerais é outro parâmetro importante no estudo das características do lodo. Através da difração de raio X (DRX) de um lodo de ETE do Rio de Janeiro, Fontes (2003) percebeu que devido aos picos de pequena intensidade, o material poder ser caracterizado como mal cristalizado, sendo que os principais compostos identificados foram: quartzo, caulinita, muscovita e goetita. Já Medeiros et al. (2006), obtiveram composição mineralógica para lodo de tanques sépticos da cidade de Natal, conforme pode ser observado na Figura 2.4 nota-se a predominância do quartzo, caulinita, constituintes das argilas.

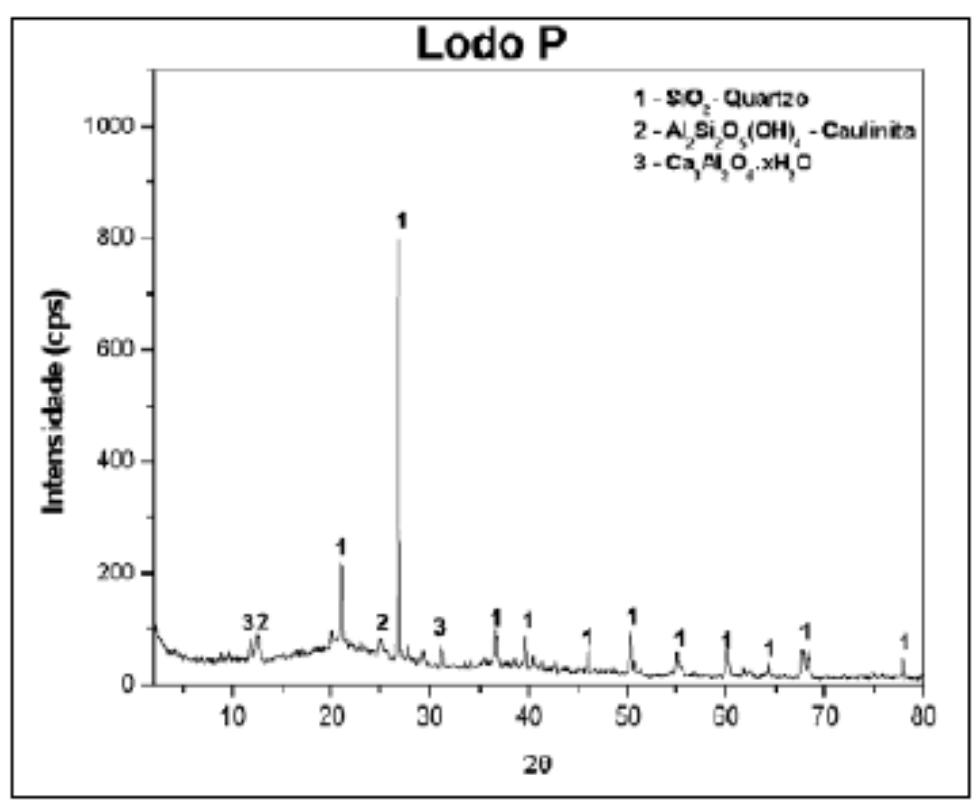

Figura 2.4 - Composição mineralógica do lodo por DRX. (Fonte: Medeiros et al. 2006).

A maioria dos metais pesados naturalmente no solo em baixas concentrações e em formas não prontamente disponíveis para as plantas e organismos vivos. A Tabela 2.5 apresenta os teores médios de alguns desses elementos nas diferentes rochas e solos. 
Tabela 2.5 - Concentração média de metais em rochas e solos $(\mathrm{mg} / \mathrm{Kg})$.

\begin{tabular}{c|c|c|c}
\hline Metal pesado & Rochas máficas & Rochas ácidas & Solos \\
\hline $\mathrm{As}$ & 1,5 & 1,5 & 1,10 \\
\hline $\mathrm{Cd}$ & - & - & $0,1-7$ \\
\hline $\mathrm{Cu}$ & 150 & 10 & $2-50$ \\
\hline $\mathrm{Pb}$ & - & - & 12 \\
\hline $\mathrm{Ni}$ & $200-1000$ & 10 & 40 \\
\hline
\end{tabular}

Fonte: Resende (2002).

\subsubsection{AVALIAÇÃO DA CONTAMINAÇÃO DE SOLOS}

Ao avaliar o efeito da solução de Cadmio (Cd) na composição do solo, por meio de ensaios com carga variável Kookana \& Naidu (1998), pode notar que esta composição está diretamente ligada a capacidade de adsorção do Cd ao solo. Nesse trabalho, a quantidade de Cd encontrada para os latossolos e solos arenosos era determinada pela baixa capacidade de troca catiônica, e ainda pelas superfícies de adsorção que os mesmo possuem.

Cornu et al. (2001) avaliaram o impacto ambiental da disposição de lodo de esgoto no solo no estado de São Paulo, com base nessa avaliação levantaram algumas hipóteses sobre a mobilidade de $\mathrm{Cu}, \mathrm{Ni}, \mathrm{Pb}$. Os resultados demonstraram que a concentração desses metais encontravam-se parcialmente nos horizontes A e B do perfil de solo, no entanto, tinham a capacidade de liberar os compostos para o horizonte C. Esse fenômeno estava condicionado à maior saturação deste horizonte. Estes autores também afirmam que a mobilidade dos metais pesados no solo depende principalmente de dois fatores: (1) de transferência da água através do solo, e (2) interação química dos metais com a fase sólida do solo (sorção/dessorção, precipitação/dissolução, complexação pela matéria orgânica). As reações que ocorrem durante a transferência de água no solo dependem basicamente das propriedades físico-químicas, mineralógicas e hidrológicas do perfil do solo.

Objetivando estudar a lixiviação de metais pesados $(\mathrm{Cu}, \mathrm{Ni}, \mathrm{Zn})$ na aplicação de lodo em florestas do Mediterrâneo, Toribio \& Romanya (2006) observaram que a concentração destes metais depende das características físicas do solo, bem como do tipo de lodo adicionado, sendo que solos com uma porcentagem predominante de argila mostraram-se com uma capacidade de retenção maior, enquanto que em solos ácidos essa capacidade de retenção foi diminuída. Este fato pode ser observado principalmente nos $30 \mathrm{~cm}$ iniciais do perfil de 
solo, quando comparado com um solo sem adição de lodo, mesmo ocorrendo este aumento nas camadas superficiais. Na maioria dos ensaios obteve-se resultados satisfatórios no que diz respeito à potabilidade de água, com a aplicação de uma única camada de lodo.

Ao tentar avaliar o impacto do lodo de esgoto e a distribuição de metais pesados em solos tropicais, Doelsch et al. (2006) observaram grandes variações na distribuição, sendo que a mobilidade potencial encontrada foi: $\mathrm{Zn}>\mathrm{Ni}>\mathrm{Cu} \approx \mathrm{Cr}$. Os resultados sugeriram que durante um período de aplicação de dois anos não houve impacto sobre a concentração total, no entanto elementos individuais possuíam a capacidade de ficar adsorvida e ser disponibilizado posteriormente como ocorreu com o $\mathrm{Zn}$ e o Ni.

Melo et al (2007) ao verificarem a quantidade do metal pesado Níquel (Ni) com a aplicação de lodo de esgoto em um latossolo vermelho distrófico por seis anos consecutivos, puderam observar uma relação direta da presença e da quantidade deste metal com a presença de substâncias húmicas.

Tentando avaliar a disponibilidade dos metais zinco $(\mathrm{Zn})$, cadmio $(\mathrm{Cd})$ e, chumbo $(\mathrm{Pb})$ após nove anos consecutivos da aplicação de lodo de esgoto Nogueira et al. (2010) observaram baixas concentrações de $\mathrm{Cd}$ e $\mathrm{Pb}$ e um aumento da fração de $\mathrm{Zn}$. Neste estudo, os autores conseguiram verificar que a quantidade de metal pesado estava diretamente ligada com a presença de ligações químicas mais estáveis, sendo assim, a matéria orgânica presente determinava a concentração maior dos metais. Após esse estudo mesmo com uma aplicação de nove anos consecutivos, notou-se uma baixa relação de disponibilidade de metais ao solo estudado (latossolo roxo distrófico).

Viotti et al. (2005), ao avaliar o transporte de contaminantes em solo não saturado, propuseram validar modelos de simulação de transporte por meio de ensaios de adsorção e biodegradação biológica.

Knop et al. (2008), ao verificar o efeito da adição de cimento em solo submetido a percolação de drenagens ácidas de minas, observaram que a condutividade hidráulica aumentou ligeiramente devido a adição de cimento e reduziu-se com o aumento do grau de acidez do percolado. Além disso, a adição de cimento foi responsável pelo aumento do coeficiente de retardo $(\mathrm{R})$ e de distribuição $\left(\mathrm{K}_{\mathrm{d}}\right)$, demonstrando que solos artificialmente cimentados tem maior capacidade de retardar a propagação de contaminação.

No Brasil inúmeras pesquisas que foram desenvolvidas com o objetivo de verificar os mecanismos de transporte de contaminantes, essas pesquisas podem ser observadas abaixo. 
Boff (1999) utilizou uma mistura compactada de materiais inconsolidados das formações Botucatu e Serra Geral para a realização de teste de colunas, a partir da percolação de soluções com diversas concentrações de $\mathrm{K}+, \mathrm{Cl}$ - e $\mathrm{Cu}++$. A escolha destes íons se deu por serem facilmente encontrados nos líquidos oriundos da percolação dos depósitos de resíduos sólidos e que podem causar efeitos tóxicos nos seres vivos. A finalidade do estudo foi avaliar o potencial do material para utilização como liner. Na modelagem dos resultados adotaram-se soluções analíticas e semi-analíticas, utilizando o programa computacional POLLUTE v6. A mistura de solo utilizada mostrou uma boa retenção para o $\mathrm{Cu}^{++}$seguida pelo $\mathrm{K}^{+}$. Para o cálculo analítico do valor de Dh foram empregados quatro pontos em cada curva de chegada, sendo os pontos $\mathrm{C} / \mathrm{Co}$ iguais a 0,$2 ; 0,4 ; 0,6$ e 0,8. O Rd foi calculado pela área acima da curva de chegada e através da resolução semi-analítica (POLLUTE), tendo sido admitido que os valores resultantes da área sejam mais aceitáveis.

Demuelenaere (2010) realizou estudo a cerca da análise geoquímica do transporte dos principais elementos constituintes do chorume em meios porosos, por meio de ensaios de coluna. Neste trabalho o autor utilizou três diferentes solos, denominados AM1, AM2, e AM3. Após os ensaios de coluna, pode-se observar que a química do solo foi alterada pelo chorume, principalmente o aumento do $\mathrm{pH}$, saturação das bases, notando-se um aumento de quase $100 \%$ da quantidade da capacidade de troca de cátions. Já as análises mineralógicas observou-se que não houve alteração. Em relação ao solo funcionar como barreira natural, o autor observou que os mesmos sozinhos não são suficientes para terem um funcionamento eficiente, o que necessitaria de materiais como mantas. $\mathrm{O}$ ensaio de coluna no seu trabalho conseguiu obter dados que permitisse verificar qual metal foi mais adsorvido pelos solos, o autor observou que os solos parecem reagir de maneira diferente para cada metal, uma sequiência foi estabelecida para cada amostra de solo, sendo elas: AM01, Níquel, Vanádio, Cromo, Ferro e Manganês; AM02, Níquel, Manganês, Ferro, Vanádio e Cromo; AM03, Manganês, Cromo, Ferro, Níquel e Vanádio.

Oliveira et al. (2007) realizaram um estudo em cinco solos de diferentes texturas do Estado de Minas Gerais,sendo um Neossolo Quartzarênico órtico - RQo; três Latossolos Vermelhos distróficos - LVd1, LVd2 e LVd3; e um Latossolo Vermelho-Amarelo distrófico LVAd, ligeiramente compactados, com o objetivo de determinar e comparar os fatores de retardamento $(\mathrm{Rd})$ e os coeficientes de dispersão-difusão $(\mathrm{Dh})$ do fosfato, potássio e amônio. O experimento foi realizado utilizando-se colunas de percolação, que receberam aplicações de uma das soluções resultantes das oito possíveis combinações de duas concentrações de 
fosfato, potássio e amônio $\left(15\right.$ e $60 \mathrm{mg} \mathrm{L}^{-1}$ de $\mathrm{P}, 75$ e $300 \mathrm{mg} \mathrm{L}^{-1}$ de $\mathrm{K}^{+}$e 15 e $60 \mathrm{mg} \mathrm{L}^{-1}$ de $\mathrm{N})$. Os resultados obtidos demonstram valores menores de $\mathrm{R}_{\mathrm{d}}$ para o potássio e o amônio, quando comparados com os do fosfato. A menor concentração de fosfato resultou em maiores valores do fator retardamento desse íon, para os cinco solos estudados. O fator retardamento $\left(R_{d}\right)$ para fosfato foi menor no solo mais arenoso $\left(R_{0}\right)$ e maior no mais oxídico $\left(\operatorname{LVd}_{2}\right)$, enquanto nos Latossolos os maiores valores do $\mathrm{Rd}$ para potássio e amônio estiveram relacionados com o incremento do teor da fração argila, sem tendência definida quanto á concentração do íon em estudo ou do íon acompanhante

Ferreira (2000) realizou estudos laboratoriais para avaliação do potencial de contaminação de água e de solo por gasolina oxigenada. $\mathrm{O}$ objetivo do trabalho foi analisar e quantificar o potencial de contaminação da água subterrânea e de solos arenosos residuais dos arenitos da Formação Botucatu por derramamento de gasolina oxigenada. As análises realizadas buscaram fornecer dados para a modelagem numérica em casos envolvendo derramamento de gasolina. Ensaios de equilíbrio em lote e de dissolução em colunas foram realizados objetivando a determinação da concentração aquosa de hidrocarbonetos da gasolina em equilíbrio de fases e a avaliação do tempo estimado para total dissolução em água dos hidrocarbonetos da gasolina pura. Ambos os ensaios analisaram também o efeito cosolvente do etanol na mistura. Verificou-se a validade da lei de Raoult e do modelo log-linear na determinação da concentração aquosa da gasolina pura e oxigenada. Em colunas de solos não saturados avaliou-se a difusão na fase vapor dos compostos orgânicos da gasolina em função do tempo. Finalizando as análises, fez-se uma simulação numérica do transporte da gasolina em zonas não saturadas fazendo-se uso do programa R-UNSAT.

Leite (2001) avaliou a migração de íons inorgânicos em alguns solos tropicais, com ênfase nos processos de sorção e difusão molecular. Este trabalho apresenta estudos sobre a migração dos íons $\mathrm{Cd}^{2+}, \mathrm{K}^{+}, \mathrm{Cl}^{-}$e $\mathrm{F}^{-}$em latossolos residuais das formações Botucatu e Serra Geral e três diferentes misturas destes solos, avaliando os processos de sorção e difusão molecular. O potencial de retenção dos íons foi avaliado com base na construção de 33 isotermas de sorção resultantes de ensaio de equilíbrio em lote. Seus parâmetros foram obtidos da adequação dos modelos linear, Freundlich e Langmuir. O potencial de transporte dos íons é avaliado através de ensaios de difusão em colunas estanques, onde curvas teóricas produzidas no programa POLLUTE foram ajustadas aos dados de concentração para a estimativa dos parâmetros de difusão. Os resultados dos estudos de retenção mostraram que o $\mathrm{Cl}^{-}$experimenta sorção sob certas condições, o $\mathrm{K}^{+}$e $\mathrm{F}^{-}$possuem taxas semelhantes de 
retenção, e que a sorção de $\mathrm{Cd}^{+2}$ mostrou-se altamente dependente da composição da solução contaminante, os ensaios de difusão resultaram em vários valores para o coeficiente de difusão efetiva (D*), mostrando que o fluxo difusivo dos íons diminui para solos mais argilosos.

Basso (2003) estudou solos do município de São Carlos, região nordeste do estado de São Paulo, provenientes das coberturas de material inconsolidado das formações Botucatu e Serra Geral. Para os ensaios utilizou uma mistura de solo seco de 60\% de Botucatu: $40 \%$ de Serra Geral. O trabalho teve como objetivo principal avaliar o transporte e retenção dos íons $\mathrm{K}^{+}, \mathrm{Cu}^{2+}$ e $\mathrm{Cl}^{-}$por percolação, a fim de desenvolver uma barreira composta de uma mistura de solos lateríticos. Foram ensaiados 6 corpos de prova compactados, sendo 3 com percolação de KCL e 3 com $\mathrm{CuCl}_{2}$. Os resultados de $\mathrm{R}_{\mathrm{d}}$ mostraram valores maiores para os cátions em relação aos ânions. A modelagem realizada para a determinação do coeficiente de dispersão hidrodinâmica $\left(D_{h}\right)$, gerou bons ajustes em relação aos pontos experimentais, principalmente para os íons $\mathrm{K}_{+}$.

Correa et al. (2004) estudaram as características dos solos tropicais aplicadas como barreiras naturais contra a contaminação de aquíferos. Com este trabalho conclui-se que:

- A fração argila dos solos tropicais é, na maioria das vezes, composta por argilominerais de baixa CTC, como a caulinita. O levantamento das características dos solos do DF mostrou que, segundo os dados da EMBRAPA, a CTC dos solos do Distrito Federal, que atenderam as condições de viabilidade em escala regional, é praticamente constante e gira em torno de 5 meq/100g de solo. Para os solos estudados, esse parâmetro foi de pouca utilidade, devido à sua uniformidade;

- A estruturação dos solos tropicais faz deles solos argilosos com comportamento diferenciado. Apesar dos altos teores de argila, os mesmos, em diversas situações, apresentam comportamento de solos arenosos. Um exemplo clássico é o de sua alta porosidade natural, que lhe confere a permeabilidade de solos arenosos.

- A recomendação de solos "ligeiramente alcalinos" também é dispensável nas regiões de solos tropicais, pois uma de suas características mais marcantes é justamente a acidez. A despeito dessa característica, tem-se observado boa capacidade de imobilização de metais por tais solos.

Gurjão (2005) avaliou estimativas de propriedades geoambientais de camadas impermeabilizantes de solos tropicais. A partir dos resultados notou-se que os solos estudados mesmo pertencendo a diferentes grupos da classificação MCT não mostraram, em 
princípio, diferenças significativas quanto ao parâmetro de sorção para um mesmo elemento, no caso dos elementos estudados, Cu e Zn. Já em relação ao coeficiente de difusão molecular não houve variação em função das concentrações da solução aplicada ao solo. O zinco apresentou maiores valores de difusão comparados ao cobre.

Arêas (2006) realizou estudos experimentais e analíticos do transporte de contaminantes em meio porosos. O ensaio de difusão pura realizado na areia apresentou bons resultados, e pôde-se verificar que a condição ideal foi atendida, já que o mesmo foi paralisado antes que se detectasse variação química na base do corpo de prova. A determinação dos parâmetros de sorção e difusão foi realizada pelo ensaio de difusão pura e o coeficiente de difusão efetivo determinado indiretamente pelo programa de computador POLLUTE. O valor do coeficiente de distribuição considerado as análises, tanto para o íon sódio como para o íon cloreto, foi nulo. Esses foram os valores que fizeram com que as curvas obtidas pelo POLLUTE melhor se ajustassem às curvas obtidas com os dados de laboratório, fornecendo, consequientemente os coeficientes de difusão $\left(\mathrm{D}_{\mathrm{e}}\right)$ para o íon sódio e o íon cloreto iguais a $2,2 \times 10^{-6} \mathrm{~cm}^{2} / \mathrm{s}$ e $3,0 \times 10^{-6} \mathrm{~cm}^{2} / \mathrm{s}$ respectivamente. O ensaio de coluna foi executado com gradiente hidráulico igual a 0,5 , já que a areia apresenta uma permeabilidade bastante elevada, o que poderia causar dificuldade no acompanhamento da variação da concentração de soluto no efluente com a evolução do ensaio. A concentração do efluente se igualou aproximadamente a $50 \%$ da concentração de entrada após ter percolado aproximadamente 1 volume de vazios, valor esperado, haja visto que o solo estudado é uma areia que em linhas gerais pode ser considerada não reativa.

Souza (2009) realizou estudos sobre a migração de poluentes orgânicos em liners compostos. Nesse trabalho utilizou-se amostras de solo compactadas, do interior do estado de São Paulo, provenientes da Formação Corumbataí, combinadas a um geocomposto bentonítico (GCL) de fabricação nacional. Foram realizados ensaios em coluna de percolação em dois corpos-de-prova, nas seguintes configurações: solo compactado acima do GCL e solo compactado abaixo do GCL. Esses ensaios permitiram a determinação da condutividade hidráulica e dos parâmetros de transporte dos materiais estudados. Após o início da percolação com solução 'K'CL' a condutividade hidráulica ('K') das duas configurações apresentou comportamento crescente. No entanto, este aumento no ' $K$ ' não afetou o desempenho hidráulico dos materiais. $\mathrm{O}$ fator de retardamento da configuração na qual o GCL encontra-se acima da camada de solo compactado se mostrou maior com relação à outra configuração analisada. No geral, considerou-se que esta configuração apresentou melhor 
desempenho como liner composto. Em geral a condutividade hidráulica não diferiu, e as configurações de liner compostos apresentaram maiores fatores de retardamento do que o liner do solo compactado isoladamente.

Wada (2011) estudou o comportamento de fluidos aquosos não miscíveis em água (óleo) no solo, onde executou ensaios de laboratório, construção de um modelo físico e comparação dos dados com simulação numérica. Dos ensaios realizados para a obtenção da curva de retenção do solo, foram observadas pequenas diferenças entre as curvas de 2, 5, 10 e $15 \%$ de óleo de isolamento de transformadores. A adição de óleo proporcionou o aumento da umidade residual, pois o material utilizado não sendo volátil à temperatura ambiente, não houve perdas significativas. No ensaio com o modelo físico com o solo seco e somente óleo, observou-se o formato da pluma de contaminação por óleo já estável. O fato de existir nível d'água em outros ensaios pode-se observar o que já era esperado, onde, pluma de contaminação permaneceu sobre o aqüífero, não atravessando o mesmo.

Arab (2011), ao avaliar o desempenho de liner compostos, frente a soluções de $\mathrm{CuCl}_{2} \cdot 2 \mathrm{H}_{2} \mathrm{O}$ utilizou solo argiloso compactado e geocomposto bentônitico como barreira, o estudo permitiu perceber que o liner composto não influenciou os valores do fator de retardamento, ao contrario da concentração das soluções, notando-se que estes resultados são inversamente proporcionais às concentrações utilizadas.

Conciani (2011), ao estudar barreiras de solos para retenção de contaminantes, observou que o transporte foi predominantemente regido pelos mecanismos físicos advectivos ou difusivos. Ao trabalhar com o $\mathrm{Ni}$ e o $\mathrm{Cr}$ na forma sintética, concluiu-se que o níquel (Ni) tem uma maior mobilidade quando se compara ao cromo $(\mathrm{Cr})$, que apresentou elevados valores de coeficiente de retardo em diferentes condições de concentração.

\subsection{METAIS PESADOS}

Segundo Sperling (2005) apesar de amplamente utilizado, o termo "metal pesado", não possui definição única, variando de acordo com o ramo da ciência que o aborda. Do ponto de vista ambiental, o metal pesado pode ser entendido como aquele metal que, em determinadas concentrações e tempo de exposição, oferece risco à saúde humana e ao ambiente, prejudicando a atividade dos organismos vivos, inclusive daqueles responsáveis pelo tratamento biológico dos esgoto. Os principais elementos químicos enquadrados neste conceito são: Ag (prata), As (arsênio), Cd (cádmio), Co (cobalto), Cr (cromo), Cu (cobre), Hg (mercúrio), Ni (níquel), Sb (antimônio), Se (selênio) e Zn (zinco). Estes elementos são 
encontrados naturalmente no solo em concentrações variáveis, porém são inferiores àquelas consideradas tóxicas para diferentes organismos vivos. As principais implicações dos metais são: toxicidade aos seres humanos e a outras formas de vida animal e vegetal.

\subsubsection{COBRE}

O cobre pode estar presente em materiais eletrônicos, latas ou em tampas de garrafa. Ele é um micronutriente indispensável às plantas e aos seres humanos quando em baixas concentrações, mas adquire propriedades tóxicas quando em concentrações elevadas. Pode ocorrer tanto com valência +1 ou +2 . $O$ cobre forma complexos com a matéria orgânica, podendo, com isso, tornar-se mais móvel. A formação de hidróxidos de Fe e Mn pode ainda também, provocar a mobilização do $\mathrm{Cu}$. A ingestão de doses excessivamente altas de $\mathrm{Cu}$ pode provocar irritação e corrosão da mucosa, danos capilares, problemas hepáticos e renais e irritação no sistema nervoso central, seguido de depressão. A intoxicação por cobre é muito rara, apesar de o metal ser bioacumulativo, podendo acarretar problemas em invertebrados e em algumas espécies de peixes. Altas concentrações de cobre podem ser encontradas nas águas de drenagem de mineração (Carvalho, 2005). A Tabela 2.6 apresenta os valores de padrões para diferentes normas.

Tabela 2.6 - Valores orientadores para o cobre.

\begin{tabular}{|c|c|c|c|}
\hline Meio & Concentração & Comentário & Referência \\
\hline Efluente $^{1}$ & $1,0 \mathrm{mg} / \mathrm{l}$ & $\begin{array}{l}\text { VM (Padrão de } \\
\text { lançamento) }\end{array}$ & $\begin{array}{c}\text { CONAMA } \\
430 / 2011\end{array}$ \\
\hline Solo & $\begin{array}{c}60 \mathrm{mg} / \mathrm{kg}^{*} \\
200 \mathrm{mg} / \mathrm{kg}^{*} \\
400 \mathrm{mg} / \mathrm{kg}^{*} \\
600 \mathrm{mg} / \mathrm{kg}^{*}\end{array}$ & $\begin{array}{c}\text { VP } \\
\text { VI Agricola } \\
\text { VI residencial } \\
\text { VI industrial } \\
\end{array}$ & $\begin{array}{l}\text { CONAMA } \\
420 / 2009\end{array}$ \\
\hline Água potável & $2 \mathrm{mg} / \mathrm{l}$ & potabilidade & Portaria 2914/2011 \\
\hline Água subterrânea & $\begin{array}{c}2000 \mu \mathrm{g} / 1 \\
500 \mu \mathrm{g} / 1 \\
200 \mu \mathrm{g} / 1 \\
1000 \mu \mathrm{g} / 1\end{array}$ & $\begin{array}{l}\text { VMP consumo } \\
\text { VMP dessedentação } \\
\text { VMP irrigação } \\
\text { VMP recreação }\end{array}$ & $\begin{array}{c}\text { CONAMA } \\
396 / 2008\end{array}$ \\
\hline Águas doces & $\begin{array}{l}0,009 \mathrm{mg} / \mathrm{l} \\
0,013 \mathrm{mg} / \mathrm{l}\end{array}$ & $\begin{array}{c}\text { VM classe } 1 \text { e } 2 \\
\text { VM classe } 3\end{array}$ & $\begin{array}{l}\text { CONAMA } \\
357 / 2005\end{array}$ \\
\hline Águas salinas & $\begin{array}{c}0,005 \mathrm{mg} / \mathrm{l} \\
7,8 \mu \mathrm{g} / \mathrm{l}\end{array}$ & $\begin{array}{l}\text { VM classe } 1 \\
\text { VM classe } 2 \\
\end{array}$ & $\begin{array}{c}\text { CONAMA } \\
357 / 2005\end{array}$ \\
\hline Águas salobras & $\begin{array}{c}0,005 \mathrm{mg} / \mathrm{l} \\
7,8 \mu \mathrm{g} / \mathrm{l}\end{array}$ & $\begin{array}{l}\text { VM classe } 1 \\
\text { VM classe } 2\end{array}$ & $\begin{array}{l}\text { CONAMA } \\
357 / 2005\end{array}$ \\
\hline
\end{tabular}

Obs: ${ }^{1}=$ cobre dissolvido; $*$ = peso seco; VI= valor máximo de investigação; $\mathrm{VMP}=$ valor máximo permitido; $\mathrm{VM}=$ valor máximo; $\mathrm{VP}=$ valor permitido 


\subsubsection{MANGANÊS}

O manganês (Mn) é um metal cinza claro que não ocorre na forma pura (elementar), mas combinado com outras substâncias, como o oxigênio, enxofre e cloro. Processos naturais e a atividade humana são capazes de modificar compostos de manganês. O Mn inorgânico (retirado de rochas) é usado na fabricação de ligas metálicas, especialmente aços, em pilhas, palitos de fósforo, vidros, fogos de artifício, na indústria química, de couro e têxtil, e como fertilizante. As formas orgânicas são usadas em fungicidas e inibidores de fumaça, entre outros usos. O metal é utilizado também em pequenas quantidades no medicamento mangafodipir trissódio (MnDPDP) como contraste na imagem por ressonância magnética (IRM). Pouco se sabe sobre a toxicidade dos compostos de manganês. No entanto, as evidências indicam que vários desses compostos podem induzir efeitos neurológicos, observados na exposição crônica humana via inalatória e na exposição crônica e intermediária de animais expostos por via oral. Não há relato de casos de deficiência em manganês na população geral. Em animais, a deficiência é associada com prejuízo do crescimento, anormalidades no esqueleto, diminuição na função reprodutora de fêmeas e degeneração testicular em machos (Cetesb, 2012). A Tabela 2.7 apresenta os valores norteadores para o manganês.

Tabela 2.7 - Valores norteadores para o manganês.

\begin{tabular}{|c|c|c|c|}
\hline Meio & Concentração & Comentário & Referência \\
\hline Águas doces ${ }^{1}$ & $\begin{array}{l}0,1 \mathrm{mg} / \mathrm{L} \\
0,5 \mathrm{mg} / \mathrm{L}\end{array}$ & $\begin{array}{c}\text { VM (classes } 1 \text { e } 2) \\
\text { VM (classe } 3)\end{array}$ & $\begin{array}{l}\text { CONAMA } \\
357 / 2005\end{array}$ \\
\hline Águas salinas ${ }^{1}$ & $0,1 \mathrm{mg} / \mathrm{L}$ & VM (classes 1 e 2 ) & $\begin{array}{c}\text { CONAMA } \\
357 / 2005\end{array}$ \\
\hline Águas salobras ${ }^{1}$ & $0,1 \mathrm{mg} / \mathrm{L}$ & VM (classes 1 e 2$)$ & $\begin{array}{l}\text { CONAMA } \\
357 / 2005\end{array}$ \\
\hline Água potável & $0,1 \mathrm{mg} / \mathrm{L}$ & $\begin{array}{l}\text { VMP (efeito } \\
\text { organoléptico) }\end{array}$ & Portaria $2914 / 2001$ \\
\hline Água subterrânea & $\begin{array}{c}100 \mu \mathrm{g} / \mathrm{L} \\
50 \mu \mathrm{g} / \mathrm{L} \\
200 \mu \mathrm{g} / \mathrm{L} \\
100 \mu \mathrm{g} / \mathrm{L}\end{array}$ & $\begin{array}{c}\text { VM - consumo } \\
\text { VM - } \\
\text { dessedentação } \\
\text { VM - irrigação } \\
\text { VM - recreação }\end{array}$ & $\begin{array}{c}\text { CONAMA } \\
396 / 2008\end{array}$ \\
\hline $\begin{array}{l}\text { Lançamento de } \\
\text { efluentes }\end{array}$ & $1,0 \mathrm{mg} / \mathrm{L}$ & VM & $\begin{array}{c}\text { CONAMA } \\
430 / 2011\end{array}$ \\
\hline
\end{tabular}

Obs: VMP = valor máximo permitido; VM= valor máximo; ${ }^{1}=$ manganês total; ${ }^{2}=$ manganês dissolvido 


\subsubsection{ZINCO}

Com massa especifica de $7,14 \mathrm{~g} \mathrm{~cm}^{-3}$, o zinco tem sido empregado na galvanização de produtos de ferro; utilizado em baterias, fertilizantes, lâmpadas, televisores e aros de rodas. Componentes de $\mathrm{Zn}$ têm sido usados em pinturas, plásticos, borrachas, em alguns cosméticos e produtos farmacêuticos. O zinco forma precipitados solúveis com os íons $\mathrm{CO}_{3}{ }^{-2}, \mathrm{SO}_{3}{ }^{-2} \mathrm{e}$ $\mathrm{PO}_{4}^{-3}$. Elemento essencial para a vida, com média diária necessária de 10 a $20 \mathrm{mg}$, tem função na síntese e metabolismo de proteínas e ácidos nucléicos e na divisão mitótica das células. Este metal tende a ser menos tóxico que os outros metais pesados, porém, os sintomas de toxicidade por Zn são vômitos, desidratação, dores no estômago, náuseas, desmaios e falta de coordenação dos músculos. O Zn apresenta relação fortemente positiva sobre o $\mathrm{Cd}$, sendo a hipertensão induzida pelo Cd pode ser reduzida na presença de Zn (Oliveira, 2004) e (Carvalho, 2005). A Tabela 2.8 apresenta os valores norteadores para o zinco.

Tabela 2.8 - Valores norteadores para o zinco.

\begin{tabular}{|c|c|c|c|}
\hline Meio & Concentração & Comentário & Referência \\
\hline Solo & $\begin{array}{c}300 \mathrm{mg} / \mathrm{kg}^{*} \\
450 \mathrm{mg} / \mathrm{kg}^{*} \\
1000 \mathrm{mg} / \mathrm{kg}^{*} \\
2000 \mathrm{mg} / \mathrm{kg}^{*}\end{array}$ & $\begin{array}{c}\text { VP } \\
\text { VI agrícola } \\
\text { VI residencial } \\
\text { Vi industrial }\end{array}$ & $\begin{array}{l}\text { CONAMA } \\
420 / 2009\end{array}$ \\
\hline Água potável & $5 \mathrm{mg} / \mathrm{l}$ & organoléptico & Portaria $2914 / 2011$ \\
\hline Água subterrânea & $\begin{array}{c}5000 \mu \mathrm{g} / \mathrm{l} \\
24000 \mu \mathrm{g} / \mathrm{l} \\
2000 \mu \mathrm{g} / 1 \\
5000 \mu \mathrm{g} / 1\end{array}$ & $\begin{array}{l}\text { VMP consumo } \\
\text { VMP dessedentação } \\
\text { VMP irrigação } \\
\text { VMP recreação }\end{array}$ & $\begin{array}{l}\text { CONAMA } \\
396 / 2008\end{array}$ \\
\hline Águas doces ${ }^{1}$ & $\begin{array}{c}0,18 \mathrm{mg} / \mathrm{l} \\
5 \mathrm{mg} / \mathrm{l}\end{array}$ & $\begin{array}{c}\text { VM classe } 1 \text { e } 2 \\
\text { VM classe } 3\end{array}$ & $\begin{array}{l}\text { CONAMA } \\
357 / 2005\end{array}$ \\
\hline Águas salinas ${ }^{I}$ & $\begin{array}{l}0,09 \mathrm{mg} / \mathrm{l} \\
0,12 \mathrm{mg} / \mathrm{l}\end{array}$ & $\begin{array}{l}\text { VM classe } 1 \\
\text { VM classe } 2\end{array}$ & $\begin{array}{l}\text { CONAMA } \\
357 / 2005\end{array}$ \\
\hline Água salobras ${ }^{\perp}$ & $\begin{array}{l}0,09 \mathrm{mg} / 1 \\
0,12 \mathrm{mg} / 1\end{array}$ & $\begin{array}{l}\text { VM classe } 1 \\
\text { VM classe } 2\end{array}$ & $\begin{array}{l}\text { CONAMA } \\
357 / 2009\end{array}$ \\
\hline Efluentes $^{1}$ & $5 \mathrm{mg} / \mathrm{l}$ & Padrão lançamento & $\begin{array}{c}\text { CONAMA } \\
430 / 2011\end{array}$ \\
\hline
\end{tabular}

Obs: ' zinco total; ${ }^{2}$ organoléptico; * = pesco seco; VI=valor de investigação; VMP=valor máximo permitido; VM= valor máximo. 


\subsubsection{CÁDMIO}

O cádmio é um elemento relativamente raro e não é encontrado na natureza em seu estado puro. Ele está associado, principalmente, a sulfetos em minérios de $\mathrm{Zn}, \mathrm{Pb}$ e $\mathrm{Cu}$ (Oliveira, 2003). Com massa especifica de $8,6 \mathrm{~g} \mathrm{~cm}^{-3}$, o cádmio é utilizado em indústrias de galvanoplastia, na fabricação de baterias, em tubos de televisão, lâmpadas fluorescentes, estando presente também como pigmento e estabilizador de plásticos polivinílicos (Carvalho, 2005).

Segundo Gutierrez (2006) o Cd apresenta várias propriedades físicas e químicas semelhantes ao zinco, o que explica a ocorrência dos dois juntos na natureza. Em minerais e minérios, o Cd e o Zn são encontrados geralmente em uma relação 1:100 a 1:1000, sendo a ocorrência principalmente sob a forma de sulfetos. Na natureza, o Cd apresenta estado de oxidação 2+. A Tabela 2.9 apresenta os valores norteadores para o cádmio.

Tabela 2.9 - Valores orientadores para o cádmio.

\begin{tabular}{|c|c|c|c|}
\hline Meio & Concentração & Comentário & Referência \\
\hline Solo & $\begin{array}{c}1,3 \mathrm{mg} / \mathrm{kg}^{*} \\
3 \mathrm{mg} / \mathrm{kg}^{*} \\
8 \mathrm{mg} / \mathrm{kg}^{*} \\
20 \mathrm{mg} / \mathrm{kg}^{*}\end{array}$ & $\begin{array}{c}\text { VP } \\
\text { VI agrícola } \\
\text { VI residencial } \\
\text { VI industrial }\end{array}$ & CONAMA 420/2009 \\
\hline Água potável & $0,005 \mathrm{mg} / \mathrm{L}$ & potabilidade & $\begin{array}{c}\text { PORTARIA } \\
2914 / 2011 \\
\end{array}$ \\
\hline Água subterrânea & $\begin{array}{c}5 \mu \mathrm{g} / \mathrm{L} \\
50 \mu \mathrm{g} / \mathrm{L} \\
10 \mu \mathrm{g} / \mathrm{L} \\
5 \mu \mathrm{g} / \mathrm{L} \\
\end{array}$ & $\begin{array}{c}\text { VMP consumo } \\
\text { VMP dessedentação } \\
\text { VMP (irrigação) } \\
\text { VMP (recreação) }\end{array}$ & CONAMA 396/2008 \\
\hline Águas doces & $\begin{array}{c}0,001 \mathrm{mg} / \mathrm{L} \\
0,01 \mathrm{mg} / \mathrm{L}\end{array}$ & $\begin{array}{l}\text { VM (classes } 1 \text { e } 2) \\
\text { VM (classe } 3\end{array}$ & CONAMA/357/2005 \\
\hline Águas salinas & $\begin{array}{c}0,005 \mathrm{mg} / \mathrm{L} \\
0,04 \mathrm{mg} / \mathrm{L}\end{array}$ & $\begin{array}{l}\text { VM (classe } 1) \\
\text { VM (classe } 2)\end{array}$ & CONAMA 357/2005 \\
\hline Águas salobras & $\begin{array}{c}0,005 \mathrm{mg} / \mathrm{L} \\
0,04 \mathrm{mg} / \mathrm{L}\end{array}$ & $\begin{array}{l}\text { VM (classe 1) } \\
\text { VM (classe 2) }\end{array}$ & CONAMA 357/2005 \\
\hline
\end{tabular}

Obs: $*$ = peso seco $;$ VI $=$ Valor de Investigação; VMP = Valor Máximo Permitido; VM = Valor Máximo;

\subsubsection{CROMO}

O cromo é um metal acinzentado muito resistente à corrosão. Possui diferentes estados de oxidação e os mais comuns são cromio (II), (III) e (VI), também denominados bi, tri e hexavalente, respectivamente. As formas tri e hexavalente são mais estáveis e aparecem na 
composição de óxidos, sulfatos, cromatos, dicromatos e sais básicos. A forma metálica não é encontrada livre na natureza, mas obtida após o processamento industrial do minério de crômio. O crômio é usado principalmente na fabricação de ligas metálicas e estruturas da construção civil, pois confere resistência à oxidação, ao desgaste e ao atrito. Os compostos de crômio possuem diversos usos industriais, como tratamento de couro (curtume), fabricação de tintas e pigmentos, preservante de madeira e galvanoplastia (Cetesb, 2012). Por ser corrosivo, pode causar ulcerações crônicas na pele e perfurações no septo nasal. A ingestão acidental de altas doses de compostos de crômio hexavalente pode causar falência renal aguda caracterizada por perda de proteínas e sangue na urina. A Tabela 2.10 apresenta os valores norteadores para o cromo, segundo as diversas normas para o referido metal.

Tabela 2.10 - Valores de referência para o cromo.

\begin{tabular}{l|c|c|c}
\hline \multicolumn{1}{c|}{ Meio } & Concentração & Comentário & Referência \\
\hline Efluente & $1,0 \mathrm{mg} / \mathrm{l}$ & VM - Padrão de & CONAMA \\
Cromo trivalente & $0,1 \mathrm{mg} / \mathrm{l}$ & lançamento & $430 / 2011$ \\
Cromo hexavalente & $75 \mathrm{mg} / \mathrm{kg} *$ & Valor de Prevenção & \\
\hline \multicolumn{1}{c|}{ Solo } & $150 \mathrm{mg} / \mathrm{kg}^{*}$ & VI agrícola-APMax & CONAMA 420/2009 \\
& $300 \mathrm{mg} / \mathrm{kg}^{*}$ & VI cenário residencial & \\
& $400 \mathrm{mg} / \mathrm{kg} *$ & VI cenário industrial & \\
\hline Água potável & $0,05 \mathrm{mg} / \mathrm{l}$ & potabilidade & Portaria 2914/2011 \\
\hline Água subterrânea ${ }^{1}$ & $50 \mu \mathrm{g} / \mathrm{l}$ & VMP consumo & \\
& $1000 \mu \mathrm{g} / \mathrm{l}$ & VMP (dessedentação) & CONAMA 396/2008 \\
& $100 \mu \mathrm{g} / \mathrm{l}$ & VMP (irrigação) & \\
\hline Águas doces & $50 \mu \mathrm{g} / \mathrm{l}$ & VMP (recreação) & \\
\hline Água salinas & $0,05 \mathrm{mg} / \mathrm{l}$ & VM (classes 1 e 2) & CONAMA 357/2005 \\
& $0,05 \mathrm{mg} / \mathrm{l}$ & VM (classe 3) & \\
\hline Águas salobras & $0,05 \mathrm{mg} / \mathrm{l}$ & VM (classe 1) & CONAMA 357/2005 \\
& $1,1 \mathrm{mg} / 1$ & VM (classe 2) & \\
\hline & $0,05 \mathrm{mg} / \mathrm{l}$ & VM (classe 1) & CONAMA 357/2005 \\
\hline & $1,1 \mathrm{mg} / \mathrm{l}$ & VM (classe 2) & \\
\hline
\end{tabular}

Obs: ${ }^{1}$ crômio (III) + (VI); * = peso seco ; APMAx = Área de Proteção Máxima; VI = Valor de Investigação; VMP = Valor Máximo Permitido; VM = Valor Máximo

\subsubsection{NÍQUEL}

O níquel é um metal prateado, razoavelmente duro, dúctil e maleável. Apresenta um fraco brilho amarelado devido, em parte, à existência de uma camada protetora de óxido. Forma compostos inorgânicos solúveis, como os hidróxidos, sulfatos, cloretos e nitratos, e insolúveis, como os óxidos e sulfetos. Também pode formar carbonila de níquel, um composto orgânico volátil e incolor. A exposição da população geral ao níquel pode ocorrer 
por inalação de ar, ingestão de água e alimentos ou contato com a pele. As atividades mais comuns que acarretam exposição ocupacional ao níquel são a mineração, a moagem e a fundição dos minérios, a partir de sulfetos e óxidos, e a utilização de produtos primários de níquel, tanto na produção de aço inoxidável e de ligas quanto em fundições. Trabalhadores que consumiram acidentalmente água contendo $250 \mathrm{ppm}$ de níquel apresentaram dor de estômago e alterações sanguíneas (aumento de glóbulos vermelhos) e renais (perda de proteínas na urina). Essa concentração é 100.000 vezes maior do que a encontrada normalmente na água potável. Efeitos graves, como bronquite crônica, diminuição da função pulmonar e câncer nos pulmões e seios nasais, foram observados em trabalhadores de refinarias e indústrias de processamento de níquel (Cetesb, 2012). A Tabela 2.11 apresenta os valores de padrões de referência para o níquel de acordo com as diferentes normatizações.

Tabela 2.11 - Valores de referência para o níquel.

\begin{tabular}{|c|c|c|c|}
\hline Meio & Concentração & Comentário & Referência \\
\hline Efluente $^{1}$ & $2,0 \mathrm{mg} / \mathrm{l}$ & VM lançamento & CONAMA 420/2011 \\
\hline Solo & $\begin{array}{c}30 \mathrm{mg} / \mathrm{kg}^{*} \\
70 \mathrm{mg} / \mathrm{kg}^{*} \\
100 \mathrm{mg} / \mathrm{kg}^{*} \\
130 \mathrm{mg} / \mathrm{kg}^{*}\end{array}$ & $\begin{array}{l}\text { Valor de Prevenção } \\
\text { VI agrícola } \\
\text { VI cenário residencial } \\
\text { VI cenário indústria }\end{array}$ & CONAMA 420/2009 \\
\hline Água potável & $0,07 \mathrm{mg} / \mathrm{l}$ & potabilidade & Portaria 2914/2011 \\
\hline Água subterrânea & $\begin{array}{c}20 \mu \mathrm{g} / \mathrm{L} \\
1000 \mu \mathrm{g} / \mathrm{L} \\
200 \mu \mathrm{g} / \mathrm{L} \\
100 \mu \mathrm{g} / \mathrm{L}\end{array}$ & $\begin{array}{l}\text { VMP consumo } \\
\text { VMP dessedentação } \\
\text { VMP irrigação } \\
\text { VMP recreação }\end{array}$ & CONAMA 396/2008 \\
\hline Águas doces & $0,025 \mathrm{mg} / \mathrm{l}$ & VM (classe 1 e 2 ) & CONAMA 357/2005 \\
\hline Águas salinas & $\begin{array}{c}0,025 \mathrm{mg} / \mathrm{l} \\
74 \mu \mathrm{g} / \mathrm{l}\end{array}$ & $\begin{array}{l}\text { VM (classe 1) } \\
\text { VM (classe 2) }\end{array}$ & CONAMA 357/2005 \\
\hline Águas salobras & $\begin{array}{c}0,025 \mathrm{mg} / \mathrm{l} \\
74 \mu \mathrm{g} / \mathrm{l}\end{array}$ & $\begin{array}{l}\text { VM (classe } 1) \\
\text { VM (classe } 2)\end{array}$ & CONAMA 357/2005 \\
\hline
\end{tabular}

\subsection{NITROGÊNIO}

Segundo Sperling (2005) dentro do ciclo do nitrogênio na biosfera, este se alterna entre várias formas e estados de oxidação. No meio aquático, o nitrogênio pode ser encontrado nas seguintes formas: (a) nitrogênio molecular $\mathrm{N}_{2}$; (b) nitrogênio orgânico (dissolvido e em suspensão); (c) amônia (livre $\mathrm{NH}_{3}$ e ionizada $\mathrm{NH}_{4}{ }^{+}$; (d) nitrito $\left(\mathrm{NO}_{2}{ }^{-}\right.$); (e) nitrato $\left(\mathrm{NO}_{3}{ }^{-}\right)$. A importância desses elementos nas diferentes formas são elencadas: 
- o nitrogênio na forma de nitrato está associado a doenças como metahemoglobinemia (síndrome do bebê azul);

- é um elemento indispensável para o crescimento de algas e, quando em elevadas concentrações em lagos e represas pode conduzir a eutrofização;

- o nitrogênio nos processos bioquímicos de conversão da amônia a nitrito e deste a nitrato pode consumir oxigênio dissolvido e comprometer a vida aquática;

- o nitrogênio na forma de amônia livre é diretamente tóxico aos peixes;

- em corpos d'água a determinação predominante na forma de nitrato pode fornecer informações do estagio da poluição.

\subsection{CURVA CARACTERISTICA DE SOLOS CONTAMINADOS}

A curva característica, também chamada de curva de retenção ou sucção, apesar de ser mais comumente estudada em relação à água no solo, pode ser determinada para qualquer fluido existente nos poros. Apesar dos poucos estudos que consideram diferentes fluidos presentes no solo, a crescente preocupação com as contaminações do meio ambiente tem originando pesquisas na área (Vivian, 2008).

Cui et al. (2003), ao avaliar solos contaminados por óleo derivado do petróleo, estudaram a curva de retenção de NAPL (líquidos não miscíveis em água)/solo. Esta relação descrita em termos de sucção versus grau de saturação do óleo revela uma informação quantitativa sobre a energia necessária para extrair o contaminante dos vazios do solo, sendo de fundamental importância em estudos geoambientais referentes a técnicas de remediação de solos de áreas contaminadas. A partir dos resultados puderam visualizar que em um teor de umidade similar, as curvas de retenção são fortemente dependentes da densidade, ou seja, do volume previamente ocupado pelo ar e disponível para a infiltração do óleo.

Moncada (2004), ao avaliar o efeito contaminante do licor caústico (efluente industrial resultante da produção de alumínio), percebeu que as curvas características de sucção mostraram um crescimento do valor da sucção após a passagem do licor. Isso era esperado, dado que aumenta o conteúdo de água intersticial. $\mathrm{O}$ aumento da água intersticial proporcionou o aumento da condutividade, fato este observado com a passagem do licor pela amostra de solo. Para os materiais sem contaminação a autora obteve curva de sucção total e sucção mátrica coincidentes, entretanto, para os solos contaminados por licor cáustico, houve um aumento de sucção total, o que caracteriza um aumento no teor de sais na água intersticial, 
para as concentrações $(29 \mathrm{~g} / \mathrm{l}),(70 \mathrm{~g} / \mathrm{l})$ e $(10 \mathrm{~g} / \mathrm{l})$. Nesse trabalho pode-se observar a ocorrência de uma pequena alteração do índice de vazios do solo após a contaminação e, como consequência, houve pouca variação da curva de sucção mátrica, visível somente em níveis de sucção elevados.

Vivian (2008) constatou que após os experimentos as curvas geradas a partir da contaminação com óleo diesel apresentaram pequena dispersão, e mesmo sendo mantido o aspecto bimodal, as curvas características do solo mudam seu aspecto de maneira gradual, em relação ao teor de contaminante. A curva tende a inclinar seu patamar, tornando-se menos horizontal, à medida que aumenta a quantidade de óleo. Esta transição de um comportamento bimodal para um unimodal revelou a alteração na estrutura do solo devido à contaminação. Entre os diferentes teores de contaminantes estudados $(2 \%, 5 \%, 10 \%$, e 15\%), pode-se afirmar que há uma tendência de reduzir a sucção total quando a porcentagem de óleo é aumentada, considerando um mesmo grau de saturação.

\subsection{CONSTITUINTES DO ESGOTO E MUDANÇA DAS CARACTERISTICAS DOS SOLOS}

Segundo Motta \& Ferreira (2011) o colapso de um solo pode ser gerado pela mudança do estado tensional (tensão vertical, estrutura e sucção) e pela interação físico-química entre o percolante e o solo. Muitos casos de colapso têm sido associados a vazamentos oriundos das redes de esgotos e de abastecimento de água, ou vazamento de sistemas de armazenamento de combustíveis e efluentes químicos. No entanto, o colapso dos solos, geralmente é estudado com água. Na literatura, encontram-se poucos relatos da influência do líquido, nas características colapsíveis dos solos.

Segundo Rodrigues et al. (2010) o lançamento ou disposição de efluentes diretamente sobre o solo se restringe à degradação dos recursos naturais representada por contaminação e poluição do solo e de mananciais superficiais e subterrâneos, havendo pouco interesse na influência de tais materiais no comportamento mecânico dos solos. Além do potencial de contaminação, a influência desse contaminante no comportamento tensão versus deformação do solo pode apresentar aspectos diferenciados pela interação solo-líquido, principalmente quando o solo possui estrutura colapsível. O colapso do solo tem sido atribuído à eliminação da sucção matricial, porém, a dissolução do cimento aglutinante ou a destruição das ligações químicas entre os minerais por infiltração de fluidos não podem ser descartadas. 
Nos efeitos físicos, tem-se a expulsão forçada do ar aprisionado nos poros do solo, por causa do umedecimento e da quebra de cimentações, por ação mecânica de sobrecargas e/ou ação do peso próprio. Já nos efeitos químicos, tem-se a dissolução de cimentações, por ação química do líquido que interage com o solo. E nos efeitos físico-químicos, tem-se a interação do líquido com a superfície dos minerais do solo, ocorrendo a hidratação da superfície com a ação de uma força repulsiva, devido ao potencial de solvatação ou afinidade de interação e ao desenvolvimento da dupla camada elétrica, e à consequente mudança de volume (Mariz, 1993).

Rodrigues \& Lollo (2007) estudaram o comportamento de dois solos colapsíveis do Município de Ilha Solteira-SP com o uso de ensaios edométricos e microscopia eletrônica de varredura. $\mathrm{O}$ colapso foi induzido pela inundação das amostras com água destilada, esgoto doméstico e soluções a base de substâncias que compõem os esgotos, como sabões e detergentes. Observaram que o colapso foi maior quando o solo foi inundado com os líquidos de $\mathrm{pH}$ alcalino, porém, não foi possível atribuir a ascendência do colapso apenas ao aumento do $\mathrm{pH}$, porque as soluções testadas possuíam características distintas como a composição química, a tensão superficial e a viscosidade. Concluíram que o conjunto de características físicas e químicas que envolvem os fluidos de inundação e os solos tem um papel relevante na compreensão do fenômeno do colapso, tornando-se discutível, devido à sua complexidade, informações que atribuem o colapso a um ou outro fenômeno somente.

Garcia et al. (2004) analisaram um solo superficial, uma areia fina argilosa laterítica com baixa compacidade, do Município de Ilha Solteira - SP. Com o objetivo de estudar o efeito de algumas substâncias isoladas no colapso dos solos, utilizaram água destilada; esgoto doméstico; soluções a base de substâncias que compõem os esgotos, como: água sanitária, detergente líquido, sabão em pó; e óleo de soja para inundação dos corpos de prova. Realizaram ensaios edométricos, simples e duplos; e conferiram o efeito da inundação do solo em provas de carga com placa, e no carregamento de um protótipo de sapata corrida. Analisaram as características e a estrutura dos solos antes e após a realização de ensaios edométricos, com ensaios de caracterização física e química dos solos e microscopia eletrônica de varredura. Constataram que o colapso depende da composição química do fluido de inundação, e a intensidade parece estar relacionada à capacidade de tais fluidos em atacar os compostos cimentantes do solo, principalmente quando estes fluidos apresentam em sua composição o elemento sódio. 
Motta (2006) avaliou o comportamento de colapso do solo submetido à inundação com diferentes contaminantes e pôde observar que as propriedades físico-químicas dos líquidos utilizados para inundação do solo mostraram influência na interação com o solo. Quanto menor a tensão superficial do líquido, maior o potencial de molhabilidade do solo, no entanto, a interação solo-líquido ocorre de forma lenta. Além disso, os líquidos de pH alcalino mostraram uma tendência a produzir potenciais de colapso do solo mais altos, principalmente nos ensaios edométricos duplos; enquanto os líquidos com maiores condutividades apresentaram uma leve tendência a definir potenciais de colapso do solo mais altos, principalmente nos ensaios edométricos simples. Estes mesmos autores concluíram que o colapso da Areia Amarelo-Avermelhada depende da sua estrutura, das variações dos estados de tensões impostas e das interações físico-químicas do líquido de inundação com os vínculos estruturais, podendo aumentar seu potencial de colapso, quando inundado por líquidos contaminantes.

Segundo Rodrigues et al. (2010), ao estudar a influência dos constituintes do esgoto no colapso de um solo arenoso ficou evidente nos resultados da microscopia eletrônica de varredura e nos ensaios edométricos. Com esses ensaios, tornou-se possível avaliar a influência da inundação dos solos considerando diferentes fluidos após os ensaios edométricos. Os resultados indicam que o mecanismo de colapso dos solos estudados está relacionado à eliminação da sucção matricial e ao enfraquecimento das ligações cimentíceas compostas por óxidos e hidróxidos de ferro e alumínio.

Ainda de acordo com Rodrigues et al. (2010) o mecanismo de colapso é o mesmo para todos os fluidos testados, porém a intensidade do colapso parece estar relacionada à capacidade de tais fluidos de atacar os compostos cimentantes do solo. O colapso foi maior quando o solo foi inundado com os líquidos de $\mathrm{pH}$ alcalino, porém, não foi possível atribuir a ascendência do colapso apenas ao aumento do $\mathrm{pH}$. As soluções testadas possuem características distintas como a composição química, a tensão superficial e a viscosidade, impossibilitando tal afirmação. A deformação por colapso depende da composição química do fluido de inundação. No entanto, a combinação e o conjunto de características físicas e químicas que envolvem os fluidos de inundação e os solos desempenham relevante papel na compreensão do fenômeno do colapso, 


\subsection{CONSIDERAÇÕES SOBRE O FLUXO EM MEIOS POROSOS}

O solo comporta-se como um reservatório, podendo armazenar água em seus vazios. As principais propriedades físicas dos solos são: a capacidade de retenção de água do solo e a velocidade de infiltração (Gurjão, 2005).

O meio poroso pode ser definido como uma matriz de partículas sólidas. Quando o efluente proveniente de fossas sépticas, lixões, rejeitos de mineração, resíduos industriais, entre outros, migram sobre um solo natural, este atravessa inicialmente uma região em que os poros são ocupados por quantidades variáveis de ar e água (zona não saturada). O fluxo nessa região depende das condições do solo sendo predominantemente vertical devido à ação da gravidade. O efluente continua a migrar descendentemente até atingir a região na qual os poros estão totalmente preenchidos por água (zona saturada). Nessa zona, os contaminantes do efluente tendem a espalhar-se horizontalmente na direção do fluxo de água subterrânea (Gurjao, 2005).

Segundo Nascentes (2006), o acúmulo de contaminantes no solo é conseqüência dos processos físicos-químicos de interação solo-contaminante originados do transporte destes contaminantes através do solo. No transporte de contaminantes através de camadas de solos argilosos saturados, os mecanismos de transporte mais importantes são os mecanismos físicos de advecção e difusão, no caso de transporte em aquífferos, a advecção e a dispersão são, usualmente, os mecanismos mais importantes.

Em várias situações práticas, como no caso do transporte de contaminantes miscíveis através de camadas de solo pouco espessas e de baixa permeabilidade, como ocorre, por exemplo, nas camadas de impermeabilização de base de aterros sanitários, o solo pode ser considerado um material homogêneo isotrópico e indeformável e se admite que a migração do contaminante é governada pelo fluxo estacionário de um fluido incompressível; além disto, processos acoplados de fluxo são, geralmente, desprezados, e apenas as reações de sorção instantâneas, lineares e reversíveis, são incluídas na análise (Freeze \& Cherry, 1979).

\subsubsection{FLUXO NA ZONA SATURADA}

Os primeiros estudos para a quantificação da densidade de fluxo laminar de água num meio poroso saturado foram realizados por Darcy em 1856. Desses estudos originou-se a equação de Darcy (equação 2.1), estabelecendo que a quantidade de água que passa por 
unidade de tempo e de área é proporcional ao produto de duas propriedades hidráulicas do meio poroso: o gradiente de potencial total e a condutividade hidráulica $(K)$.

$$
q=-K \frac{\Delta \Psi_{t}}{\Delta z}
$$

Na condição do solo saturado, o potencial total é obtido pelo somatório do potencial gravitacional $\left(\Psi_{\mathrm{z}}\right)$ que representa a distância entre o ponto em questão no interior do solo e um nível de referencia (geralmente tomado como sendo a superfície do solo), e do potencial de pressão $\left(\Psi_{p}\right)$ que representa a carga ou coluna de água que atua sobre o ponto em consideração. O sinal negativo da equação indica que o fluxo se dá em direção a um decréscimo do potencial hidráulico. Durante o fluxo saturado, a condutividade (K) é considerada uma constante e representa uma característica do solo em transmitir água, dependendo da permeabilidade intrínseca do solo que está relacionada com sua geometria porosa e com a viscosidade do fluido que escoa.

\subsubsection{FLUXO NA ZONA NÃO SATURADA}

A zona não saturada corresponde à porção superficial do material geológico situada entre a superfície do solo e o topo do lençol freático, e que serve como via para a água a caminho do aquíffero freático após os eventos de infiltração. Caracteriza-se por ser um meio cujos poros estão ocupados pelas fases liquidas e gasosa em diferentes proporções no espaço e no tempo, e onde as forças da gravidade, capilares e adsortivas do meio poroso desempenham papel importante na circulação da água, juntamente com as atividades climáticas e biológicas (Bertolo, 2001).

Um solo não saturado difere de um meio poroso saturado devido à presença de ar nos poros. A proporção relativa de ar e de água nos poros pode variar e com isto haverá mudanças nas propriedades hidráulicas do solo. O solo, como material poroso, possui um determinado volume de vazios. Em solos saturados todos os vazios estão completamente preenchidos com água e, portanto, todos participam do fluxo de água. Estes vazios podem estar com proporção de água e de ar formando assim os solos não saturados. Neste caso o fluxo fica restrito aos poros preenchidos por água (Vasconcelos, 2008). 
Segundo Fredlund e Rahardjo (1993), duas fases de um solo não saturado podem ser classificadas como fases fluidas, a água e o ar. O fluxo em um solo não saturado pode ocorrer de três formas, com a fase do ar predominantemente contínua, para baixos valores do grau de saturação $(\mathrm{S}<80 \%)$. O ar pode estar ocluso, para graus de saturação acima de $95 \%$, e finalmente, pode haver fluxo de ar com a água, quando ocorre a difusão do ar na água. A análise de fluxo requer uma lei para relacionar a taxa de fluxo com uma diferença de carga adequada usando um coeficiente apropriado. As leis de fluxo podem variar para cada um dos casos acima.

Para Gurjão (2005) a água se movimenta de áreas de alto potencial (carga) para áreas de baixo potencial. Sob condições de solo não saturado, o movimento da água no meio ocorre devido à existência, principalmente, do potencial gravitacional e matricial. Esse potencial ou carga total de água do solo $(\Psi \mathrm{t})$ corresponde, portanto, à soma da carga ou potencial gravitacional $(\Psi \mathrm{g})$ com o potencial matricial ou pressão capilar $(\Psi \mathrm{m})$, esse, função da umidade do solo. O fluxo não saturado obedece às leis do fluxo saturado, com modificações tal como a de Buckingham que modificou a equação 2.1 de Darcy, para um fluxo não saturado unidimensional, com representação pela Equação (2.2).

$$
q=-K(\Psi)\left[\left(\frac{d \Psi}{d Z}\right)-1\right]
$$

Onde: K $(\Psi)$ representa a condutividade hidráulica em condição não-saturada. Esse valor varia com a umidade do solo.

O potencial matricial ( $\Psi)$, segundo Reichardt (1996), corresponde ao resultado do efeito combinado das forças de capilaridade e de adsorção da água na matriz sólida, mas que não são facilmente separadas. O potencial matricial representa, portanto, resultante das forças de sucção que retém a água na matriz do solo. Em materiais geológicos arenosos, a adsorção é pouco importante e os fenômenos capilares predominam na determinação do potencial matricial, ao passo que o contrário se dá nos materiais com texturas finas.

\subsection{FLUXO DE CONTAMINANTES EM SOLOS}

O transporte de solutos na água do subsolo é estudado como transporte de massa em meios porosos, em que a massa considerada é a de algum soluto (poluente) que se move com o solvente (água) nos interstícios de um meio poroso (solo), tanto na zona saturada como na 
insaturada. Os principais mecanismos envolvidos no transporte de um soluto em um meio poroso são: advecção, a dispersão mecânica, a difusão, as reações químicas entre o soluto e os sólidos e as reações químicas do próprio soluto (Boscov, 2008).

\subsubsection{ADVECÇÃO}

A advecção é o mecanismo de transporte que representa o movimento do poluente devido ao fluxo do fluido no qual esta dissolvido, movendo-se na direção das linhas de fluxo. Este mecanismo é resultante de gradientes de pressão existente entre as diferentes regiões do ambiente interno do meio poroso e a atmosfera, além de estar relacionado com a velocidade de percolação no meio poroso (Paula, 2006). A Figura 2.5 apresenta o mecanismo de advecção.

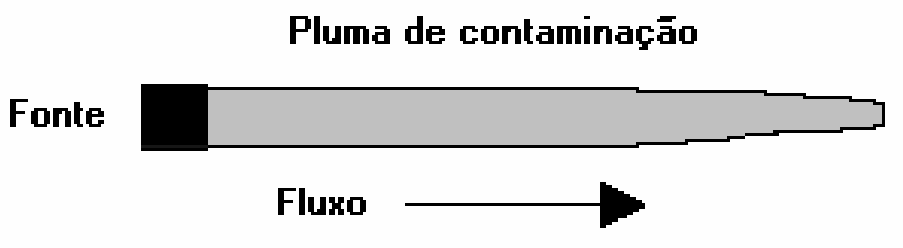

Figura 2.5 - Mecanismos de advecção

Segundo Boscov (2008) solutos não reativos são transportados a uma velocidade média igual à velocidade especifica ou de fluxo da água, $\mathrm{u}=\mathrm{v} / \mathrm{n}$, sendo $\mathrm{v}$ a velocidade de percolação, aproximação ou descarga (ou ainda velocidade de Darcy) e $n$ a porosidade do solo. A advecção pode ser considerada um fluxo químico causado por um gradiente hidráulico: a água dos vazios contendo soluto escoa sob a ação de um gradiente hidráulico e carrega consigo partículas de soluto.

\subsubsection{DISPERSÃO MECÂNICA OU HIDRÁULICA}

A mistura mecânica é resultante das variações locais da velocidade de fluxo no meio poroso que ocorrem devido à heterogeneidade do meio (Telles, 2001).

Para Boscov (2008), a dispersão mecânica ou hidráulica é a mistura que ocorre durante a advecção; é causada inteiramente pelo movimento do fluido. Deve ser explicada na escala microscópica, dentro do volume de vazios. A velocidade da água varia tanto em magnitude, 
com em direção a qualquer seção transversal de um vazio. As velocidades também são diferentes em diferentes vazios ou em diferentes segmentos longitudinais de um vazio: o diâmetro dos vazios varia ao logo das linhas de fluxo, e a velocidade média de fluxo em um vazio depende da razão entre a área superficial e a rugosidade relativas ao volume de água no vazio.

Esta componente da dispersão hidrodinâmica, quando numa escala microscópica, resulta de três mecanismos básicos, conforme pode ser observado na Figura 2.6. O primeiro consiste na variação da velocidade de fluxo devido à rugosidade das paredes dos canais formados pelas interligações dos poros do solo. O segundo mecanismo é consequência dos diferentes tamanhos dos poros ao longo da trajetória de fluxo, fazendo com que ocorram diferentes velocidades médias nos diferentes canais existentes. E o terceiro mecanismo de mistura corresponde às mudanças de direção das partículas devido à tortuosidade dos canais de fluxo, que faz com que algumas partículas se movam mais rápido que outras (Paula, 2006) e (Freeze \& Cherry, 1979)

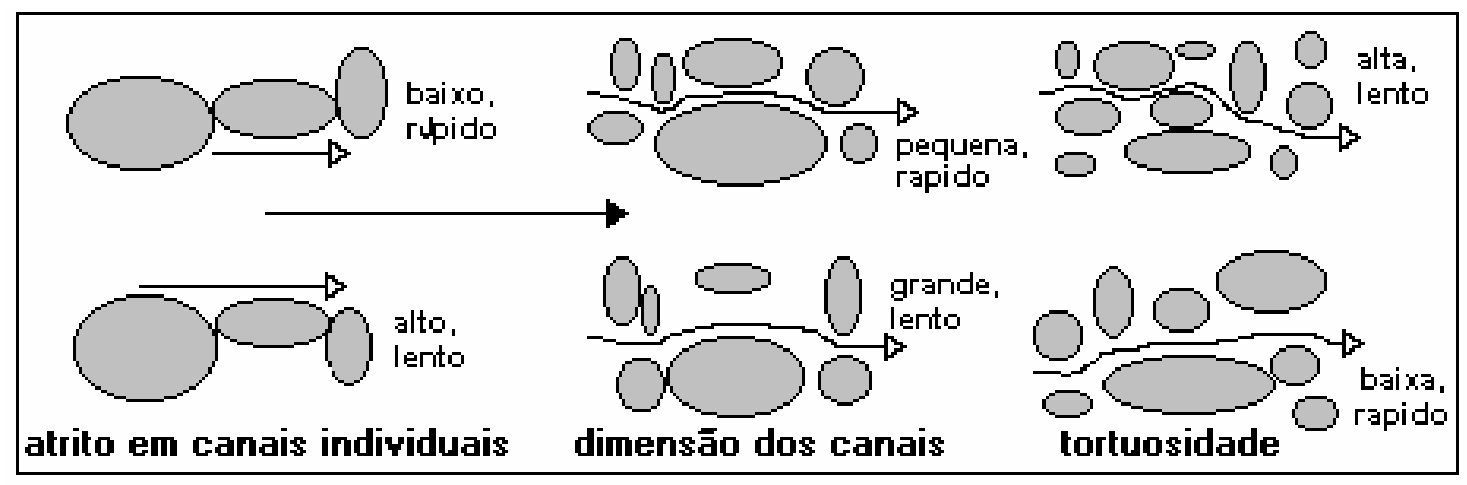

Figura 2.6 - Mecanismos de mistura mecânica em escala microscópica (Bedient, 1994) citados por Paula (2006).

\subsubsection{DIFUSÃO}

Segundo Boscov (2008), a difusão consiste no transporte de massa simultâneo á dispersão mecânica, que resulta de variações na concentração de soluto na fase líquida. É o processo pelo qual constituintes iônicos ou moleculares se movem em razão da sua energia térmico-cinética na direção do gradiente de concentração e em sentido oposto a este. A difusão causa um fluxo de partículas de soluto no nível microscópico das regiões de maior para as de menor concentração. A difusão ocorre mesmo na ausência de qualquer movimento 
hidráulico da solução, se a solução estiver escoando, difusão é o mecanismo, com a dispersão mecânica, que causa a mistura de constituintes iônicos ou moleculares.

Para Fetter (1993) a difusão molecular dos solutos caracteriza-se pela difusão de íons, átomos ou moléculas por forças de natureza molecular. Este tipo de transporte ocorre em função do gradiente de concentração das espécies químicas, independentemente da existência ou não de um movimento do fluido. A difusão envolve o movimento de contaminante de pontos de baixo potencial osmótico (concentração) para pontos de mais alto potencial osmótico. Deste modo, pode haver difusão em sentido contrário ao do transporte por advecção. A difusão ocorre em solos e é representada (equação 2.3) pelo coeficiente de difusão efetivo, $\mathrm{D}_{\mathrm{e}}\left(\mathrm{L}^{2} \mathrm{~T}^{-1}\right)$, dado por:

$$
\mathrm{D}_{\mathrm{e}}=\mathrm{w} \cdot \mathrm{D}_{0}
$$

$\mathrm{D}_{\mathrm{e}}\left(\mathrm{L}^{2} \mathrm{~T}^{-1}\right)$ - coeficiente de difusão efetivo em solução livre;

$\mathrm{w}$ - constante empírica.

Duas características da Primeira Lei de Fick devem ser mencionadas. Primeiramente, esta lei está descrita por uma equação linear e, por maior que seja a diferença de concentração entre dois pontos, o fluxo das partículas da direção positiva do eixo x, é proporcional ao gradiente da concentração de partículas, ou seja, não existe um processo de saturação. Além disto, esta lei implica em uma independência de fluxos: o fluxo de um soluto independe do fluxo de outros solutos, ou seja, não existe acoplamento entre os fluxos (Jesus, 2004).

A segunda componente da dispersão hidrodiâmica, a difusão, consiste no movimento de solutos dissolvidos na água em decorrência de um gradiente químico. Os íons se movem de pontos de maior concentração para pontos de menor concentração, tendendo a estabilizar a concentração em todo o fluido (Jesus, 2004). O deslocamento pode ocorrer mesmo sem haver gradiente hidráulico conforme pode ser observado na Figura 2.7 ou até em direções oposta à do fluxo dominante 


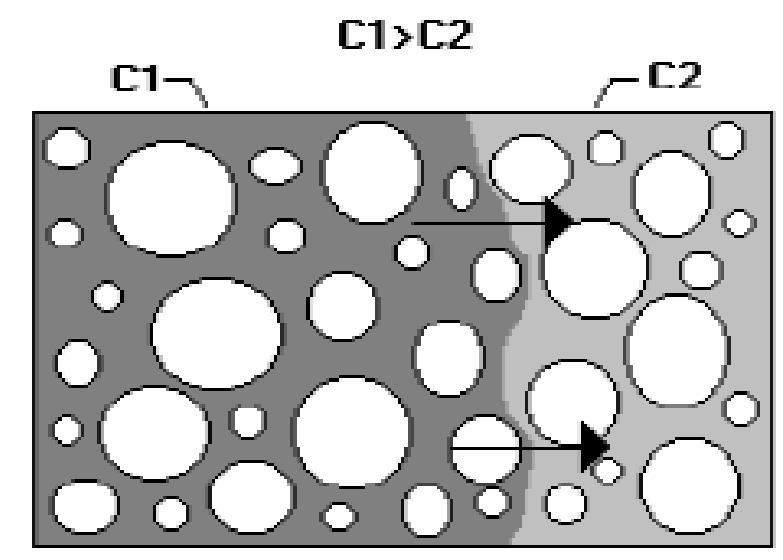

Figura 2.7 - Mecanismos de difusão. Fonte: Costa (2002).

A presença de partículas de solo, em particular argilominerais adsorventes e matéria orgânica, dificulta o processo difusão. Este processo, através dos vazios das partículas de argila, envolve o movimento difusivo de solutos no fluido intersticial. Na Figura 2.8, pode-se observar uma ilustração da difusão de cátions e ânios através de um solo saturado (Rowe et al., 1995).

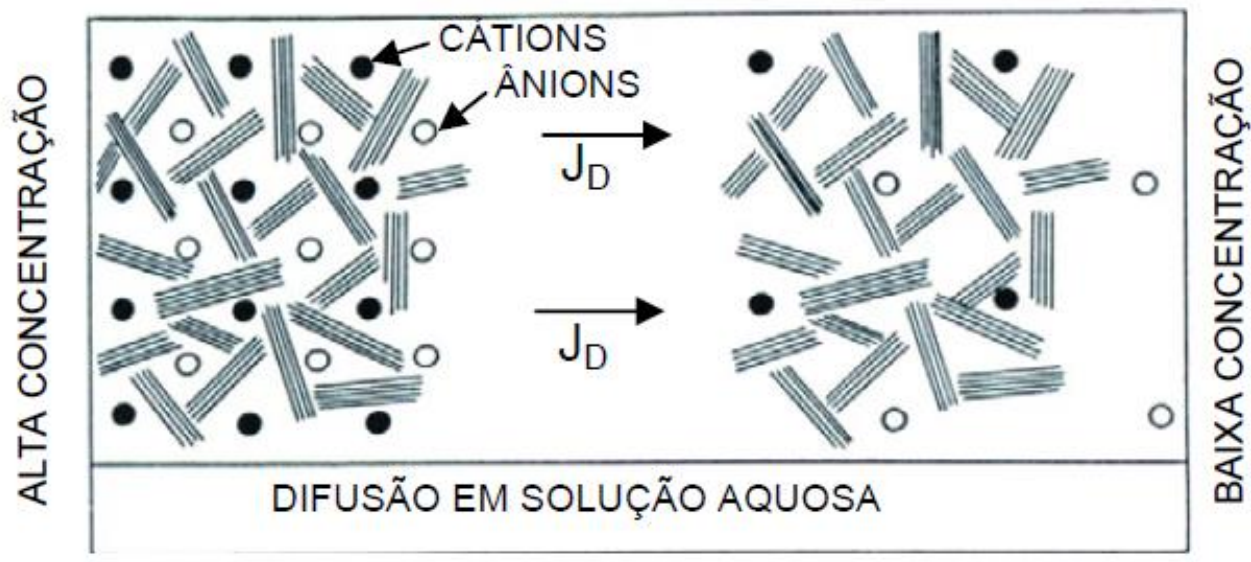

Figura 2.8 - Esquema da difusão de cátions e ânios de uma região de alta concentração para outra de baixa concentração em um solo argiloso saturado. Fonte: Rowe et al. (1995).

A difusão de solutos através de um solo, especialmente de granulometria fina, poderá ser mais lenta do que em solução livre, já que os caminhos de migração são mais tortuosos devido a presença das partículas sólidas de solo que ocupam parte da área da seção transversal, conforme pode-se verificar na Figura 2.9. 


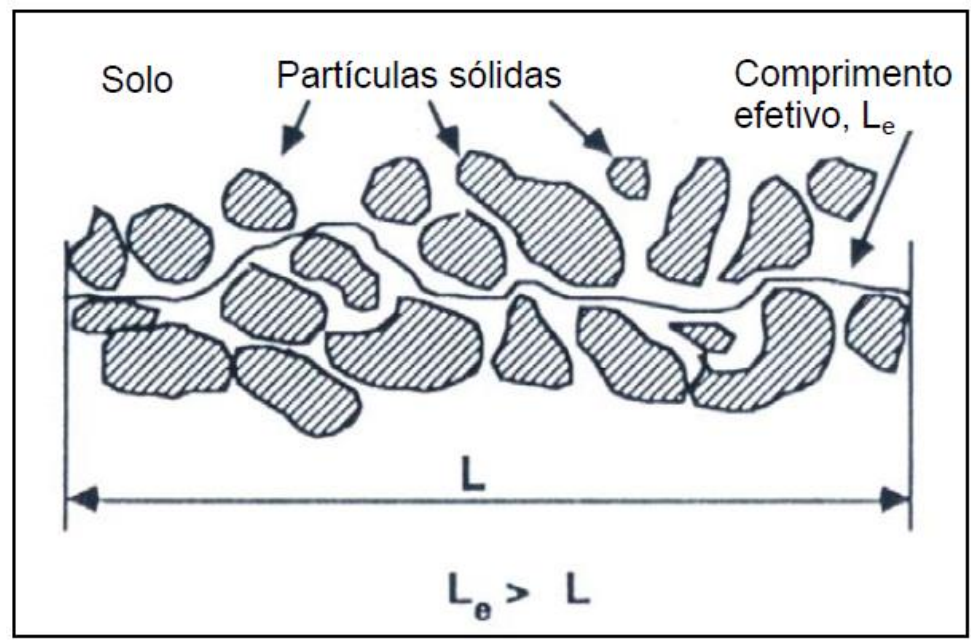

Figura 2.9 - Conceito de comprimento efetivo no transporte em solo. Fonte: Shackelford \& Daniel (1999) citados por Jesus (2004).

Rowe et al. (1995), elenca alguns fatores que estariam influenciando diretamente para uma difusão mais lenta no solo:

- reduções na seção transversal de fluxo;

- caminhos de migração mais tortuosos no solo (associado ao coeficiente de tortuosidade;

- fluxo com pequeno volume de fluido (associado à porosidade, $n$, ou teor de umidade volumétrico;

- aumento da viscosidade, especialmente, da água contida na dupla camada difusa;

- retardamento de certas espécies devido às trocas catiônica e aniônica com minerais de argila e matéria orgânica;

- biodegradação de solutos orgânicos;

- fluxo osmótico contrário;

- desequilíbrio elétrico, possivelmente por exclusão aniônica.

\subsubsection{DISPERSÃO HIDRODINÂMICA}

Para Boscov (2008), a dispersão hidrodinâmica consiste no espalhamento no nível macroscópico resultante tanto da dispersão mecânica como da difusão. Alguns autores consideram artificial a separação entre os dois processos, já que a dispersão mecânica induz gradientes de concentração que provocam difusão, sendo que à medida que um soluto é espalhado ao longo de um vazio capilar, como resultado da dispersão mecânica, é criado um 
gradiente de concentrações na direção longitudinal, e a difusão tenderá a equalizar as concentrações ao logo do vazio, ao mesmo tempo, um gradiente de concentrações de soluto será produzido entre linhas de fluxo adjacentes em virtude da variação de velocidades na seção transversal.

O efeito da dispersão pode ser representado em laboratório pelo ensaio de coluna, que consiste no fluxo unidimensional através de uma amostra de solo saturado com água. Considerando o fluxo permanente, a partir do instante $t=0$, uma solução, contendo substância numa determinada concentração inicial $-\mathrm{C}_{0}$ passa a ser introduzida continuamente no solo, por onde começa a permear expulsando, gradativamente a água dos vazios. No início, a interface que separa os dois fluidos é bem delineada e perceptível, porém com o passar do tempo, esta deixa de ser definida, e passa a ter uma faixa de transição entre a solução que avança e a água. A concentração do soluto nessa faixa de transição varia desde a sua concentração inicial na solução $\left(\mathrm{C}=\mathrm{C}_{0}\right)$ até zero, que é sua concentração inicial na água dos poros (COSTA, 2002). Este efeito pode ser observado na Figura 2.10.

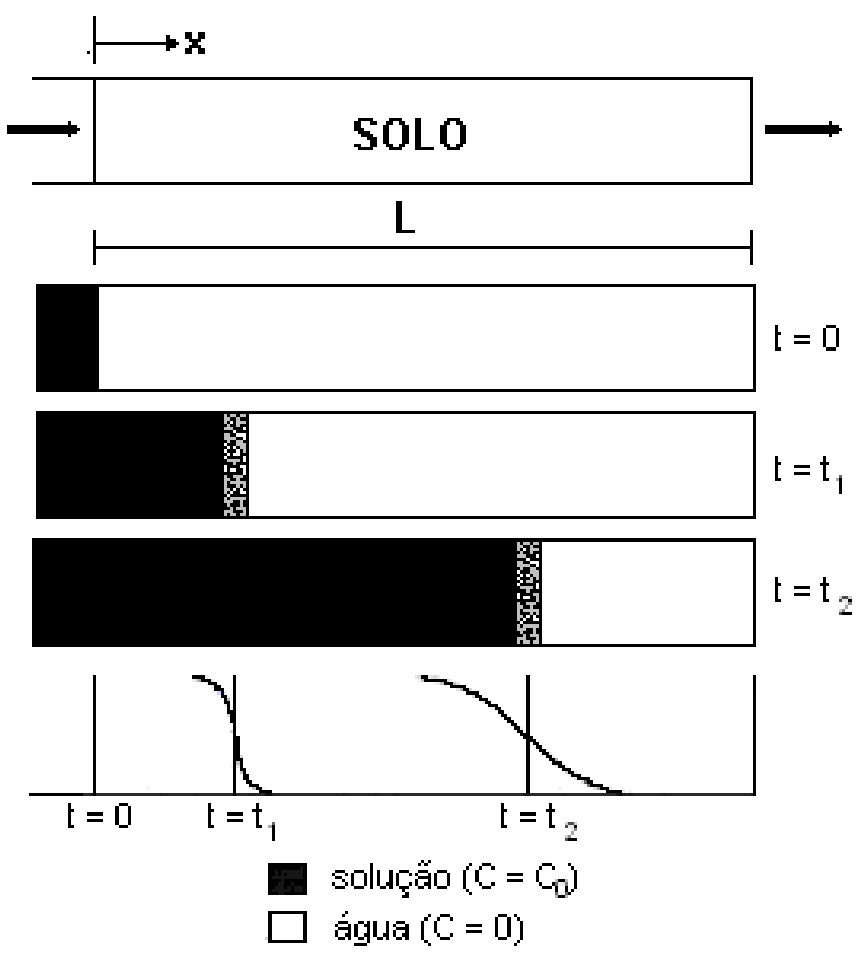

Figura 2.10 - Efeito da dispersão

Segundo Freeze \& Cherry (1979) a dispersão hidrodinâmica é um fenômeno em que um soluto durante seu movimento em sub-superfície se mistura com água não contaminante causando a redução na concentração original. A dispersão pode ocorrer tanto na direção do 
fluxo - dispersão longitudinal - como em direções perpendiculares a esta - dispersão transversal, sendo que, a primeira é mais acentuada do que a segunda.

Para Nascentes (2006) nos casos de fluxo não confinado e/ou bi ou tridimensional, a componente transversal de dispersão deve ser considerada. Na Figura 2.11 está ilustrando um esquema do mecanismo de dispersão para um fluxo horizontal bidimensional, em que podem ser observadas suas duas componentes longitudinal e transversal.
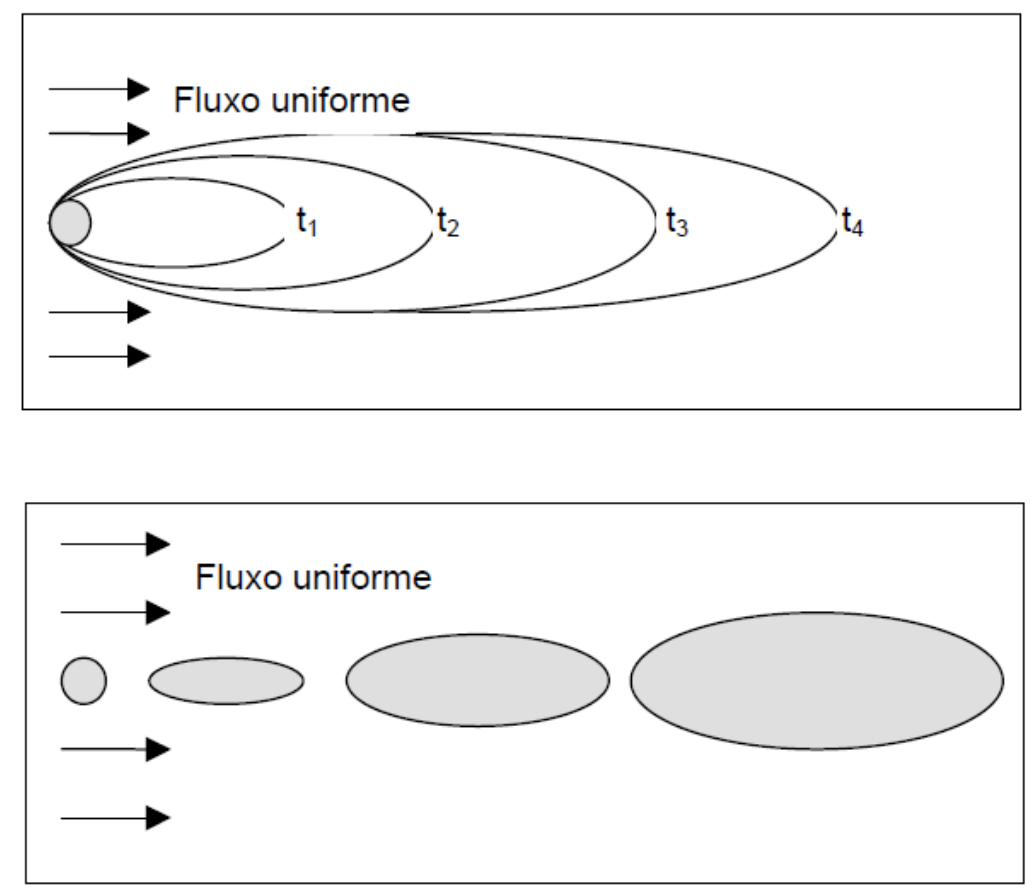

(b)

Figura 2.11 - Mecanismo de dispersão em fluxo uniforme bidimensional em areia isotrópica. (a) fonte contínua; (b) fonte instantânea. Fonte: Nascentes (2006).

Nas direções longitudinal e transversal, a dispersão hidrodinâmica é, calculada, respectivamente a partir das equações 2.3 (a), e 2.3 (b).

$$
\begin{gathered}
D_{h L}=\alpha_{L} V_{x}+D_{e} \\
D_{h t}=\alpha_{t} V_{x}+D_{e}
\end{gathered}
$$

O processo de dispersão mecânica tende a anisotropia, ou seja, depende da direção. Mesmo que o meio poroso seja isotrópico com respeito à textura e condutividade hidráulica, a dispersão é mais forte na direção do fluxo (dispersão longitudinal) do que nas direções normais ao fluxo (dispersão transversal). Em caso de baixas velocidades, no entanto, em que a 
difusão molécular é o mecanismo dispersivo dominante, a dispersão longitudinal e a transversal são aproximadamente iguais (Boscov, 2008).

\subsubsection{REAÇÕES QUÍMICAS}

Os solutos dissolvidos na água subterrânea estão sujeitos a um grande numero de interações nos quais eles podem ser removidos. Reações de adsorção/desorção, precipitação/dissolução, oxi-redução, complexação e quelação e biodegradação podem ocorrer a depender do contaminante e do tipo de solo, alem do decaimento radioativo. Em conseqüência desses processos alguns solutos movem-se mais lentamente que o solvente que o está transportando. Essas reações diminuirão a concentração do soluto na pluma de contaminação, mas não podem necessariamente diminuir a taxa de movimento da pluma (Fetter, 1993).

\subsubsection{ADSORÇÃO-DESSORÇÃO}

A adsorção é um processo físico-químico no qual uma substância é acumulada em uma interface entre fases. Quando substâncias contidas em um líquido se acumulam em uma interface sólido-líquido, denomina-se adsorvato à substância que esta sendo removida da fase líquida e adsorvente à fase sólida na qual a acumulação ocorre. A adsorção ocorre porque há forças que atraem o adsorvato da solução para a superfície do adsorvente, essas forças de atração podem ser físicas ou químicas. A adsorção física ocorre principalmente em razão das forças eletrostáticas atração e repulsão segundo a Lei de Coulomb, interações dipolo-dipolo, interações de dispersão e pontes de hidrogênio. A adsorção química é uma ligação química real, geralmente covalente, entre uma molécula e átomos superficiais, formando novos compostos. A dessorção é a liberação de espécies químicas previamente adsorvidas, ocorre, quando a concentração afluente da substância diminui, ou pelo deslocamento provocado pela competição com outra substância mais fortemente adsorvida (Boscov, 2008).

Segundo Nascentes (2006), a sorção química corresponde ao processo em que o soluto é incorporado à partícula sólida por uma reação química. Muitos minerais e substâncias orgânicas em contanto com a água são capazes de atrair moléculas de água ou íons ou liberar certos constituintes, por processos físico-químicos de simples adsorção, devido às forças eletrostáticas e, de sorção química, que é consequência da reação química entre o íon 
adsorvido e a superfície sólida adsorvente. Quando as espécies iônicas trocam as suas posições, o processo é chamado de troca iônica. A adsorção em solos ocorre principalmente nos argilominerais, que apresentam um desbalanceamento elétrico devido a substituições de cátions no retículo cristalino por outros de menor valência. $\mathrm{O}$ excesso de carga elétrica negativa é compensado por um acumulo de íons de carga oposta e moléculas de água em torno da superfície da partícula.

Segundo Costa (2002) a partícula de argila é negativamente carregada e para equilibrar sua carga é necessária a adesão de cátions em volta da superfície da mesma. Essa 'nuvem' de cátions formada ao redor das partículas é conhecida como 'camada dupla', e a quantidade de cátions aderidos necessária para neutralizar a partícula do solo é chamada de 'capacidade de troca catiônica - CTC'. Um dos fatores mais importantes nos processos de interação solocontaminante e no transporte de substâncias através do solo é o fenômeno de expansão/contração da camada dupla. A contração da camada dupla devido, por exemplo, à substituição de cátions monovalentes por cátions bivalentes, na superfície da partícula argilosa, aumenta os espaços vazios entre as partículas, aumentando a condutividade hidráulica e acelerando o avanço do fluido percolante. Se determinada troca iônica vier a favorecer a expansão da camada dupla, analogamente ocorrerá o contrário, a condutividade hidráulica irá diminuir e o avanço do fluido percolante será retardado. Tal fenômeno pode ser observado na Figura 2.12.

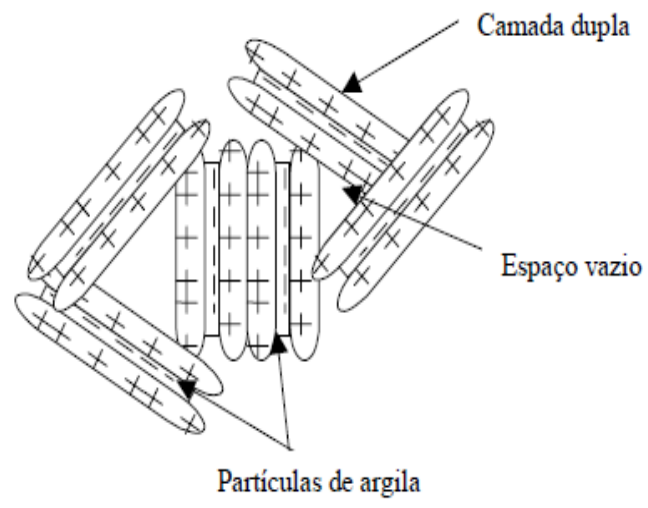

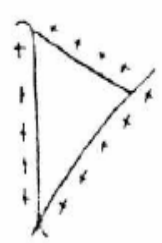

(a)

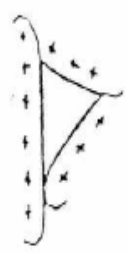

(b)

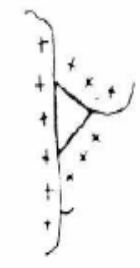

(c)

Figura 2.12 - Fenômeno de expansão/contração da camada dupla (a) expansão; (b) normal referência acima; (c) contração (Rowe et al. (1995). 
Segundo Boscov (2008), adsorção iônica é reversível, isto é, os íons são trocáveis. A troca ocorre em quantidades equivalentes, com preferência para cátions de maior valência. Alguns fatores que influem na adsorção de íons na superfície dos argilo-minerais são: valência, raio do íon hidratado, concentração, tipo de argilo mineral e afinidade.

Para Nascentes (2006) os materias que se comportam como adsorventes são os minerais de argila, oxi-hidróxidos de $\mathrm{Fe}$ e $\mathrm{Al}$ e as substâncias orgânicas (húmus), que são colóides eletronegativos, ou seja, têm uma carga superficial negativa capaz de fixar e trocar cátions. Os íons adsorvidos podem ser trocados por outros, desde que se mantenha o equilíbrio elétrico, o que significa que a adsorção é reversível. Valores atribuídos à capacidade de troca catiônica dos principais argilominerais e das frações silte e areia dos solos, bem como a sua superfície especifica, estão apresentados na Tabela 2.12.

Tabela 2.12 - CTC e superfície específica dos principais argilo-minerais e das frações silte e argila

\begin{tabular}{c|c|c}
\hline Mineral ou partícula & Superfície especifica $\left(\mathrm{m}^{2} \mathrm{~g}^{-1}\right)$ & $\mathrm{CTC}\left(\mathrm{cmol}_{\mathrm{c}} \mathrm{kg}^{-1}\right)$ \\
\hline caulinita & $10-20$ & $3-15$ \\
\hline Ilita & $70-120$ & $10-40$ \\
\hline Clorita & $79-150$ & $10-40$ \\
\hline Vermiculita & $300-500$ & $100-150$ \\
\hline Esmectita & $700-800$ & $60-150$ \\
\hline Silte & $<1$ & Muito pequena \\
\hline Areia grossa & $<0,1$ & Muito pequena \\
\hline Areia fina & $<0,01$ & pequena \\
\hline
\end{tabular}

A adsorção pode ser determinada por ensaios de laboratório, através do ensaio BET (Batch Equilibrium Test), com a definição de isotermas de adsorção. Esses processos que tendem a retirar ou introduzir certa quantidade de massa do soluto na água são normalmente agrupados num processo mais geral conhecido como sorção. A sorção é, portanto, um processo geral, onde a massa de soluto dissolvida na fase líquida é atraída pelas partículas da matriz sólida. O principal efeito da sorção é que o solvente se move mais lentamente que a água. Esse efeito é conhecido como retardo. $\mathrm{O}$ fator de retardamento $\left(\mathrm{R}_{\mathrm{d}}\right)$, é o responsável pela baixa velocidade de movimento que o soluto apresenta quando o mesmo é adsorvido pelo solo. Seu movimento se torna mais lento do que o da água responsável pelo transporte (Gurjão, 2005). 
Segundo Costa (2002), coeficiente de distribuição D e o fator de retardamento $R_{d}$ podem ser estimados com a análise das isotermas, curvas obtidas a partir de ensaios de equilíbrio em lote que, por sua vez, consistem na agitação de misturas compostas por uma porção de solo e uma solução contendo um contaminante numa concentração inicial conhecida. Essa agitação deve manter as partículas sólidas em suspensão, disponibilizando toda sua área ao contato com a solução, durante o tempo necessário para que ocorram as reações químicas de interação solocontaminante. Em seguida, é feita a separação das fases sólida e líquida e determina-se a concentração de equilíbrio da solução, sendo que pela diferença entre as concentrações inicial e de equilíbrio tem-se a concentração do contaminante que foi retida pelo solo.

A quantidade de material adsorvido por massa unitária de adsorvente cresce com o aumento da concentração. A capacidade de adsorção das partículas de argila tende a diminuir com o aumento de quantidade de soluto adsorvido, até que um limite máximo de soluto adsorvido seja atingido. Para solos, as isotermas mais utilizadas são a linear, a de Freundlich e a de Langmuir (Gurjão 2008). O modelo mais simples de adsorção é a isoterma linear, admitindo proporcionalidade direta. Senso expresso pela equação 2.4.

$\mathrm{S}=K_{\mathrm{d}} \mathrm{C}$

Em que: $S$ é o grau de adsorção ou concentração de soluto na parte sólida; $K_{d}$ é o coeficiente de distribuição ou adsorção; C é a concentração de equilíbrio.

Segundo Gurjão (2005) o coeficiente de distribuição (Kd) é um valor constante e depende basicamente do tipo de solo e do tipo de soluto, ou seja, depende da interação entre a matriz sólida e o soluto. Para incorporar esse modelo de sorção ao modelo de transporte fazse:

$$
\frac{\partial \mathrm{s}}{\partial \mathrm{t}}=K \mathrm{~d} \frac{\partial \mathrm{C}}{\partial \mathrm{t}}
$$




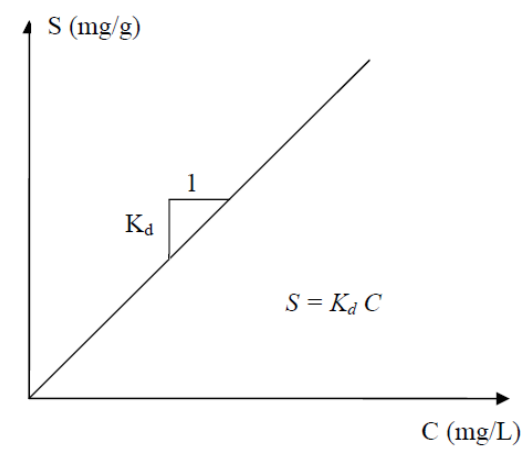

Figura 2.13 - Isoterma linear. Fonte: Gurjão (2005).

Segundo Boscov (2008), outro modelo muito utilizado para adsorção em solo é o de Freundlich ou de van Bemmelen, basicamente empírico conforme pode ser observado nas equações 2.6.

$\mathrm{S}=\mathrm{K}_{\mathrm{f}} \mathrm{C}^{\varepsilon} \quad$ ou $\quad \log \mathrm{S}=\log \mathrm{K}_{\mathrm{f}}+\varepsilon \log \mathrm{C}$

Em que: $\mathrm{K}_{\mathrm{f}}$ e $\varepsilon$-coeficientes empíricos da isoterma de Freundlich

A forma logarítmica resulta em um reta com declividade $\varepsilon$ e intercepto igual a $\log \mathrm{K}_{\mathrm{f}}$ para $\mathrm{C}=1$, conforme representado na Figura 2.14, o valor do intercepto é um indicador da capacidade de adsorção, e a declividade, da intensidade de adsorção.

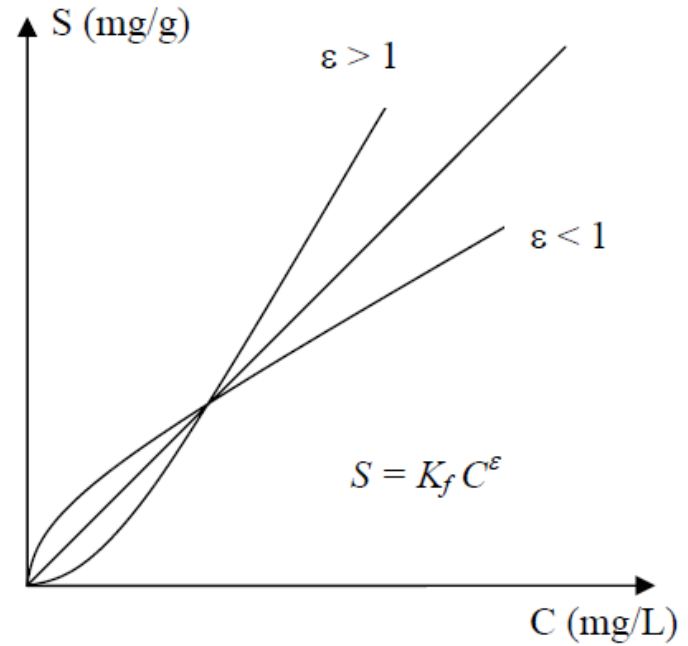

(a)

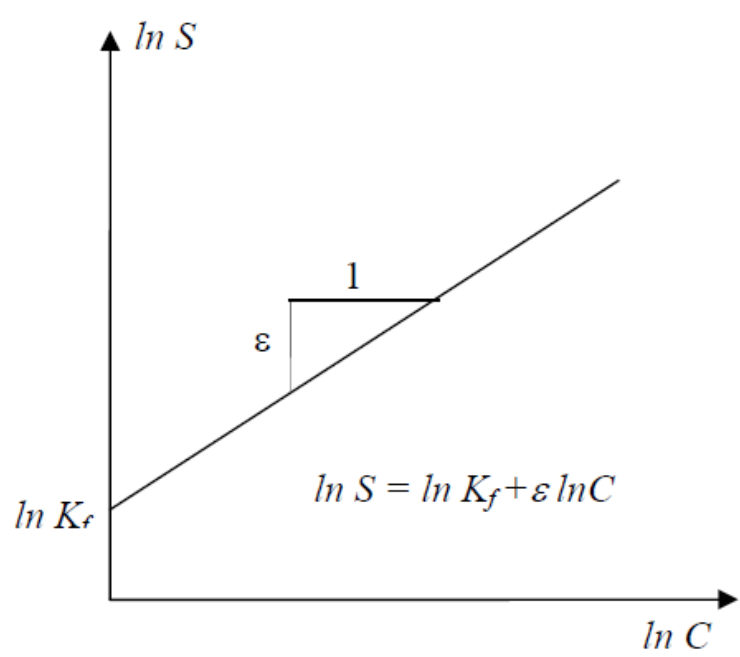

(b)

Figura 2.14 - Isoterma de Freundlich: (a) curva mostrando a sorção em função da concentração e (b) log usando os parâmetros determinados. Fonte: Gurjão (2005). 
Finalmente, o modelo de Langnuir, de 1915, foi deduzido a partir da termodinâmica da adsorção. Representada pela equação 2.7 .

$$
S=\frac{(S m b C)}{(1+b C)}
$$

Em que: $\mathrm{S}_{\mathrm{m}}$ é o número de moles do soluto adsorvido por unidade de peso do adsorvente ao formar uma monocamada completa na superfície, e b é uma constante relacionada à energia ou à entalpia líquida da adsorção (Boscov, 2008).

Para Gurjão (2005), os parâmetros $S_{m}$ e b são melhores obtidos pelo ensaio BET (ensaio de sorção), conhecendo-se o volume do contaminante, a concentração e a massa de solo seco. Estes parâmetros podem obtidos plotando-se $1 / \mathrm{S}$ versus $1 / \mathrm{C}$, conforme mostrado na Figura 2.15.

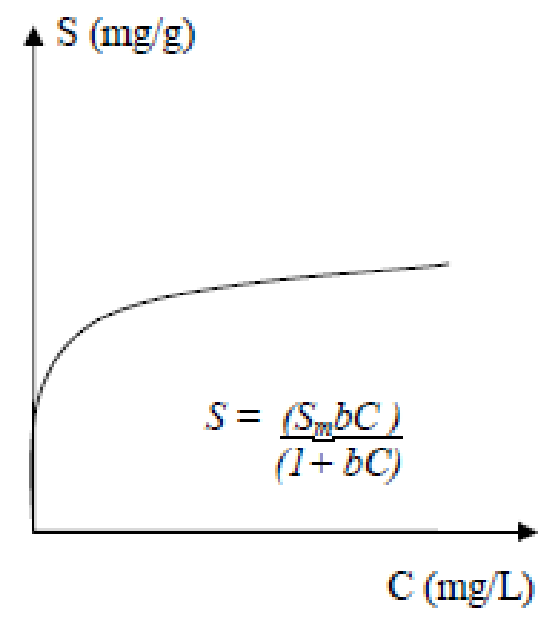

(a)

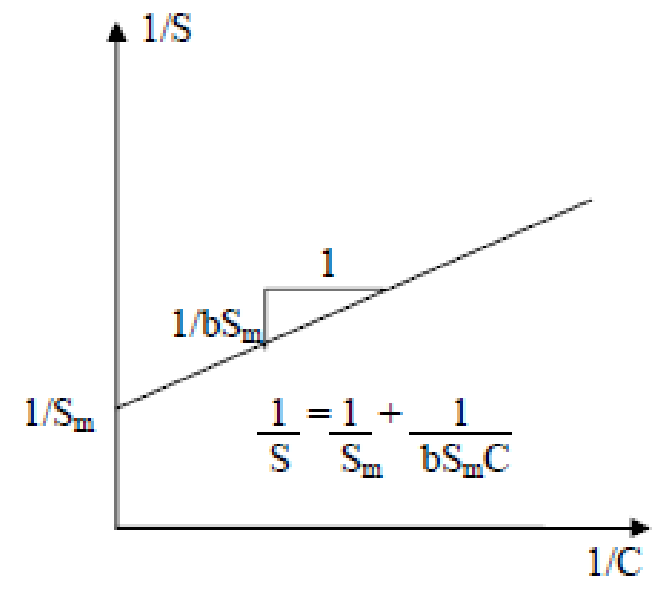

(b)

Figura 2.15 - Isoterma de Langmuir: (a) curva mostrando a sorção em função da concentração e (b) valores plotados usando os parâmetros determinados. Fonte: Gurjão (2005). 


\section{MATERIAIS E MÉTODOS}

Este capítulo apresenta os critérios de escolha e coleta dos solos estudados para a elaboração desta tese, além das metodologias aplicadas para a caracterização e classificação dos materiais.

Foram realizadas sondagens a trado manual com coleta de amostras para a classificação expedita e completa, ensaios de permeabilidade e alguns ensaios de compatibilidade com o solo contaminado, sendo eles: limites de Atterberg, granulometria com granulometro a laser e expansão livre. Foram realizados experimentos de verificação da variação da resistência do solo que interage com a contaminação, sendo eles: cisalhamento direto, adensamento, compressão simples, e tração por compressão diametral. Ensaios de verificação do fluxo de contaminantes sendo eles: difusão, sorção. Curvas de sucção para diferentes concentrações de contaminantes. Os experimentos foram realizados no Laboratório de Geotecnia, Laboratório de Saneamento da Universidade de Brasília, Laboratório Solo Química e Laboratório Quinosan.

\subsection{SOLOS DA ÁREA DE ESTUDO}

Este estudo iniciou-se com a busca de parceria entre a UnB/Geotecnia e a Companhia de Saneamento Ambiental do Distrito Federal (CAESB), onde foi apresentado o projeto de pesquisa. A partir da confirmação da parceria, uma estação de tratamento de esgoto foi definida para o estudo de caso, sendo que a estação escolhida por disponibilidade de área foi a Estação de Tratamento de Esgoto ETE - Samambaia/Melchior. Estas ETE's utilizam sistemas de tratamento do tipo lagoas de estabilização, e reatores anaeróbicos seguidos de póstratamento.

Inicialmente foram realizadas 15 sondagens com trado manual na área da estação de tratamento de esgoto (ETE Melchior). Posteriormente foram realizados ensaios de classificação expedita com o objetivo de conhecer os solos locais da área de estudo. Esta classificação preliminar objetivava conhecer os solos locais e identificar possíveis áreas para a 
implantação das células de difusão em campo. A Tabela 3.1 apresenta a localização das sondagens, a nomenclatura utilizada para cada furo e a profundidade atingida.

Tabela 3.1 - Localização das sondagens e nomenclatura utilizada.

\begin{tabular}{|c|c|c|}
\hline Sondagem/Nomenclatura & Profundidade (m) & Coordenadas \\
\hline Seção 1/ P11 & 4,0 & $\begin{array}{l}15^{\circ} 51^{\prime} 46.50^{\prime \prime} \mathrm{S} \\
48^{\circ} 08^{\prime} 54.38^{\prime \prime} \mathrm{W}\end{array}$ \\
\hline Seção 1/P12 & 5,0 & $\begin{array}{l}15^{\circ} 51^{\prime} 39.71 \text { " S } \\
48^{\circ} 08^{\prime} 50.71 \text { "W }\end{array}$ \\
\hline Seção 1/P13 & 5,0 & $\begin{array}{l}15^{\circ} 51^{\prime} 32.06^{\prime \prime ~ S} \\
48^{\circ} 08^{\prime} 46.61 \text { "W }\end{array}$ \\
\hline Seção 2/P21 & 4,5 & $\begin{array}{l}15^{\circ} 51^{\prime} 56.62^{\prime \prime ~ S} \\
48^{\circ} 09^{\prime} 03.63 " \mathrm{~W}\end{array}$ \\
\hline Seção 2/P22 & 5,0 & $\begin{array}{l}15^{\circ} 51^{\prime} 56.80^{\prime \prime} \mathrm{S} \\
48^{\circ} 08^{\prime} 57.20^{\prime \prime} \mathrm{W}\end{array}$ \\
\hline Seção 2/P23 & 5,0 & $\begin{array}{l}15^{\circ} 51^{\prime} 57.11^{\prime \prime ~ S} \\
48^{\circ} 08^{\prime} 49.54^{\prime \prime} \mathrm{W}\end{array}$ \\
\hline Seção 3/P31 & 2,5 & $\begin{array}{c}15^{\circ} 52^{\prime} 10.58^{\prime \prime} \mathrm{S} \\
48^{\circ} 08^{\prime} 53.59^{\prime \prime} \mathrm{W}\end{array}$ \\
\hline Seção 3/P32 & 5,0 & $\begin{array}{l}15^{\circ} 52^{\prime} 10.73 " \mathrm{~S} \\
48^{\circ} 08^{\prime} 46.70 \text { "W }\end{array}$ \\
\hline Seção 3/P33 & 5,0 & $\begin{array}{l}15^{\circ} 52^{\prime} 10.66 \text { "S } \\
48^{\circ} 08^{\prime} 41.77^{\prime \prime} \mathrm{W}\end{array}$ \\
\hline Seção 4/P41 & 5,0 & $\begin{array}{l}15^{\circ} 52^{\prime} 26.10^{\prime \prime S} \\
48^{\circ} 08^{\prime} 53.88 \text { "W }\end{array}$ \\
\hline Seção 4/P42 & 3,0 & $\begin{array}{l}15^{\circ} 52^{\prime} 25.91 " \mathrm{~S} \\
48^{\circ} 08^{\prime} 53.88^{\prime \prime} \mathrm{W}\end{array}$ \\
\hline Seção 4/P43 & 3,0 & $\begin{array}{l}15^{\circ} 52^{\prime} 25.85 \text { "S } \\
48^{\circ} 08^{\prime} 40.91 \text { "W }\end{array}$ \\
\hline Seção 5/P51 & 5,0 & $\begin{array}{l}15^{\circ} 52^{\prime} 50.05 \text { "S } \\
48^{\circ} 09^{\prime} 04.56 \text { "W }\end{array}$ \\
\hline Seção 5/P52 & 5,0 & $\begin{array}{l}15^{\circ} 52^{\prime} 46.21 \text { "S } \\
48^{\circ} 08^{\prime} 54.75 \text { "W }\end{array}$ \\
\hline Seção 5/P53 & 5,0 & $\begin{array}{l}15^{\circ} 52^{\prime} 42.67 " \mathrm{~S} \\
48^{\circ} 08^{\prime} 45.28^{\prime \prime W}\end{array}$ \\
\hline
\end{tabular}

De acordo com o levantamento de solos do Distrito Federal realizado pela Embrapa (1978), a área da região engloba quatro classes, sendo elas: Cd 3 (cambissolo álico), argila de atividade baixa, A moderado, textura argilosa cascalhenta, fase floresta subcadufifólia, relevo suave ondulado, substrato filito, xisto, metassiltito e ardósia; Cd 9 (associação de cambissolo), textura argilosa cascalhenta, fase concrecionária mais cambissolo raso textura média ou argila média fase cascalhenta, ambos álicos argila de atividade baixa, A moderado, cerrado subcaducifólio, relevo plano e suave ondulado, substrato filito, xisto, metassiltito e ardósia; LEd1 (latossolo vermelho-escuro álico ou distrófico a moderado ou proeminente textura 
argilosa fase floresta subcaducifolia, relevo plano e suave ondulado; LVd1 (latossolo vermelho álico), A moderado, textura argilosa, fase floresta subcaducifólia, relevo plano e suave ondulado. Na Figura 3.1 são apresentados a localização dos perfis amostrados e as classes de solos da área.

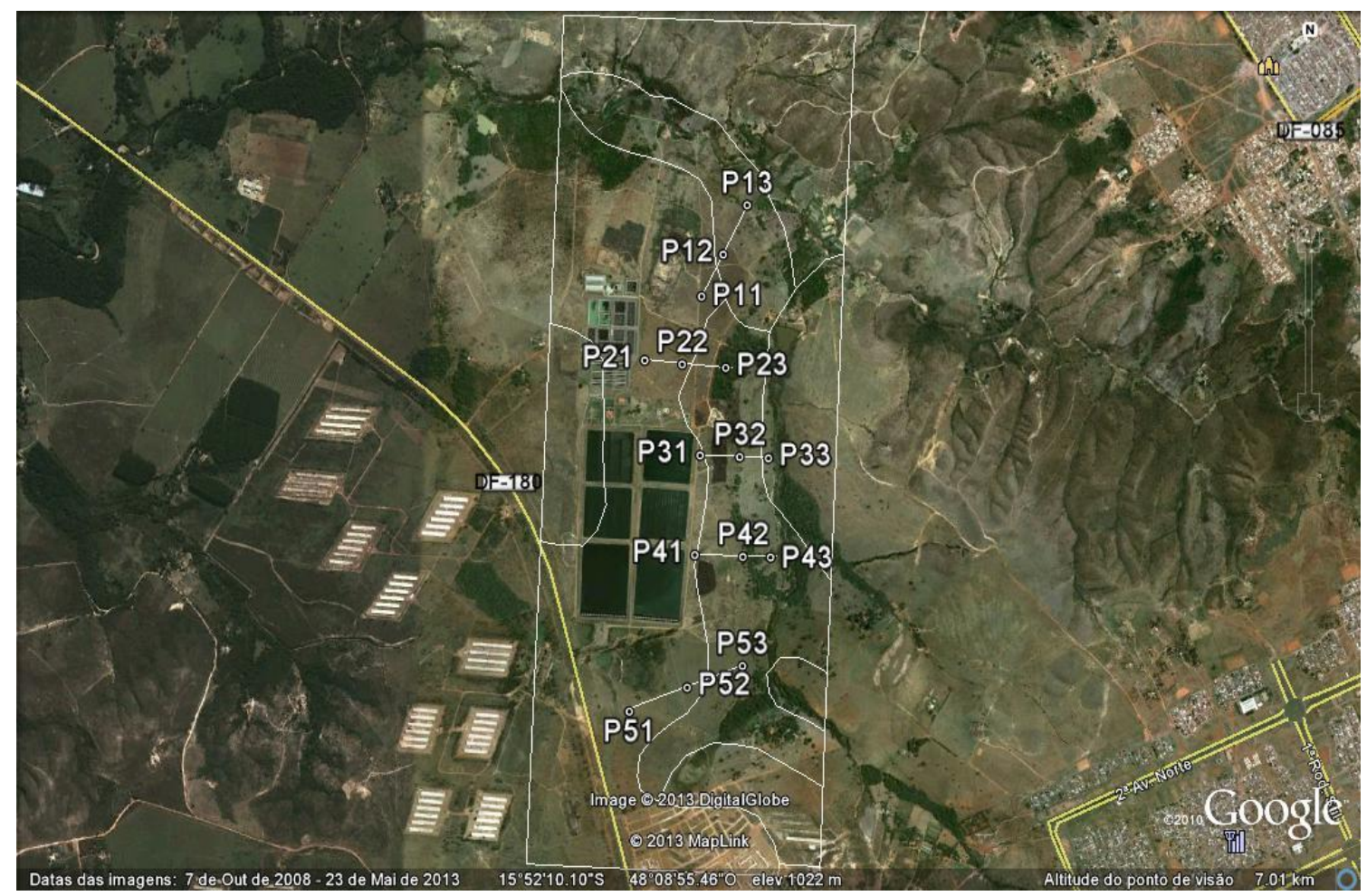

Figura 3.1 - Locação dos perfis de sondagens e classes de solos da ETE Melchior.

Os perfis de sondagens foram realizados nas três classes de solos encontrados na área de estudo sendo eles: Cd3, Led1, Lvd1. Nas Figuras 3.2 e 3.3 mostram a sondagem a trado, e a coleta de amostras para posterior classificação em laboratório.
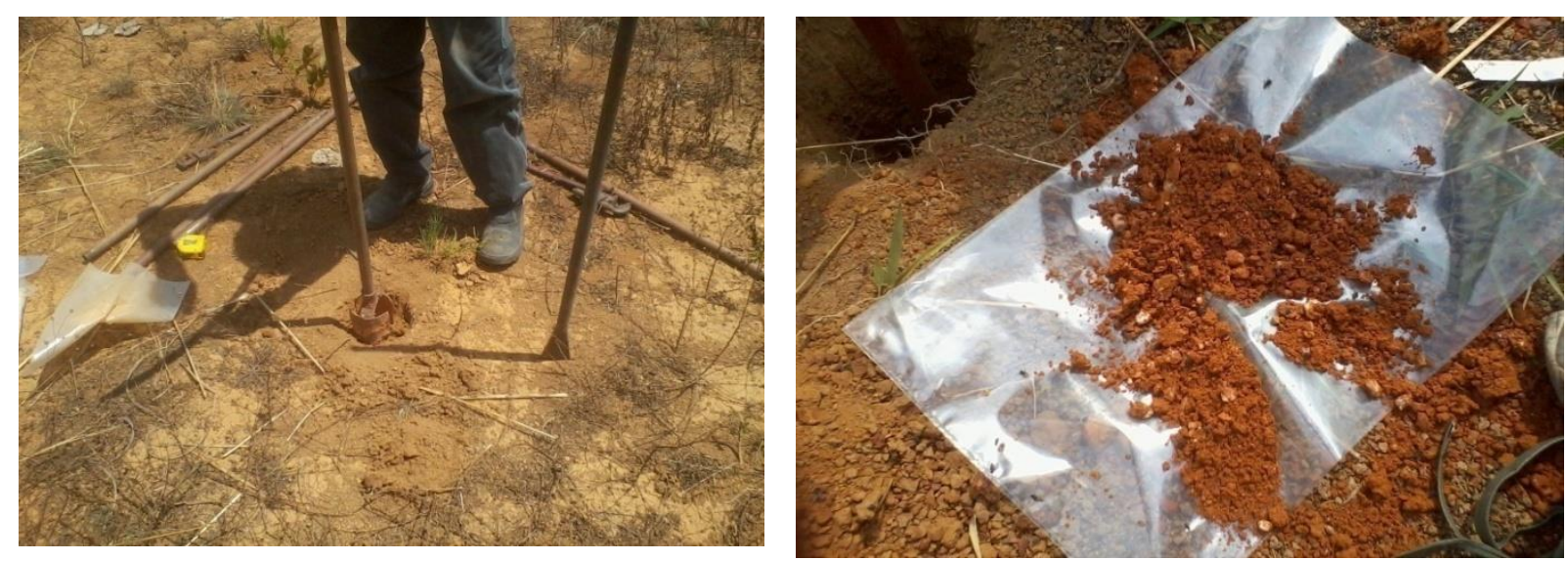

Figura 3.2 e 3.3 - (a) Sondagem a trado; (b) coleta de solos para caracterização preliminar em laboratório. 


\subsection{CARACTERIZAÇÃO FÍSICA DOS PERFIS}

Após a coleta dos solos em camadas de $0,50 \mathrm{~m}$ ao longo dos 15 perfis de sondagem foram realizados ensaios de caracterização. Esta caracterização consistiu na determinação da umidade, limite de plasticidade e caracterização MCT (Miniatura Compactada Tropical) expedita. Ressalta-se que para as demais análises foram coletados solo a cada camada de 0,50 m.

Todos os ensaios executados nesta etapa da pesquisa foram realizados no laboratório de Geotecnia da UnB, seguindo procedimentos estabelecidos pela Associação Brasileira de Normas Técnicas (ABNT) e metodologias estabelecidas pelo Departamento Nacional de Estradas e Rodagem (DNER).

\subsubsection{Determinação do Teor de Umidade Natural de Cada Camada}

Após coleta dos solos em cada um dos 15 perfis de sondagem, as amostras foram separadas para realizar os ensaios de determinação de umidade natural no laboratório. Para obtenção deste parâmetro foi coletado solo a cada 0,25 m no perfil de sondagem. A Figura 3.4 apresenta 2 perfis distintos com as amostras pesadas para a determinação de umidade natural. O método de ensaio foi o da estufa regulamentado pela norma NBR 6457 (ABNT, 1986).
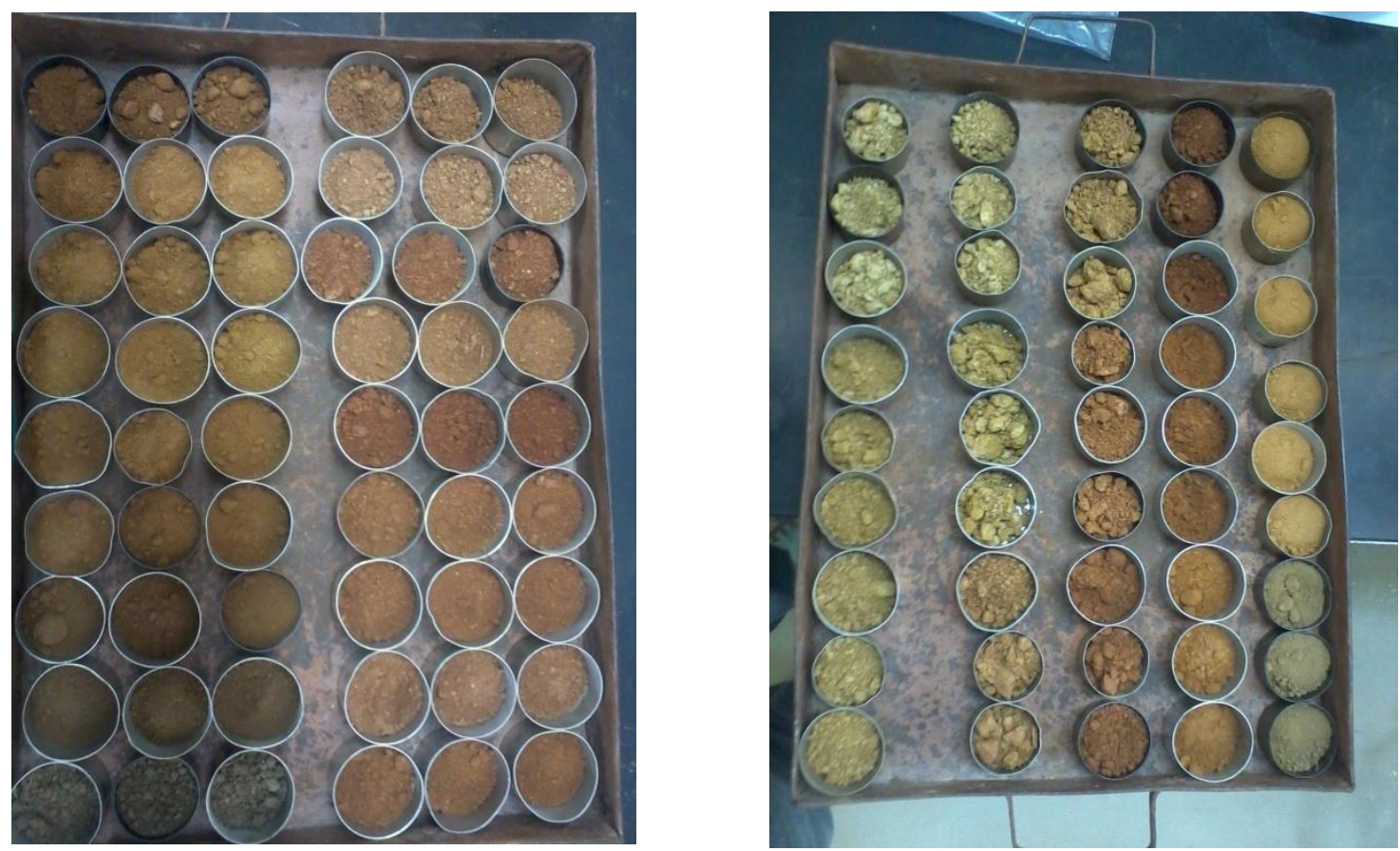

Figura 3.4 - (a) Amostras de solos Perfil P33; (b) Amostras de solos Perfil P22. 


\subsubsection{Ensaio das pastilhas METODOLOGIA MCT}

Este método permite a classificação do solo, a partir do comportamento de pastilhas moldadas em anéis de $20 \mathrm{~mm}$ de diâmetro interno e $5 \mathrm{~mm}$ de altura.

A fração do solo que passa na peneira de 0,42 $\mathrm{mm}$ de abertura é umedecida, espatulada até apresentar consistência plástica e resistência avaliada pela penetração de uma agulha padronizada com ponta chata, massa de $10 \mathrm{~g}$ e diâmetro de $1,30 \mathrm{~mm}$ que deve ser de 1 mm. Com o solo nessa consistência são moldadas as pastilhas (anéis). As mesmas devem ser secas ao ar na posição vertical e após a secagem medida a contração pela diferença entre o diâmetro do anel e o diâmetro da pastilha seca. Após a medida da contração os anéis contendo os corpos de prova foram colocados sobre uma pedra porosa (Figura 3.5) com livre suprimento de água. Ao absorver a água devem ser observados os fenômenos como inchamento, trincamento e amolecimento. Este último deve ser determinado com o mesmo penetrômetro utilizado para medir a consistência de moldagem.

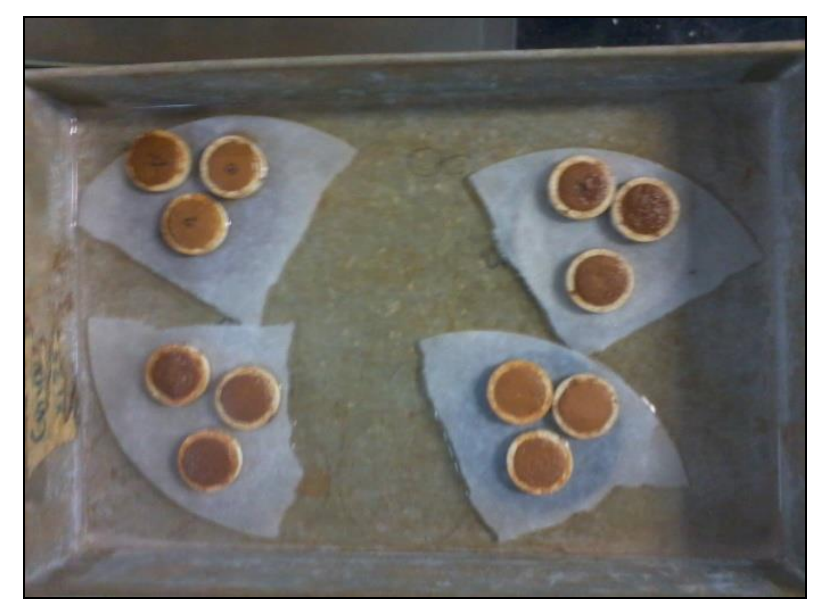

Figura 3.5 - Pastilhas sobre pedra porosa para posterior penetração da agulha.

O ensaio é executado com três pastilhas e posteriormente é efetuada a média dos valores obtidos, tanto de contração, quanto de penetração. Obtendo-se os valores de contração e penetração de cada amostra.

Com este método pode-se classificar os solos quanto a sua textura e poder dividi-los em duas grandes classes: os lateríticos e os não lateríticos, no total são sete grupos de solos com características distintas quanto ao seu comportamento geotécnico. Os solos lateríticos são subdivididos em argilosos (LG'), arenosos (LA'), e areias (LA). E os não lateríticos que são subdividios em argilosos (NG'), siltosos (NS'), arenosos (NA') e areias (NA). 
Este ensaio foi realizado em todas as amostras de cada perfil e furo escavados em campo. Para a classificação MCT expedita foram analisadas amostras coletadas a cada $0,50 \mathrm{~m}$ de profundidade no perfil, sendo que, em todos os perfis foi possível montar a classificação em função da profundidade.

\subsubsection{Limite de Plasticidade}

Dos índices de consistência somente o limite de plasticidade foi determinado para as amostras coletadas nos 15 perfis e cada camada. O ensaio foi executado de acordo com os previstos na norma NBR 7180 (ABNT, 1984). Ressalta-se que somente o ensaio de plasticidade foi realizado, uma vez que, esta parte da tese consistiu em verificar de forma rápida as características do solo local. Outro ponto a ser mencionado foi à quantidade de amostras que foram coletadas ao longo dessa fase de exploração em campo, gerando aproximadamente cerca de 150 amostras de solo, o que tornaria difícil a determinação do limite de liquidez pela quantidade de amostras.

\subsubsection{Carta Munsel para a determinação da cor dos solos}

A cor do solo é resultante de todos os seus componentes (minerais, matéria orgânica, umidade) e constitui uma das maneiras mais simples de descrevê-los. Neste trabalho a utilização da determinação deste atributo visou à determinação da razão entre hematita e goethita nas amostras. A determinação da cor do solo por meio da Tabela de Munsell foi realizada para este trabalho, comparando-se a cor encontrada com as contidas na tabela de cores. Para a determinação da cor moldou-se bolinhas na mesma umidade de moldagem para o ensaio de pastilhas (classificação MCT Expedita).

Após a determinação de cor, a partir dos resultados encontrados foi possível estabelecer a razão hematita goetitha. Neste caso utilizou-se a relação proposta por Santana (1986), adaptada de Torrent et al (1983), citados por Cardoso (2002), que emprega a cor obtida na Carta de Munssel, como segue, Equação 3.1:

$\mathrm{RGH}=(\mathrm{FV}-3,5) / 8,33$

Onde, FV é o fator de vermelho como definido n Equação 3.2:

$\mathrm{FV}=\mathrm{M}^{*}+\mathrm{C} / \mathrm{V}$ 
onde, C é o croma e V o valor. Os matizes (M) dos materiais estudados apresentam amarelo e vermelho (YR) ou somente vermelho (R). $\mathrm{M}^{*}$ assume valores complementares de $\mathrm{M}$ quando são misturas de amarelo e vermelhos, como, por exemplo para 2,5 YR, M* é igual a 7,5, ou para $5 \mathrm{YR}, \mathrm{M}^{*}$ é igual a 5 . No caso da matiz apenas com vermelho, os valores de $\mathrm{M}^{*}$ são os mesmos de M, por exemplo, para 10R, $\mathrm{M}^{*}$ é igual a 10.

\subsection{CARACTERIZAÇÃo do SOLO PARA A ÁREA DE EXECUÇÃo das CÉLULAS DE DIFUSÃO EM CAMPO}

Após a caracterização preliminar dos perfis e conhecimento das classes de solos, foi possível selecionar uma área para estudos de caracterização mais completa e detalhada para que posteriormente fossem construídas as células de difusão em campo. Inicialmente esperava-se que esta escolha fosse feita em função das características dos resultados dos ensaios preliminares, no entanto, só foi possível, em função de disponibilidade de uma área dentro da estação de tratamento fornecida pela Caesb. A partir desta seleção, amostras de solos deformadas e indeformadas foram coletadas para caracterização completa, determinação dos parâmetros de resistência, e determinação dos atributos de fluxo de contaminantes.

Os ensaios de caracterização física consistiram basicamente de umidade higroscópica $\left(\mathrm{w}_{0}\right)$, massa específica real dos grãos $(\rho s)$, análise granulométrica convencional e com granulômetro a laser, limite de liquidez $(w L)$, limite de plasticidade (wP), índice de plasticidade (IP), massa específica aparente seca ( $\rho$ d), índice de vazios (e) e porosidade (n).

A umidade higroscópica $\left(\mathrm{w}_{\mathrm{o}}\right)$ foi determinada de acordo com o ensaio preconizado pela NBR 6457 (ABNT, 1986). A massa específica real dos grãos ( $\rho$ s) determinada de acordo com a norma da NBR 6508 (ABNT, 1984). Análise granulométrica, determinação preconizada das normas da NBR 7181 (ABNT, 1984) e NBR 13602 (ABNT, 1996). Esta metodologia foi aplicada de duas maneiras: com e sem o uso do defloculante hexametafosfato de sódio. Além disso, utilizou-se o granulômetro a laser modelo "Microtrac s 3500". Foram realizados então os ensaios de compactação em equipamento em miniatura ME 228 (DNER, 1994), solos compactados em equipamento em miniatura Mini-MCV ME 258 (DNER, 1994), Solos compactados em miniatura - Determinação da perda de massa por imersão ME 256 (DNER, 1994).

Os limites de consistência foram determinados conforme a NBR 6459 (ABNT, 1984) limite de liquidez, e limite de plasticidade NBR 7180 (ABNT, 1984). O ensaio de 
compactação para obtenção da curva de compactação e a massa especifica aparente seca foi determinada conforme a NBR 7182 (ABNT, 1986), obtendo-se a massa específica aparente seca para cada umidade de solo compactado de forma dinâmica, ensaio tipo Proctor Normal, gerando desta forma uma curva de compactação. A permeabilidade foi determinada a partir da norma NBR 14545 (ABNT, 2000), que determina o coeficiente de permeabilidade de solos argilosos a carga variável. Neste ensaio a determinação foi feita tanto com o corpo de prova moldado no bloco em estado natural e compactado em diferentes umidades. O índice de vazios (e) foi determinado a partir da Equação (3.3):

$$
e=\frac{G \rho w}{\rho d}-1
$$

Onde: $\mathrm{G}=$ massa específica real dos grãos $\left(\mathrm{g} / \mathrm{cm}^{3}\right)$

$$
\rho d=\text { massa específica aparente seca máxima }\left(\mathrm{g} / \mathrm{cm}^{3}\right)
$$

A porosidade (n) foi determinada a partir da Equação (3.4):

$$
n=\frac{e}{1+e}
$$

Onde: e=índice de vazio.

\subsection{CARACTERIZAÇÃO DO EXTRATO DE LODO CENTRIFUGADO}

Após a caracterização física dos solos procedeu-se a caracterização do extrato de lodo. A estação de tratamento de esgoto no qual o extrato foi coletado foi a ETE Melchior, nessa Estação o sistema de tratamento consiste em: Reator anaeróbio de fluxo ascendente (RAFA) + lagoa facultativa + lagoa de alta taxa + lagoa de polimento + polimento Final. O lodo então é encaminhado para a unidade de processamento e centrifugação. Nesta fase o lodo é centrifugado e sai com uma umidade de aproximadamente $80 \%$, o extrato centrifugado (líquido retirado pelo processo de centrifugação) retorna ao sistema de tratamento na unidade de polimento. O extrato de lodo foi coletado e armazenado conforme as Figuras 3.6. 

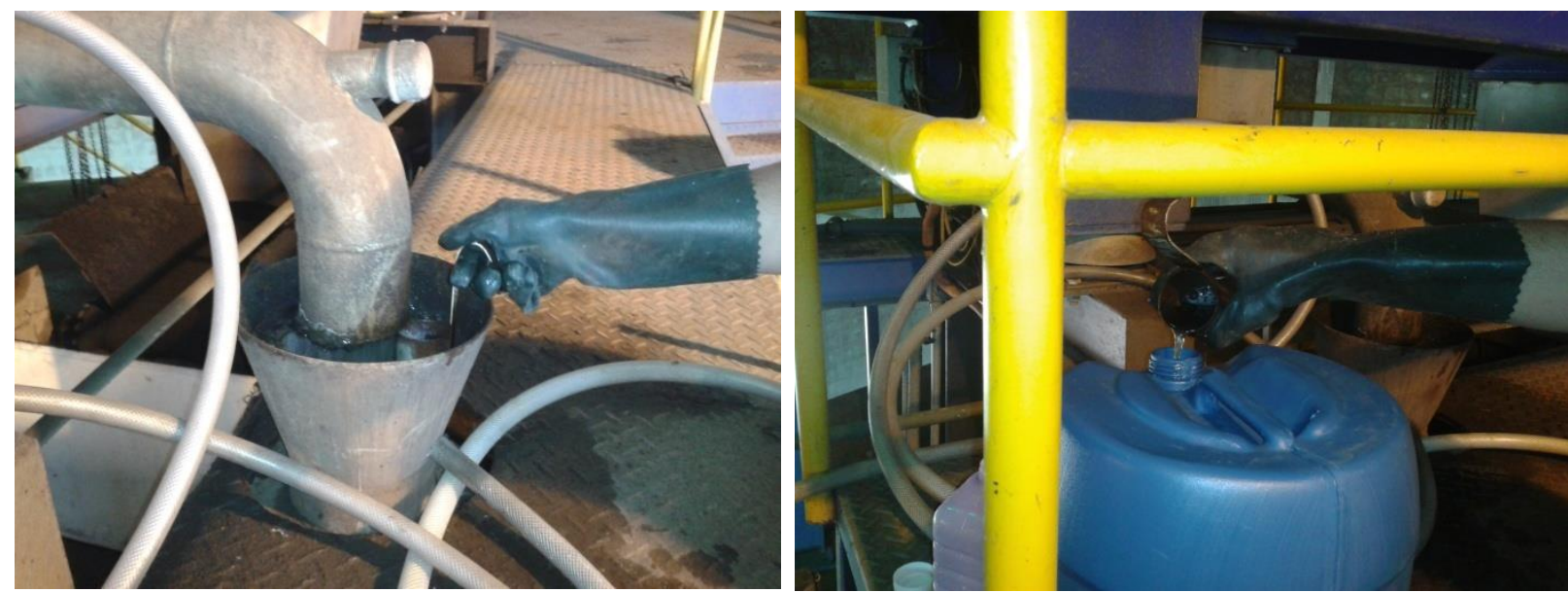

Figuras 3.6 (a), (b) - (a) Coleta do extrato centrifugado; (b) armazenamento do extrato de lodo centrifugado.

Após coleta o extrato de lodo foi encaminhado para o laboratório Solo Química, onde cerca de 1,5 litros utilizado para a determinação da concentração dos parâmetros: arsênio, cádmio, chumbo, cobre, cromo, mercúrio, níquel, zinco, nitrato, alumínio, boro, cálcio, cobre, sulfato, ferro, magnésio, manganês, potássio, sódio, sulfeto, cianeto, cloreto. $\mathrm{O} \mathrm{pH}$ e a condutividade foram determinados no laboratório de Saneamento da UnB. O restante do extrato foi armazenado no Laboratório de Geotecnia para os ensaios de compatibilidade solo/contaminante, determinação de $\mathrm{pH}$, para a determinação da curva característica e para contaminar as amostras a serem submetidas a ensaios de comportamento mecânico e hidráulico. Ressalta-se que o extrato de lodo ao retornar ao sistema de tratamento recebe dosagem de cal para a correção do $\mathrm{pH}$, e evitar efluentes mais ácidos no meio de tratamento.

Neste caso somente foi feita essa caracterização do extrato sem a adição de cal. Esta caracterização do extrato de lodo foi importante para conhecimento inicial da composição química e dos elementos que poderiam ser utilizados para o ensaio de difusão em laboratório.

No entanto após caracterização, verificaram-se concentrações baixas, dos elementos, o que configuraria que este efluente contaminante, não poderia ser utilizado nos ensaio de difusão e sorção, uma vez que a quantidade de metais apresentados não seriam detectados pelos limites de quantificação. Desta maneira, toda a parte de difusão e sorção o contaminante utilizado foi o coletado antes do processo de centrifugação, denominado de lodo bruto. 


\subsection{ENSAIOS GEOAMBIENTAIS}

Neste item serão apresentados os ensaios utilizados para o conhecimento e entendimento do fluxo de contaminantes do lodo de esgoto no solo, sendo eles: ensaio de sorção e ensaio de difusão $\left(\mathrm{D}^{*}\right)$. Além de ensaios de compatibilidade, propostos por Shackelford (1994).

\subsubsection{ENSAIO DE SORÇÃO}

O ensaio de sorção também conhecido como ensaio de batelada ou BET (batch equilíbrium test), objetiva determinar a relação entre massa de soluto adsorvida, normalizada em relação à massa de solo utilizada. $\mathrm{O}$ ensaio consiste basicamente em levar a agitação o contaminante de interesse, por um determinado tempo, com a mesma massa de solo, no entanto modificando as concentrações do contaminante.

Foram realizados os ensaios de sorção para as seguintes configurações: sorção com o contaminante de lodo de esgoto bruto, ensaio com a solução sintética de cloreto de cromo 3 e níquel, ensaio com o contaminante de lodo bruto para a determinação de nitrato.

O lodo bruto de esgoto foi coletado na estação de tratamento de esgoto da ETE Samambaia/Melchior, e encaminhado para o laboratório de Geotecnia da Universidade de Brasília. No laboratório esse contaminante foi utilizado puro $100 \%$ e diluído em água (1L), nas seguintes concentrações 80\%, 60\%, 40\%, 20\%. Foram essas as concentrações utilizadas para a determinação da sorção do nitrato no lodo de esgoto bruto e dos metais pesados, cádmio, cromo, níquel, manganês, zinco e cobre.

Já para a determinação da sorção de cromo 3, os cálculos e o procedimento da quantidade de cloreto de cromo 3 hexahidratado que seria utilizado para a produção de cada concentração, será descrito de forma detalhada para o entendimento do cálculo e obtenção das concentrações.

Os cálculos foram realizados por meio de regra de três simples, sendo que preferiu-se calcular relacionando a quantidade somente de cromo 3 da solução sintética de cloreto de cromo hexahidratado, sendo assim, assim bastava saber os valores para:

1 - cálculo da concentração molar do cloreto de cromo 3 hexahidratado;

2- cálculo da quantidade de cloreto de cromo 3 hexahidratado para cada concentração de cromo desejada. 
Após saber os valores da massa molar do cloreto de cromo hexahidratado, a molaridade do cromo 3, e a quantidade de cromo que se desejaria em cada concentração, os valores foram calculados por meio de regra de três simples. Conforme pode ser observado abaixo, com o cálculo para a solução de $0,25 \mathrm{~g}, 0,50 \mathrm{~g}, 1 \mathrm{~g}, 2 \mathrm{~g} \mathrm{e} 4 \mathrm{~g} \mathrm{de} \mathrm{Cr}^{3+}$.

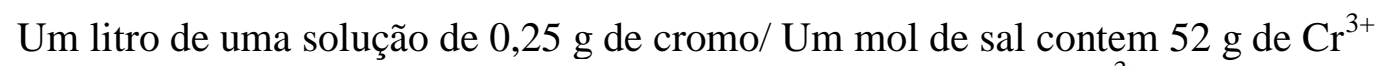

$$
\begin{aligned}
& \text { 266,5g } \mathrm{CrCl}_{3} .6 \mathrm{H}_{2} \mathrm{O} \text {.................52 } \mathrm{g} \mathrm{Cr}^{3+} \\
& \mathrm{x} \mathrm{g....................................} 0,25 \mathrm{~g} \mathrm{Cr}^{3+} \\
& \mathrm{x}=1,28125 \mathrm{~g} \text { de } \mathrm{CrCl} 3.6 \mathrm{H} 2 \mathrm{O}
\end{aligned}
$$

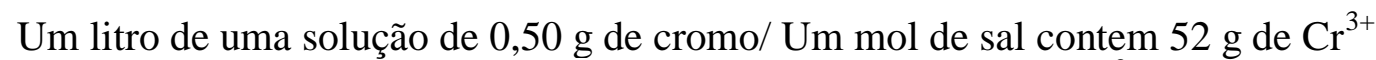

$$
\begin{aligned}
& \text { 266,5g } \mathrm{CrCl}_{3} .6 \mathrm{H}_{2} \mathrm{O} \ldots \ldots \ldots \ldots \ldots \ldots . . .52 \mathrm{~g} \mathrm{Cr}^{3+}
\end{aligned}
$$

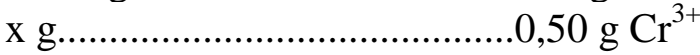

$$
\begin{aligned}
& \mathrm{x}=2,2625 \mathrm{~g} \text { de } \mathrm{CrCl} 3.6 \mathrm{H} 2 \mathrm{O}
\end{aligned}
$$

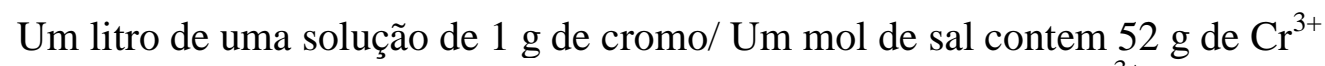

$$
\begin{aligned}
& \text { 266,5g } \mathrm{CrCl}_{3} .6 \mathrm{H}_{2} \mathrm{O} \text {.................52 } \mathrm{g} \mathrm{Cr}^{3+} \\
& \mathrm{x} \text { g.................................... } 0,25 \mathrm{~g} \mathrm{Cr}^{3+} \\
& \mathrm{x}=5,125 \mathrm{~g} \text { de } \mathrm{CrCl} 3.6 \mathrm{H} 2 \mathrm{O}
\end{aligned}
$$

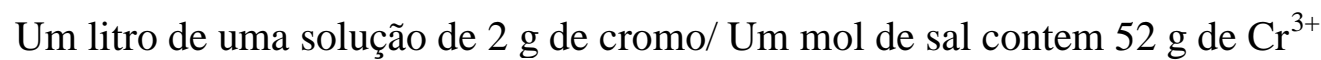

$$
\begin{aligned}
& \text { 266,5g } \mathrm{CrCl}_{3} .6 \mathrm{H}_{2} \mathrm{O} \text {.................52 } \mathrm{g} \mathrm{Cr}^{3+}
\end{aligned}
$$

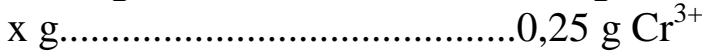

$$
\begin{aligned}
& \mathrm{x}=10,25 \mathrm{~g} \text { de } \mathrm{CrCl} 3.6 \mathrm{H} 2 \mathrm{O}
\end{aligned}
$$

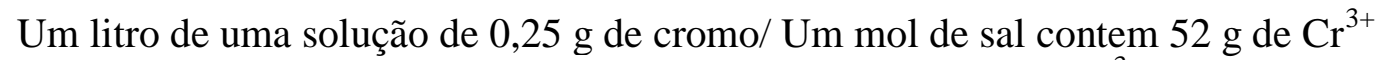

$$
\begin{gathered}
266,5 \mathrm{~g} \mathrm{CrCl}_{3} .6 \mathrm{H}_{2} \mathrm{O} \ldots \ldots \ldots \ldots \ldots \ldots . .52 \mathrm{~g} \mathrm{Cr}^{3+} \\
\mathrm{x} \mathrm{g. \ldots \ldots \ldots \ldots \ldots \ldots \ldots \ldots \ldots \ldots \ldots \ldots \ldots ..0,25} \mathrm{g} \mathrm{Cr}^{3+} \\
\mathrm{x}=20,5 \mathrm{~g} \mathrm{de} \mathrm{CrCl} 3.6 \mathrm{H} 2 \mathrm{O}
\end{gathered}
$$

A Tabela 3.2 apresenta as concentrações, calculadas, tanto para os valores em g de cromo 3, como os valores em mg/L da solução.

Tabela 3.2 - Valores de $\mathrm{Cr}^{3+}$ para a produção da solução sintética.

\begin{tabular}{c|c|c}
\hline $1,28125 \mathrm{~g} \mathrm{de} \mathrm{CrCl}_{3} \cdot 6 \mathrm{H}_{2} \mathrm{O}$ & $0,25 \mathrm{~g} \mathrm{de} \mathrm{Cr}^{3+}$ & $250 \mathrm{mg} / \mathrm{L}$ \\
\hline $2,5625 \mathrm{~g} \mathrm{de} \mathrm{CrCl}_{3} \cdot 6 \mathrm{H}_{2} \mathrm{O}$ & $0,5 \mathrm{~g} \mathrm{Cr}^{3+}$ & $500 \mathrm{mg} / \mathrm{L}$ \\
\hline $5,125{\mathrm{~g} \mathrm{de} \mathrm{CrCl}_{3} \cdot 6 \mathrm{H}_{2} \mathrm{O}}_{10,25 \mathrm{~g} \mathrm{de} \mathrm{CrCl}_{3} \cdot 6 \mathrm{H}_{2} \mathrm{O}}$ & $2 \mathrm{~g} \mathrm{Cr}^{3+}$ & $1000 \mathrm{mg} / \mathrm{L}$ \\
\hline $20,5 \mathrm{~g} \mathrm{de} \mathrm{grCl}_{3} \cdot 6 \mathrm{H}_{2} \mathrm{O}$ & $4 \mathrm{~g} \mathrm{Cr}^{3+}$ & $2000 \mathrm{mg} / \mathrm{L}$ \\
\hline
\end{tabular}


Para a determinação da sorção do níquel, os cálculos e o procedimento da quantidade de cloreto de níquel hexahidratado que foi utilizado para a produção de cada concentração. Os cálculos foram realizados por meio de regra de três simples, sendo que preferiu-se calcular relacionando a quantidade somente de níquel da solução sintética de cloreto de níquel hexahidratado, sendo assim, assim bastava saber os valores para:

1 - cálculo da concentração molar do cloreto de níquel hexahidratado;

2- cálculo da quantidade de cloreto de níquel hexahidratado para cada concentração de cromo desejada.

Após saber os valores da massa molar do cloreto de níquel hexahidratado, a molaridade do níquel, e a quantidade de cromo que se desejaria em cada concentração, os valores foram calculados por meio de regra de três simples. Conforme pode ser observado abaixo, com o calculo para a solução de, $0,50 \mathrm{~g}, 1 \mathrm{~g}, 2 \mathrm{~g}$ e $4 \mathrm{~g}$ e $8 \mathrm{~g}$ de Ni.

Um litro de uma solução de $0,50 \mathrm{~g}$ de níquel/ Um mol de sal contem 58,69 g de $\mathrm{Ni}$

$$
\begin{aligned}
& 237,66 \mathrm{~g} \quad \mathrm{NiCl}_{2} 6 \mathrm{H}_{2} \mathrm{O} \ldots \ldots \ldots \ldots \ldots . . . . .58,69 \mathrm{Ni} \\
& \text { x g...................................... } 0,5 \mathrm{~g} \mathrm{Ni} \\
& \mathrm{x}=2,02470 \mathrm{~g} \text { de } \mathrm{NiCl}_{2} 6 \mathrm{H}_{2} \mathrm{O}
\end{aligned}
$$

Um litro de uma solução de $1 \mathrm{~g}$ de níquel/ Um mol de sal contem 58,69 g de Ni

$$
\begin{aligned}
& \text { 237,66g } \mathrm{NiCl}_{2} 6 \mathrm{H}_{2} \mathrm{O} \text {.................58,69 Ni } \\
& \mathrm{x} \text { g...................................... } \mathrm{g} \mathrm{Ni} \\
& \mathrm{x}=4,04941 \mathrm{~g} \text { de } \mathrm{NiCl}_{2} 6 \mathrm{H}_{2} \mathrm{O}
\end{aligned}
$$

Um litro de uma solução de $2 \mathrm{~g}$ de níquel/ Um mol de sal contem 58,69 g de Ni

$$
\begin{aligned}
& 237,66 \mathrm{~g} \quad \mathrm{NiCl}_{2} 6 \mathrm{H}_{2} \mathrm{O} \ldots \ldots \ldots \ldots \ldots . . . .58,69 \mathrm{Ni} \\
& \mathrm{x} \text { g.......................................... } \mathrm{g} \mathrm{Ni} \\
& \mathrm{x}=8,09882 \mathrm{~g} \text { de } \mathrm{NiCl}_{2} 6 \mathrm{H}_{2} \mathrm{O}
\end{aligned}
$$

Um litro de uma solução de $4 \mathrm{~g}$ de níquel/ Um mol de sal contem 58,69 g de Ni

$$
\begin{aligned}
& 237,66 \mathrm{~g} \quad \mathrm{NiCl}_{2} 6 \mathrm{H}_{2} \mathrm{O} \ldots \ldots \ldots \ldots \ldots \ldots . .58,69 \mathrm{Ni} \\
& \mathrm{x} \text { g.................................... } 4 \mathrm{~g} \mathrm{Ni} \\
& x=16,19764 \mathrm{~g} \text { de } \mathrm{NiCl}_{2} 6 \mathrm{H}_{2} \mathrm{O}
\end{aligned}
$$

Um litro de uma solução de $8 \mathrm{~g}$ de níquel/ Um mol de sal contem 58,69 g de Ni

$$
\begin{aligned}
& \text { 237,66g } \mathrm{NiCl}_{2} 6 \mathrm{H}_{2} \mathrm{O} \text {................58,69 Ni } \\
& \mathrm{x} \text { g...................................... } 8 \mathrm{~g} \mathrm{Ni} \\
& \mathrm{x}=32,39529 \mathrm{~g} \text { de } \mathrm{NiCl}_{2} 6 \mathrm{H}_{2} \mathrm{O}
\end{aligned}
$$

A Tabela 3.3 apresenta as concentrações, calculadas, tanto para os valores em g de níquel, como os valores em mg/L da solução. 
Tabela 3.3 - Valores de Ni para a produção da solução sintética

\begin{tabular}{c|c|c}
\hline $2,02470 \mathrm{~g}$ de $\mathrm{NiCl}_{2} 6 \mathrm{H}_{2} \mathrm{O}$ & $0,5 \mathrm{~g} \mathrm{Ni}$ & $500 \mathrm{mg} / \mathrm{L}$ \\
\hline $4,04941 \mathrm{~g} \mathrm{de} \mathrm{NiCl}_{2} 6 \mathrm{H}_{2} \mathrm{O}$ & $1 \mathrm{~g} \mathrm{Ni}$ & $1000 \mathrm{mg} / \mathrm{L}$ \\
\hline $8,09882 \mathrm{~g} \mathrm{de} \mathrm{NiCl}_{2} 6 \mathrm{H}_{2} \mathrm{O}$ & $2 \mathrm{~g} \mathrm{Ni}$ & $2000 \mathrm{mg} / \mathrm{L}$ \\
\hline $16,19764 \mathrm{~g} \mathrm{de} \mathrm{NiCl}_{2} 6 \mathrm{H}_{2} \mathrm{O}$ & $4 \mathrm{~g} \mathrm{Ni}$ & $4000 \mathrm{mg} / \mathrm{L}$ \\
\hline $32,39529 \mathrm{~g} \mathrm{de} \mathrm{NiCl}_{2} 6 \mathrm{H}_{2} \mathrm{O}$ & $8 \mathrm{~g} \mathrm{NI}$ & $8000 \mathrm{mg} / \mathrm{L}$ \\
\hline
\end{tabular}

O ensaio de sorção em laboratório foi efetuado seguindo as recomendações da norma ASTM ES-1085 (ou D4319), os procedimentos após foram:

1 - preparou-se as concentrações para o contaminante de lodo de esgoto, e as concentrações para o cloreto de cromo 3 hexahidratado;

2 - preparou-se o solo, previamente seco, o mesmo foi passado na peneira de $\mathrm{n}^{\circ} 10(2 \mathrm{~mm}$ de abertura) e homogeneizado;

3 - colocou-se as amostras de solo preparadas em frascos de coleta universal com capacidade de $50 \mathrm{ml}$ graduados e com tampa. A massa utilizada foi de $4 \mathrm{~g}$ de solo, e o volume de $40 \mathrm{ml}$, com uma razão de 1:10 de solo-solução;

4 - Os frascos com as relações 1:10 das soluções solo contaminante de lodo bruto de esgoto, solo solução sintética de cloreto de cromo hexaidratado, solo solução sintética de cloreto de níquel e solo contaminante de lodo bruto com nitrato, permaneceram em agitação por 24 horas, no agitador do laboratório de Saneamento e Recursos Hídricos, da UNB,

5 - Após o tempo de mistura, a solução 1:10 de todas as configurações do item 4 , foram transferidos para tudo de centrífugas e foram centrifugados durante 5 minutos na centrífuga do laboratório de Saneamento e Recursos Hídricos da UnB;

6 - Após o tempo de mistura, o sobrenadante foi retirado e encaminhado imediatamente para laboratório para análise de metais pesados. Para a análise da concentração de cromo 3, as amostras foram filtradas em membrana (filtro analítico em fibra de vidro $47 \mathrm{~mm}$ ), e determinada a absorbância por espectrofotometria, para posterior cálculo da concentração. A concentração de nitrato também foi determinada por espectrofotometria. Tanto as análises com a solução sintética como a de nitrato foram realizadas no laboratório de Saneamento e Recursos Hídricos no SG-12.

7 - determinações da massa de soluto adsorvida pelo solo/ massa do solo (s) e plotagem de $\mathrm{S}$ (massa de soluto/massa de solo) X (mg de soluto/litros de solução). 
A adsorção para cada razão solo/solução é calculada pela seguinte fórmula:

$$
S(\%)=\frac{(C o-C)}{m} x V
$$

Onde: $\mathrm{S}=$ sorção, $\mathrm{mg} / \mathrm{g}$

$\mathrm{C}_{0}=$ concentração inicial da solução, colocada em contanto com o solo, mg/L

$\mathrm{C}=$ concentração final obtida após o equilíbrio, $\mathrm{mg} / \mathrm{L}$;

$\mathrm{V}=$ volume da solução utilizada, $\mathrm{L}$;

$\mathrm{m}=$ massa de solo, $\mathrm{g}$.

\subsubsection{ENSAIO DE DIFUSÃO}

O ensaio de difusão utilizado foi o desenvolvido por Barone et al. (1989) e adaptado por Boscov (1997) para solos compactados. Ressalta-se que modificações na metodologia foi desenvolvida para este trabalho. Para o ensaio de difusão, quatro configurações foram montadas, sendo elas: difusão com o corpo de prova não saturado e solução contaminante de lodo bruto de esgoto antes de passar pelo processo de centrifugação (difusão multiespécie); difusão com o corpo de prova saturado e solução contaminante de lodo bruto de esgoto antes de passar pelo processo de centrifugação (difusão multiespécie); difusão com solução sintética de cloreto de cromo em concentração decrescente no reservatório; difusão com solução sintética de cloreto de níquel em concentração decrescente no reservatório e difusão com a solução contaminante de lodo bruto de esgoto antes de passar pelo processo de centrifugação para determinação da difusão de nitrato com concentração decrescente nos reservatórios.

\subsubsection{ENSAIOS DE DIFUSÃO MULTIESPÉCIE NÃO SATURADO E SATURADO}

As células de difusão utilizadas foram às desenvolvidas por Gurjão (2005), essas células foram construídas em acrílico medindo $11.7 \mathrm{~cm}$ de altura e $9.7 \mathrm{~cm}$ de diâmetro, com base e topo parafusáveis e anéis de vedação (o-rings), a fim de se obter uma estanqueidade total da célula. O corpo de prova utilizado tinha $3 \mathrm{~cm}$ de altura e diâmetro igual a 9,7 cm.

Os corpos de prova foram compactados estaticamente na célula de difusão (Figura 3.7). O solo foi umificado na umidade ótima de Energia Proctor Normal e calculada a 
quantidade em massa necessária para ocupar o volume da célula com a massa especifica aparente seca máxima obtida no ensaio de compactação. Ao todo foram compactados 10 corpos de prova nas células de difusão para o ensaio de condição não saturada (Figura 3.8) e 6 corpos de prova na condição saturada (Figura 3.9).

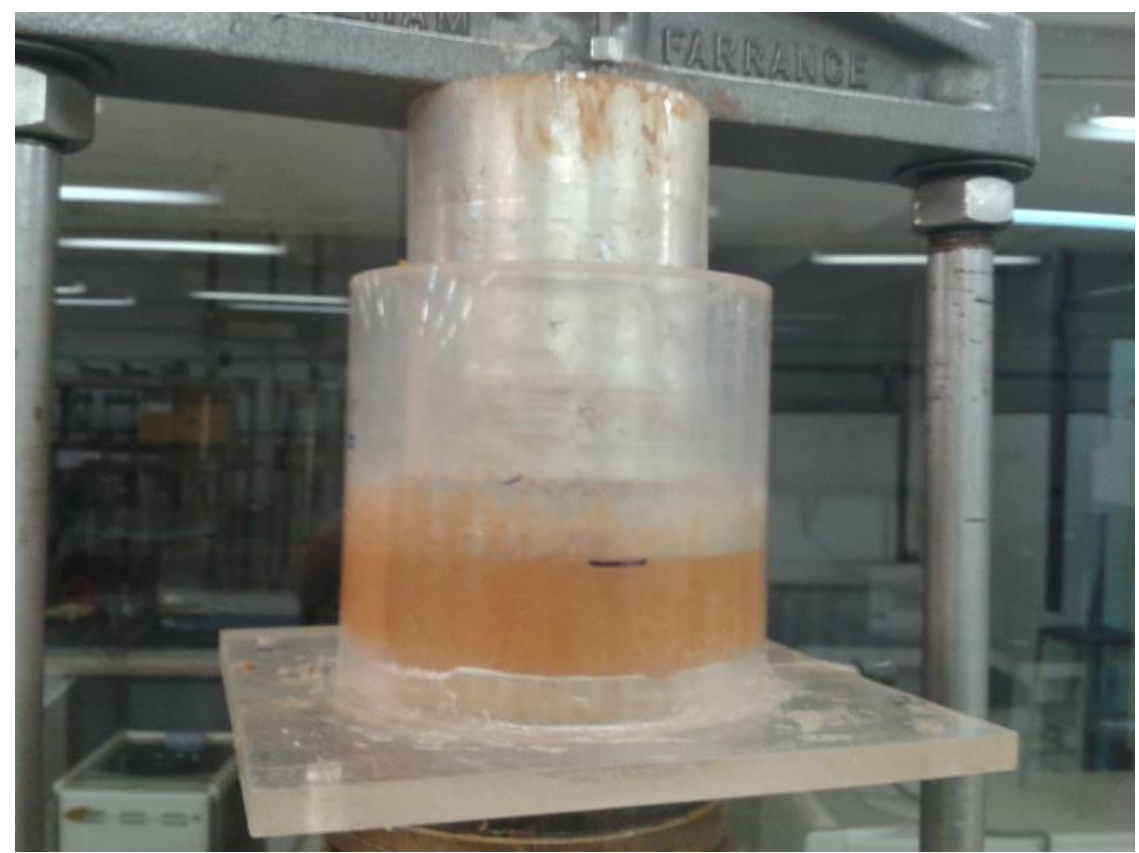

Figura 3.7 - Compactação do corpo de prova na célula de difusão

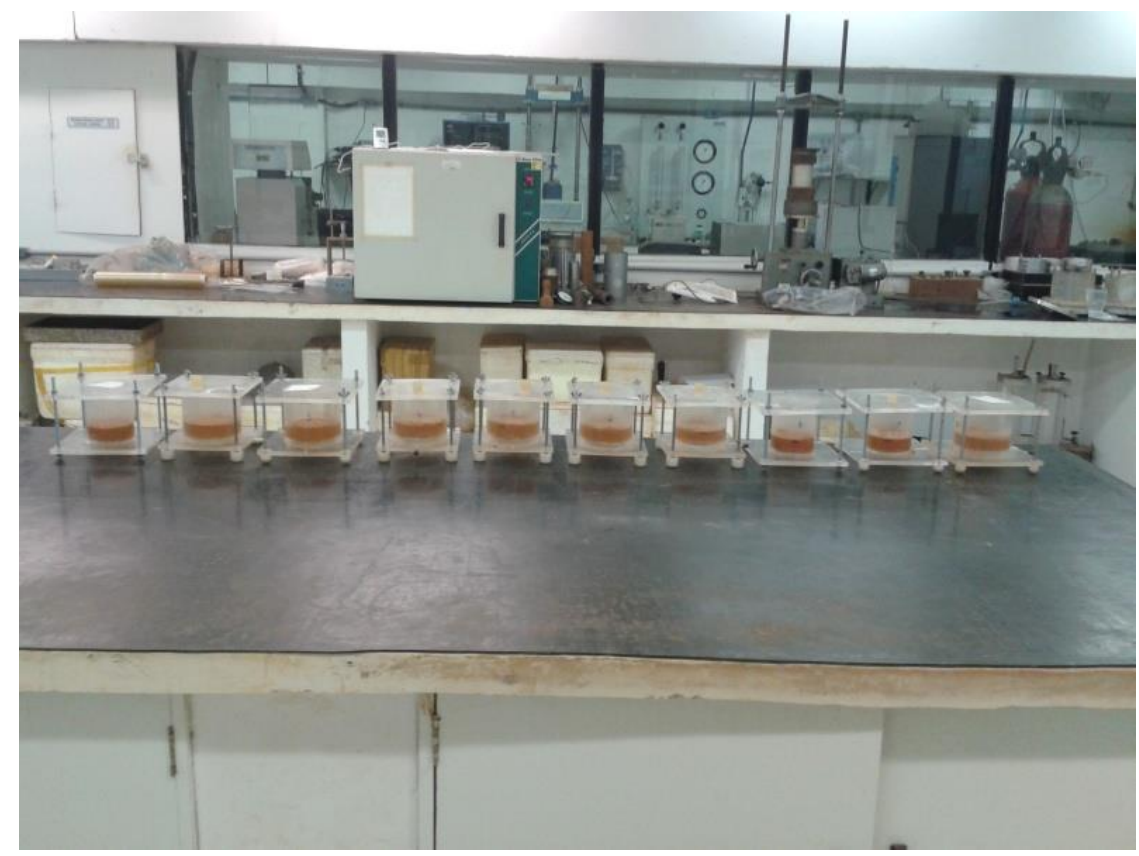

Figura 3.8 - Células de difusão para o ensaio com o corpo de prova não saturado 


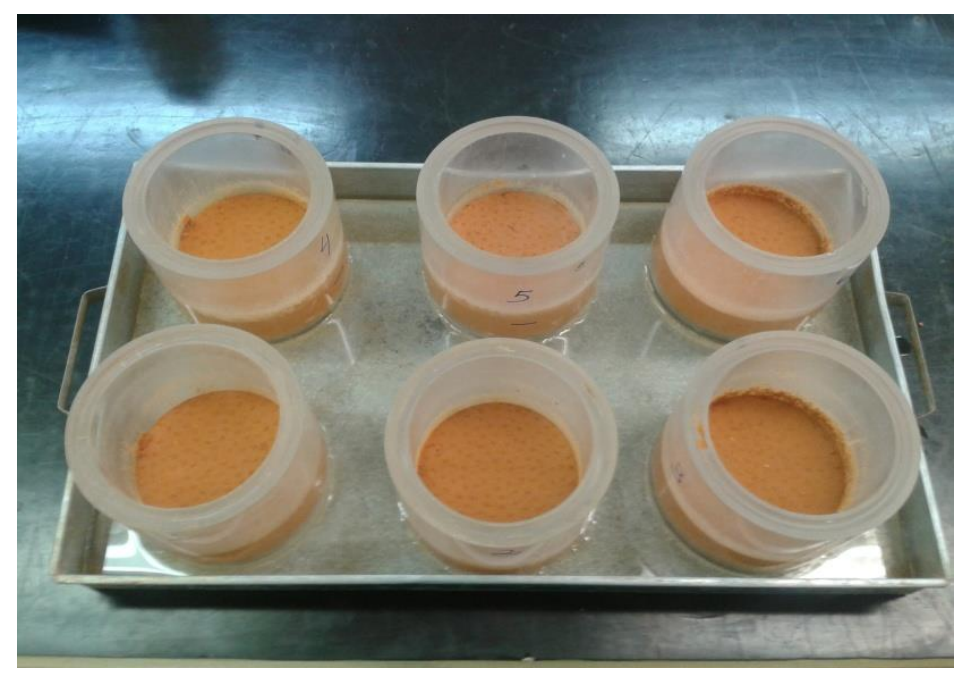

Figura 3.9 - Células saturando.

Os corpos de prova foram compactados com graus de compactação da ordem de $100 \%$ e com a umidade no ponto ótimo da curva de compactação.

As células foram preenchidas com solução contaminante de lodo bruto de esgoto, coletado na ETE Melchior e após preenchimento, colocadas em local adequado para a execução do ensaio. A Figura 3.10 mostra (a) a solução contaminante (b) o preenchimento da célula; e a e a Figura 3.11 (c) célula preenchida; (d) células em local para a execução do ensaio.

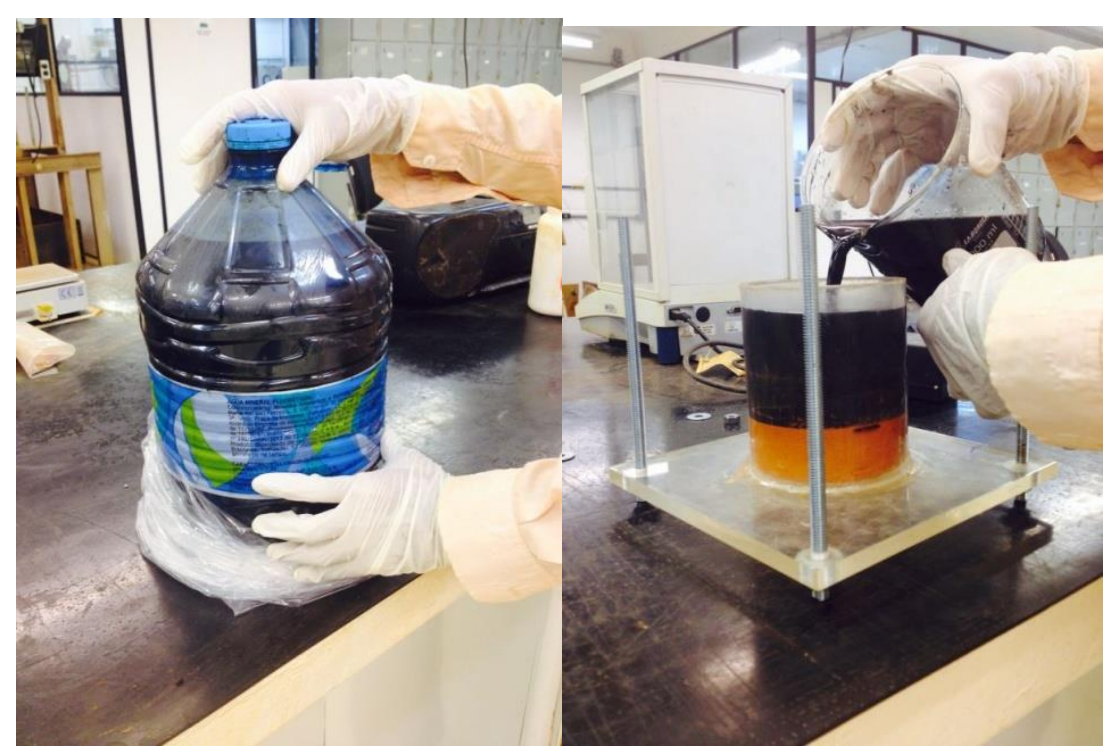

Figura 3.10 - Contaminante: (a) solução contaminante coletada; (b) preenchimento da célula. 


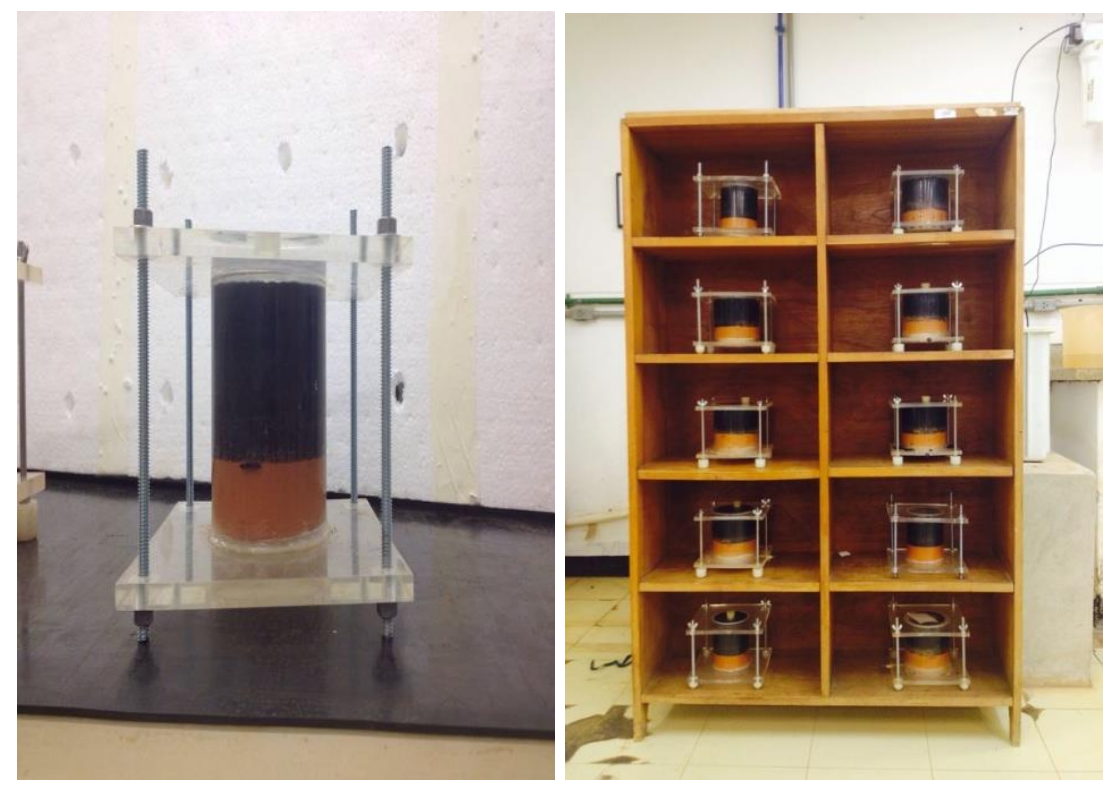

Figura 3.11 - Contaminante: (c) célula preenchida; (d) células para execução do ensaio.

O procedimento de execução do ensaio consistiu em verificar a difusão para 30 dias (corpo de prova não saturado), e 18 dias (corpo de prova saturado). Diferentemente dos ensaios de difusão já realizados e citados pela literatura com concentrações decrescentes nos reservatórios, modificações na execução foram realizadas, que será explicada a seguir.

O experimento foi realizado onde cada célula compactada e preenchida com a solução de lodo de esgoto foi encerrada a cada 3 dias, ou seja, iniciou-se o ensaio no tempo $t=0$ e no terceiro dia foi encerrada a primeira célula, assim sucessivamente até a décima célula (para a condição não saturada). $\mathrm{O}$ mesmo procedimento foi realizado com as células que continham o liner saturado, o que diferenciava, era a duração do ensaio, 18 dias. Ao encerrar cada célula a solução contaminante era coletada e armazenada em recipiente para posteriores análises dos metais selecionados. Após encerrar, o corpo de prova compactado era pesado, fatiado a cada 1 cm e determinada a umidade para verificação e do momento em que houve a saturação do liner pela própria solução contaminante, neste caso, este procedimento era realizado somente para a condição não saturada.

O ensaio consistiu em monitorar a concentração dos metais: cádmio $(\mathrm{Cd})$, cromo $(\mathrm{Cr})$, níquel $(\mathrm{Ni})$, manganês $(\mathrm{Mn})$, cobre $(\mathrm{Cu})$ e zinco $(\mathrm{Zn})$, tanto na solução contaminante, como no liner. Para o liner a determinação da concentração de metais foi realizada a cada $1 \mathrm{~cm}$, totalizando três amostras de solo, para cada célula encerrada Este procedimento foi realizado, tanto para o experimento com liner não saturado, como para o liner saturado. A determinação 
dos metais, tanto no lodo bruto de esgoto como no solo foi realizada pelo laboratório Quinosan, credenciado pelo Conselho de Química.

\subsubsection{ENSAIO DE DIFUSÃo COM A SOLUÇÃo SINTÉTICA DE CLORETO DE CROMO $3 \mathrm{Cr}_{3}^{+}$}

Este experimento foi realizado conforme os descritos por Gurjão (2005), com concentrações decrescentes em cada reservatório. Os corpos de prova foram compactados nas células de difusão com a energia proctor normal, com grau de compactação de forma a assegurar que os mesmos ficassem com a massa específica aparente seca determinada na curva de compactação. Os corpos de prova foram saturados de forma a obter no mínimo 95\% de saturação. Todo este experimento foi realizado na condição saturada.

A solução sintética de cloreto de cromo foi produzida nas concentrações de $0,25 \mathrm{~g}$, 0,5g, 1g, 2,g e 4g de cromo para a solução de um litro de cloreto de cromo 3 hexahidratato, ou seja, $250 \mathrm{mg} / \mathrm{L}, 500 \mathrm{mg} / \mathrm{L}, 1000 \mathrm{mg} / \mathrm{L}, 2000 \mathrm{mg} / \mathrm{L}$ e $4000 \mathrm{mg} / \mathrm{L}$ de cromo para cada célula ensaiada (Figura 3.12).

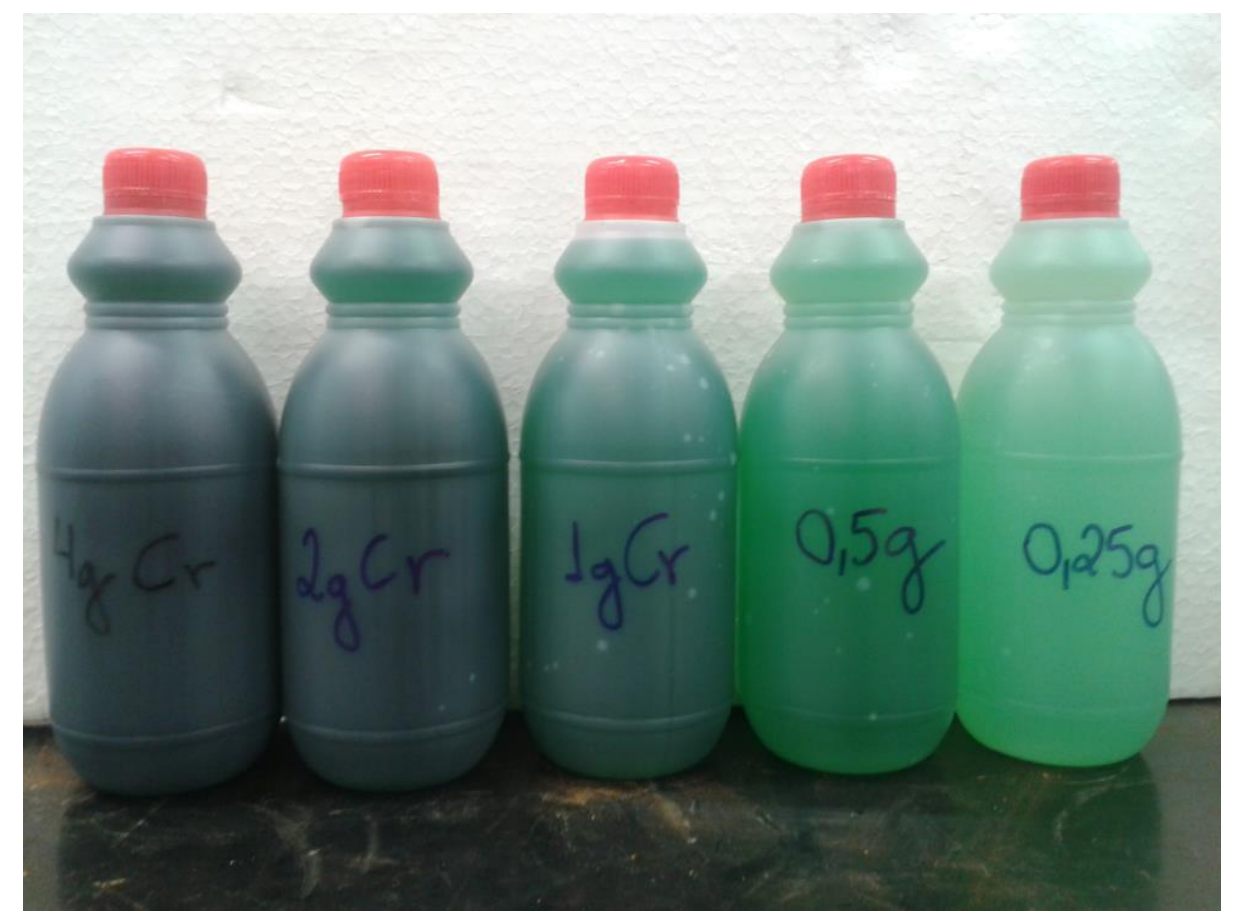

Figura 3.12 - Soluções de $\mathrm{Cr}^{3+}$ preparadas nas diferentes concentrações 
Amostras da solução na célula (Figura 3.13) foram coletadas em intervalos de 4, 8, 12, $16,20,24,28,32$ e 36 dias através do orifício na tampa da célula, por meio de uma seringa descartável, para monitoramento da concentração em ensaio de absorção atômica. Esta determinação foi realizada no Laboratório de Saneamento da Universidade de Brasília.

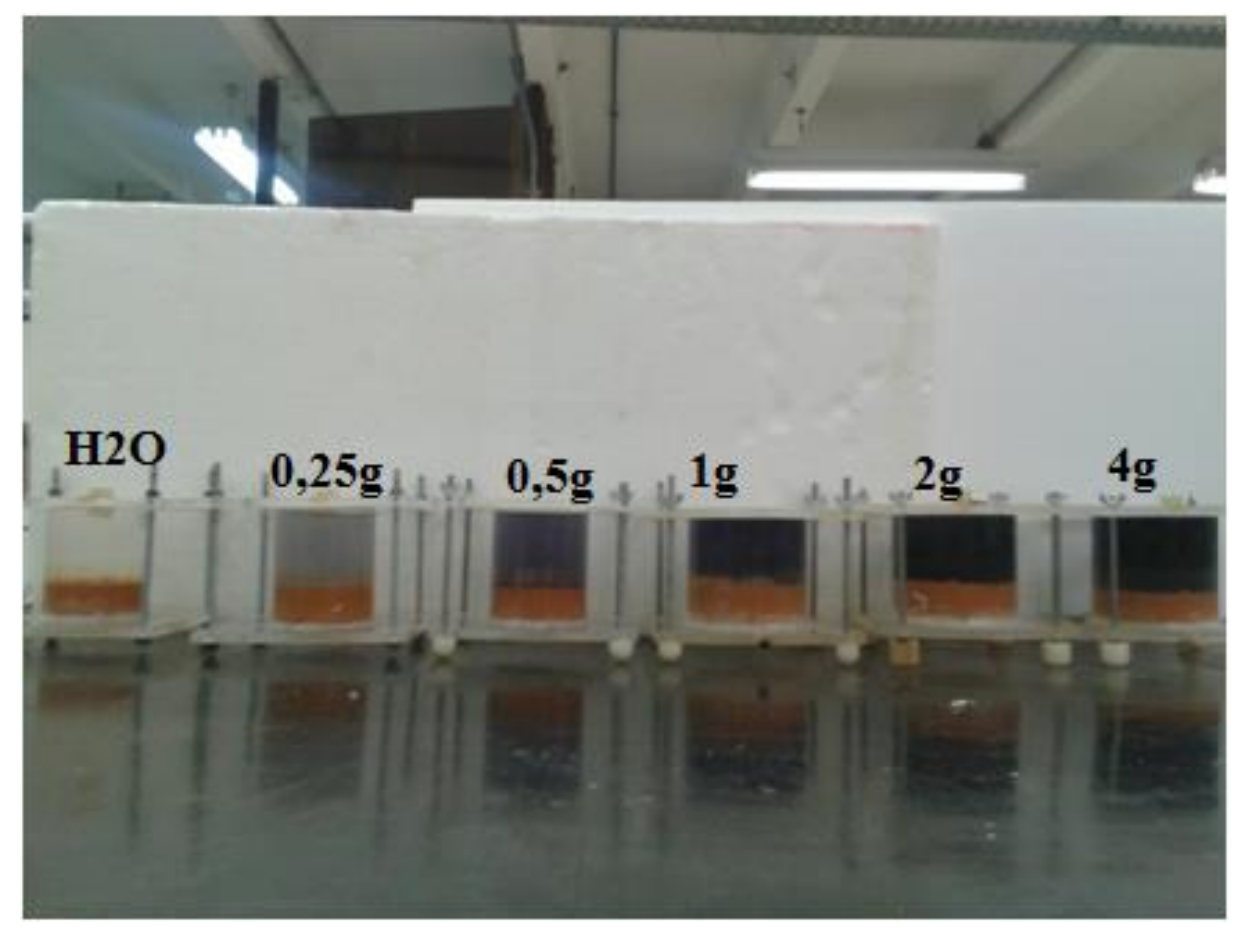

Figura 3.13 - Diferentes concentrações da solução contaminante.

\subsubsection{ENSAIO DE DIFUSÃO CLORETO DE NÍQUEL $\mathbf{N}^{+2}$}

Para o ensaio de difusão com a solução sintética de níquel, os liners foram compactados nas células de difusão com a energia proctor normal, com grau de compactação de forma a assegurar que os mesmos ficassem com a massa específica aparente seca determinada na curva de compactação. Os corpos de prova foram saturados de forma a obter 95\% de saturação. Todo este experimento foi realizado na condição saturada.

As soluções sintéticas de cloreto de níquel (Figura 3.12) foram produzidas nas concentrações de $1 \mathrm{~g}, 2 \mathrm{~g}$ e $4 \mathrm{~g}$ de níquel para a solução de cloreto de níquel hexahidratado, ou seja 1000 mg/L, 2000 mg/L e 4000 mg/L de níquel para cada célula ensaiada. 


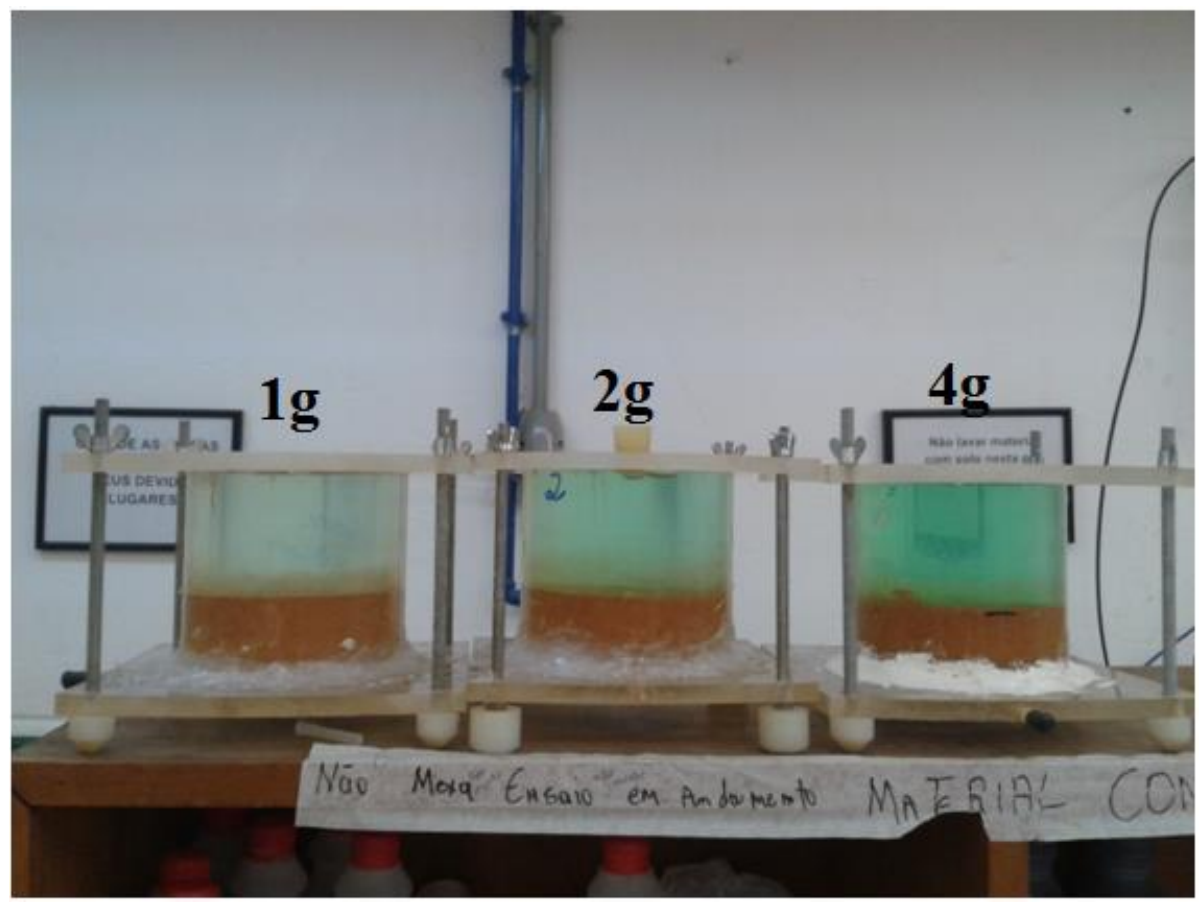

Figura 3.14 - Diferentes concentrações da solução sintética de $\mathrm{Ni}^{+2}$

Amostras da solução, na célula, foram coletadas em intervalos de 2, 4, 6, 8, 10, 12, 14, 16, 18, 20, 22 dias através do orifício na tampa da célula, por meio de uma seringa descartável, para monitoramento da concentração em ensaio de absorção atômica. Esta determinação foi realizada no Laboratório de Saneamento da Universidade de Brasília. Para a determinação de níquel o solo foi fatiado em três camadas e as amostras foram encaminhada para o Laboratório Solo Química.

\subsubsection{ENSAIO DE DIFUSÃO COM NITRATO}

Os corpos de prova foram compactados nas células de difusão conforme os parâmetros da compactação já mencionados nos demais ensaios de difusão. Os ensaios realizados foram do tipo reservatório simples com concentração da fonte decrescente. Ao todo foram compactados seis corpos de prova, sendo que um deles foi preenchido com água deionizada servindo como branco do experimento. O contaminante utilizado foi o lodo de esgoto bruto coletado na lagoa de lodo da estação de tratamento de esgoto da ETE Samambaia/Melchior, o mesmo utilizado para o ensaio de difusão multiespécie, conforme pode ser observado na Figura 3.14. Este contaminante de lodo de esgoto foi o mesmo utilizado para o ensaio de difusão multiespécie com metais. 


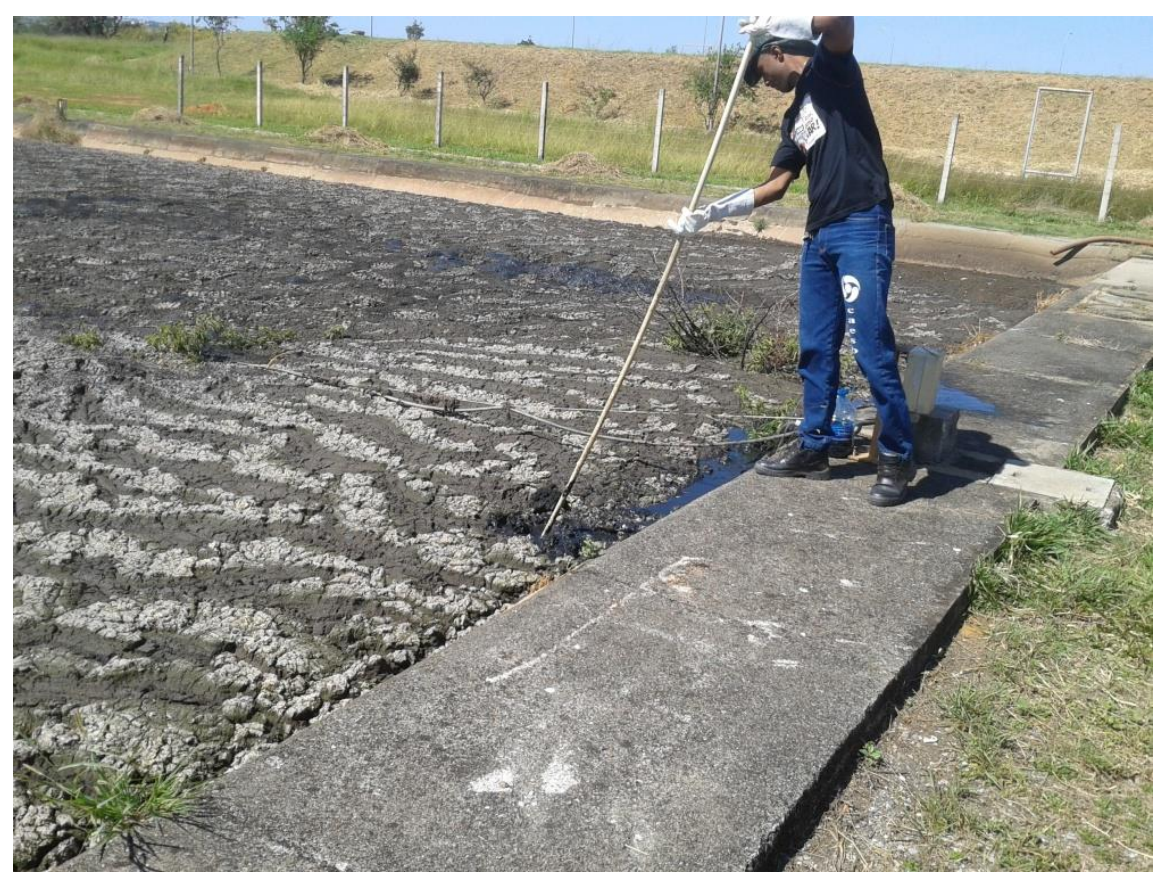

Figura 3.15 - Coleta do contaminante de lodo de esgoto.

O procedimento experimental consistiu em medir a concentração de nitrato do contaminante de lodo de esgoto colocado em contato com o liner compactado na célula de difusão dos reservatórios. Nos CP1 e CP2 o ensaio teve a duração de 4 dias, para o CP3 e CP4 duração de 8 dias e o CP5 duração de 32 dias. A concentração utilizada foi (CP1 100\%), (CP2 60\%), (CP3 100\%), (CP4 60\%), (CP 5 100\%). A Figura (3.16) mostra os corpos de prova $\mathrm{CP} 1, \mathrm{CP} 2, \mathrm{CP} 3$ e CP4.

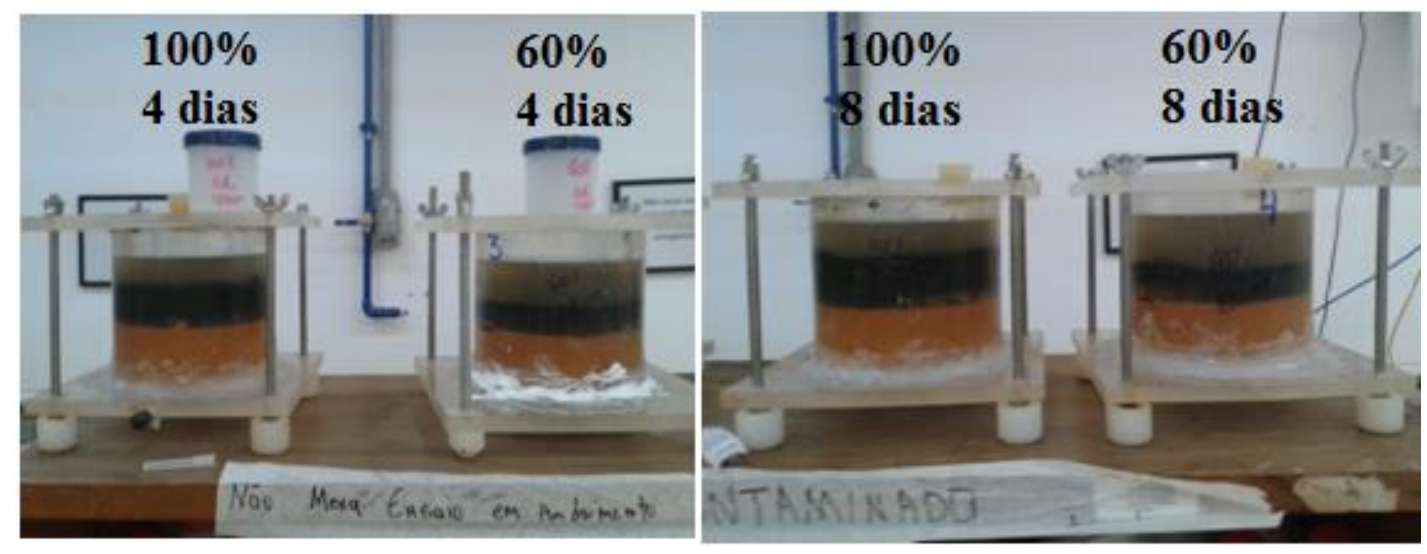

Figura 3.16 - Células de difusão. (a) CP1 e CP2, (b) CP 2 e CP4. 
Periodicamente as amostras do contaminante eram retiradas dos reservatórios com seringa para a determinação da concentração de nitrato. As coletas foram realizadas da seguinte maneira:

1 - para o ensaio de 4 dias, foram coletadas 3 amostras no primeiro dia, e duas amostras nos demais dias, sempre as 09:00 e 18:00;

2 - para o ensaio de 8 dias, foram coletadas 3 amostras no primeiro dia, e uma nos demais dias, sempre as 15:00;

3 - para o ensaio de 32 dias, foram coletadas amostras com intervalos de dois dias.

As determinações da concentração de nitrato foram realizadas no Laboratório de Saneamento da Universidade de Brasília. Para a determinação da concentração, utilizou-se o método colorimétrico de redução por cádmio utilizando o kit da Hach Nitraver 5. As amostras eram diluídas num fator de 50 vezes para as amostras de $100 \%$, e 20 vezes para as amostras de $60 \%$, conforme pode ser observado na Figura 3.17, após a diluição uma alíquota de $25 \mathrm{~mL}$ era transferido para a cubeta, e acrescentado o sache Nitraver 5 para reação e redução, de forma que o espectrofotômetro (Figura 3.18) realizasse a leitura. Ressalta-se que a diluição era necessária, uma vez que este método tem sensibilidade de detecção na faixa de 0,3 a 30 $\mathrm{mg} / \mathrm{L} \mathrm{de}^{-3}$.

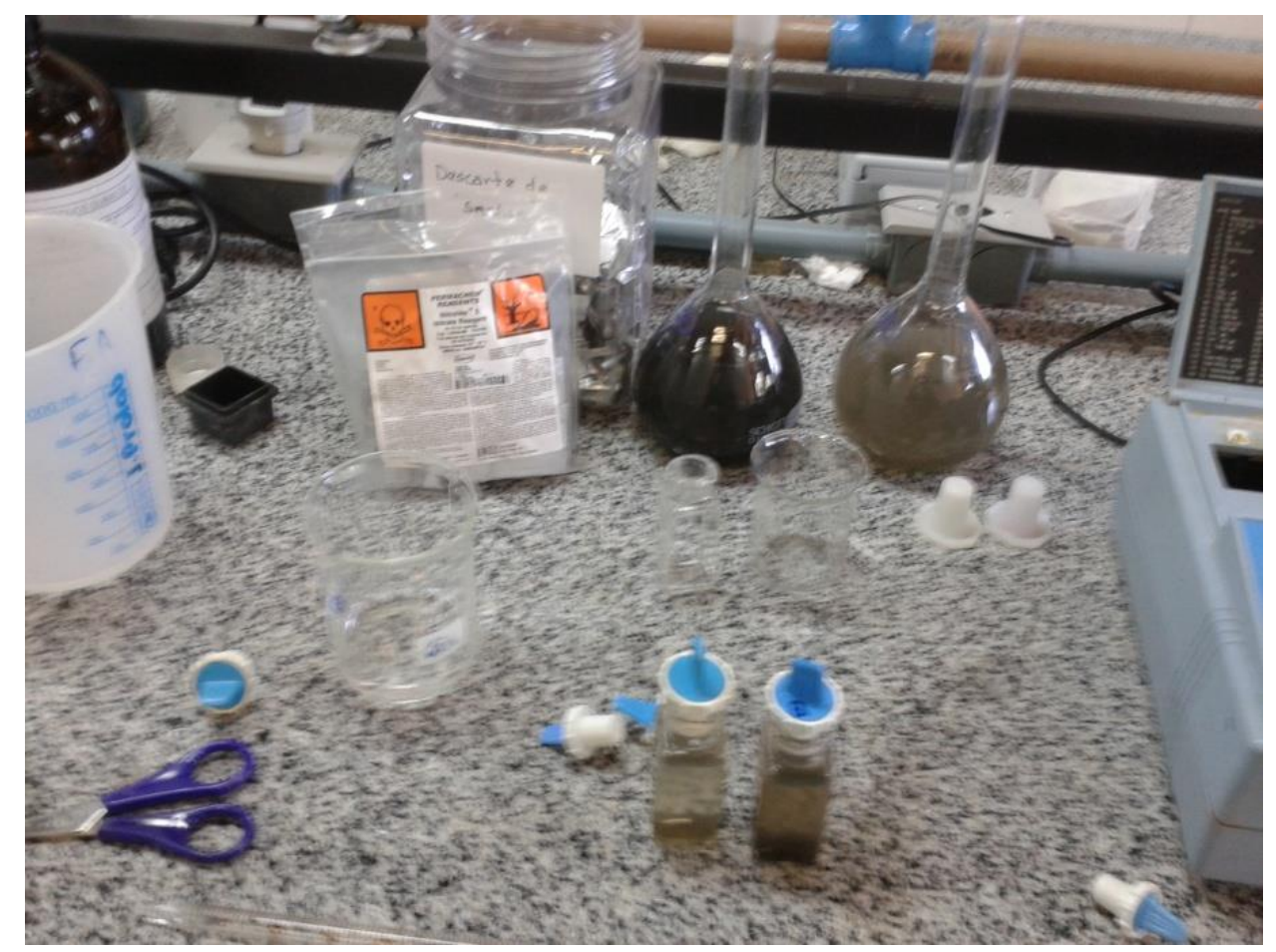

Figura 3.17 - Preparação das amostras. 


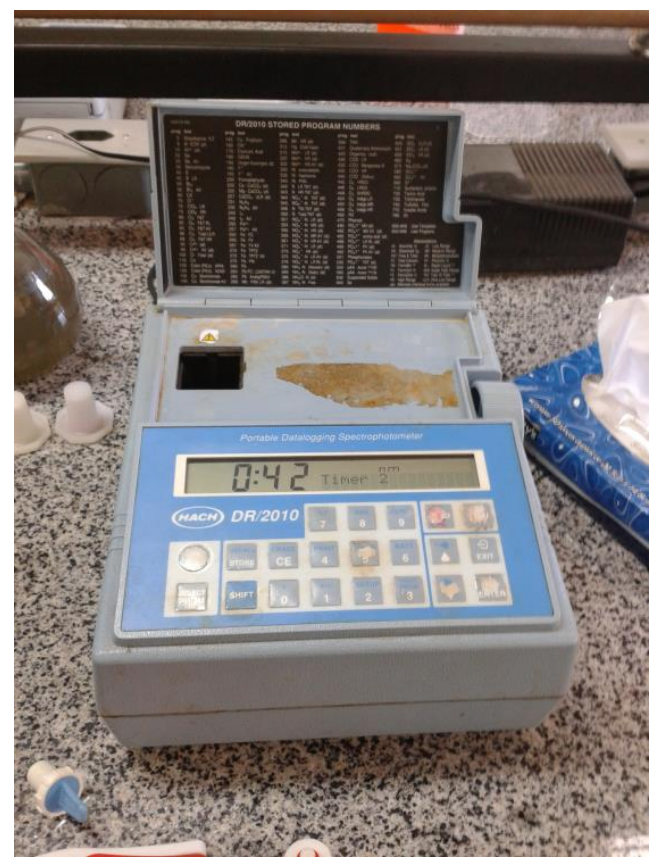

Figura 3.18 - Espectrofotômetro para leitura de $\mathrm{NO}^{3-}$.

Para a determinação de nitrato no solo, o liner foi retirado das células de difusão e fatiado, sendo que cada fatia possuía $1 \mathrm{~cm}$. De cada fatia foram pesadas cerca de $25 \mathrm{~g}$ de solo em triplicata para cada camada e colocados em coletores universais com $50 \mathrm{~mL}$ de água destilada, os mesmos foram levados para mesa de agitação, mostrada na Figura 3.19, por 24 horas. Após agitação as amostras eram transferidas para frascos de centrifugas, centrifugados, retirado o sobrenadante e determinado o teor nitrato via método de redução de cádmio.

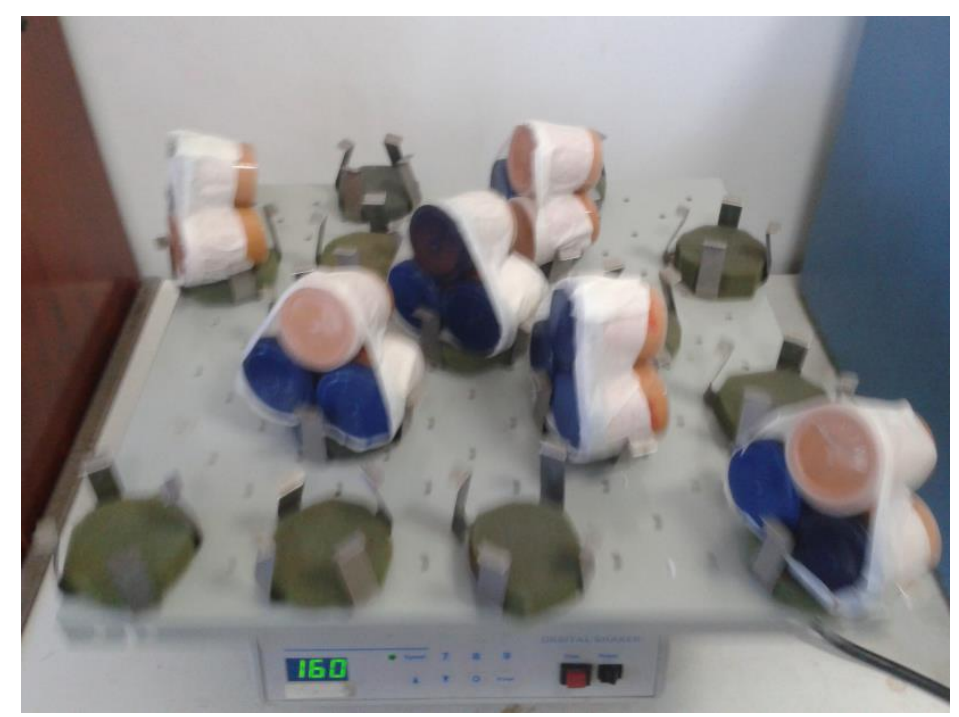

Figura 3.19 - Amostras em mesa agitadora. 


\subsubsection{ENSAIOS DE DIFUSÃO EM CAMPO}

Para o ensaio de difusão em campo, utilizou-se a área que a Caesb forneceu dentro das adjacências da ETE Samambaia/Melchior. A Figura 3.2 apresenta o local da área juntamente com os perfis de sondagens.

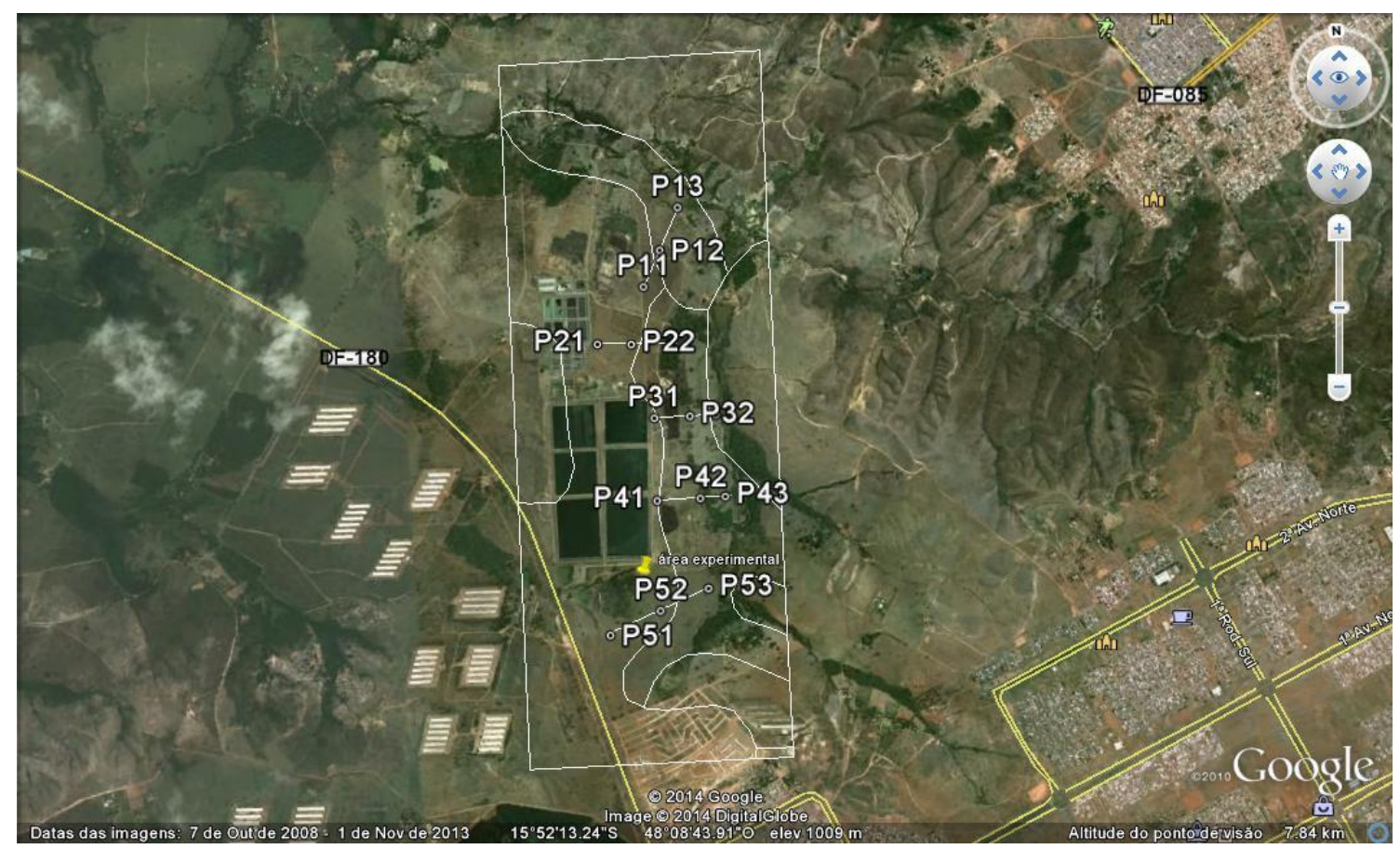

Figura 3.20 - Locação dos perfis com o local das células de difusão em campo.

Os trabalhos iniciaram com uma visita ao local e realização de seis furos de sondagens com 0,5 m cada uma, coletando solo para a determinação da umidade em laboratório. Ressalta-se que as sondagens foram realizadas de forma a obter o valor de umidade em campo para o cálculo da quantidade de solo e água a ser adicionados para obtenção da umidade ótima para compactação do liner.

Após determinação do valor de umidade, procedeu-se aos cálculos, com os valores dos resultados dos ensaios de caracterização inicial, sendo que a massa de solo para cada liner de $10 \mathrm{~cm}$ foi em torno de $171 \mathrm{~kg}$ de solo, e 5,10 kg de água. Ao todo foram executadas em campo 12 células com dimensão de $1 \mathrm{~m}^{3}$, para a simulação do ensaio de difusão em escala real. Ressalta-se que foram construídas em campo duas configurações distintas, sendo elas: 1 - seis células escavadas sequencialmente com $1 \mathrm{~m}^{3}$, esta configuração não possuía nenhuma intervenção de contenção, pois, o objetivo era verificar a migração dos contaminantes no estado real, sem intervenção de obras de engenharia; 
2 - seis células escavadas sequencialmente com $1 \mathrm{~m}^{3}$, já esta configuração apresentava em seu fundo duas camadas de $10 \mathrm{~cm}$ de liner compactado e revestida nas suas laterais com lona plástica.

As escavações foram realizadas por posseiro contratado. A Figura 3.21 a seguir apresenta a seqüência da escavação para as células sem compactação do liner e sem revestimento das laterais.
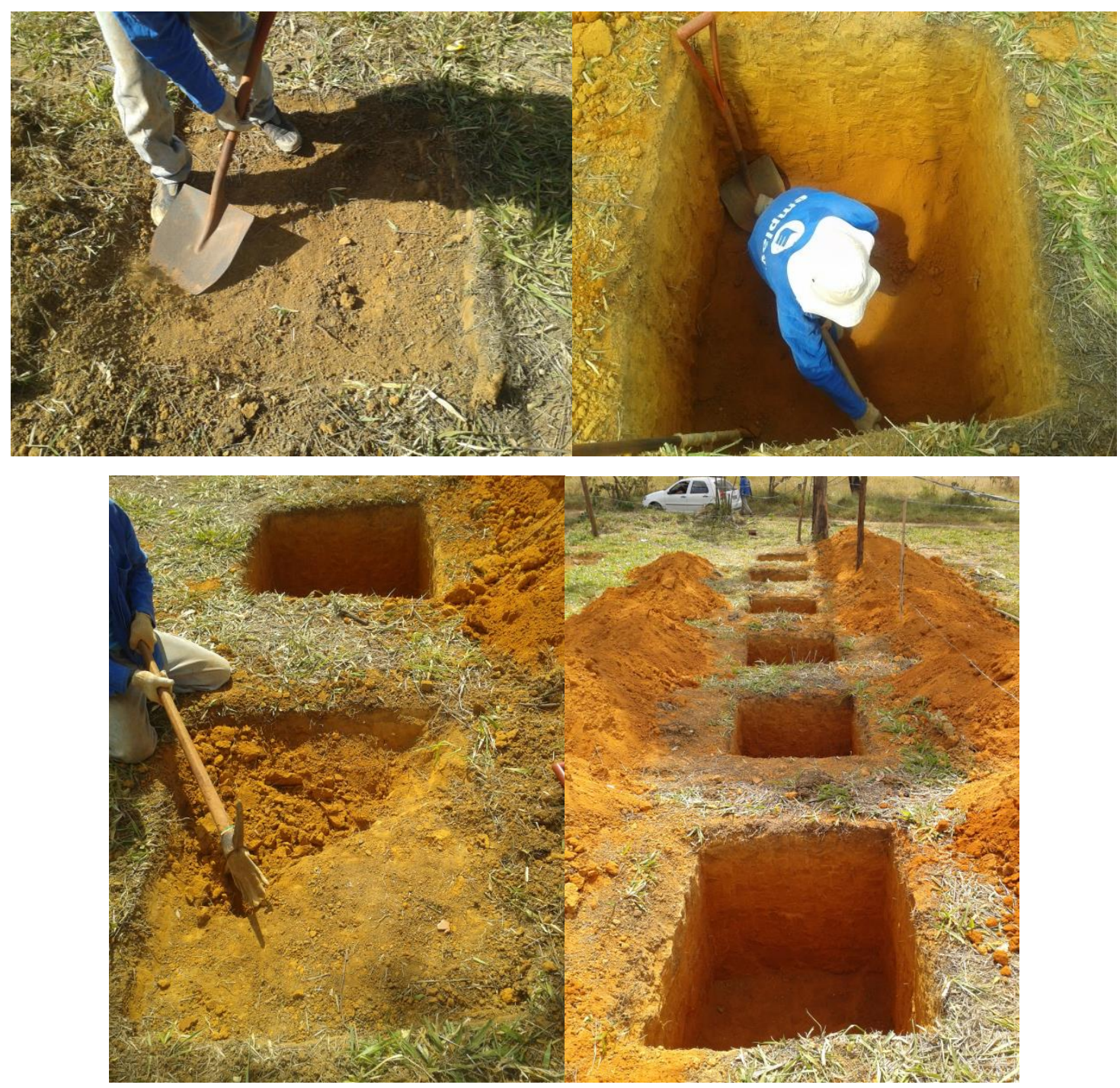

Figura 3.21 - Escavação das células em campo. (a) início da escavação; (b) célula sendo escavada; (c) abertura de novas células; (d) células já escavadas

Já para as células escavadas em que foram compactadas duas camadas de liners de 10 $\mathrm{cm}$ cada, utilizou-se um compactador manual fabricado em haste de madeira e recipiente de tinta vazio (5L), esta haste foi colocada no centro do recipiente e preenchido com concreto de 
forma a obter um compactador de $5 \mathrm{~kg}$, com base de $20 \mathrm{~cm}$ de diâmetro. O procedimento de compactação foi realizado da seguinte maneira:

1 - pesagem e determinação da quantidade de solo e água a ser adicionado e compactado em cada liner da célula;

2 - homogeneização do material para obter a umidade ótima de compactação, e transferência do mesmo para o interior da célula;

3 - compactação do material para a obtenção da primeira camada do liner de $10 \mathrm{~cm}$;

4 - controle de compactação feita com fita métrica e medição ao nível da boca da célula para verificar se já havia atingido os $10 \mathrm{~cm}$ do liner. Uma vez atingido, o procedimento era executado para outra camada de $10 \mathrm{~cm}$ de liner. Este procedimento foi realizado para todas as seis células com o fundo construído com liner compactado. A Figura 3.22 monstra o procedimento de compactação.

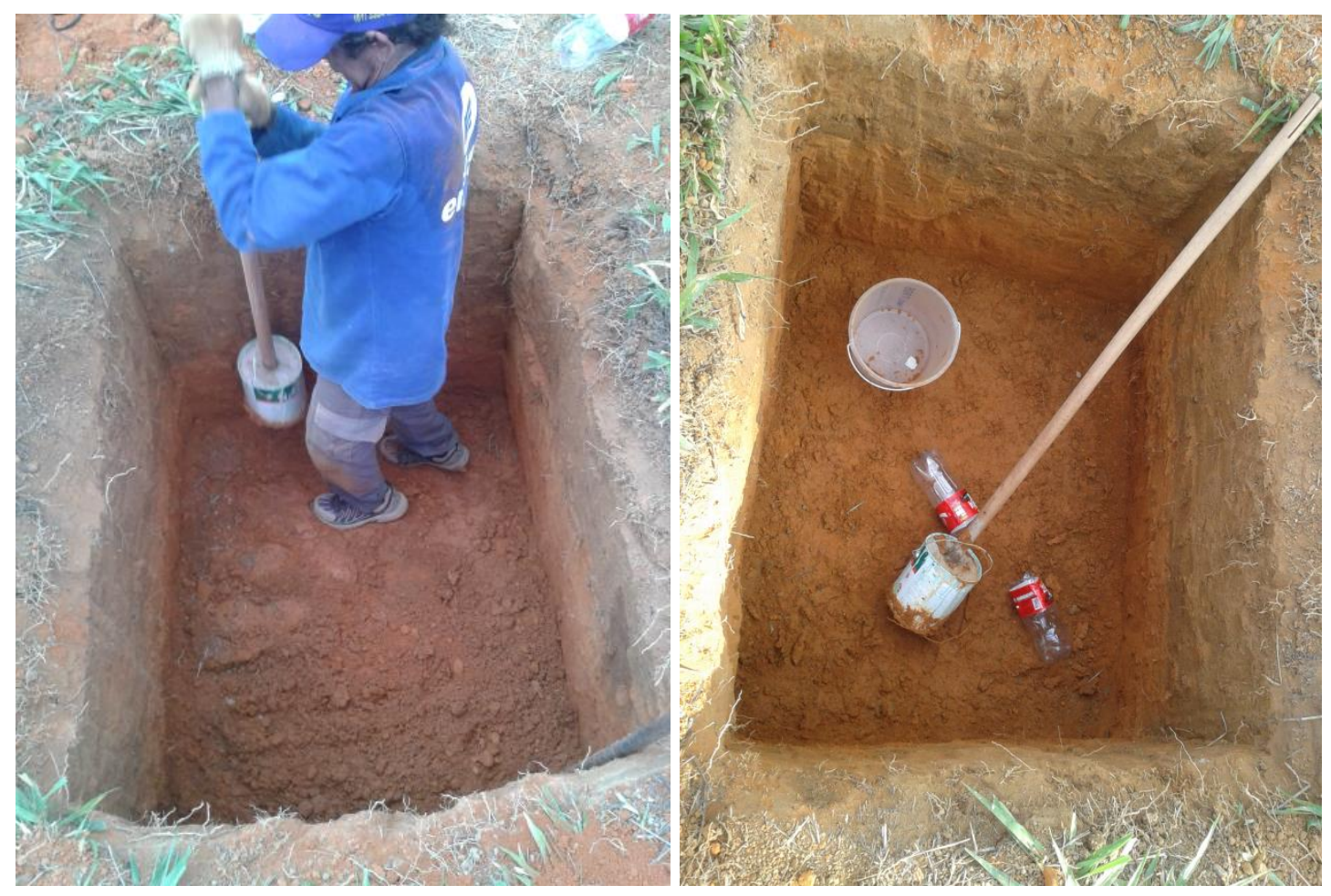

Figura 3.22 - Compactação das camadas de solo

Após a escavação das células em campo, de ambas configurações, as mesmas foram preenchidas com cerca de $1 \mathrm{~m}^{3}$ de lodo de esgoto. Inicialmente um caminhão com capacidade para 15 toneladas de lodo depositou o lodo numa área adjacente, em seguida a retro escavadeira preencheu a célula com o lodo de esgoto. A Figura 3.23 mostra a seqüência do preenchimento com lodo de esgoto. 

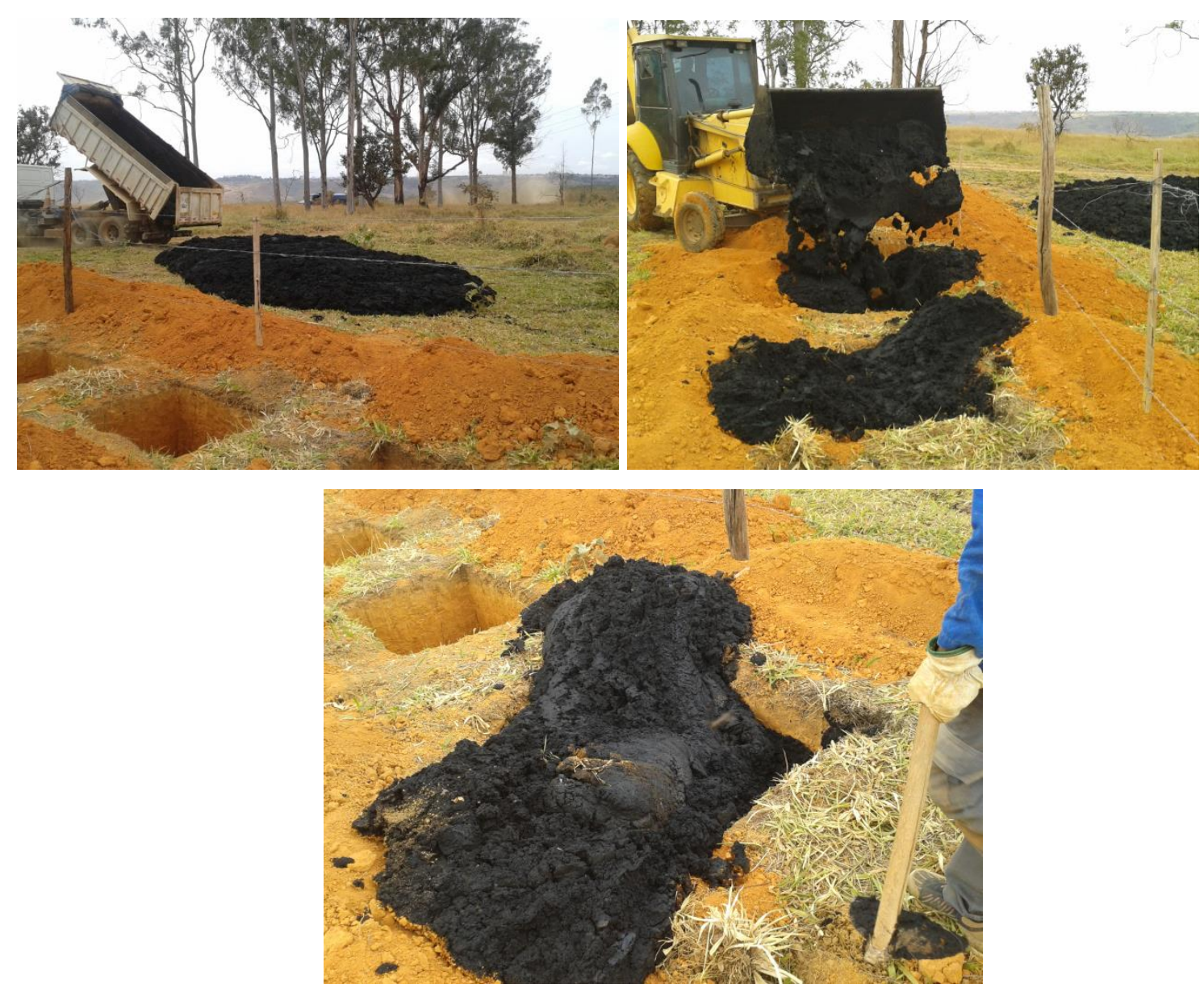

Figura 3.23 - Preenchimento das células com lodo de esgoto. (a) basculamento do lodo na área. (b) pá carregadeira preenchendo a célula com lodo; (c) célula preenchida com lodo de esgoto.

Após preenchimento com o lodo de esgoto, e com a simulação numérica de fluxo de contaminantes as mesma foram abertas com seis meses de disposição de lodo, sendo que somente pôde ser aberta e finalizada, uma sequência de ambas configurações, ou seja, uma célula sem intervenção, e uma célula com o liner compactado.

A abertura foi realizada retirando o lodo de esgoto com pá manual e sendo depositado nas imediações da célula de difusão. Amostras de lodo foi retirada a 0,5 m e imediatamente acima da camada de solo, para obter-se o valor de umidade da massa de lodo. Após retirada de toda a massa de lodo o solo foi coletado em tubos de PVC de $10 \mathrm{~cm}$, sendo que as coletas foram realizadas de forma triangular no fundo das células. Na célula em que houve o procedimento de compactação, também determinou-se o valor do peso especifico aparente máximo, este cálculo foi realidado para verificar se o valor alterou com os seis meses de 
disposição. A Figura 3.24 mostra as etapas do processo de abertura das células, e coleta do solo.
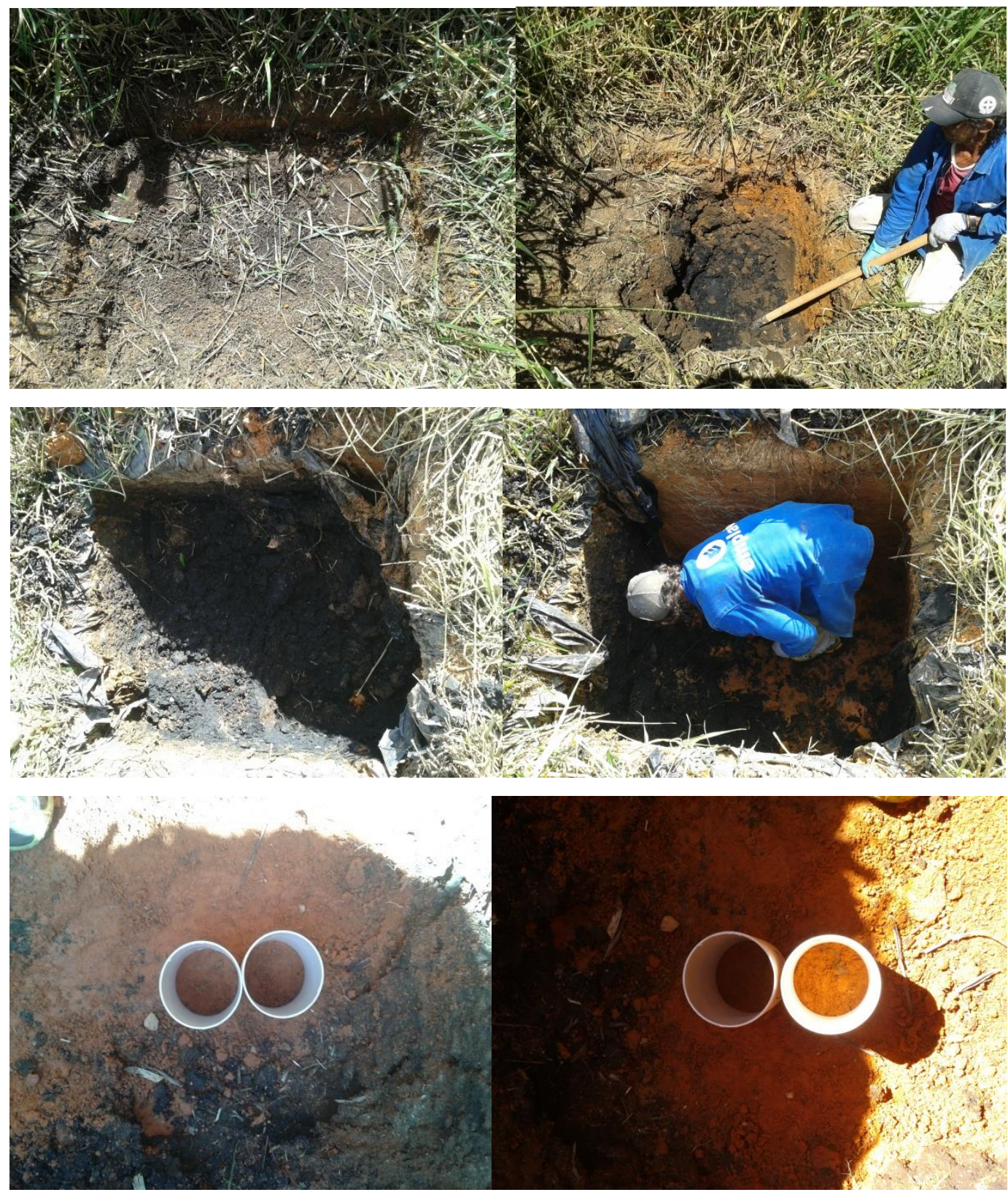

Figura 3.24 - Abertura e coleta de solo. (a) limpeza da célula; (b), (c) e (d) retirada material; (e) e (f) coleta de solo no tubo de PVC.

\subsubsection{COMPATIBILIDADE (Shackelford, 1994)}

Os ensaios de compatibilidade, interação solo/contaminante, foram os seguintes: (i) limites de Atterberg com o solo após contaminação; (ii) granulometria no granulômetro a laser com os solos contaminados: e (iii) ensaio de expansão livre. 
Esses ensaios apontam de forma indireta as reações que ocorrem com as partículas e na microestrutura do solo. Os ensaios de expansão livre são extremamente simples de execução e oferecem uma ótima resposta quanto à compatibilidade do sistema solocontaminante.

O sistema consiste na observação do volume ocupado pelo solo após sedimentação em proveta contendo a solução a ser estudada conforme pode ser observado na Figura 3.25. O ensaio consiste em colocar cerca de $50 \mathrm{~mL}$ de solo em uma proveta e adicionar o contaminante de interesse até atingir a marcar de $200 \mathrm{~mL}$, agitar para que ocorra contato solo/contaminante e observar o comportamento do meio após 24 horas da mistura em repouso. O ensaio de expansão livre foi realizado com o contaminante com e sem a cal, nas proporções de $100 \%, 80 \%, 60 \%, 40 \%, 20 \% 10 \%, 2 \%$ e $1 \%$ do contaminante, além do branco com água destilada.

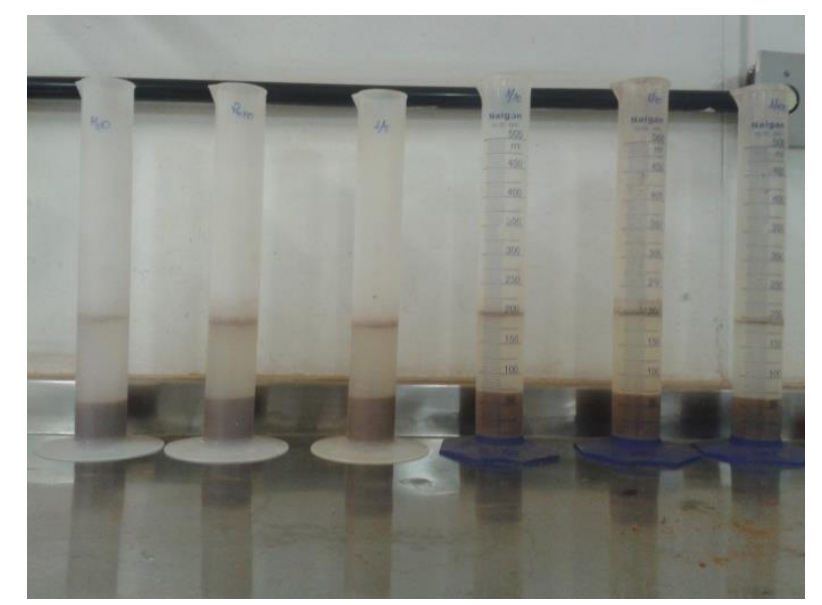

Figura 3.25 - Teste de Expansão livre com água, 100\%, 80\%, 60\%, 40\%, $20 \%$.

Os limites de Atterberg foram determinados com amostras preparadas conforme recomendações da NBR 6459 (ABNT, 1984) e NBR 7180 (ABNT, 1984). Para esses ensaios utilizou-se cerca de 500g de solo. Após a determinação da umidade higroscópica, foi possível obter a quantidade de contaminante que seria adicionado na massa de solo, de forma a obter as diferentes concentrações de: $100 \%, 80 \%, 60 \%, 40 \%, 20 \% 10 \%, 2 \%$ e $1 \%$ do contaminante. O solo foi armazenado na câmara úmida durante 24 horas, de forma, que o contaminante ficasse totalmente homogêneo na massa de solo. Em seguida o solo foi então espatulado até atingir a umidade necessária para a determinação dos limites de consistência, sendo que o incremento de umidade foi atingido adicionado contaminante para as diferentes proporções 
analisadas. Além dos índices de consistência também foi determinada a granulometria. Nesse ensaio determinou-se a curva granulométrica para dois tipos de distribuição, solos passantes na peneira de $\mathrm{n}^{\circ} 10$ (solos do ensaio de compatibilidade) e $\mathrm{n}^{\circ} 40$ (solos do ensaio de limites de consistência), nas mesmas proporções 100\%, 80\%, 60\%, 40\%, 20\% 10\%, 2\% e 1\% do contaminante. Além das terminações da distribuição granulométrica citada acima, foi realizado um teste em que o próprio contaminante foi utilizado como meio dispersor, nas concentração de $100 \%, 80 \%, 60 \%, 40 \%, 20 \%$; $100 \%$ cal, $80 \%$ cal, $60 \%$ cal, $40 \%$ cal, $20 \%$ cal.

\subsubsection{DETERMINAÇÃO DO pH}

Foram efetuadas determinações de $\mathrm{pH}$ em água e em $\mathrm{KCl}$, na relação de $10 \mathrm{~mL}$ de solo e $25 \mathrm{~mL}$ de água ou solução de $\mathrm{KCl}(1 \mathrm{M})$, conforme descreve metodologia de análise de solos da Embrapa (1998). Neste caso o pH foi determinado para cada proporção de contaminação $100 \%, 80 \%, 60 \%, 40 \%, 20 \% 10 \%, 2 \%$ e 1\%, além do solo no estado natural. A diferença entre os valores de $\mathrm{pH}\left(\Delta \mathrm{pH}=\mathrm{pHKCl}-\mathrm{pHH}_{2} \mathrm{O}\right)$, quando positivo indica alto conteúdo de óxidos e hidróxidos de ferro e alumínio e quando negativo, tem-se a predominância de argilas silicatas. Destaca-se que essas determinações foram feitas na mesma proporção dos solos contaminados.

\subsubsection{MASSA ESPECIFICA DOS GRÃOS}

Estes ensaios foram realizados com o emprego do pentapicnometro modelo pentapyc 5200e da "Quantachome Instruments". O equipamento utiliza o principio de Arquimedes (deslocamento de fluido) e a lei de Boyle (expansão de gás) para determinar a densidade e o volume verdadeiro de materiais sólidos. Para a determinação da massa especifica utilizou-se os solos contaminados com $100 \%, 80 \%, 60 \%, 40 \%, 20 \% 10 \%, 2 \%$ e $1 \%$ do contaminante.

\subsubsection{DETERMINAÇÃO DA CURVA CARACTERISTICA DE RETENÇÃO}

A determinação da curva característica para solos contaminados descrita em termos de sucção versus grau de saturação do extrato de lodo centrifugado revela uma informação quantitativa sobre a energia necessária para extrair o contaminante dos vazios do solo. Para esta pesquisa determinações de sucção matricial foi realizada pela técnica do papel filtro em corpos de prova, seguindo metodologia descrita pela norma Americana D5298 (ASTM,1992) 
com modificação propostas por Lima (2003), onde a mesma utilizou-se três papeis filtro no conjunto.

Com os dados da curva de compactação e as dimensões do corpo de prova calculou-se a quantidade de solo a ser compactada para obter-se um corpo de prova com dimensões de 2 $\mathrm{cm}$ de altura e $5 \mathrm{~cm}$ de diâmetro. O solo foi então contaminado na umidade ótima de compactação, nessa fase a umidade foi atingida utilizando as proporções de $100 \%, 80 \%, 60 \%$, $40 \%, 20 \% 10 \%, 2 \%$ e $1 \%$ do contaminante com e sem a cal, além da umidade com água. Posteriormente cada corpo de prova foi compactado estaticamente na prensa CBR nas condições de umidade e massa especifica definida no ensaio de Proctor com energia normal. Ressalta-se que os corpos de provas que foram submetidos à saturação utilizou-se as soluções com as diferentes concentração para o processo de saturação.

O ensaio iniciou-se após compactação da amostra, onde foram moldados 12 corpos de prova para cada proporção contaminada, ou seja, 96 corpos de prova contaminados com o extrato de lodo sem a cal, 96 corpos de prova contaminados com o extrato de lodo contendo cal, e 12 corpos de prova umidificados com água destilada, totalizando 204 corpos de prova. A faixa de umidade prevista foi de 1\%, 4\%, $7 \%, 10 \%, 13 \%, 16 \%, 19 \%, 22 \%, 25 \%, 28 \%, 31 \%$ e $34 \%$.

Para determinação da sucção foram usados três papeis filtros sobrepostos, o primeiro deles colocado em contato direto com o corpo de prova. Ressalta-se que o papel filtro do meio é de diâmetro menor que o da base e do topo, conforme pode ser observado na Figura 3.26, onde apenas o primeiro entra em contato direto com o solo, sendo passível de contaminação por solo, onde no final do ensaio e descartado. O resultado de sucção é obtido a partir dos dois papeis de filtro restantes, sendo o do meio o principal e o outro utilizado para eventuais correções.

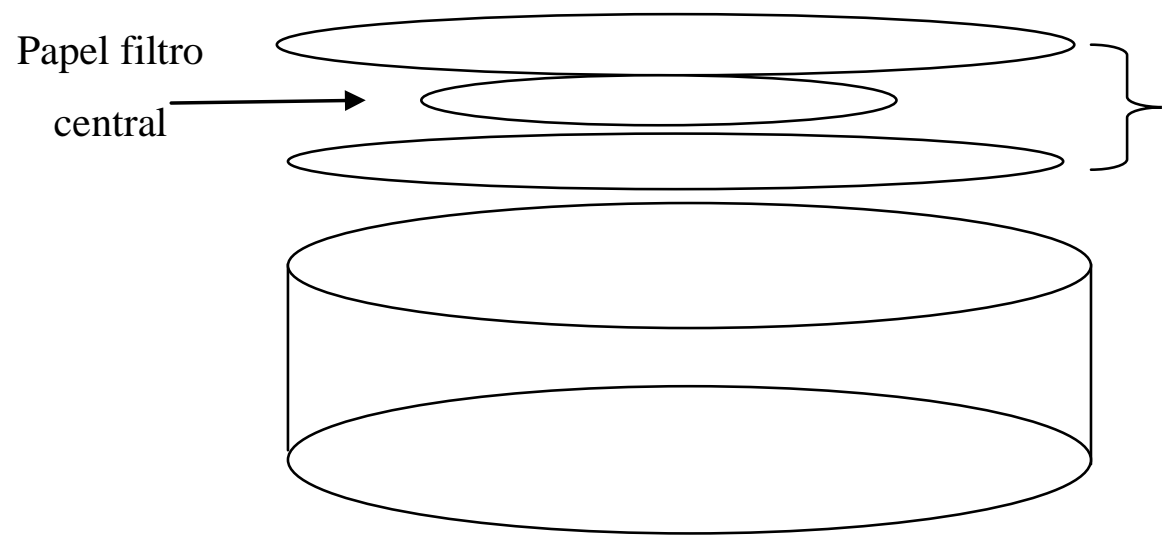

Papel filtro de proteção

Figura 3.26 - Montagem do ensaio de sucção. 


\subsection{ENSAIOS DE COMPRESSÃO DIAMETRAL}

O ensaio de compressão diametral foi realizado com os corpos de prova empregados para a determinação da curva característica, onde os mesmos apresentavam diferentes umidades (determinadas após o ensaio) e concentrações de contaminantes. Após a pesagem dos papeis filtros cada corpo de prova foi submetido ao ensaio com uma velocidade de aplicação da carga de 1,00 mm/min. Este ensaio foi realizado de com função de verificar se a contaminação dos corpos de prova poderiam alterar a resistência.

\subsection{ENSAIO DE CISALHAMENTO}

O ensaio de cisalhamento direto teve por objetivo verificar como o contaminante de lodo de esgoto poderia alterar as características de resistência mecânica dos solos a partir da determinação do ângulo de atrito $(\varphi)$ e coesão (c). O procedimento de preparação das amostras e execução do ensaio seguiu os mesmos procedimentos de preparação para o ensaio de sucção. A seguir será descrito este procedimento. O procedimento foi feito conforme os descritos na norma D3080 (ASTM, 2013).

1 - determinação da umidade higroscópica, e cálculo da quantidade de água e contaminante a ser adicionado no solo para obtenção da umidade ótima de compactação. Neste caso, o solo foi compactado na umidade ótima, utilizando água e o contaminante de lodo de esgoto nas seguintes concentrações: $100 \%, 80 \%, 60 \%, 40 \%, 20 \%$, e ainda com a concentração de $100 \%$ com cal. Uma vez que o extrato de lodo centrifugado retorna ao sistema de tratamento adicionando cal para correção de $\mathrm{pH}$ da ordem de $0.6 \mathrm{~m}^{3}$ a cada $20 \mathrm{~m}^{3}$ de lodo de esgoto centrifugado.

2 - moldagens dos corpos de prova compactados e no estado natural (bloco indeformado) (Figura 3.27).

3 - a determinação da envoltória de resistência nas amostras foram a três níveis de tensões normais iguais a $100 \mathrm{kPa}, 200 \mathrm{kPa}$ e $400 \mathrm{kPa}$ e a velocidade de deslocamento para a fase de cisalhamento foi de $0,033 \mathrm{~mm} / \mathrm{min}$, definida em função do adensamento, com um período de duração de 4 horas . 


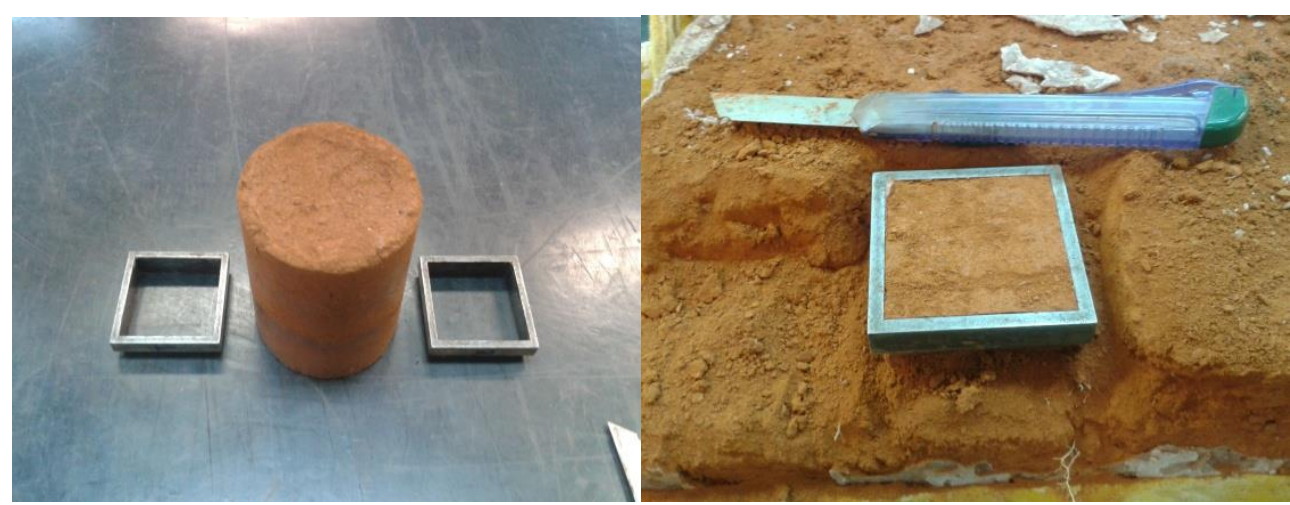

Figura 3.27 - Moldagem corpos de prova. (a) corpo de prova compactado; (b) corpo de prova do bloco indeformado.

Nesta primeira etapa foram realizados os ensaios de cisalhamento para os pontos compactos na umidade natural com: água, 100\%, 80\%, 60\%, 40\%, 20\%, 100\% com cal, e solo natural moldado do bloco indeformado coletado em campo.

Observa-se que o processo de disposição de lodo de esgoto em campo é um fluxo contínuo onde o solo recebe inúmeras camadas de material, passando por processo de secagem e recebimento de uma nova frente de umidade advinda de uma nova disposição do lodo de esgoto, e como esta parte tem como objetivo verificar como os constituintes do lodo de esgoto pode alterar as características do solo, foi realizado em laboratório uma sequiência de 5 aplicações do contaminante de lodo de esgoto. $\mathrm{O}$ procedimento consistiu em levar às amostras de solo a umidade ótima de compactação com o extrato de lodo centrifugado e repouso em câmara úmida por uma semana, após o repouso a amostra era seca a umidade higroscópica e levado novamente a umidade de compactação com o contaminante, este ciclo seguiu até o momento em que a simulação pudesse atingir cinco aplicações. Nessa fase as concentrações que receberam esse ciclo de molhagem e secagem com o contaminante foram às seguintes: água, 100\%, 80\%, 60\%, 40\%, 20\%, 100\% cal. Essas concentrações foram submetidas às mesmas tensões normais.

A determinação dos pontos da envoltória de resistência para obtenção dos parâmetros de coesão e ângulo de atrito foi definida por meio da análise das tensões cisalhantes máximas e residuais de cada ensaio realizado. Ao todo foram realizados 48 ensaios de cisalhamento. 


\subsection{ENSAIO EDOMÉTRICO}

Os ensaios edométricos simples foram realizados objetivando a obtenção dos parâmetros de deformabilidade relacionado ao colapso do solo em estudo com diferentes concentrações de contaminantes e líquidos de inundação. Esta avaliação tornou-se necessária uma vez que camadas de solos compactadas podem ser executadas nos locais de transbordo como prevenção da migração dos contaminantes do lodo de esgoto, sendo assim avaliou-se a capacidade do contaminante de lodo bruto em alterar as características do "liner" compactado. O procedimento de preparação das amostras foram os mesmos seguidos para a obtenção no ensaio de sucção e de cisalhamento direto, no entanto para este ensaio foram realizados mais pontos, sendo eles:

1 - água, 100\%, 80\%, 60\%, 40\%, 20\%, e ainda 100\% contaminante do ensaio de difusão;

$2-100 \%, 60 \%, 20 \%$ (contaminante com cal);

3 - solo natural com líquido de inundação nas seguintes concentrações: água, 100\%, $80 \%, 60 \%, 40 \%, 20 \%$, e $100 \%$ com cal;

4 - solo com os cinco ciclos de aplicação: 100\%, 60\%, 20\%, água e 100\% com cal.

5 - teste com líquidos alcalinos: água sanitária e solução de soda caústica.

Os ensaios foram realizados no laboratório de Geotecnia da Universidade de Brasília de acordo com os procedimento da norma NBR 3336 (ABNT, 1990). Os corpos de prova foram compactados e moldados no anel da célula de adensamento. $\mathrm{O}$ carregamento inicial adotado foi de $12,5 \mathrm{kPa}$ e os demais estágios de carregamento foram de $25 \mathrm{kPa}, 50 \mathrm{kPa}, 100$ $\mathrm{kPa}, 200 \mathrm{kPa}, 400 \mathrm{kPa}, 800 \mathrm{kPa}$ e $1200 \mathrm{kPa}$, os quais foram aplicados sucessivamente, após a estabilização das leituras de deformabilidade.

O descarregamento foi realizado em cinco estágios, $800 \mathrm{kPa}, 500 \mathrm{kPa}, 250 \mathrm{kPa}, 100$ $\mathrm{kPa}$ e $50 \mathrm{kPa}$. Destaca-se que o contaminante que foi utilizado para obtenção da umidade ótima de compactação foi o mesmo utilizado para a inundação na célula de adensamento. 
Os valores dos potenciais de deformação (PD), obtidos por meio dos ensaios edométricos simples, foram calculados utilizando-se a equação 3.6:

$$
P D(\%)=\frac{\Delta H}{H i} \times 100 \%
$$

Onde:

PD é o potencial de deformação;

$\Delta \mathrm{H}$ é a variação da altura do corpo de prova, devido a inundação e carga;

Hi é a altura do corpo de prova, antes da inundação e carga.

\subsection{RESISTÊNCIA A COMPRESSÃO SIMPLES}

Os corpos de prova para este ensaio foram compactados em 5 camadas. Cada uma deles com diâmetro de $50 \mathrm{~mm}$ e altura de $20 \mathrm{~mm}$, e um corpo de prova de $50 \mathrm{~mm}$ e $100 \mathrm{~mm}$ de altura. Durante o processo de compactação a superfície da camada já compactada era escarificada para que houvesse uma aderência entre essa camada e a seguinte. As configurações foram às seguintes:

1 - água, 100\%, 60\%, 20\% (contaminante de extrato de lodo);

$2-100 \%, 60 \%$ e $20 \%$ com cal (contaminante de extrato de lodo).

Os tempos de cura foram de 15, 45 e 75 dias. Todos os ensaios foram realizados seguindo o procedimento descrito pela norma NBR 12770 (ABNT, 1992). 


\subsection{RESULTADOS E DISCUSSÕES}

Neste item são apresentados os resultados da caracterização preliminar e das propriedades físicas estudadas com relação às amostras deformadas e indeformadas. Neste item os resultados aqui discutidos são referentes ao estudo de caso realizado com solo laterítico na Estação de Tratamento de Esgoto Samambaia/ Melchior. São apresentados também os dados de transporte de contaminantes e comportamento mecânico dos solos contaminados, objetivo central e principal desta tese.

\subsection{CARACTERIZAÇÃO FÍSICA DA ÁREA DE ESTUDO INSTALAÇÃO DOS EXPERIMENTOS EM CAMPO}

As Figuras 4.1 a 4.5 apresentam os resultados de umidade natural, umidade seca ao ar e umidade de moldagem de bola, das sessões de 1 a 5 .
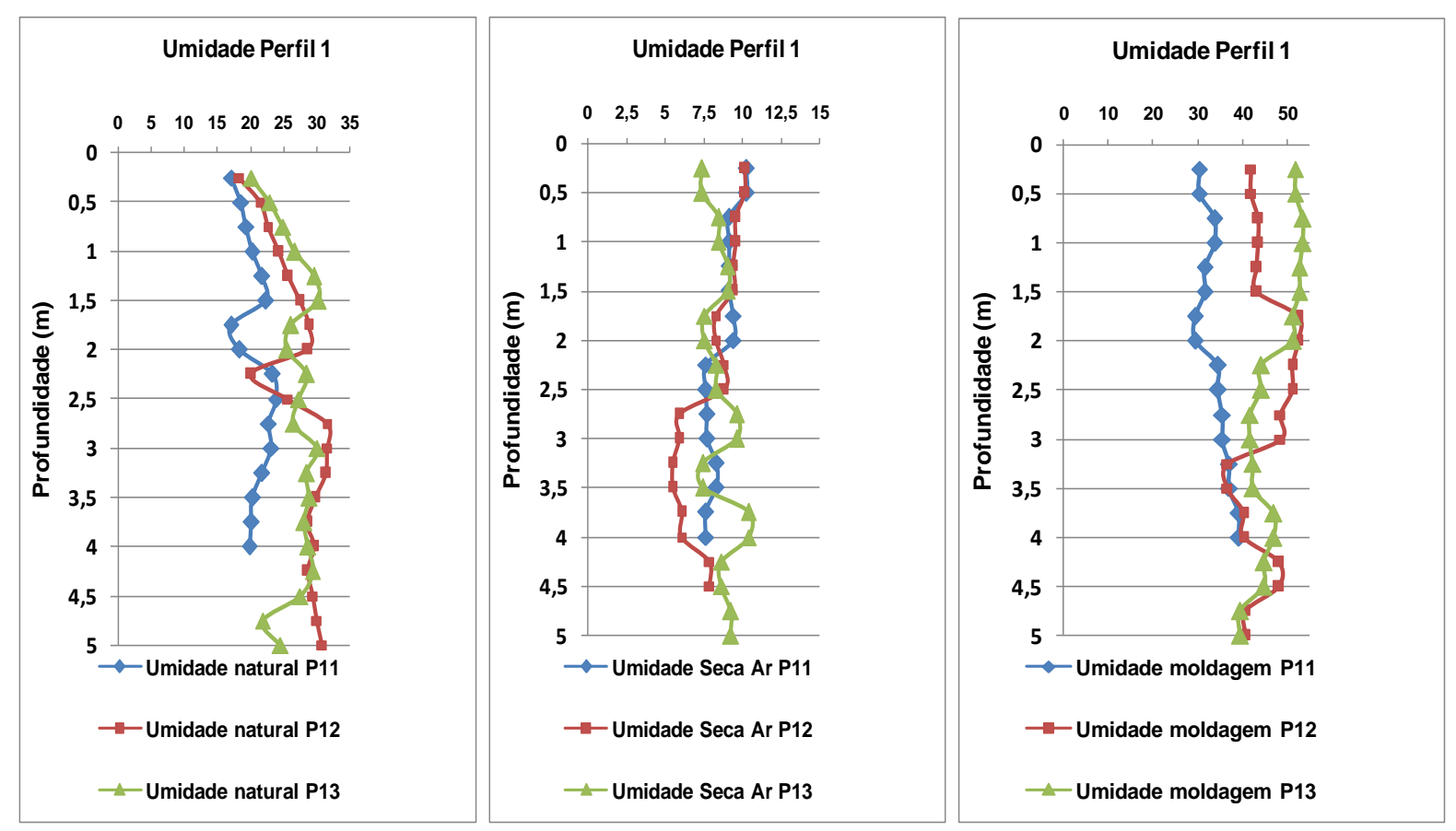

Figura 4.1 - Diferentes umidades para a sessão 1 (natural, seca ao ar, moldagem de bola). 


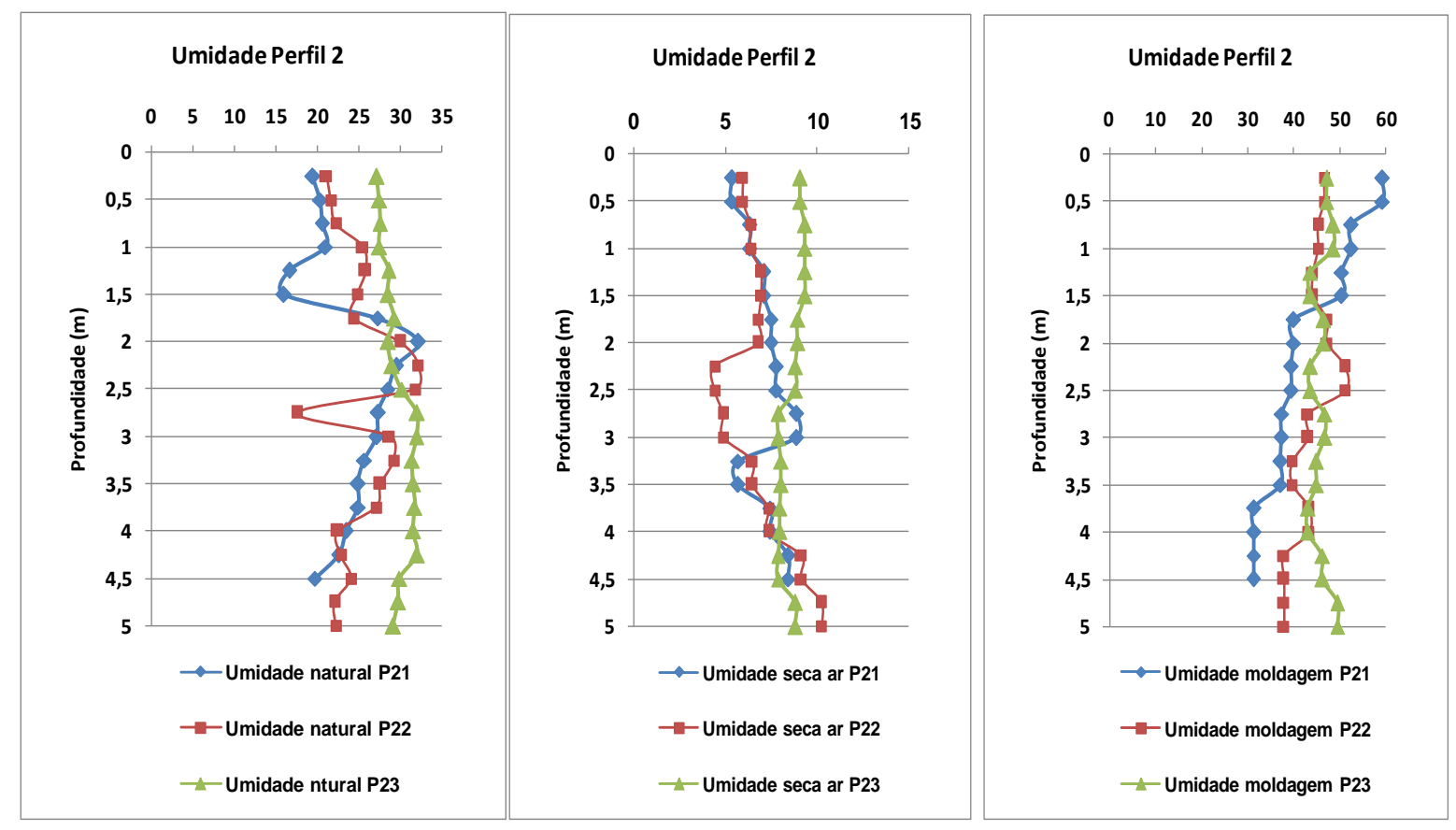

Figura 4.2 - Diferentes umidades para o perfil P2 (natural, seca ao ar, moldagem de bola).

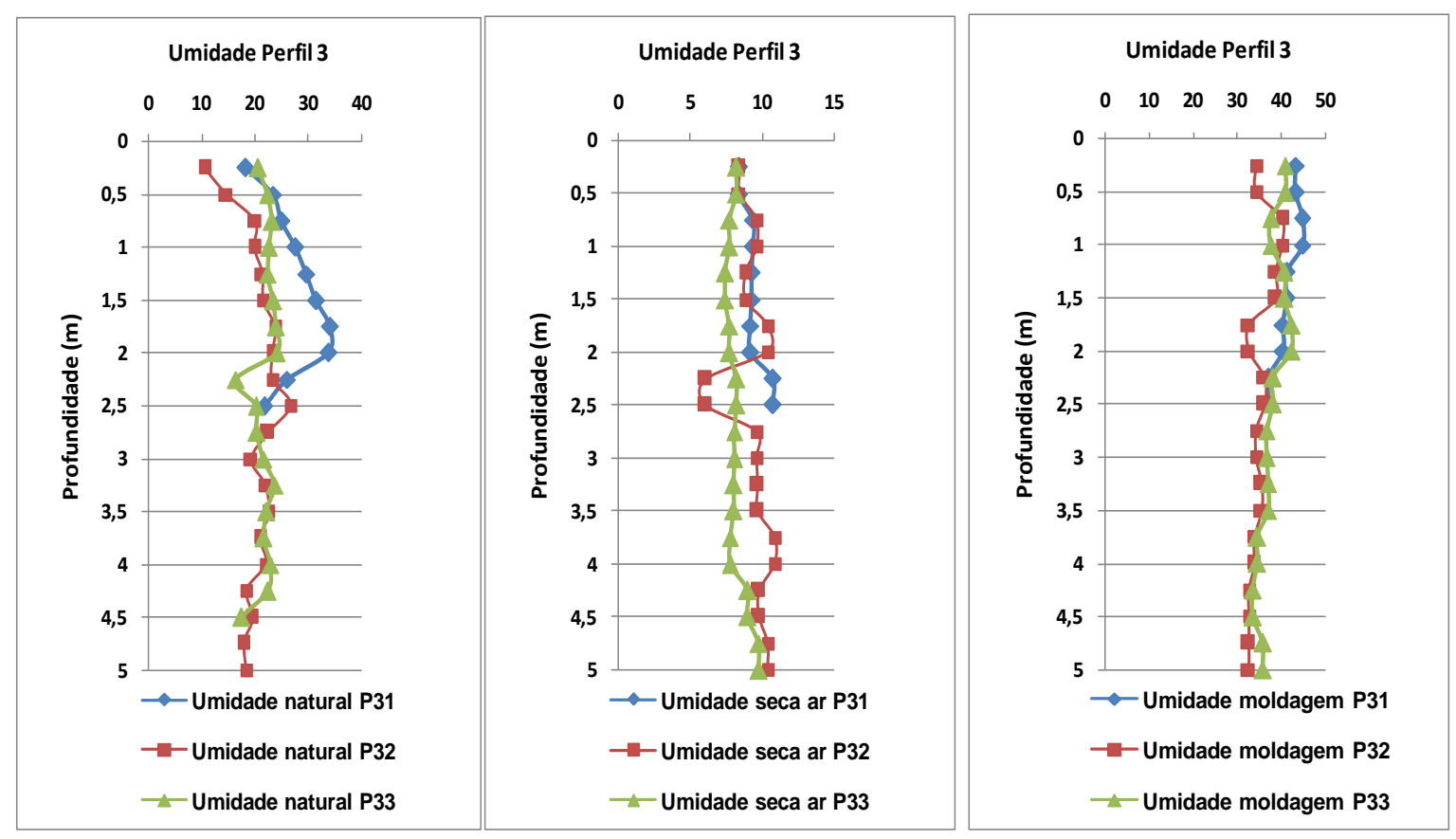

Figura 4.3 - Diferentes umidades para o perfil P3 (natural, seca ao ar, moldagem de bola). 


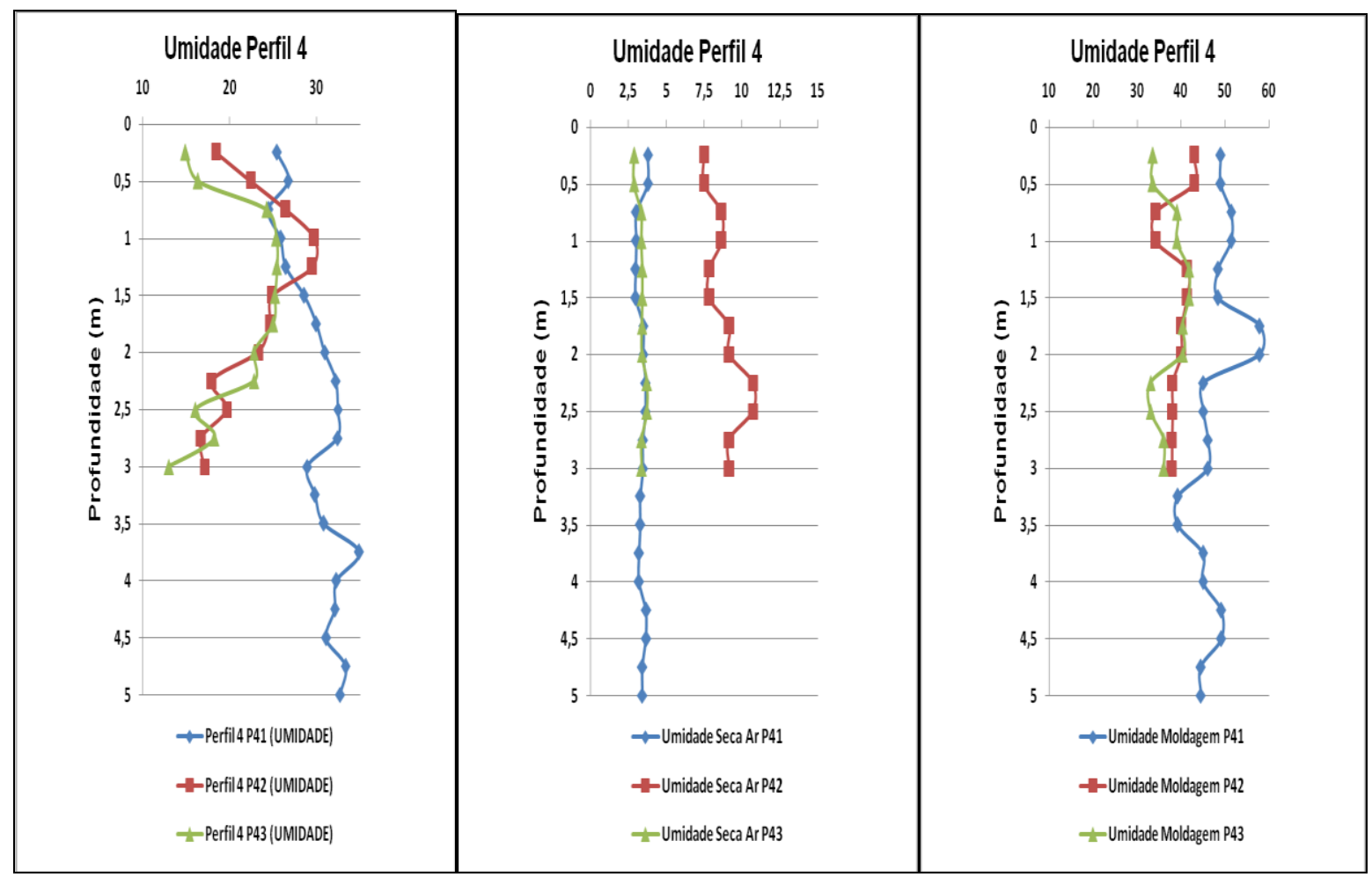

Figura 4.4 - Diferentes umidades para o perfil P4 (natural, seca ao ar, moldagem de bola).

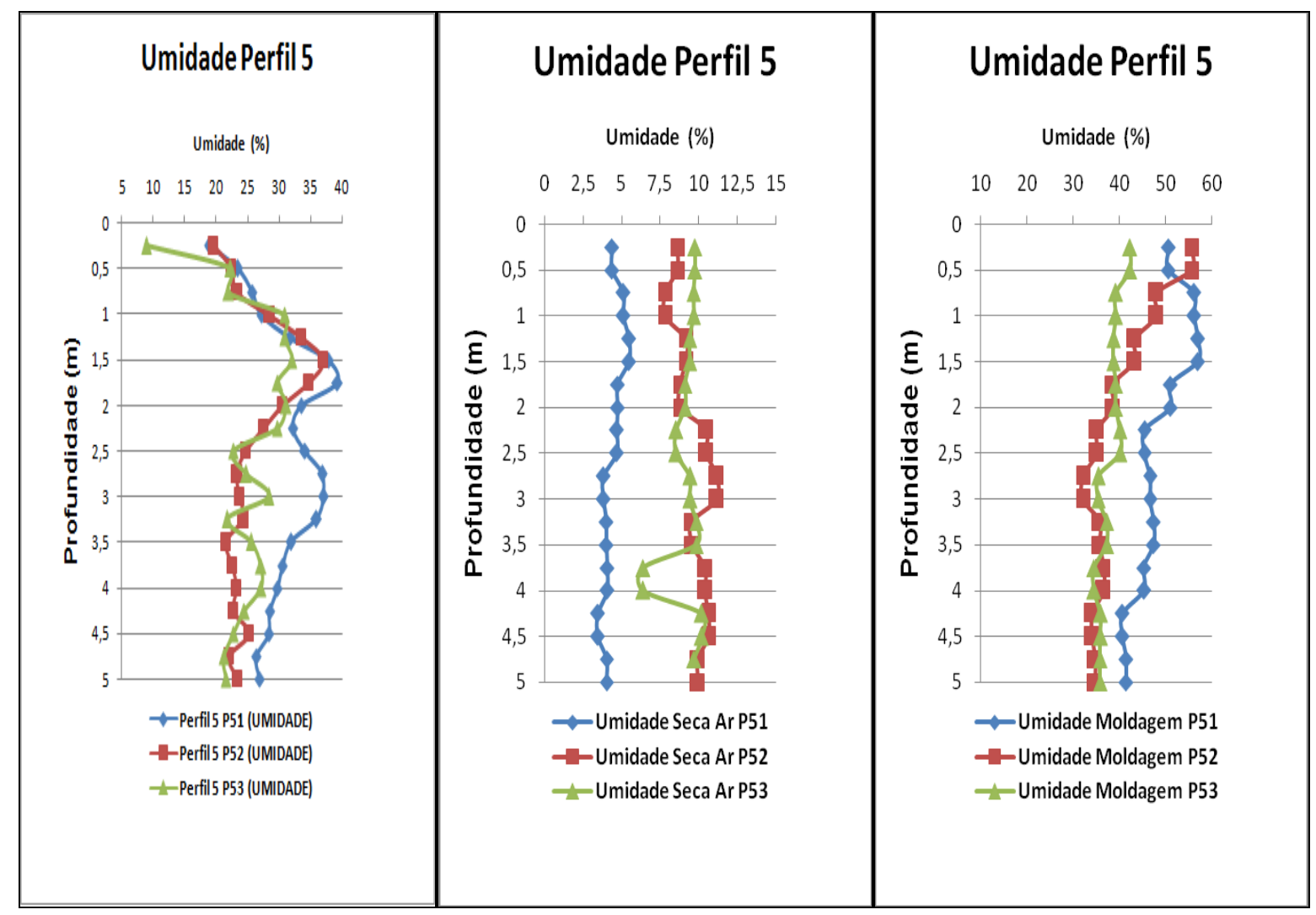

Figura 4.5 - Diferentes umidades para o perfil P5 (natural, seca ao ar, moldagem de bola). 
Ressalta-se que as sessões aqui discutidas e analisadas se referem as dos perfis que se encontram próximos á área de construção das células de difusão em campo. Observa-se uma tendência para os perfis no que diz respeito a umidade natural, ou seja o aumento de umidade de uma camada para outra, se estabilizando com o acréscimo de profundidade. Correa (2001), ao realizar sondagens a trado na área da ETE Melchior, observou essa mesma tendência para os dois furos de sondagens analisados.

Já em relação aos dados obtidos de umidade de moldagem de bola, nota-se uma diferença de valores entre as sondagens. Sendo que as sondagens P41 e P43 com uma diferença de $3 \%$, e P42 da ordem de $8 \%$ com leve tendência de acréscimo ate a profundidade de 2,5m, tal como ocorre com o P52 e P53. Já o P51 têm valores da ordem de 4 a 5\%, sendo que essas diferenças indicam uma possível variação na textura e na composição. Fato este podendo ser correlacionado com a deposição de lodo.

A classificação MCT Expedita permitiu conhecer de forma mesmo que simplificada a existência das diferentes classes de solos para as diferentes profundidades de solos estudados, ressalta-se que este ensaio foi realizado em amostras coletadas para o perfil em camadas de 0,50m cada. Os resultados demonstram a ocorrência de classes, arenosas lateríticas, siltosas e argilosas lateriticas, no entanto verifica-se a predominância do grupo das areias lateriticas. As Tabelas com a classificação MCT expedita para todos os perfis encontra-se no Anexo A.

Já a determinação de cores pela carta Munssell observou a presença da classe de cor do solo 5YR e 10 YR conforme pode ser observado nas Figuras 4.6 e 4.7.

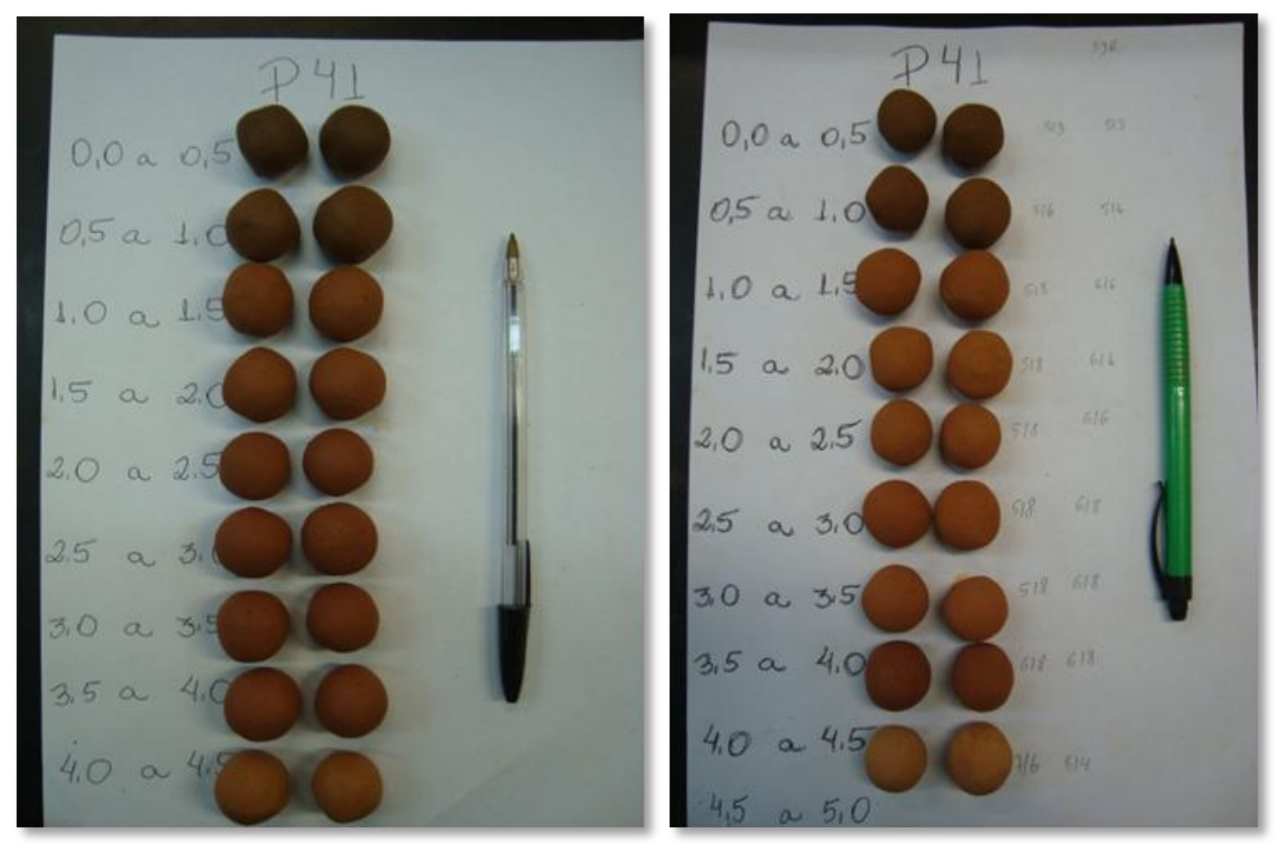

Figura 4.6 - Perfil P41 (a) cor úmida; (b) cor seca. 

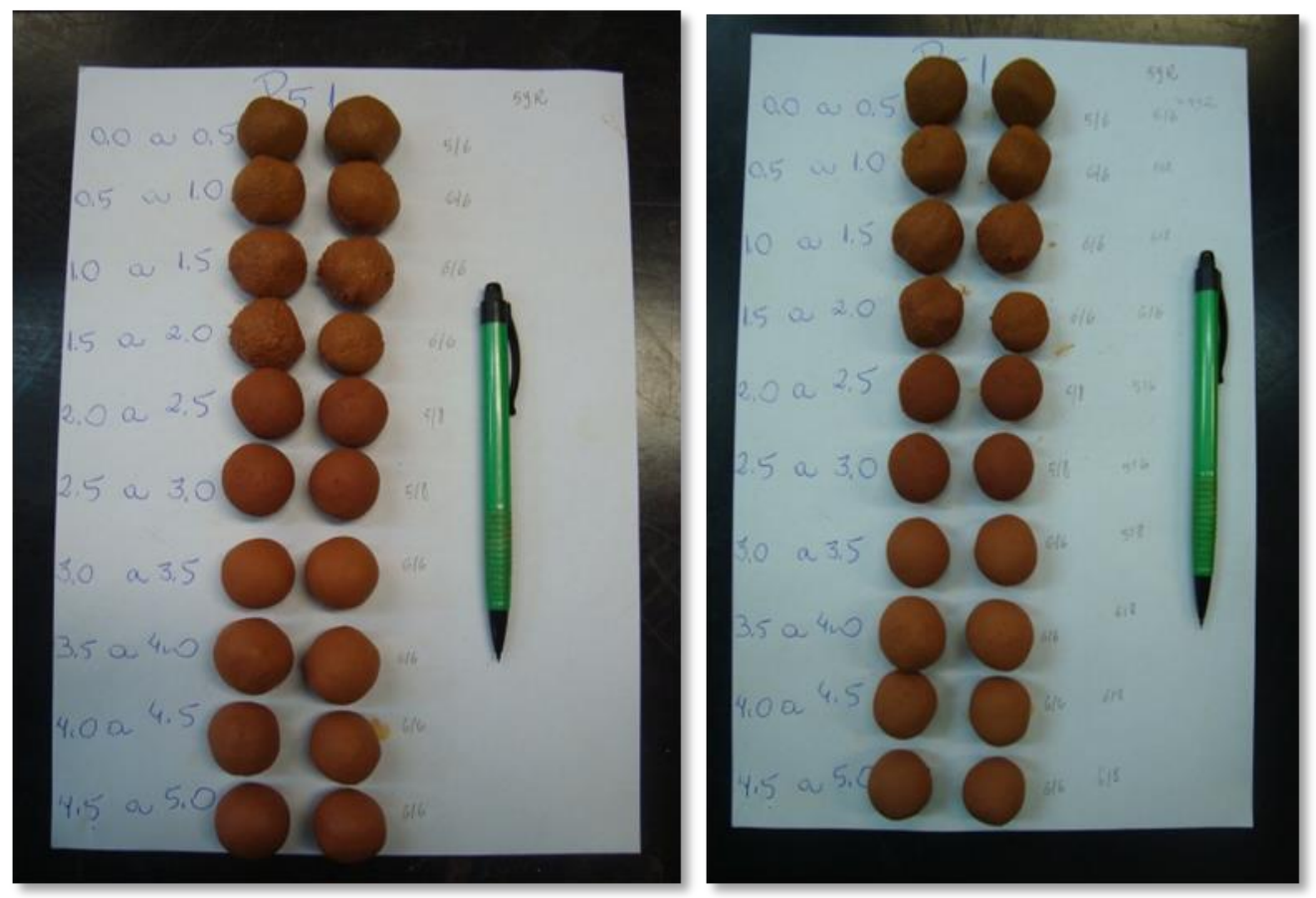

Figura 4.7 - Perfil P51 (a) cor úmida; (b) cor seca.

As Tabelas 4.1 e 4.2 apresentam os dados referentes ao perfis para as cores, matiz, e valor da croma das bolas de moldagens tanto úmidas como secas. Ressalta-se que as cores aqui apresentadas são para o Perfis mais próximos a área de estudo de caso. As demais Tabelas encontram-se no Anexo A.

Tabela 4.1 - Cores, matizes para o perfil P41.

\begin{tabular}{|c|c|c|c|c|c|c|}
\hline Perfil & Profundidade & Matiz & $\begin{array}{c}\text { Valor/Croma } \\
\text { (úmido) }\end{array}$ & $\begin{array}{c}\text { Valor/Croma } \\
\text { (seco) }\end{array}$ & Cor umida & Cor seca \\
\hline P41 & 0,0 a 0,5 & $5 \mathrm{YR}$ & $(5 / 3)$ & $(5 / 3)$ & $\begin{array}{c}\text { Bruno } \\
\text { avermelhado }\end{array}$ & $\begin{array}{c}\text { Bruno } \\
\text { avermelhado }\end{array}$ \\
\hline & 0,5 a 1,0 & $5 \mathrm{YR}$ & $(5 / 6)$ & $(5 / 6)$ & $\begin{array}{c}\text { Vermelho } \\
\text { amarelado }\end{array}$ & $\begin{array}{c}\text { Vermelho } \\
\text { amarelado }\end{array}$ \\
\hline & 1,0 a 1,5 & $5 \mathrm{YR}$ & $(5 / 8)$ & $(5 / 6)$ & $\begin{array}{c}\text { Vermelho } \\
\text { amarelado }\end{array}$ & $\begin{array}{c}\text { Vermelho } \\
\text { amarelado }\end{array}$ \\
\hline & 1,5 a 2,0 & $5 \mathrm{YR}$ & $(5 / 8)$ & $(6 / 6)$ & $\begin{array}{c}\text { Vermelho } \\
\text { amarelado }\end{array}$ & $\begin{array}{c}\text { Amarelo } \\
\text { avermelhado }\end{array}$ \\
\hline & 2,0 a 2,5 & $5 \mathrm{YR}$ & $(5 / 8)$ & $(6 / 6)$ & $\begin{array}{c}\text { Vermelho } \\
\text { amarelado }\end{array}$ & $\begin{array}{c}\text { Amarelo } \\
\text { avermelhado }\end{array}$ \\
\hline & 2,5 a 3,0 & $5 \mathrm{YR}$ & $(5 / 8)$ & $(6 / 8)$ & $\begin{array}{c}\text { Vermelho } \\
\text { amarelado }\end{array}$ & $\begin{array}{c}\text { Amarelo } \\
\text { avermelhado }\end{array}$ \\
\hline & 3,0 a 3,5 & $5 \mathrm{YR}$ & $(5 / 8)$ & $(6 / 8)$ & $\begin{array}{c}\text { Vermelho } \\
\text { amarelado }\end{array}$ & $\begin{array}{c}\text { Amarelo } \\
\text { avermelhado }\end{array}$ \\
\hline & 3,5 a 4,0 & $5 \mathrm{YR}$ & $(6 / 8)$ & $\begin{array}{c}*(6 / 8) \\
\text { Amarelo } \\
\text { avermelhado }\end{array}$ & $\begin{array}{c}\text { Amarelo } \\
\text { avermelhado }\end{array}$ \\
\hline & 4,0 a 4,5 & $5 \mathrm{YR}$ & $(7 / 6)$ & $(8 / 4)$ & $\begin{array}{c}\text { Amarelo } \\
\text { avermelhado }\end{array}$ & rosado \\
\hline
\end{tabular}


Tabela 4.2 - Cores e matizes para o perfil P51.

\begin{tabular}{|c|c|c|c|c|c|c|}
\hline Perfil & Profundidade & Matiz & $\begin{array}{c}\text { Valor/Croma } \\
\text { (úmido) }\end{array}$ & $\begin{array}{c}\text { Valor/Croma } \\
\text { (seco) }\end{array}$ & Cor umida & Cor seca \\
\hline P51 & 5 YR & & & & \\
\hline & 0,0 a 0,5 & 5 YR & $(5 / 6)$ & $(6 / 6)$ & Bruno claro & Brumo claro \\
\hline & 0,5 a 1,0 & 5 YR & $(6 / 6)$ & $(6 / 8)$ & Brumo claro & $\begin{array}{c}\text { Amarelo } \\
\text { avermelhado }\end{array}$ \\
\hline & 1,0 a 1,5 & 5 YR & $(6 / 6)$ & $6 / 8)$ & $\begin{array}{c}\text { Amarelo } \\
\text { avermelhado }\end{array}$ & $\begin{array}{c}\text { Amarelo } \\
\text { avermelhado }\end{array}$ \\
\hline & 2,0 a 2,5 & 5 YR & $(5 / 8)$ & $(5 / 6)$ & $\begin{array}{c}\text { Amarelo } \\
\text { avermelhado }\end{array}$ & $\begin{array}{c}\text { Amarelo } \\
\text { avermelhado }\end{array}$ \\
\hline & 2,5 a 3,0 & 5 YR & $(5 / 8)$ & $(5 / 6)$ & $\begin{array}{c}\text { Vermelado } \\
\text { amarelado }\end{array}$ & $\begin{array}{c}\text { Vermelho } \\
\text { amarelado } \\
\text { amarelado }\end{array}$ \\
\hline & 3,0 a 3,5 & 5 YR & $(6 / 6)$ & $(5 / 8)$ & $\begin{array}{c}\text { Amarelo } \\
\text { avermelhado }\end{array}$ & $\begin{array}{c}\text { Vermelho } \\
\text { amarelado }\end{array}$ \\
\hline & 3,5 a 4,0 & 5 YR & $(6 / 6)$ & $(6 / 8)$ & $\begin{array}{c}\text { Amarelo } \\
\text { avermelhado }\end{array}$ & $\begin{array}{c}\text { Amarelo } \\
\text { avermelhado }\end{array}$ \\
\hline & 4,0 a 4,5 & 5 YR & $(6 / 6)$ & $(6 / 8)$ & $\begin{array}{c}\text { Amarelo } \\
\text { avermelhado }\end{array}$ & $\begin{array}{c}\text { Amarelo } \\
\text { avermelhado }\end{array}$ \\
\hline & 4,5 a 5,0 & 5 YR & $(6 / 6)$ & $(6 / 8)$ & $\begin{array}{c}\text { Amarelo } \\
\text { avermelhado }\end{array}$ & $\begin{array}{c}\text { Amarelo } \\
\text { avermelhado }\end{array}$ \\
\hline
\end{tabular}

\subsection{CARACTERIZAÇÃo dO SOLO PARA A CONSTRUÇÃo DAS CÉlULAS DE DIFUSÃO EM CAMPO}

Após a classificação preliminar nos 15 perfis de solo estudados, foi possível selecionar a área para a construção das células que irão simular o ensaio de difusão em campo, essa escolha se deu em função do tipo de solo encontrado e disponibilidade de área pela CAESB.

A Figura 4.8 apresenta a curva granulométrica do solo da área que será construída às células de difusão em campo.

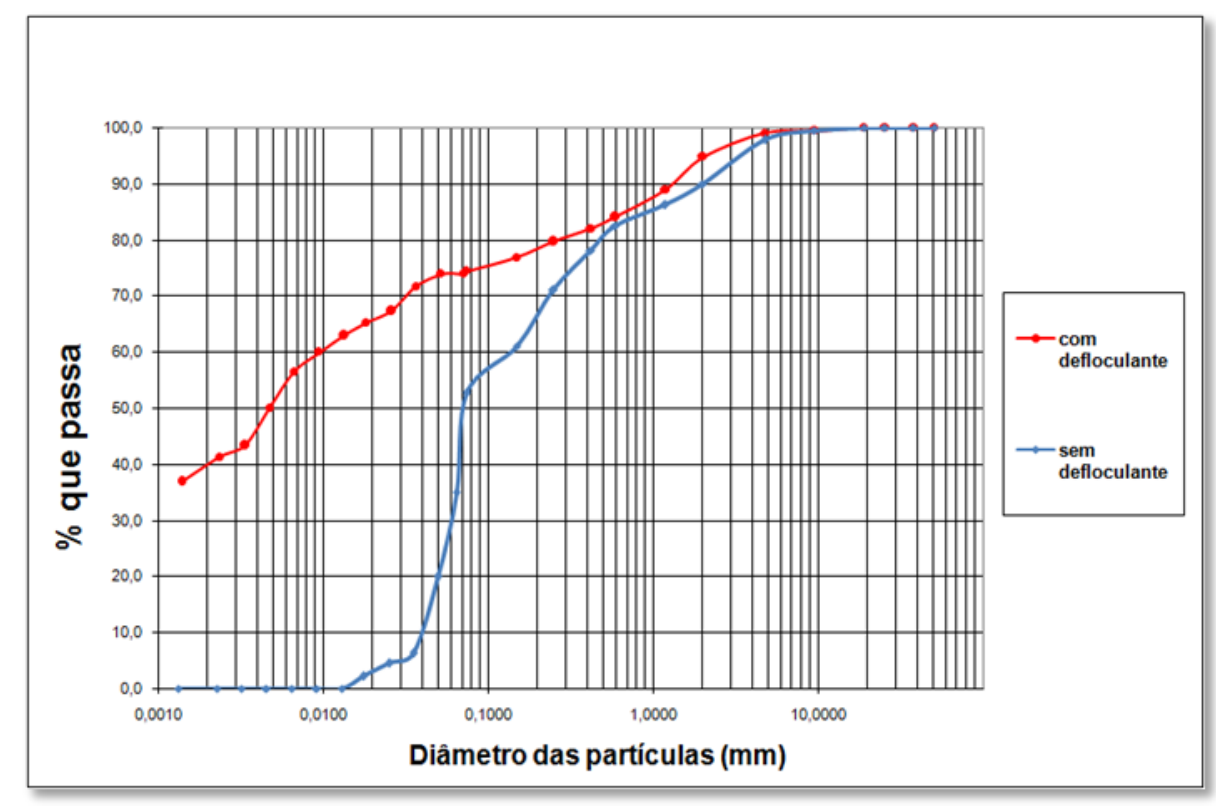

Figura 4.8 - Curva Granulométrica. 
A partir das curvas granulométricas elaborou-se a Tabela 4.3 com as porcentagens passantes em cada peneira. Nota-se que quando o solo é ensaiado sem defloculante, não há identificação da presença de argila, mas somente pedregulho, areia e silte, sendo o silte predominante com $45 \%$. Dessa forma o solo sem defloculante classifica-se como silte arenoso. Já para o solo ensaiado com defloculante têm-se $42 \%$ de argila e 32\% de silte, o que determina uma classificação como argila siltosa.

Tabela 4.3 - Resultado da análise granulométrica.

\begin{tabular}{|c|c|c|c|}
\hline $\mathrm{D}(\mathrm{mm})$ & Classificação & $\begin{array}{c}\text { Sem defloculante } \\
(\%)\end{array}$ & $\begin{array}{c}\text { Com defloculante } \\
(\%)\end{array}$ \\
\hline $6,0-20,0$ & Pedregulho médio & 1,8 & 0,9 \\
\hline $2,0-6,0$ & Pedregulho fino & 8,2 & 4,3 \\
\hline $0,6-2,0$ & Areia grossa & 7,4 & 10,6 \\
\hline $0,2-0,6$ & Areia média & 16,4 & 5,9 \\
\hline $0,06-0,2$ & Areia fina & 20,8 & 4,4 \\
\hline $0,002-0,006$ & Silte & 45,4 & 32,02 \\
\hline$<0,002$ & argila & 0,0 & 41,75 \\
\hline \multicolumn{2}{|c|}{ Solo } & $\begin{array}{l}\text { Silte arenoso com } \\
\text { pedregulho }\end{array}$ & Argila Siltosa \\
\hline
\end{tabular}

O ensaio de massa especifica dos grãos foi realizado de forma convencional (NBR6507) encontrando-se um valor de $2,68 \mathrm{~g} / \mathrm{cm}^{3}$. O mesmo procedimento foi realizado para o ensaio de limite de Atterberg, onde observa um limite de liquidez de 54\%, e limite de plasticidade de $39 \%$, conforme pode ser observado na Tabela 4.4.

Tabela 4.4 - Limites de Atterberg de massa especifica.

\begin{tabular}{c|c}
\hline Ensaios & Resultados \\
\hline Limite de Liquidez & $54,3 \%$ \\
\hline Limite de Plasticidade & $39,1 \%$ \\
\hline Índice de Plasticidade & $15,2 \%$ \\
\hline Massa Especifica dos grãos & 2,68 \\
\hline
\end{tabular}

Os sistemas de classificação que se baseiam nas características dos grãos que constituem os solos têm como objetivo a definição de grupos que apresentam comportamentos semelhantes sob aspectos de interesse da engenharia civil. Para se classificar o solo deste estudo, utilizou-se as mais conhecidas e utilizadas classificações da engenharia geotécnica. 


\subsubsection{CLASSIFICAÇÃO SUCS}

No gráfico de plasticidade, a linha A é uma fronteira arbitrária entre argila orgânica (CL e CH) que estão acima desta linha e os siltes inorgânicos e argilas orgânicas (ML, MH, OL, e OH) que estão abaixo. As argilas e siltes são ainda divididas naqueles de alta e baixa compressibilidade de acordo com o wL. Isto é baseado na observação empírica em que a compressibilidade do solo cresce com o wL. Solos com wL superior a 50\% são classificados como de alta compressibilidade ( $\mathrm{MH}, \mathrm{CH})$.

Inserindo-se os dados de ensaio $\mathrm{wL}=54 \%$ e $\mathrm{IP}=15 \%$ na Figura 4.9, observa-se que o ponto fica sobre a região de $\mathrm{OH}$ ou $\mathrm{MH}$.

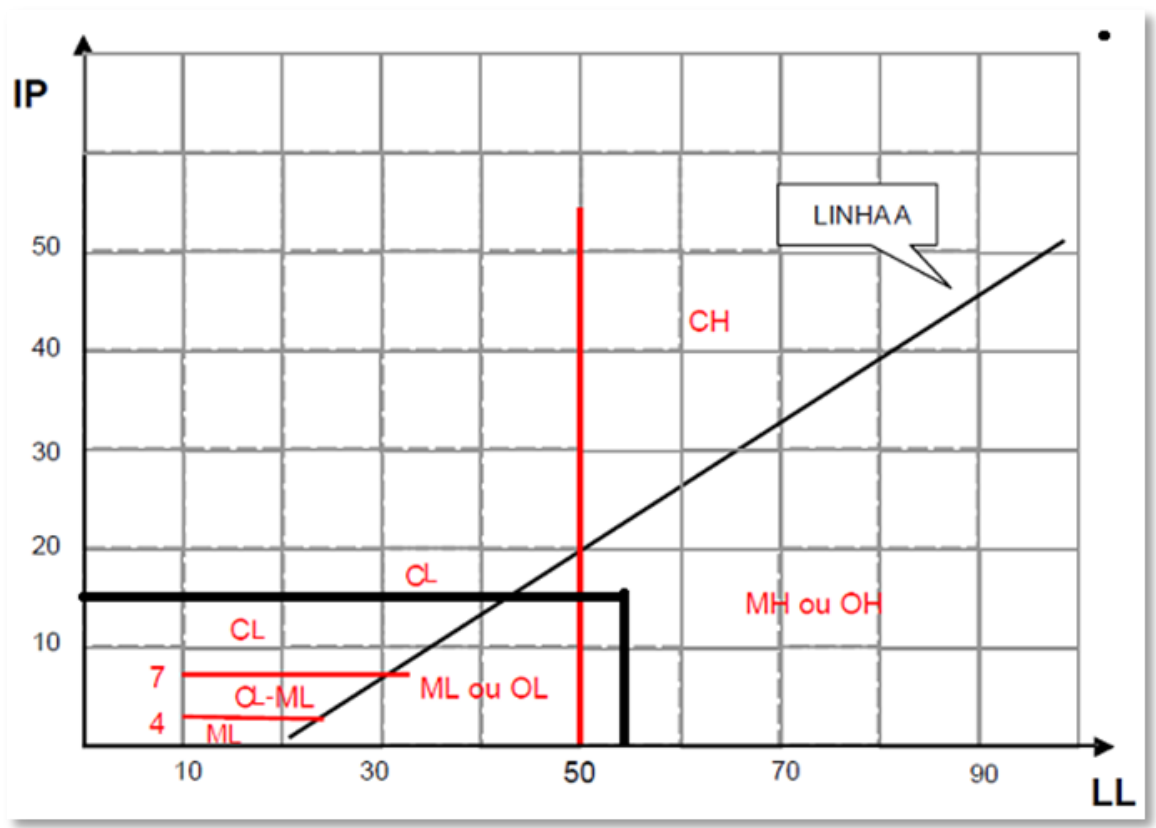

Figura 4.9 - Carta de Plasticidade para a classificação SUCS.

O solo ao qual se está estudando, provavelmente se classifica como MH.Os solos que estão classificados como MH sãosiltes inorgânicos, micáceos ou diatomáceos, finos arenosos ou solos siltosos, siltes elásticos.

\subsubsection{CLASSIFICAÇÃO MCT}

\subsubsection{Classificação MCT Expedita}

A classificação MCT expedita foi feita após a moldagem das pastilhas com a amostra previamente preparada, e pronta para a moldagem de acordo com a metodologia. 
O valor de c' obtido foi de 0,64 com uma penetração de $2 \mathrm{~mm}$. Com base na carta de classificação do método das pastilhas, ilustrada na Figura 4.10, conclui-se que se trata de um soloarenoso laterítico (LA').

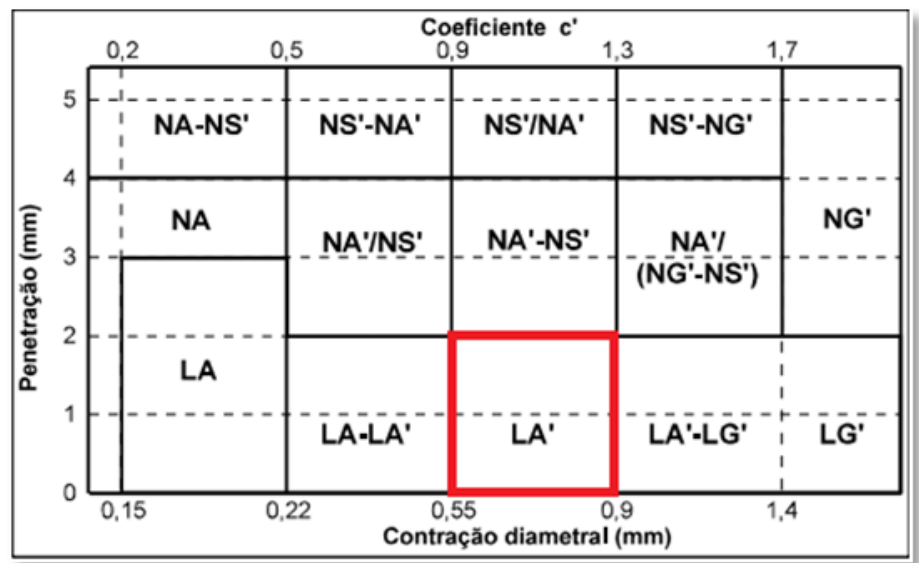

Figura 4.10 - Carta de classificação pelo método das pastilhas.

Diferentemente dos observados na curva granulométrica, o solo foi classificado como arenoso lateritico, no entanto corroboram com a grande quantidade de areia para o mesmo.

\subsubsection{Classificação MCT Tradicional}

De acordo com a metodologia para a classificação de solos tropicais, após a compactação dos corpos de prova em miniatura, plotou-se os gráficos para a determinação do tipo de solo. $\mathrm{O}$ primeiro gráfico apresenta a diferença de altura versus número de golpes, conforme pode ser observado na Figura 4.11.

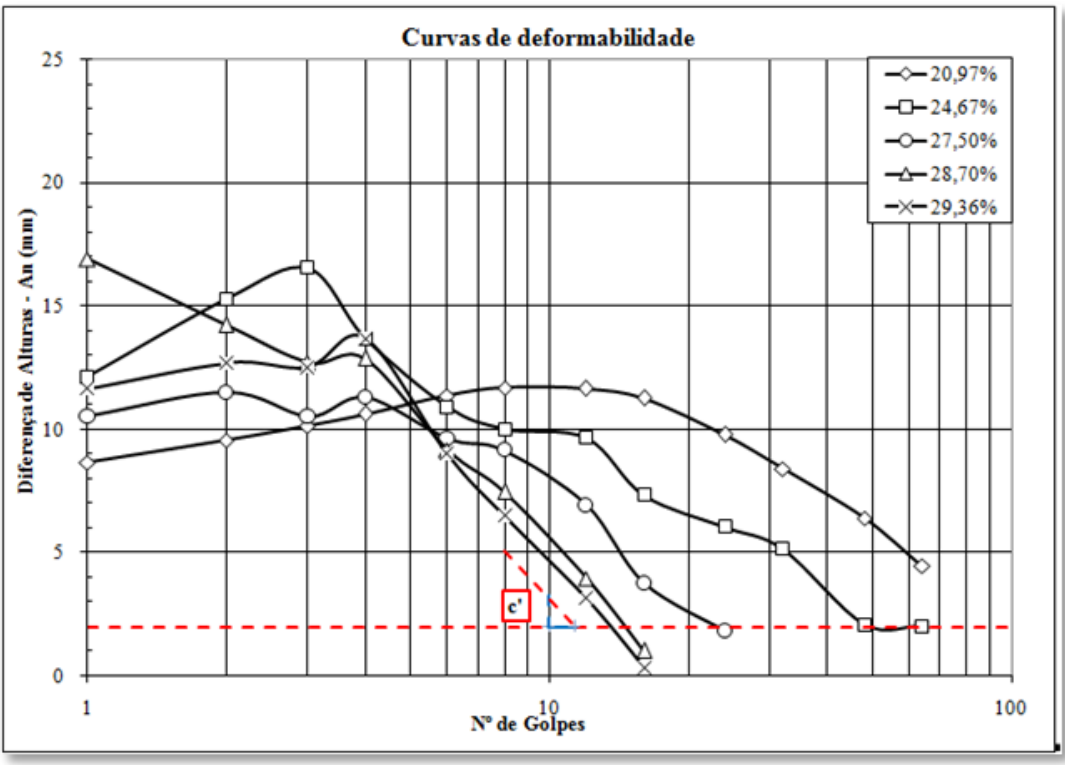

Figura 4.11 - Curva de deformabilidade 
O segundo gráfico gerado, Figura 4.12 apresenta as famílias de curvas de compactação geradas onde pode-se se conhecer a inclinação do ramos seco o d'(55,0). O último parâmetro é extraído do ensaio de perda de massa por imersão. Cada um dos corpos de prova compactados são submetidos à submersão total em água. A massa desprendida é coletada e então se calcula o parâmetro Pi pela equação fornecida pelo método. Com o valor de Pi (69,0), calcula-se, finalmente o e' $(1,02)$, também por meio de uma relação dada pelo método. Com os valores de c'(0,92) e e', procura-se no gráfico de classificação de solos tropicais em qual região se refere o solo, conforme pode ser observado na Figura 4.13, o solo classifica-se como um LA'.

\section{Famílias de curvas de compactação}

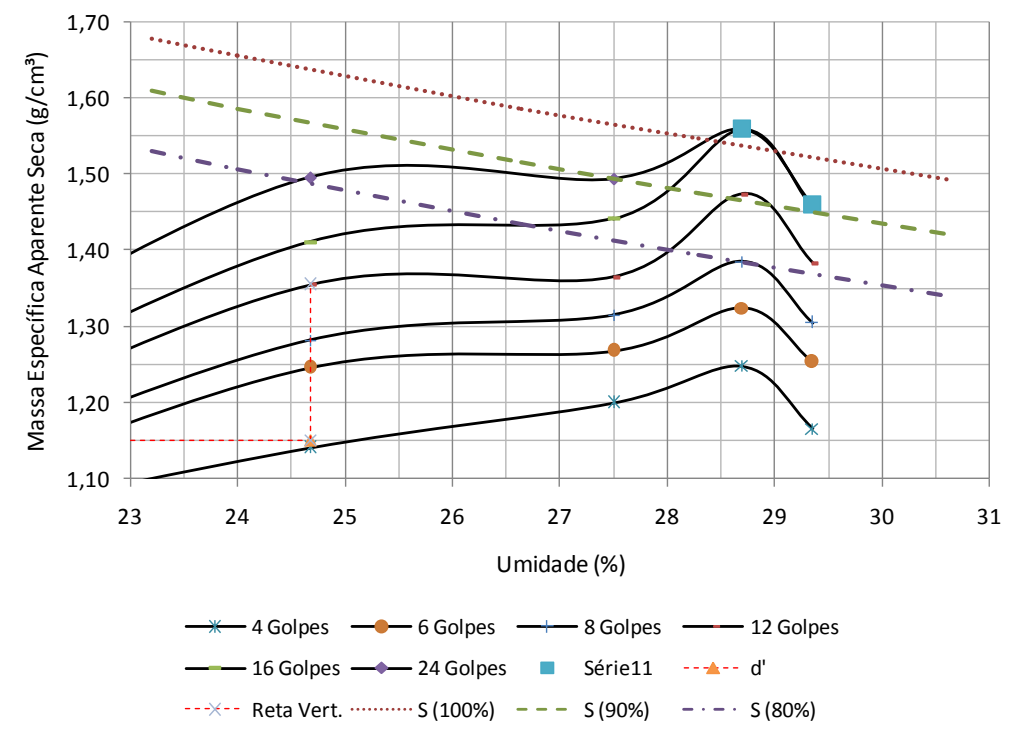

Figura 4.12 - Família das curvas de compactação.

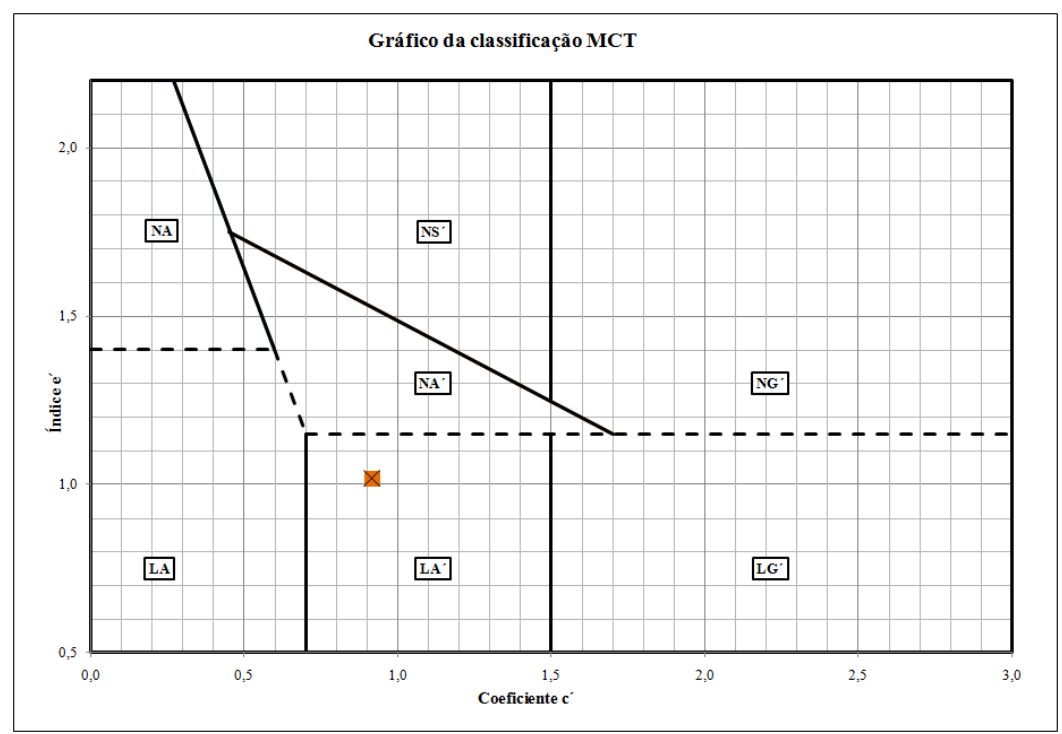

Figura 4.13 - Carta para classificação MCT, com resultados do solo. 


\subsection{CURVA DE COMPACTAÇÃO}

A curva de compactação do ensaio Proctor normal pode ser observada na Figura 4.14

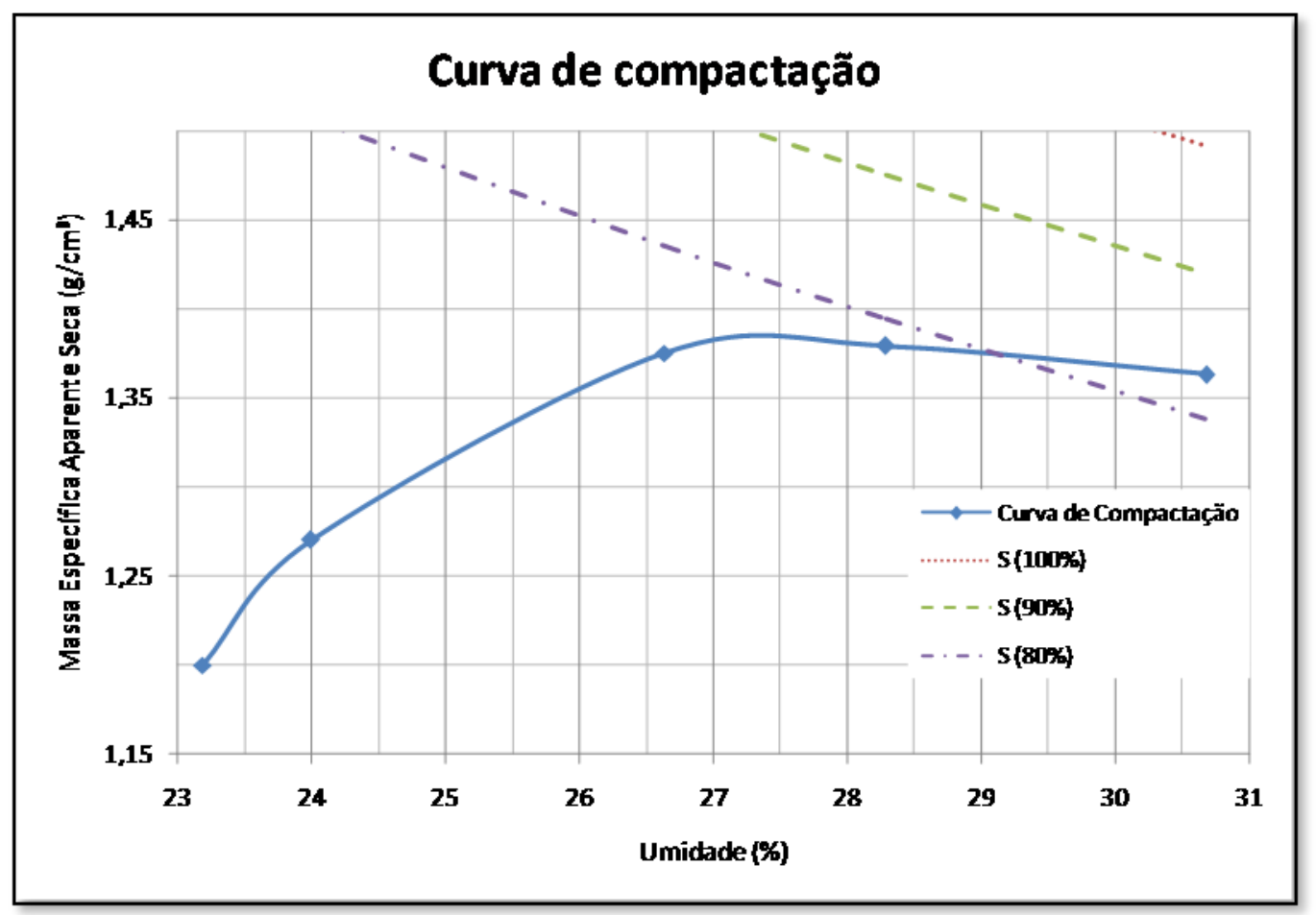

Figura 4.14 - Curva de compactação proctor normal.

A massa específica aparente seca máxima foi $1,38 \mathrm{~g} / \mathrm{cm}^{3}$ e umidade ótima de 27,5\%, índice de vazios de 0,94 e porosidade de $48 \%$.

\subsection{ENSAIO DE PERMEABILIDADE $(k)$}

O ensaio de permeabilidade foi realizado com a amostra indeformada natural, moldado no cilindro de compactação, e amostras compactadas na umidade ótima de compactação (27,5\%), e mais dois pontos de umidade, um acima da ótima (28,7\%), e outro abaixo da ótima $(25,2 \%)$. A Tabela 4.5 apresenta os valores encontrados para permeabilidade.

Tabela 4.5 - Valores de umidade, índice de vazios, porosidade e permeabilidade solo natural/compactado.

\begin{tabular}{l|l|c|c|c|c}
\hline Solo & wi $(\boldsymbol{\%})$ & wf $(\boldsymbol{\%})$ & e & n & $(\mathbf{k})(\mathbf{m} / \mathbf{s})$ \\
\hline \multirow{5}{*}{ LA $^{\prime}$} & $21,21 \%$ (natural) & 66,7 & 1,85 & $65 \%$ & $2,2 \times 10^{-5}$ \\
\cline { 2 - 6 } & $25,2 \%$ compactado & 29,4 & 1,06 & $51 \%$ & $5,2 \times 10^{-8}$ \\
\cline { 2 - 6 } & $27,5 \%$ compactado & 31,1 & 0,94 & $48 \%$ & $4,5 \times 10^{-9}$ \\
\cline { 2 - 6 } & $28,7 \%$ compactado & 32,6 & 0,97 & $49 \%$ & $4,9 \times 10^{-8}$ \\
\hline
\end{tabular}


De acordo com Nogami e Villibor (1995), os solos da classe LA', são solos de baixa permeabilidade ou impermeáveis quando compactados variando numa faixa de $10^{-9}$ a $10^{-8}$ $\mathrm{m} / \mathrm{s}$, observa-se que os valores ficaram dentro dos previstos para este tipo de solo.

\subsection{ANÁLISES QUÍMICAS}

Foram realizadas análises químicas no solo, no lodo de esgoto, e no extrato de lodo de esgoto para caracterização preliminar, além disso, análise química somente dos metais pesados para o contaminante do ensaio de difusão e sorção.

A Tabela 4.6 apresenta os valores do resultado para a caracterização do solo da área experimental na ETE Samambaia/Melchior.

Tabela 4.6 - Caracterização do solo no local do experimento da ETE Samambaia/Melchior.

\begin{tabular}{|c|c|}
\hline Valores medidos & Valor \\
\hline $\mathrm{pH}$ em $\mathrm{H}_{2} \mathrm{O}$, sem unidade & 6,0 \\
\hline pH em KCl, sem unidade & 4,8 \\
\hline Fósforo $-\mathrm{P}, \mathrm{em} \mathrm{mg} / \mathrm{dm}^{3}=\mathrm{ppm}$ & 0,2 \\
\hline Cálcio $-\mathrm{Ca}, \mathrm{em} \mathrm{cmol}_{\mathrm{d}} / \mathrm{dm}^{3}=\mathrm{mE} / 100 \mathrm{~mL}$ & 0,6 \\
\hline Magnésio $-\mathrm{Mg}$, em $\mathrm{cmol}_{\mathrm{d}} / \mathrm{dm}^{3}=\mathrm{mE} / 100 \mathrm{~mL}$ & 0,1 \\
\hline Potássio $-\mathrm{K}$, em $\mathrm{cmol}_{\mathrm{d}} / \mathrm{dm}^{3}=\mathrm{mE} / 100 \mathrm{~mL}$ & 0,07 \\
\hline Sódio $-\mathrm{Na}$, em $\mathrm{cmol}_{\mathrm{c}} / \mathrm{dm}^{3}=\mathrm{mE} / 100 \mathrm{~mL}$ & 0,03 \\
\hline Alumínio $-\mathrm{Al}, \mathrm{em} \mathrm{cmol}_{\mathrm{c}} / \mathrm{dm}^{3}=\mathrm{mE} / 100 \mathrm{~mL}$ & 0,0 \\
\hline Acidez $(\mathrm{H}+\mathrm{Al}), \mathrm{em} \mathrm{cmol}_{\mathrm{d}} / \mathrm{dm}^{3}=\mathrm{mE} / 100 \mathrm{~mL}$ & 3,2 \\
\hline Soma das bases, em $\mathrm{cmol}_{\mathrm{c}} / \mathrm{dm}^{3}=\mathrm{mE} / 100 \mathrm{~mL}$ & 0,8 \\
\hline CTC, ou T, em $\mathrm{cmol}_{\mathrm{c}} / \mathrm{dm}^{3}=\mathrm{mE} / 100 \mathrm{~mL}$ & 4,0 \\
\hline Saturação de Bases - V, em \% & 20,0 \\
\hline Saturação por Alumínio - m, em \% & 0,0 \\
\hline Saturação com Sódio - ISNa, em \% & 0,8 \\
\hline Carbono Orgânico - C, em g/kg & 11,5 \\
\hline Matéria orgânica - MO, em g/kg & 19,8 \\
\hline \multicolumn{2}{|l|}{ Metais pesados } \\
\hline Cromo & $<0,01$ \\
\hline Cádmio & $<0,01$ \\
\hline Níquel & $<0,01$ \\
\hline Cobre disponível $-\mathrm{Cu}$, em $\mathrm{mg} / \mathrm{dm}^{3}=\mathrm{ppm}$ & 1,24 \\
\hline Manganês $-\mathrm{Mn}, \mathrm{em} \mathrm{mg} / \mathrm{dm}^{3}=\mathrm{ppm}$ & 0,22 \\
\hline Zinco $-\mathrm{ZN}, \mathrm{em} \mathrm{mg} / \mathrm{dm}^{3}=\mathrm{ppm}$ & 1,04 \\
\hline
\end{tabular}

Com relação aos dados do complexo sortido, verifica-se valores baixos, o que influência diretamente na capacidade de troca de cátions, ressalta-se, que o solo ao possuir baixa quantidade de elementos irá diminuir a CTC, e consequentemente influenciar na sorção. 
A caracterização do extrato centrifugado de lodo foi realizada inicialmente para saber a composição em termos de metais pesados, os atributos analisados foram: $\mathrm{pH}$, condutividade, sólidos totais, arsênio, cádmio, chumbo, cobre, cromo, mercúrio, níquel, zinco, nitrato, alumínio, boro, cálcio, cobre, sulfato, ferro, magnésio, manganês, potássio, sódio, sulfeto, cianeto, cloreto; que são apresentados na Tabela 4.7.

Tabela 4.7 - Atributos analisados para o extrato de lodo centrifugado.

\begin{tabular}{|c|c|}
\hline Parâmetros Analisados & Resultados \\
\hline $\mathrm{pH}$ & 7,21 \\
\hline Condutividade & $1527 \mu \mathrm{S} / \mathrm{cm}$ \\
\hline Sólidos Totais & $759 \mathrm{mg} / \mathrm{L}$ \\
\hline Alumínio & $0,00 \mathrm{mg} / \mathrm{L}$ \\
\hline Potássio & $0,78 \mathrm{mg} / \mathrm{L}$ \\
\hline Sódio & $0,23 \mathrm{mg} / \mathrm{L}$ \\
\hline Cloreto & $12,42 \mathrm{mg} / \mathrm{L}$ \\
\hline Cobre & $1,18 \mathrm{mg} / \mathrm{L}$ \\
\hline Manganês & $1,90 \mathrm{mg} / \mathrm{L}$ \\
\hline Ferro & $4,64 \mathrm{mg} / \mathrm{L}$ \\
\hline Zinco & $0,67 \mathrm{mg} / \mathrm{L}$ \\
\hline Nitrato & $<0,05 \mathrm{mg} / \mathrm{L}$ \\
\hline Boro & $0,03 \mathrm{mg} / \mathrm{L}$ \\
\hline Cálcio & $6,01 \mathrm{mg} / \mathrm{L}$ \\
\hline Magnésio & $1,22 \mathrm{mg} / \mathrm{L}$ \\
\hline Arsênio & $<0,01 \mathrm{mg} / \mathrm{L}$ \\
\hline Cádmio & $<0,01 \mathrm{mg} / \mathrm{L}$ \\
\hline Chumbo & $0,02 \mathrm{mg} / \mathrm{L}$ \\
\hline Níquel & $0,01 \mathrm{mg} / \mathrm{L}$ \\
\hline Cromo & $<0,01 \mathrm{mg} / \mathrm{L}$ \\
\hline Sulfeto & $<0,01 \mathrm{mg} / \mathrm{L}$ \\
\hline Cianeto & $<0,01 \mathrm{mg} / \mathrm{L}$ \\
\hline Sulfato & $1,99 \mathrm{mg} / \mathrm{L}$ \\
\hline
\end{tabular}

Os resultados dos atributos do extrato de lodo de esgoto permitem observar uma quantidade muito grande de elementos encontrados, mesmo que esses se apresentam em quantidades traços. Os elementos manganês e cobre, tiveram seus resultados acima dos recomendados pelas normatizações de padrões de referência, o que poderia comprometer a qualidade ambiental do meio onde o mesmo fosse lançado. Ressalta-se que a referida estação de tratamento não possui tratamento químico específico para a remoção de metais pesados, ficando o tratamento condicionado a remoção de matéria orgânica, patógenos e nutrientes. 
A Tabela 4.8, apresenta os valores da caracterização do complexo sortido e dos metais referente ao lodo de esgoto da ETE Samambaia/Melchior.

Tabela 4.8 - Caracterização do lodo de esgoto.

\begin{tabular}{|c|c|}
\hline Lodo de esgoto & Valor \\
\hline $\mathrm{pH}$ em $\mathrm{H}_{2} \mathrm{O}$, sem unidade & 6,8 \\
\hline Fósforo $-\mathrm{P}, \mathrm{em} \mathrm{mg} / \mathrm{dm}^{3}=\mathrm{ppm}$ & 117,0 \\
\hline Cálcio $-\mathrm{Ca}, \mathrm{em} \mathrm{cmol}_{\mathrm{d}} / \mathrm{dm}^{3}=\mathrm{mE} / 100 \mathrm{~mL}$ & 1,21 \\
\hline Magnésio $-\mathrm{Mg}, \mathrm{em} \mathrm{cmol}_{\mathrm{C}} / \mathrm{dm}^{3}=\mathrm{mE} / 100 \mathrm{~mL}$ & 0,47 \\
\hline Potássio $-\mathrm{K}, \mathrm{em} \mathrm{cmol}_{\mathrm{d}} / \mathrm{dm}^{3}=\mathrm{mE} / 100 \mathrm{~mL}$ & 0,46 \\
\hline Sódio $-\mathrm{Na}, \mathrm{em} \mathrm{cmol}_{\mathrm{d}} / \mathrm{dm}^{3}=\mathrm{mE} / 100 \mathrm{~mL}$ & 0,07 \\
\hline Alumínio $-\mathrm{Al}, \mathrm{em} \mathrm{cmol}_{\mathrm{d}} / \mathrm{dm}^{3}=\mathrm{mE} / 100 \mathrm{~mL}$ & 0,2 \\
\hline Acidez $(\mathrm{H}+\mathrm{Al}), \mathrm{em} \mathrm{cmol}_{\mathrm{d}} / \mathrm{dm}^{3}=\mathrm{mE} / 100 \mathrm{~mL}$ & 3,4 \\
\hline Soma das bases, em $\mathrm{cmol}_{\mathrm{c}} / \mathrm{dm}^{3}=\mathrm{mE} / 100 \mathrm{~mL}$ & 1,21 \\
\hline CTC, ou T, em cmol $/ \mathrm{dm}^{3}=\mathrm{mE} / 100 \mathrm{~mL}$ & 21,0 \\
\hline Saturação de Bases - V, em \% & 26 \\
\hline Saturação por Alumínio - m, em \% & 14,8 \\
\hline Saturação com Sódio - ISNa, em \% & 5,8 \\
\hline Carbono Orgânico - C, em g/kg & 16,8 \\
\hline Matéria orgânica $-\mathrm{MO}, \mathrm{em} \mathrm{g} / \mathrm{kg}$ & 28,9 \\
\hline Relação CTC/C orgânico, sem unidade & 0,7 \\
\hline Relação C/N & 62,5 \\
\hline $\begin{array}{l}\text { Demanda química de oxigênio - DQO - } \\
\mathrm{mg} / \mathrm{g}\end{array}$ & 749 \\
\hline Soma dos sais $\mathrm{mg} / \mathrm{kg}$ ou $\mathrm{ppm}$ & 222 \\
\hline \multicolumn{2}{|l|}{ Metais $\left(\mathrm{em} \mathrm{mg} / \mathrm{dm}^{3}=\mathrm{PPM}\right)$} \\
\hline Boro & 104 \\
\hline Cromo & 0,02 \\
\hline Cádmio & $<0,01$ \\
\hline Ferro & 6,98 \\
\hline Níquel & $<0,01$ \\
\hline Cobre disponível & 0,10 \\
\hline Manganês & 0,06 \\
\hline Zinco & 0,4 \\
\hline
\end{tabular}

Inicialmente foram determinados os valores de umidade seca ao ar com 48 horas $145,93 \%$, seca nas lâmpadas, $236,73 \%$, seca na estufa com temperatura de $109^{\circ} \mathrm{C}$ com umidade de $253,5 \%$. Além da umidade foi determinada a quantidade de cinzas com as temperaturas de 250 e $500^{\circ} \mathrm{C}$, os valores encontrados foram 8,01 e $13,75 \%$ respectivamente, indicando assim alta quantidade de material orgânica volátil.

Comparando-se os valores do lodo de esgoto com os do solo, nota-se uma elevação dos valores, principalmente do fósforo, CTC, e $\mathrm{V}(\%)$. Valores altos de CTC indicam 
possibilidade de troca de cátions e consequentemente favorecimento do mecanismo de sorção. Nota-se que o material lodo de esgoto apresenta característica de material orgânico e grande capacidade de ser utilizado como adubo, no entanto, isso deve ser feito com cautela, uma vez que, mesmo apresentando traços de metais pesados, o mesmo possui capacidade de contaminação do solo.

\subsection{ENSAIO DE DIFUSÃO}

Foram realizados ensaios de difusão para o contaminante de lodo de esgoto, com o liner na condição não saturada e saturada, difusão com solução sintética de cloreto de cromo 3, e níquel, além de difusão para o nitrato. Na condição saturada e não saturada obteve-se os valores de metais multiespécie, e ainda separadamente para o cromo e nitrato. Os ensaios teve duração de 30 dias para a condição não saturada, 18 dias para a condição saturada, 36 dias difusão com cromo, configurações de 4,8 e 32 dias para o nitrato.

\subsubsection{ENSAIO DE DIFUSÃO MULTIESPÉCIE LINER NÃO SATURADO}

O ensaio de difusão para análise do transporte de contaminantes presentes no lodo de esgoto foi realizado para os metais: cobre, manganês, cromo, níquel, zinco e cádmio, a seguir são apresentado os resultados para o efluente no reservatório e nas camadas do solo. O ensaio de difusão nessa condição (liner não saturado) teve a duração de 30 dias. Nas figuras 4.15 a 4.30, são apresentados os valores das concentrações no efluente e nas camadas de solo. No Anexo C apresentam-sedados complementares referentes aos corpos de prova.

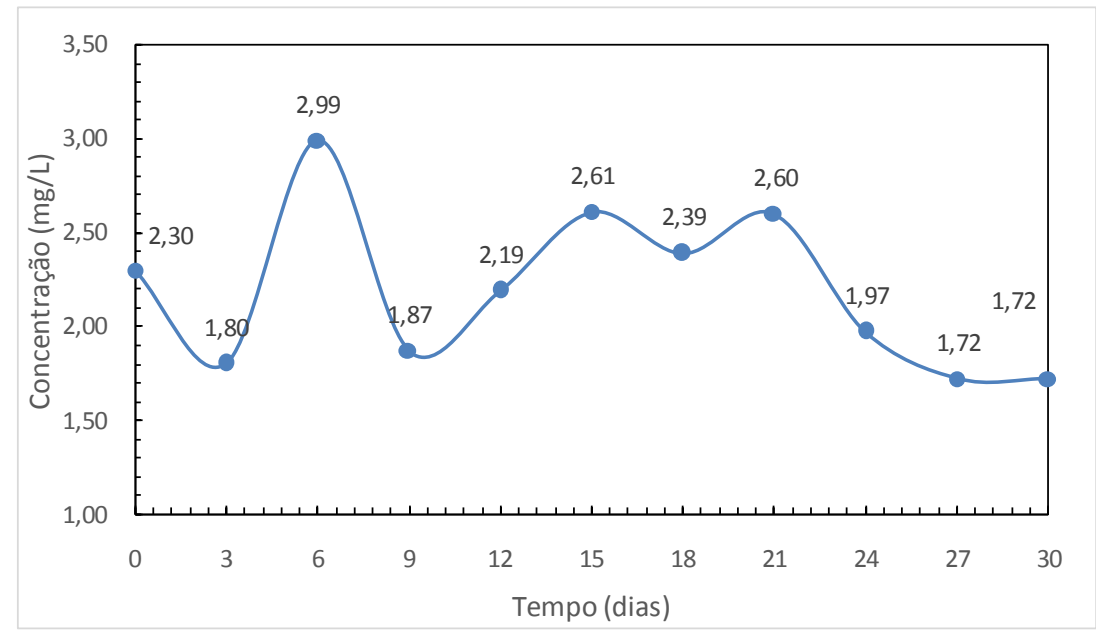

Figura 4.15 - Concentração de cobre no contaminante de lodo de esgoto. 


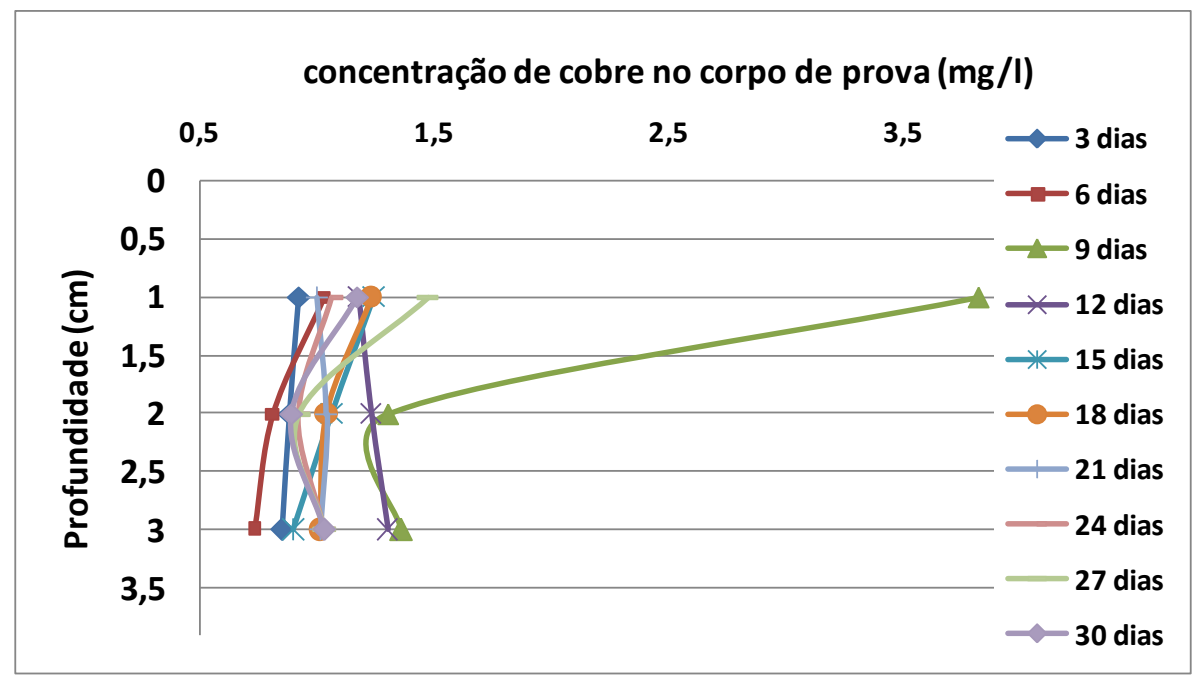

Figura 4.16 - Concentração de cobre no corpo de prova

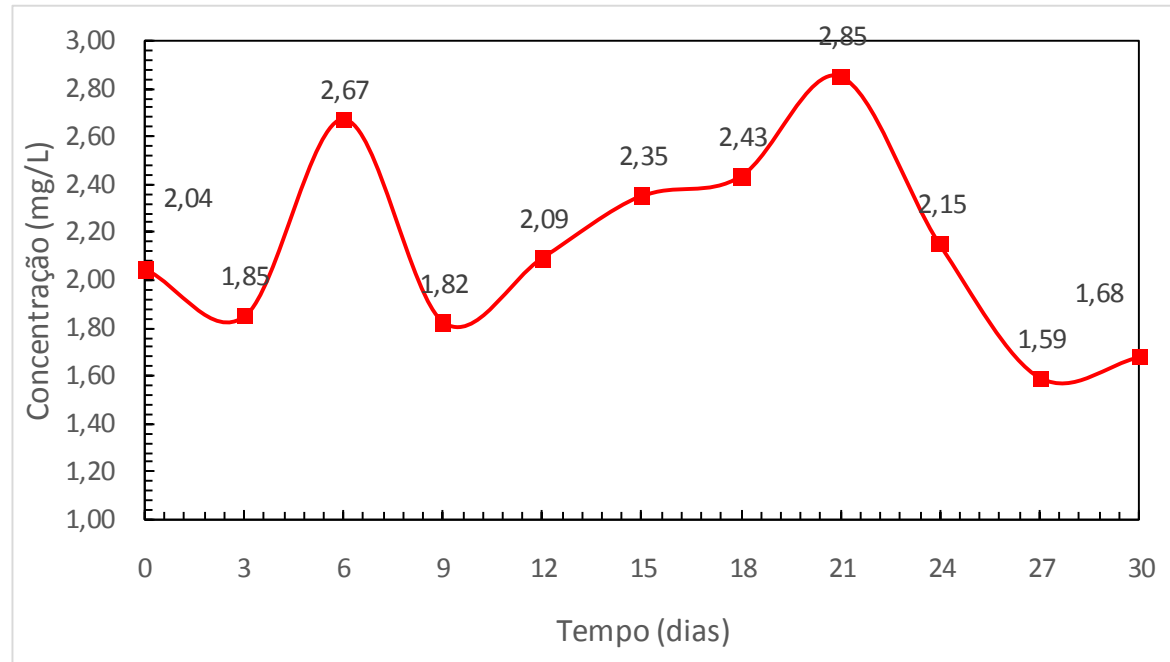

Figura 4.17 - Concentração de manganês no contaminante de lodo de esgoto.

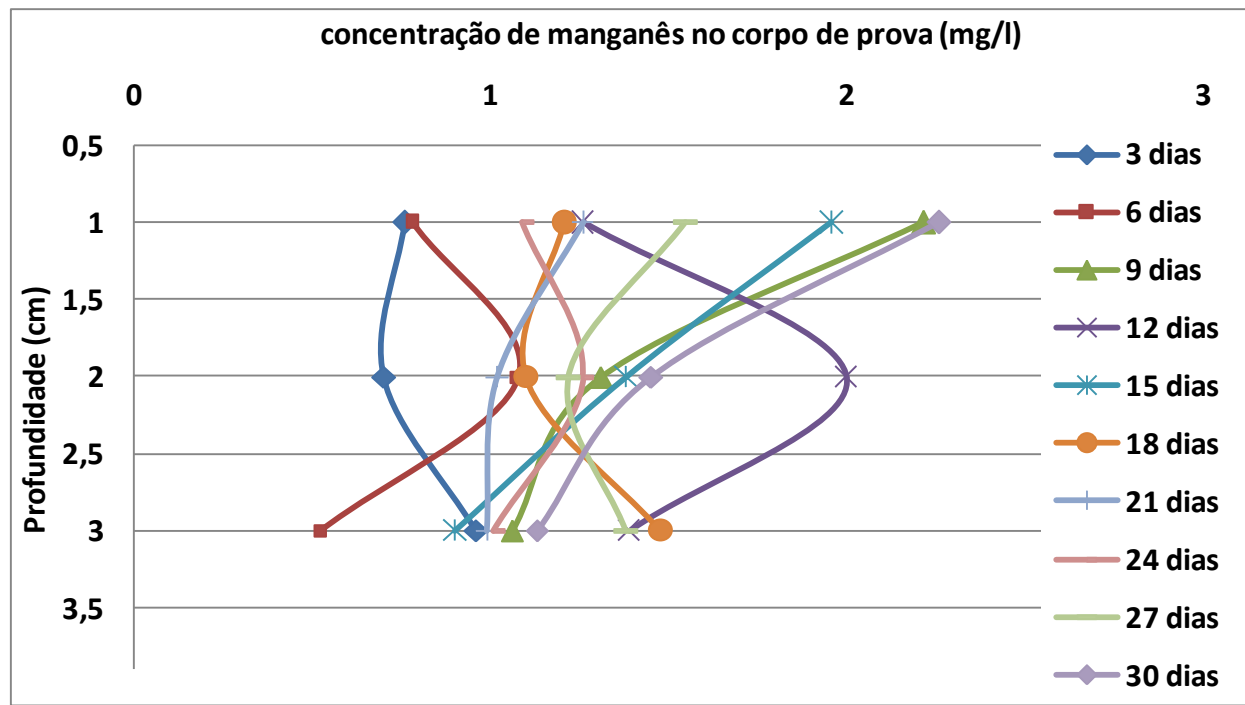

Figura 4.18 - Concentração de manganês no corpo de prova. 


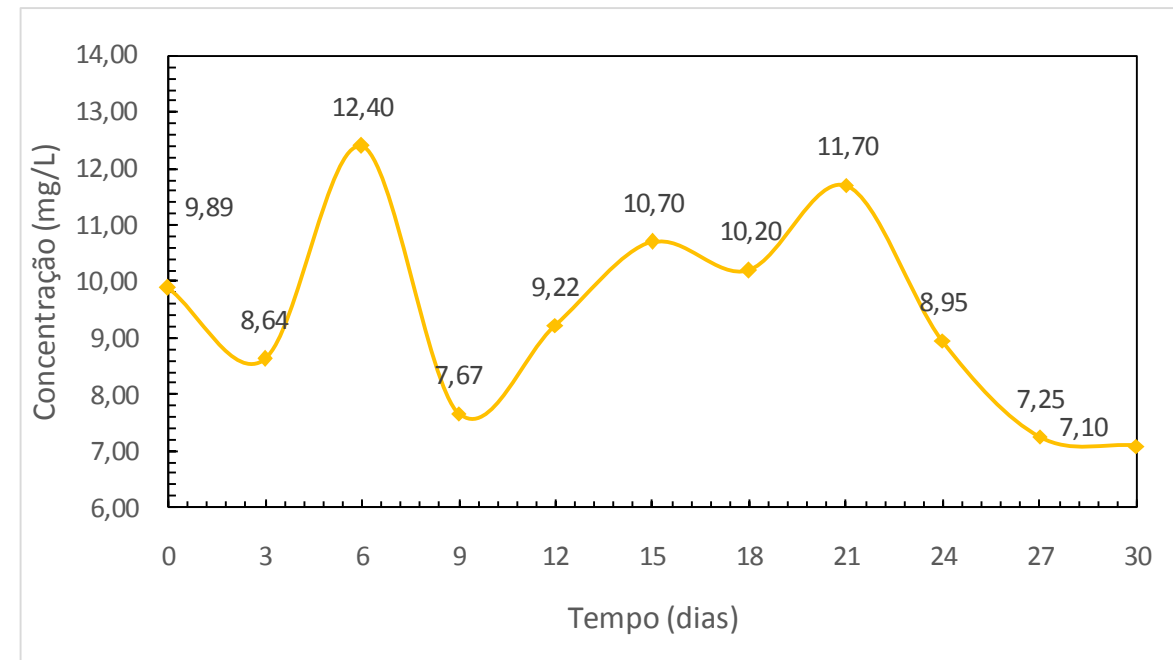

Figura 4.19 - Concentração de zinco no contaminante de lodo de esgoto.

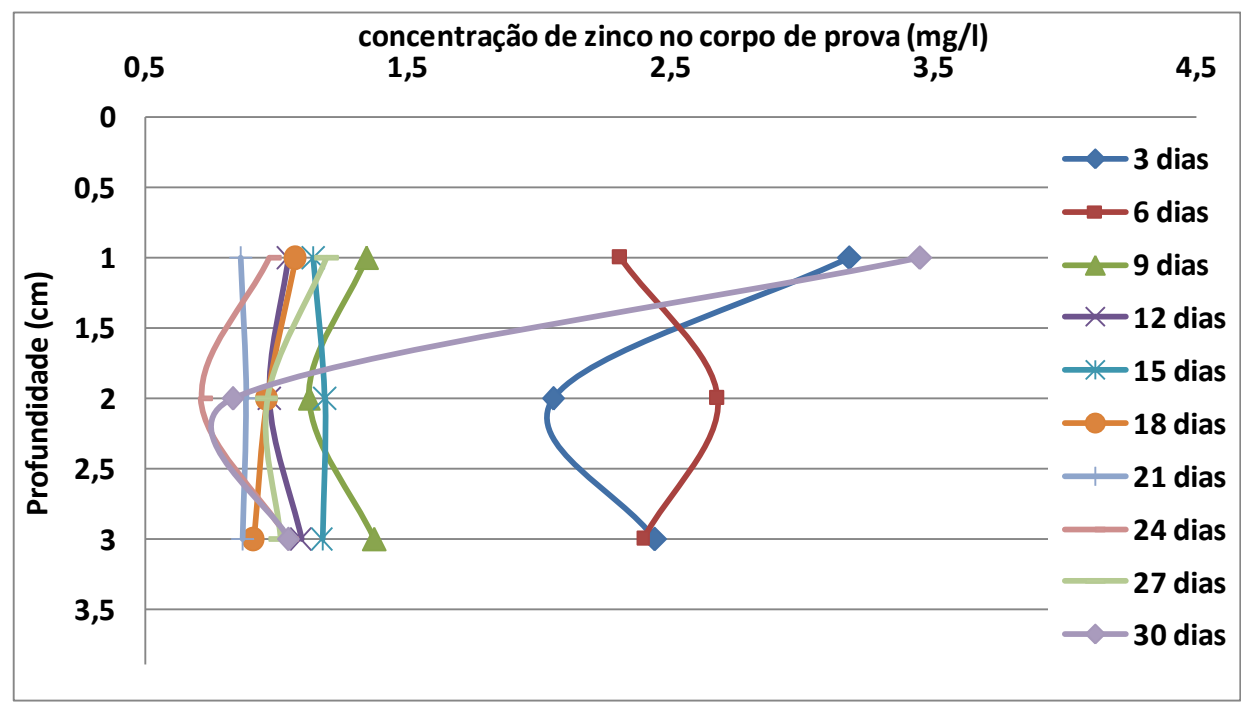

Figura 4.20 - Concentração de zinco no corpo de prova.

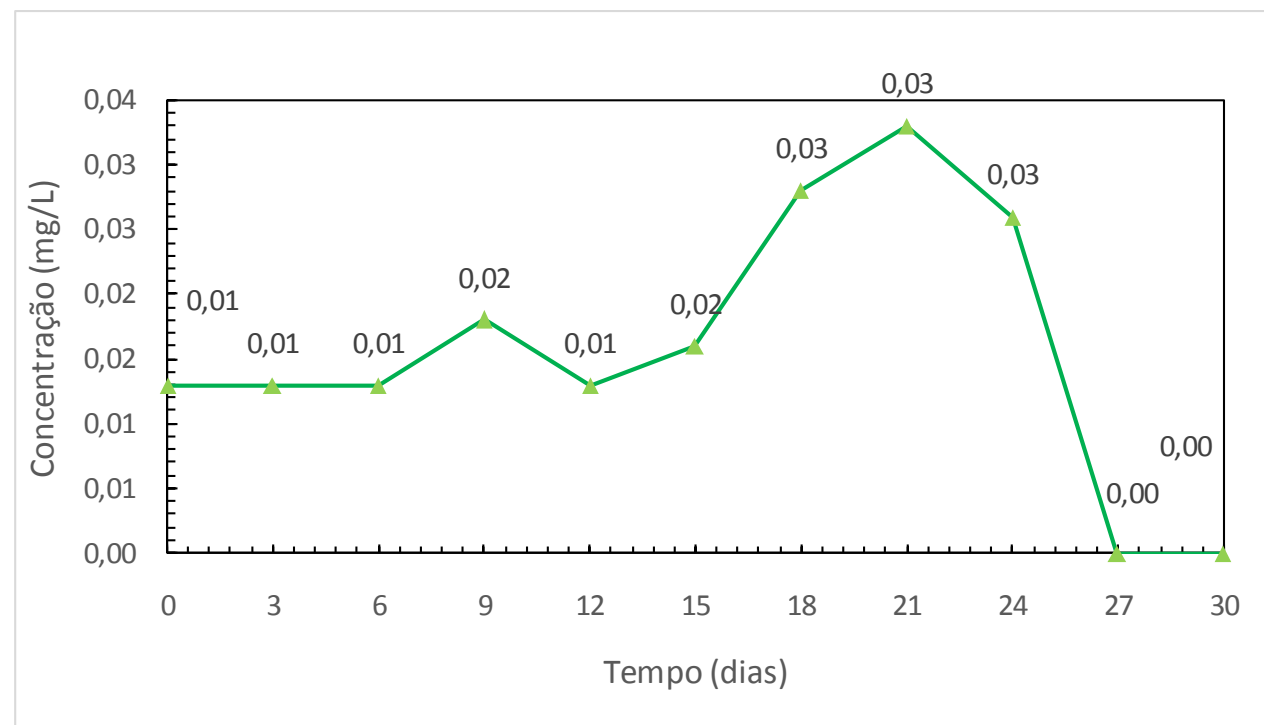

Figura 4.21 - Concentração de cádmio no contaminante de lodo de esgoto. 


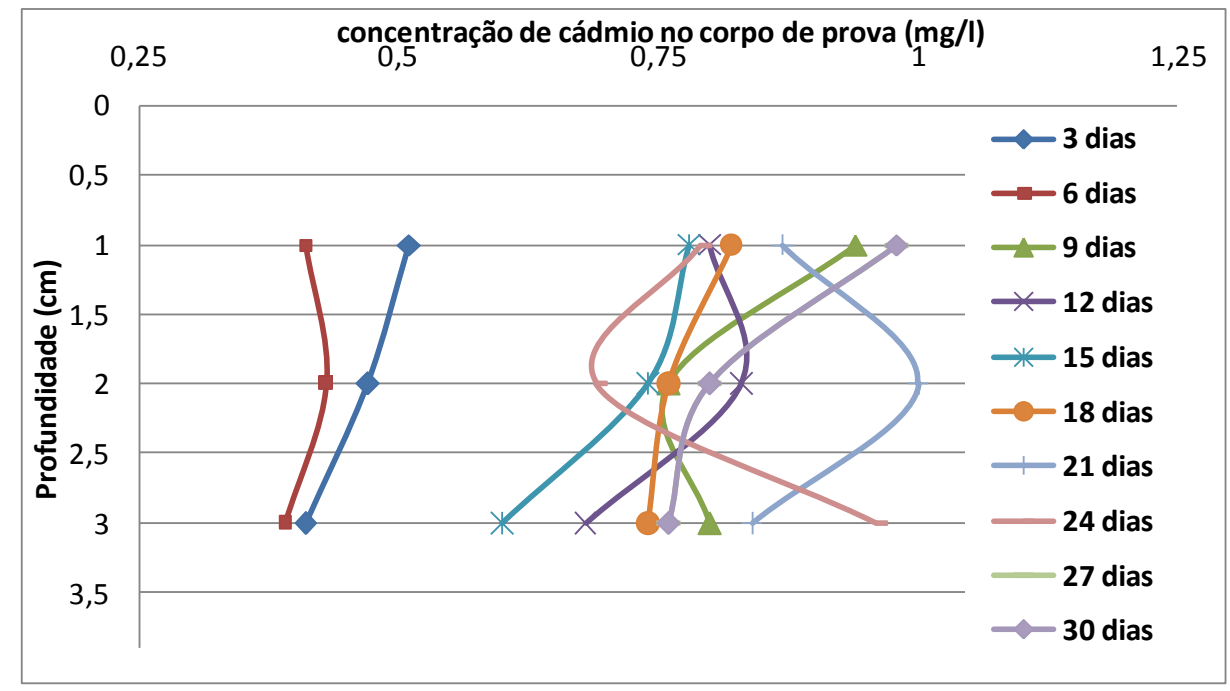

Figura 4.22 - Concentração de cádmio no corpo de prova.

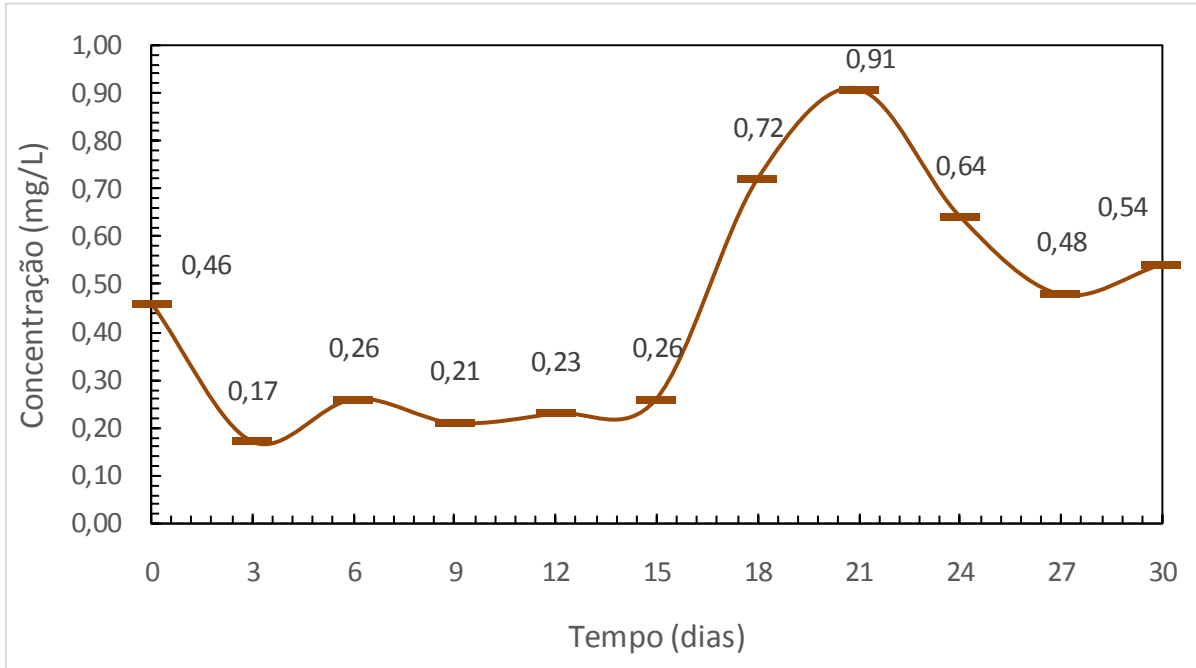

Figura 4.23 - Concentração de cromo no contaminante de lodo de esgoto.

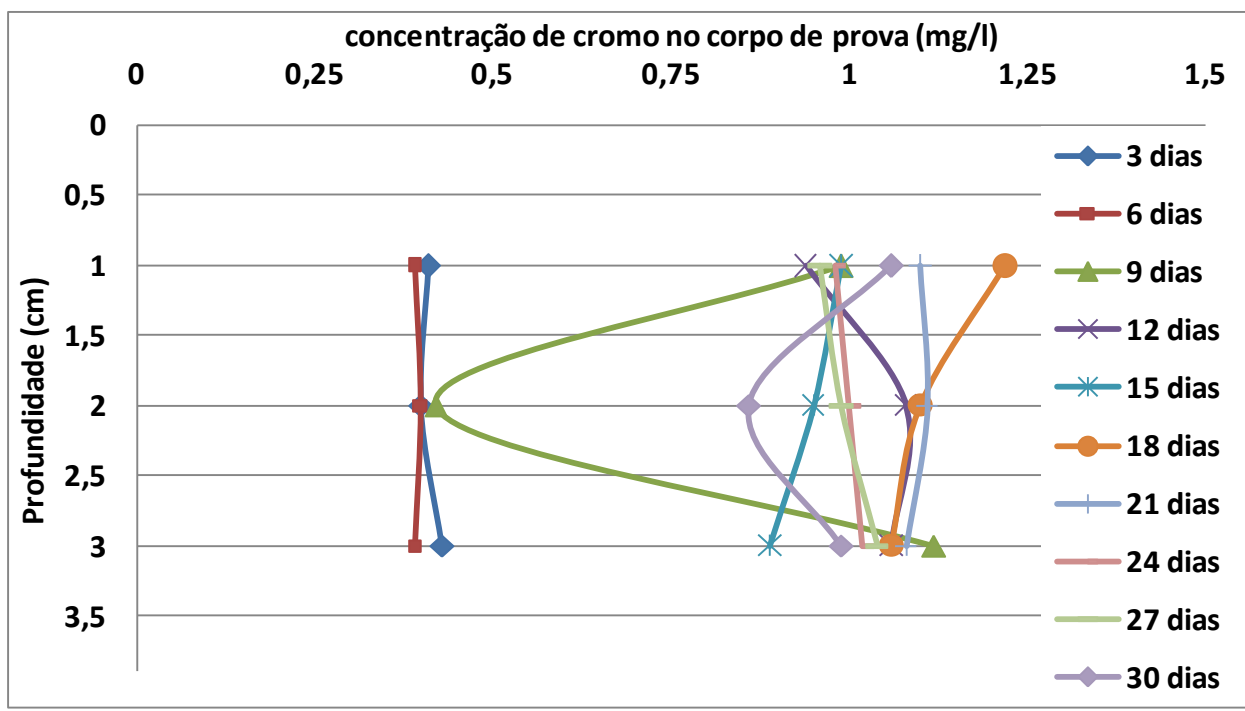

Figura 4.24 - Concentração de cromo no corpo de prova. 


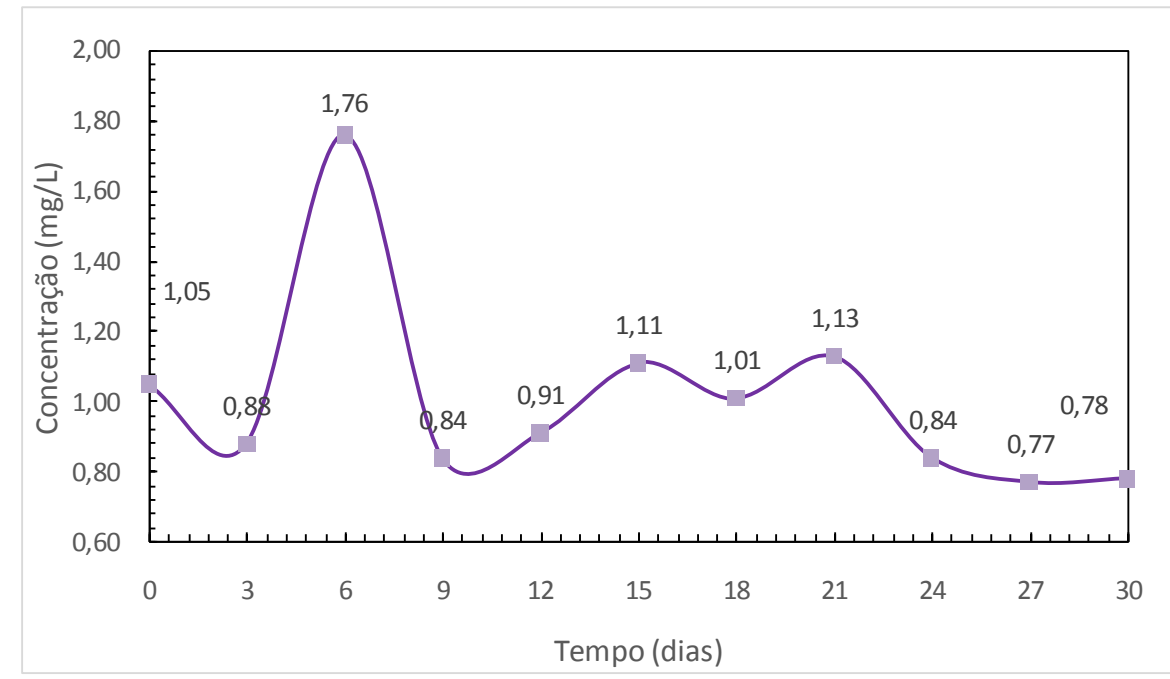

Figura 4.25 - Concentração de cromo no contaminante de lodo de esgoto.

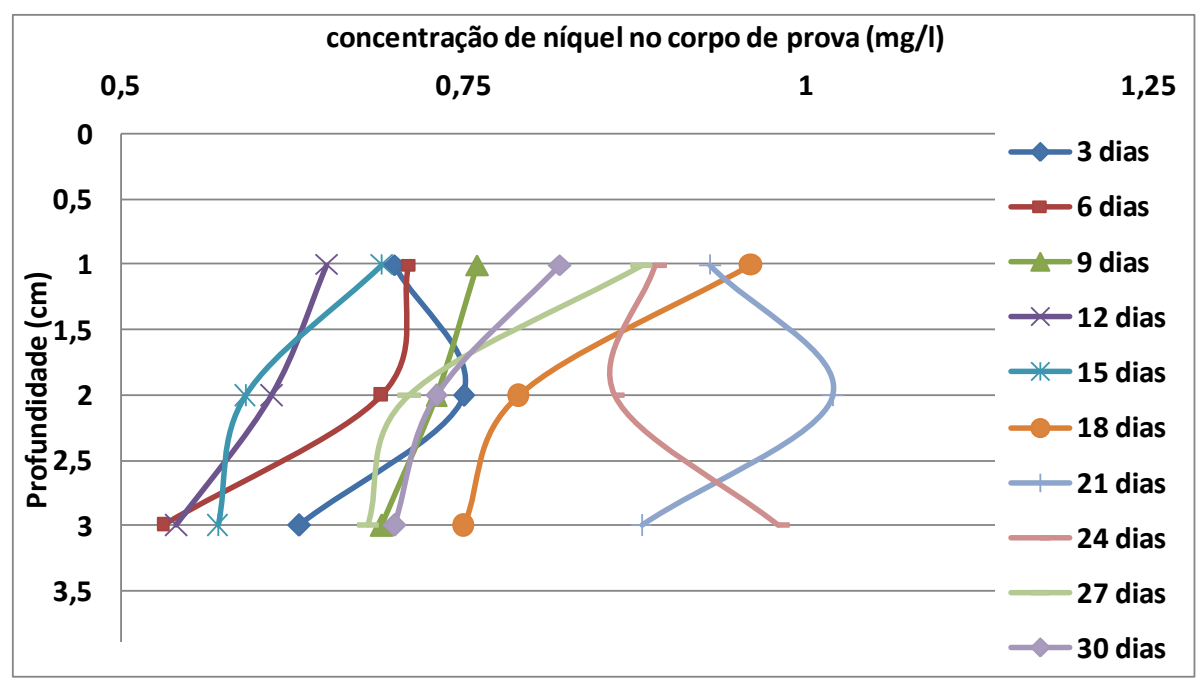

Figura 4.26 - Concentração de cromo no corpo de prova.

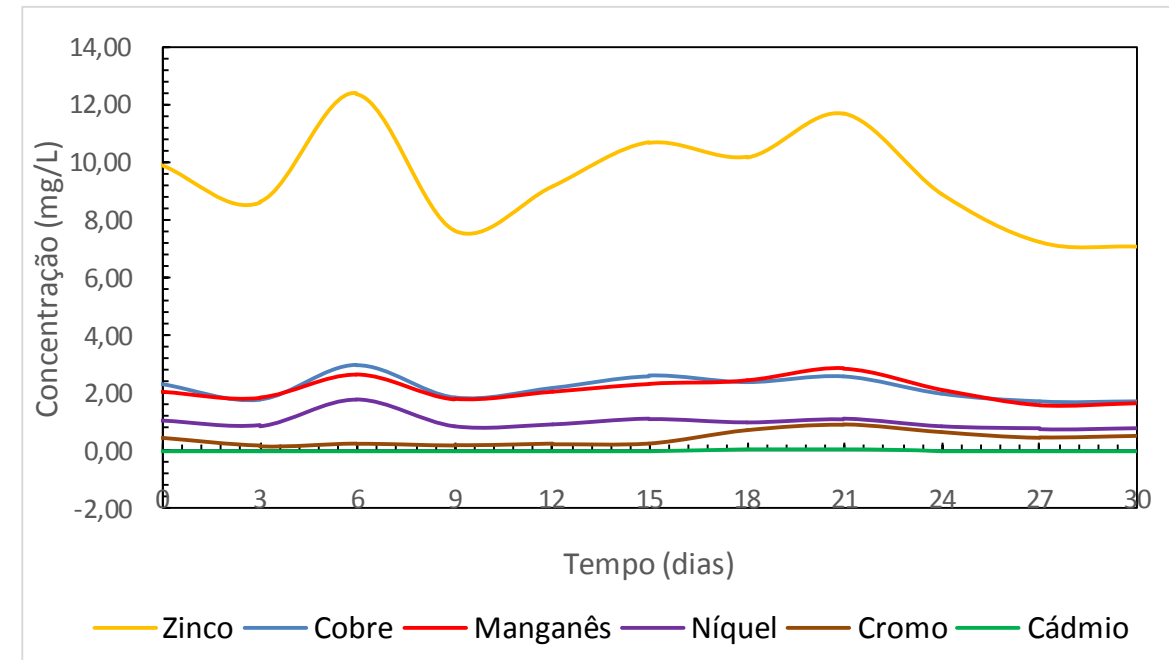

Figura 4.27 - Concentração multiespécie no contaminante de lodo de esgoto. 


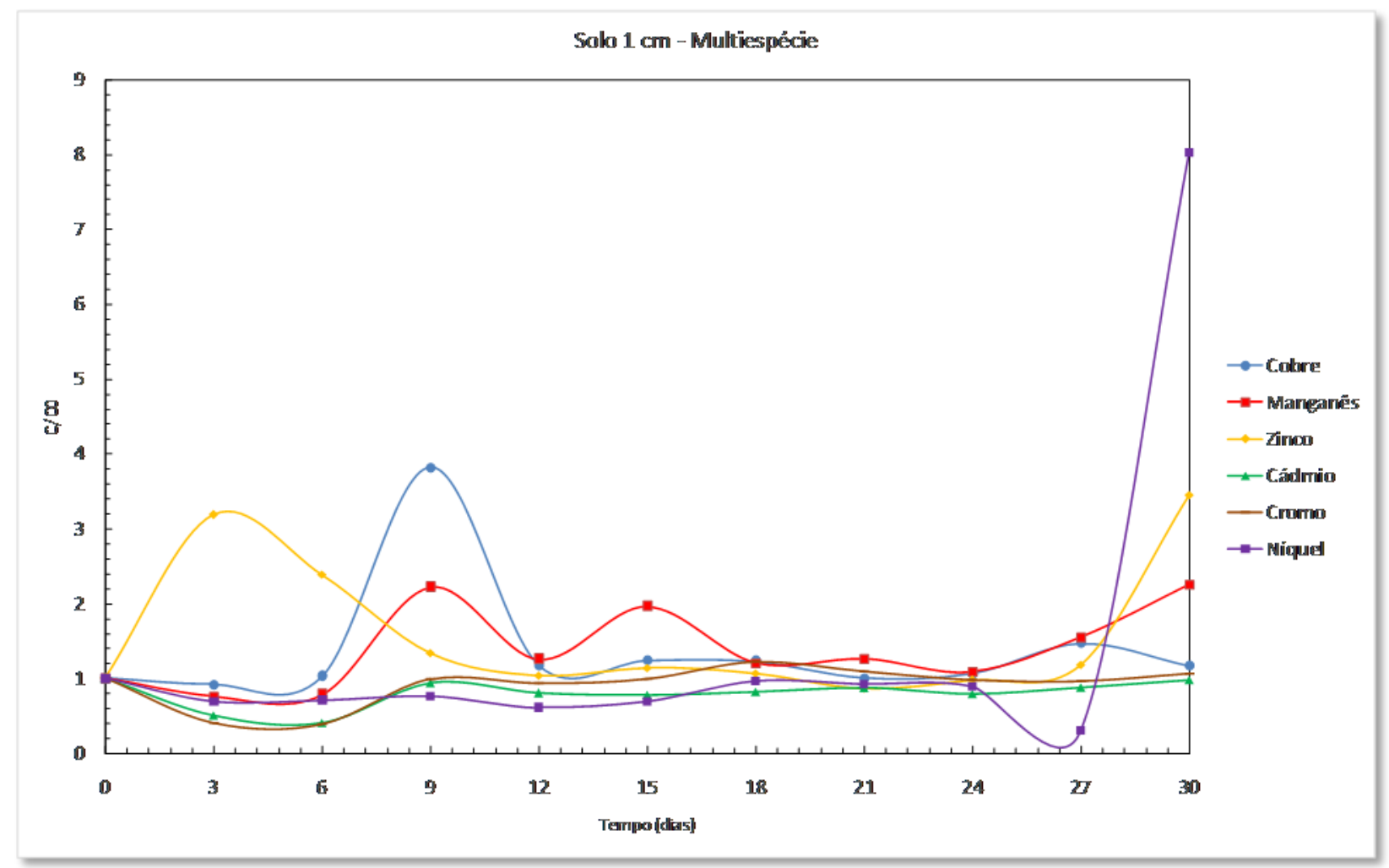

Figura 4.28 - Concentração multiespécie primeira camada no corpo de prova

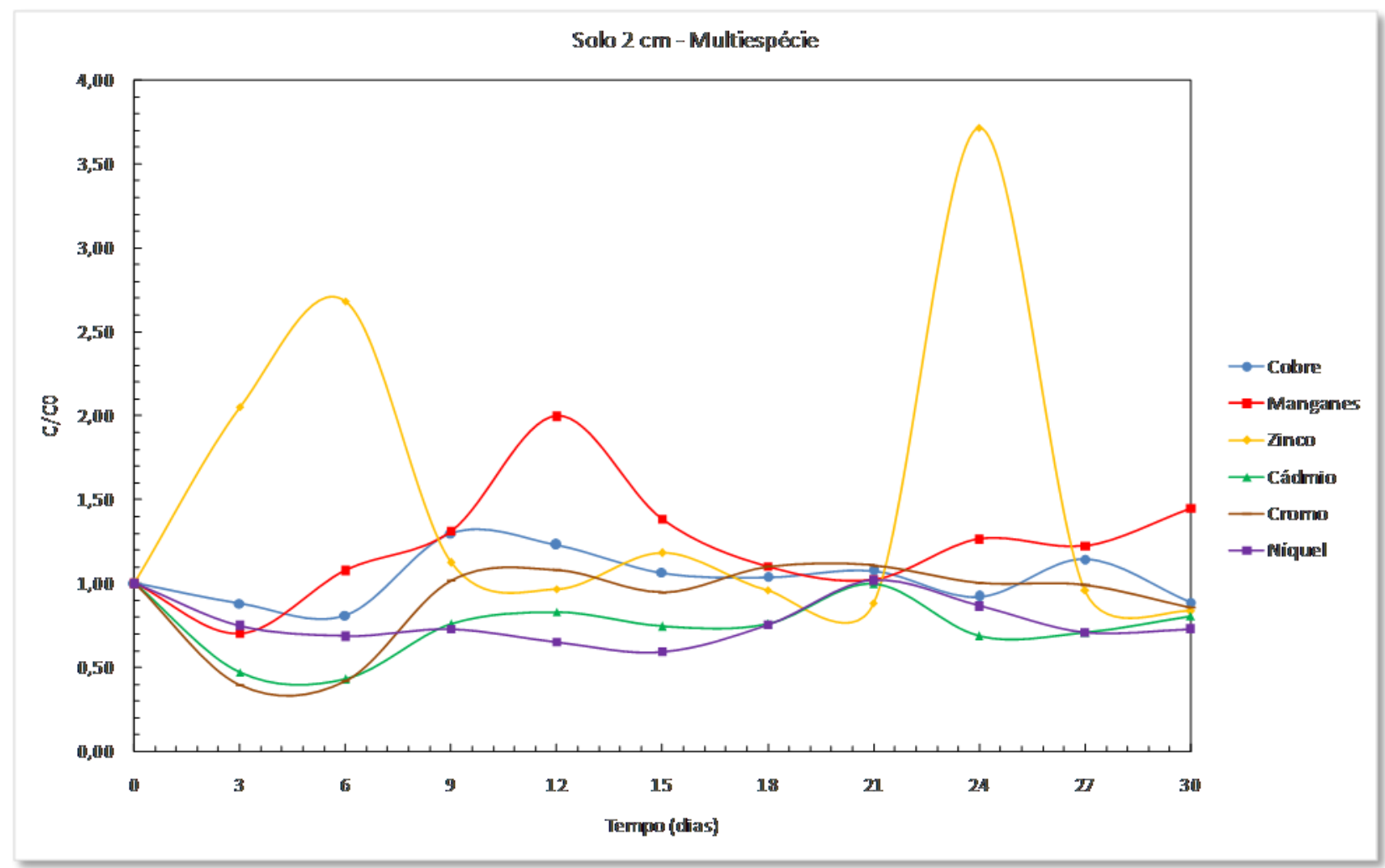

Figura 4.29 - Concentração multiespécie segunda camada de solo 


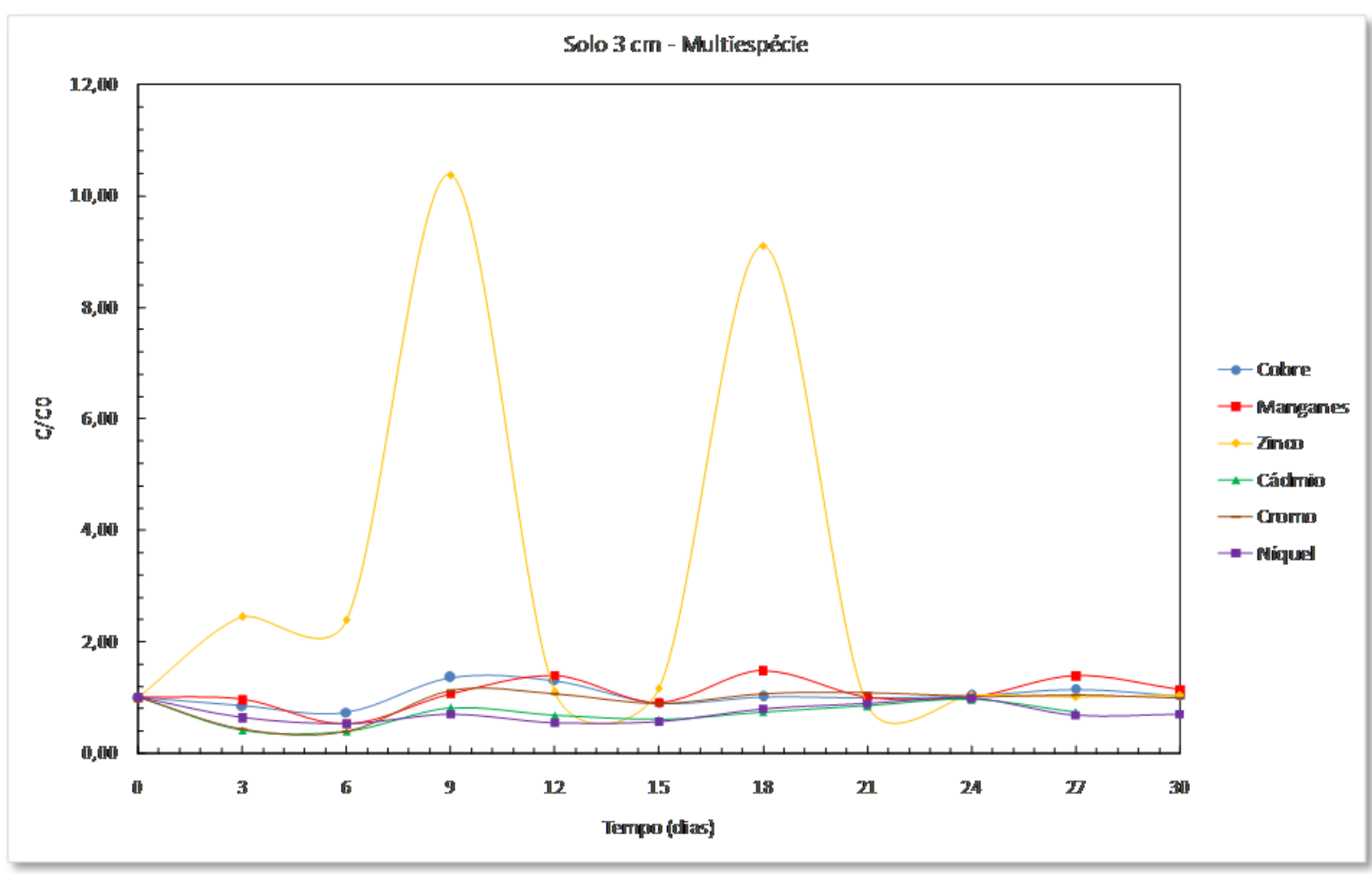

Figura 4.30 - Concentração multiespécie terceira camada de solo.

As curvas de concentração dos metais analisados no contaminante do reservatório em função do tempo apresentaram dispersão dos dados, principalmente para os corpos de prova correspondentes aos sexto dia e vigésimo primeiro dia. Como se trata de um contaminante real, o mesmo apresenta atividade biológica intensa, produzindo e interferindo nas reações químicas que ocorrem no meio.

Ressalta-se que para este caso especifico, cada célula de difusão apresentou características de um "reator" onde, nos intervalos de tempo haviam tanto o fenômeno de difusão, de sorção e de adsorção e ainda fenômenos químicos de ordem bastante complexa, uma vez que a composição deste material apresenta em sua constituição grande parte de matéria orgânica e que precisa ser estabilizada, alterando valores de $\mathrm{pH}$, condutividade, produzindo reações químicas que ora disponibilizavam os metais, ou aprisionavam os mesmos. Esses picos de metais, principalmente do sexto dia refere-se ao momento em que o processo de conversão de matéria orgânica estava no pico de maior intensidade o que favorecia a disponibilidade do metal ser prontamente detectável pelo método extração e ou determinação. 
Ao analisar a evolução da concentração dos metais no reservatório observa-se a seguinte ordem $\mathrm{Zn}>\mathrm{Cu}>\mathrm{Mn}>\mathrm{Ni}$. Alguns metais como o $\mathrm{Cu}$ e $\mathrm{Ni}$ apresentam a capacidade de formar complexos estáveis com a matéria orgânica, e a formação desses complexos organosolúveis favorecem o mecanismo de mobilidade desses metais de uma fase para outra. Outra hipótese que pode ser levantada, é a alta capacidade de adsorção do solo com a mudança da CTC devido a presença do lodo de esgoto bruto que variou de $6 \mathrm{mE} / 100 \mathrm{~mL}$ para 125 $\mathrm{mE} / 100 \mathrm{~mL}$, favorecendo a troca desses cátions e migração dos mesmos para o solo. Neste caso especifico como se tratava de um liner não saturado os mecanismos de sucção também podem estar relacionado à maior mobilidade dos metais no meio, no entanto como se trata de um solo laterítico valores maiores de sucção consegue reter umidade e impedir a capacidade de atenuação da pluma de contaminação.

Já analisando a distribuição dos metais nas camadas de solo nota-se uma pequena variação ao longo do perfil no corpo de prova, principalmente para o cobre, níquel, cromo e cádmio, essa baixa mobilidade no solo pode estar relacionado à formação de complexos de esfera interna com a fase sólida do solo. Já a maior mobilidade dos metais zinco e níquel pode está relacionado a formação de complexos de esfera interna com a fração orgânica disponibilizada pelo contaminante, fato este observado também pela curva de concentração no reservatório.

Segundo Alloway (1995) a ligação entre micronutriente e a matéria orgânica pode ser vista como uma troca iônica entre $\mathrm{H}^{+}$de grupos funcionais e os íons micronutrientes, o alto grau de seletividade mostrado pelas substancias húmicas por certos micronutrientes sugere que eles coordenam diretamente com aqueles grupos funcionais, formando complexos de esfera interna, formando uma sequiência típica de seletividade em ordem decrescente: $\mathrm{Cu}>\mathrm{Fe}>\mathrm{Mn}>\mathrm{Zn}$.

Já Camargo (2001) orienta que essa mobilidade pode se dar em função da reação de sorção entre o metal e o material orgânico. A sorção neste caso forma uma nuvem difusa perto dos grupos funcionais periféricos ionizados e metis formando complexos de esfera externa e interna, evidenciando que a natureza da ligação numa reação vai de ligação puramente eletrostática a fortemente covalente.

O fato da concentração dos metais no reservatório aumentar em relação ao valor inicial levanta-se a suspeita de estar ocorrendo dissolução dos minerais do solo, fato este também observado por Boscov (1997). 
A Tabela 4.9 mostra os picos máximos de cada metal para o solo e seu respectivo valor normativo.

Tabela 4.9 - Valores máximos de metais no solo após o ensaio de difusão (liner não saturado).

\begin{tabular}{c|c|c}
\hline Metal & Concentração solo & Conama 396/2008 \\
\hline manganês & $2260 \mu \mathrm{g} / \mathrm{L}$ & $400 \mu \mathrm{g} / \mathrm{L}$ \\
\hline cádmio & $980 \mu \mathrm{g} / \mathrm{L}$ & $5 \mu \mathrm{g} / \mathrm{L}$ \\
\hline cobre & $3820 \mu \mathrm{g} / \mathrm{L}$ & $2000 \mu \mathrm{g} / \mathrm{L}$ \\
\hline níquel & $1002 \mu \mathrm{g} / \mathrm{L}$ & $20 \mu \mathrm{g} / \mathrm{L}$ \\
\hline zinco & $3180 \mu \mathrm{g} / \mathrm{L}$ & $1050 \mu \mathrm{g} / \mathrm{L}$ \\
\hline cromo & $1220 \mu \mathrm{g} / \mathrm{L}$ & $50 \mu \mathrm{g} / \mathrm{L}$ \\
\hline
\end{tabular}

Classificando o solo após o ensaio com as concentrações máximas de cada metal no corpo de prova de acordo com a Resolução Conama $n^{\circ} 420$ de 2008, observa-se que todos os valores dos metais estão abaixo dos requisitos para o enquadramento em áreas sujeitas a prevenção ou investigação, ou ainda em suas respectivas classes (classe 1), (classe 2), (classe 3) e (classe 4), no entanto, como a grande preocupação e questão ambiental é a migração desses poluentes para o lençol subterrâneo, observa-se que todos os metais mereceriam atenção, pois os valores ficaram acima dos normatizados para a água subterrânea.

\subsubsection{ENSAIO DE DIFUSÃO MULTIESPÉCIE LINER SATURADO}

Para o conhecimento do transporte de contaminantes na condição em que o liner encontrava-se saturado, saturação em torno de $95 \%$, foi realizado a determinação dos metais: cobre, manganês, cromo, níquel, zinco e cádmio, a seguir é apresentado os resultados para o efluente no reservatório e nas camadas do solo.

O ensaio de difusão nessa condição (condição em que o liner encontrava-se saturado), teve a duração de 18 dias. E todas as determinações de metais no efluente e no solo foram determinados pelo Laboratório Quinosan. Nas figuras 4.31 a 4.39, é apresentado os valores das concentrações no efluente e nas camadas de solo. No Anexo C apresentam-se os dados complementares referentes aos corpos de prova. 


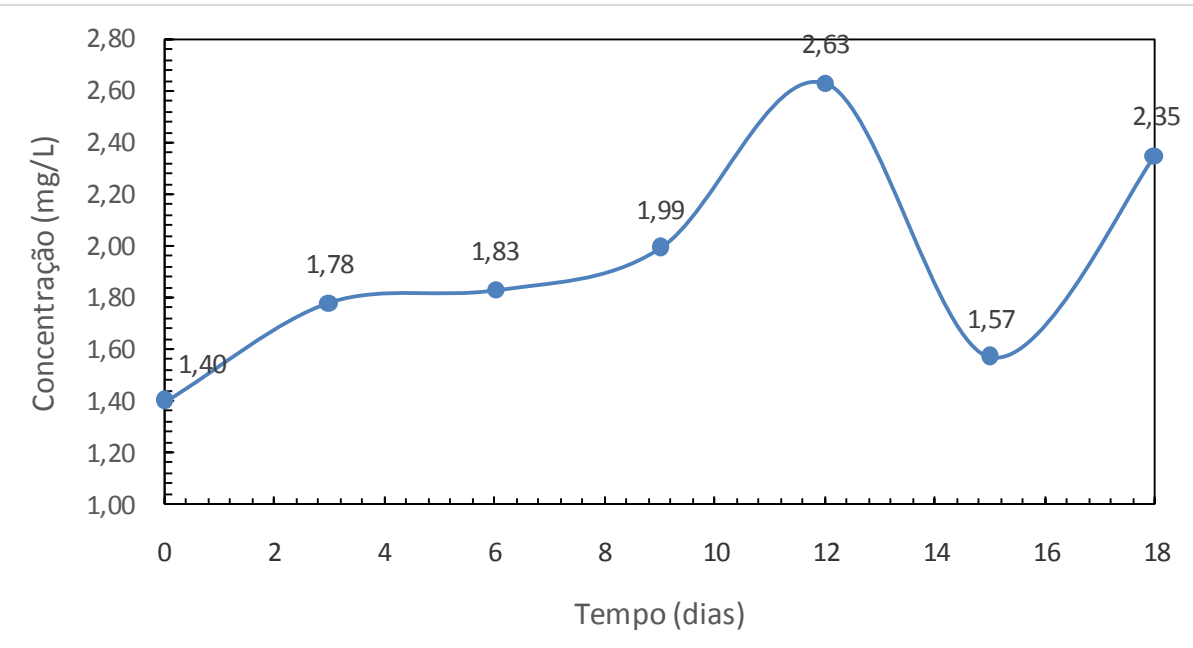

Figura 4.31 - Concentração de cobre no contaminante de lodo de esgoto (liner saturado).

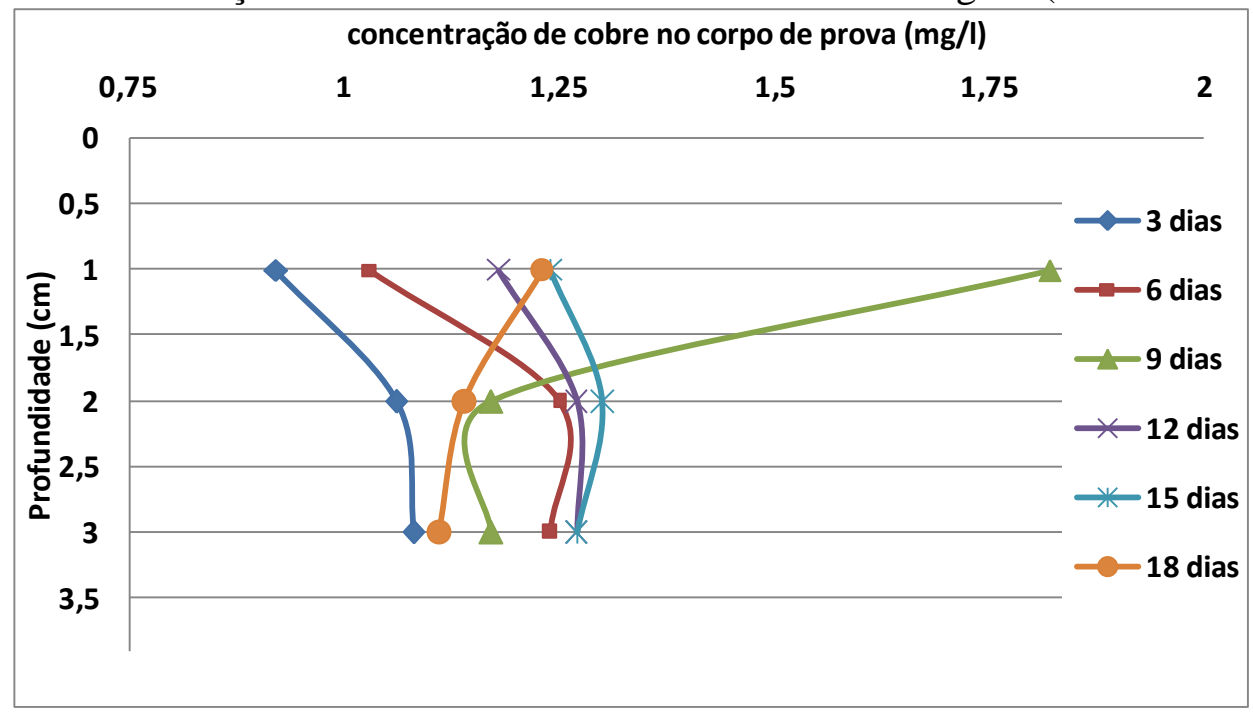

Figura 4.32 - Concentração de cobre no corpo de prova (liner saturado).

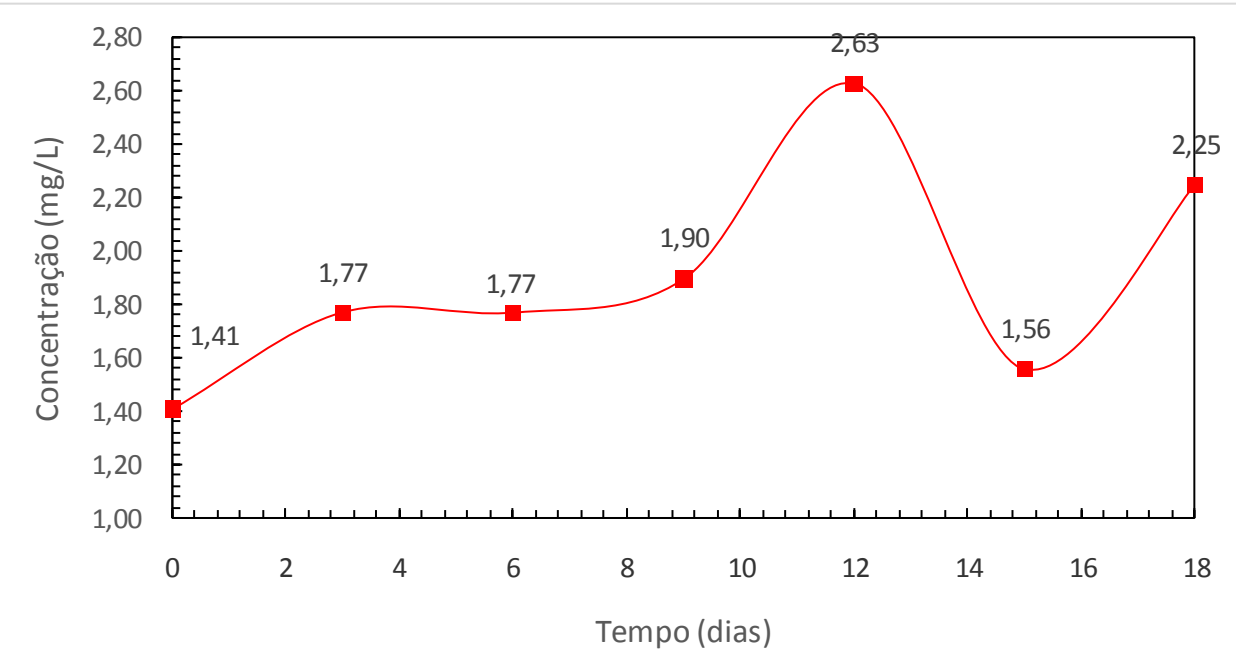

Figura 4.33 - Concentração de manganês no contaminante de lodo de esgoto (liner saturado). 


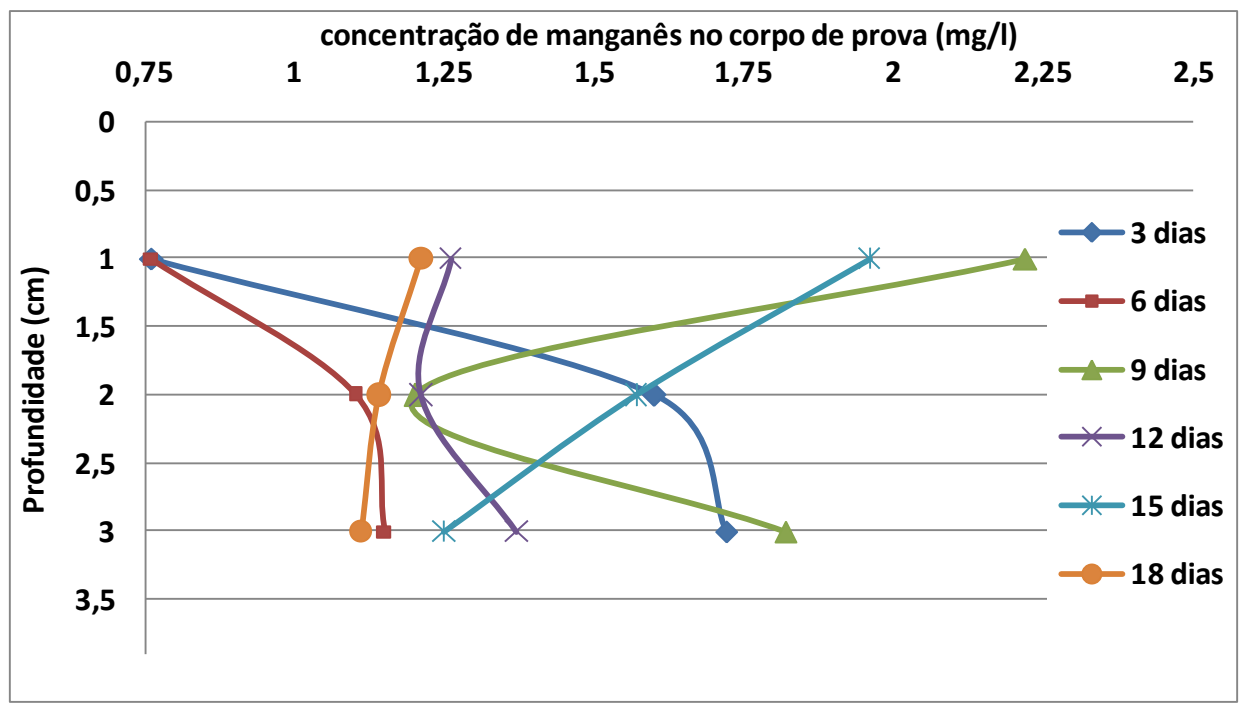

Figura 4.34 - Concentração de manganês no corpo de prova (liner saturado).

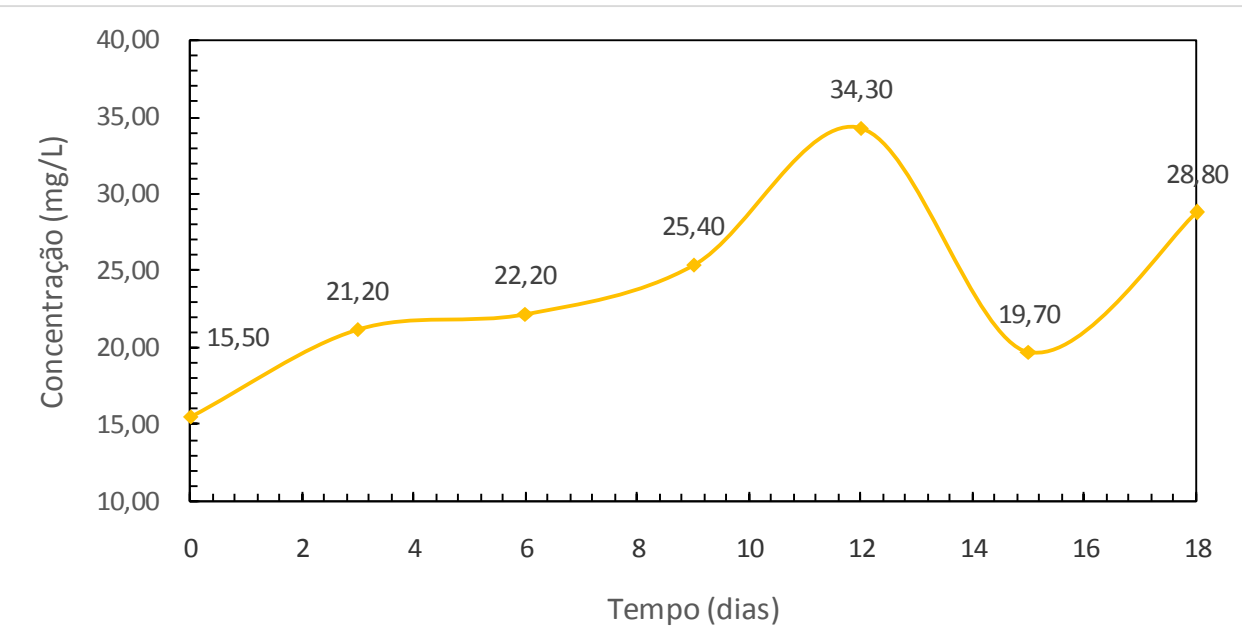

Figura 4.35 - Concentração de zinco no contaminante de lodo de esgoto (liner saturado).

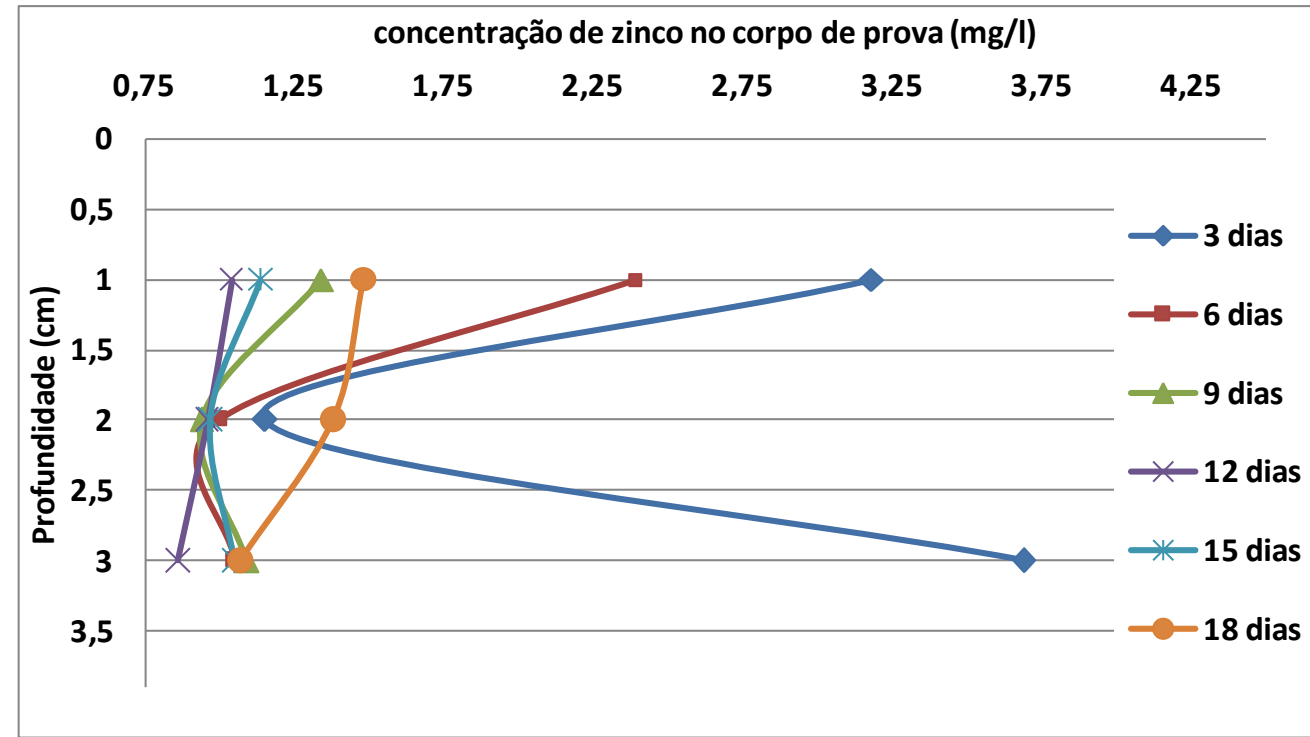

Figura 4.36 - Concentração de zinco no corpo de prova (liner saturado). 


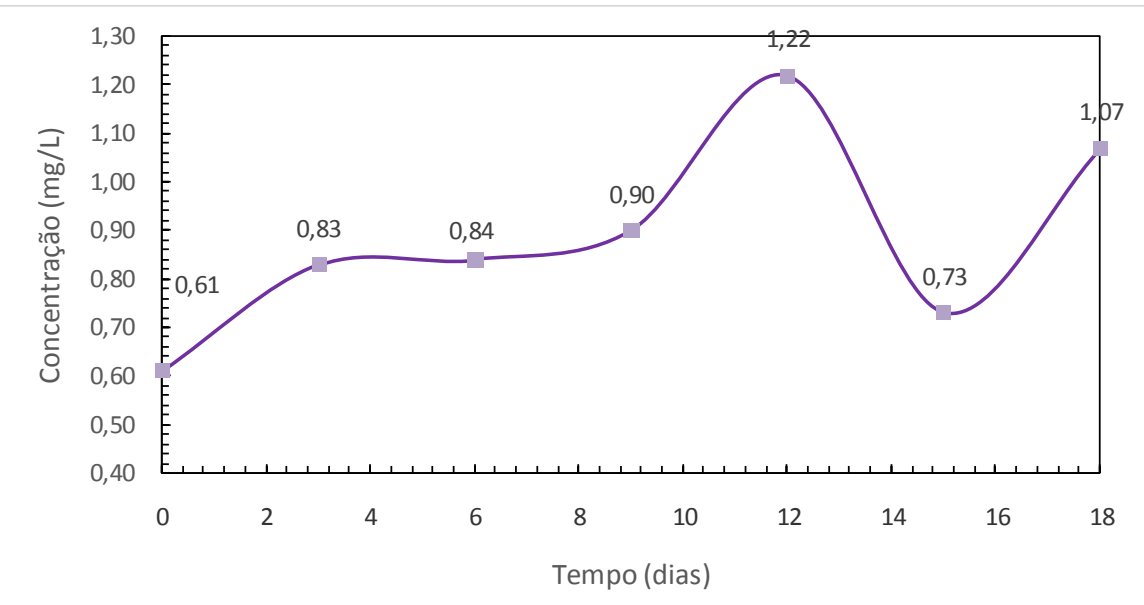

Figura 4.37 - Concentração de níquel no contaminante de lodo de esgoto (liner saturado).

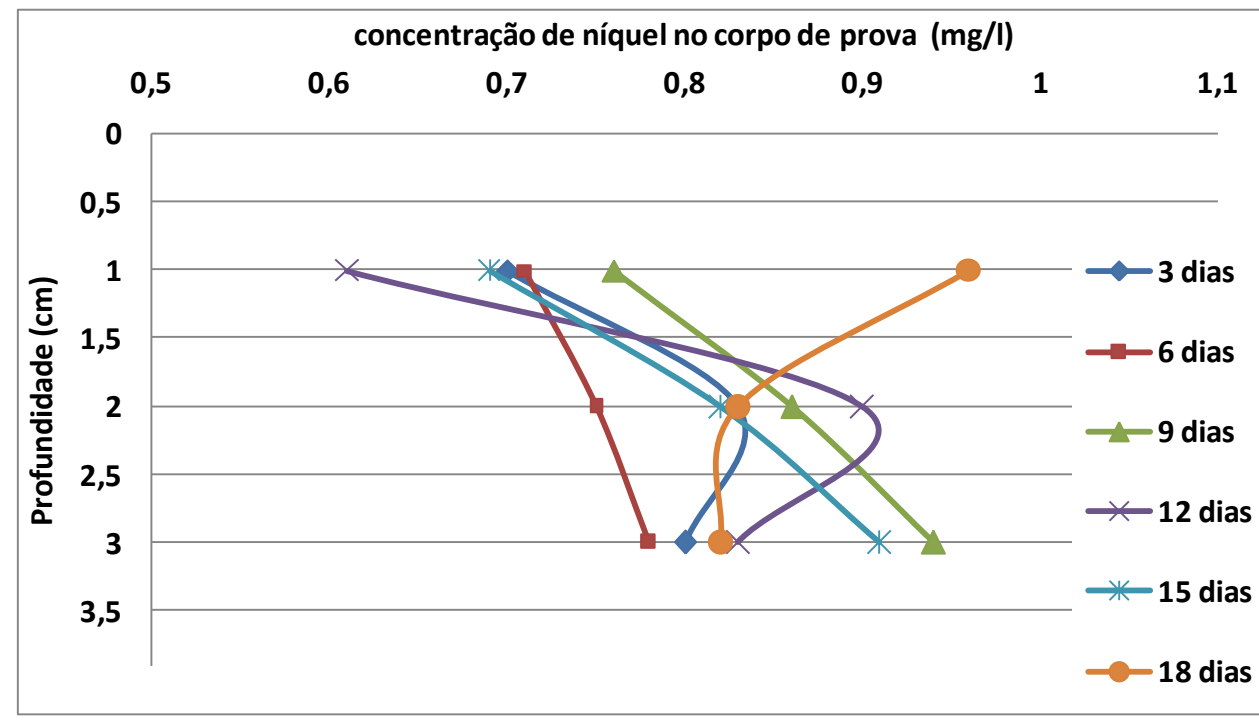

Figura 4.38 - Concentração de níquel no corpo de prova (liner saturado).

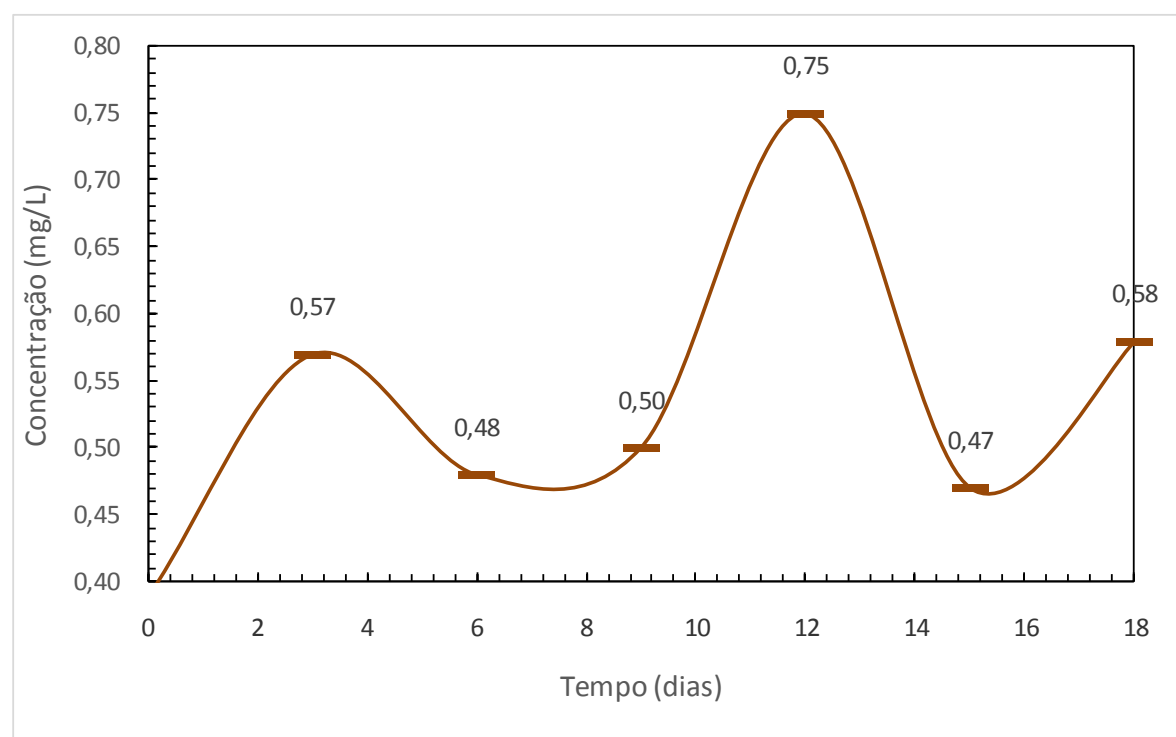

Figura 4.39 - Concentração de cromo no contaminante de lodo de esgoto (liner saturado). 


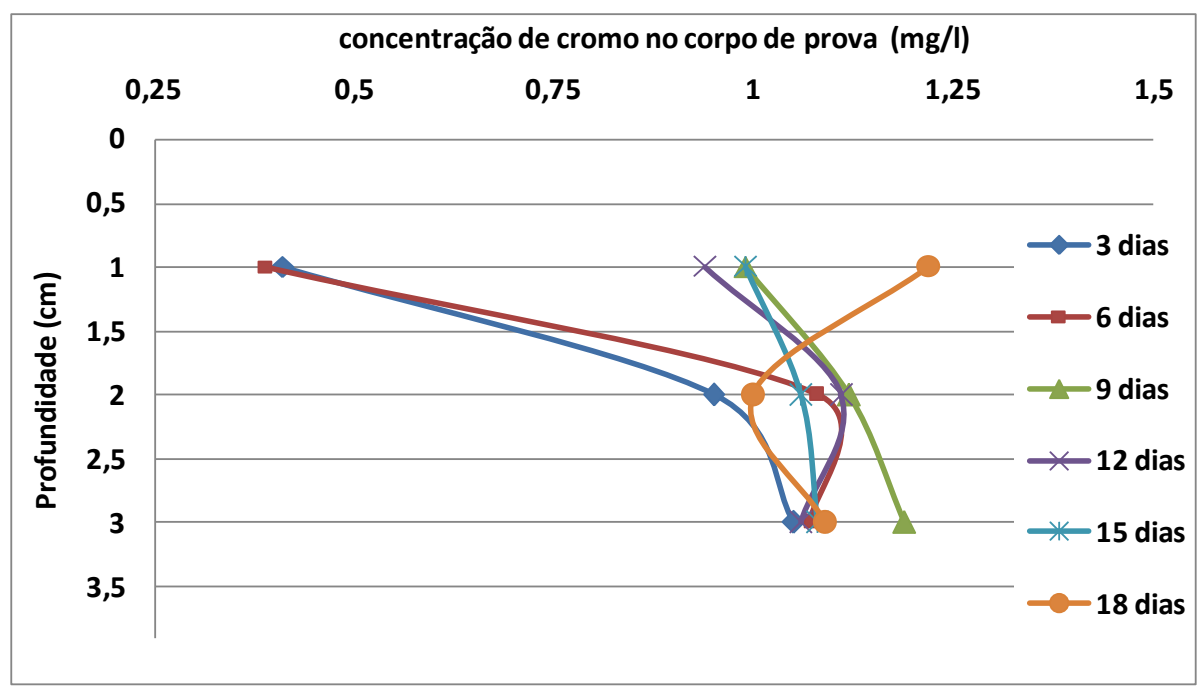

Figura 4.40 - Concentração de cromo no corpo de prova (liner saturado).

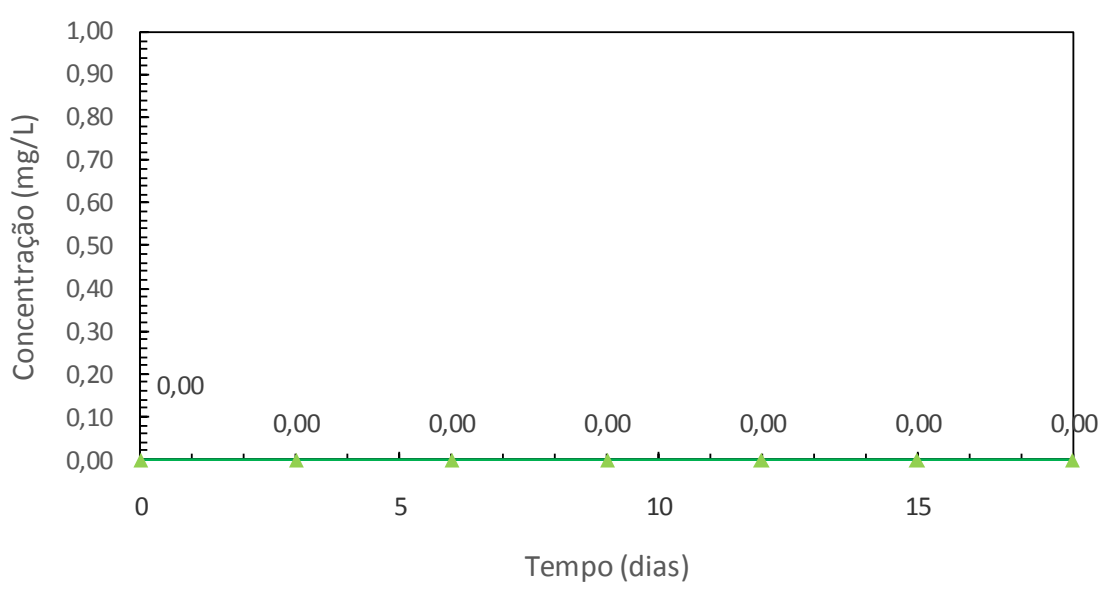

Figura 4.41 - Concentração de cádmio no contaminante de lodo de esgoto (liner saturado).

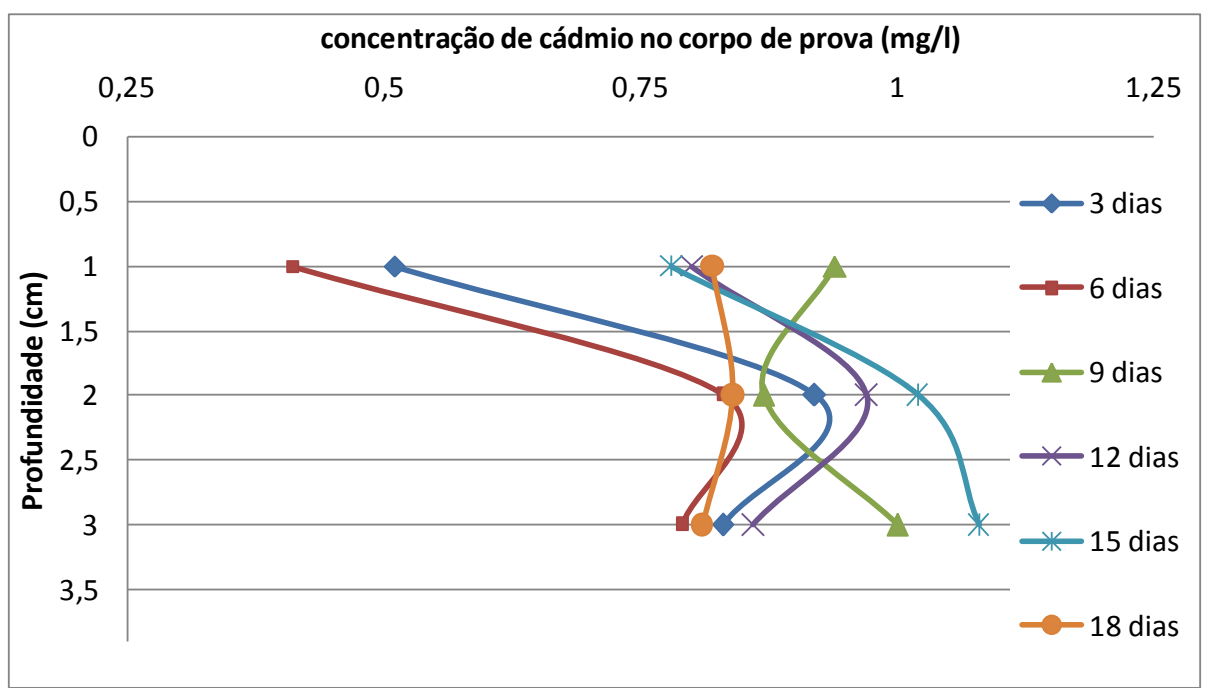

Figura 4.42 - Concentração de cromo no corpo de prova (liner saturado). 


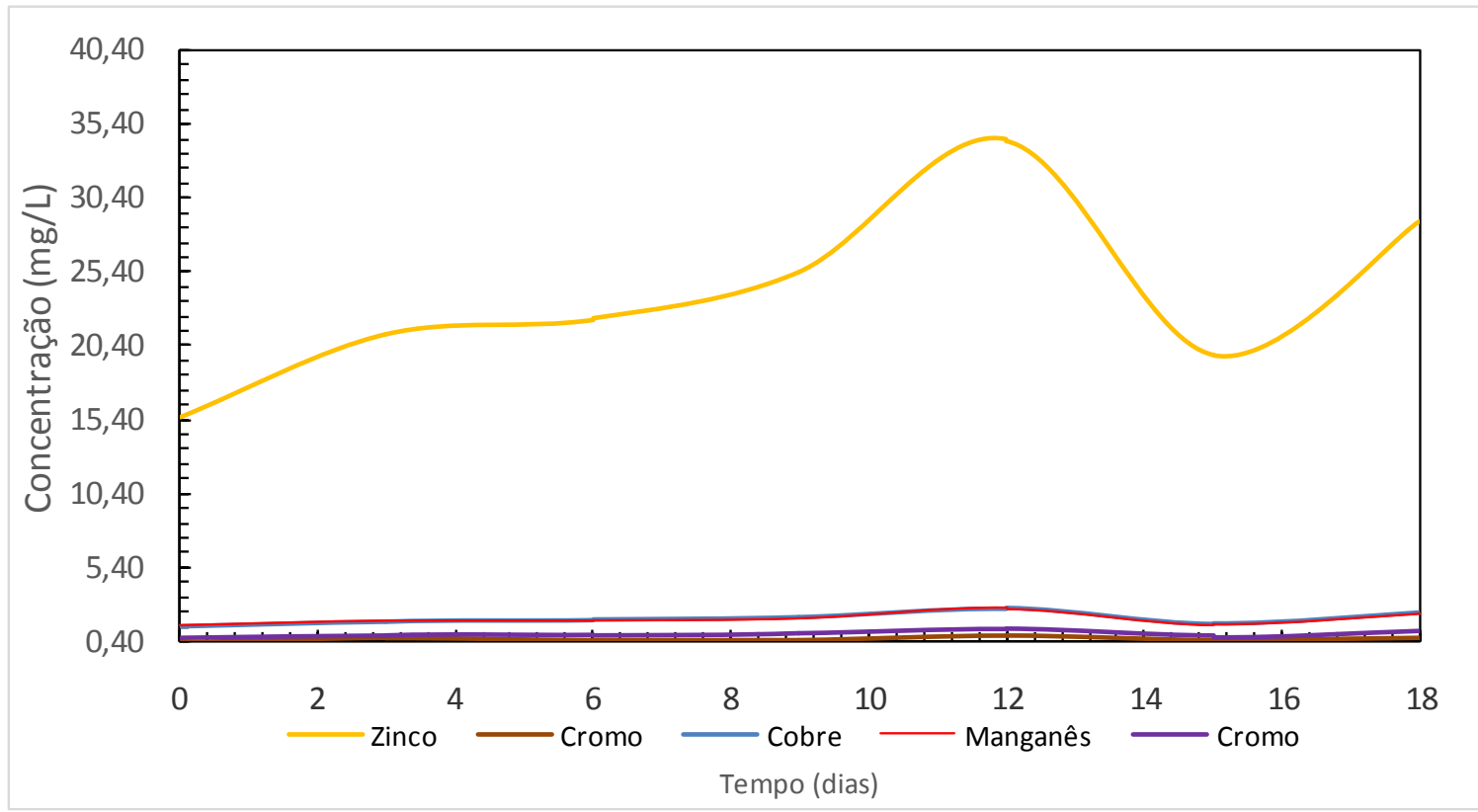

Figura 4.43 - Concentração multiespécie no contaminante de lodo de esgoto (liner saturado).

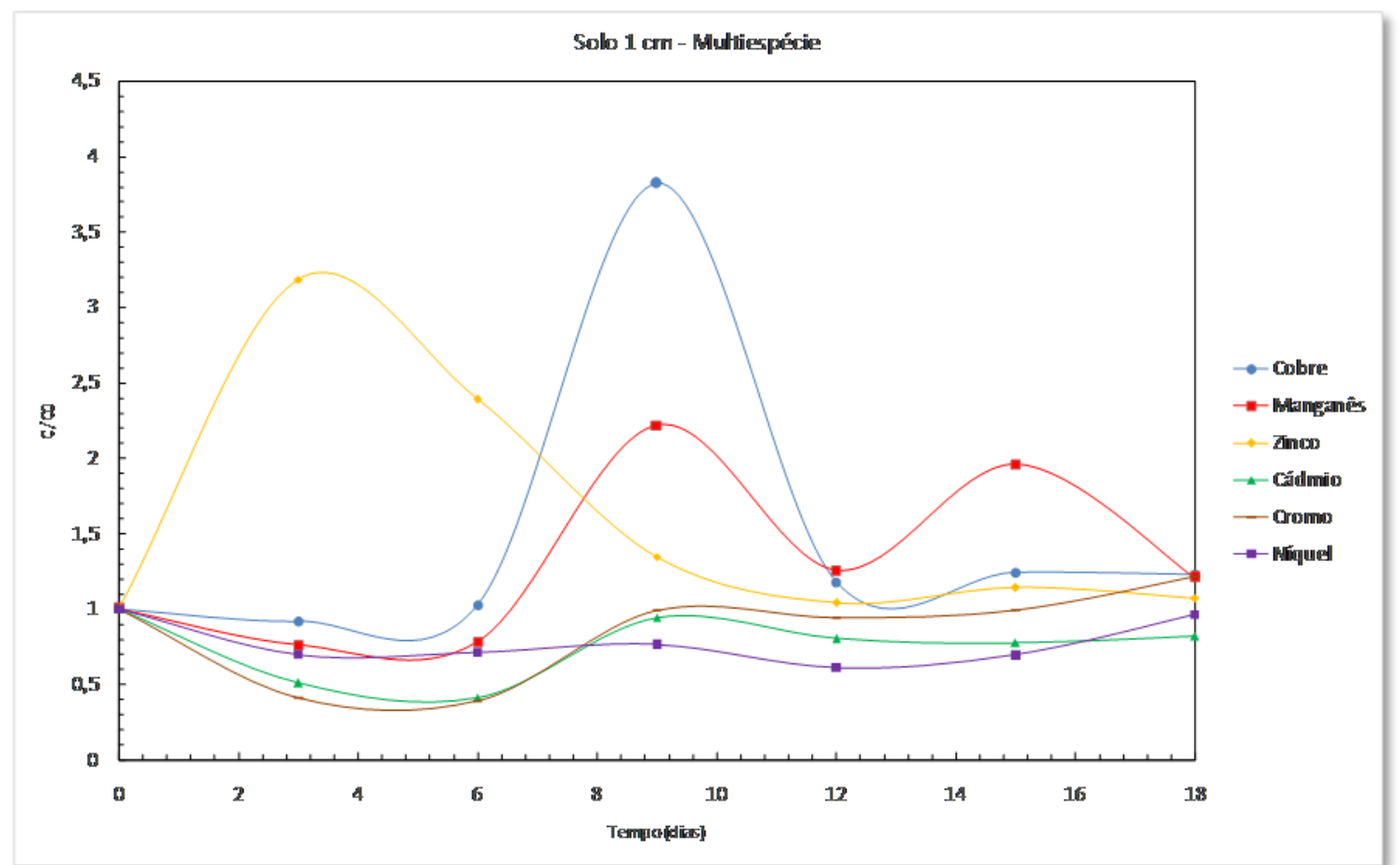

Figura 4.44 - Concentração multiespécie primeira camada de solo (liner saturado). 


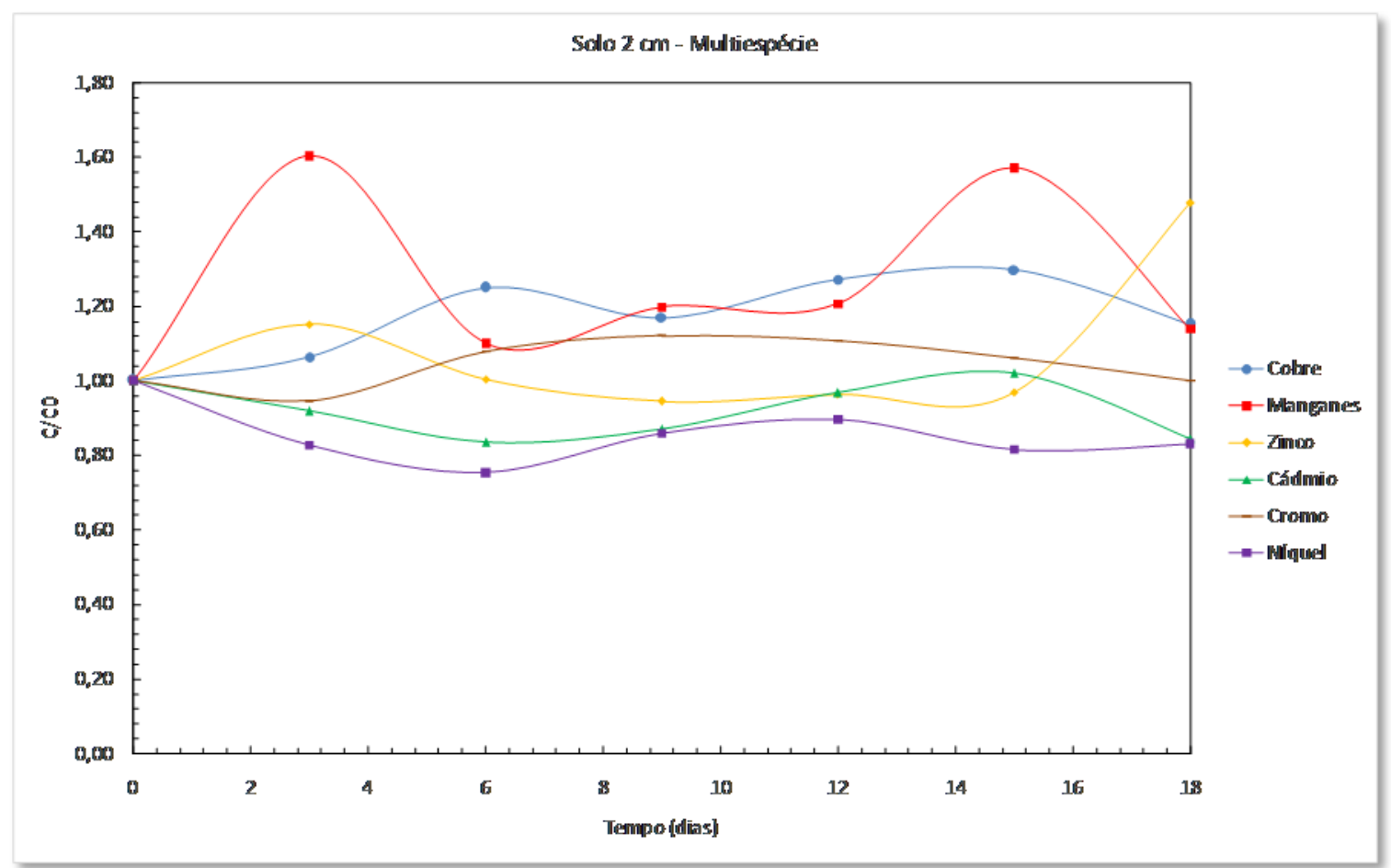

Figura 4.45 - Concentração multiespécie segunda camada de solo (liner saturado).

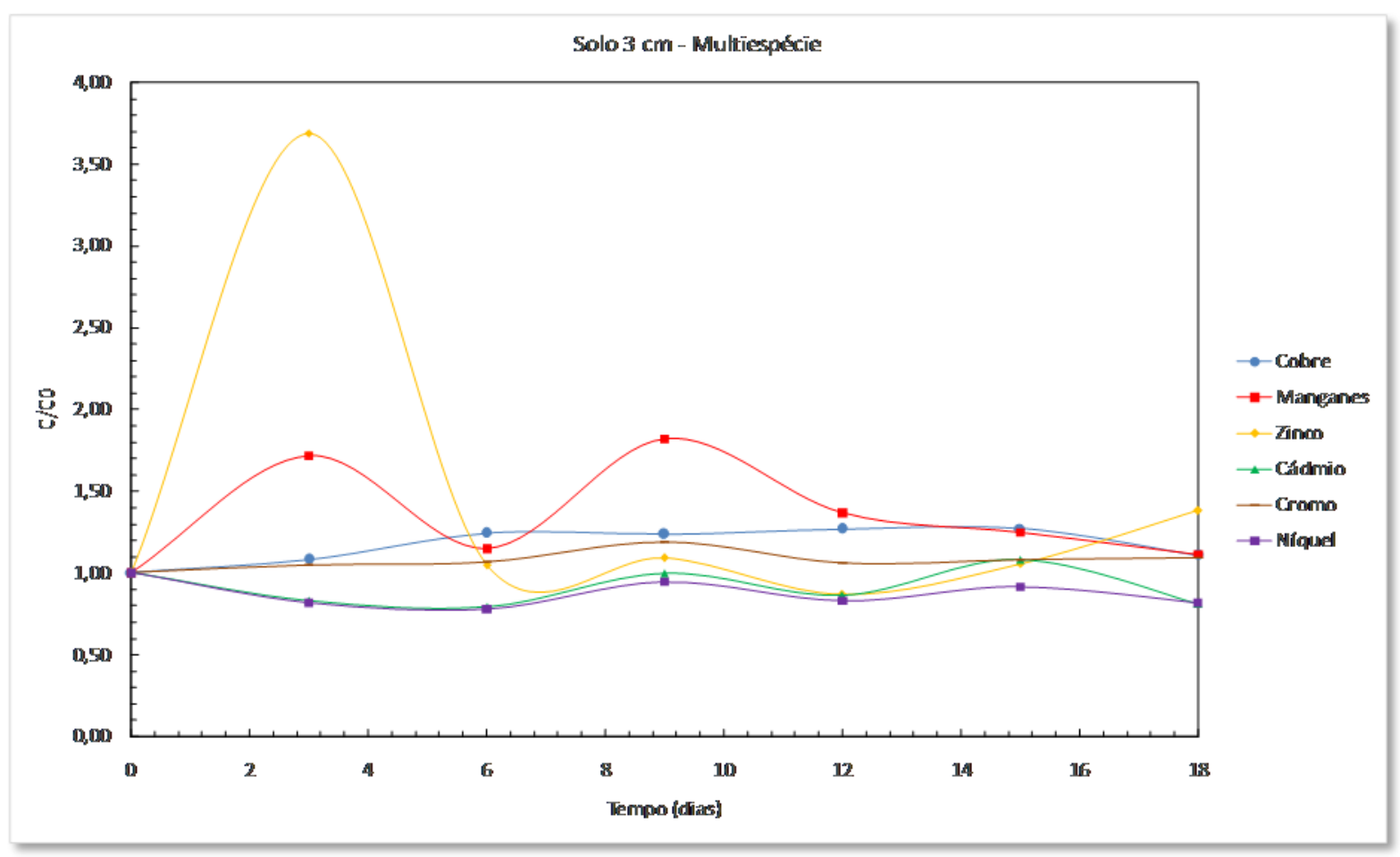

Figura 4.46 - Concentração multiespécie terceira camada de solo (liner saturado). 
Analisando as curvas de concentração dos metais na condição saturada também foi possível observar dispersão nos dados de metais para todos os períodos analisados, destaca-se que essa dispersão dos dados com elevação dos metais no décimo segundo dia, seja os mesmos levantados para a condição não saturada, no entanto diferentemente observa-se uma grande variação e até mesmo um acréscimo dos metais quando compara-se os valores determinados no tempo $t=3$ e $t=18$. Para essa configuração não foi possível montar a ordem de migração em função do tempo no efluente.

Diferentemente dos observados ao longo da camada de solo para a condição não saturada, nota-se uma inversão em alguns pontos da tendência que era esperada, ou, seja, concentração diminuindo do topo do corpo de prova em função da profundidade, isso pode estar relacionado à maior facilidade dos metais migrarem em função do corpo de prova estar em condição saturada, não havendo bolhas de ar e impedimentos para a ligação desses metais aos sítios específicos no solo. Outra possibilidade além da saturação do corpo de prova, é a alta CTC observada para essa configuração, da ordem de $390 \mathrm{mE} / 100 \mathrm{~mL}$, o que poderia propiciar a capacidade maior de trocar esses íons com o solo. Outra hipótese seria a possibilidade dessa maior mobilidade está relacionada à capacidade de formar complexos pela alta CTC, dando mobilidade aos metais ao longo do corpo de prova.

A ocorrência da solubilização e da difusão poderia justificar os aparentes e incoerentes perfis de concentrações obtidos tanto para o efluente na condição não saturada como na saturada. Boscov (1997) ressalta que a camada superior do corpo de prova, onde é iniciada a solubilização devido à maior concentração de íons na água intersticial, eventualmente até superior à da solução. Seria desencadeada, então a difusão do corpo de prova para o reservatório, e da camada superior do corpo de prova para as camadas inferiores. À medida que a camada superior vai entrando em equilíbrio com o reservatório, é possível que a frente de solubilização vá penetrando no corpo de prova. Podendo assim em determinados tempos, haver picos de concentração em alguma das camadas inferiores do corpo de prova.

Boscov (1997), ainda ressalta que é de grande importância prever a variável correspondente a dissolução dos minerais do solo devido ao contato com uma solução, em função do tempo, da composição do $\mathrm{pH}$ da solução, entre outros possíveis fatores relevantes. Cabe então atentar para a complexidade dos fenômenos envolvidos, e para necessidade de compreender o mecanismo da solubilização, inclusive ao ponto de expressar por meio de um modelo matemático. 
Classificando o solo de acordo com a Resolução Conama n 420 de 2009 pode observar a mesma tendência para o ensaio na configuração não saturada. A Tabela 4.10 apresenta a classificação.

Tabela 4.10 - Valores máximos de metais no solo após o ensaio de difusão (liner saturado).

\begin{tabular}{c|c|c}
\hline Metal & Concentração solo & $\begin{array}{c}\text { Conama 420/2009 } \\
\text { Conama 396/2008 }\end{array}$ \\
\hline manganês & $1960 \mu \mathrm{g} / \mathrm{L}$ & $400 \mu \mathrm{g} / \mathrm{L}$ \\
\hline cádmio & $970 \mu \mathrm{g} / \mathrm{L}$ & $5 \mu \mathrm{g} / \mathrm{L}$ \\
\hline cobre & $1820 \mu \mathrm{g} / \mathrm{L}$ & $2000 \mu \mathrm{g} / \mathrm{L}$ \\
\hline níquel & $960 \mu \mathrm{g} / \mathrm{L}$ & $20 \mu \mathrm{g} / \mathrm{L}$ \\
\hline zinco & $3090 \mu \mathrm{g} / \mathrm{L}$ & $1050 \mu \mathrm{g} / \mathrm{L}$ \\
\hline cromo & $1250 \mu \mathrm{g} / \mathrm{L}$ & $50 \mu \mathrm{g} / \mathrm{L}$ \\
\hline
\end{tabular}

Esta classificação foi realizada utilizando a resolução para água subterrâneas, uma vez que, não foi observado valores máximos para ser enquadrados em classes de usos. Observa-se assim que os dados encontrados estão bem acima dos normatizados, é que se essa frente de contaminação chegar ao lençol subterrâneo terá a possibilidade de contaminar o mesmo.

\subsubsection{ENSAIO DE DIFUSÃO SOLUÇÃO SINTÉTICA DE $\mathrm{Cr}^{+3}$}

O ensaio de difusão para a solução de cromo, foi realizado com a concentração crescente no reservatório, sendo elas: $250 \mathrm{mg} / \mathrm{L}, 500 \mathrm{mg} / \mathrm{L}, 1000 \mathrm{mg} / \mathrm{L}, 2000 \mathrm{mg} / \mathrm{L}$, e 4000 mg/L, o ensaio teve a duração de 36 dias. As Figuras 4.47 e 4.48 apresentam os resultados para a concentração no reservatório, e nas camadas de solo respectivamente. Já a Figura 4.49 apresenta os dados de coeficiente de difusão, e as curvas dos dados experimentais e as curvas do modelo matemático.

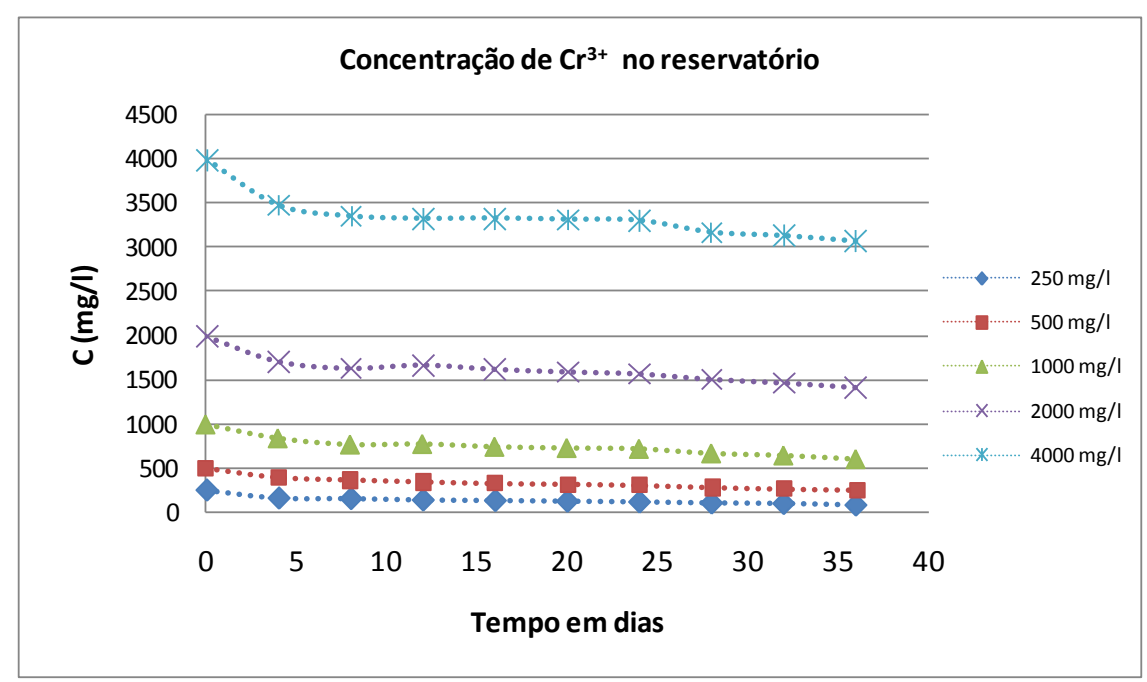

Figura 4.47 - Concentração de cromo no reservatório. 


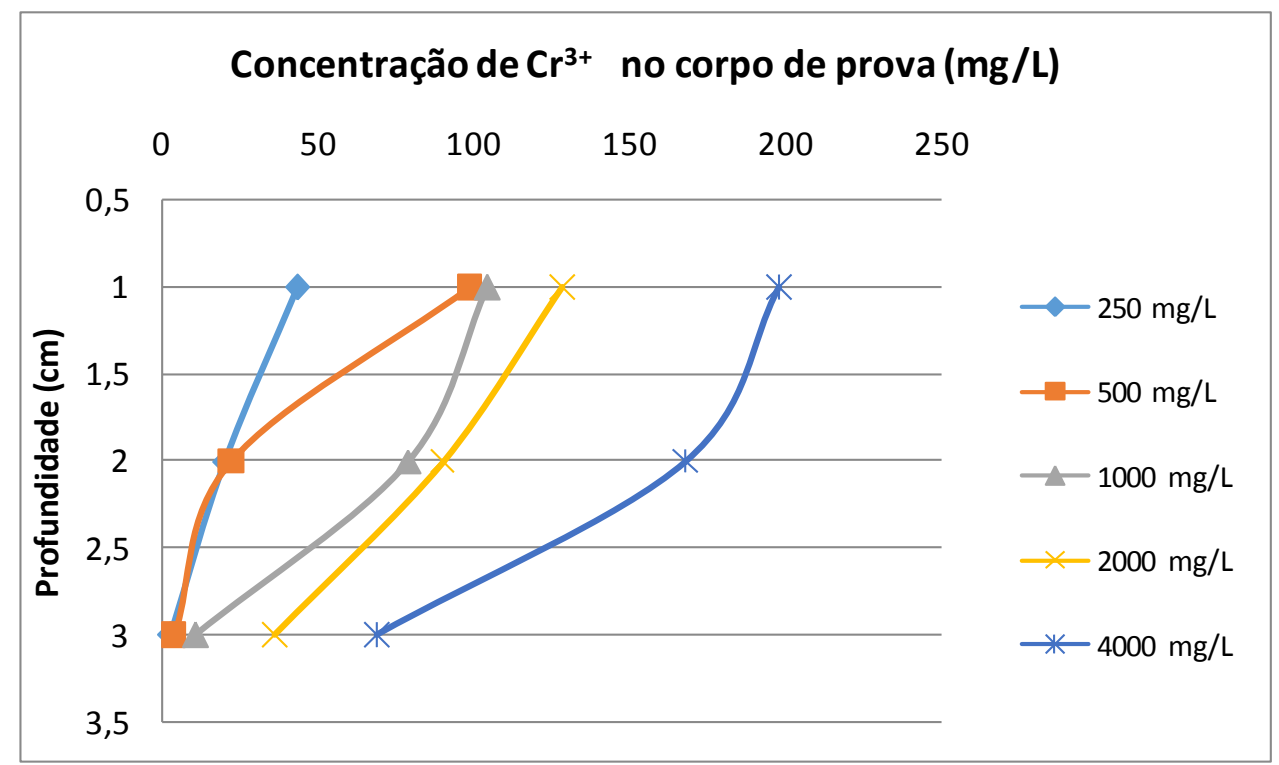

Figura 4.48 - Concentração de cromo nas camadas de solo no $36^{\circ}$ dia.

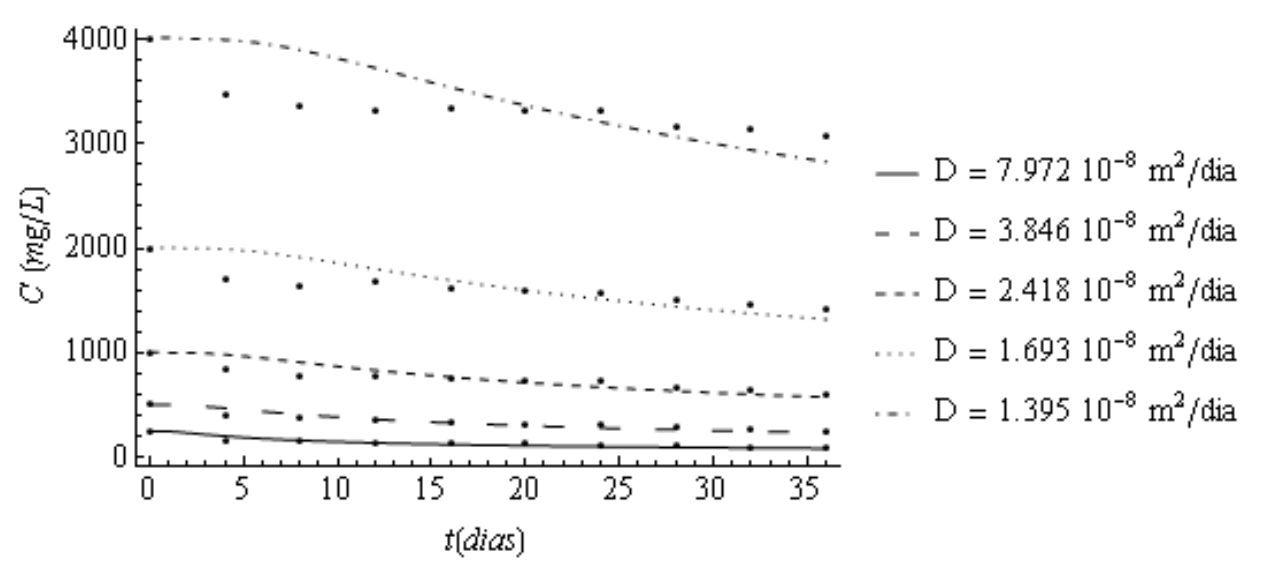

- Dados experimentais

Figura 4.49 - Coeficientes de difusão para as diferentes concentrações.

Ao analisar a Figura 4.47, quando se trata de um ensaio de difusão com uma única espécie, observa-se claramente a diminuição dos valores da concentração em função do tempo, isso se torna mais perceptível para as concentrações de $2000 \mathrm{mg} / \mathrm{L} \mathrm{e} 4000 \mathrm{mg} / \mathrm{L}$.

As quedas de concentração ocorrem até no máximo no décimo dia, depois estabilizando, fato este relacionado à capacidade máxima do solo em sorver este metal. Todas as curvas de concentração ao longo do corpo de prova, Figura 4.48, para as diferentes concentrações, observa-se uma diminuição do topo para a base. Nota-se que quando não há competição multiespécies (ensaio com uma única espécie) a diminuição da concentração do 
metal no solo diminui a medida que se afasta da fonte contaminante. As concentrações adotadas para o referido ensaio estão bem acima dos normatizados para este referido metal, e isso ocorreu pelo fato da determinação ser realizada via absorbância.

Analisando a Figura 4.49 observa-se valores de coeficiente de difusão da mesma ordem de $10^{-8} \mathrm{~m}^{2} /$ dia, variando somente os valores decimais, ainda pode-se notar um bom ajuste do modelo matemático e dos dados experimentais.

Já a classificação de acordo com a Norma Conama nº420 de 2009, observa-se que todos os valores estão acima dos citados para o valor de classe 4, ou seja, são solos que apresentam pelo menos uma substância química com os valores acima dos valores de investigação, sejam ele, agrícola, residencial, ou industrial.

\subsubsection{ENSAIO DE DIFUSÃO SOLUÇÃO SINTÉTICA DE Ni ${ }^{+2}$}

A determinação da difusão para o níquel foi realizada em três concentrações 1000 , 2000 e $4000 \mathrm{mg} / \mathrm{L}$, com a duração de 22 dias. A Figura 4.50 apresenta os dados da concentração no reservatório, já a Figura 4.51 apresenta a concentração nas camadas de solo, e a Figura 4.52 os valores de coeficiente de difusão.

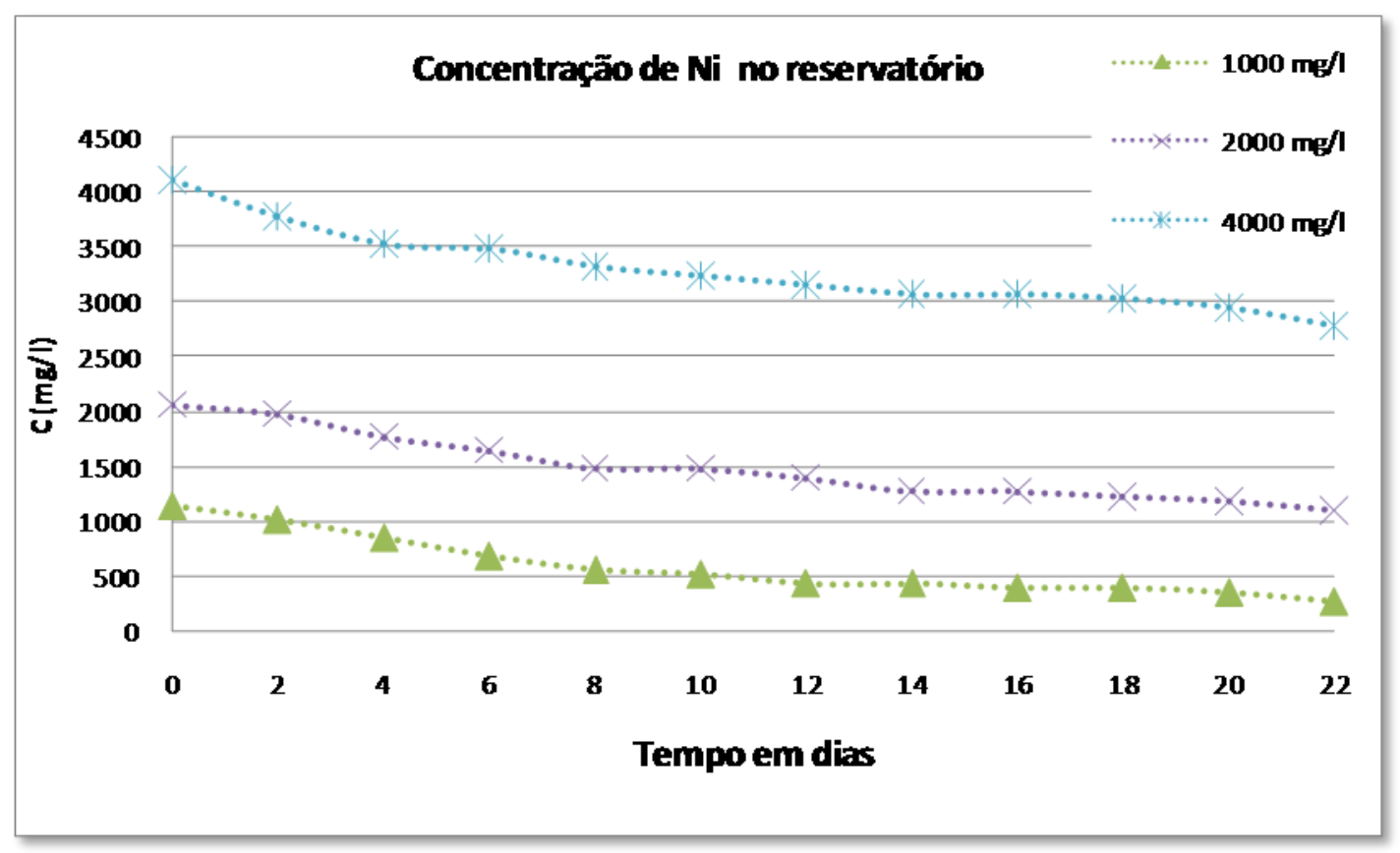

Figura 4.50 - Concentração de níquel no reservatório. 


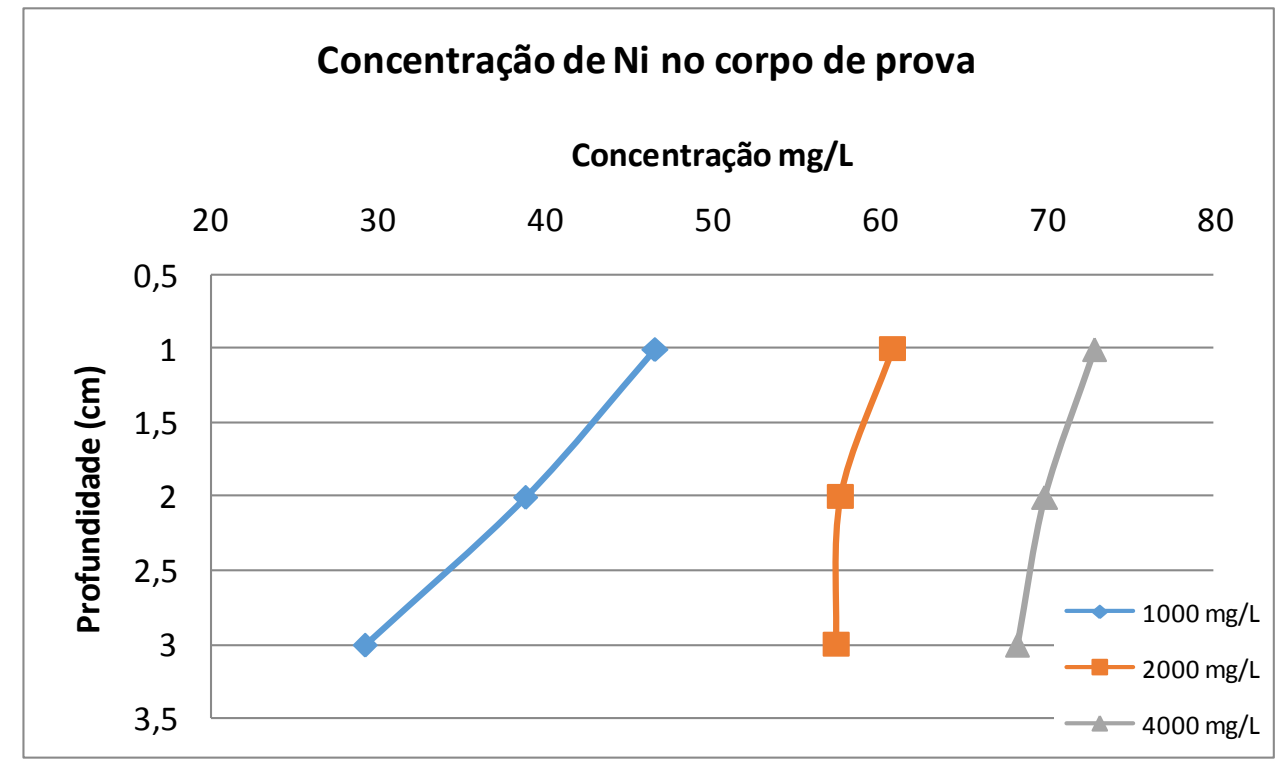

Figura 4.51 - Concentração de níquel nas camadas de solo.

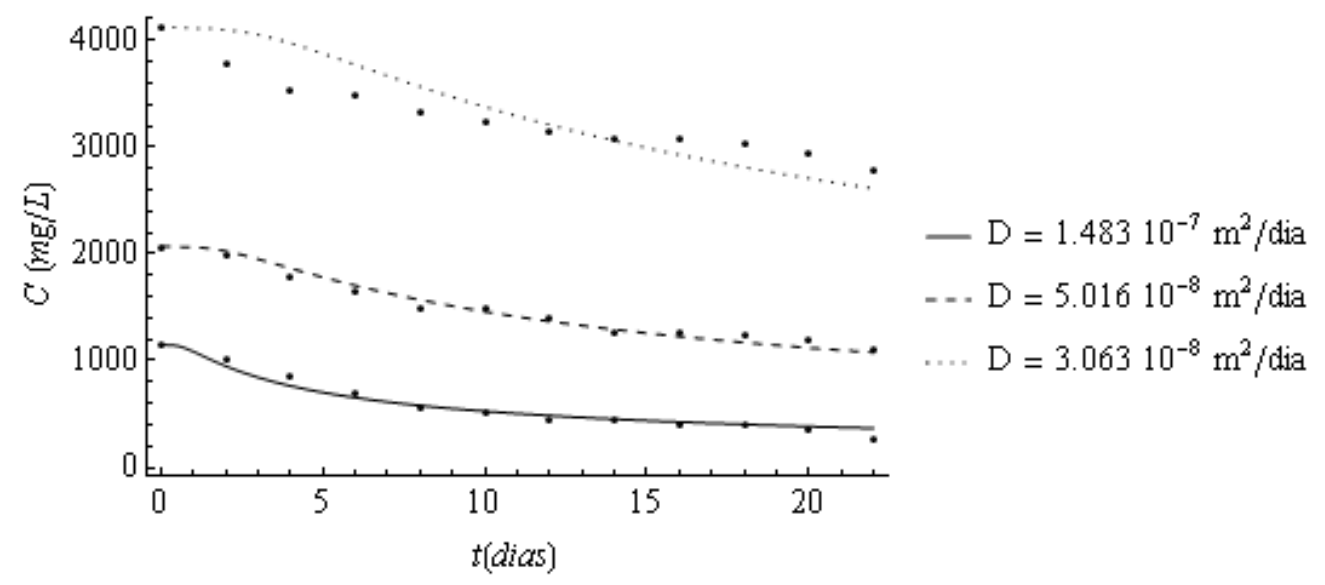

- Dados experimentais

Figura 4.52 - Coeficiente de difusão para as diferentes concentrações.

O ensaio de difusão com a solução sintética de níquel apresentou os resultados conforme esperado, ou seja, os valores das concentrações diminuindo em função do tempo até atingir o valor máximo de adsorção do solo. Já em relação aos dados de difusividade observase que a concentração de $4000 \mathrm{mg} / \mathrm{L}$, obteve coeficiente de difusão maior que as demais concentrações. Classificando o solo após o ensaio de difusão, de acordo com o Conama 420 de 2009, o mesmo seria classificado como classe 3, ou seja seriam os solos que apresentam concentrações de pelo menos uma substância química maior que o valor de prevenção e menor ou igual ao valor de investigação. 


\subsubsection{ENSAIO DE DIFUSÃO COM NITRATO $\mathrm{NO}_{3}{ }^{-}$}

A determinação da difusão de $\mathrm{NO}_{3}{ }^{-}$, foi realizada em três configurações, sendo elas: 4 dias, 8 dias e 32 dias. As Figuras 4.53, 4.54 e 4.55 apresentam os perfis de concentração do fluído no reservatório. Já as Figuras 4.56 e 4.57, apresentam-se as concentrações para as camadas de solo.

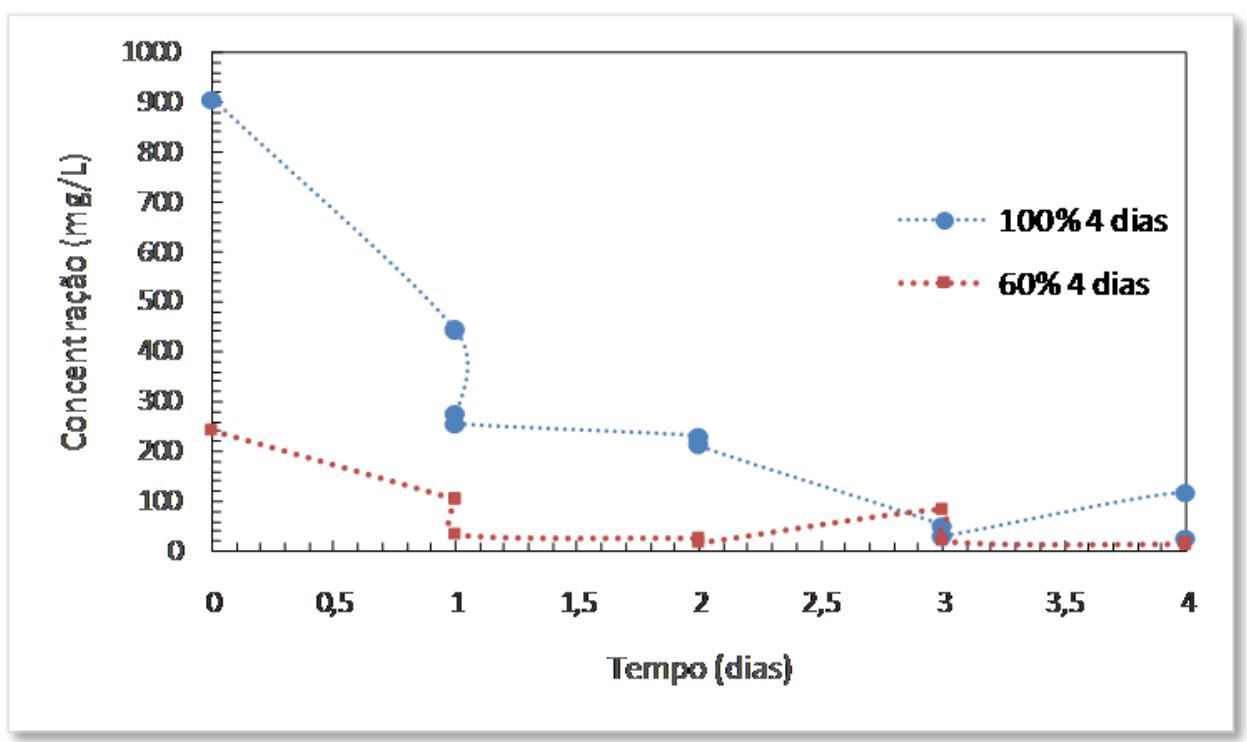

Figura 4.53 - Concentração de nitrato no reservatório (4 dias).

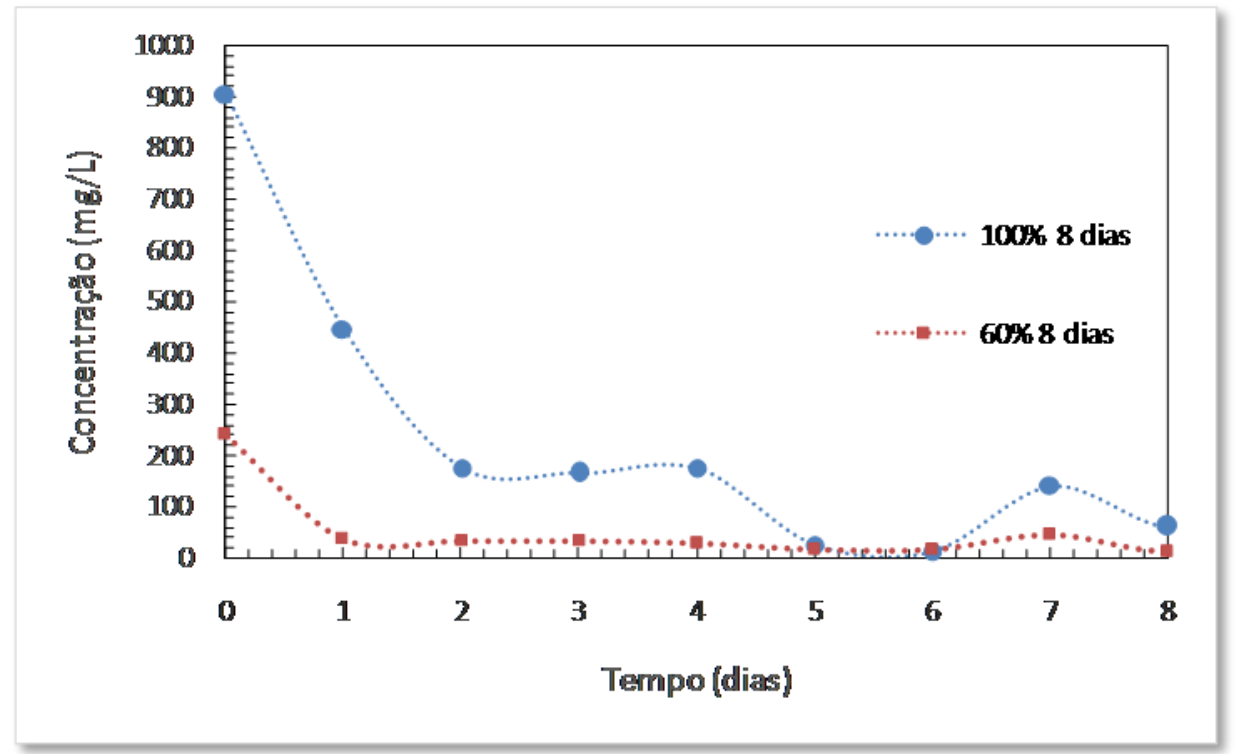

Figura 4.54 - Concentração de nitrato no reservatório (8 dias). 


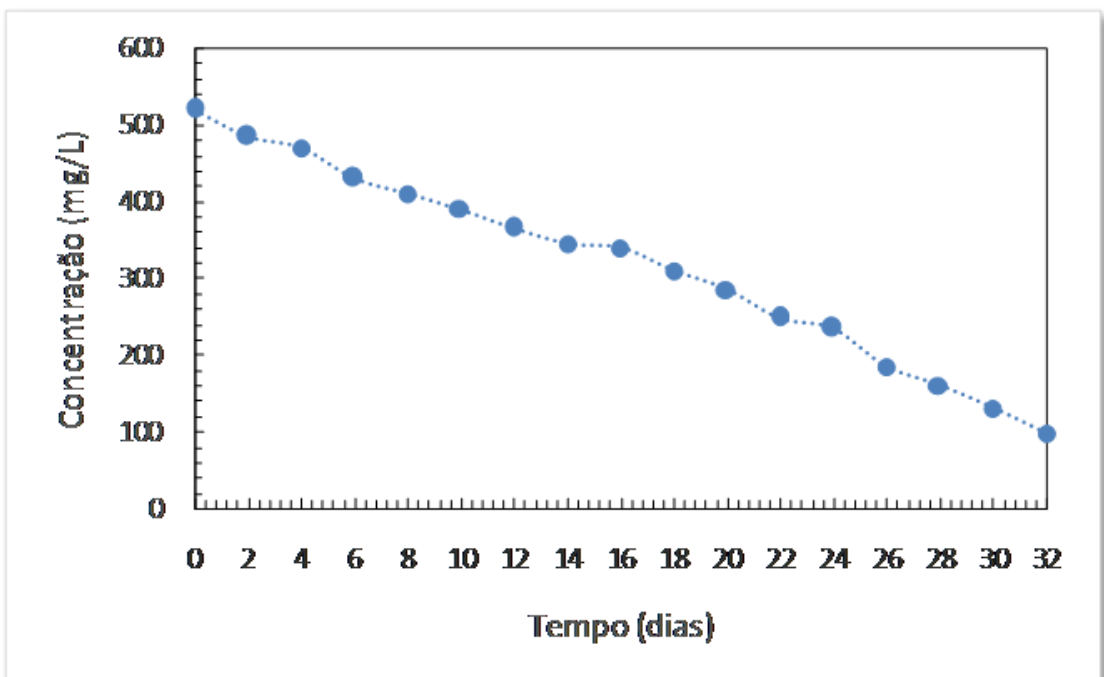

Figura 4.55 - Concentração de nitrato no reservatório (32 dias).

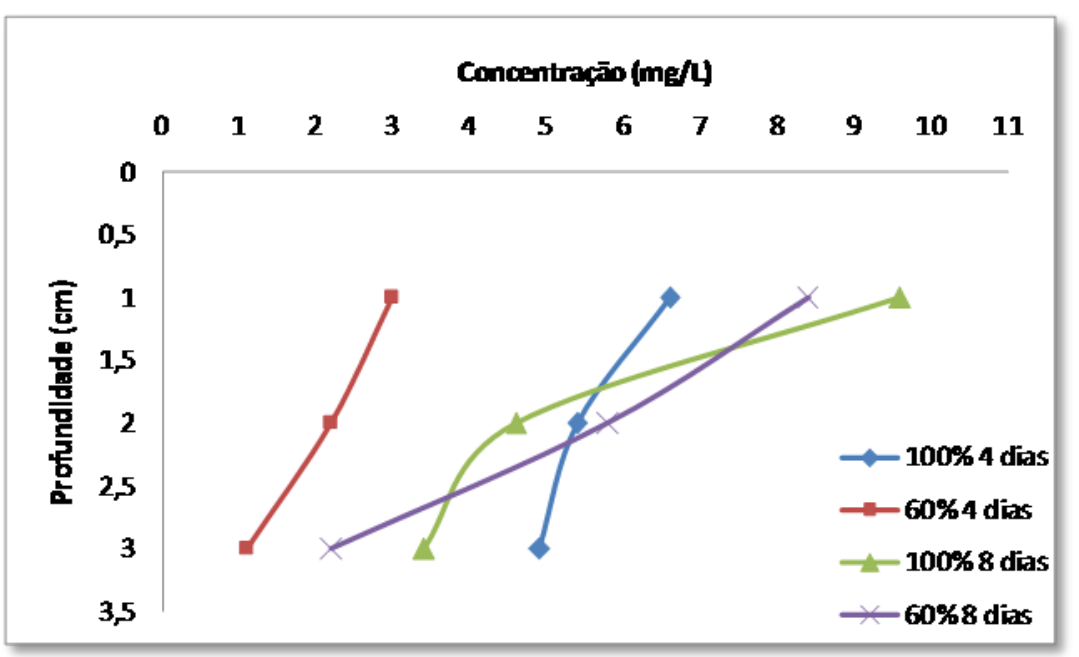

Figura 4.56 - Concentração de nitrato no solo ( 4 e 8 dias).

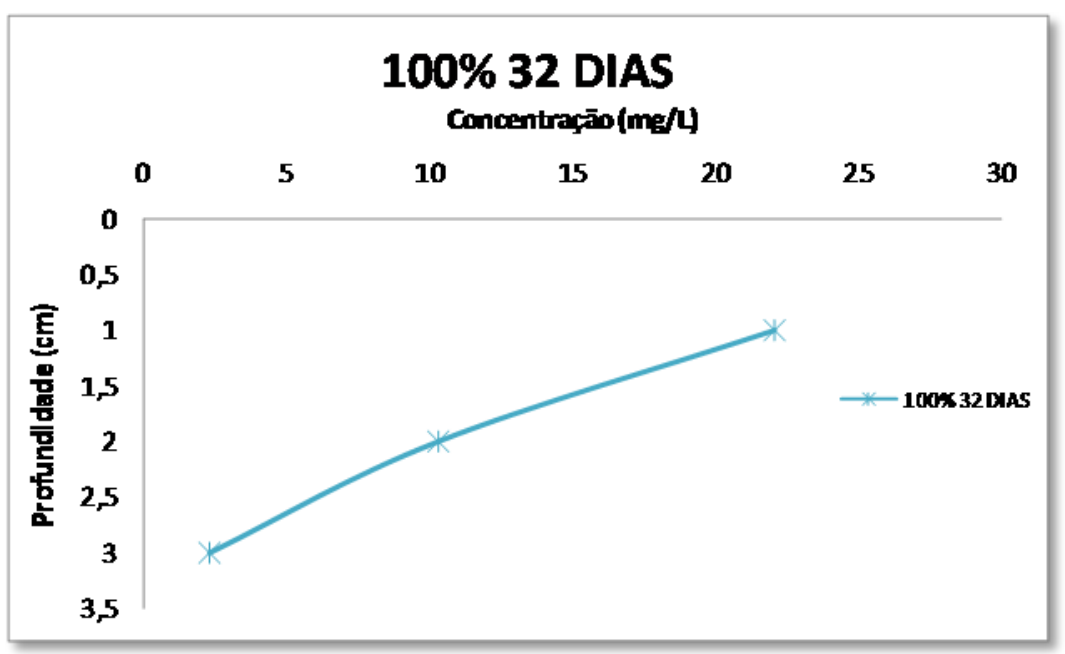

Figura 4.57 - Concentração de nitrato na camada de solo (32 dias). 
O ensaio de difusão de nitrato apresentou pouca dispersão, uma vez que nota-se a tendência de diminuição dos valores nos efluentes dos reservatórios, somenteo CP1 e CP2 cujo ensaio demorou quatro dias observa-se uma maior dispersão do nitrato para lodo bruto de esgoto, uma vez que o processo de conversão e estabilização da matéria orgânica pode converter e produzir nitrogênio na forma de nitrato, fato este observado pelos picos nas Figuras 4.53 e 4.54. Outra hipótese para o aumento de nitrato perceptível em alguns pontos é o fato do liquido no reservatório apresentar duas fases bastante distintas, ou seja, parte superior mais clara e parte inferior mais escura e densa, e como as coletas se processou ao longo do tempo, houve momentos em que a coleta realizada foi com o líquido mais abaixo escuro e denso, onde encontra-se a maior concentração de nitrato, que o método de redução cádmio conseguia determinar. No entanto com a realização do ensaio CP5 com duração de 32 dias, foi possível observar a constante queda dos valores de nitrato, e isso se deu em função da homogeneização da amostra diariamente, e toda vez que era realizada a coleta, diminuindo assim partes preferenciais de concentração de $\mathrm{NO}_{3}{ }^{-}$

Já as figuras 4.56 e 4.57 pode-se notar que ocorreu difusão ao longo do perfil de solo, como se observou nas amostras ensaiadas por oito dias e 32 dias, houve aumento na quantidade de íons adsorvidos e/ou difundidos, indicando ser a duração um fator importante nesse tipo de ensaio. Nascentes et al. (2009) e Fonseca Neto (2007), ao estudar a difusão de nitrato em solo tropical observou os mesmos fenômenos de mudanças na concentração em função do tempo. Já classificando o solo, a norma não apresenta classificação em classe de usos, no entanto classifica como zona de investigação, uma vez que todos os valores ficaram acima de $1 \mathrm{mg} / \mathrm{L}$.

\subsection{ENSAIO DE SORÇÃO}

As Tabelas 4.11 a 4.16 apresentam os resultados referentes aos dados do ensaio de sorção, ressalta-se que somente os metais níquel e cromo obtiveram ajustes nos modelos de isotermas, sendo assim, os demais apresenta-se somente os dados obtidos. Já a Tabela 4.16 apresenta os dados de sorção para os elementos em que pode-se obter os dados nas isotermas de sorção. 
Tabela 4.11 - Dados de sorção para o zinco.

\begin{tabular}{c|c|c|c|c}
\hline Solução & $\mathrm{C}_{\mathrm{O}}(\mathrm{mg} / \mathrm{L})$ & $\mathrm{C}_{\mathrm{e}}(\mathrm{mg} / \mathrm{L})$ & M. sorvida $(\mathrm{g})$ & $\mathrm{S}(\mathrm{mg} / \mathrm{g})$ \\
\hline $100 \%$ & 8,32 & 0,0160 & 0,33 & 0,08 \\
\hline $80 \%$ & 7,02 & 0,0190 & 0,28 & 0,07 \\
\hline $60 \%$ & 4,51 & 0,01067 & 0,18 & 0,04 \\
\hline $40 \%$ & 3,24 & 0,1000 & 0,13 & 0,03 \\
\hline $20 \%$ & 1,05 & 0,0783 & 0,04 & 0,01 \\
\hline
\end{tabular}

Tabela 4.12 - Dados sorção para o manganês.

\begin{tabular}{c|c|c|c|c}
\hline Solução & $\mathrm{C}_{\mathrm{O}}(\mathrm{mg} / \mathrm{L})$ & $\mathrm{C}_{\mathrm{e}}(\mathrm{mg} / \mathrm{L})$ & M. sorvida $(\mathrm{g})$ & $\mathrm{S}(\mathrm{mg} / \mathrm{g})$ \\
\hline $100 \%$ & 2,10 & 0,1083 & 0,079 & 0,019 \\
\hline $80 \%$ & 1,65 & 0,0813 & 0,062 & 0,015 \\
\hline $60 \%$ & 1,12 & 0,111 & 0,010 & 0,010 \\
\hline $40 \%$ & 0,84 & 0,0827 & 0,030 & 0,007 \\
\hline $20 \%$ & 0,29 & 0,0643 & 0,009 & 0,002 \\
\hline
\end{tabular}

Tabela 4.13 - Dados sorção para o cobre.

\begin{tabular}{c|c|c|c|c}
\hline Solução & $\mathrm{C}_{\mathrm{o}}(\mathrm{mg} / \mathrm{L})$ & $\mathrm{C}_{\mathrm{e}}(\mathrm{mg} / \mathrm{L})$ & M. sorvida $(\mathrm{g})$ & $\mathrm{S}(\mathrm{mg} / \mathrm{g})$ \\
\hline $100 \%$ & 1,81 & 0,010 & 0,072 & 0,018 \\
\hline $80 \%$ & 1,60 & 0,011 & 0,063 & 0,015 \\
\hline $60 \%$ & 1,07 & 0,016 & 0,042 & 0,010 \\
\hline $40 \%$ & 0,79 & 0,010 & 0,031 & 0,007 \\
\hline $20 \%$ & 0,26 & 0,021 & 0,008 & 0,002 \\
\hline
\end{tabular}

Tabela 4.14 - Dados sorção para o níquel.

\begin{tabular}{c|c|c|c|c}
\hline Solução & $\mathrm{C}_{\mathrm{O}}(\mathrm{mg} / \mathrm{L})$ & $\mathrm{C}_{\mathrm{e}}(\mathrm{mg} / \mathrm{L})$ & M. sorvida $(\mathrm{g})$ & $\mathrm{S}(\mathrm{mg} / \mathrm{g})$ \\
\hline $100 \%$ & 0,022 & 0,009 & 0,0005 & 0,0001 \\
\hline $80 \%$ & 0,018 & 0,008 & 0,0004 & 0,001 \\
\hline $60 \%$ & 0,010 & 0,007 & - & - \\
\hline $40 \%$ & 0,09 & 0,004 & - & - \\
\hline $20 \%$ & $<0,005$ & - & - & - \\
\hline
\end{tabular}


Tabela 4.15 - Dados sorção para o cromo.

\begin{tabular}{c|c|c|c|c}
\hline Solução & $\mathrm{C}_{\mathrm{o}}(\mathrm{mg} / \mathrm{L})$ & $\mathrm{C}_{\mathrm{e}}(\mathrm{mg} / \mathrm{L})$ & M. sorvida $(\mathrm{g})$ & $\mathrm{S}(\mathrm{mg} / \mathrm{g})$ \\
\hline $100 \%$ & 0,64 & 0,096 & 0,021 & 0,0054 \\
\hline $80 \%$ & 0,46 & 0,073 & 0,015 & 0,0039 \\
\hline $60 \%$ & 0,31 & 0,025 & 0,011 & 0,0029 \\
\hline $40 \%$ & 0,26 & 0,017 & 0,009 & 0,0024 \\
\hline $20 \%$ & 0,0082 & 0,005 & 0,003 & 0,008 \\
\hline
\end{tabular}

Tabela 4.16 - Valores de isotermas, kd, E, kf, Sm, b.

\begin{tabular}{c|c|c}
\hline Nitrato & Cromo sintético & Níquel sintético \\
\hline $\mathrm{kd}=0,0029$ & $\mathrm{kd}=0,0096$ & $\mathrm{kd}=0,0029$ \\
\hline $\mathrm{E}=0,5$ & $\mathrm{E}=0,154$ & $\mathrm{E}=0,652$ \\
\hline $\mathrm{kf}=0,0684$ & $\mathrm{kf}=0,4828$ & $\mathrm{kf}=0,019$ \\
\hline $\mathrm{Sm}=1,6529$ & $\mathrm{Sm}=1,14$ & $\mathrm{Sm}=10,10$ \\
\hline $\mathrm{b}=0,0082$ & $\mathrm{~b}=0,1393$ & $\mathrm{~b}=0,0002$ \\
\hline
\end{tabular}

Já as Figuras 4.58 a 4.60 apresenta-se as isotermas em que houve um ajuste satisfatório para o lodo bruto de esgoto. Somente o modelo de Freundlich foi possível ajustar o cromo para obtenção da isoterma.

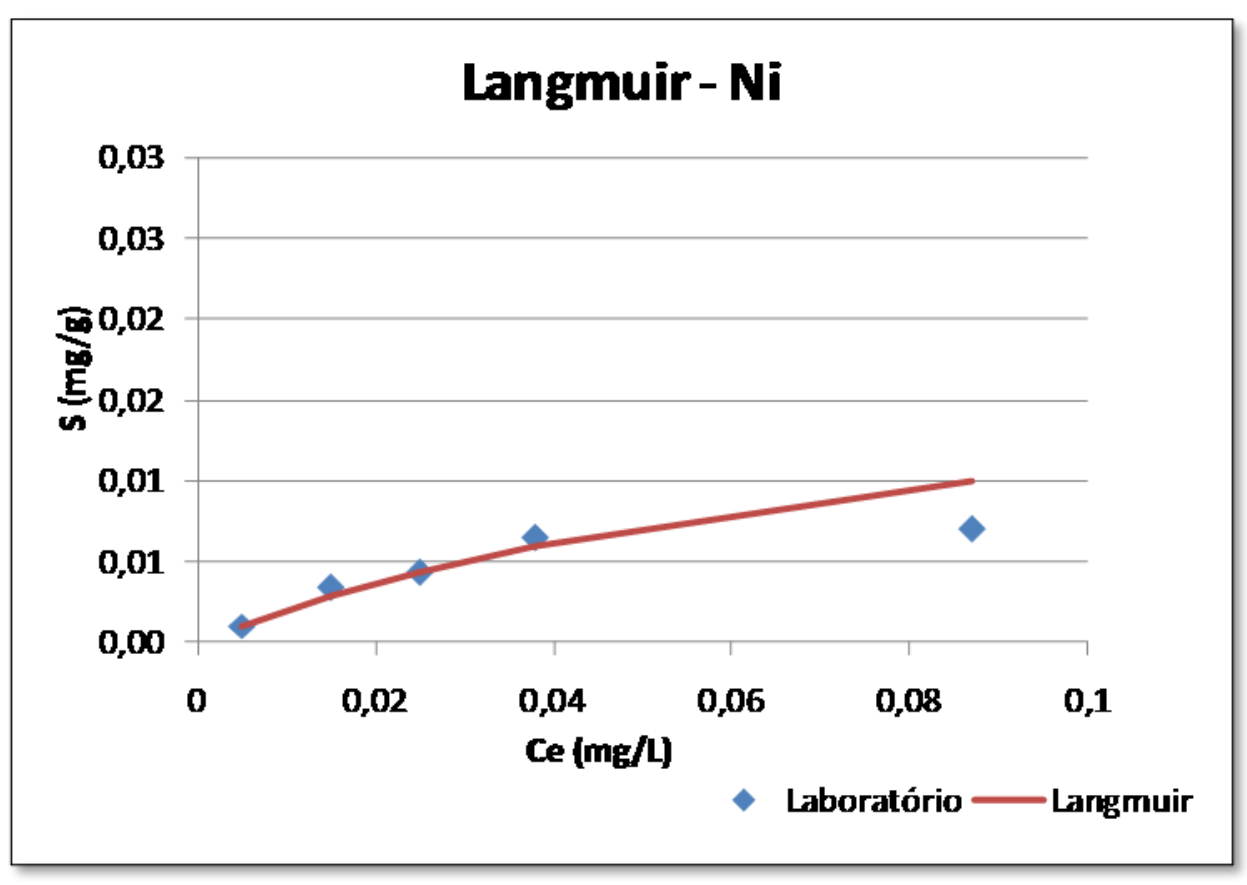

Figura 4.58 - Isotermar de Lagmuir de Ni (in natura). 


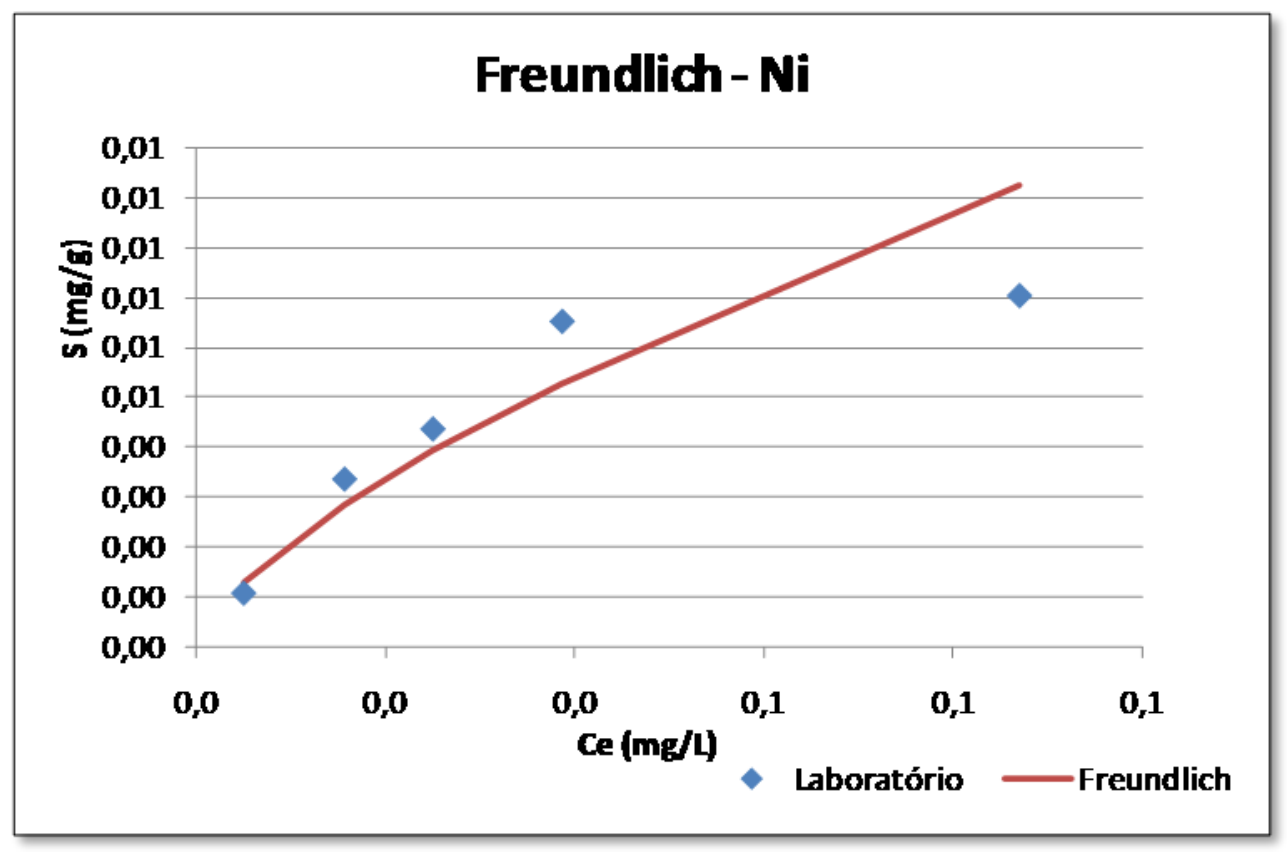

Figura 4.59 - Isoterma de Freundlich de Ni (in natura).

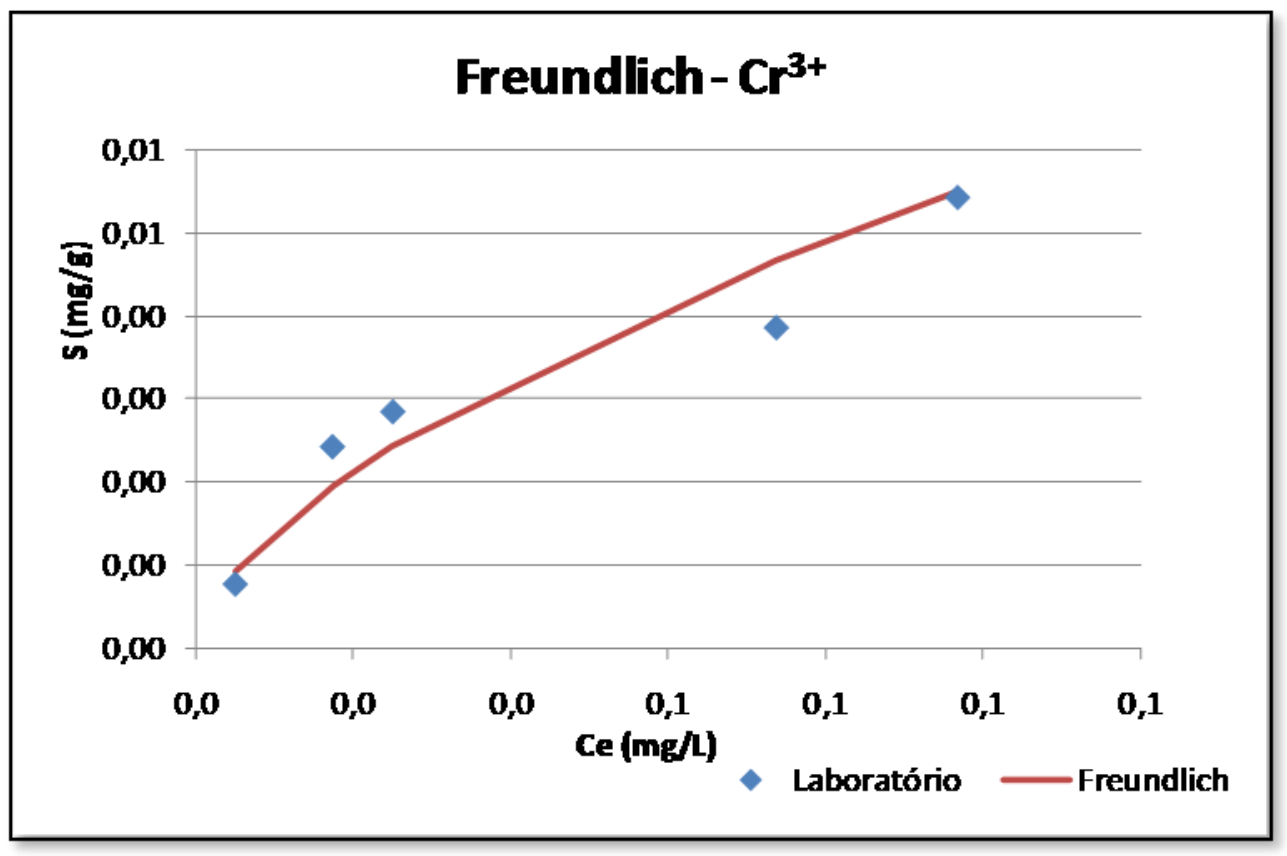

Figura 4.60 - Isoterma de Freundlich de $\mathrm{Cr}^{3+}$ (in natura).

As Figuras 4.61 e 4.62 apresentam as isotermas para o efluente sintético de cromo. E a Figura 4.63 é apresentado ambos modelos de ajustes. 


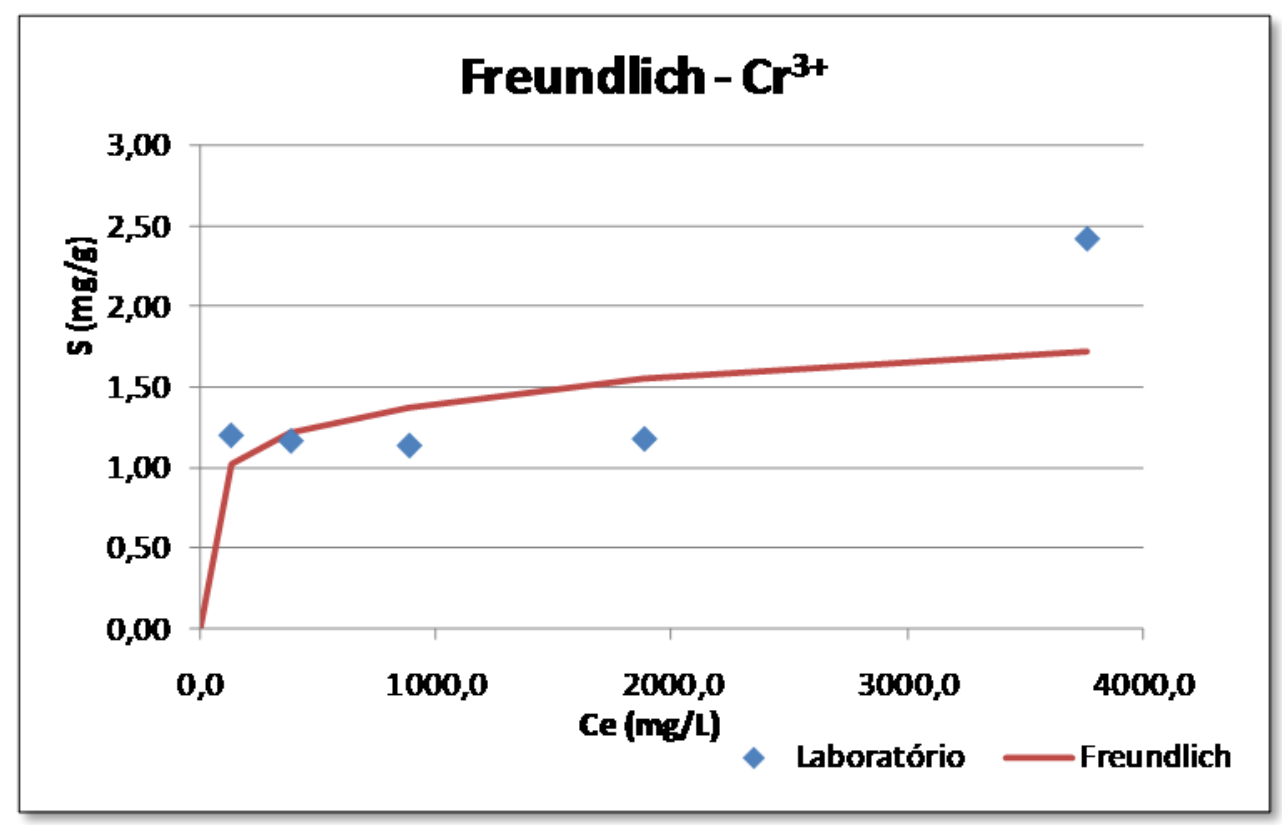

Figura 4.61 - Isoterma de Freundlich de $\mathrm{Cr}^{3+}$ (sintético).

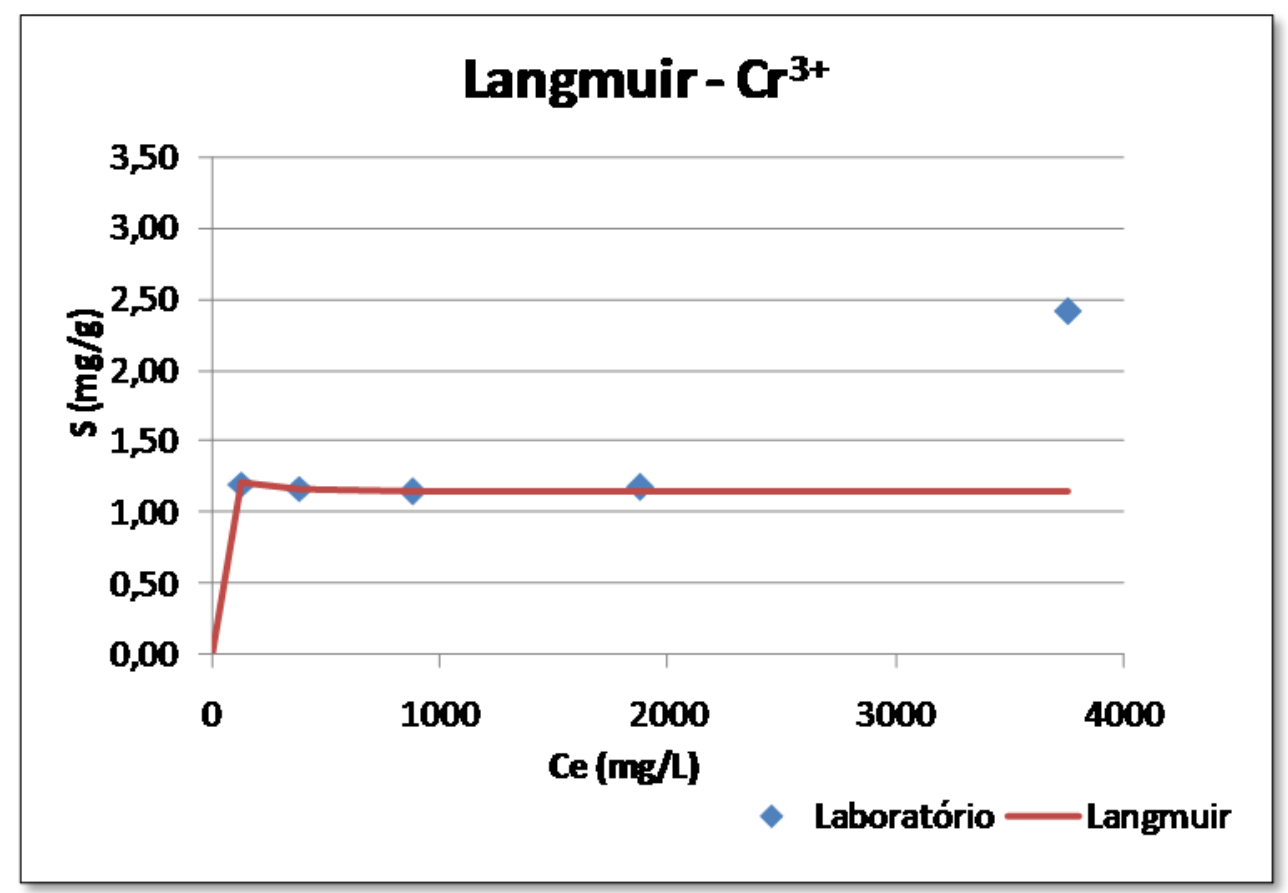

Figura 4.62 - Isoterma de Langmuir de $\mathrm{Cr}^{3+}$ (sintético). 


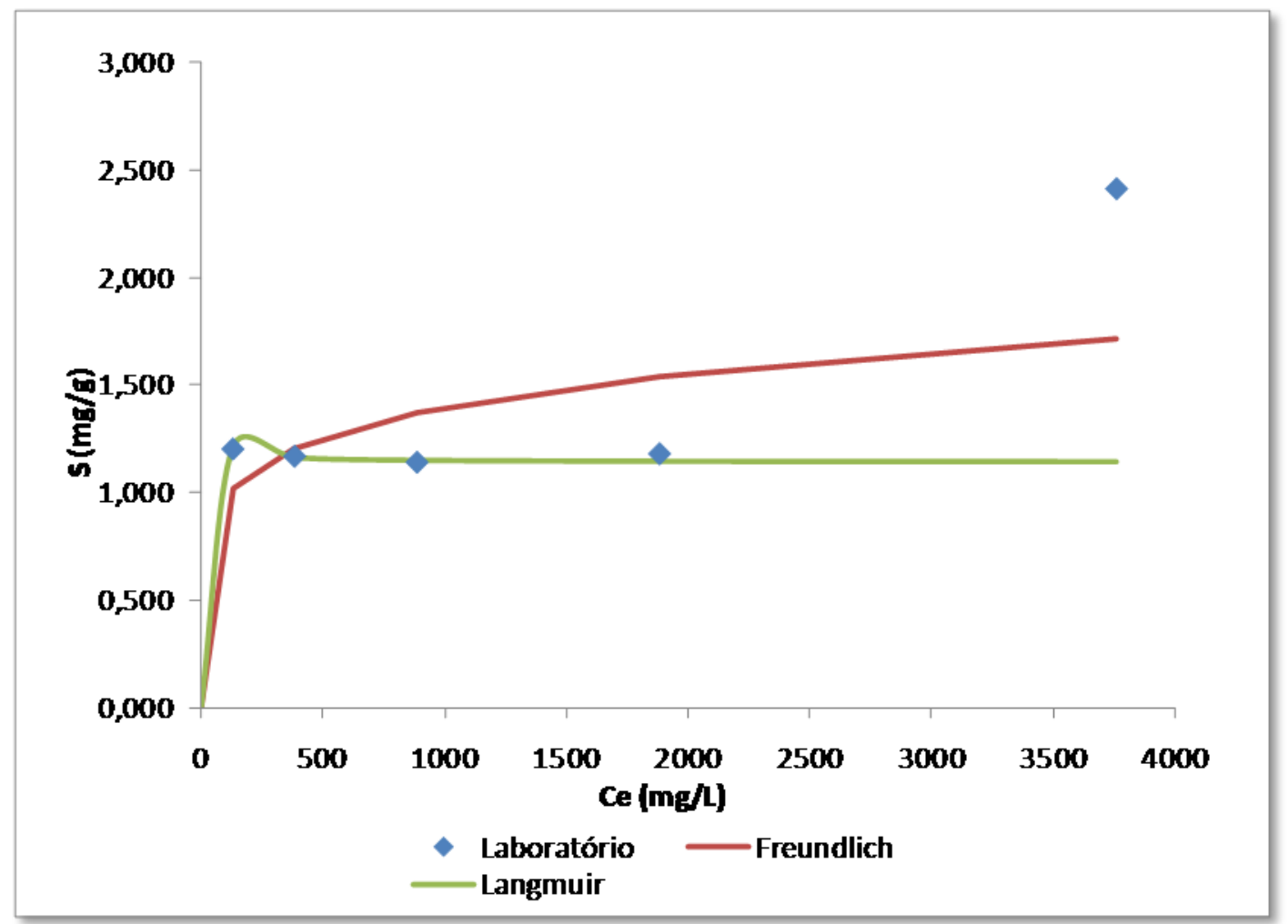

Figura 4.63 - Isotermas de Langmuir e Freundlich para o cromo (sintético).

As Figuras 4.64 e 4.65 apresentam os dados referente aos modelos de isotermas para contaminante com a solução sintética de níquel. Já a Figura 4.66 apresenta ambos modelos de ajustes para as isotermas.

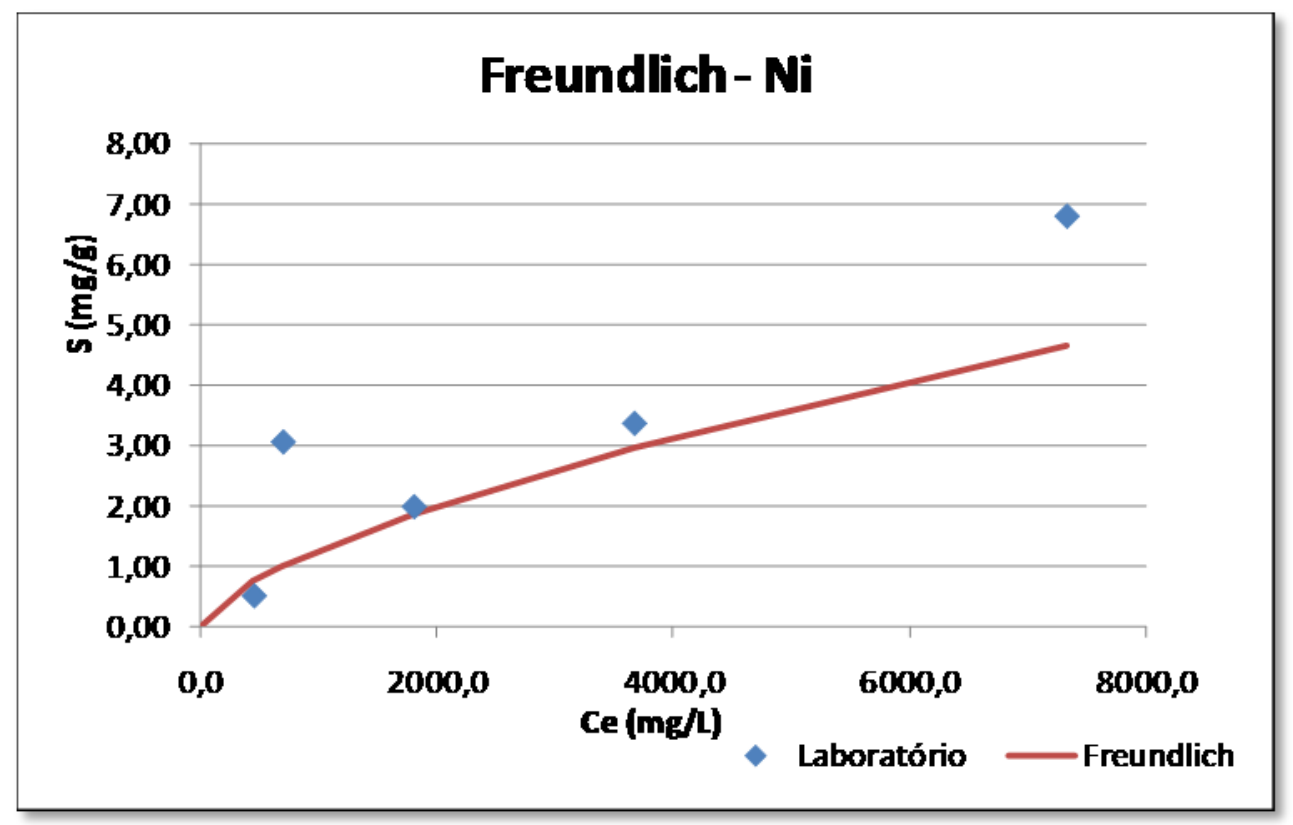

Figura 4.64 - Isotermas de Freundlich para o níquel (sintético). 


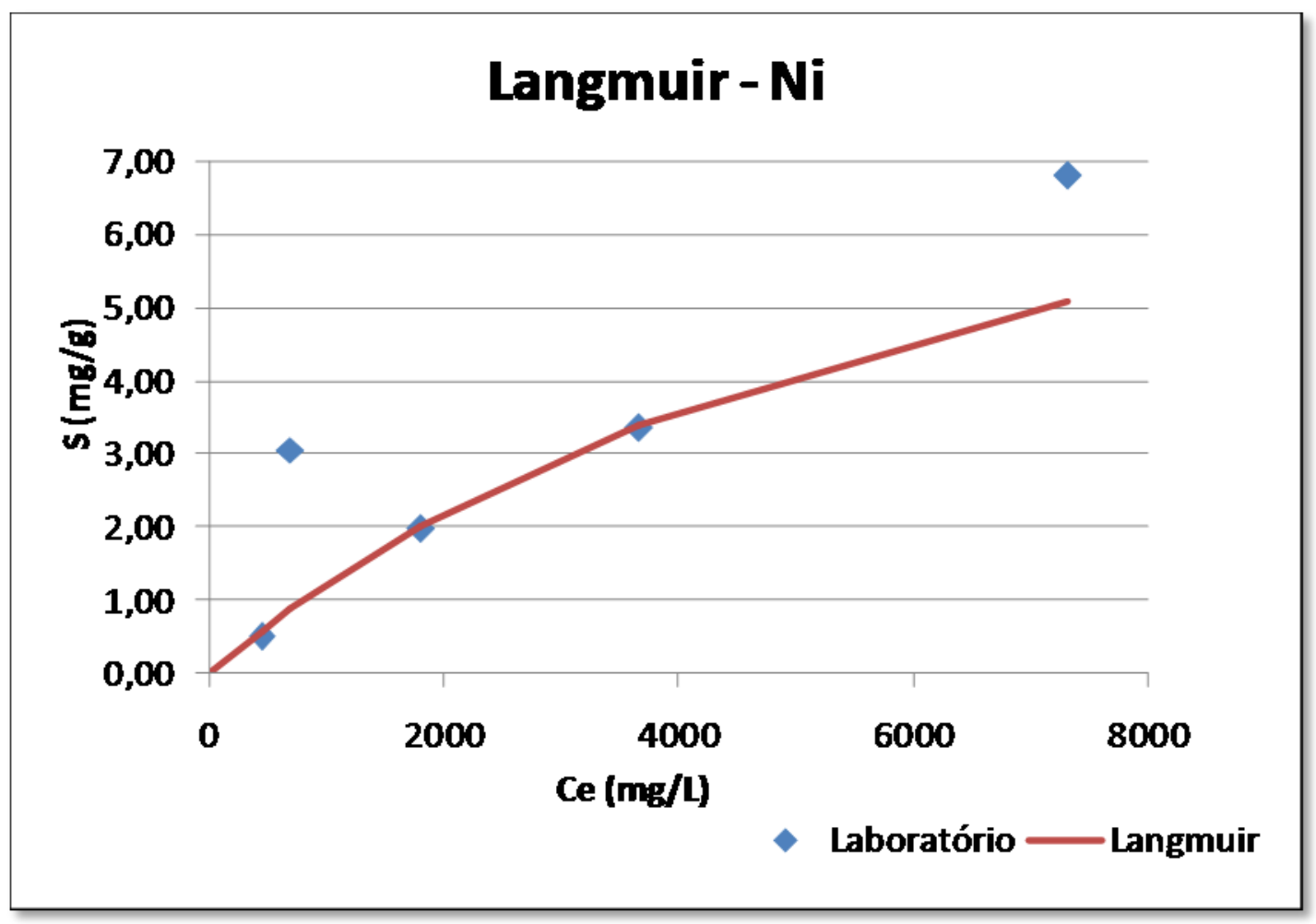

Figura 4.65 - Isotermas de Langmuir para o níquel (sintético).

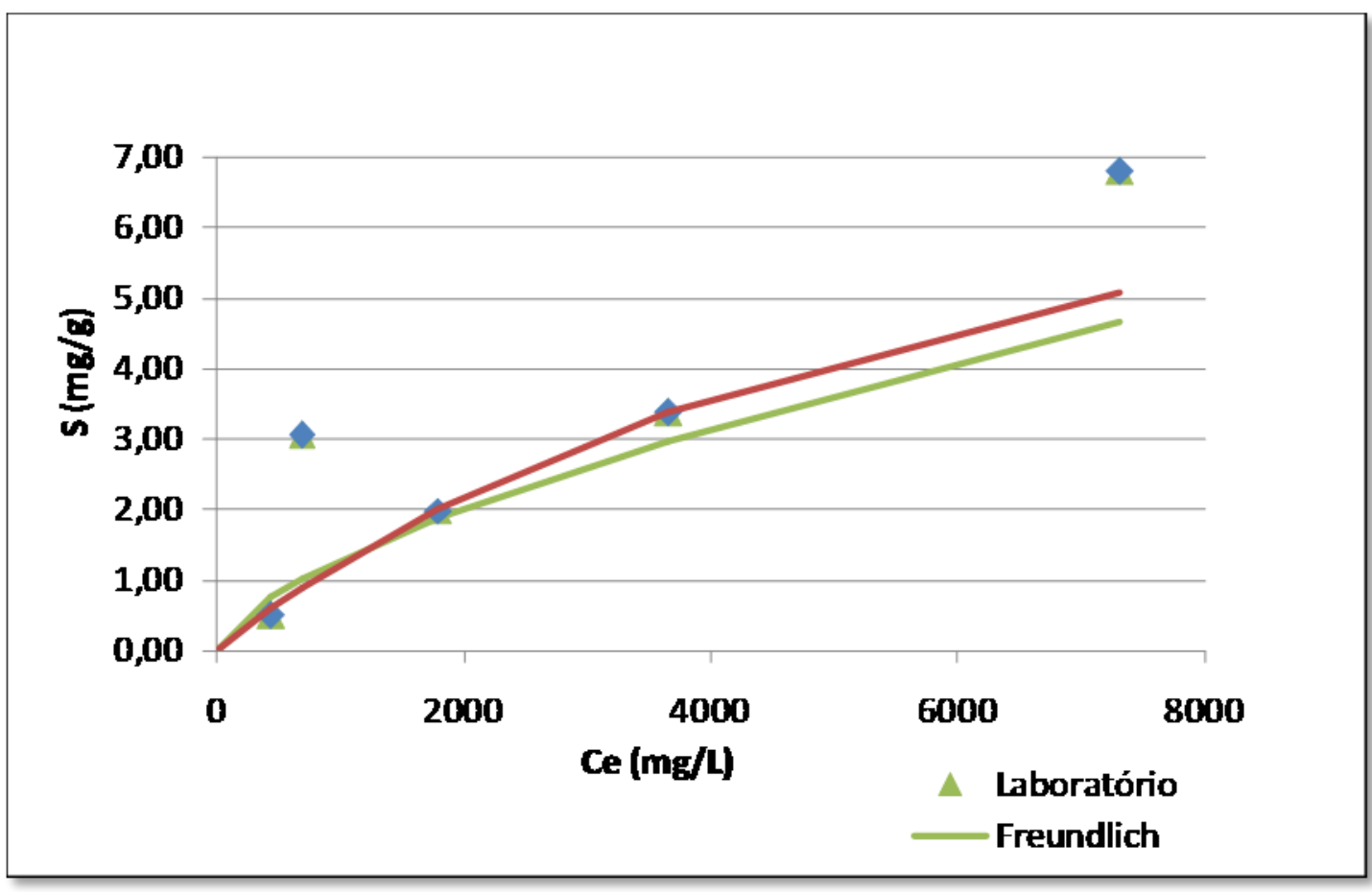

Figura 4.66 - Isotermas de Freundlich e Langmuir (sintético). 
Já as Figuras 4.67 a 4.68 apresentam os dados referente aos modelos de isotermas para contaminante com a solução sintética de níquel. Já a Figura 4.69 apresenta ambos modelos de ajustes para as isotermas.

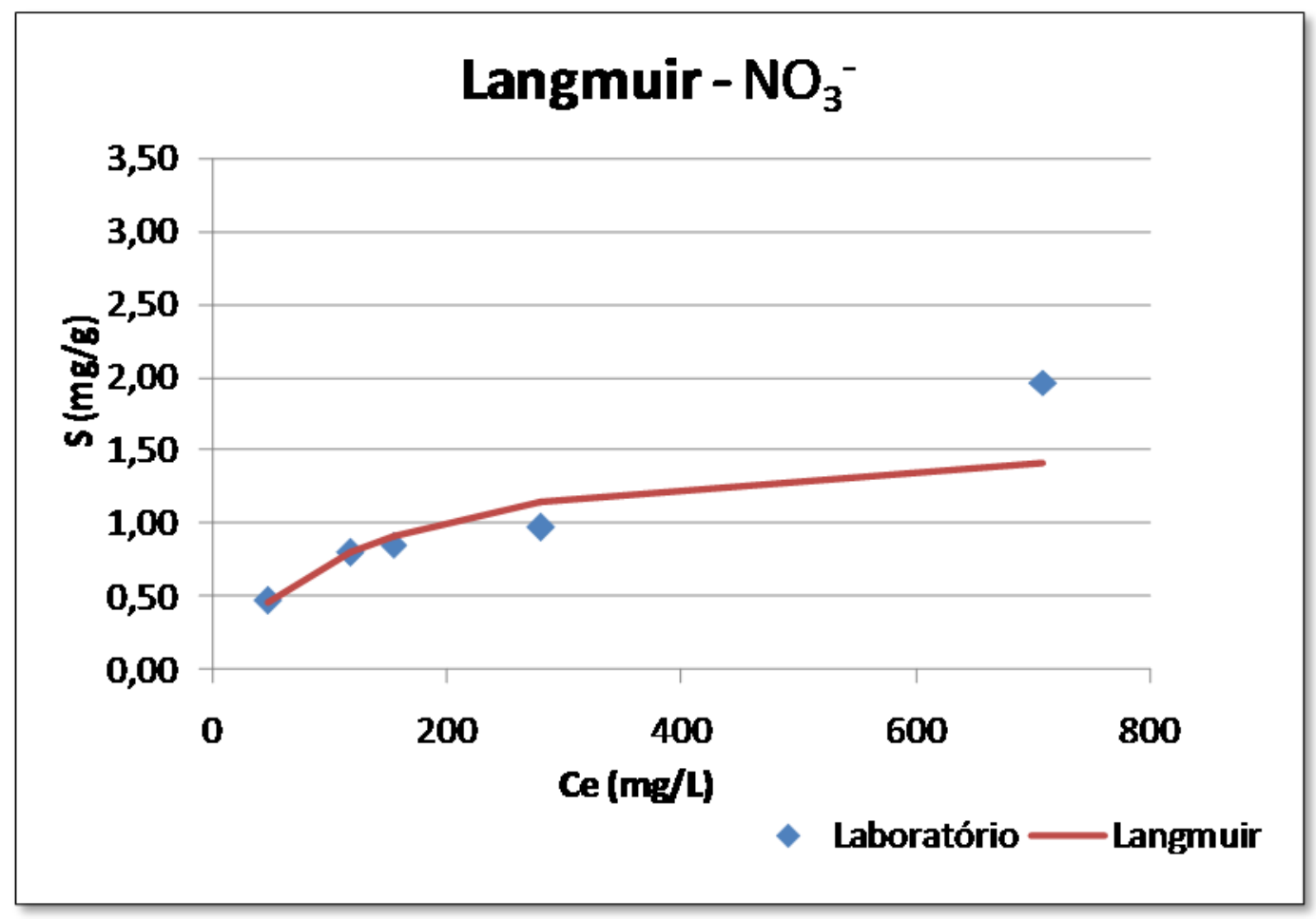

Figura 4.67 - Isoterma de Langmuir para o $\mathrm{NO}_{3}{ }^{-}$

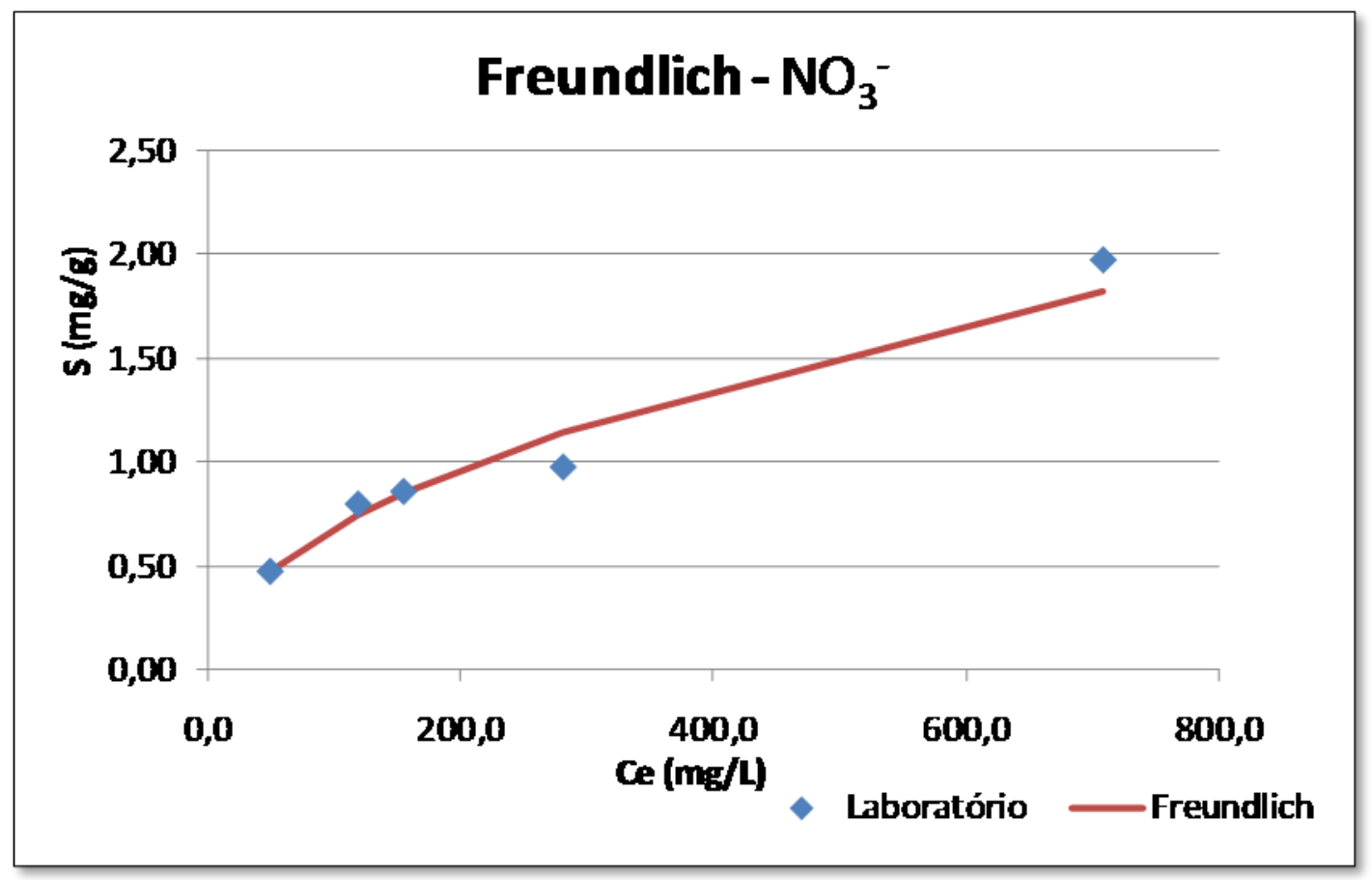

Figura 4.68 - Isotermas de Freundlich para $\mathrm{O}_{3}{ }^{-}$ 


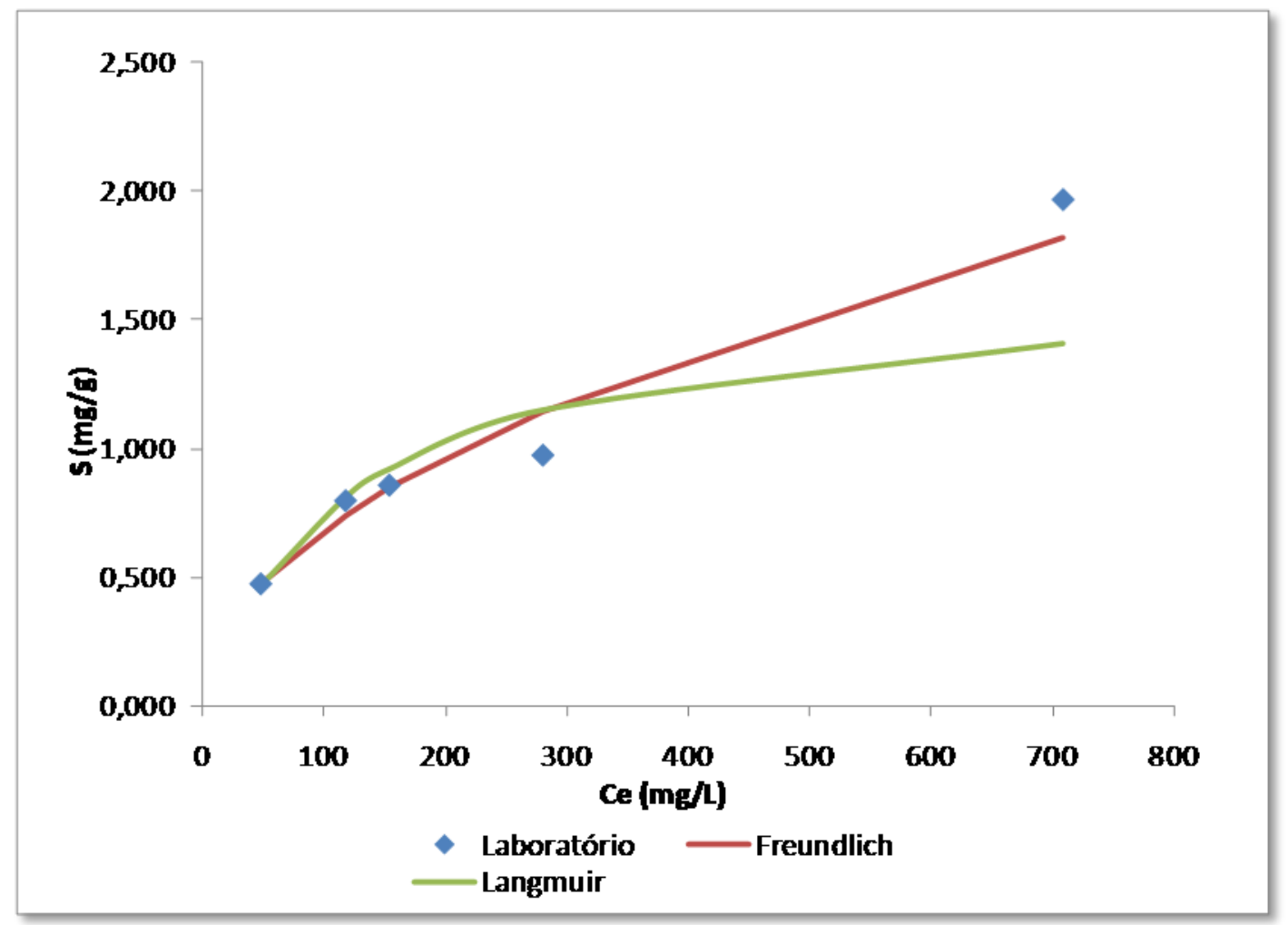

Figura 4.69 - Isotermas de Freundlich e Langmuir para o $\mathrm{NO}_{3}{ }^{-}$

Ao lançar os dados nos gráficos para a obtenção das isotermas na condição multiespécie, foram encontradas retas que não representavam o fenômeno de sorção. $\mathrm{O}$ contaminante estudado apresenta-se em sua composição grande parte de matéria orgânica o que pode ter afetado os resultados. Estudo semelhante comprova essa teoria, pois Yin et al. (2001) mostrou que os metais ligados à matéria orgânica são rapidamente adsorvidos, enquanto que na dessorção ocorre de maneira bem mais lenta.

Observa-se que para as curvas de isotermas Figuras 4.58, 4.59, 4.60 em que o contaminante era o lodo de esgoto somente o níquel e o cromo foi possível montar as curvas, sendo que isoterma de Langmuir foi a que apresentou o melhor ajuste para ambos os metais.

Já as isotermas para a solução contaminante sintética Figuras 4.61, 4.62, 4.64 e 4.65 observa-se um bom ajuste para ambas isotermas. Nessas isotermas nota-se também que o ponto de máxima concentração $4000 \mathrm{mg} / \mathrm{L}$ ficou bem distante da linearidade, e isso pode estar correlacionado a quantidade de cromo ser bem acima da capacidade de sorção do solo.

Para o nitrato tanta a isoterma de Langmuir como de Freundlich apresentou ajuste satisfatório, no entanto é possível observar nas Figuras 4.67 e 4.68, pontos fora da linearidade, 
e isso pode ser justificado pela dessorção, ou seja, isso pode ter ocorrido quando o solo satura sua capacidade de sorção, e começa a dessorver o íon introduzido.

\subsection{CURVA CARACTERISTICA DE RETENÇÃO DE ÁGUA E CONTAMINANTE}

As curvas características têm importância maior na indicação do comportamento do solo no campo, pois na condição de barreira, ou de base contra contaminação em aterros, a zona completamente saturada quase sempre é limitada. As forças de sucção do solo passam a ser relevantes no processo de avanço da pluma de contaminantes. No início do processo de saturação, a força de gravidade que atua sobre a massa do fluido junta-se à força de sucção matricial, que é máxima na condição de solo seco. Com o umedecimento progressivo da frente de saturação, as forças de sucção matricial diminuem, passando a ter importância a sucção osmótica (Correa, 2001).

A introdução de contaminantes no solo quase sempre provoca a desagregação, por outro lado as curvas características indicam uma variação na capacidade de retenção de umidade. A Figura 4.70 apresenta as curvas características ajustadas conforme o Modelo de Vang Bimodal com adaptações de Otalvaro \& Cordão Neto (2011).

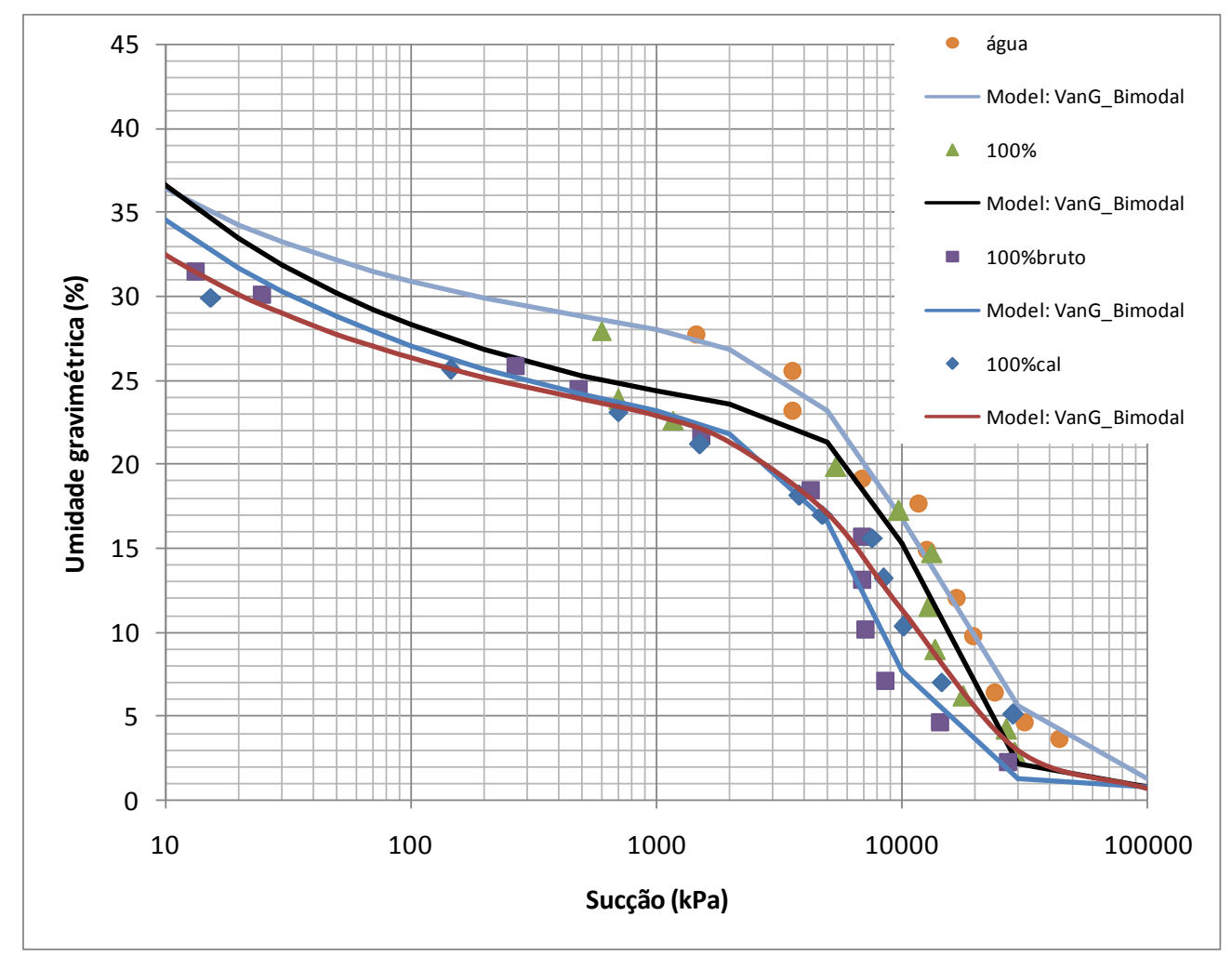

Figura 4.70 - Curva característica de retenção de água e contaminantes. 
A analise das curvas característica demonstram que o solo ao contaminar apresenta uma tendência de diminuir sua sucção matricial. Na figura 4.70, pode-se perceber claramente essa tendência, uma vez que a curva para a água é a que apresenta os maiores valores de sucção, sendo que as demais curvas estão todas abaixo, quando se compara com o solo no estado natural sem contaminação. Além disso, pode perceber os locais de entrada de ar nos microporos com uma sucção em torno de $5000 \mathrm{kPa}$, e entrada de ar nos macroporos com uma sucção em torno de 30000 $\mathrm{kPa}$. As demais curvas características encontram-se no Anexo B.

\subsection{TRAÇÃO POR COMPRESSÃO DIAMETRAL}

Os ensaios de tração por compressão diametral teve por objetivo verificar a resistência dos corpos de prova contaminados com o estrato de lodo de esgoto. Para tanto foram ensaiados todos os corpos de prova do ensaio de sucção obtendo-se os dados de resistência, As Figuras 4.71 a 4.72 apresentam os resultados da relação umidade e resistência, já as Figuras 4.73 a 4.74 apresentam a relação saturação e resistência, e as Figuras 4.75 a 4.76 apresentam a relação sucção e resistência. Ressalta-se que os gráficos gerados são para os corpos de prova contaminados tanto com o extrato de lodo de esgoto sem cal, como os com a cal.

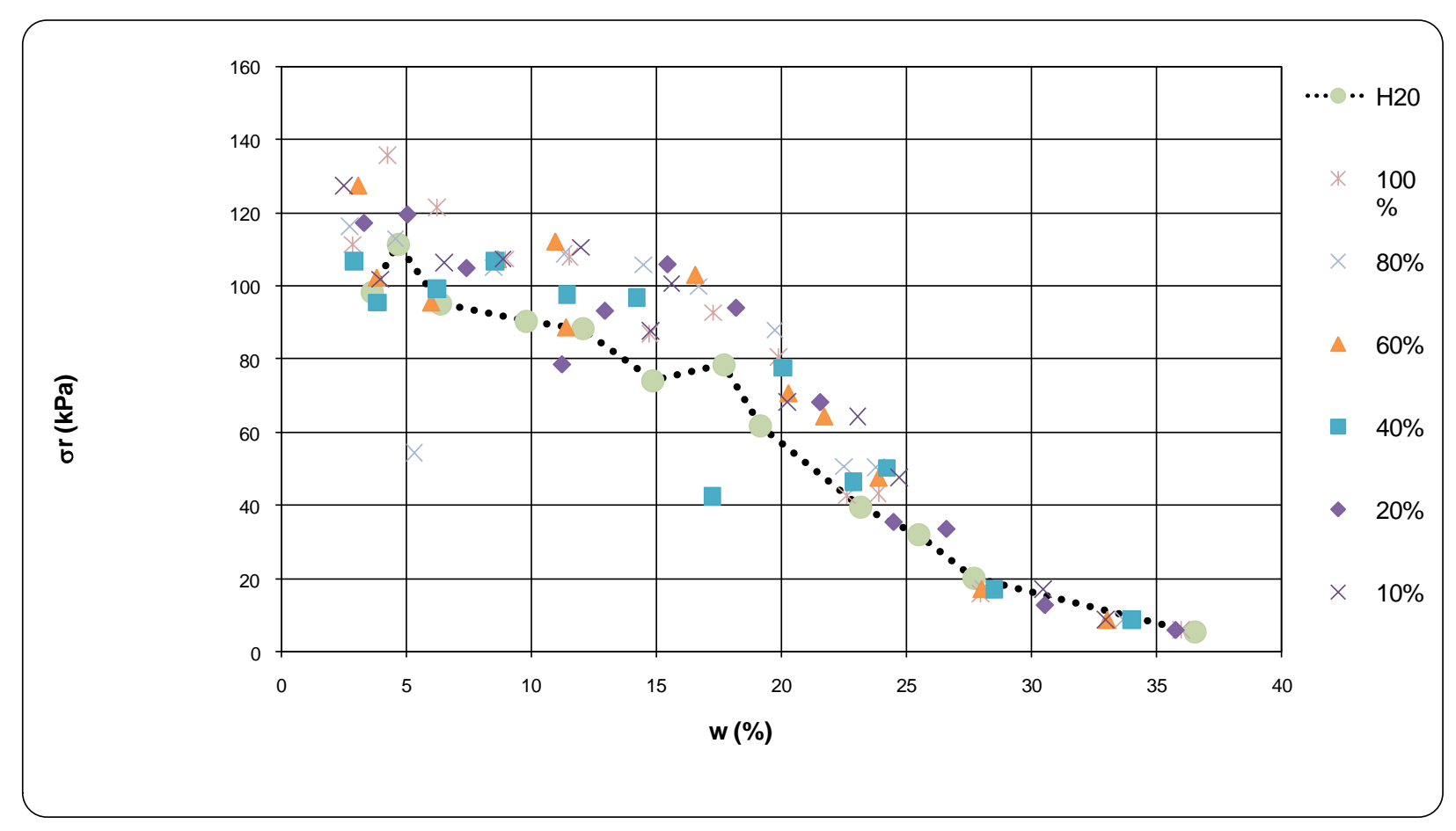

Figura 4.71 - Relação umidade e resistência a tração sem cal. 


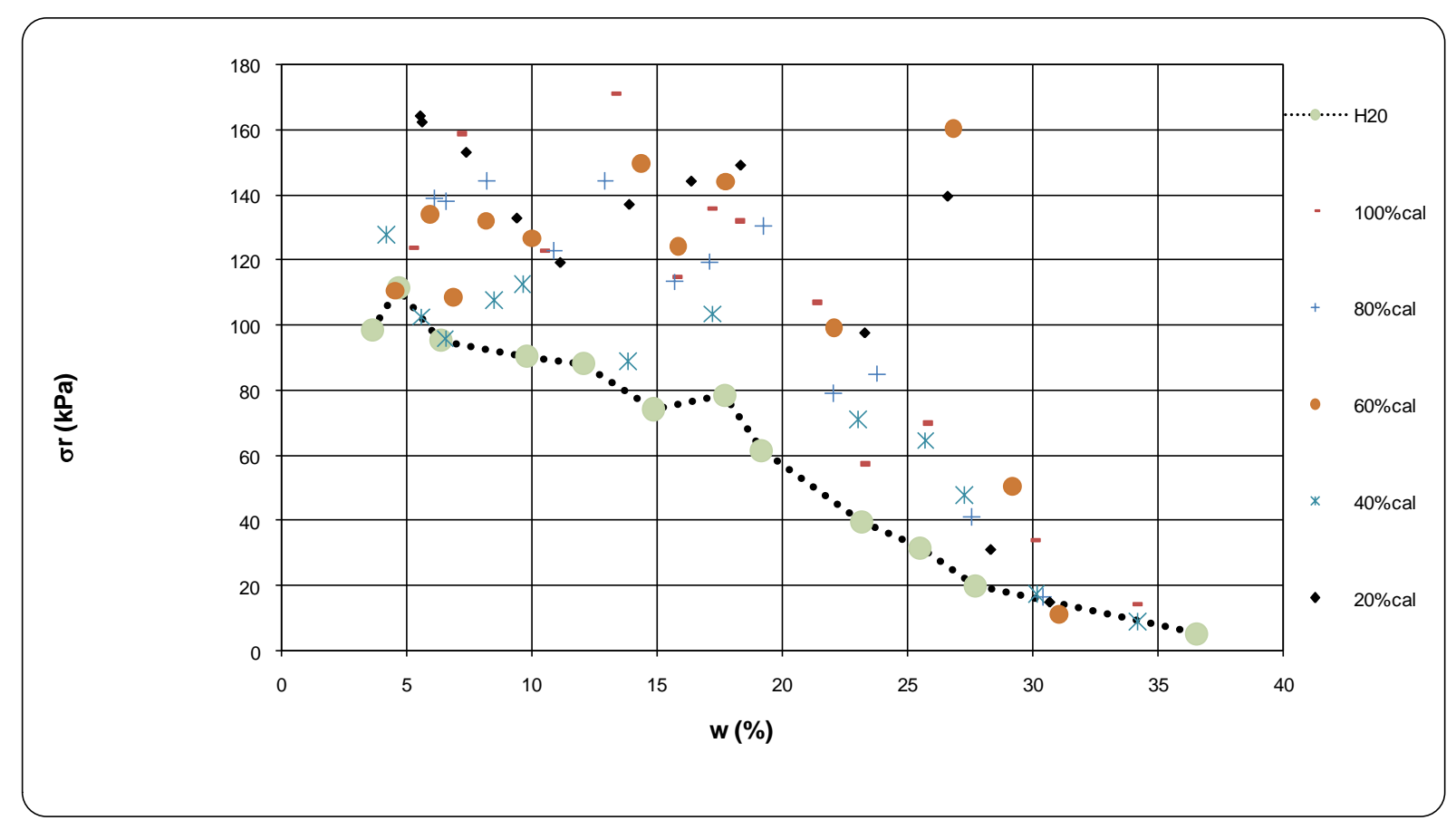

Figura 4.72 - Relação umidade e resistência a tração com cal.

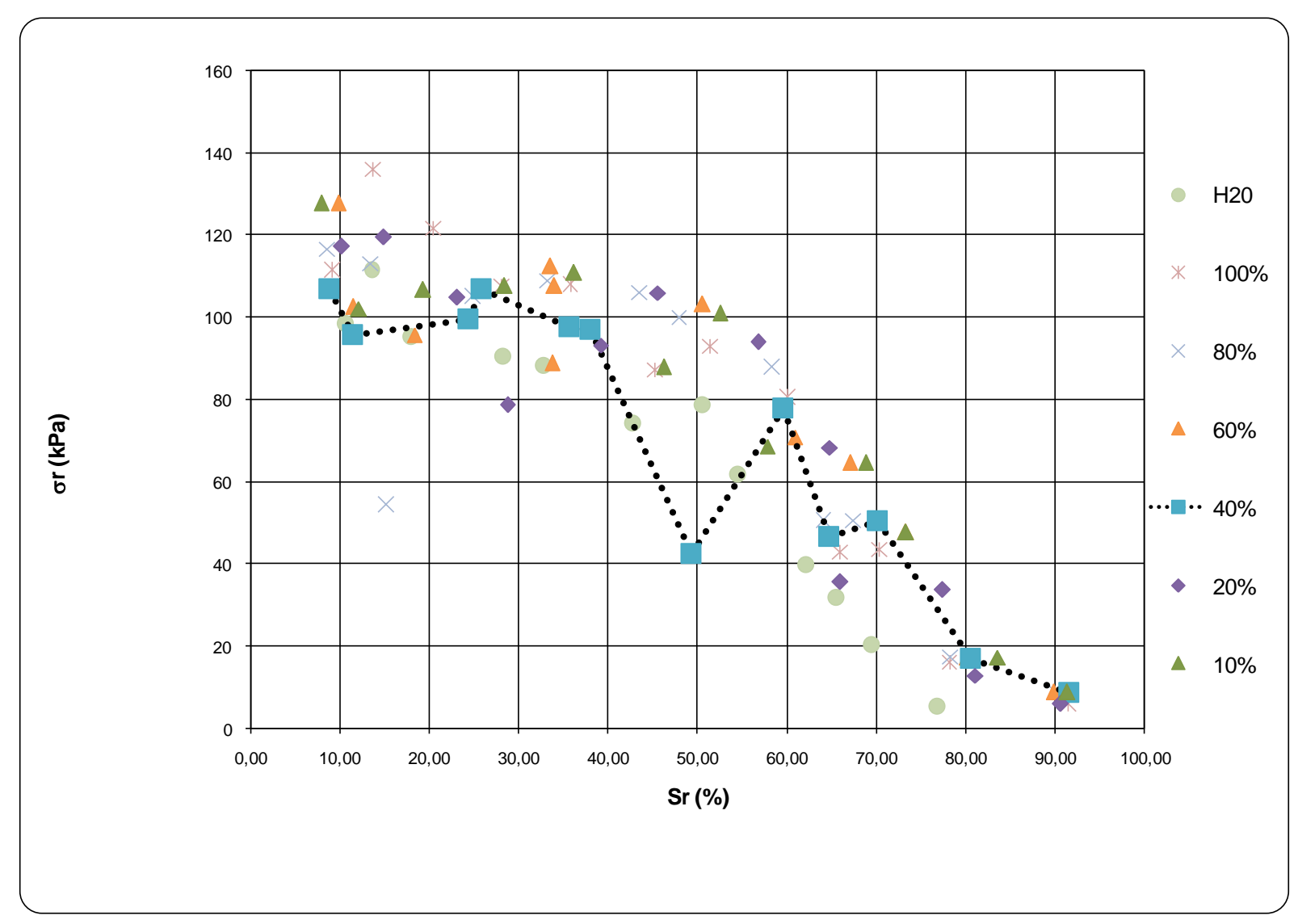

Figura 4.73 - Relação saturação e resistência a tração sem cal. 


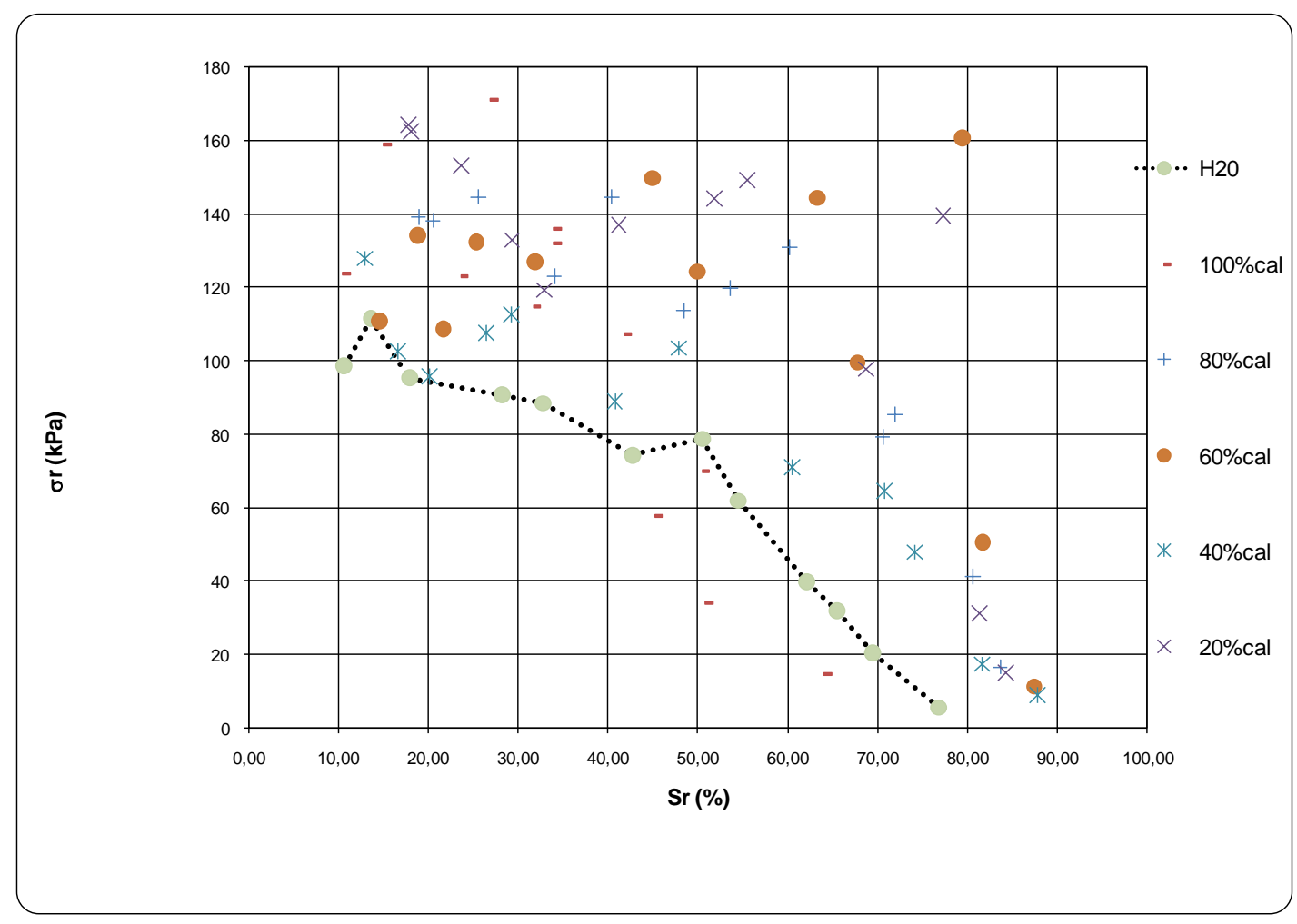

Figura 4.74 - Relação saturação e resistência a tração com cal.

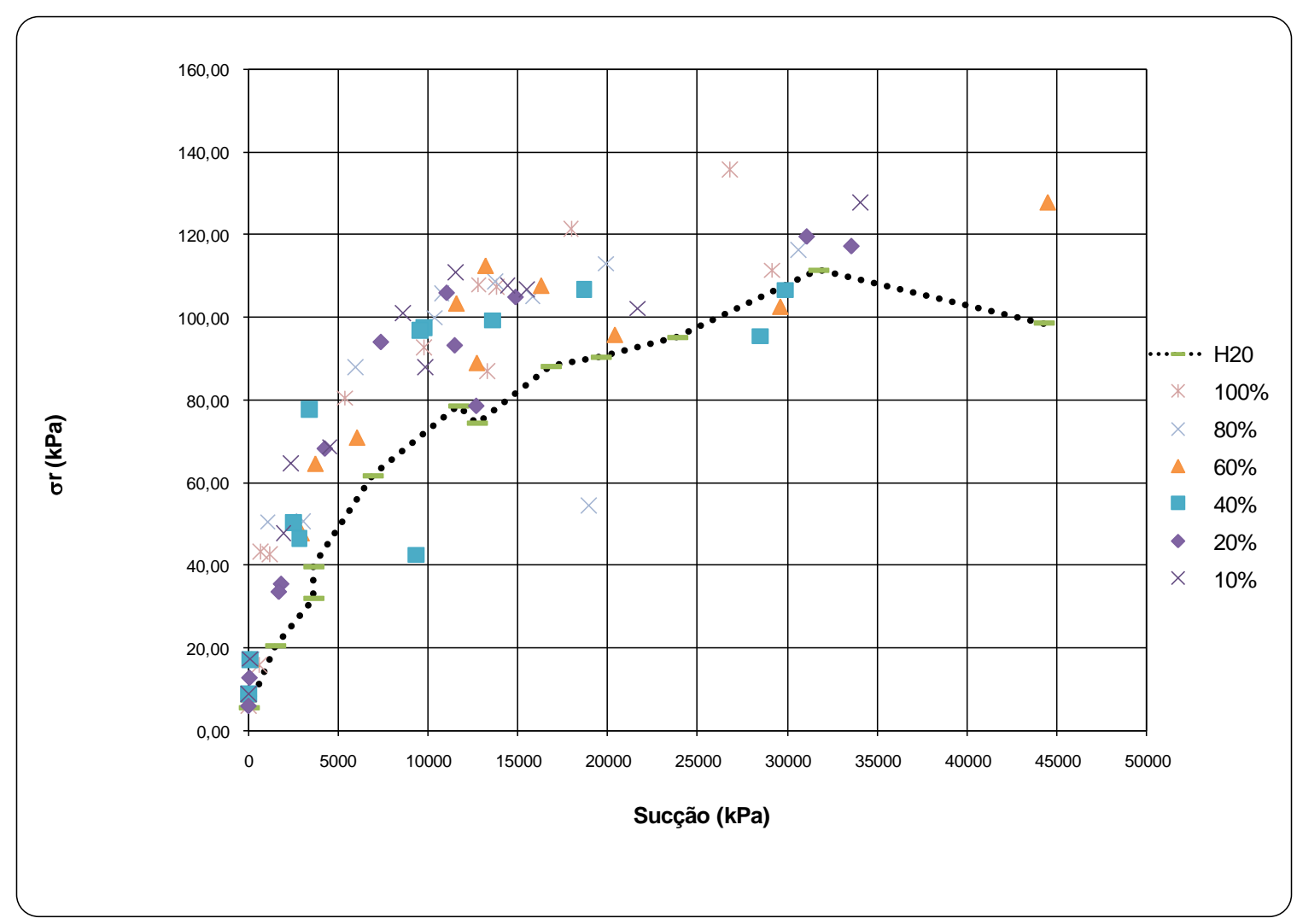

Figura 4.75 - Relação sucção e resistência a tração sem cal 


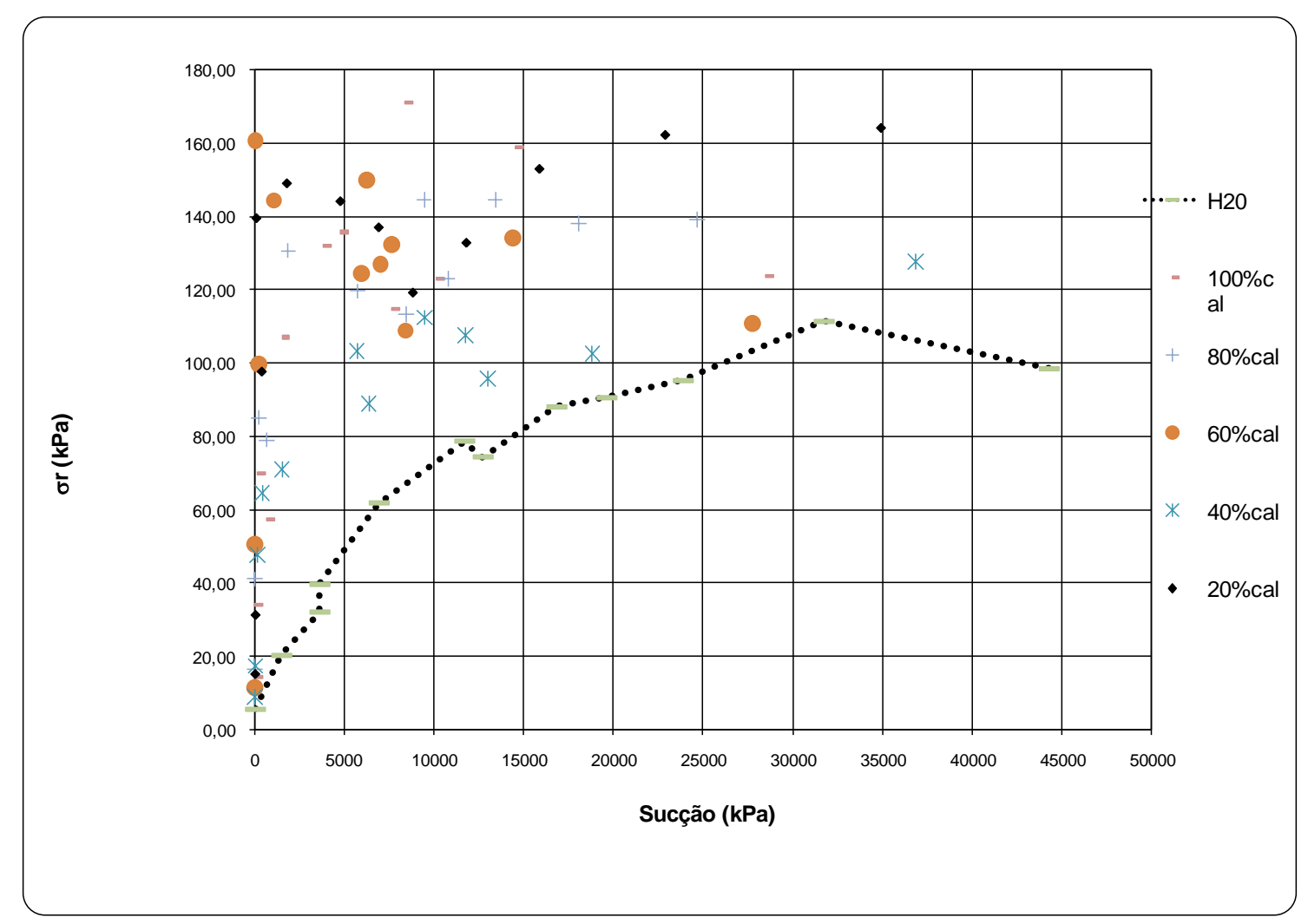

Figura 4.76 - Relação sucção e resistência a tração com cal.

Ao analisar as figuras 4.71 a 4.76, pode-se observar que com a entrada de ar no microporos ocorre um aumento da resistência a tração. As Figuras 4.75 e 4.76 nota-se que a resistência aumenta com a diminuição da umidade de forma acentuada até a entrada de água nos micro poros a partir daí o crescimento da resistência diminui até se estabilizar a partir da entrada d'água nos macro poros.

Este fato ocorre pelo fato do solo sofrer processo de desidratação e ocorrer perda do fluido sobre ação de sucção. Este fato acompanha os observados nas curvas características. Sendo assim à medida que a umidade aumenta e passa a entrar água nos macroporos, a resistência diminui significativamente tanto para o solo no estado natural, como contaminado nas diferentes concentrações. Fato este observado em umidades acima de 15\%, ou saturação de $40 \%$. As Figuras 4.75, 4.76, pode-se notar a relação entre os valores de resistência a tração e sucção. Nota-se o efeito de mudança de resistência e sucção com a adição de contaminante em qualquer uma das concentrações utilizadas. E ainda pode-se perceber o incremento da resistência para o contaminante com a cal. 


\subsection{ENSAIOS DE COMPATIBILIDADE}

Os ensaios de compatibilidade visam verificar o efeito da percolação de poluentes nas características geotécnicas do solo. Foram realizados os ensaios de índices de consistência, granulometria e expansão livre nos solos contaminados. Esses ensaios são importantes para o conhecimento de transporte de poluentes em solos, visto que a literatura tem demonstrando que a percolação de uma solução pelo solo pode alterar suas características geotécnicas. Os limites de Atterberg encontrados estão mostrados nas Figuras 4.77 e 4.78, para o solo natural, 100\%, $80 \%, 60 \%, 40 \%, 20 \%, 10 \%, 2 \%$ e $1 \%$ contaminados, com e sem cal.

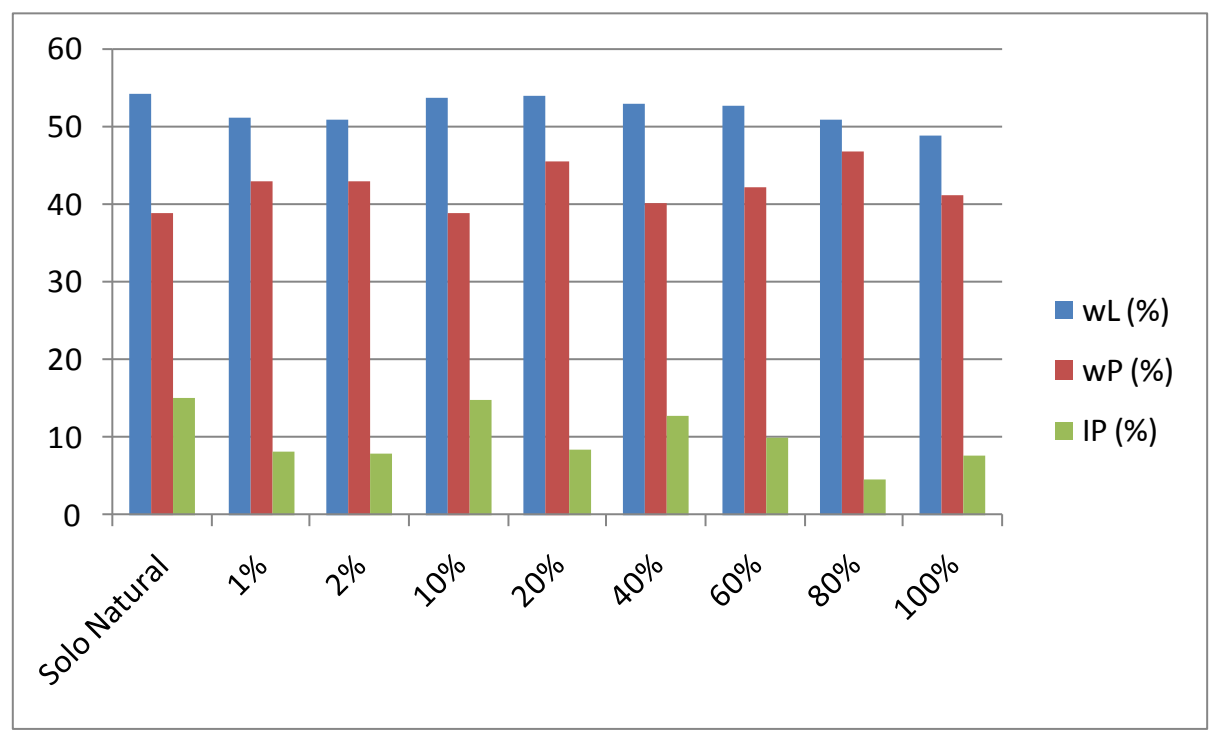

Figura 4.77 - Limites de Atterberg contaminante sem cal.

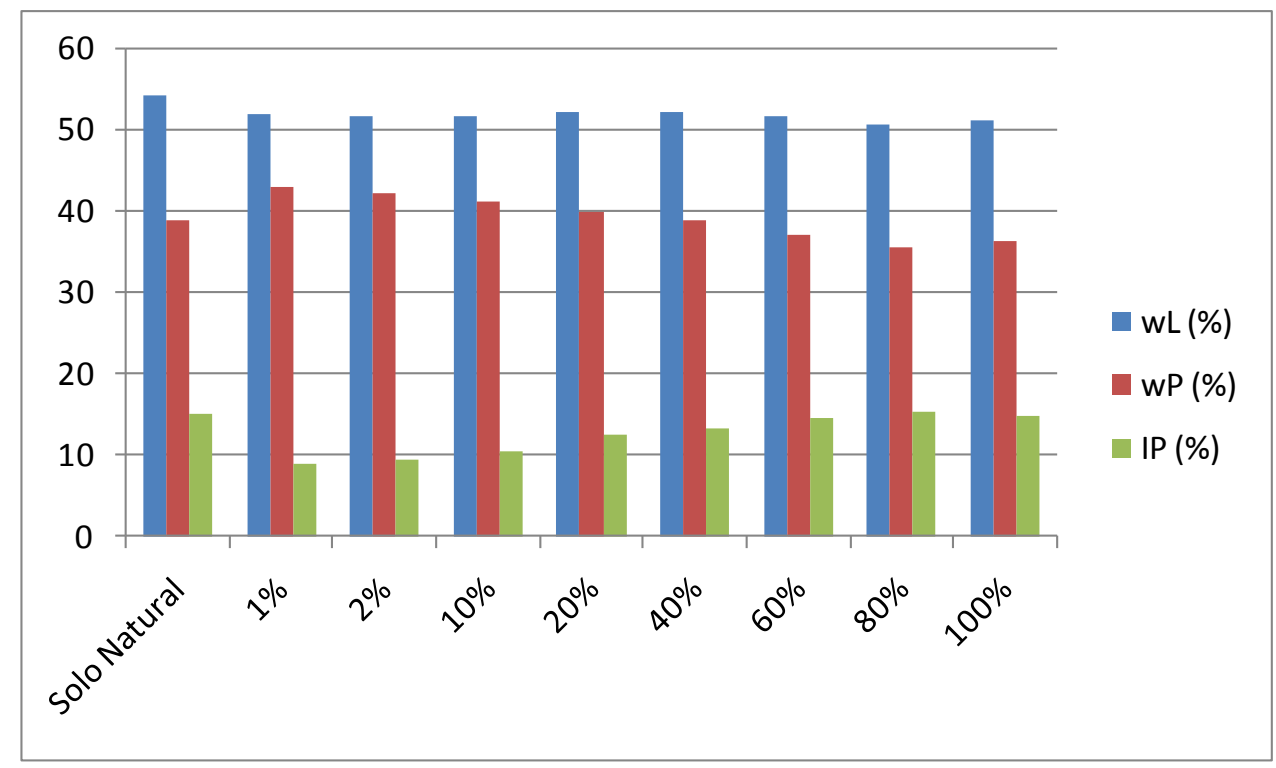

Figura 4.78 - Limites de Atterberg contaminante com cal. 
Observa-se pelo gráfico que os valores tanto de wP, wL, como IP sofreram variações ao serem contaminados nas diferentes concentrações avaliadas. Isso pode está relacionado a capacidade do contaminante (extrato de lodo centrifugado) mudar a plasticidade do solo e consequentemente alterar os limites de consistência, esse fato pode ser observado devido mudanças da salinidade do solo e consequentemente mudanças nas forças de sucção do solo.

Já em relação à granulometria dos solos contaminados, procedeu-se a análise granulométrica nas faixas de leitura no granulômetro a laser, solos passantes na peneira \#10 de abertura $2 \mathrm{~mm}$, e os solos dos índices de consistência passantes na peneira \#40. As Figuras 4.79 e 4.80 apresentam as curvas granulométricas do solo passante na \#10, tanto contaminado com e sem cal.

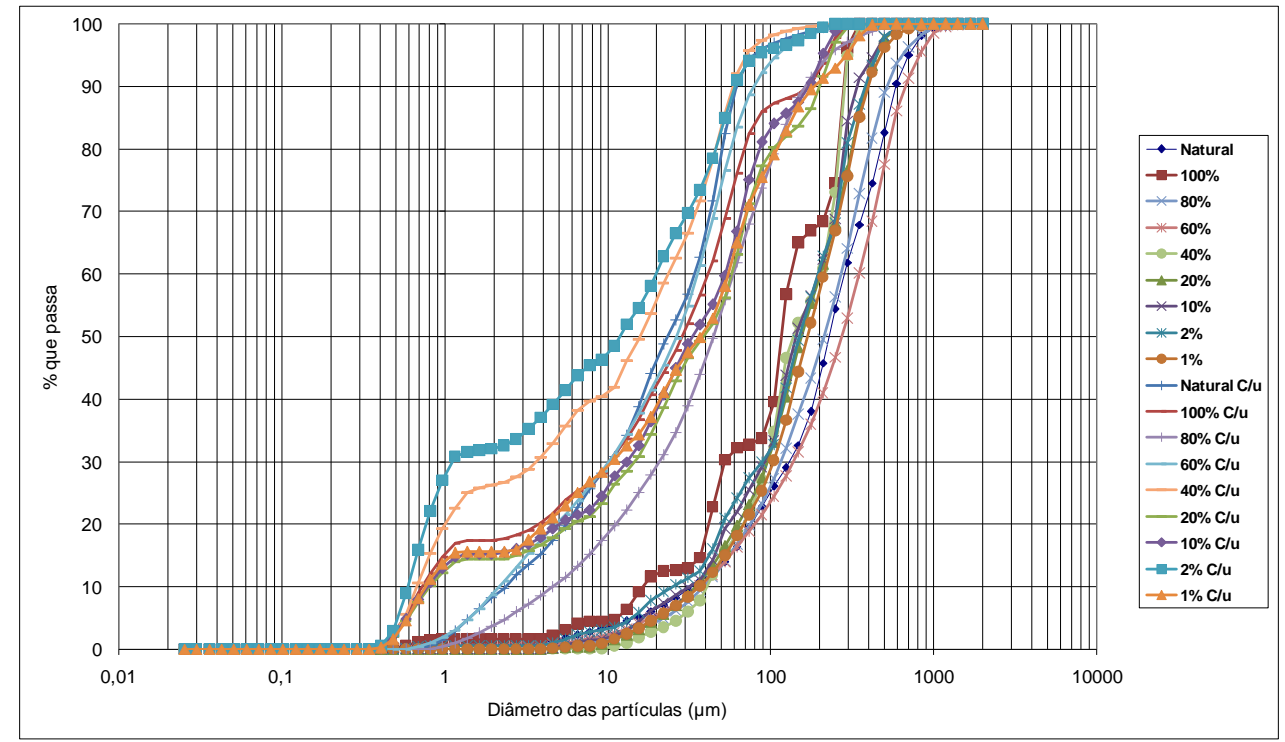

Figura 4.79 - Curva granulométrica solo (<\#10) contaminado com extrato de lodo sem cal.

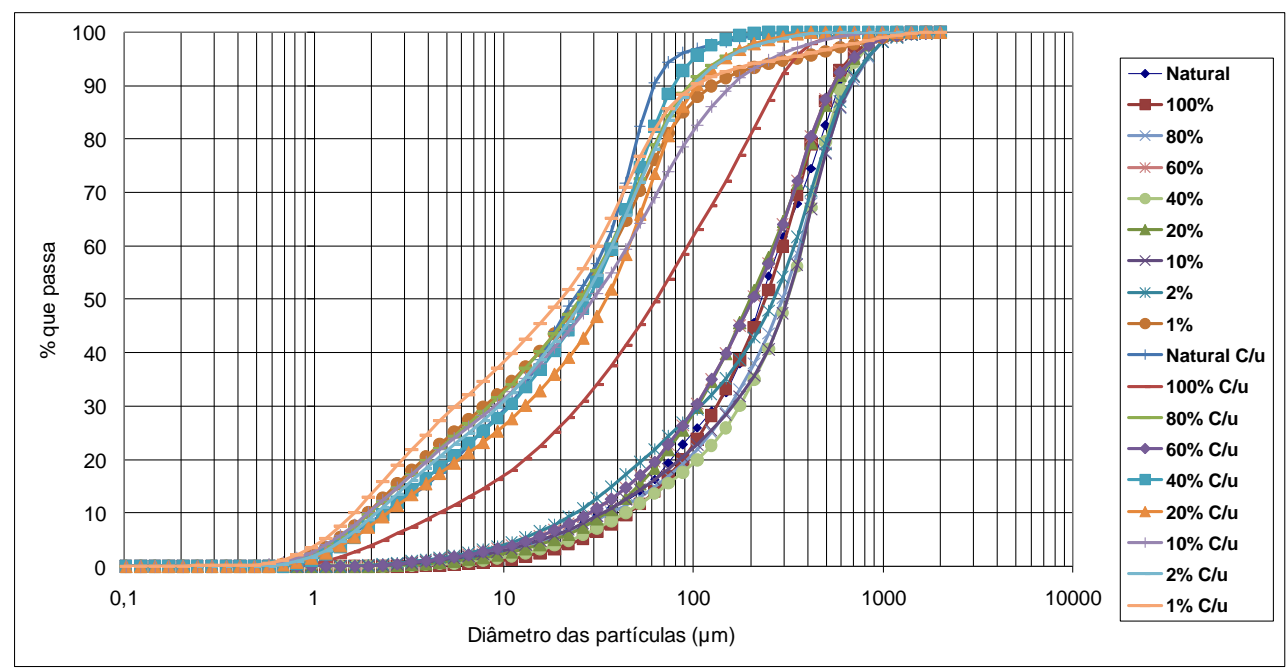

Figura 4.80 - Curva Granulometrica solo (<\#10) contaminado com extrato de lodo com cal. 
Já as Figuras 4.81 e 4.82 apresentam as curvas granulométricas para os solos dos ensaios de limites de Atterberg.

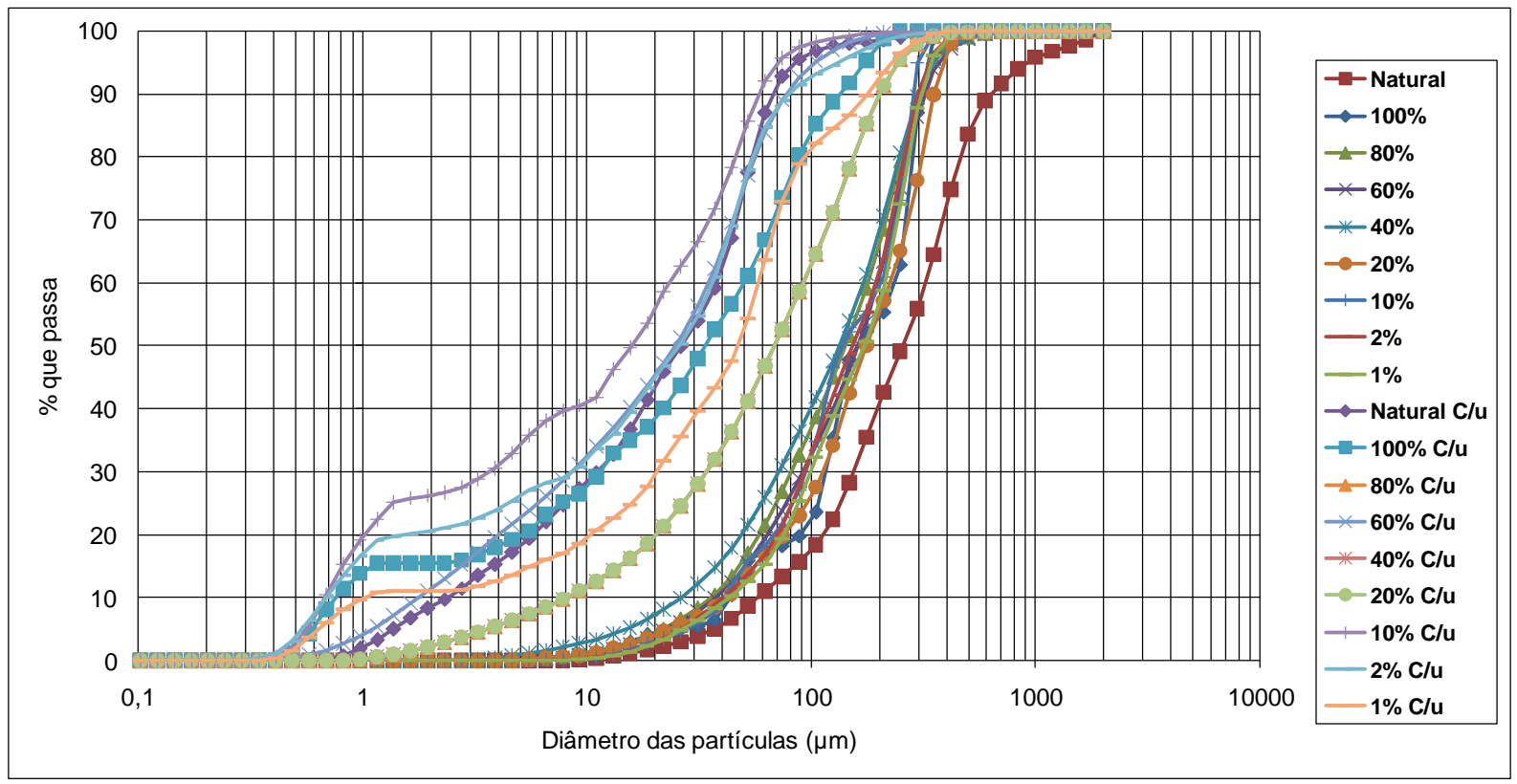

Figura 4.81 - Curva granulométrica solos limite Atterberg sem cal.

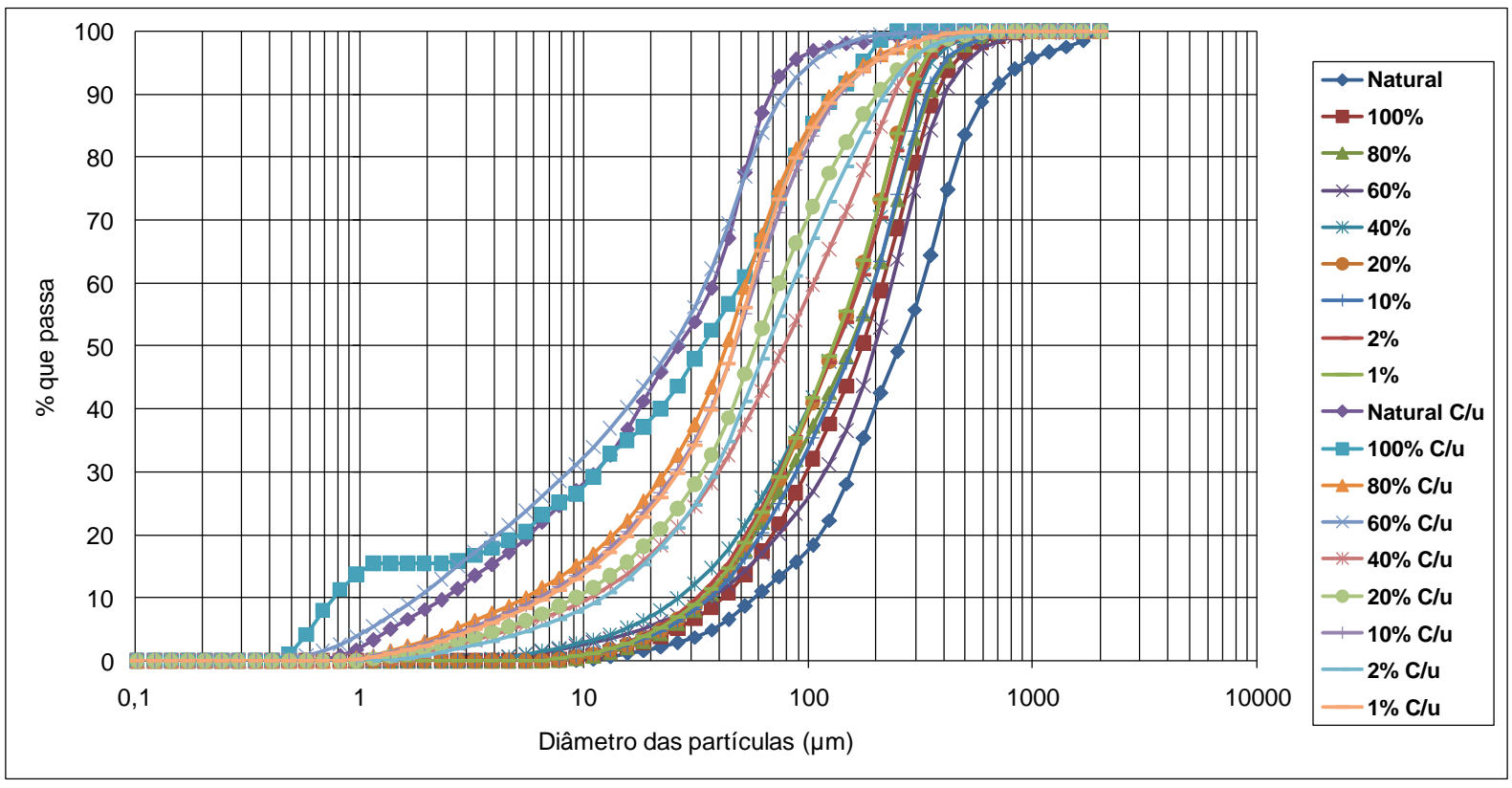

Figura 4.82 - Curva granulométrica limite Atterberg com cal.

A partir da análise das curvas granulométricas contaminante sem cal, pode-se observar uma tendência do extrato de lodo de esgoto funcionar como agente defloculante, aspectos estes observados também por Côrrea (2001), ao analisar o efeito do chorume sob as mudanças 
do comportamento das curvas granulométricas. Já as curvas em que o meio contaminante era o extrato de lodo com cal, observou-se uma pequena tendência do meio floculador, ou seja, o mesmo que de forma pequena funcionou como meio agregador de partículas, confirmando assim o papel desempenhado pela cal como meio floculador. Já as Figuras 4.83 e 4.84 apresentam os dados da distribuição granulométrica onde o próprio contaminante foi utilizado como meio dispersor.

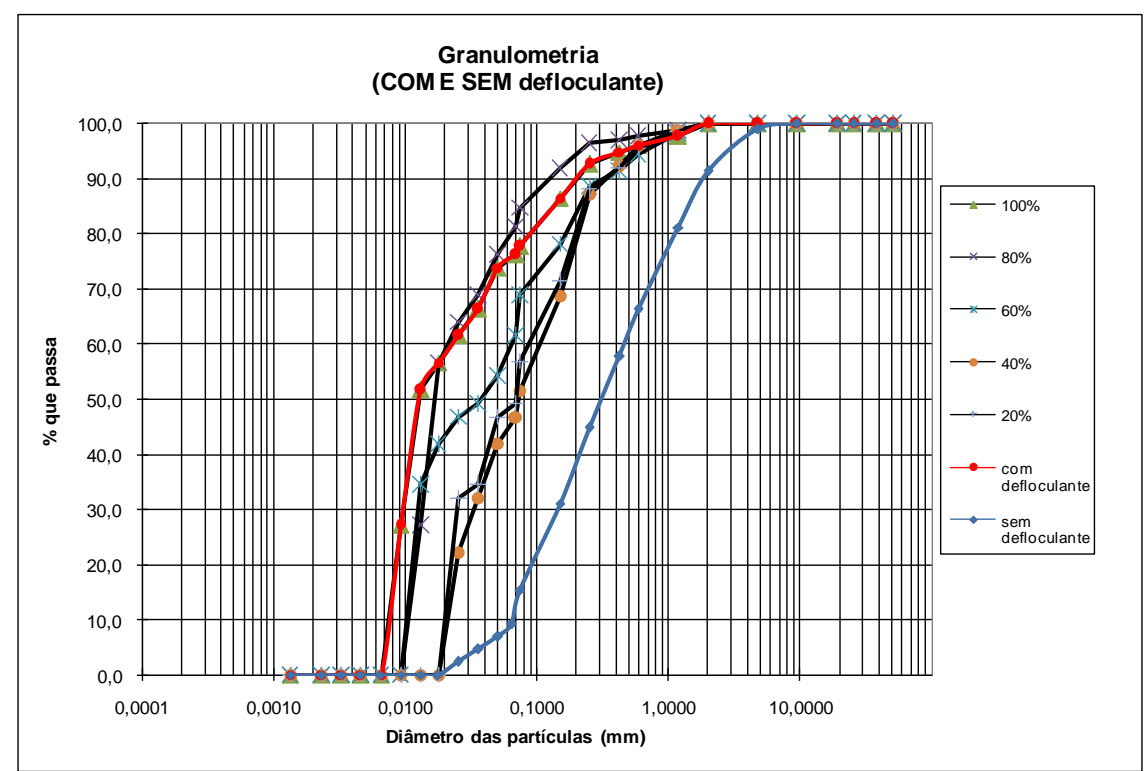

Figura 4.83 - Curva granulométrica com contaminante.

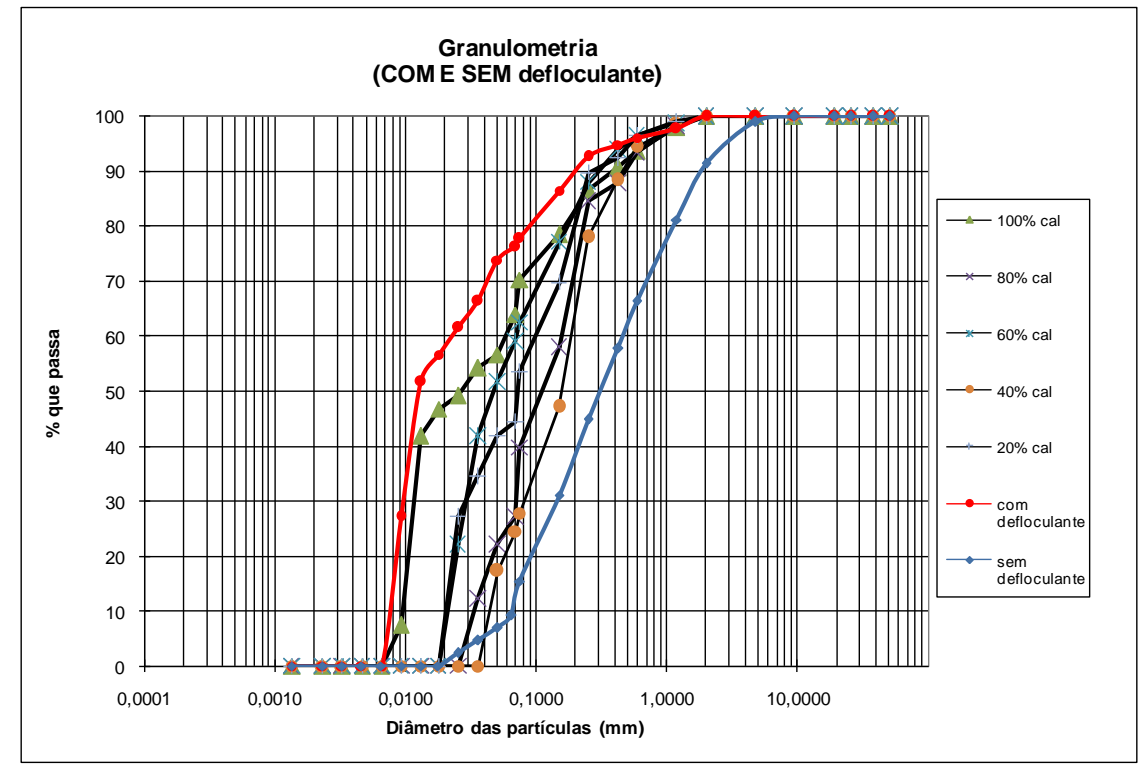

Figura 4.84 - Curva granulométrica com contaminante e cal.

Ao analisar as Figuras 4.83 e 4.84 nota-se nitidamente o efeito do contaminante hora como defloculante, hora como floculante, sendo assim o contaminante de lodo de esgoto 
possui propriedade de modificar as características do solo e agir sobre os finos dispersando o mesmo.

Os ensaios de expansão livre são extremamente simples de execução e oferecem uma ótima resposta à compatibilidade do sistema solo-contaminante. Ensaio descrito por LAMBE et WHITMAN (1969) e proposto por SHACKELFORD (1994) para a verificação da reatividade do solo quando exposto à contaminação, este ensaio consiste em observar o volume ocupado pelo solo após a sedimentação em proveta contendo a solução estudada, neste caso o extrato de lodo, com e sem cal.

A Figura 4.85 pode observar os resultados de compatibilidade solo-contaminante, tanto para água (branco), como para as diferentes concentrações ao qual o solo foi submetido ao contato por 24 horas.

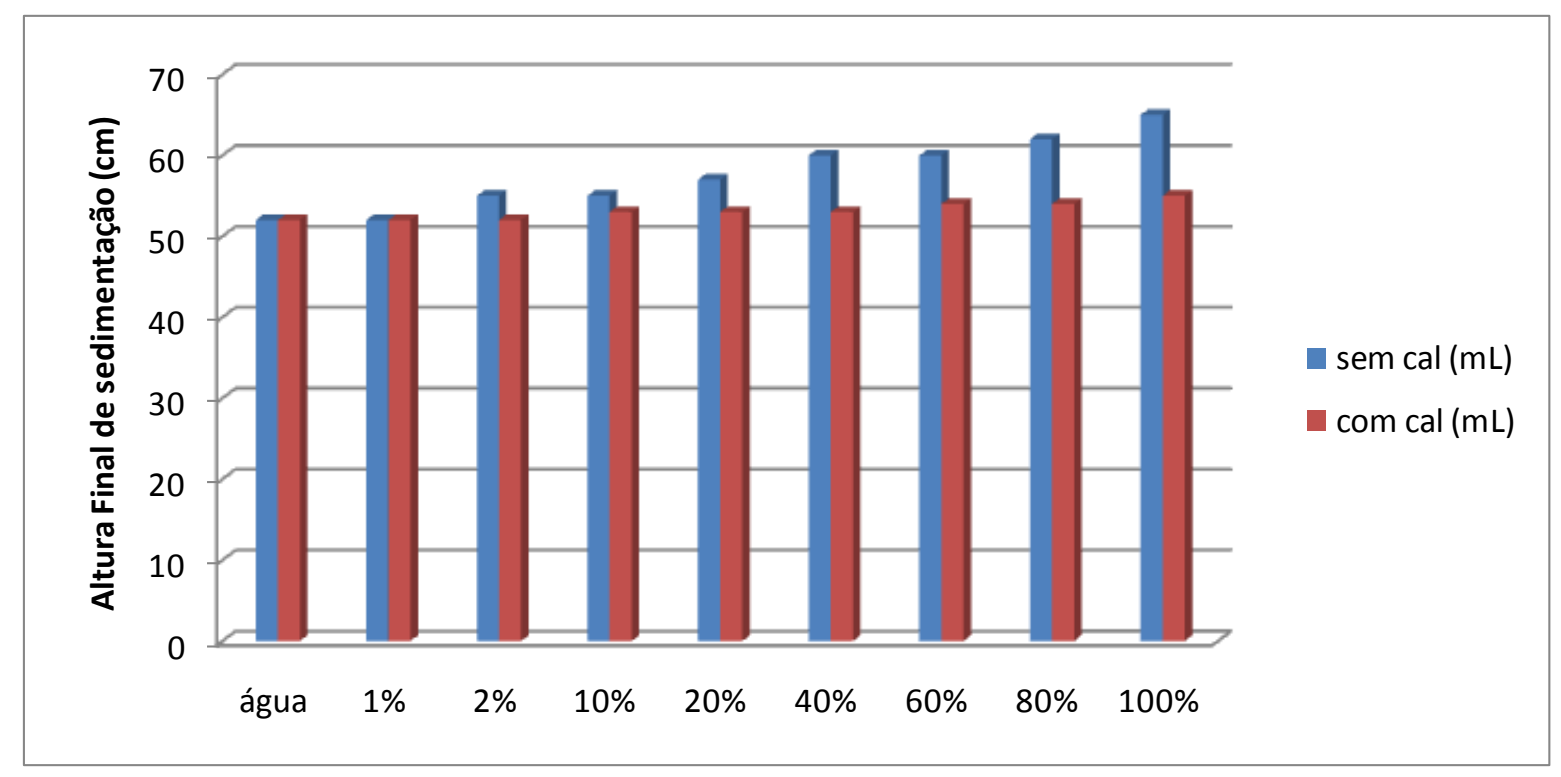

Figura 4.85 - Alturas finais de sedimentação dos solos.

Após 24 horas de contato do solo com o contaminante, pode observar que houve um aumento do volume de solo, para as provetas que continham o solo+contaminante sem cal, confirmando assim os aspectos observados nas curvas granulométricas de agente dispersor. Já as provetas que continham os solo+contaminante com cal, nota-se um menor volume ocupado confirmando assim mesmo que pequeno, a sua capacidade de flocular. 


\subsection{DETERMINAÇÃO DE pH e MASSA ESPECIFICA DOS GRÃOS}

Além dos ensaios de compatibilidade solo contaminante, foi realizada a determinação do potencial hidrogênionico, dos solos após a contaminação, além da massa especifica dos grãos (GS). As Figuras 4.86 e 4.87 apresentam os resultados de pH e a Figura 4.88 os resultados de massa específica dos grãos.

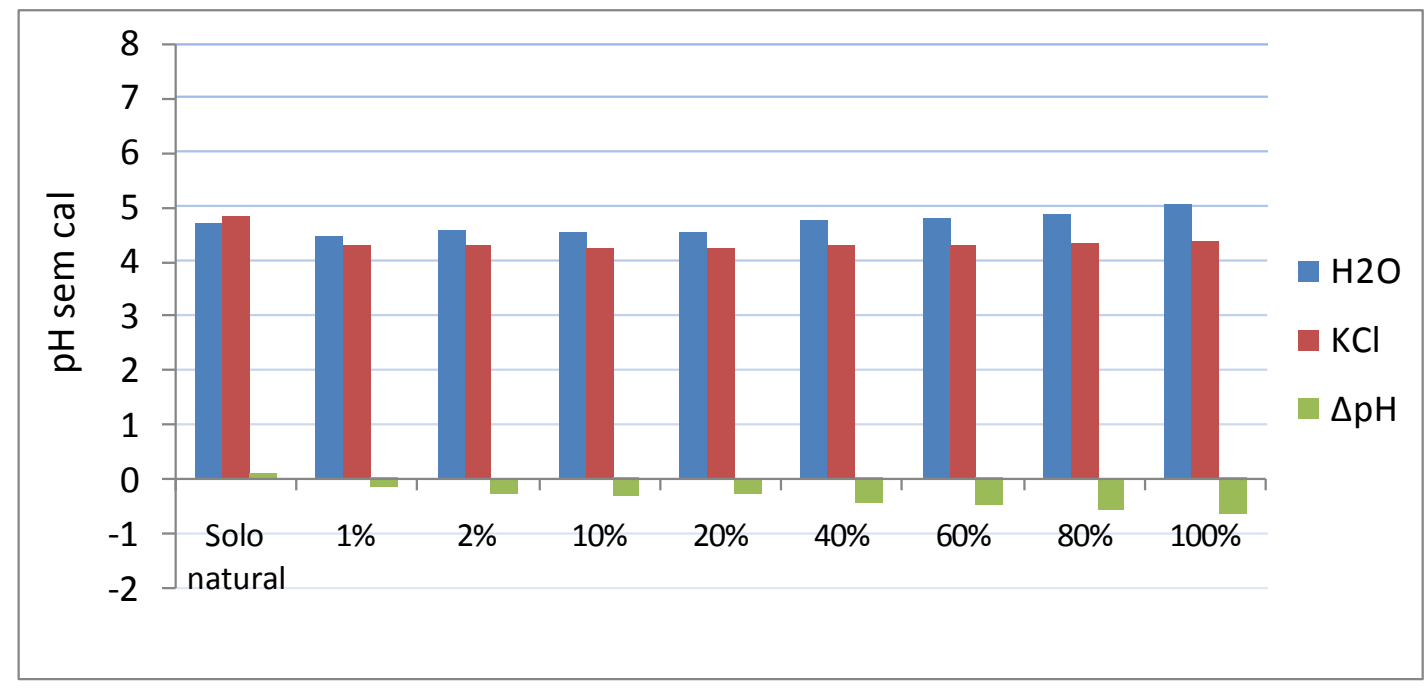

Figura 4.86 - Determinações de pH contaminante sem cal.

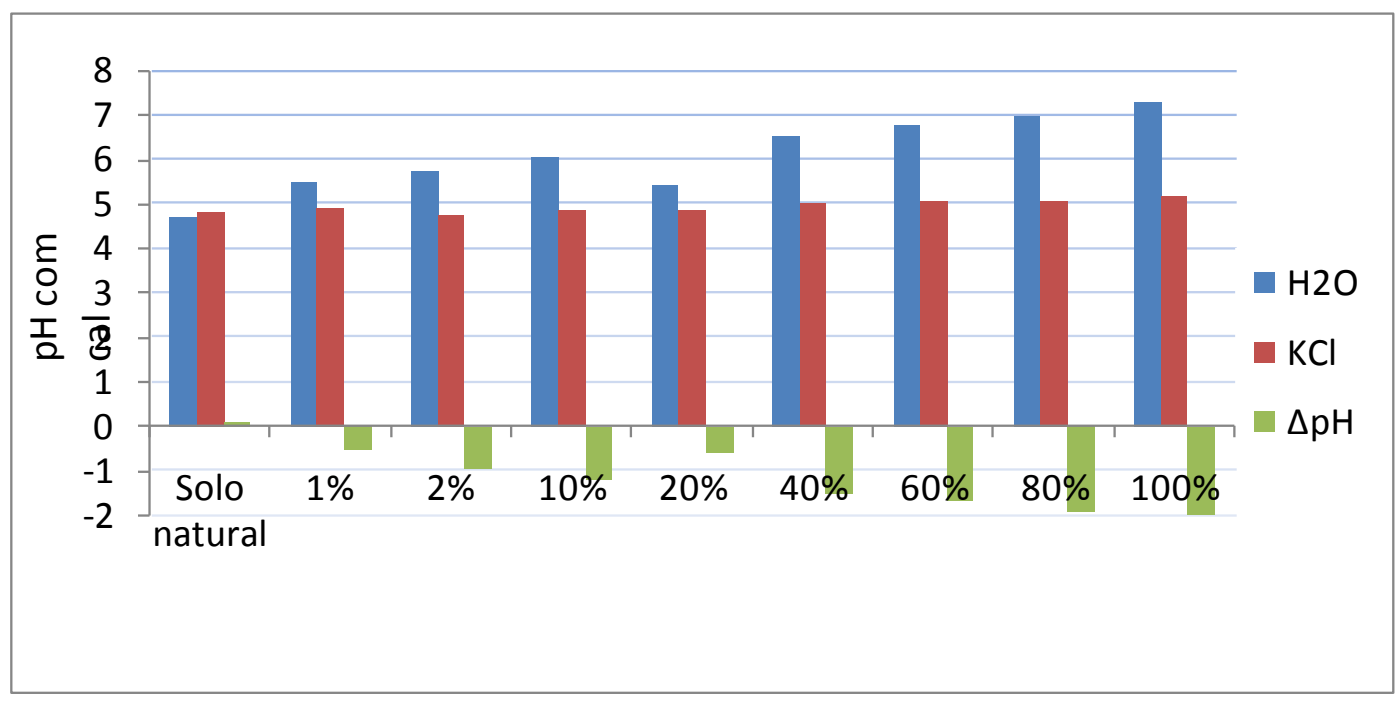

Figura 4.87 - Determinações de pH contaminante com cal. 


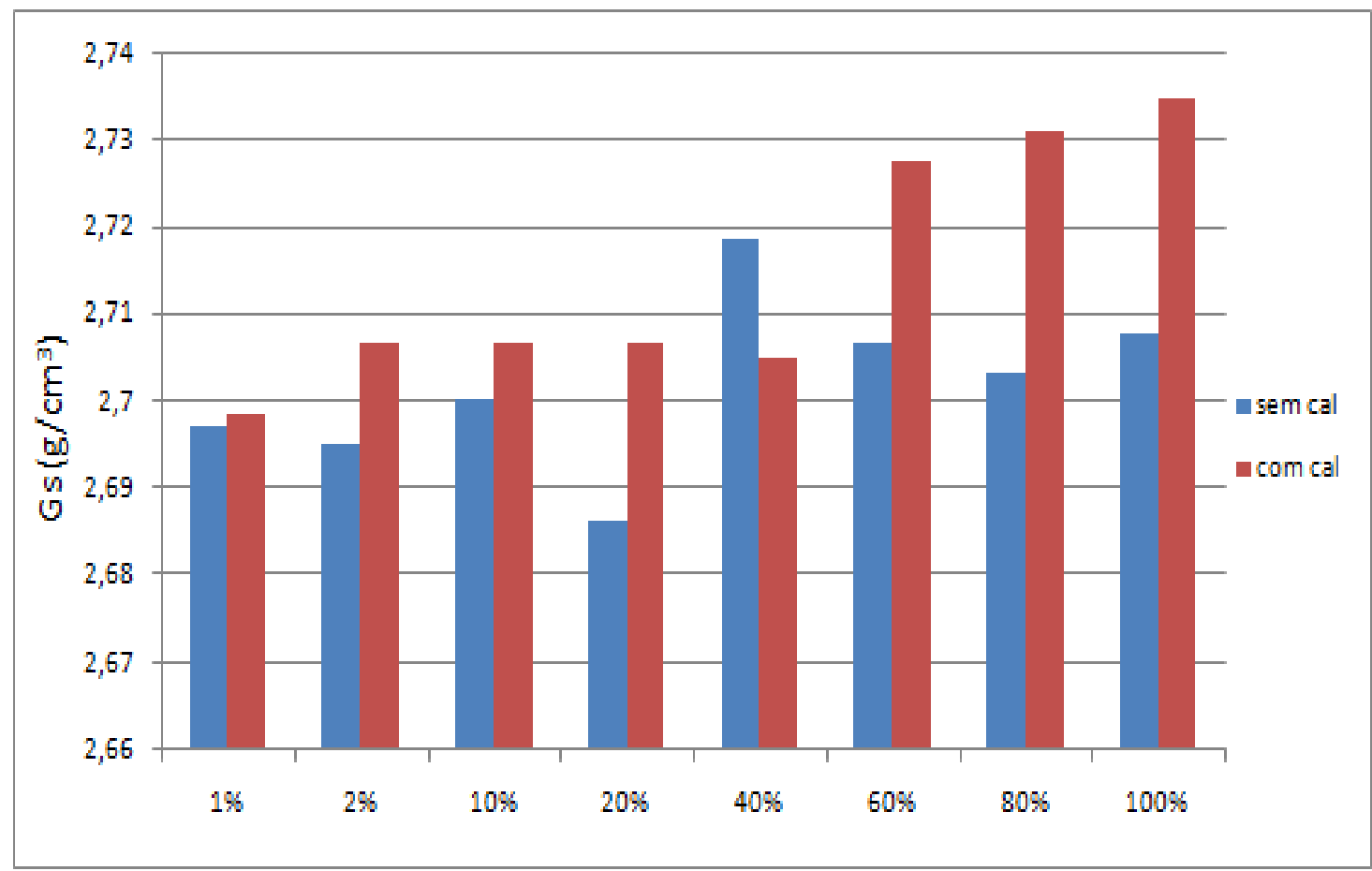

Figura 4.88 - Massa especifica dos grãos após contaminação.

Ao analisar as figuras para os valores de $\mathrm{pH}$ em água, nota-se uma influência direta da concentração ou configuração com e sem cal, verificando-se assim a capacidade de mudança do valor com o contato do solo com o contaminante. Já os valores de massa especifica dos grãos, os mesmo apresentaram um acréscimo quando comparado com o solo no estado natural que é de $2,68 \mathrm{~g} / \mathrm{cm}^{3}$, esses valores se acentuam mais com os solos contaminados com o extrato que possuía cal para estabilização do pH no sistema de tratamento, esse fenômeno de aumento pode estar relacionado a capacidade da cal em aglutinar os grãos e fazer ligações cimentantes.

\subsection{ENSAIO DE ADENSAMENTO}

Foram realizados 23 ensaios de adensamento para obtenção dos dados de índices de vazios versus tensão vertical de consolidação. As Tabelas 4.17 a 4.19 apresentam os dados das condições iniciais e finais, o potencial de deformação de cada corpo de prova ensaiado, além do coeficiente de compressibilidade (cc) e a tensão de pré-adensamento.

Já as Figuras 4.89 a 4.96 apresentam os gráficos que relacionam índices de vazios versus tensão aplicada. Ressalta-se que além das configurações do solo contaminado com o lodo de esgoto, ainda foi realizado o ensaio com o contaminante de água sanitária, e soda cáustica para verificar o potencial de deformação de líquido contaminantes com $\mathrm{pH}$ alcalinos. 
Tabela 4.17 - Potencial de deformação (pd), coeficiente de compressibilidade (cc), tensão de pré- adensamento e índices de vazios iniciais e finais dos corpos de prova.

\begin{tabular}{c|c|c|c|c|c}
\hline Amostra & PD $(\%)$ & cc & tp (kPa) & $\mathbf{e}_{\mathbf{i}}$ & $\mathbf{e}_{\mathbf{f}}$ \\
\hline $\mathrm{H}_{2} \mathrm{O}$ & 9,95 & 0,34 & 200 & 1,23 & 1,01 \\
\hline $100 \%$ & 12,7 & 0,35 & 250 & 1,23 & 0,98 \\
\hline $80 \%$ & 11,51 & 0,16 & 200 & 1,23 & 1,04 \\
\hline $60 \%$ & 8,75 & 0,32 & 170 & 1,36 & 1,10 \\
\hline $40 \%$ & 8,5 & 0,23 & 150 & 1,38 & 1,18 \\
\hline $20 \%$ & 7,91 & 0,42 & 200 & 1,43 & 1,07 \\
\hline $100 \%$ (difusão) & 7,95 & 0,31 & 170 & 1,23 & 1,06 \\
\hline $100 \%$ cal & 6,35 & 0,18 & 200 & 1,23 & 1,09 \\
\hline $60 \%$ cal & 6,45 & 0,14 & 200 & 1,23 & 1,09 \\
\hline $20 \%$ cal & 5,05 & 0,16 & 200 & 1,19 & 1,09 \\
\hline
\end{tabular}

Tabela 4.18 - Potencial de deformação (pd), coeficiente de compressibilidade (cc), tensão de pré- adensamento e índices de vazios iniciais e finais dos corpos de prova, (solo natural, indeformado).

\begin{tabular}{c|c|c|c|c|c}
\hline Amostra & PD $(\%)$ & cc & tp $(\mathbf{k P a})$ & $\mathbf{e}_{\mathbf{i}}$ & $\mathbf{e}_{\mathbf{f}}$ \\
\hline $100 \%$ natural & 38,03 & 1,22 & 33 & 2,37 & 1,19 \\
\hline $80 \%$ natural & 38,53 & 0,80 & 25 & 2,23 & 0,99 \\
\hline $60 \%$ natural & 38,73 & 0,75 & 25 & 2,41 & 1,09 \\
\hline $40 \%$ natural & 38,6 & 0,73 & 25 & 2,23 & 0,99 \\
\hline $20 \%$ natural & 36,13 & 0,69 & 23 & 2,21 & 1,06 \\
\hline $100 \%$ cal & 34,8 & 0,7 & 22 & 2,37 & 1,07 \\
\hline Natural água & 33,38 & 0,87 & 50 & 2,24 & 1,16 \\
\hline
\end{tabular}

Tabela 4.19 - Potencial de deformação (pd), coeficiente de compressibilidade (cc), tensão de pré- adensamento e índices de vazios iniciais e finais dos corpos de prova, ( cinco aplicações e soluções alcalinas).

\begin{tabular}{c|c|c|c|c|c}
\hline Amostra & PD $(\%)$ & $\mathbf{c c}$ & tp $(\mathbf{k P a})$ & $\mathbf{e}_{\mathbf{i}}$ & $\mathbf{e}_{\mathbf{f}}$ \\
\hline $\mathrm{H}_{2} \mathrm{O} 5 \mathrm{x}$ & 6,25 & 0,17 & 75 & 1,15 & 1,02 \\
\hline $100 \% 5 \mathrm{x}$ & 16,61 & 0,35 & 200 & 1,15 & 0,80 \\
\hline $60 \% 5 \mathrm{x}$ & 13,70 & 0,15 & 100 & 1,15 & 1,01 \\
\hline $20 \% 5 \mathrm{x}$ & 10,76 & 0,20 & 100 & 1,15 & 1,03 \\
\hline $100 \%$ cal 5x & 7,0 & 0,10 & 49 & 1,18 & 1,03 \\
\hline $\begin{array}{c}\text { Água } \\
\text { sanitária }\end{array}$ & 12,76 & 0,30 & 170 & 1,26 & 0,98 \\
\hline Soda cáustica & 14,81 & 0,32 & 180 & 1,27 & 1,02 \\
\hline
\end{tabular}




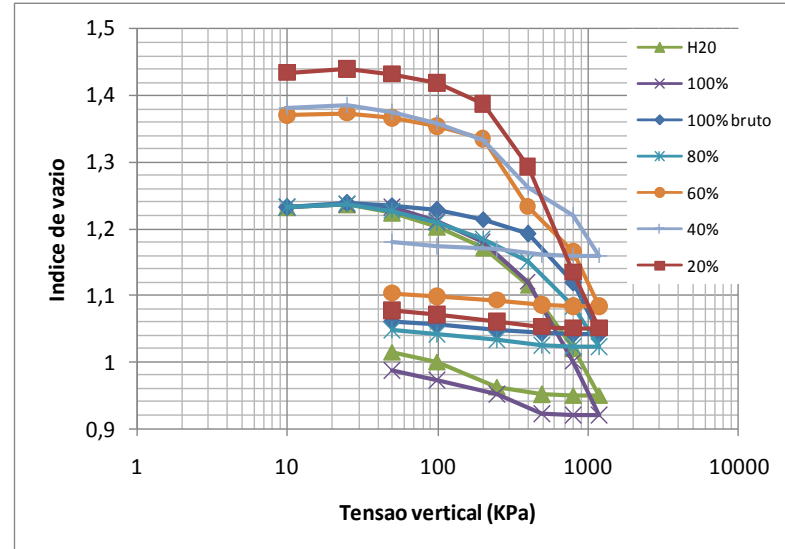

Figura 4.89 - Tensão vertical de consolidação contaminante.

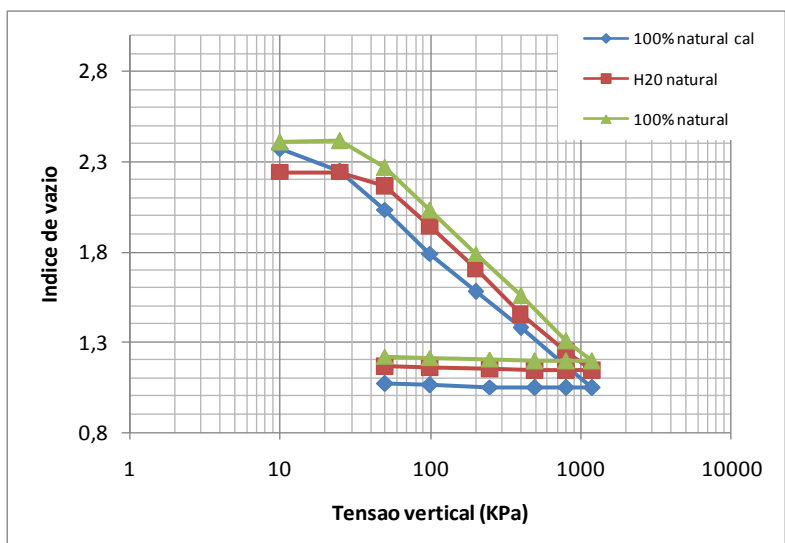

Figura 4.91 - Tensão vertical de consolidação contaminante solo natural.

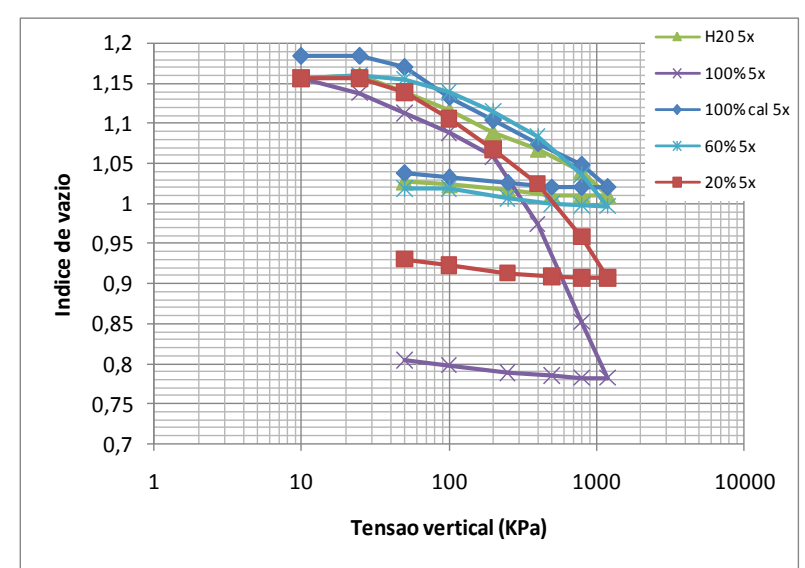

Figura 4.93 - Tensão de consolidação com 5 aplicações de contaminantes com e sem cal.

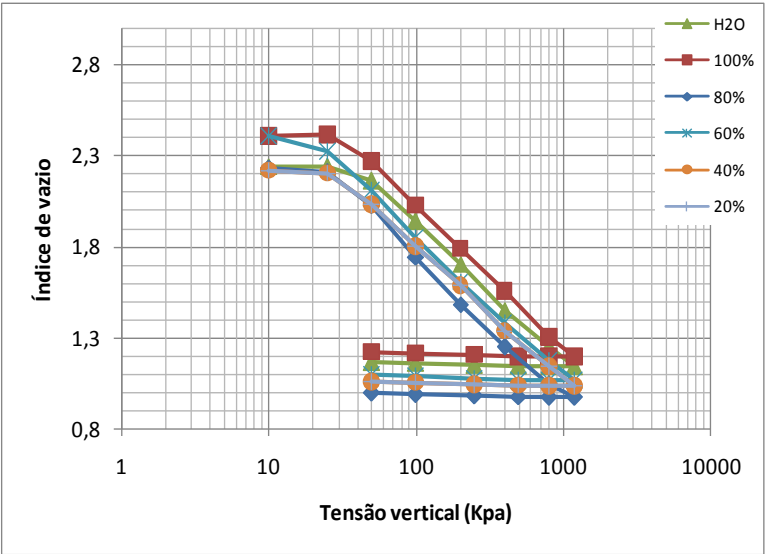

4.90 - Tensão vertical de consolidação solo natural.

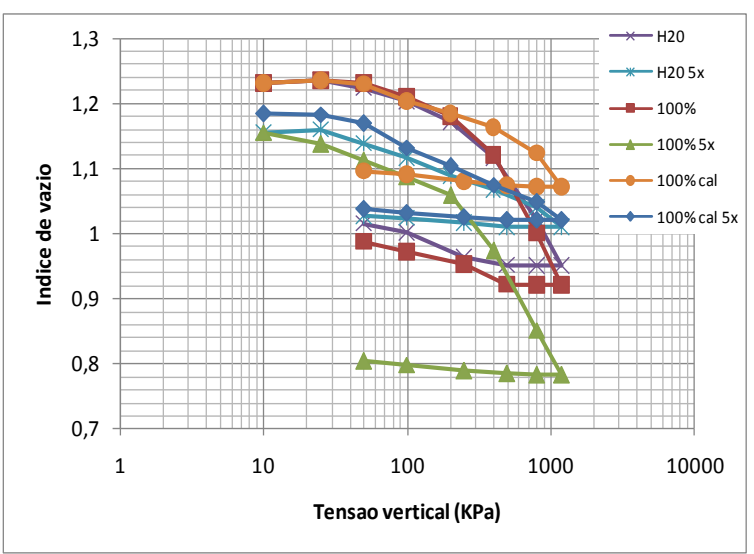

4.92 - Tensão vertical de consolidação com 5x aplicações.

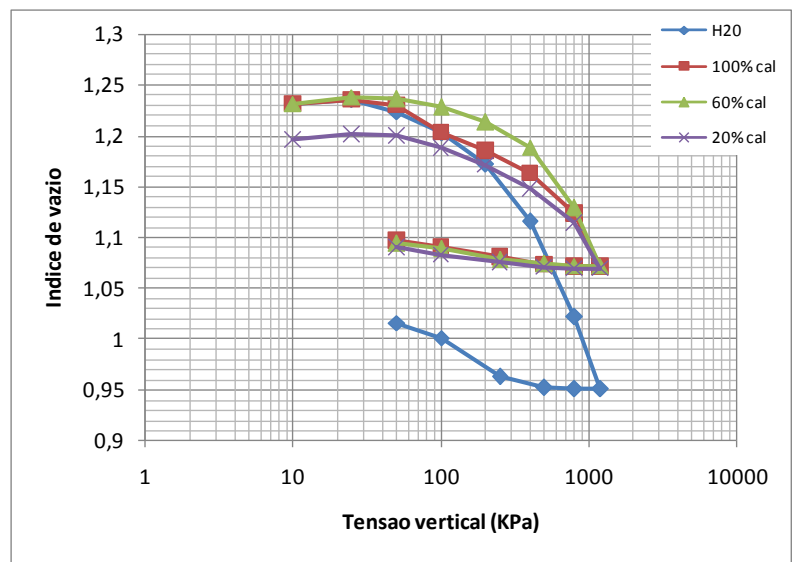

Figura 4.94 - Tensão vertical de consolidação contaminante com cal. 


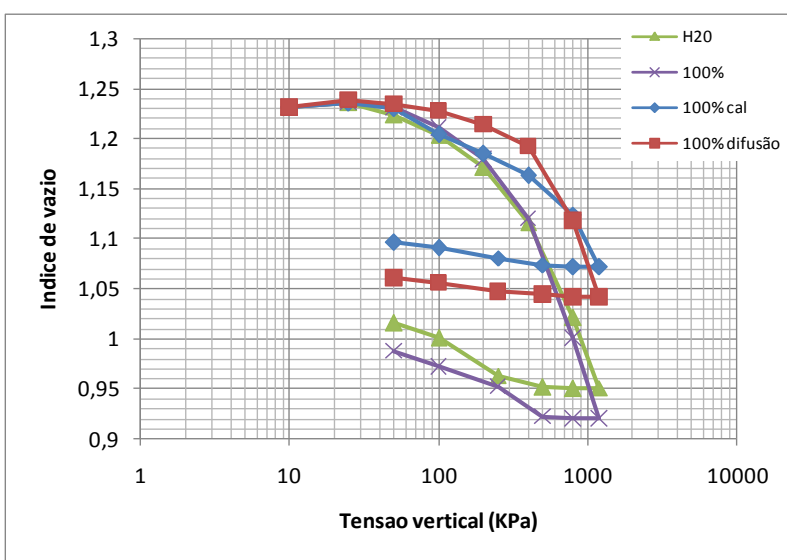

Figura 4.95 - Tensão vertical de consolidação contaminante $100 \%$.

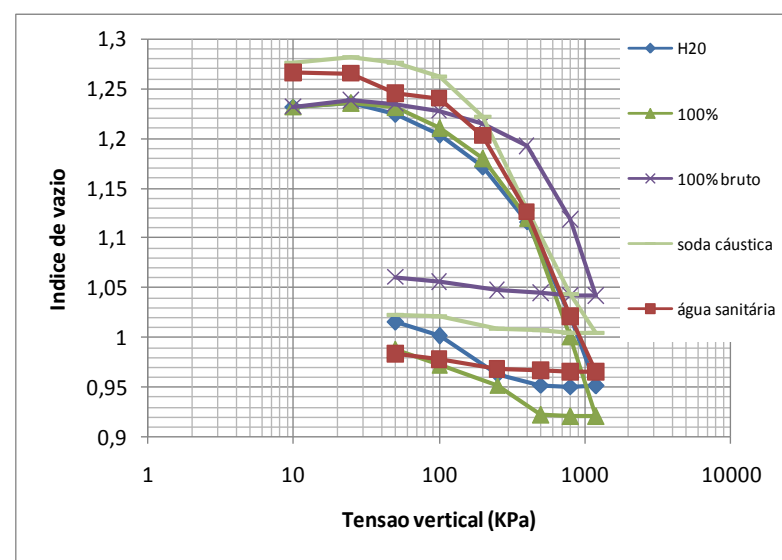

Figura 4.96 - Tensão vertical de consolidação contaminante com cal sem cal e soluções alcalinas.

Os corpos de provas que foram contaminados com o contaminante de lodo de esgoto apresentaram potencial de colapso e deformação especifica superior ao da água destilada. A solução contaminante com concentração igual a 100\%, água sanitária e soda cáustica no ensaio odométrico simples, apresentou potencial de deformação igual 12,70\%; 12,76; 14,81\% respectivamente, sendo que ficou superior ao valor para a água destilada na ordem de $2,75 \%$ ( $100 \%$ contaminante), $2,81 \%$ (água sanitária) e 4,86\% soda cáustica.

Quando o ensaio foi realizado com a amostra do corpo de prova no estado natural, ou seja, moldado no bloco indeformado, sendo somente inundado com o líquido contaminante nota-se um acréscimo de potencial de deformação da ordem de 5,35\% comparando á água destilada.

Já a configuração para simular o processo de sucessivas aplicações do contaminante, tal como ocorre em campo, o potencial de deformação subiu da ordem de 2,75\% com uma aplicação, para 10,36\% para cinco ciclos de aplicações de contaminantes. Os ensaios que foram aplicados contaminantes contendo a cal foram os que obtiveram os menores valores potenciais de deformação, mostrando assim o potencial da cal em aglomerar as partículas de solo aumentando a sua resistência e dificultando o processo de adensamento.

O acréscimo de potencial de deformação para os solos contaminados com o líquido de lodo de esgoto, pode ser atribuído à presença de hidróxido de sódio em sua composição, pois se sabe que o sódio tem efeito desagregador da estrutura do solo. Supõe-se que o mecanismo de colapso (deformação) desse solo, poderia estar relacionado à eliminação de sucção 
matricial e, especialmente, ao enfraquecimento das ligações cimentícias compostas por óxidos de ferro e alumínio.

Considera-se, ainda, que o mecanismo de colapso seja um fenômeno físico-químico, pois o colapso (deformação) mais atuante ocorre quando sobre ação direta de sobrecargas no solo. O líquido de lodo de esgoto pode apresentar aspectos diferenciados com relação à água, uma vez que passou por processos de intensa atividade biológica, mudanças de $\mathrm{pH}$, e ainda por apresentar potencialidade de ataque sobre os compostos cimentantes de ferro e alumínio. Sabe-se, por exemplo que o ácido sulfídrico resultante da digestão da matéria orgânica e que está presente tanto no efluente tratado como no lodo resultante, propicia um meio agressivo aos cimentos de óxidos de ferro. Resultados encontrados por Motta (2006), Rodrigues e Lolo (2006), Rodrigues et al. (2010) e Mota e Ferreira (2011), corroboram com a hipótese de que os constituintes do líquido de inundação influencia diretamente nas ligações cimentícias enfraquecendo o solo e propiciando o acréscimo de potencial de colapso (deformação).

\subsection{ENSAIO DE CISALHAMENTO}

Os ensaios de cisalhamento foram realizados para todas as amostras, natural, e compactadas na umidade ótima, para as tensões normais de $100 \mathrm{kPa}, 200 \mathrm{kPa}$, e $400 \mathrm{kPa}$. As Figuras 4.97 a 4.112 apresentam os deslocamentos horizontais para as diferentes concentrações e configurações. A Tabela 4.18 apresenta os dados de coesão e ângulo de atrito.

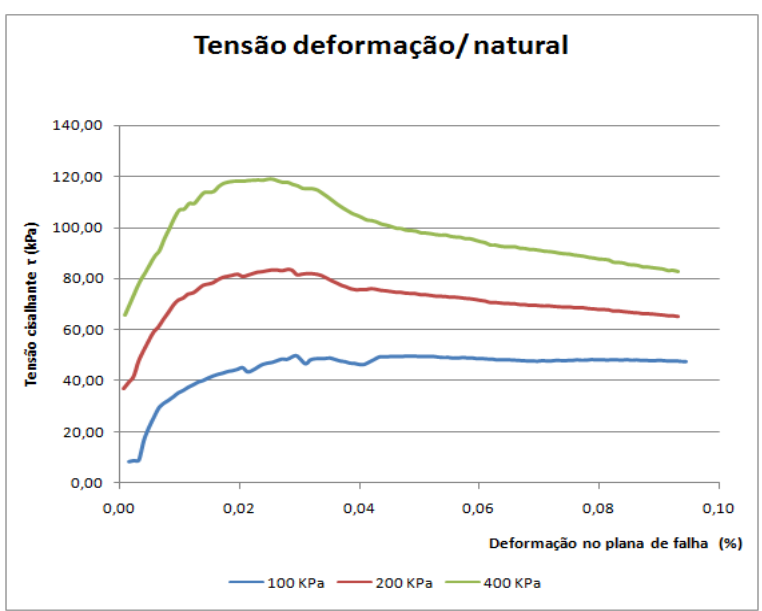

Figura 4.97 - Curva tensão cisalhante $\mathrm{x}$ deslocamento horizontal (solo natural).

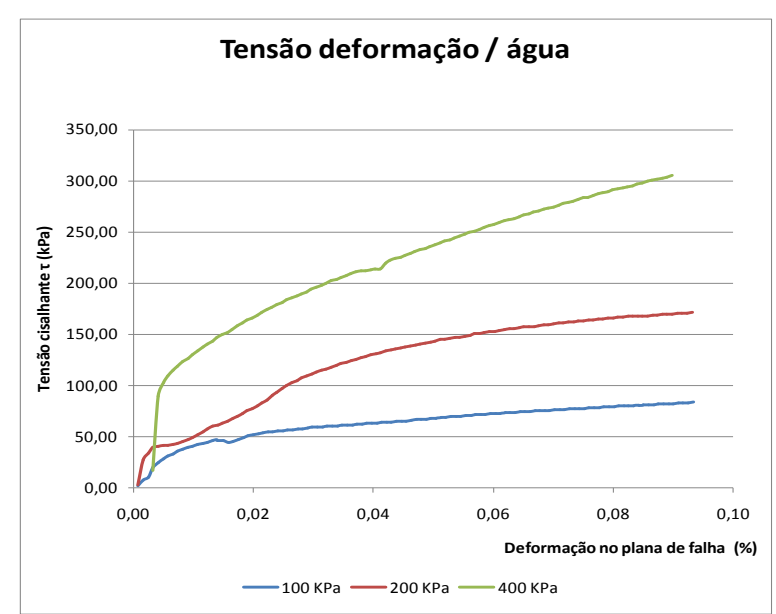

Figura 4.98 - Curva tensão cisalhante $\mathrm{x}$ deslocamento horizontal água (solo compactado). 


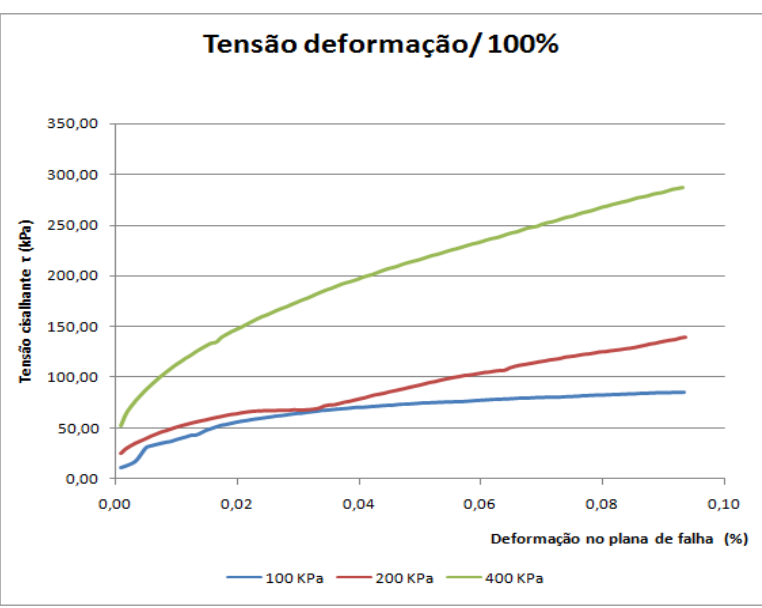

Figura 4.99 - Curva tensão cisalhante $\mathrm{x}$ deslocamento horizontal 100\% (solo compactado).

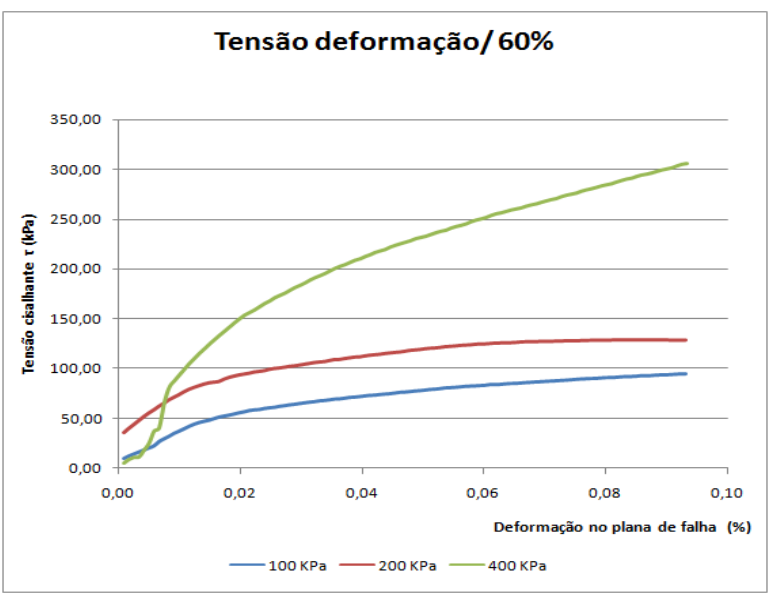

Figura 4.101 - Curva tensão cisalhante $\mathrm{x}$ deslocamento horizontal 60\% (solo compactado).

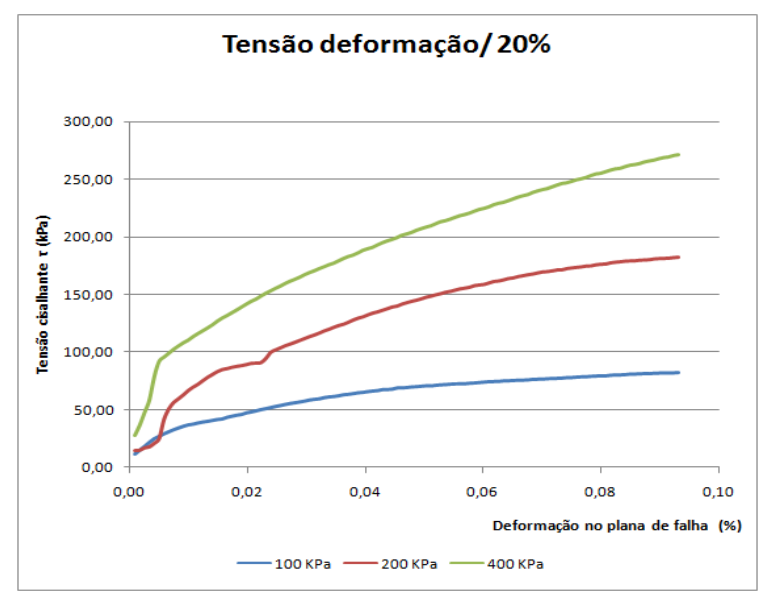

Figura 4.103 - Curva tensão cisalhante $\mathrm{x}$ deslocamento horizontal lateral 20\% (solo compactado).

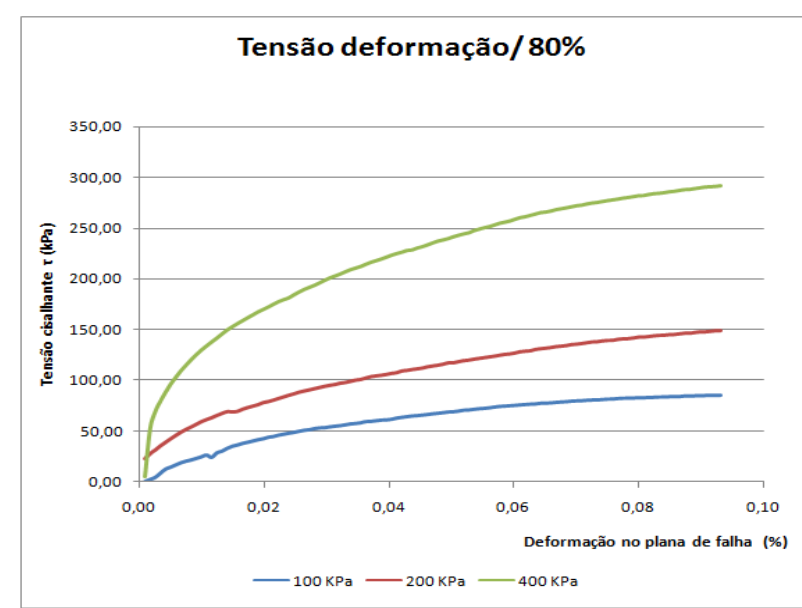

Figura 4.100 - Curva tensão cisalhante x deslocamento horizontal $80 \%$ (solo compactado).

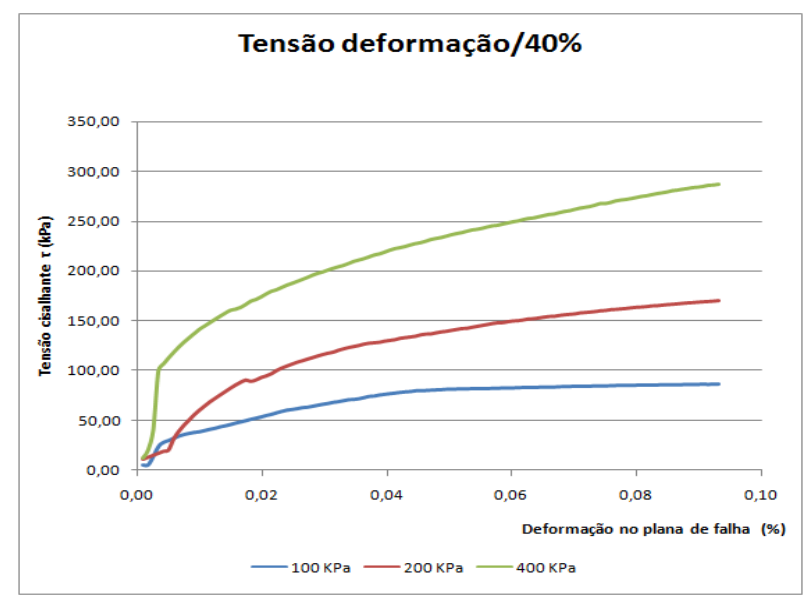

Figura 4.102 - Curva tensão cisalhante $\mathrm{x}$ deslocamento horizontal 40\% (solo compactado).

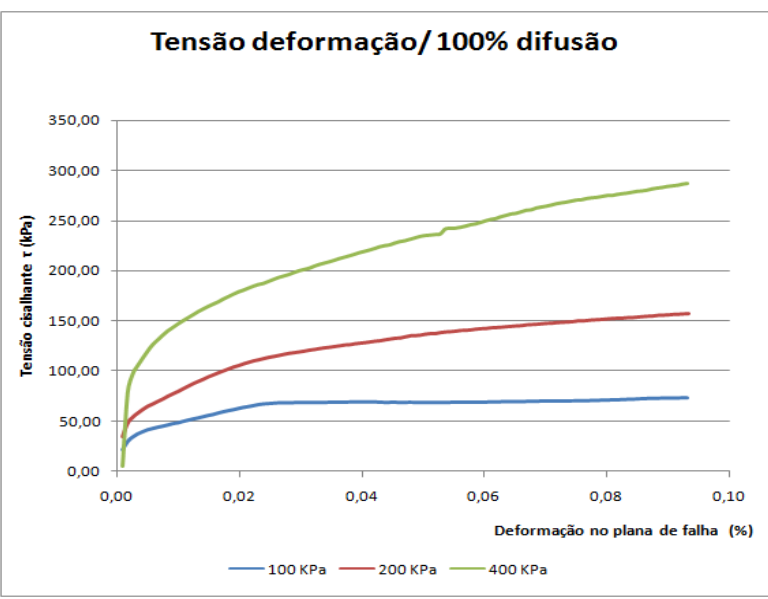

Figura 4.104 - Curva tensão cisalhante $\mathrm{x}$ deslocamento horizontal lateral $100 \%$ difusão (solo compactado). 


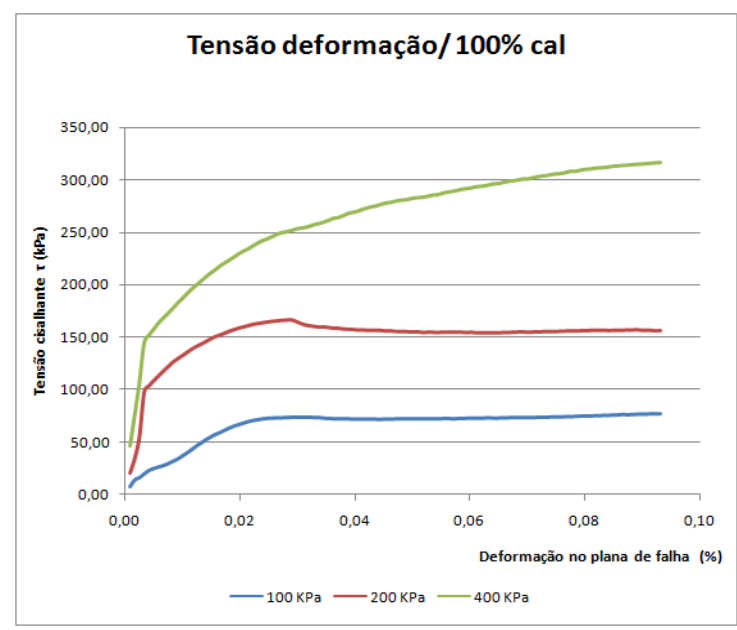

Figura 4.105 - Curva tensão cisalhante $\mathrm{x}$ deslocamento horizontal 100\% cal (solo compactado).

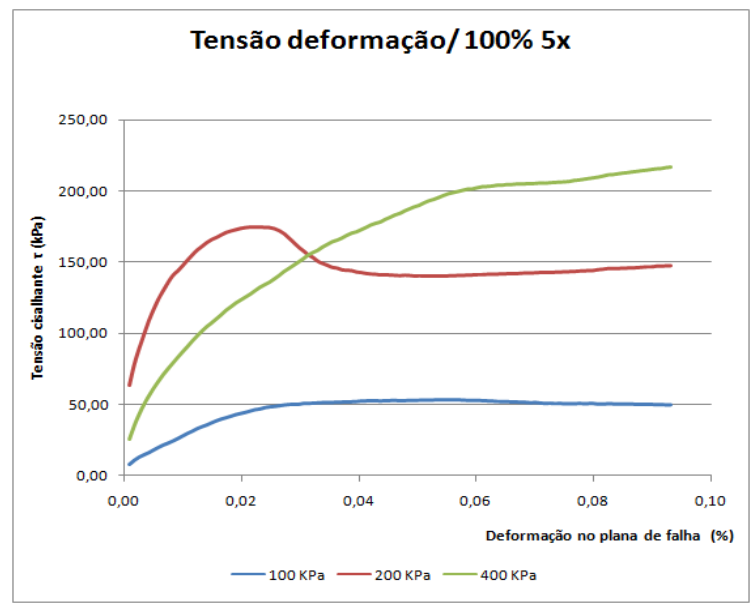

Figura 4.107 - Curva tensão cisalhante $\mathrm{x}$ deslocamento horizontal 100\% 5x (solo compactado).

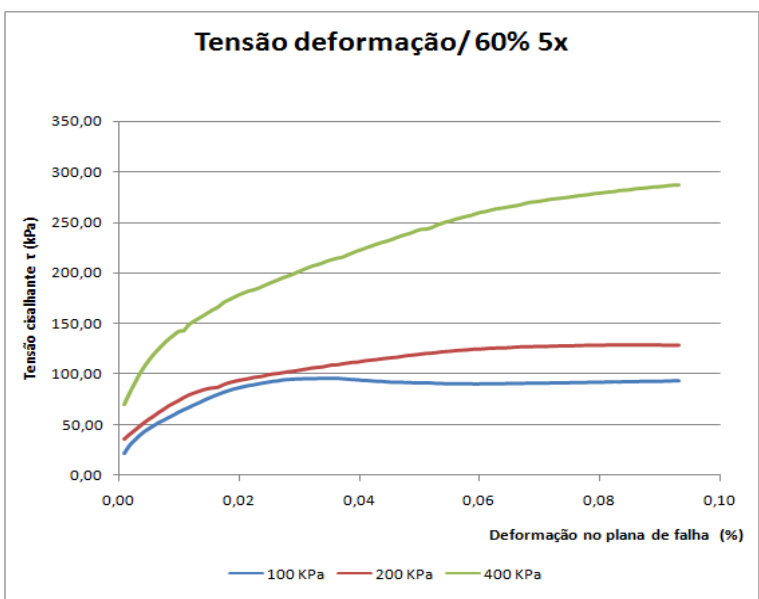

Figura 4.109 - Curva tensão cisalhante $\mathrm{x}$ deslocamento horizontal 60\% 5x (solo compactado).

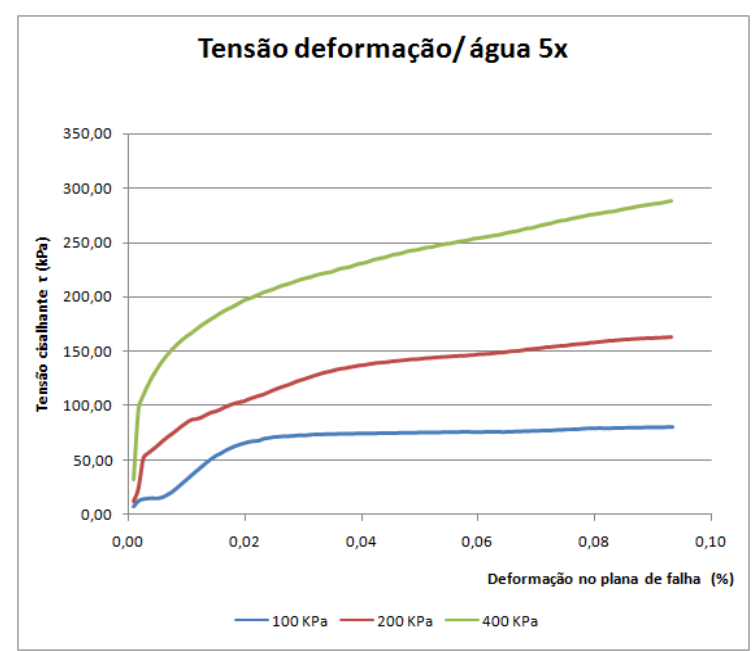

Figura 4.106 - Curva tensão cisalhante x deslocamento horizontal água $5 \mathrm{x}$ (solo compactado).

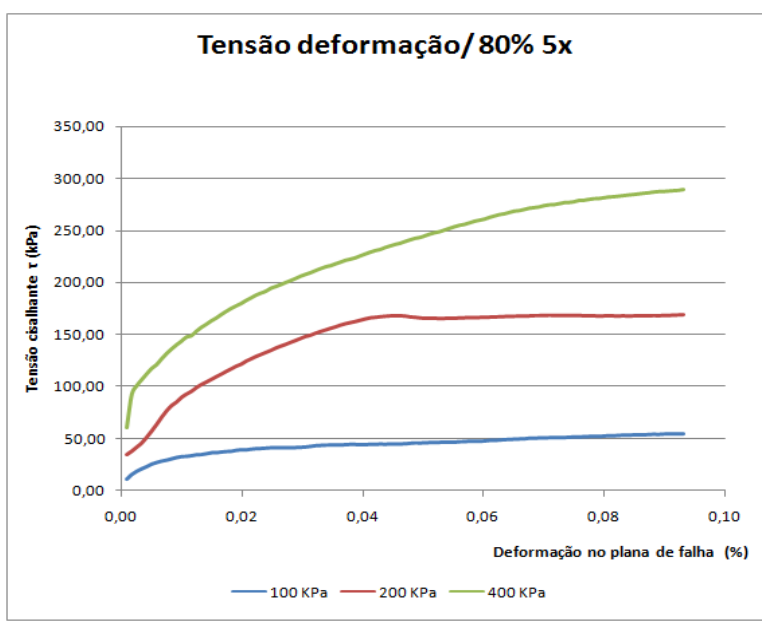

Figura 4.108 - Curva tensão cisalhante $\mathrm{x}$ deslocamento horizontal $80 \%$ 5x (solo compactado).

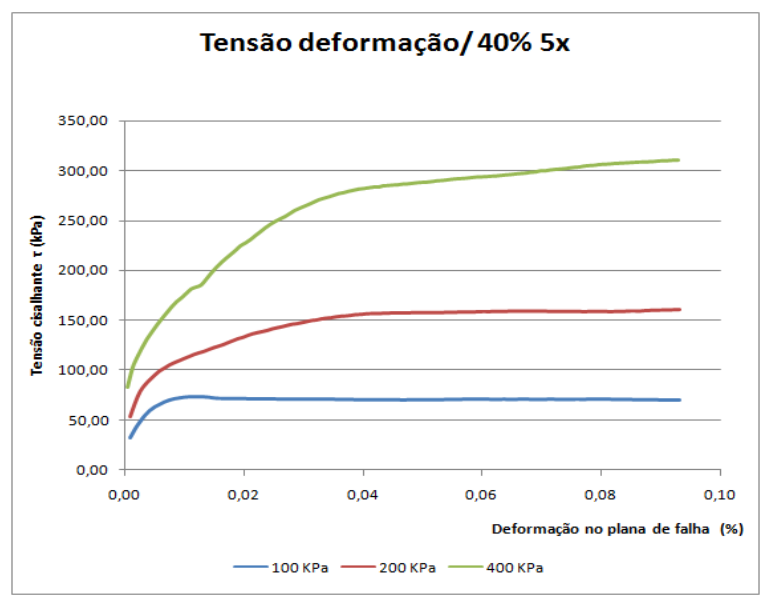

Figura 4.110 Curva tensão cisalhante $\mathrm{x}$ deslocamento horizontal 40\% 5x (solo compactado). 


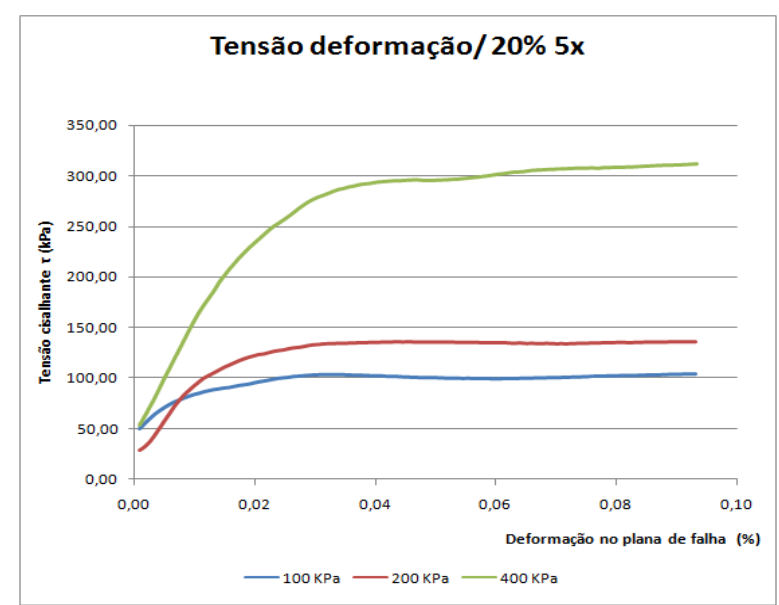

Figura 4.111 - Curva tensão cisalhante $\mathrm{x}$ deslocamento horizontal 20\% 5x (solo compactado).

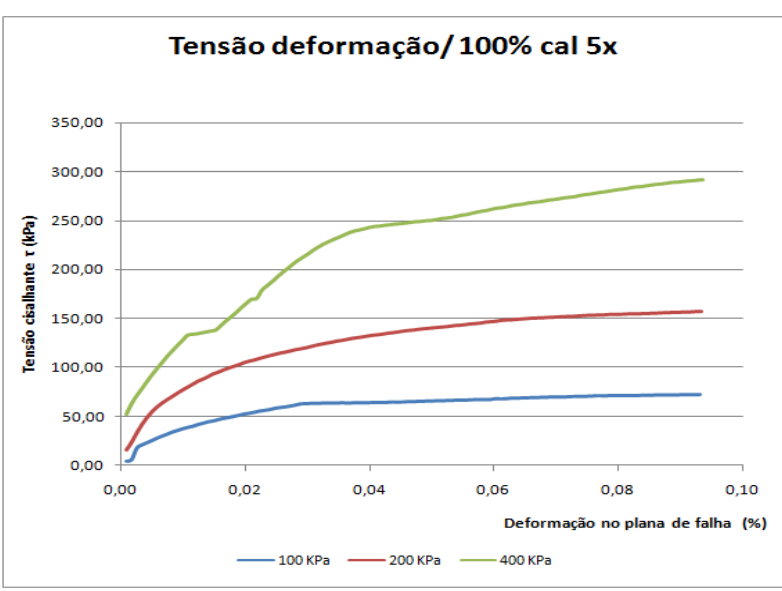

Figura 4.112 - Curva tensão cisalhante $\mathrm{x}$ deslocamento horizontal100\% cal 5x (solo compactado).

Tabela 4.20 - Valores de ângulo de atrito e coesão.

\begin{tabular}{c|c|c}
\hline Amostra & $\varnothing\left(^{\circ}\right)$ & Coesão $(\mathrm{kPa})$ \\
\hline Água & 40 & 12,2 \\
\hline $100 \%$ & 39 & 8,3 \\
\hline $80 \%$ & 38 & 20,6 \\
\hline $60 \%$ & 37 & 11,8 \\
\hline $40 \%$ & 37 & 21,7 \\
\hline $20 \%$ & 35 & 26,8 \\
\hline $100 \%$ cal & 22 & 5,2 \\
\hline $100 \%$ (difusão) & 40 & 7,8 \\
\hline natural & 13 & 31,2 \\
\hline $100 \% 5 \mathrm{x}$ & 28 & 18,5 \\
\hline $80 \% 5 \mathrm{x}$ & 39 & 9,5 \\
\hline $60 \% 5 \mathrm{x}$ & 37 & 8,1 \\
\hline $40 \% 5 \mathrm{x}$ & 40 & 8,7 \\
\hline $20 \% 5 \mathrm{x}$ & 37 & 12,3 \\
\hline $100 \%$ cal 5x & 37 & 4,4 \\
\hline água 5x & 38 & 13,0 \\
\hline
\end{tabular}

A partir do ensaio de cisalhamento se obteve a envoltória para 18 configurações diferentes, onde se objetivava identificar como o contaminante de lodo de esgoto poderia alterar valores de ângulo de atrito e coesão.

De forma geral os valores de ângulo de atrito não obtiveram uma alteração muito alta para primeira configuração, onde o solo foi compactado na umidade ótima com as concentrações e diluições do contaminante. O solo no estado natural obteve valor de coesão dentro do esperado para solos lateríticos. Já a configuração em que houve o ciclo de cinco aplicações do contaminante nota-se uma ligeira queda dos valores tanto de coesão como de 
ângulo de atrito, e isso pode estar associado ao fato desse contaminante possuir em sua composição constituintes que enfraquece as ligações de cimentação entre os grãos. Ressaltase que todos os ensaios de cisalhamento as amostras foram levadas a umidade ótima com as respectivas concentrações de diluições, além disso, os ensaios foram não drenados e o líquido de inundação foi o contaminante na respectiva concentração no qual o solo foi compactado na umidade ótima. Ao analisar o mecanismo de interação solo contaminante, ou solo líquido de inundação observa-se uma relação de ordem físico-química. Ainda pode-se inferir a diferenciação dos resultados com o líquido de lodo de esgoto em relação à água, aos processos de intensa atividade biológica para estabilização da matéria orgânica, mudanças de pH da fase hidrolítica para a fase acetogênica, propiciando ainda a geração de ácidos e acetatos que podem apresentar potencialidade de ataque sobre os compostos cimentantes de ferro e alumínio. Trabalhos como os de Rodrigues e Lolo (2006), Rodrigues et al. (2010) e Mota e Ferreira (2011) tem demonstrado que os ácidos gerados como o acido sulfídrico que é resultante da digestão da matéria orgânica, via digestão anaeróbica, que está presente tanto no esgoto como no lodo, propicia um meio agressivo e que os mesmo podem atacar aos cimentos de óxidos de ferro

\subsection{ENSAIO DE COMPRESSÃO SIMPLES}

Os ensaios de compressão simples foram realizados para as seguintes configurações: água, $100 \%, 60 \%, 20 \%, 100 \%$ cal, $60 \%$ cal e $20 \%$ cal, com tempos de cura de 15, 45 e 75 dias. As Figuras 4.113 a 4.120 apresentam os resultados de compressão simples.

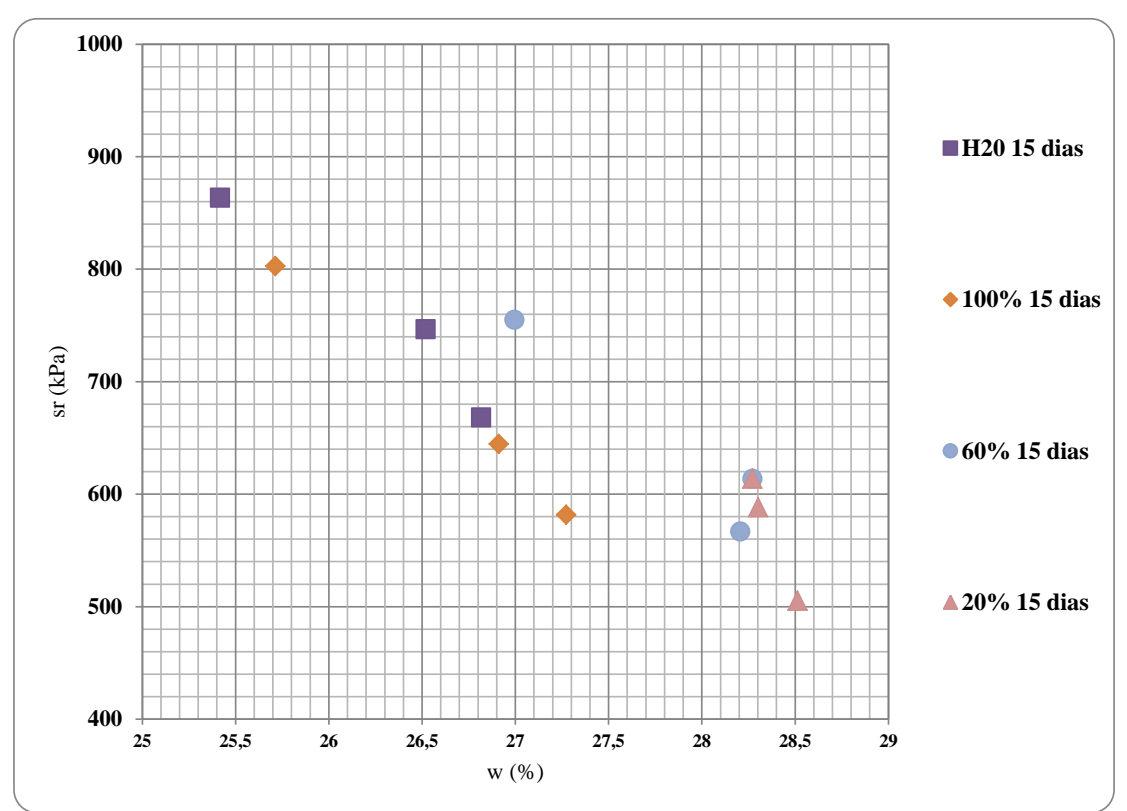

Figura 4.113 - Relação resistência umidade sem cal (15 dias de cura). 


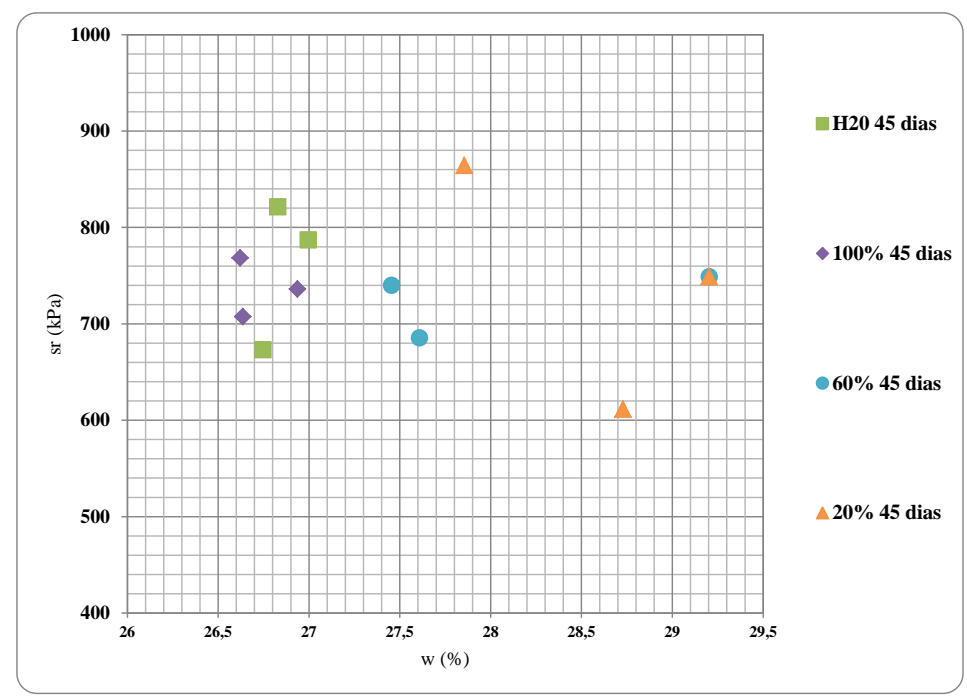

Figura 4.114 - Relação resistência umidade sem cal (45 dias de cura).

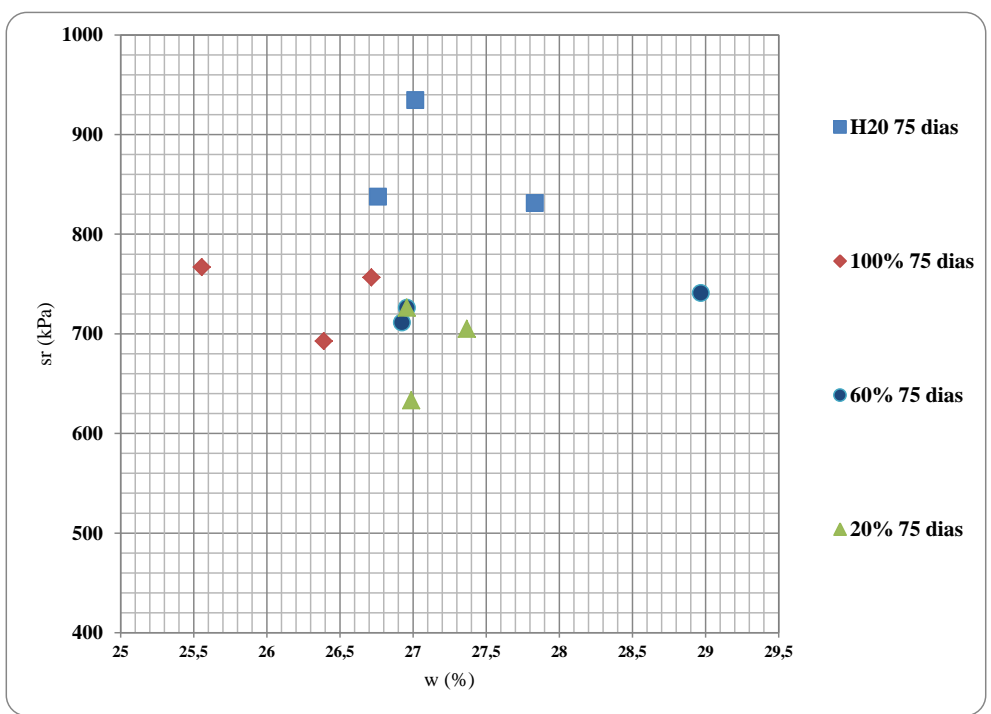

Figura 4.115 - Relação resistência umidade sem cal (75 dias de cura).

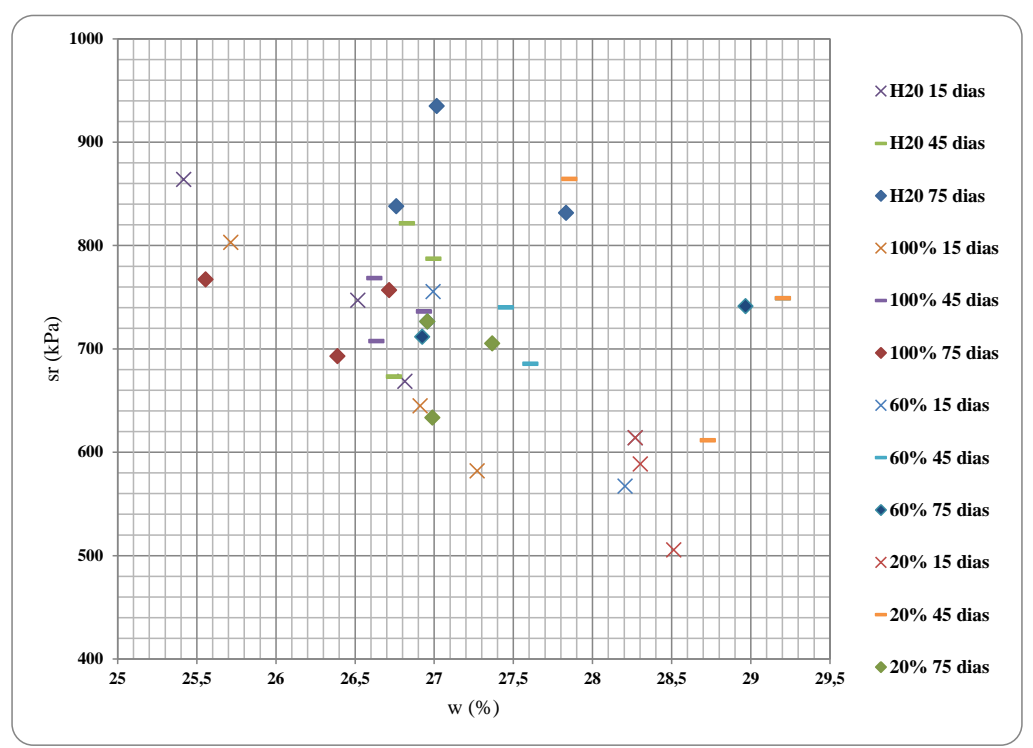

Figura 4.116 - Relação resistência umidade sem cal 


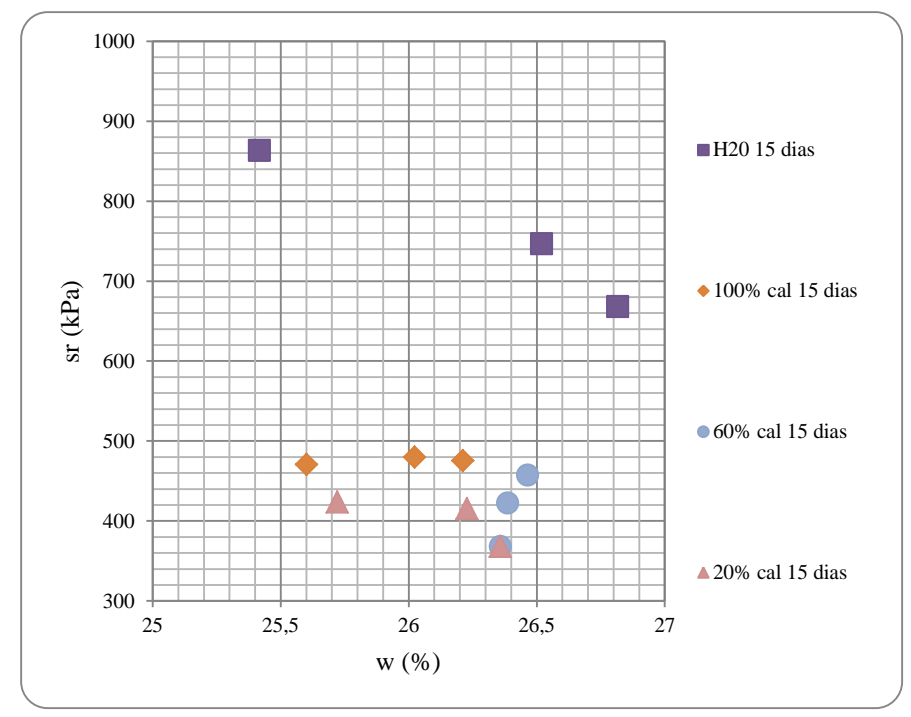

Figura 4.117 - Relação resistência umidade com cal (15 dias de cura).

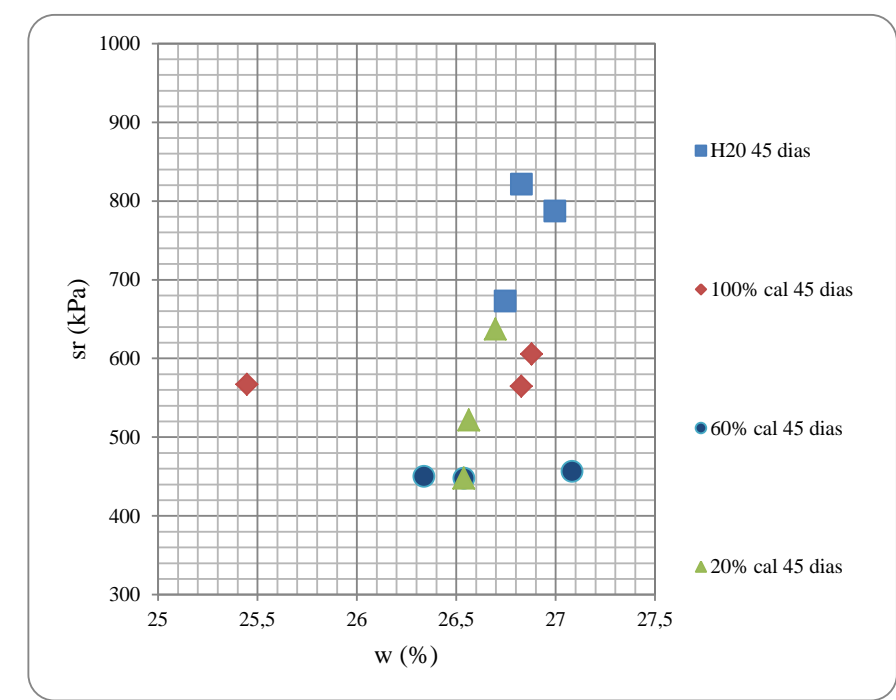

Figura 4.118 - Relação resistência umidade com cal (45 dias de cura).

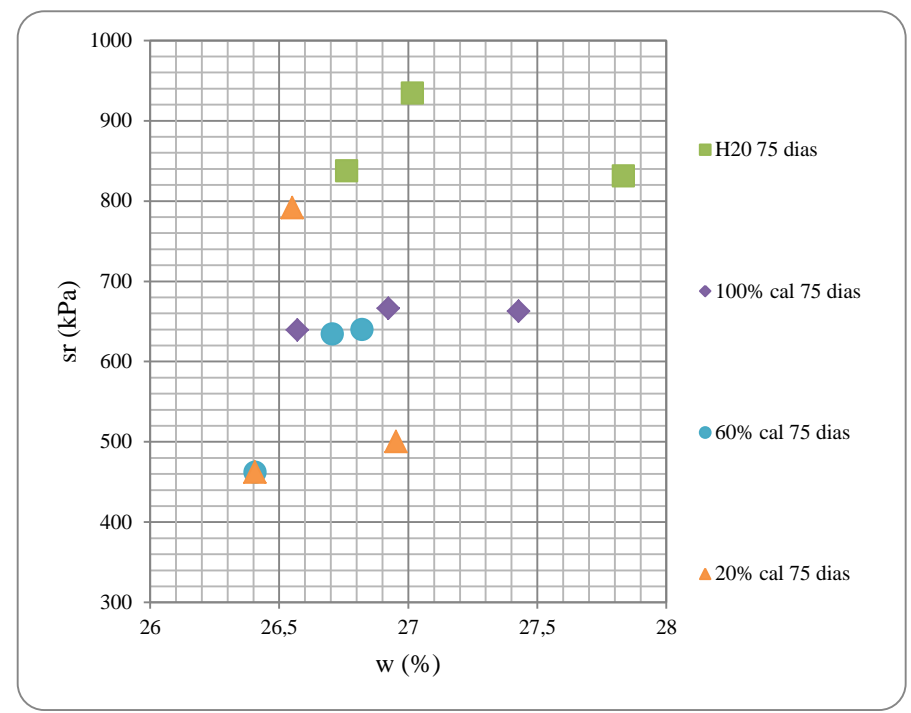

Figura 4.119 - Relação resistência umidade com cal (75 dias de cura). 


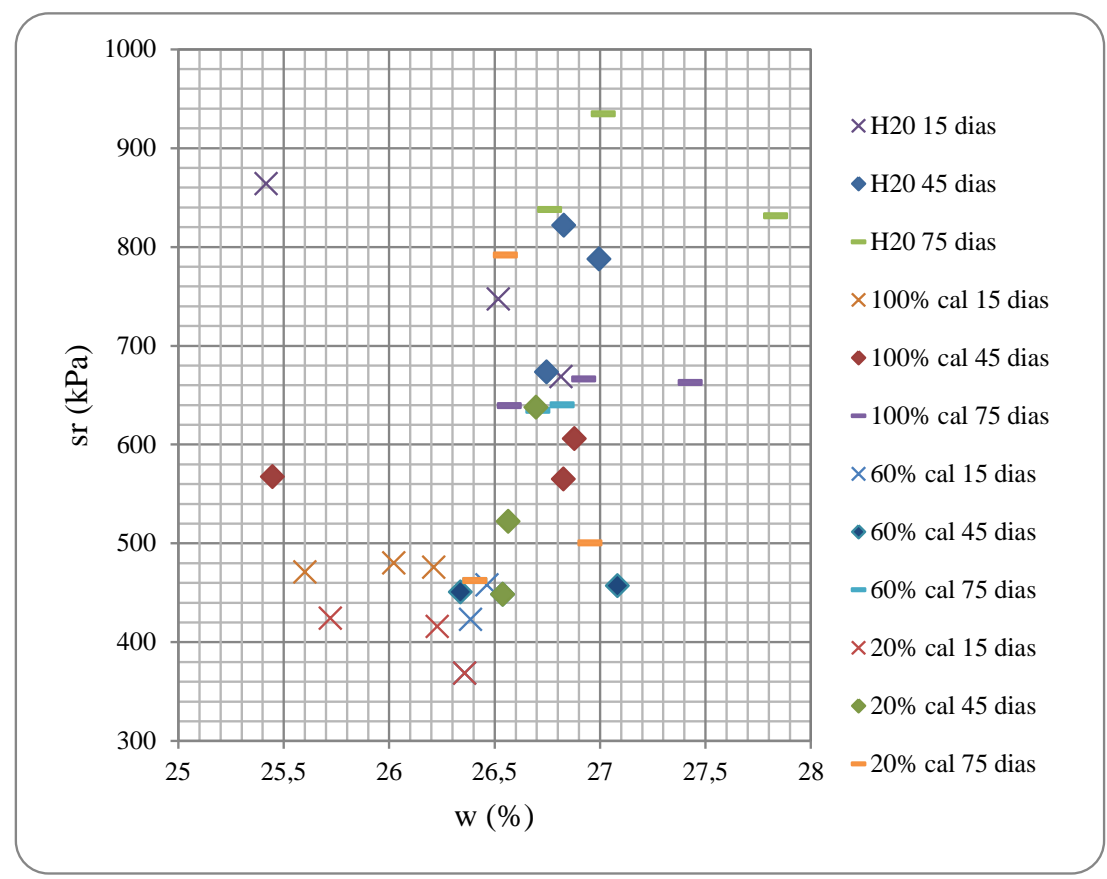

Figura 4.120 - Relação resistência umidade com cal.

Ao analisar as Figuras 4.113 a 4.115 pode-se observar que o valor de resistência está intimamente ligado ao valor da umidade do corpo de prova e a concentração/diluição com contaminante. Para o ensaio com tempo de cura de 15 dias as diluições de $20 \%$ e $60 \%$ foram as que obtiveram os menores valores de resistência, e a concentração de $100 \%$ obteve valores ligeiramente acima. Já para o tempo de cura de 45 dias manteve o nível de resistência alterado tanto pelo valor de umidade do corpo de prova como da concentração do contaminante utilizado. Para o tempo de cura de 75 dias esse fenômeno continua a repetir, sendo a umidade e a concentração o papel que determina a resistência, ficando praticamente no mesmo patamar para todas as concentrações.

Observa-se que os corpos de prova em que foram compactados com água destilada foram os que obtiveram os melhores resultados de resistência para os tempos de cura de 15, 45 e 75 dias. Sendo assim fica evidente que o contaminante de lodo de esgoto possui constituintes que podem modificar a estrutura de arranjo e cimentação dos grãos.

Analisando as Figuras 4.117 a 4.119 em que os corpos de prova foram compactados com o contaminante de lodo de esgoto com adição de cal no sistema de tratamento, observase que os corpos de prova que receberam o contaminante nas diferentes concentrações para 15 dias foram os que obtiveram os menores valores de resistência. Ao verificar os valores de resistência para 45 dias essa tendência manteve-se sendo que a ordem de grandeza de resistência repetiu-se $\mathrm{H}_{2} 0>100 \%>60 \%>20>$, neste caso a cal não funcionou como meio em 
que fornecesse aos solos constituintes para fortalecer as ligações de óxidos de alumínio e ferro.

Com relação aos resultados para 75 dias de cura, os corpos de prova compactados com água destilada, foram os que obtiveram os maiores valores de resistência quando se compara com os corpos de prova de $100 \%, 60 \%, 20 \%$, ressalta-se que mesmo havendo a adição de contaminante que possuía cal, o mesmo não configurou aumento de resistência em função do tempo de cura. Sendo assim, reforça-se que o contaminante de lodo de esgoto apresenta capacidade de enfraquecimento das ligações o que compromete os valores de resistência. 


\section{CONSIDERAÇÕES FINAIS}

Este item apresenta as conclusões obtidas a partir dos resultados dos ensaios laboratoriais e de campo realizados para verificar os aspectos geotécnicos e ambientais da disposição adequada de lodo de esgoto e apresenta sugestões para trabalhos e pesquisas futuras.

\subsection{CONCLUSÕES}

O trabalho de pesquisa realizado no solo da Estação de Tratamento de Esgoto ETE Samambaia/Melchior teve seu enfoque dividido em três partes principais: caracterização do solo, transporte de contaminantes e mudança das propriedades pelos constituintes do líquido contaminante.

A partir dos resultados de caracterização do solo, conclui-se:

- As diferentes sondagens permitiu o conhecimento das classes de solos existentes no local, no que se refere, a umidade natural, umidade de moldagem e umidade seca ao ar, além do limite de liquides;

- O índice de vazios de 0,94 , porosidade de $48 \%$ e permeabilidade no estado natural de $2,2 \times 10^{-5} \mathrm{~m} / \mathrm{s}$ podem configurar ao solo um maior potencial de contaminação;

- O solo trata-se de uma argila siltosa, quando compactado apresenta uma permeabilidade de $4,5 \times 10^{-9} \mathrm{~m} / \mathrm{s}$, o que o confere como bom material para confecção de liner compactado;

- A caracterização química do solo mostrou que o mesmo possui baixa quantidade de elementos o que configura numa baixa capacidade de troca de cátions, o que poderá influenciar diretamente nos mecanismos de sorção.

A partir dos resultados de transporte de contaminantes, conclui-se:

- Os dados de transporte de contaminante para o experimento em que continha o lodo de esgoto no estado in natura apresentou dispersão dos resultados, tanto para a configuração do contaminante ao longo dos 30 dias para a condição do liner não saturado e 18 dias para o liner saturado; 
- A evolução da concentração dos metais no contaminante de lodo de esgoto no reservatório seguiu-se a seguinte ordem: $\mathrm{Zn}>\mathrm{Cu}>\mathrm{Mn}>\mathrm{Ni}$, para a condição em que o liner estava não saturado, esta mesma ordem não foi possível montar para o liner na condição saturada;

- A variação da concentração de metais ao longo do tempo está associada à quantidade de matéria orgânica, e a intensa atividade biológica que se ocorre no lodo de esgoto para a estabilização da parte orgânica carbonácea;

- A CTC do liner na configuração não saturada alterou de $6 \mathrm{mE} / 100 \mathrm{~mL}$ para 125 $\mathrm{mE} / 100 \mathrm{~mL}$ e de $6 \mathrm{mE} / 100 \mathrm{~mL}$ para $390 \mathrm{mE} / 100 \mathrm{~mL}$ na condição saturada, o que pode favorecer a migração de cátions;

- As concentrações dos metais em estudo no solo do liner na condição não saturada e saturada após o ensaio, não apresentou valores que pudessem classificar o mesmo em classes de acordo com a Resolução Conama no 420 de 2009;

- O ensaio de difusão única espécie tanto para o cromo como o níquel apresentou diminuição em função do tempo de ensaio, estabilizando a sorção, no momento em que solo havia saturado a sua capacidade de absorver esses elementos;

- A difusão para o nitrato apresentou pouca dispersão, e a variação no corpo de prova seguiu-se a concentração diminuindo do topo para a base;

- O solo do liner após o ensaio de difusão com o cromo, foi classificado de acordo com a Norma Conama n ${ }^{\circ} 420$ de 2009, em classe 4, ou seja, são solos que apresentam pelo menos uma substância química com os valores acima dos valores de investigação, sejam ele, agrícola, residencial, ou industrial. Já o ensaio de difusão com o níquel o solo foi classificado como classe 3, ou seja seriam os solos que apresentam concentrações de pelo menos uma substância química maior que o valor de prevenção e menor ou igual ao valor de investigação.

- Os modelos de sorção de Freundlich e Langmuir apresentaram melhor ajustes para as condições em que os elementos estavam separados em uma única espécie;

- As curvas características mostraram que o solo ao contaminar apresenta uma diminuição da sua sucção total;

- Os índices de consistência sofreram pequena variação em contato com o contaminante de lodo de esgoto;

- A granulometria do solo é alterada quando o meio dispersante é trocado e utilizado o contaminante de lodo de esgoto nas duas diferentes diluições; 
- $\mathrm{O}$ pH do solo é afetado quando o mesmo entra em contanto com o contaminante, estando ele com ou sem a cal;

A partir dos resultados dos ensaios de resistência, conclui-se:

- O líquido do contaminante utilizado para levar o solo à umidade ótima de compactação, bem como o liquido de inundação na célula de adensamento, aumentou o potencial de colapso do solo nas diferentes diluições estudadas;

- O solo no estado natural moldado a partir de amostra indeformada em que se mudou somente o líquido de inundação apresentou 5,3\% a mais de deformação comparando-se com a água;

- As maiores deformações foram observadas para o solo contaminado com o líquido de lodo de esgoto. Notam-se também deformações expressivas com a soda cáustica e água sanitária;

- As cinco aplicações que foram feitas simulando o que possivelmente ocorreria em campo aumentou em até $10 \%$ o potencial de colapso do solo;

- O fenômeno de colapso está relacionado à interação físico-química e as sobrecargas que solo é solicitado;

- Os valores de ângulo de atrito e coesão para as 18 configurações do ensaio de cisalhamento sofreram alterações, sendo que, a quantidade de aplicações e o líquido contaminante foi o fator preponderante;

- Os menores valores de coesão foram os do solo contaminado e compactado na umidade ótima com o contaminante de lodo de esgoto que continha cal;

- Os menores valores de tensões para o ensaio de compressão simples foi observado para as diluições de $20 \%$ e $60 \%$ com os corpos de prova ensaiados em 15 dias;

- Os corpos de prova que foram compactados na umidade ótima com o contaminante de lodo de esgoto que continha cal, foi o que apresentou os menores valores de resistência para o tempo de cura de 15 dias, sendo observado também uma diminuição da resistência para os tempos de cura de 45 e 75 dias.

- Os corpos de prova que foram compactados com água foram os que obtiveram os melhores valores de resistência para os períodos de cura de 15, 45 e 75 dias;

- O valor de resistência no ensaio de compressão simples está intimamente ligado ao valor da umidade do corpo de prova e a concentração/diluição do contaminante, sendo que o 
contaminante de lodo de esgoto apresenta capacidade de enfraquecimento das ligações o que compromete os valores de resistência.

\subsection{SUGESTÕES A TRABALHOS FUTUROS}

A partir dos resultados obtidos nesta tese, assim como o conhecimento adquirido no desenvolvimento desta pesquisa, são apresentadas algumas sugestões para pesquisas futuras:

- Realizar ensaios de coluna com o contaminante de lodo de esgoto no estado in natura, e com solução sintética monoespécie;

- Realizar ensaios de DBO, DQO, sulfatos, série nitrogenada, série de fósforo, para conhecimento de outros fatores que possa influenciar no ensaio de difusão;

- Realizar ensaios de sorção com outras proporções solo contaminante;

- Realizar ensaios de permeabilidade onde o liquido percolante seja o contaminante de lodo de esgoto e a solução sintética monoéspecie;

- Realizar ensaios microestruturais nos solos do ensaio de adensamento;

- Realizar ensaios químicos para quantificar os efeitos observados no comportamento mecânico.

- Continuar os experimentos de difusão em campo para avaliar por mais tempo o processo de fluxo de contaminantes em escala real. 


\section{REFERÊNCIAS}

ABNT (1984). Grãos de solos que passam na peneira de 4,8mm - Determinação da massa especifica. NBR-6508. ABNT. Rio de Janeiro. RJ. 8p.

ABNT (1984). Solo - Análise Granulométrica. NBR-7181. ABNT. Rio de Janeiro. RJ. 13 p.

ABNT- Associação Brasileira de Normas Técnicas - NBR 7180 (1984) - Solo - Determinação do limite de Plasticidade. 3 p.

ABNT (1984). Determinação do Limite de Liquidez. NBR-6459. ABNT. Rio de Janeiro. RJ. $6 \mathrm{p}$.

ABNT (1986). Determinação do Limite de Plasticidade. NBR-7180. Rio de Janeiro. RJ. 3 p.

ABNT (1986). Amostras de solo - Preparação para ensaios de compactação e ensaios de caracterização (método de ensaio). NBR-6457/1986. Rio de Janeiro. RJ. 8 p.

ABNT- Associação Brasileira de Normas Técnicas - NBR 7182 (1986) - Solos - Ensaio de Compactação. 10 p.

ABNT (1990). Solo - Ensaio de adensamento unidimensional. NBR-3336. Rio de Janeiro, RJ.13p.

ABNT (1996). Solo - Avaliação da dispersividade de solos argilosos pelo método sedimentométrico comparativo - Ensaio de dispersão SCS. NBR-13602. Rio de Janeiro, RJ.5 p.

ABNT (1997). Determinação do coeficiente de permeabilidade de solos argilosos a carga variável. NBR-14545. Rio de Janeiro, RJ. 12 p.

ALLOWAY, B. J. Heavy metals in soils. $2^{\circ}$ edição. London: Blackie Academic, 1995.368p.

AMARAL SOBRINHO, N. M. B.(1998). Mobilidade de metais pesados em solo tratado com resíduo siderúrgico ácido. Revista brasileira de ciência do solo, v 22: 345-353.

ANDREOLI, C. (2006). Usos Alternativos de Lodos de Estações de Tratamento de Água e Estações de Tratamento de Esgoto. Programa de Pesquisa em Saneamento Básico. Curitiba, PR, 398 p. Disponível em:<http://www.finep.gov.br/prosab/produtos.htm>. Acesso em jun de 2014.

ANJOS, A.R.M.; MATTIAZZO, M.E. Extratorespara $\mathrm{Cd}, \mathrm{Cr}, \mathrm{Cu}, \mathrm{Mn}, \mathrm{Ni}, \mathrm{Pb}$ e $\mathrm{Zn}$ em Latossolos tratados com biossólido e cultivados com milho.Scientia Agricola, Piracicaba, v.58, n. 2, p.337-344,2001.

ARAB, P. B (2011). Transporte de $\mathrm{Cu}^{2+}$ em liners compostos de solo argiloso compactado (CCL) e geocompostobentonítico (GCL). Dissertação de Mestrado em Geotecnia, São Carlos, 

jun de 2013.

ARÊAS, V.F. (2006). Estudo Experimental e Analítico do Transporte de Contaminantes em Meios Porosos. Dissertação de Mestrado. Faculdade de Engenharia Civil, Rio de Janeiro, RJ, 119 p.

Disponível em:〈http://wwwp.coc.ufrj.brteses/mestrado/inter/2006/Teses/AREAS_VF_06_t_M_int.pdf >. Acesso em jun de 2013.

ASTM, D3080 (2013). Stand test method for direct shear test osf soil under consolidated drained condition, $9 \mathrm{p}$.

BASSO, J.B. (2003). Transporte e retenção de $\mathrm{K}^{+}, \mathrm{Cu}^{2+}$ e $\mathrm{Cl}^{-}$em uma mistura compactada de solos lateríticos para uso em barreiras selantes: procedimentos de homogeneização da mistura e adaptações em equipamentos de percolação em colunas. Dissertação de Mestrado em Geotecnia, São $\quad$ Carlos, $\quad$ SP, $215 \quad$ p. $\quad$ Disponível em:<http://www.eesc.usp.br/geopos/disserteses/julianabasso.pdf >. Acesso em jan de 2013.

BERTOLO, R. A. (2001). Hidrodinâmica e hidrogeoquímica da zona são saturada do aqüífero adamantina em URÂNIA -SP. Tese de Doutorado em Geociências, Universidade de São Paulo, USP, São Paulo, SP. 231p.

BEZERRA, F. B. et al.(2006). Lodo de Esgoto em Revegetação de Área Degradada. Revista Pesquisa Agropecuária Brasileira, v 41(3): 469-476.

BRASIL, Lei $\mathrm{n}^{\circ}$ 9605, de 12 de fevereiro de 1998. Dispõe sobre as sanções penais e administrativas derivadas de condutas e atividades lesivas ao meio ambiente, e dá outras providências. Diário Oficial da União [da] República Federativa do Brasil, Brasília, DF, 12 de fev. 1998.

BRASIL, Lei $\mathrm{n}^{\circ} 11.445$, de 5 de janeiro de 2005. Estabelece as diretrizes nacionais para o saneamento básico e dá outras providências. Diário Oficial União [da] República Federativa do Brasil, Brasília, DF, 5 de jan. 2007.

BRASIL. Resolução n³57 do CONAMA, de 18 de março de 2005. Dispõe sobre a classificação dos corpos de água ediretrizes ambientais para o seu enquadramento,bem como estabelece as condições e padrões de lançamento de efluentes, e dá outras providências. Diário Oficial União [da] República Federativa do Brasil, Brasília, DF,18 de março. 2005.

BRASIL. Resolução n 375 do CONAMA, de 29 de agosto de 2006. Define critérios e procedimentos, para o uso agrícola de lodos de esgoto gerados em estações de tratamento de esgoto sanitário e seus produtos derivados, e dá outras providências..Diário Oficial União [da] República Federativa do Brasil, Brasília, DF,30 de agosto. 2006.

BRASIL. Resolução n 396 do CONAMA, de 7 de abril de 2008. Dispõe sobre a classificação e diretrizes ambientais para o enquadramento das águas subterrâneas e dá outras providências. Diário Oficial União [da] República Federativa do Brasil, Brasília, DF,7 de abril. 2005. 
BRASIL. Resolução $n^{\circ} 420$ do CONAMA, de 28 de dezembro de 2009. Dispõe sobre critérios e valores orientadores de qualidade do solo quanto à presença de substâncias químicas e estabelece diretrizes para o gerenciamento ambiental de áreas contaminadas por essas substâncias em decorrência de atividades antrópicas. Diário Oficial União [da] República Federativa do Brasil, Brasília, DF, 28 de dez. 2009.

BRASIL. Lei $\mathrm{n}^{\circ}$ 12.305, de 2 de agosto de 2010. Institui a Política Nacional de Resíduos Sólidos . Diário Oficial [da] República Federativa do Brasil, Brasília, DF, 2 de ago. 2010.

BRASIL. Portaria n 2914 de 12 de dezembro de 2011. Dispõe sobre os procedimentos de controle e de vigilância da qualidade da água para consumo humano e seu padrão de potabilidade. Dispõe sobre os procedimentos de controle e de vigilância da qualidade da águapara consumo humano e seu padrão de potabilidade. Diário Oficial [da] República Federativa do Brasil, Brasília, DF, 12 de dez de 2011.

BOFF, F.E. Avaliação do comportamento de uma mistura compactada de solos lateríticos frente a soluções de $\mathrm{Cu}^{2+}, \mathrm{K}^{+}$e $\mathrm{Cl}^{-}$em colunas de percolação. São Carlos, 1999. 180 p. Dissertação (Mestrado) - Escola de Engenharia de São Carlos, Universidade de São Paulo.

BOSCOV, M. E. G. (1997). Contribuição ao Projeto de Sistemas de Contenção de Resíduos Perigosos Utilizando Solos Lateríticos. Tese de Doutorado. EPUSP, São Paulo.

BOSCOV, M. E. G., (2008). Geotecnia Ambiental. Ofinica de textos, São Paulo, SP, 248 p.

CAESB, (2014). Companhia de Saneamento do Distrito Federal. Estações de tratamento de esgoto. Estações de Tratamento de Esgoto: ETE Samambaia e Melchior. Disponível em:< http://www.caesb.df.gov.br/esgoto/conheca-as-unidades.html>. Acesso em setembro de 2014.

CAMARGO, O. A.; AlleONI, L. R. F.; CASAGRANDE, J. C. (2001). Reações dos micronutrientes e elementos tóxicos no solo. 2001. Cap5, p. 89-117.

CAMPOS, F.S \& ALVES M. C.(2008).Uso de Lodo de Esgoto na Reestruturação de Solo Degradado. Revista Brasileira de Ciência do Solo, v 32(1): 1389-1397.

CARDOSO, F. B. F. Propriedade e comportamento mecânico de solos do planalto central brasileiro. (2002). Tese de Doutorado em Geotecnia, Universidade de Brasília, Brasília, DF, 204p.

CARVALHO, A. L. (2005). Efeitos da recirculação do percolado sobre a qualidade do efluente de lixo doméstico de diferentes idades. Tese (Doutorado em Engenharia Agrícola) Universidade Federal de Viçosa, UFV, 2005, 115p.

CASTRO et al. (1997). Manual de Saneamento e proteção ambiental para os municípios. Universidade Federal de Minas Gerais, Belo Horizonte, MG, 1 vol., 221 p.

CETESB. Companhia Ambiental do Estado de São Paulo. Ficha de informações toxicológicas. Substâncias Diversas. 2012. Disponível em:< http://www.cetesb.sp.gov.br/tecnologia-ambiental/laboratorios/109-informacoes-toxicologicas >. Acesso em agosto de 2014. 
CONCIANI, R. (2011). Estudos de barreiras de solo compactado para retenção de contaminantes. Dissertação de Mestrado e Geotecnia, Brasília, DF, 160p.

COSTA, C. N.C.; MEURES, E. J.; BISSANI, C. A.; TEDESCO, M. J. Fracionamento seqüencial de cádmio e chumbo em solos. Revista Ciência do solo. v 35(5): 1323-1328.

CORNU, S. et al.(2001). The environmental impact of heavy metals from sewage sludge in ferrasols (São Paulo, Brasil). The Science of the Total Environment, v 271: 27-48.

CORREA, A. C. S. S. (2001). Avaliação da capacidade de confinamentos dos solos tropicais: uma contribuição à escolhas de novas áreas para disposição de resíduos sólidos urbanos.

Tese de Doutorado em Geotecnia, Brasília, DF, 239p.

CORREAA, A. S.C.; SOUSA, T. C.; SOUZA, N. M.(2004). Características dos solos tropicais aplicadas como barreiras naturais contra a contaminação de aqüíferos. In: XII Congresso Brasileiro de Águas Subterraneas, Anais, 2004.

COSTA, P. O. S. (2002). Avaliação em laboratório do transporte de contaminantes no solo do aterro sanitário de SAUÍPE/BA. Dissertação de Mestrado em Engenharia Civil - Geotecnia, PUC-RIO, Rio de Janeiro, RJ, 188p.

CUI, Y. J.; DELAGE, P.; ALZOBHIBI, P. (2003). Retencion and Transporto f a Hudricarbon in silt.Géotechnique, vol.53, $\mathrm{n}^{\circ} 1$, p. 83-91.

DNER (1994) - Departamento Nacional de Estradas e Rodagem - ME228 - Solos Compactação em equipamento miniatura. $14 \mathrm{p}$.

DNER (1994) - Departamento Nacional de Estradas e Rodagem - ME256 - Solos Compactação em equipamento miniatura - determinação da perda de massa por imersão. 6 p.

DNER (1994) - Departamento Nacional de Estradas e Rodagem - ME258 - Solos Compactação em equipamento miniatura - Mini-MCV.14 p.

DEMUELENAERE, R. G. A. (2004). Caracterização de propriedades de transporte de metais pesados em solos residuais do Rio de Janeiro. Dissertação de Mestrado em Engenharia Civil, PUC-RIO. Rio de Janeiro, RJ, 120p. Disponível em:< http://www.maxwell.vrac.pucrio.br/5462/5462_1.PDF>. Acesso em outubro de 2014.

DEMUELENAERE, R. G. A. (2010). Análise geoquímica do transporte dos principais elementos constituintes do chorume em meios porosos. Tese de Doutorado Geociência Geoquímica, Universidade Federal Fluminense, RJ, 196p. Disponível em:< http://www.bdtd.ndc.uff.br/tde_arquivos/8/TDE-2012-01-04T052928Z-

3154/Publico/Tese\%20Rafael\%20Gerard\%202_protected.pdf >. Acesso em outubro de 2014.

DOELSCH, E., DEROCHE, B., KERCHOVE, V. V. (2006). Impact of sewage sludge spreading on heavy metal speciation in tropical soils (Réunion, Indian Ocean).Chemosphere, v 65: 286-293. 
EMPRESA BRASILEIRA DE PESQUISA AGROPECUÁRIA. EMBRAPA. (1978). Mapa de reconhecimento de solos do Distrito Federal.

FERREIRA, S. B. (2000). Estudo Laboratorial para Avaliação do Potencial de Contaminação de Água e de Solo por Gasolina Oxigenada. Tese de Doutorado em Geotecnia, São Carlos, SP, 257 p. Disponível em: <http://www.eesc.usp.br/geopos/disserteses/brederode.pdf $>$. Acesso em jan de 2013.

FETTER, C. W. (1993). Contaminant Hydrogeology, Macmillan Publishing Company, New York.

FRENDLUND, D. G.; RAHARDJO, H. (1993). Soil mechanics for unsaturated soils, WILLEY, Interscience Publications.

FREEZE, R. A. e Cherry, J. A., (1979). Groundwater. Prentice Hall. New Jersey. 604p.

FONSECA NETO, F. D. (2007). Determinação da difusão efetiva de nitrato e potássio em solo argiloso compactado. Dissertação de Mestrado em Ciência da Tecnologia - Engenharia Civil, Universidade Estadual do Norte Fluminense, Rio de Janeiro, RJ, 113p. Disponível em:< http://uenf.br/Uenf/Downloads/LECIV_1693_1225287911.pdf>. Acesso em julho de 2014.

FONTES, C. M. A. (2003). Potencialidades da cinza de lodo de Estações de Tratamento de Esgoto como material suplementar para a produção de concretos com cimento Portland. 113p. Dissertação (Mestrado em Engenharia Civil) - Universidade Federal do Rio de Janeiro, COPPE.

FORTES, R.M. (1997) Método das Pastilhas para Identificação Expedita do Grupo MCT Miniatura, Compactada, Tropical" $-1^{\text {a }}$ Câmara Permanente de Desenvolvimento Tecnológico, Universidade Mackenzie, São Paulo, Brasil.

GABORIAU, H.; SAADA, A. (2001).Influence of heavy organic pollutants of anthropic origin on PAH retention by kaolinite. Chemosphere, v 44: 1633-1639.

GARCIA, J. R.; SOUZA, A.; RODRIGUES, R. A.; LOLLOM J.A. (2004). Análise do comportamento mecânico de um solo colapsível frente a diferentes fluidos de inundações objetivando-se seu efeito em fundações rasas. V SEFE - Seminário de Engenharia de Fundações Especiais e Geotecnia, São Paulo, PP. 245-256.

GODOY, L. C. (2013). A logística da destinação do lodo de esgoto. Revista Cientifica Online Tecnologia - Gestao - Humanisno. v.2(1):79 - 90.

GOMES, P.C. (1997). Extração fracionada de metais pesados em latossolo vermelho-amarelo. Revista brasileira de ciência do solo, v 21:543-551.

GURJÃO, C.M.C. (2005). Estimativa de Propriedades Geoambientais de Camadas Impermeabilizantes de Solos Tropicais. Tese de Doutorado em Geotecnia, Brasília, DF, 257 p. Disponível em:<http://www.geotecnia.unb.br/index.php?p=posgrad\&pos=teses $>$. Acesso em jan de 2011. 
GUTIERREZ, K. G. (2006). Remoção de metais pesados de percolado submetido à recirculação em células de resíduo sólido urbano. Dissertação (Engenharia Agrícola) Universidade Federal de Viçosa, UFV, 88p.

JESUS, S. C. (2004). Difusão de zinco em camada compactada de solo residual de gnaisse. Dissertação de Mestrado em Engenharia Civil, Universidade de Viçosa, Viçosa, MG, 74p.

JORDÃO, E. P \& PESSOA, C.A. (2009). Tratamento de Esgotos Domésticos. Escola Politécnica UFRJ, Rio de Janeiro, RJ, 5 vol., 941 p.

JORDAO, E.P.; PESSOA, C.A., Tratamento de esgotos domésticos. 6a ed. Rio de Janeiro, Associacao Brasileira de Engenharia Sanitaria e Ambiental (ABES), 2011.

KELM, T. A. (2014). Avaliação do uso de lodo de estação de tratamento de esgoto na estabilização de materiais para pavimentação. Dissertação de Mestrado em Engenharia Civil, COPPE, Rio de Janeiro, RJ, 230p.

KNOP, A. et al. (2008).Compacted artificially cemented soil-acid leachate contaminant interactions: Breakthrough curves and transpor parameters. JournalHazardousMaterials, v 155: 269-276.

KOOKANA, R.R.; NAIDU, R. Effect of solution composition on cadmium transport through variable charge soils. Geoderma, 84, pp.235-248. 1998.

LAMBE, T. W. \& WHITMAN, R. V., (1995). Macânica dos Solos (espanhol). Editora Limusa -

México, $5^{\mathrm{a}}$ - reimpressão, 582p.

LEITE, A.L. (2001). Migração de Íons Inorgânicos em Alguns Solos Tropicais, com Ênfase nos Processos de Sorção e Difusão Molecular. Tese de Doutorado em Geotecnia, São Carlos, SP, 274 p. Disponível em:〈http://www.eesc.usp.br/geopos/disserteses/lagoleite.pdf $>$. Acessoemjan de 2013.

LUDUVICE, M. \& FERNANDES, F. Principais tipos de transformação e descarte do lodo. In: Andreoli, C.V. et al. Lodo de esgotos: Tratamento e disposição final. Belo Horizonte, MG: Departamento de Engenharia Ambiental - UFMG e Companhia do Paraná, 2001.

MARIZ, D. F. (1993). Um estudo físico químico mecânico sobre o colapso de solos residuais sesquioxídicos micro-agregados. Dissertação de Mestrado em Engenharia Civil - COPPE, Universidade Federal do Rio de Janeiro, RJ, 179p.

MEDEIROS, S. A. (2006). Incorporação do lodo de tanque séptico como matéria-prima de uma mistura asfaltica. Dissertação de Mestrado em Engenharia Sanitária. Universidade Federal do Rio Grande do Norte, Natal, RN, 81p.

MELO, W. J et al (2007). Nickel in a tropical soil treated with sewage sludge and cropped wit maize in a long-term fiel study. Soil\&Biochemistry, v 39:1341-1347. 
MONCADA, M. P. H. (2004). Estudo em laboratório de características de colapso de solutos associados a infiltração de licor caústico em um solo laterítico. Dissertação de Mestrado. Departamento de Engenharia Civil, Pontifícia Universidade Católica do Rio de Janeiro, Rio de Janeiro, $219 \mathrm{p}$.

MOTTA, E. Q. (2006). Análise do colapso de um solo compactado devido à inundação e a interação solo-líquido contaminante. Dissertação de Mestrado, Faculdade de Engenharia Civil, Recife, $\quad$ PE, $131 \quad$ p. $\quad$ Disponível em:< http://www.dominiopublico.gov.br/pesquisa/ResultadoPesquisaObraForm.do?first=50\&skip= $31100 \& d s \_t i t u l o=\& c o \_a u t o r=\&$ no_autor $=\&$ co_categoria $=57 \&$ pagina $=623 \&$ select_action $=$ Su bmit\&co_midia $=2 \&$ co_obra $=\&$ co_idioma $=\&$ colunaOrdenar $=$ NO_AUTOR\&ordem $=$ asc $>$.Ace sso em jan de 2014

MOTTA, E. Q.; FERREIRA, S. R.M. Variações da compressibilidade e do potencial de colapso de um solo perante diferentes líquidos de inundação. Revista Estudos Ambientais. V 13(1): $28-41.2011$.

NASCENTES, R., (2006). Estudo da mobilidade de metais pesados em um solo residual compactado. Viçosa, MG, Brazil: Universidade Federal de Viçosa. Tese de doutorado 155p. 2006.

NASCENTES, R.; AZEVEDO, I. C. D.; JESUS, S. C.; FONSECA NETO, F. D.; TIBANA, S.; GUIMARAES, L. M.; PORTELINHA, F. H. . (2009). Coeficiente de difusão de nitrato e potássio em solo fertirrigado com vinhaça. Revista Luso Brasileira de Geotecnia. $n^{\circ} 117$. PP. 43-70.

Disponível

em: $<$ http://www.dec.ufv.br/modules/mastop_publish/files/PublicacoesdoPrograma/IZABEL_Artig o_RevistaGeotecnia_Azevedo.pdf>. Acesso em julho de 2014.

NOGUEIRA, T. A. R et al (2010). Fractination of $\mathrm{Zn}, \mathrm{Cd}$ and $\mathrm{Pb}$ in a Tropical Soil After Nine-Year Sewage Sludge Applications. Pedosphere, v 20(5): 545-556.

NUVOLARI, A. et al. Esgoto sanitário: coleta, transporte, tratamento e reuso agrícola. $2^{\mathrm{a}}$ ed. São Paulo: Blucher, 2011. 565p.

OLIVEIRA, S. (2004). Avaliação da qualidade da água subterrânea a jusante do deposito de resíduos sólidos municipais de Botucatu/SP - Determinação de alguns parâmetros indicadores de poluição por efluente líquido de um aterro sanitário. Tese (Doutorado em Agronomia/Energia na Agricultura) - Faculdade de Ciências Agronomicas, Universidade Estadual Paulista. 92p.

OLIVEIRA, C. et al. (2007). Efeitos da aplicação do lodo de esgoto enriquecido com cádmio e zinco na cultura de arroz. Revista Brasileira de Ciência do Solo, v 29(1): 109-116.

OTALVARO, I. F.; CORDÃO NETO, M. P. Características de La curva de retención de água em um suelo tropical compactado. In: Pan-Am CGS GeotechicalConference, 2011.

PAULA, F. R. A. (2006). Determinação do coeficiente de difusão através de um fluxo unidimensional em um solo não saturado.Dissertação de Mestrado em Engenharia Civil, Universidade Estadual no Norte Fluminense, Rio de Janeiro, RJ, 59p. 
PEDROZA, M. M.; VIEIRA, G. E. G.; SOUZA, J. F.; PICKLER, A. C.; LEAL, E. R. M.; MILHOMEM, C. C. (2010). Produção e tratamento de lodo de esgoto - uma revisão. Revista Liberato, v. 11 (16): 148-157.

PELOZATO, M.; CAMPOS, M. L.; ALMEIDA, J. A.; SILVEIRA, C. B.; MIQUELLUTI, D. J.; SOUZA, M. C. Comparação entre métodos de extração de cádmio, cobre e zinco de solo catarinenses derivados de basalto e granito-migmatito. Revista de Ciências Agroveterinárias. v 10(1): 54-61.

PICARELLI, S. (2003). Avaliação da contaminação de solos por hidrocarbonetos e metais pesados em diques de contenção. Dissertação de Mestrado em Engenharia de Minas, Metalurgia e Minerais, Porto Alegre, Rio Grande do Sul, 95p. Disponível em : <http://www.lume.ufrgs.br/bitstream/handle/10183/3039/000380877.pdf $>$. Acesso em maio de 2013.

RAURET, G. Extraction procedures for thedetermination of heavy metals in contaminated soil and sediment. Talanta, Amsterdam, v. 46, n. 3, p.449-455, 1998.

REICHARDT, K. (1996). Dinâmica da matéria e da energia em ecosistemas. Departamento de Física e Meteorologia - ESALQ-USP. $2^{\circ}$ edição. 513p.

RODRIGUES, R. A.; LOLLO, J. A. Influence of domestic sewage leakage on the collapse of tropical soils. Bull Eng Geol Environ. v 66: p. 215 - 233. 2007.

RODRIGUES, R. A.; MOLINA JÚNIOR, V. E.; LOLLO, J. A. Influência dos constituintes do esgoto no colapso de um solo arenoso.Revista Brasileira de Engenharia Sanitária e Ambiental. v 15(1): 29 - 36. 2010.

ROWE, R. K.; QUIGLEY, R. M.; BOOKER, J. R. (1995). Clayey barrier sustems for waste disposal facilities, E\&FN Spon, London. 390p.

SHACKELFORD, C. D., (1994). Waste-Soil Interactions that Alter Hydraulic Conductivity and

Waste Contaminant Transport in Soil.ASTM STP 1142, David E. Daniel and Stephen J. Trautwein, Eds., American Society for Testing and Materials, Philadelphia, p. 111-169.

SALDANHA, M. F. C.; PÉREZ, D. V.; MENEGUILli, N. A.; MOREIRA, J. COSTA.; VAITSMAN, D. S. Avaliação de cinco tipos de abertura para determinação dos teores de ferro, manganês e zinco em alguns solos brasileiros. Pesquisa Agropecuária Brasileira. n(1): $1-10$.

SANEPAR (1999). Uso e manejo do lodo na agricultura . Programa de Pesquisa em Saneamento Básico, Curitiba, PR, 98 p. Disponível em:<http://www.finep.gov.br/prosab/produtos.htm>. Acesso em julho de 2014.

SILVA, C.M. (2005). Dinâmica de metais potencialmente tóxicos no solo após aplicação de lodo de esgoto. Dissertação de Mestrado, Faculdade de Engenharia Civil Arquitetura e Urbanismo, Unicamp, Campinas, SP, 157 p. 
SOUZA, R.F.C. (2009). Migração de poluentes inorgânicos em linerscompostos. Dissertação de Mestrado em Geotecnia, São Carlos, SP, 124 p. Disponível em:〈http://www.teses.usp.br/teses/disponiveis/18/18132/tde-23032010-101309/pt-br.php〉.

Acesso em jan de 2011.

SPERLING, V, M. (2005). Princípios do Tratamento Biológico de Águas Residuárias. Universidade Federal de Minas Gerais, Belo Horizonte, MG, 1 vol., 452 p.

TELLES, I. A. (2001), Aplicação de métodos de análise numérica de transporte reativo de multicompostos em meios porosos - Pontifícia Universidade Católica do Rio de Janeiro Departamento de Engenharia Civil - Dissertação de Mestrado.

TEÓDULO, M.J.R. et al. Comparação de métodos de extração parcial de metais traço em solos e sedimentos de um estuário tropical sob influência de um complexo industrial portuário, Pernambuco, Brasil. Estudos Geológicos, Pernambuco, v.13, n. 1, p.23- 34, 2003.

TORIBIO, M \&ROMANYÁ, J. (2006).Leaching of heavy metals $(\mathrm{Cu}, \mathrm{Ni}$ and $\mathrm{Zn}$ ) and organic matter after sewage sludge application to Mediterranean Forest soils. Science of The Total Environment, v 363: 11-21.

WADA, L.M. (2011). Estudo do Comportamento de Solos Contaminados com Óleo de Isolamento de Transfomadores. Dissertação de Mestrado em Engenharia Geoténica., Universidade de São Paulo, São Paulo, SP, 90 p.

VIOTTI, P. et al. (2005). Contaminant transport in an unsaturated soil: laboratory tests and numerical simulation model as produce for parameters evaluation. Ecological Modelling, $\mathrm{v}$ 182: 131-148.

VAN, G. M. T. 1980. A closed-form equation for predicting the hydraulic conductivity of unsaturated soils.Soil Science Society American Journal44: 892-898.

VIVIAN, J. B. Utilização do Método do Papel Filtro para a Determinação das Curvas características de um solo Coluvionar Não Saturado Contaminado com Óleo Diesel. (2008). Dissertação de Mestrado em Engenharia, Universidade Federal do Rio Grande do Sul, Porto Alegre, RS, 102p.

YIN, Y.; IMPELLITTERI, C. A.; YOU, S.; ALLEN, H. E. The importance of organic matter distribution and extract soil: solution ratio on the desorption of heavy metals from soils. The Science of the Total Environment. v 287: 107-119. 
ANEXO A.

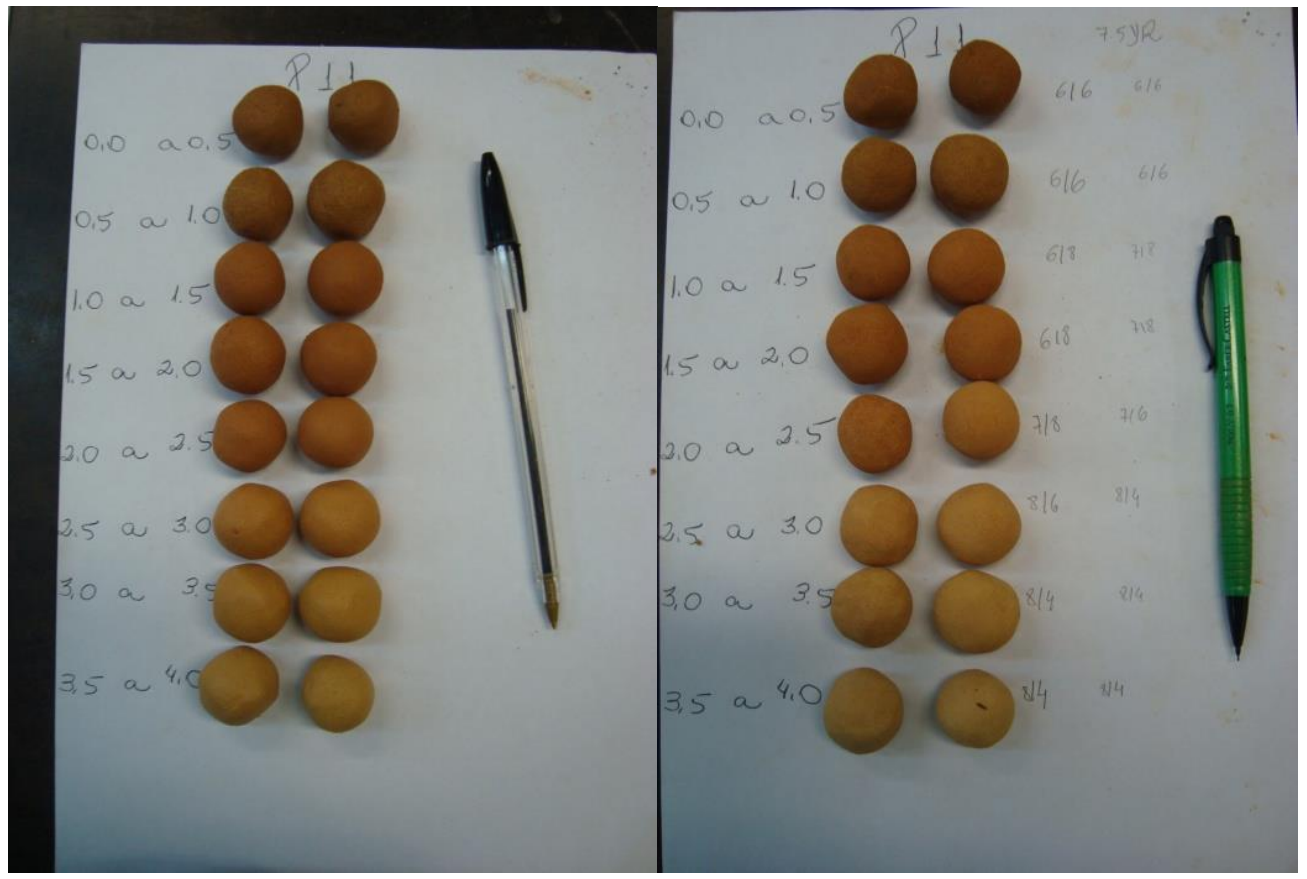

Figura A1 - Cores Perfil 11. (a) úmido; (b) seco.

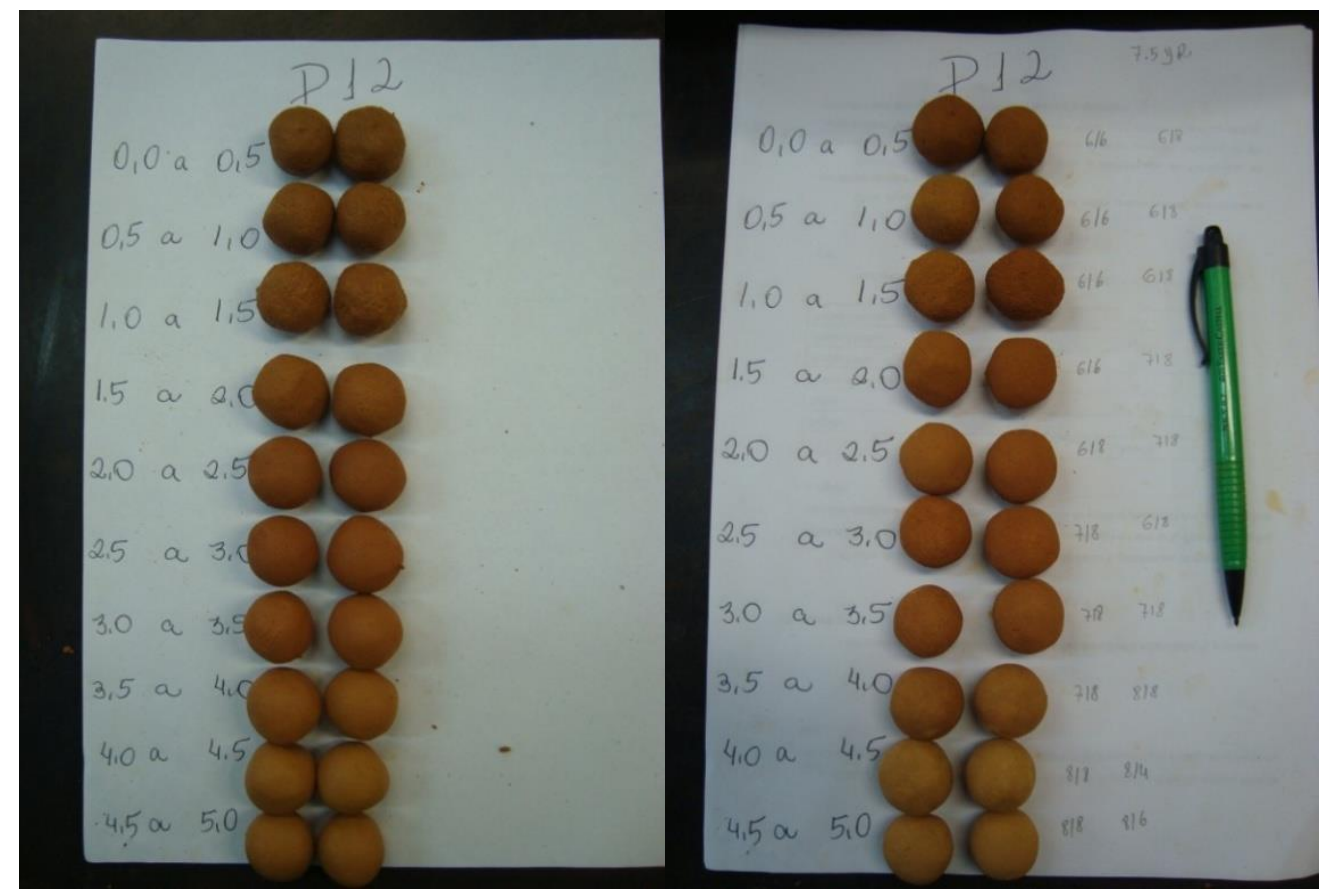

Figura A2 - Cores Perfil 12. (a) úmido; (b) seco. 


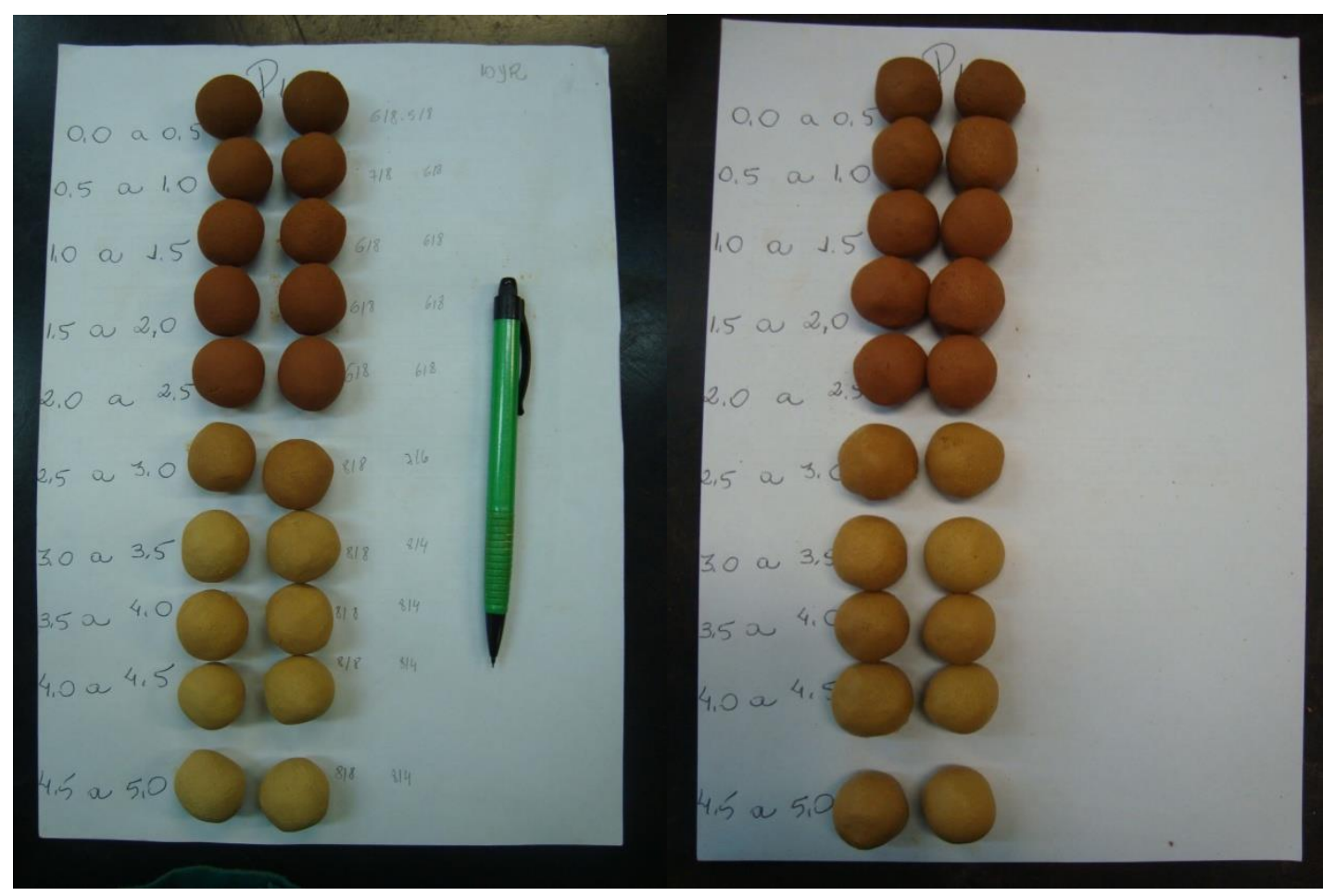

Figura A3 - Cores Perfil 13. (a) úmido; (b) seco.

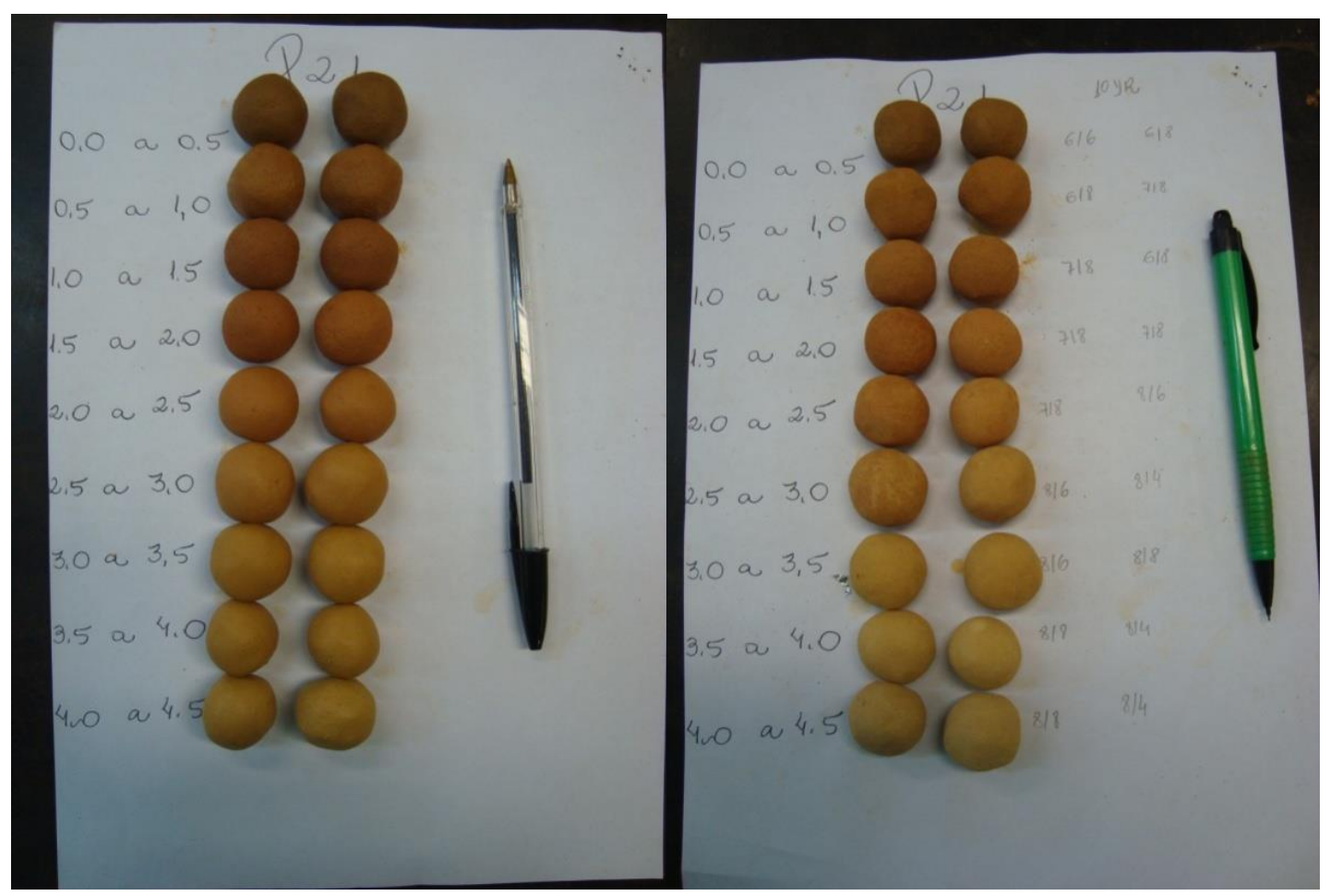

Figura A4 - Cores Perfil 21. (a) úmido; (b) seco. 


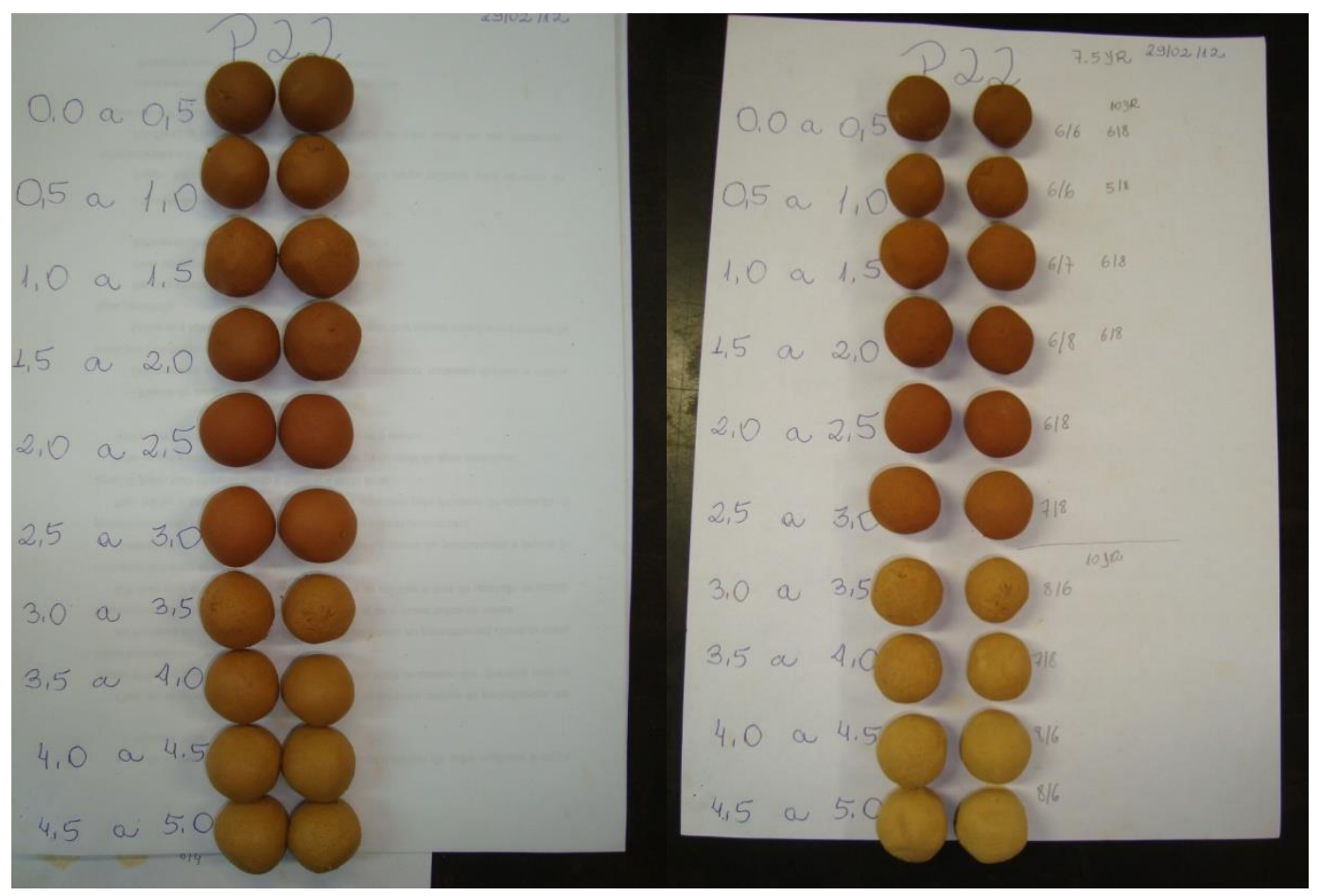

Figura A5 - Cores Perfil 22. (a) úmido; (b) seco.

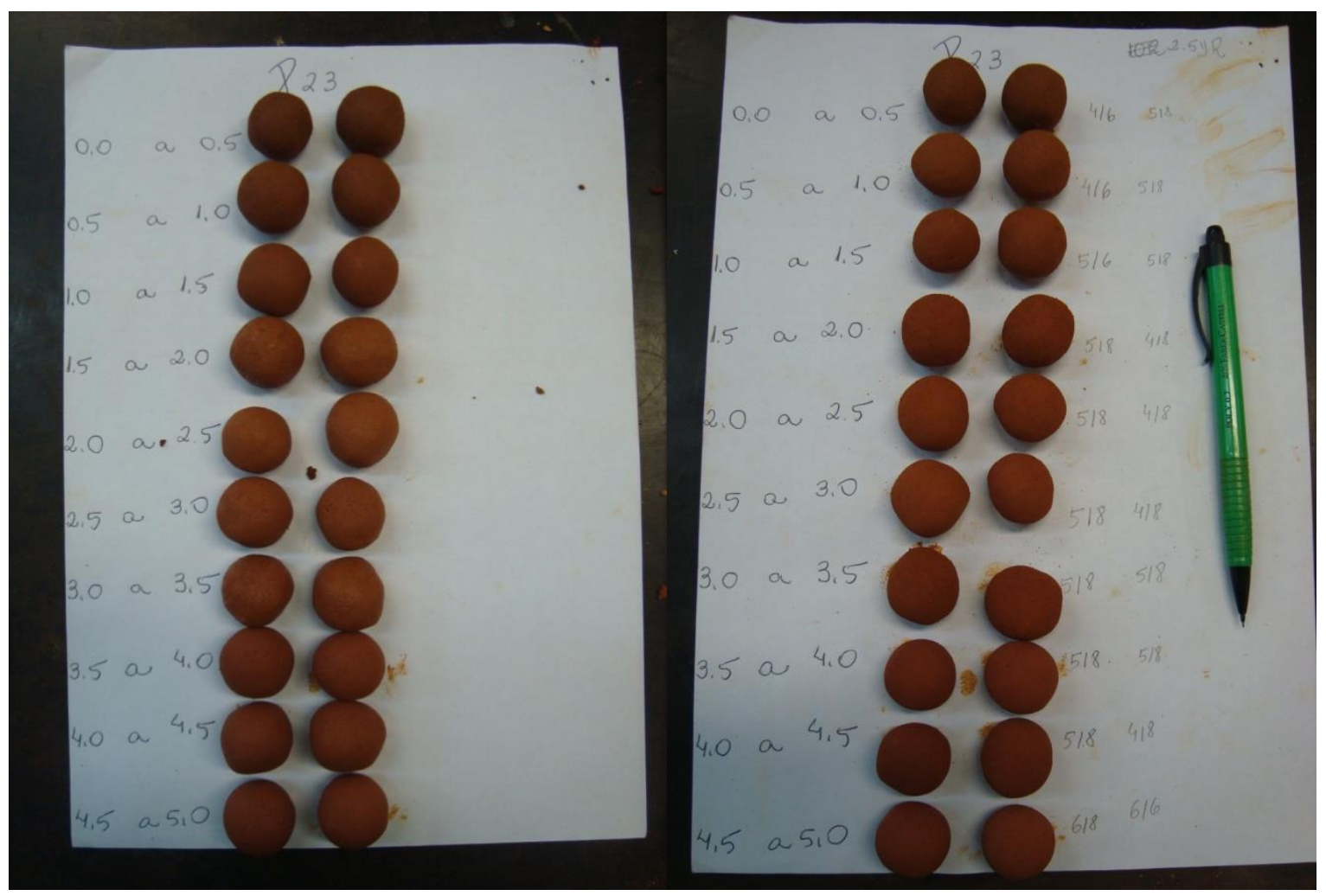

Figura A6 - Cores Perfil 23. (a) úmido; (b) seco. 


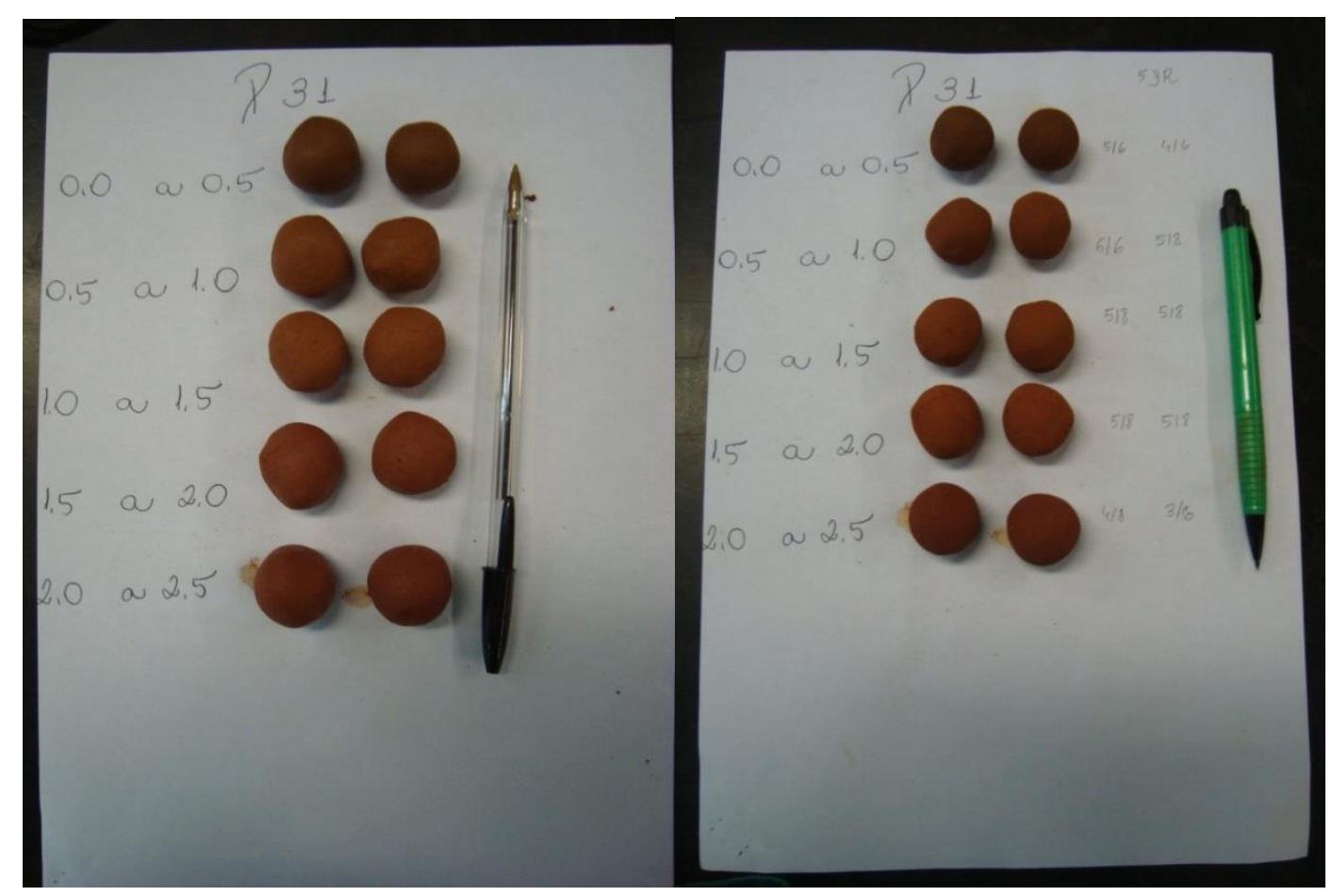

Figura A7 - Cores Perfil 31. (a) úmido; (b) seco.

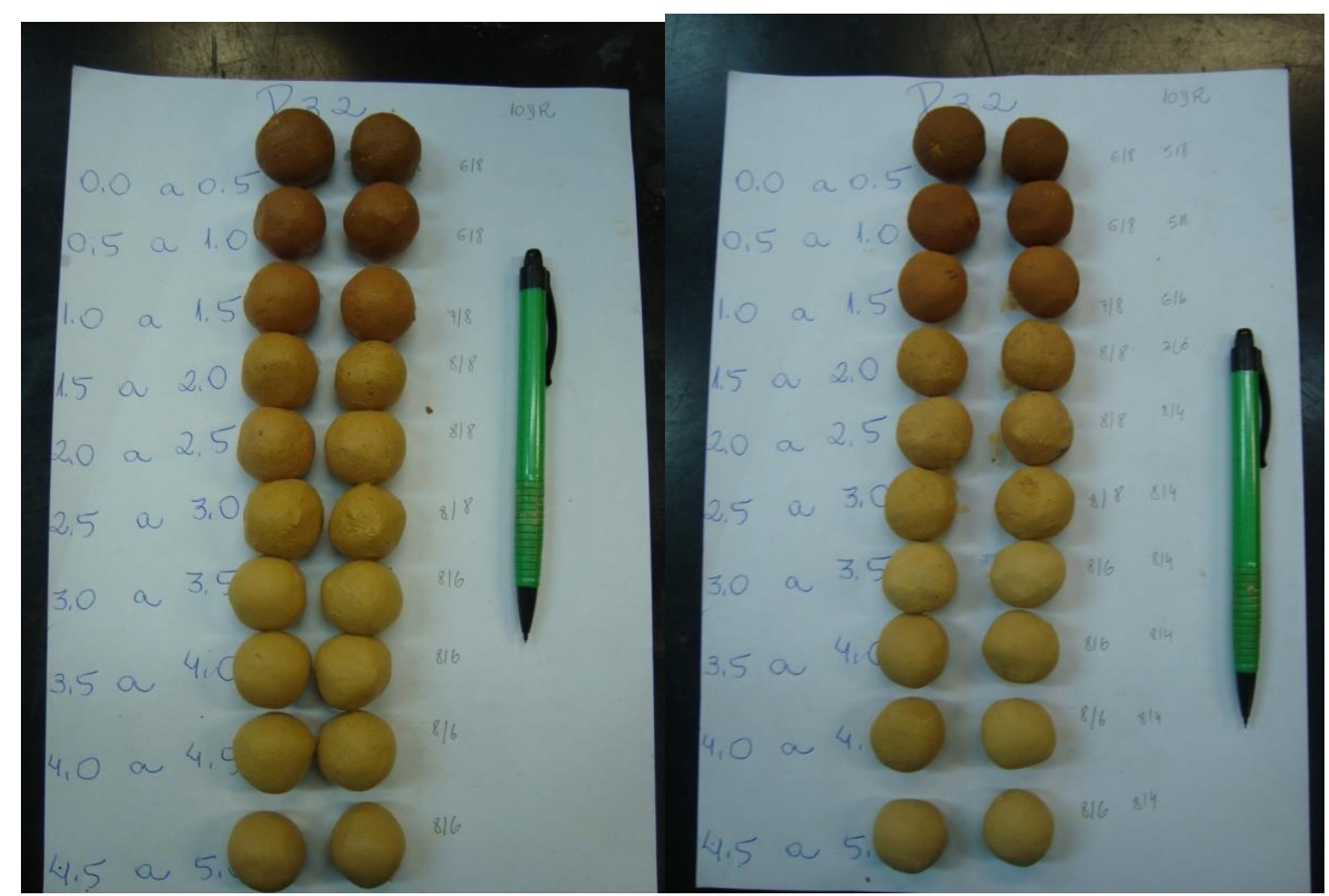

Figura A8 - Cores Perfil 32. (a) úmido; (b) seco. 


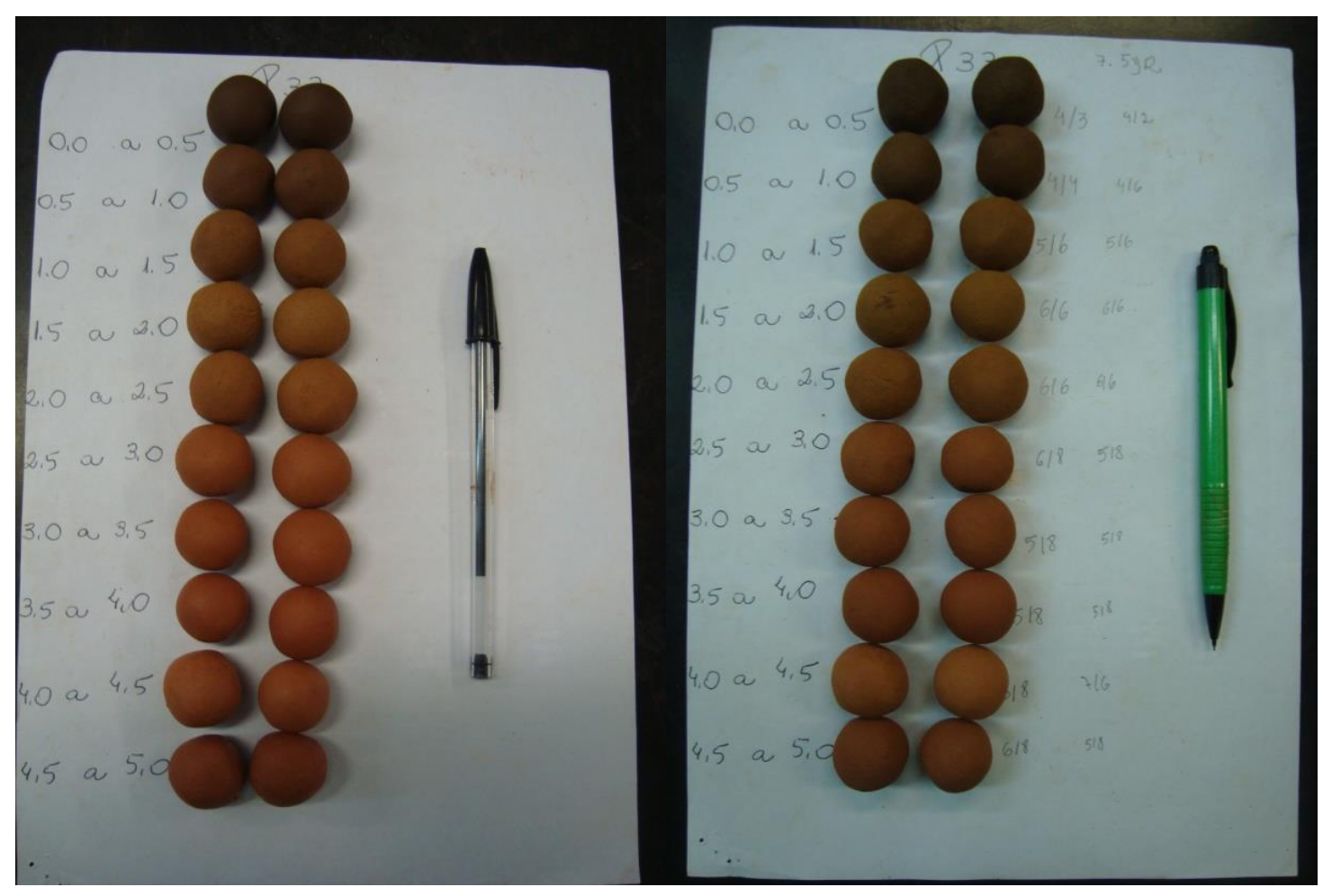

Figura A9 - Cores Perfil 33. (a) úmido; (b) seco.

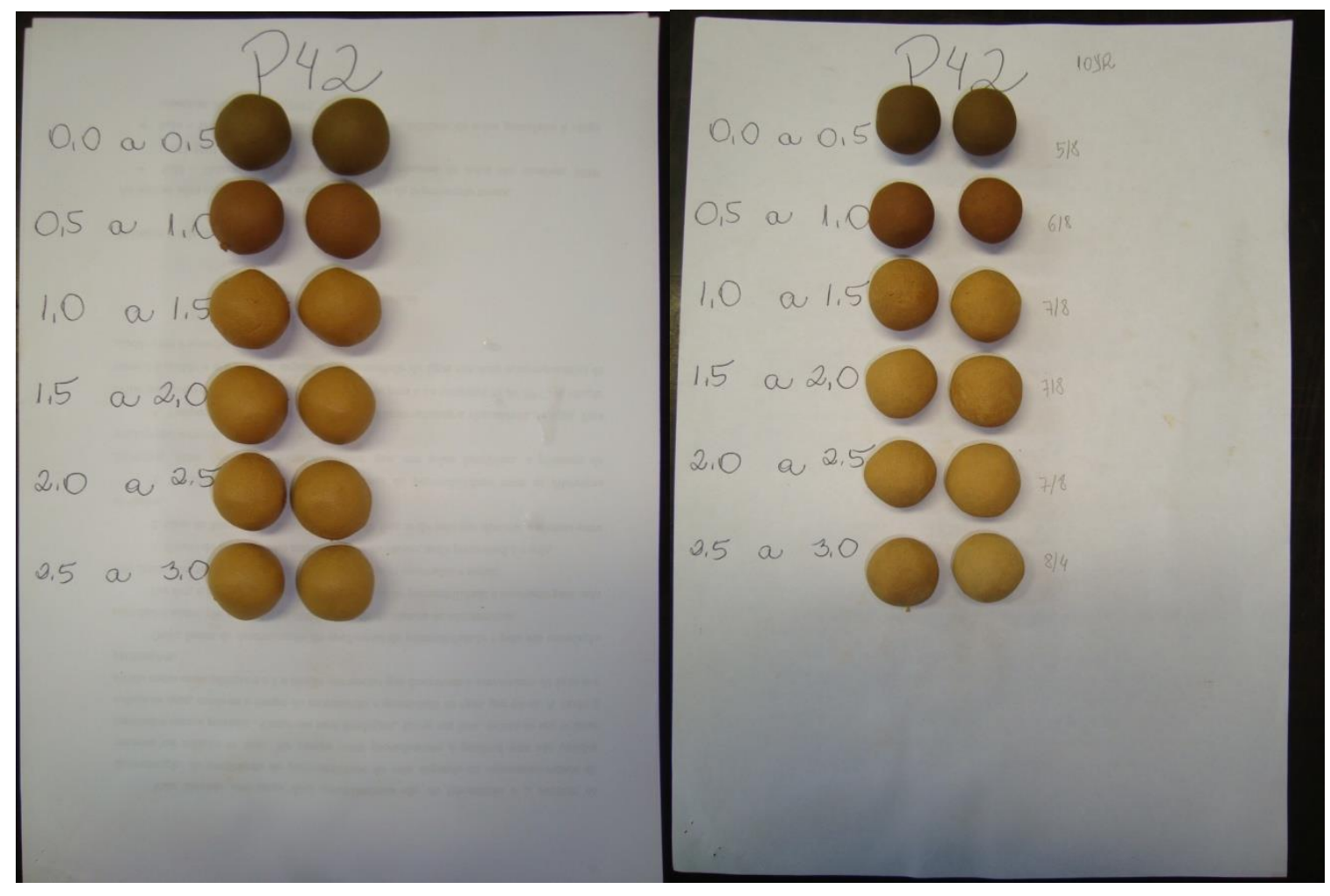

Figura A10 - Cores Perfil 42. (a) úmido; (b) seco. 


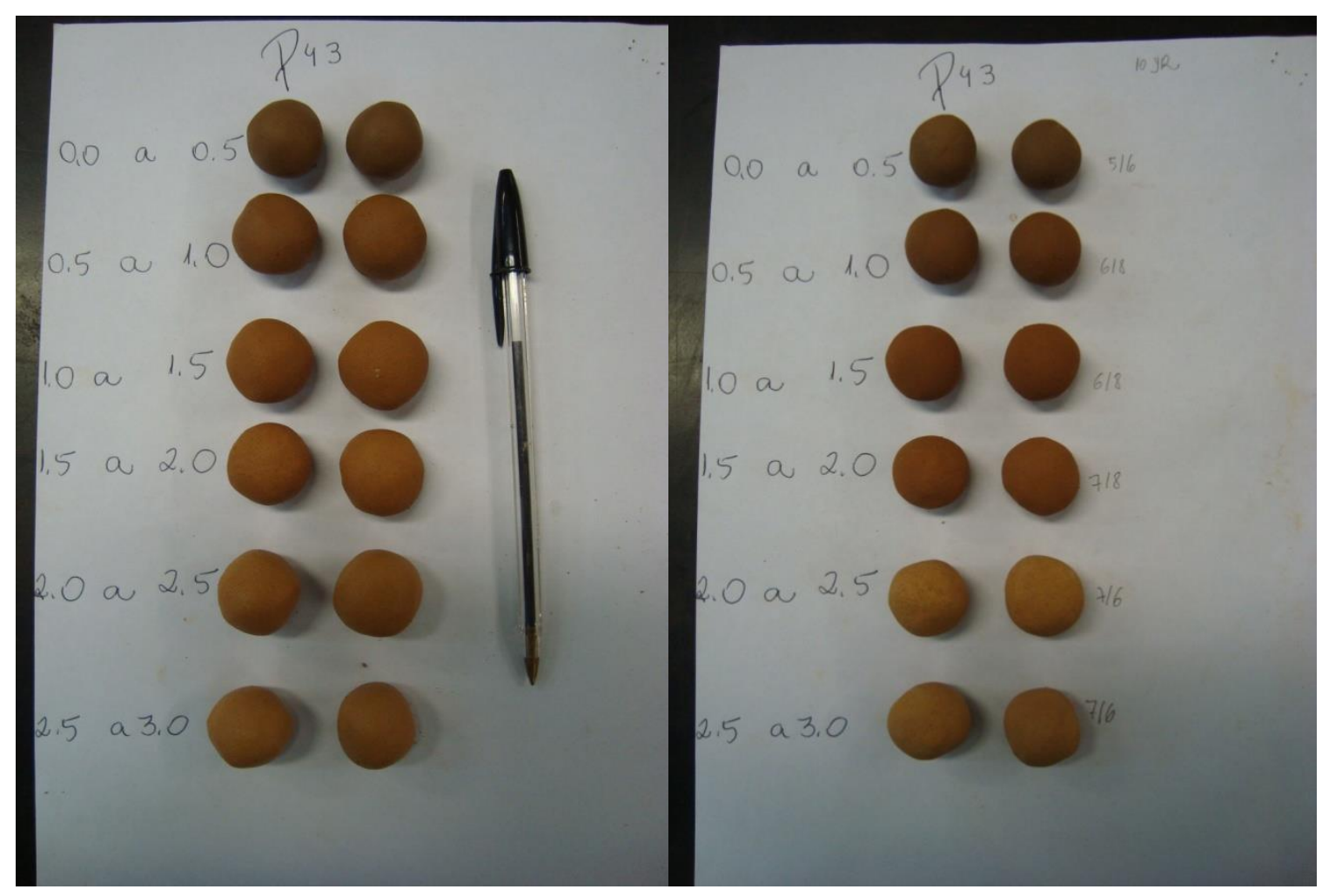

Figura A11 - Cores Perfil 43. (a) úmido; (b) seco.

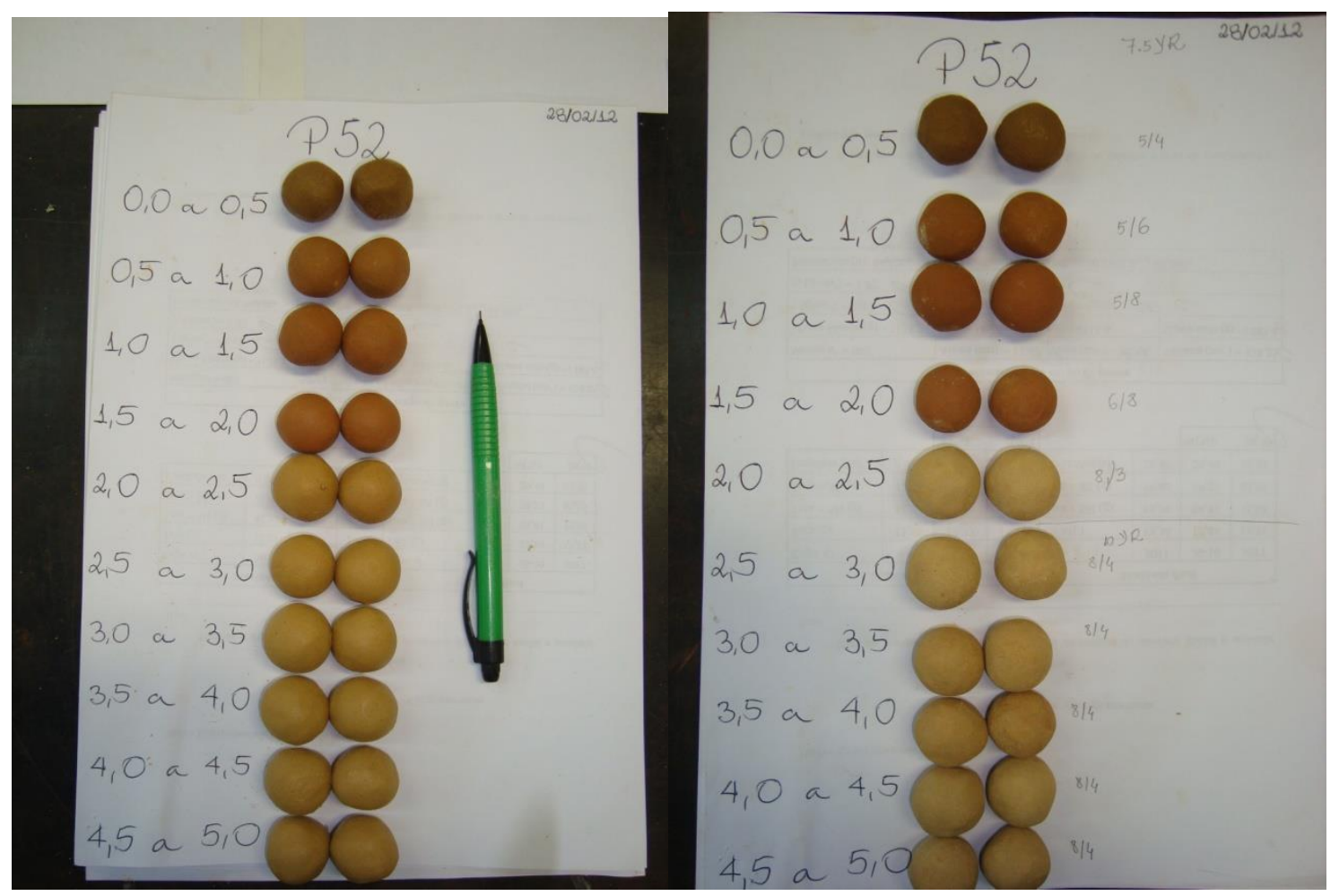

Figura A12 - Cores Perfil 52. (a) úmido; (b) seco. 


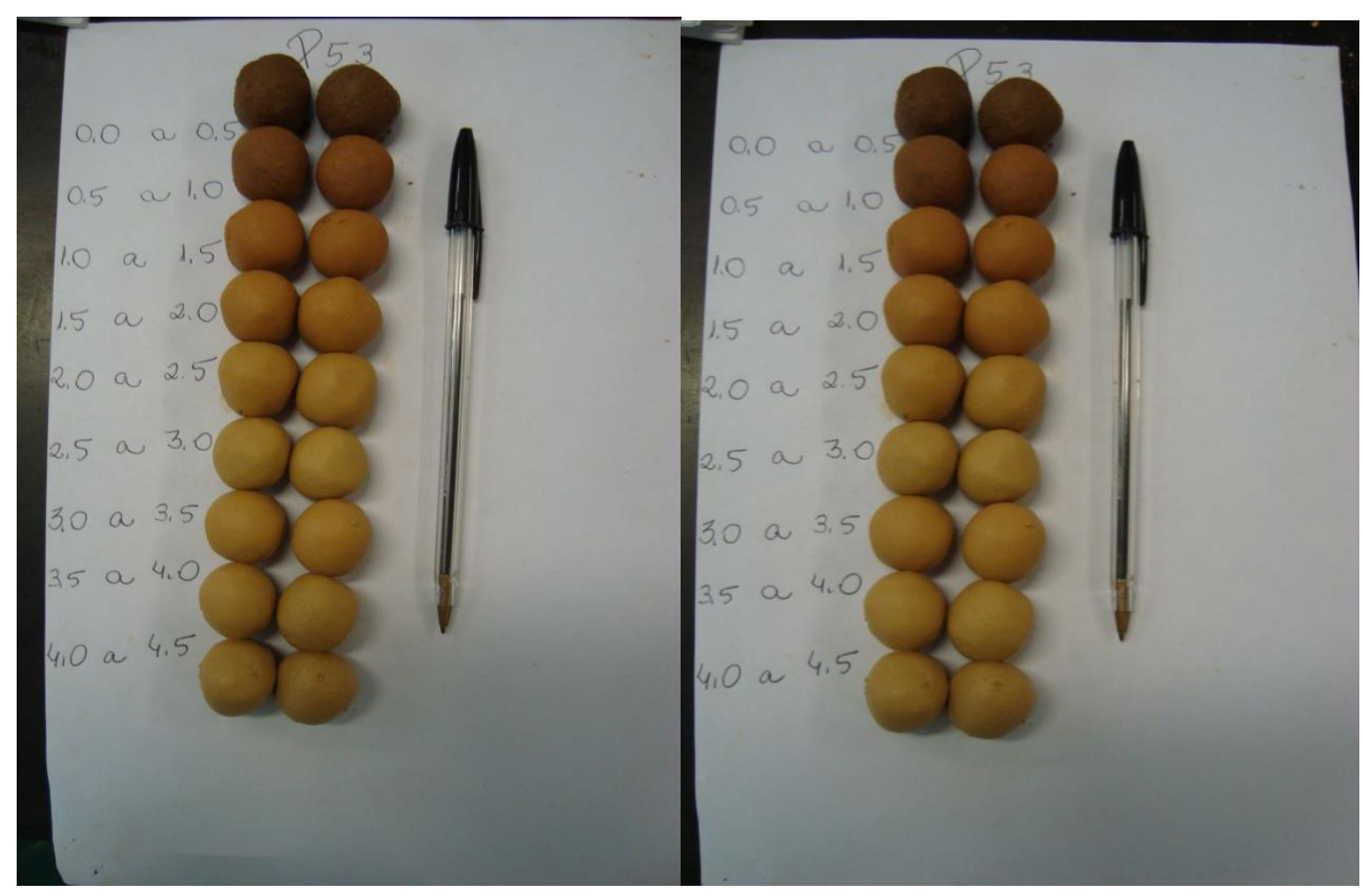

Figura A14 - Cores Perfil 53. (a) úmido; (b) seco.

Tabela A1 - Classificação MCT Perfil 1.

\begin{tabular}{|c|c|c|c|c|c|c|c|c|c|c|c|c|c|c|}
\hline & & Perfil P11 & & & & & Perfil P12 & & & & & Perfil P13 & & \\
\hline Profundidade $(\mathrm{m})$ & WP $(\%)$ & $c^{\prime}(\mathrm{mm})$ & $p(\mathrm{~mm})$ & Grupo MCT & Profundidade (m) & WP $(\%)$ & $c^{\prime}(\mathrm{mm})$ & $\mathrm{p}(\mathrm{mm})$ & Grupo MCT & Profundidade $(\mathrm{m})$ & WP $(\%)$ & $c^{\prime}(\mathrm{mm})$ & $p(\mathrm{~mm})$ & Grupo MCT \\
\hline 0,25 & $\mathrm{NP}$ & 0,48 & 4 & $\mathrm{NA} / \mathrm{NS}^{\prime}$ & 0,25 & $\mathrm{NP}$ & 0,81 & 0,7 & LA/LA' & 0,25 & $\mathrm{NP}$ & 0,71 & 5 & NS'-NA' \\
\hline 0,5 & $\mathrm{NP}$ & 0,48 & 4 & $\mathrm{NA} / \mathrm{NS}^{\prime}$ & 0,5 & $\mathrm{NP}$ & 0,81 & 0,7 & LA/LA' & 0,5 & NP & 0,71 & 5 & NS'-NA' \\
\hline 0,75 & NP & 0,5 & 4,6 & $\mathrm{NA} / \mathrm{NS}^{\prime}$ & 0,75 & NP & 0,64 & 3,3 & $N A^{\prime}-N S^{\prime}$ & 0,75 & NP & 0,54 & 5 & NA/NS' \\
\hline 1 & $\mathrm{NP}$ & 0,5 & 4,6 & $\mathrm{NA} / \mathrm{NS}^{\prime}$ & 1 & $\mathrm{NP}$ & 0,64 & 3,3 & $N A^{\prime}-N S^{\prime}$ & 1 & $\mathrm{NP}$ & 0,54 & 5 & $\mathrm{NA} / \mathrm{NS}^{\prime}$ \\
\hline 1,25 & $\mathrm{NP}$ & 0,47 & 4 & $\mathrm{NA} / \mathrm{NS}^{\prime}$ & 1,25 & NP & 0,37 & 5 & NA'-NS' & 1,25 & $\mathrm{NP}$ & 0,61 & 5 & NS'NA' \\
\hline 1,5 & NP & 0,47 & 4 & $\mathrm{NA} / \mathrm{NS}^{\prime}$ & 1,5 & NP & 0,37 & 5 & $N A^{\prime}-N S^{\prime}$ & 1,5 & NP & 0,61 & 5 & NS'NA' \\
\hline 1,75 & $\mathrm{NP}$ & 0,78 & 4 & NS'-NA' & 1,75 & $\mathrm{NP}$ & 0,35 & 5 & $N A^{\prime}-N S^{\prime}$ & 1,75 & NP & 0,64 & 3,3 & $N A^{\prime} \cdot \mathrm{NS}^{\prime}$ \\
\hline 2 & NP & 0,78 & 4 & NS'-NA' & 2 & $\mathrm{NP}$ & 0,35 & 5 & NA'-NS' & 2 & $\mathrm{NP}$ & 0,64 & 3,3 & $N A^{\prime} \cdot \mathrm{NS}^{\prime}$ \\
\hline 2,25 & 30,18 & 1,24 & 3,3 & $\mathrm{NA}^{\prime}$ & 2,25 & $\mathrm{NP}$ & 0,37 & 0 & $N A^{\prime}-N S^{\prime}$ & 2,25 & baixa & 1,17 & 0,3 & LA' $^{\prime}$ \\
\hline 2,5 & 30,18 & 1,24 & 3,3 & $\mathrm{NA}^{\prime}$ & 2,5 & $\mathrm{NP}$ & 0,37 & 0 & $N A^{\prime}-N S^{\prime}$ & 2,5 & baixa & 1,17 & 0,3 & $\mathrm{LA}^{\prime}$ \\
\hline 2,75 & 31,92 & 1,11 & 5 & NS' & 2,75 & NP & 0,99 & 0 & LA/LA' & 2,75 & baixa & 1,41 & 4 & $N S^{\prime}-N G^{\prime}$ \\
\hline 3 & 31,92 & 1,11 & 5 & NS' & 3 & NP & 0,99 & 0 & LA/LA' & 3 & baixa & 1,41 & 4 & NS'NG' \\
\hline 3,25 & 31,26 & 1,17 & 5 & NS' & 3,25 & baixa & 0,96 & 0 & LA/LA' & 3,25 & baixa & 1,35 & 5 & NS' \\
\hline 3,5 & 31,26 & 1,17 & 5 & NS' & 3,5 & baixa & 0,96 & 0 & LA/LA' & 3,5 & baixa & 1,35 & 5 & NS' \\
\hline 3,75 & 31,19 & 0,78 & 5 & NS'-NA' & 3,75 & 34,28 & 1,36 & 5 & NS' & 3,75 & baixa & 1,31 & 5 & NS' \\
\hline 4 & 31,19 & 0,78 & 5 & NS'-NA' & 4 & 34,28 & 1,36 & 5 & NS' & 4 & baixa & 1,31 & 5 & NS' \\
\hline 4,25 & & & & & 4,25 & 33,51 & 1,24 & 3,6 & $\mathrm{NS}^{\prime}$ & 4,25 & baixa & 1,39 & 5 & NS' \\
\hline 4,5 & & & & & 4,5 & 33,51 & 1,24 & 3,6 & $\mathrm{NS}^{\prime}$ & 4,5 & baixa & 1,39 & 5 & NS' \\
\hline 4,75 & & & & & 4,75 & & & & & 4,75 & baixa & 1,16 & 5 & NS' \\
\hline 5 & & & & & 5 & & & & & 5 & baixa & 1,16 & 5 & NS' \\
\hline
\end{tabular}


Tabela A2 - Classificação MCT Perfil 2.

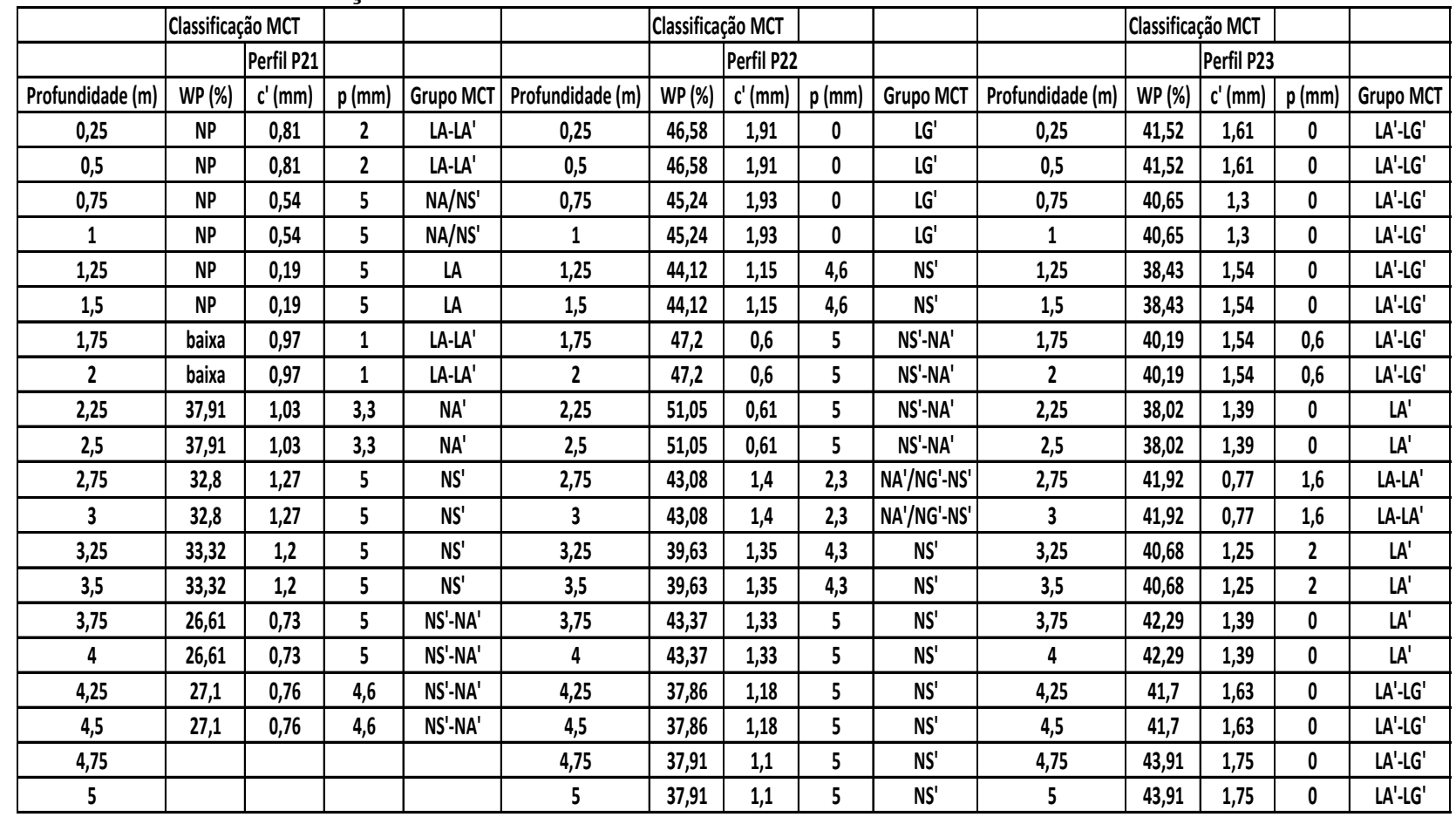

Tabela A3 - Classificação MCT Perfil 3.

\begin{tabular}{|c|c|c|c|c|c|c|c|c|c|c|c|c|c|c|}
\hline & \multicolumn{4}{|c|}{ Classificação MCT } & \multicolumn{5}{|c|}{ Classificação MCT } & \multicolumn{5}{|c|}{ Classificação MCT } \\
\hline & & Perfil P31 & & & & & Perfil P32 & & & & & Perfil P33 & & \\
\hline Profundidade (m) & WP (\%) & $c^{\prime}(\mathrm{mm})$ & $p(\mathrm{~mm})$ & Grupo MCT & Profundidade $(\mathrm{m})$ & WP (\%) & $c^{\prime}(\mathrm{mm})$ & $p(\mathrm{~mm})$ & Grupo MCT & Profundidade (m) & WP $(\%)$ & $c^{\prime}(\mathrm{mm})$ & $p(m m)$ & Grupo MCT \\
\hline 0,25 & 36,44 & 1,67 & 0 & $\angle A^{\prime} \cdot-G^{\prime}$ & 0,25 & 33,63 & 1,56 & 0 & $L A^{\prime} \cdot L G^{\prime}$ & 0,25 & 36,08 & 1,77 & 0,33 & $\angle A^{\prime} \cdot-G^{\prime}$ \\
\hline 0,5 & 36,44 & 1,67 & 0 & $L A^{\prime}-L G^{\prime}$ & 0,5 & 33,63 & 1,56 & 0 & $L A^{\prime} \cdot L G^{\prime}$ & 0,5 & 36,08 & 1,77 & 0,33 & $L A^{\prime}-L G^{\prime}$ \\
\hline 0,75 & 41,33 & 1,72 & 0 & $L A^{\prime} \cdot \mathrm{LG}^{\prime}$ & 0,75 & 35,66 & 1,67 & 0 & $L A^{\prime} \cdot L^{\prime}$ & 0,75 & 36,25 & 1,63 & 0 & $L A^{\prime} \cdot L G^{\prime}$ \\
\hline 1 & 41,33 & 1,72 & 0 & LA'-LG' & 1 & 35,66 & 1,67 & 0 & $L A^{\prime} \cdot L G^{\prime}$ & 1 & 36,25 & 1,63 & 0 & $\angle A^{\prime} \cdot L G^{\prime}$ \\
\hline 1,25 & 37,22 & 1,63 & 0 & $L A^{\prime} \cdot L G^{\prime}$ & 1,25 & 35,24 & 1,52 & 3 & NA'/NG'NS' & 1,25 & 35,47 & 1,82 & 0 & $L^{\prime}$ \\
\hline 1,5 & 37,22 & 1,63 & 0 & $L A^{\prime} \cdot L G^{\prime}$ & 1,5 & 35,24 & 1,52 & 3 & NA'/NG'.NS' & 1,5 & 35,47 & 1,82 & 0 & LG' \\
\hline 1,75 & 37,93 & 1,58 & 0 & $L A^{\prime}-L G^{\prime}$ & 1,75 & 29,88 & 1,05 & 4,6 & NS' $^{\prime}$ & 1,75 & 37,09 & 1,75 & 0 & $L A^{\prime}-L G^{\prime}$ \\
\hline 2 & 37,93 & 1,58 & 0 & $\angle A^{\prime}-L G^{\prime}$ & 2 & 29,88 & 1,05 & 4,6 & NS' & 2 & 37,09 & 1,75 & 0 & $L A^{\prime}-L G^{\prime}$ \\
\hline 2,25 & 31,44 & 1,49 & 2 & LA'-LG' & 2,25 & 35,06 & 1,13 & 5 & NS' & 2,25 & 34,78 & 1,64 & 0 & $\angle A^{\prime} \cdot L G^{\prime}$ \\
\hline 2,5 & 31,44 & 1,49 & 2 & $\angle A^{\prime}-L G^{\prime}$ & 2,5 & 35,06 & 1,13 & 5 & $\mathrm{NS}^{\prime}$ & 2,5 & 34,78 & 0,64 & 0 & $\angle A^{\prime} \cdot L G^{\prime}$ \\
\hline 2,75 & & & & & 2,75 & 32,94 & 0,85 & 5 & NS'-NA' & 2,75 & 31,7 & 1,74 & 1,6 & $L A^{\prime}-L G^{\prime}$ \\
\hline 3 & & & & & 3 & 32,94 & 0,85 & 5 & NS'-NA' & 3 & 31,7 & 1,74 & 1,6 & $L A^{\prime} \cdot L G^{\prime}$ \\
\hline 3,25 & & & & & 3,25 & 35,1 & 1,18 & 5 & $\mathrm{NS}^{\prime}$ & 3,25 & 34,35 & 1,55 & 3,3 & NA'/NG'-NS' \\
\hline 3,5 & & & & & 3,5 & 35,1 & 1,18 & 5 & NS' & 3,5 & 35,35 & 1,55 & 3,3 & $N A^{\prime} / N^{\prime}-N S^{\prime}$ \\
\hline 3,75 & & & & & 3,75 & 32,68 & 1,12 & 5 & $\mathrm{NS}^{\prime}$ & 3,75 & 33,61 & 1,5 & 2 & $\angle A^{\prime} \cdot L G^{\prime}$ \\
\hline 4 & & & & & 4 & 32,68 & 1,12 & 5 & NS' & 4 & 33,61 & 1,5 & 2 & $\angle A^{\prime}-L G^{\prime}$ \\
\hline 4,25 & & & & & 4,25 & 33,1 & 0,84 & 5 & NS'-NA' & 4,25 & 32,65 & 1,23 & 4,3 & $\mathrm{NS}^{\prime}$ \\
\hline 4,5 & & & & & 4,5 & 33,1 & 0,84 & 5 & NS'-NA' & 4,5 & 32,65 & 1,23 & 4,3 & $\mathrm{NS}^{\prime}$ \\
\hline 4,75 & & & & & 4,75 & 28,25 & 1,06 & 5 & NS' & 4,75 & 33,33 & 1,57 & 5 & NS' $^{\prime}$ \\
\hline 5 & & & & & 5 & 28,25 & 1,06 & 5 & $\mathrm{NS}^{\prime}$ & 5 & 33,33 & 1,57 & 5 & $\mathrm{NS}^{\prime}$ \\
\hline
\end{tabular}


Tabela A4 - Classificação MCT Perfil 4.

\begin{tabular}{|c|c|c|c|c|c|c|c|c|c|c|c|c|c|c|}
\hline & \multicolumn{3}{|c|}{ Classificação MCT } & & & \multicolumn{3}{|c|}{ Classificação MCT } & & & \multicolumn{3}{|c|}{ Classificação MCT } & \\
\hline & \multicolumn{3}{|c|}{ Perfil P41 } & & & \multicolumn{3}{|c|}{ Perfil P42 } & & & \multicolumn{3}{|c|}{ Perfil P43 } & \\
\hline Profundidade $(\mathrm{m})$ & WP (\%) & $c^{\prime}(\mathrm{mm})$ & $\mathrm{p}(\mathrm{mm})$ & \begin{tabular}{|l|} 
Grupo MCT \\
\end{tabular} & Profundidade $(\mathrm{m})$ & WP (\%) & $c^{\prime}(\mathrm{mm})$ & $p(\mathrm{~mm})$ & Grupo MCT & Profundidade $(\mathrm{m})$ & WP (\%) & $c^{\prime}(\mathrm{mm})$ & $p(m m)$ & Grupo MCT \\
\hline 0,25 & NP & 0,95 & 0 & LA-LA' & 0,25 & 37,46 & 2,04 & 0 & LG' $^{\prime}$ & 0,25 & 31,13 & 1,75 & 0 & LA'-LG' \\
\hline 0,5 & NP & 0,95 & 0 & LA-LA' & 0,5 & 37,46 & 2,04 & 0 & $L^{\prime} G^{\prime}$ & 0,5 & 31,13 & 1,75 & 0 & 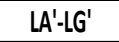 \\
\hline 0,75 & $\mathrm{NP}$ & 0,64 & 2 & LA-LA' & 0,75 & 32,93 & 1,74 & 0 & $L A^{\prime}-\mathrm{LG}^{\prime}$ & 0,75 & 35,39 & 1,91 & 0 & $\mathrm{LG}^{\prime}$ \\
\hline 1 & NP & 0,64 & 2 & LA-LA' & 1 & 32,93 & 1,74 & 0 & $\angle A^{\prime}-L G^{\prime}$ & 1 & 35,39 & 1,91 & 0 & $\mathbf{L G}^{\prime}$ \\
\hline 1,25 & $\mathrm{NP}$ & 0,45 & 2,6 & LA & 1,25 & 34,5 & 1,65 & 5 & NS'-NG' & 1,25 & 36,13 & 1,85 & 0 & $\mathrm{LG}^{\prime}$ \\
\hline 1,5 & $\mathrm{NP}$ & 0,45 & 2,6 & LA & 1,5 & 34,5 & 1,65 & 5 & NS'-NG' & 1,5 & 36,13 & 1,85 & 0 & LG' $^{\prime}$ \\
\hline 1,75 & NP & 0,08 & 5 & NA-NS' & 1,75 & 33,55 & 1,65 & 5 & NS'-NG' & 1,75 & 33,39 & 1,91 & 0 & $L^{\prime} G^{\prime}$ \\
\hline 2 & $\mathrm{NP}$ & 0,08 & 5 & NA-NS' & 2 & 33,55 & 1,65 & 5 & NS'-NG' & 2 & 33,39 & 1,91 & 0 & LG' $^{\prime}$ \\
\hline 2,25 & $\mathrm{NP}$ & 0,51 & 2 & $L A$ & 2,25 & 31,3 & 1,58 & 5 & NS'-NG' & 2,25 & 30,15 & 1,46 & 0 & NS'-NG' \\
\hline 2,5 & $N P$ & 0,51 & 2 & LA & 2,5 & 31,3 & 1,58 & 5 & $N^{\prime}-$ NG $^{\prime}$ & 2,5 & 30,15 & 1,46 & 0 & NS'-NG' \\
\hline 2,75 & $\mathrm{NP}$ & 0,61 & 1 & LA-LA' & 2,75 & 34,13 & 1,32 & 5 & NS' $^{\prime}$ & 2,75 & 29,1 & 1,28 & 5 & $\mathrm{NS}^{\prime}$ \\
\hline 3 & NP & 0,61 & 1 & LA-LA' & 3 & 34,13 & 1,32 & 5 & NS' & 3 & 29,1 & 1,28 & 5 & NS' $^{\prime}$ \\
\hline 3,25 & baixa & 0,75 & 0 & LA-LA' & 3,25 & & & & & 3,25 & & & & \\
\hline 3,5 & baixa & 0,75 & 0 & LA-LA' & 3,5 & & & & & 3,5 & & & & \\
\hline 3,75 & 42,38 & 1,45 & 0 & $L^{\prime}-\mathrm{LG}^{\prime}$ & 3,75 & & & & & 3,75 & & & & \\
\hline 4 & 42,38 & 1,45 & 0 & $L^{\prime}-\mathrm{LG}^{\prime}$ & 4 & & & & & 4 & & & & \\
\hline 4,25 & 42,09 & 1,5 & 3,3 & NA'$^{\prime} / \mathrm{NG}^{\prime}-\mathrm{NS}^{\prime}$ & 4,25 & & & & & 4,25 & & & & \\
\hline 4,5 & 42,09 & 1,5 & 3,3 & NA'/NG'-NS' $^{\prime}$ & 4,5 & & & & & 4,5 & & & & \\
\hline 4,75 & 42,23 & 1,45 & 3,6 & $\mathrm{NA}^{\prime} / \mathrm{NG}^{\prime}-\mathrm{NS}{ }^{\prime}$ & 4,75 & & & & & 4,75 & & & & \\
\hline 5 & 42,23 & 1,45 & 3,6 & NA'/NG'-NS' & 5 & & & & & 5 & & & & \\
\hline
\end{tabular}

Tabela A5 - Classificação MCT Perfil 5.

\begin{tabular}{|c|c|c|c|c|c|c|c|c|c|c|c|c|c|c|}
\hline & \multicolumn{2}{|c|}{ Classificação MCT } & & & & \multicolumn{4}{|c|}{ Classificação MCT } & & & \multicolumn{3}{|c|}{ Classificação MCT } \\
\hline & & \begin{tabular}{|l|} 
Perfil P51 \\
\end{tabular} & & & & & $\begin{array}{l}\text { Perfil P52 } \\
\end{array}$ & & & & & \begin{tabular}{|l|l|} 
Perfil P53 \\
\end{tabular} & & \\
\hline Profundidade $(\mathrm{m})$ & WP (\%) & $c^{\prime}(\mathrm{mm})$ & $\mathrm{p}(\mathrm{mm})$ & Grupo MCT & Profundidade (m) & WP (\%) & $c^{\prime}(\mathrm{mm})$ & $p(\mathrm{~mm})$ & Grupo MCT & Profundidade $(\mathrm{m})$ & WP (\%) & $\begin{array}{ll}c^{\prime}(\mathrm{mm}) \\
\end{array}$ & $\mathrm{p}(\mathrm{mm})$ & Grupo MCT \\
\hline 0,25 & NP & 0,52 & 5 & $\mathrm{NA} / \mathrm{NS}^{\prime}$ & 0,25 & NP & 0,85 & 5 & NS'-NA' & 0,25 & baixa & 1,6 & 0 & LA'-LG' \\
\hline 0,5 & $\mathrm{NP}$ & 0,52 & 5 & $\mathrm{NA} / \mathrm{NS}^{\prime}$ & 0,5 & NP & 0,85 & 5 & NS'-NA' & 0,5 & baixa & 1,6 & 0 & $\angle A^{\prime}-L G^{\prime}$ \\
\hline 0,75 & $\mathrm{NP}$ & 0,3 & 5 & NA/NS' & 0,75 & $\mathrm{NP}$ & 0,085 & 5 & NA-NS' & 0,75 & baixa & 1,23 & 0 & LA' \\
\hline 1 & $\mathrm{NP}$ & 0,3 & 5 & NA/NS' & 1 & $\mathrm{NP}$ & 0,085 & 5 & NA-NS' & 1 & baixa & 1,23 & 0 & $\mathrm{LA}^{\prime}$ \\
\hline 1,25 & $\mathrm{NP}$ & 0,33 & 5 & NA/NS' & 1,25 & $\mathrm{NP}$ & 0,68 & 1,6 & LA-LA' & 1,25 & baixa & 1,17 & 3,6 & $\mathrm{NA}^{\prime}$ \\
\hline 1,5 & NP & 0,33 & 5 & NA/NS' & 1,5 & NP & 0,68 & 1,6 & LA-LA' & 1,5 & baixa & 1,17 & 3,6 & $\mathrm{NA}^{\prime}$ \\
\hline 1,75 & baixa & 0,79 & 0 & LA-LA' & 1,75 & baixa & 0,81 & 0 & LA-LA' & 1,75 & 32,91 & 1,2 & 5 & $\mathrm{NS}^{\prime}$ \\
\hline 2 & baixa & 0,79 & 0 & LA-LA' & 2 & baixa & 0,81 & 0 & LA-LA' & 2 & 32,91 & 1,2 & 5 & NS' \\
\hline 2,25 & 40,44 & 1,09 & 0 & LA' $^{\prime}$ & 2,25 & 31,86 & 1,27 & 5 & NS' & 2,25 & 33,17 & 1,18 & 5 & NS' \\
\hline 2,5 & 40,44 & 1,09 & 0 & LA' & 2,5 & 31,86 & 1,27 & 5 & NS' & 2,5 & 33,17 & 1,18 & 5 & NS' \\
\hline 2,75 & 46,62 & 1,66 & 0 & $L A^{\prime} \cdot-G^{\prime}$ & 2,75 & 31,34 & 0,97 & 5 & NS'-NA' & 2,75 & 29,55 & 0,8 & 5 & NS'NA' \\
\hline 3 & 46,62 & 1,66 & 0 & $L A^{\prime} \cdot-G^{\prime}$ & 3 & 31,34 & 0,97 & 5 & NS'-NA' & 3 & 29,55 & 0,8 & 5 & NS'NA' \\
\hline 3,25 & 46,02 & 1,5 & 0 & LA'-LG' & 3,25 & 28,22 & 0,84 & 5 & NS'-NA' & 3,25 & 29,45 & 1,12 & 5 & NS' \\
\hline 3,5 & 46,02 & 1,5 & 0 & $\angle A^{\prime}-\mathrm{LG}^{\prime}$ & 3,5 & 28,22 & 0,84 & 5 & NS'-NA' & 3,5 & 29,45 & 1,12 & 5 & $\mathrm{NS}^{\prime}$ \\
\hline 3,75 & 39,07 & 1,56 & 1,3 & LA'-LG' & 3,75 & 28,7 & 0,85 & 5 & NS'-NA' & 3,75 & 30,89 & 0,81 & 5 & NS'NA' \\
\hline 4 & 39,07 & 1,56 & 1,3 & LA'-LG' & 4 & 28,7 & 0,85 & 5 & NS'-NA' & 4 & 30,89 & 0,81 & 5 & NS'NA' \\
\hline 4,25 & 47,73 & 1,85 & 5 & $\mathrm{NG}^{\prime}$ & 4,25 & 28,87 & 0,82 & 5 & NS'-NA' & 4,25 & 31,41 & 1,02 & 5 & $\mathrm{NS}^{\prime}$ \\
\hline 4,5 & 47,73 & 1,85 & 5 & $\mathrm{NG}^{\prime}$ & 4,5 & 28,87 & 0,82 & 5 & NS'-NA' & 4,5 & 31,41 & 1,02 & 5 & NS' $^{\prime}$ \\
\hline 4,75 & 38,46 & 1,34 & 5 & NS' & 4,75 & 31,57 & 0,8 & 5 & NS'-NA' & 4,75 & 31,15 & 1,15 & 5 & NS' \\
\hline 5 & 38,46 & 1,34 & 5 & NS' $^{\prime}$ & 5 & 31,57 & 0,8 & 5 & NS'-NA' & 5 & 31,15 & 1,15 & 5 & NS' $^{\prime}$ \\
\hline
\end{tabular}


Tabela A6 - Matiz, valores de croma, e cor perfil P11.

\begin{tabular}{|c|c|c|c|c|c|c|}
\hline Perfil & Profundidade & Matiz & $\begin{array}{c}\text { Valor/Croma } \\
\text { (úmido) }\end{array}$ & $\begin{array}{c}\text { Valor/Croma } \\
\text { (seco) }\end{array}$ & Cor umida & Cor seca \\
\hline P11 & 0,0 a 0,5 & 10 YR & $(4 / 8)$ & $(4 / 8)$ & $\begin{array}{c}\text { Bruno- } \\
\text { amarelado }\end{array}$ & $\begin{array}{c}\text { Bruno- } \\
\text { amarelado }\end{array}$ \\
\hline & 0,5 a 1,0 & 10 YR & $(5 / 8)$ & $(5 / 8)$ & $\begin{array}{c}\text { Bruno } \\
\text { amarelado }\end{array}$ & $\begin{array}{c}\text { Bruno- } \\
\text { amarelado }\end{array}$ \\
\hline & 1,0 a 1,5 & 10 YR & $(6 / 6)$ & $(6 / 6)$ & $\begin{array}{c}\text { Amarelo } \\
\text { brunado }\end{array}$ & $\begin{array}{c}\text { Amarelo } \\
\text { brunado }\end{array}$ \\
\hline & 1,5 a 2,0 & 10 YR & $(6 / 6)$ & $(6 / 6)$ & $\begin{array}{c}\text { Amarelo } \\
\text { brunado }\end{array}$ & $\begin{array}{c}\text { Amarelo } \\
\text { brunado }\end{array}$ \\
\hline & 2,0 a 2,5 & 10 YR & $(7 / 6)$ & $(7 / 6)$ & $\begin{array}{c}\text { Amarelo/alara } \\
\text { njado forte }\end{array}$ & $\begin{array}{c}\text { Amarelo/alara } \\
\text { njado forte }\end{array}$ \\
\hline & 2,5 a 3,0 & 10 YR & $(7 / 6)$ & $(7 / 6)$ & $\begin{array}{c}\text { Amarelo/alara } \\
\text { njado forte }\end{array}$ & $\begin{array}{c}\text { Amarelo/alara } \\
\text { njado forte }\end{array}$ \\
\hline & 3,0 a 3,5 & 10 YR & $(7 / 6)$ & $(7 / 6)$ & $\begin{array}{c}\text { Amarelo/alara } \\
\text { njado forte }\end{array}$ & $\begin{array}{c}\text { Amarelo/alara } \\
\text { njado forte }\end{array}$ \\
\hline & 3,5 a 4,0 & 10 YR & $(7 / 6)$ & $(7 / 6)$ & $\begin{array}{c}\text { Amarelo/alara } \\
\text { njado forte }\end{array}$ & $\begin{array}{c}\text { Amarelo/alara } \\
\text { njado forte }\end{array}$ \\
\hline
\end{tabular}

Tabela A7 - Matiz, valores de croma, e cor perfil P12.

\begin{tabular}{|c|c|c|c|c|c|c|}
\hline Perfil & Profundidade & Matiz & $\begin{array}{c}\text { Valor/Croma } \\
\text { (úmido) }\end{array}$ & $\begin{array}{c}\text { Valor/Croma } \\
\text { (seco) }\end{array}$ & Cor umida & Cor seca \\
\hline \multirow[t]{11}{*}{ P12 } & & $7,5 \mathrm{YR}$ & & & & \\
\hline & 0,0 a 0,5 & $7,5 \mathrm{YR}$ & $(6 / 6)$ & $(6 / 8)$ & $\begin{array}{c}\text { Bruno- } \\
\text { amarelado } \\
\text { claro }\end{array}$ & $\begin{array}{c}\text { Amarelo } \\
\text { avermelhado }\end{array}$ \\
\hline & 0,5 a 1,0 & $7,5 \mathrm{YR}$ & $(6 / 6)$ & $(6 / 8)$ & $\begin{array}{c}\text { Bruno- } \\
\text { amarelado } \\
\text { claro }\end{array}$ & $\begin{array}{c}\text { Amarelo } \\
\text { avermelhado }\end{array}$ \\
\hline & 1,0 a 1,5 & $7,5 \mathrm{YR}$ & $(6 / 6)$ & $(6 / 8)$ & $\begin{array}{c}\text { Bruno- } \\
\text { amarelado } \\
\text { claro }\end{array}$ & $\begin{array}{c}\text { Amarelo } \\
\text { avermelhado }\end{array}$ \\
\hline & 1,5 a 2,0 & $7,5 \mathrm{YR}$ & $(6 / 6)$ & (7/8) & $\begin{array}{c}\text { Bruno- } \\
\text { amarelado } \\
\text { claro }\end{array}$ & $\begin{array}{c}\text { Amarelo } \\
\text { avermelhado }\end{array}$ \\
\hline & 2,0 a 2,5 & $7,5 \mathrm{YR}$ & $(7 / 8)$ & $(7 / 8)$ & $\begin{array}{c}\text { Amarelo } \\
\text { avermelhado }\end{array}$ & $\begin{array}{c}\text { Amarelo } \\
\text { avermelhado }\end{array}$ \\
\hline & 2,5 a 3,0 & $7,5 \mathrm{YR}$ & $(7 / 8)$ & $(6 / 8)$ & $\begin{array}{c}\text { Amarelo } \\
\text { avermelhado }\end{array}$ & $\begin{array}{c}\text { Amarelo } \\
\text { avermelhado }\end{array}$ \\
\hline & 3,0 a 3,5 & $7,5 \mathrm{YR}$ & $(7 / 8)$ & $(7 / 8)$ & $\begin{array}{c}\text { Amarelo } \\
\text { avermelhado }\end{array}$ & $\begin{array}{c}\text { Amarelo } \\
\text { avermelhado }\end{array}$ \\
\hline & 3,5 a 4,0 & $7,5 \mathrm{YR}$ & $(7 / 8)$ & $(8 / 8)$ & $\begin{array}{c}\text { Amarelo } \\
\text { avermelhado }\end{array}$ & $\begin{array}{c}\text { Amarelo } \\
\text { avermelhado }\end{array}$ \\
\hline & 4,0 a 4,5 & $7,5 \mathrm{YR}$ & $(8 / 8)$ & $(8 / 4)$ & $\begin{array}{c}\text { Amarelo } \\
\text { avermelhado }\end{array}$ & Rosado \\
\hline & 4,5 a 5,0 & $7,5 \mathrm{YR}$ & $(8 / 8)$ & $(8 / 6)$ & $\begin{array}{c}\text { Amarelo } \\
\text { avermelhado }\end{array}$ & $\begin{array}{c}\text { Amarelo } \\
\text { avermelhado }\end{array}$ \\
\hline
\end{tabular}


Tabela A8 - Matiz, valores de croma, e cor perfil P13.

\begin{tabular}{|c|c|c|c|c|c|c|}
\hline Perfil & Profundidade & Matiz & $\begin{array}{l}\text { Valor/Croma } \\
\text { (úmido) }\end{array}$ & $\begin{array}{c}\text { Valor/Croma } \\
\text { (seco) }\end{array}$ & Cor umida & Cor seca \\
\hline \multirow[t]{11}{*}{$\mathbf{P 1 3}$} & & $10 \mathrm{YR}$ & & & & \\
\hline & $0,0 \mathrm{a} \mathrm{0,5}^{2}$ & $10 \mathrm{YR}$ & $(6 / 8)$ & $(5 / 8)$ & $\begin{array}{l}\text { Amarelo } \\
\text { brunado }\end{array}$ & $\begin{array}{c}\text { Bruno- } \\
\text { amarelado }\end{array}$ \\
\hline & 0,5 a 1,0 & $10 \mathrm{YR}$ & $(7 / 8)$ & $(6 / 8)$ & amarelo & $\begin{array}{l}\text { Amarelo } \\
\text { brunado }\end{array}$ \\
\hline & 1,0 a 1,5 & $10 \mathrm{YR}$ & $(6 / 8)$ & $(6 / 8)$ & $\begin{array}{l}\text { Amarelo } \\
\text { brunado }\end{array}$ & $\begin{array}{l}\text { Amarelo } \\
\text { brunado }\end{array}$ \\
\hline & 1,5 a 2,0 & $10 \mathrm{YR}$ & $(6 / 8)$ & $(6 / 8)$ & $\begin{array}{l}\text { Amarelo } \\
\text { brunado }\end{array}$ & $\begin{array}{l}\text { Amarelo } \\
\text { brunado }\end{array}$ \\
\hline & $2,0 \times 2,5$ & $10 \mathrm{YR}$ & $(6 / 8)$ & $(6 / 8)$ & $\begin{array}{l}\text { Amarelo } \\
\text { brunado }\end{array}$ & $\begin{array}{l}\text { Amarelo } \\
\text { brunado }\end{array}$ \\
\hline & $2,5 \mathrm{a} 3,0$ & $10 \mathrm{YR}$ & $(8 / 8)$ & $(7 / 6)$ & $\begin{array}{c}\text { Amarelo- } \\
\text { alaranjado } \\
\text { forte }\end{array}$ & amarelado \\
\hline & $3,0 \times \mathbf{a} 3,5$ & $10 \mathrm{YR}$ & $(8 / 8)$ & $(8 / 4)$ & $\begin{array}{c}\text { Amarelo- } \\
\text { alaranjado } \\
\text { forte }\end{array}$ & $\begin{array}{c}\text { Bruno muito } \\
\text { claro } \\
\text { acinzentado }\end{array}$ \\
\hline & 3,5 a 4,0 & $10 \mathrm{YR}$ & $(8 / 8)$ & $(8 / 4)$ & $\begin{array}{c}\text { Amarelo- } \\
\text { alaranjado } \\
\text { forte }\end{array}$ & $\begin{array}{c}\text { Bruno muito } \\
\text { claro } \\
\text { acinzentado }\end{array}$ \\
\hline & 4,0 a 4,5 & $10 \mathrm{YR}$ & $(8 / 8)$ & $(8 / 4)$ & $\begin{array}{c}\text { Amarelo- } \\
\text { alaranjado } \\
\text { forte }\end{array}$ & $\begin{array}{c}\text { Bruno muito } \\
\text { claro } \\
\text { acinzentado }\end{array}$ \\
\hline & 4,5 a 5,0 & $10 \mathrm{YR}$ & $(8 / 8)$ & $\overline{(8 / 4)}$ & $\begin{array}{c}\text { Amarelo- } \\
\text { alaranjado } \\
\text { forte }\end{array}$ & $\begin{array}{c}\text { Bruno muito } \\
\text { claro } \\
\text { acinzentado }\end{array}$ \\
\hline
\end{tabular}

Tabela A9 - Matiz, valores de croma e cor perfil P21.

\begin{tabular}{|c|c|c|c|c|c|c|}
\hline Perfil & Profundidade & Matiz & $\begin{array}{c}\text { Valor/Croma } \\
\text { (úmido) }\end{array}$ & $\begin{array}{c}\begin{array}{c}\text { Valor/Croma } \\
\text { (seco) }\end{array} \\
\end{array}$ & Cor umida & Cor seca \\
\hline \multirow[t]{10}{*}{$\mathbf{P 2 1}$} & & $10 \mathrm{YR}$ & & & & \\
\hline & 0,0 a 0,5 & $10 \mathrm{YR}$ & $(6 / 6)$ & $(6 / 8)$ & $\begin{array}{c}\text { Bruno } \\
\text { amarelado } \\
\text { claro }\end{array}$ & $\begin{array}{l}\text { Amarelo } \\
\text { brunado }\end{array}$ \\
\hline & 0,5 a 1,0 & 10YR & $(6 / 8)$ & (7/8) & $\begin{array}{l}\text { Amarelo } \\
\text { brunado }\end{array}$ & amarelo \\
\hline & 1,0 a 1,5 & $10 \mathrm{YR}$ & (7/8) & $(6 / 8)$ & amarelo & $\begin{array}{l}\text { Amarelo } \\
\text { brunado }\end{array}$ \\
\hline & 1,5 a 2,0 & 10YR & $(7 / 8)$ & $(7 / 8)$ & amarelo & Amarelo \\
\hline & 2,0 a 2,5 & $10 \mathrm{YR}$ & $(7 / 8)$ & $(8 / 6)$ & amarelo & Amarelo \\
\hline & 2,5 a 3,0 & $10 \mathrm{YR}$ & $(8 / 6)$ & $(8 / 4)$ & amarelo & $\begin{array}{c}\text { Bruno muito } \\
\text { claro } \\
\text { acinzentado }\end{array}$ \\
\hline & 3,0 a 3,5 & 10YR & $(8 / 6)$ & $(8 / 8)$ & amarelo & Amarelo \\
\hline & 3,5 a 4,0 & $10 \mathrm{YR}$ & $(8 / 8)$ & $(8 / / 4)$ & Amarelo & $\begin{array}{c}\text { Bruno muito } \\
\text { claro } \\
\text { acinzentado }\end{array}$ \\
\hline & 4,0 a 4,5 & $10 \mathrm{YR}$ & $(8 / 8)$ & $(8 / 4)$ & amarelo & $\begin{array}{c}\text { Bruno muito } \\
\text { claro } \\
\text { acinzentado }\end{array}$ \\
\hline
\end{tabular}


Tabela A10 - Matiz, valores de croma, e cor perfil P22.

\begin{tabular}{|c|c|c|c|c|c|}
\hline Perfil & Profundidade & $\overline{\text { Matiz }}$ & $\begin{array}{c}\text { Valor/Croma } \\
\text { (úmido) }\end{array}$ & $\begin{array}{c}\text { Valor/Croma } \\
\text { (seco) }\end{array}$ & Cor umida \\
\hline \multirow[t]{11}{*}{$\mathbf{P 2 2}$} & & $7,5 \mathrm{YR}$ & & & \\
\hline & 0,0 a 0,5 & $7,5 \mathrm{YR}$ & $(6 / 6)$ & $(6 / 8)$ & $\begin{array}{c}\text { Bruno } \\
\text { amarelado } \\
\text { claro }\end{array}$ \\
\hline & 0,5 a 1,0 & $7,5 \mathrm{YR}$ & (6/6) & $(5 / 8)$ & $\begin{array}{c}\text { Bruno } \\
\text { amarelado } \\
\text { claro }\end{array}$ \\
\hline & 1,0 a 1,5 & $7,5 \mathrm{YR}$ & $(6 / 6)$ & (6/8) & $\begin{array}{c}\text { Bruno } \\
\text { amarelado } \\
\text { claro }\end{array}$ \\
\hline & 1,5 a 2,0 & 7,5 YR & (6/8) & (5/8) & $\begin{array}{c}\text { Amarelo } \\
\text { avermelhado }\end{array}$ \\
\hline & 2,0 a 2,5 & $7,5 \mathrm{YR}$ & $(6 / 8)$ & $(6 / 8)$ & $\begin{array}{c}\text { Amarelo } \\
\text { avermelhado }\end{array}$ \\
\hline & 2,5 a 3,0 & 7,5 YR & (7/8) & (7/8) & $\begin{array}{c}\text { Amarelo } \\
\text { avermelhado }\end{array}$ \\
\hline & 3,0 a 3,5 & $7,5 \mathrm{YR}$ & (8/6) & $(8 / 4)$ & $\begin{array}{c}\text { Bruno } \\
\text { avermelhado }\end{array}$ \\
\hline & 3,5 a 4,0 & $7,5 \mathrm{YR}$ & (7/8) & $(8 / 6)$ & $\begin{array}{c}\text { Amarelo } \\
\text { avermelhado }\end{array}$ \\
\hline & 4,0 a 4,5 & 7,5 YR & $(8 / 6)$ & $(8 / 4)$ & $\begin{array}{c}\text { Amarelho } \\
\text { avermelhado }\end{array}$ \\
\hline & 4,5 a 5,0 & $7,5 \mathrm{YR}$ & $(8 / 6)$ & $(8 / 4)$ & $\begin{array}{c}\text { Amarelo } \\
\text { avermelado }\end{array}$ \\
\hline
\end{tabular}

Tabela A11 - Matiz, valores de croma, e cor perfil P23.

\begin{tabular}{|c|c|c|c|c|c|c|}
\hline Perfil & Profundidade & $\overline{\text { Matiz }}$ & $\begin{array}{c}\text { Vakor/Croma } \\
\text { (úmido) }\end{array}$ & $\begin{array}{c}\text { Valor/Croma } \\
\text { (seco) }\end{array}$ & Cor umida & Cor seca \\
\hline \multirow[t]{11}{*}{$\mathbf{P 2 3}$} & & $2,5 \mathrm{YR}$ & & & & \\
\hline & $0,0 \mathrm{a} 0,5$ & $2,5 \mathrm{YR}$ & $(4 / 6)$ & (5/8) & $\begin{array}{c}\text { Bruno } \\
\text { avermelhado }\end{array}$ & $\begin{array}{c}\text { Bruno forte } \\
\text { (brilhante) } \\
\text { vermelho }\end{array}$ \\
\hline & 0,5 a 1,0 & $2,5 \mathrm{YR}$ & $(4 / 6)$ & (5/8) & $\begin{array}{c}\text { Bruno } \\
\text { avermelhado }\end{array}$ & $\begin{array}{c}\text { Bruno forte } \\
\text { (brilhante) } \\
\text { vermelho }\end{array}$ \\
\hline & 1,0 a 1,5 & $2,5 \mathrm{YR}$ & $(5 / 6)$ & (5/8) & Bruno charo & $\begin{array}{l}\text { Bruno forte } \\
\text { (brilhante) } \\
\text { vermelho }\end{array}$ \\
\hline & 1,5 a 2,0 & $2,5 \mathrm{YR}$ & $(5 / 8)$ & (4/8) & $\begin{array}{l}\text { Bruno forte } \\
\text { (brilhante) } \\
\text { vermelho }\end{array}$ & $\begin{array}{c}\text { Bruno } \\
\text { avermelhado }\end{array}$ \\
\hline & $2,0 \times 2,5$ & $2,5 \mathrm{YR}$ & $(5 / 8)$ & $(4 / 8)$ & $\begin{array}{l}\text { Bruno forte } \\
\text { (brilhante) } \\
\text { vermelho }\end{array}$ & $\begin{array}{c}\text { Bruno } \\
\text { avermelhado }\end{array}$ \\
\hline & 2,5 a 3,0 & $2,5 \mathrm{YR}$ & (5/8) & (4/8) & $\begin{array}{l}\text { Bruno forte } \\
\text { (brilhante) } \\
\text { vermelho }\end{array}$ & $\begin{array}{c}\text { Bruno } \\
\text { avermelhado }\end{array}$ \\
\hline & 3,0 a 3,5 & $2,5 \mathrm{YR}$ & $(5 / 8)$ & (4/8) & $\begin{array}{l}\text { Bruno forte } \\
\text { (brilhante) } \\
\text { vermelho }\end{array}$ & $\begin{array}{l}\text { Bruno forte } \\
\text { (brilhante) } \\
\text { vermelho }\end{array}$ \\
\hline & 3,5 a 4,0 & $2,5 \mathrm{YR}$ & $(5 / 8)$ & $(5 / 8)$ & $\begin{array}{l}\text { Bruno forte } \\
\text { (brilhante) } \\
\text { vermelho }\end{array}$ & $\begin{array}{l}\text { Bruno forte } \\
\text { (brilhante) } \\
\text { vermelho }\end{array}$ \\
\hline & 4,0 a 4,5 & $2,5 \mathrm{YR}$ & $(5 / 8)$ & (5/8) & $\begin{array}{l}\text { Bruno forte } \\
\text { (brilhante) } \\
\text { vermelho }\end{array}$ & $\begin{array}{c}\text { Bruno } \\
\text { avermelhado }\end{array}$ \\
\hline & 4,5 a 5,0 & $2,5 \mathrm{YR}$ & (5/8) & (4/8) & $\begin{array}{c}\text { Vermelho } \\
\text { claro }\end{array}$ & Bruno claro \\
\hline
\end{tabular}


Tabela A12 - Matiz, valores de croma, e cor perfil P31.

\begin{tabular}{|c|c|c|c|c|c|c|}
\hline Perfil & Profundidade & Matiz & $\begin{array}{c}\text { Valor/Croma } \\
\text { (úmido) }\end{array}$ & $\begin{array}{c}\text { Valor/Croma } \\
\text { (seco) }\end{array}$ & Cor umida & Cor seca \\
\hline P31 & & 5 YR & & & & \\
\hline & 0,0 a 0,5 & 5 YR & $(5 / 6)$ & $(4 / 6)$ & $\begin{array}{c}\text { Bruno } \\
\text { amarelado }\end{array}$ & $\begin{array}{c}\text { Bruno } \\
\text { avermelhado }\end{array}$ \\
\hline & 0,5 a 1,0 & 5 YR & $(6 / 6)$ & $(5 / 8)$ & $\begin{array}{c}\text { Amarelo } \\
\text { avermelhado }\end{array}$ & $\begin{array}{c}\text { Vermelho } \\
\text { amarelado }\end{array}$ \\
\hline & 1,0 a 1,5 & 5 YR & $(5 / 8)$ & $(5 / 8)$ & $\begin{array}{c}\text { Vermelho } \\
\text { amarelado }\end{array}$ & $\begin{array}{c}\text { Vermelho } \\
\text { amarelado }\end{array}$ \\
\hline & 1,5 a 2,0 & $5 Y R$ & $(5 / 8)$ & $(5 / 8)$ & $\begin{array}{c}\text { Vermelho } \\
\text { amarelado }\end{array}$ & $\begin{array}{c}\text { Vermelho } \\
\text { amarelado }\end{array}$ \\
\hline & 2,0 a 2,5 & $5 Y R$ & $(4 / 8)$ & $(3 / 6)$ & Bruno forte & $\begin{array}{c}\text { Bruno } \\
\text { avermelhado } \\
\text { escuro }\end{array}$ \\
\hline
\end{tabular}

Tabela A13 - Matiz, valores de croma, e cor perfil P32.

\begin{tabular}{|c|c|c|c|c|c|c|}
\hline Perfil & Profundidade & Matiz & $\begin{array}{c}\text { Valor/Croma } \\
\text { (úmido) }\end{array}$ & $\begin{array}{c}\text { Valor/Croma } \\
\text { (seco) }\end{array}$ & Cor umida & Cor seca \\
\hline \multirow[t]{11}{*}{$\mathbf{P 3 2}$} & & $10 \mathrm{YR}$ & & & & \\
\hline & 0,0 a 0,5 & $10 \mathrm{YR}$ & $(6 / 8)$ & $(5 / 8)$ & $\begin{array}{l}\text { Amarelo } \\
\text { brunado }\end{array}$ & $\begin{array}{c}\text { Bruno } \\
\text { amarelado }\end{array}$ \\
\hline & 0,5 a 1,0 & $10 \mathrm{YR}$ & $(6 / 8)$ & $(5 / 8)$ & $\begin{array}{l}\text { Amarelo } \\
\text { brunado }\end{array}$ & $\begin{array}{c}\text { Bruno } \\
\text { amarelado }\end{array}$ \\
\hline & 1,0 a 1,5 & $10 \mathrm{YR}$ & $(7 / 8)$ & $(6 / 6)$ & amarelo & $\begin{array}{l}\text { Amarelo } \\
\text { brunado }\end{array}$ \\
\hline & 1,5 a 2,0 & $10 \mathrm{YR}$ & $(8 / 8)$ & $(7 / 6)$ & amarelo & amarelo \\
\hline & 2,0 a 2,5 & $10 \mathrm{YR}$ & $(8 / 8)$ & $(8 / 4)$ & amarelo & $\begin{array}{c}\text { Bruno muito } \\
\text { claro } \\
\text { acinzentado }\end{array}$ \\
\hline & 2,5 a 3,0 & $10 \mathrm{YR}$ & $(8 / 8)$ & $(8 / 4)$ & amarelo & $\begin{array}{c}\text { Bruno muito } \\
\text { claro } \\
\text { acinzentado }\end{array}$ \\
\hline & 3,0 a 3,5 & $10 \mathrm{YR}$ & $(8 / 6)$ & $(8 / 4)$ & Amarelo & $\begin{array}{c}\text { Bruno muito } \\
\text { claro } \\
\text { acinzentado }\end{array}$ \\
\hline & 3,5 a 4,0 & $10 \mathrm{YR}$ & $(8 / 6)$ & $(8 / 4)$ & Amarelo & $\begin{array}{c}\text { Bruno muito } \\
\text { claro } \\
\text { acinzentado }\end{array}$ \\
\hline & 4,0 a 4,5 & $10 \mathrm{YR}$ & $(8 / 6)$ & $(8 / 4)$ & Amarelo & $\begin{array}{c}\text { Bruno muito } \\
\text { claro } \\
\text { acinzentado }\end{array}$ \\
\hline & 4,5 a 5,0 & $10 \mathrm{YR}$ & $(8 / 6)$ & $(8 / 4)$ & amarelo & $\begin{array}{c}\text { Bruno muito } \\
\text { claro } \\
\text { acinzentado }\end{array}$ \\
\hline
\end{tabular}


Tabela A14 - Matiz, valores de croma, e cor perfil P33.

\begin{tabular}{|c|c|c|c|c|c|c|}
\hline Perfil & Profundidade & Matiz & $\begin{array}{l}\text { Valor/Croma } \\
\text { (úmido) }\end{array}$ & $\begin{array}{c}\text { Valor/Croma } \\
\text { (seco) }\end{array}$ & Cor umida & Cor seca \\
\hline \multirow[t]{11}{*}{$\overline{\mathbf{P 3 3}}$} & & $7,5 \mathrm{YR}$ & & & & \\
\hline & $\overline{0,0}$ a 0,5 & $7,5 \mathrm{YR}$ & $(4 / 3)$ & $(4 / 2)$ & $\begin{array}{c}\text { Bruno } \\
\text { acinzentado }\end{array}$ & $\begin{array}{c}\text { Bruno } \\
\text { acinzentado }\end{array}$ \\
\hline & 0,5 a 1,0 & $7,5 \mathrm{YR}$ & $(4 / 4)$ & $(4 / 6)$ & $\begin{array}{c}\text { Bruno } \\
\text { amarelo }\end{array}$ & $\begin{array}{c}\text { Bruno } \\
\text { amarelo }\end{array}$ \\
\hline & 1,0 a 1,5 & $7,5 \mathrm{YR}$ & $(5 / 6)$ & $(5 / 6)$ & bruno amarelo & $\begin{array}{c}\text { Bruno } \\
\text { amarelo }\end{array}$ \\
\hline & 1,5 a 2,0 & $7,5 \mathrm{YR}$ & $(6 / 6)$ & $(6 / 6)$ & $\begin{array}{c}\text { Bruno } \\
\text { amarelado } \\
\text { claro }\end{array}$ & $\begin{array}{c}\text { Bruno } \\
\text { amarelado } \\
\text { claro }\end{array}$ \\
\hline & 2,0 a 2,5 & $7,5 \mathrm{YR}$ & $(6 / 6)$ & $(6 / 6)$ & $\begin{array}{c}\text { Bruno } \\
\text { amarelado } \\
\text { claro }\end{array}$ & $\begin{array}{c}\text { Bruno } \\
\text { amarelado } \\
\text { claro }\end{array}$ \\
\hline & 2,5 a 3,0 & $7,5 \mathrm{YR}$ & $(6 / 8)$ & $(5 / 8)$ & \begin{tabular}{|c|} 
Amarelo \\
avermelhado
\end{tabular} & Bruno forte \\
\hline & $3,0 \times 3,5$ & $7,5 \mathrm{YR}$ & $(5 / 8)$ & $(5 / 8)$ & Bruno forte & Bruno forte \\
\hline & 3,5 a 4,0 & $7,5 \mathrm{YR}$ & $(5 / 8)$ & $(5 / 8)$ & Bruno forte & Bruno forte \\
\hline & 4,0 a 4,5 & $7,5 \mathrm{YR}$ & $(6 / 8)$ & $(7 / 6)$ & \begin{tabular}{|c|} 
Amarelo \\
avermelhado
\end{tabular} & $\begin{array}{c}\text { Amarelo } \\
\text { avermelhado }\end{array}$ \\
\hline & 4,5 a 5,0 & $7,5 \mathrm{YR}$ & $(6 / 8)$ & $(5 / 8)$ & $\begin{array}{c}\text { Amarelo } \\
\text { avermelhado }\end{array}$ & Bruno forte \\
\hline
\end{tabular}

Tabela A15 - Matiz, valores de croma, e cor perfil P41.

\begin{tabular}{|c|c|c|c|c|c|c|}
\hline Perfil & Profundidade & Matiz & $\begin{array}{c}\text { Valor/Croma } \\
\text { (úmido) }\end{array}$ & $\begin{array}{c}\text { Valor/Croma } \\
\text { (seco) }\end{array}$ & Cor umida & Cor seca \\
\hline P41 & 0,0 a 0,5 & 5 YR & $(5 / 3)$ & $(5 / 3)$ & $\begin{array}{c}\text { Brino } \\
\text { avermelhado }\end{array}$ & $\begin{array}{c}\text { Bruno } \\
\text { avermelhado }\end{array}$ \\
\hline & 0,5 a 1,0 & 5 YR & $(5 / 6)$ & $(5 / 6)$ & $\begin{array}{c}\text { Vermelho } \\
\text { amarelado }\end{array}$ & $\begin{array}{c}\text { Vermelho } \\
\text { amarelado }\end{array}$ \\
\hline & 1,0 a 1,5 & 5 YR & $(5 / 8)$ & $(5 / 6)$ & $\begin{array}{c}\text { Vermelho } \\
\text { amarelado }\end{array}$ & $\begin{array}{c}\text { Vermelho } \\
\text { amarelado }\end{array}$ \\
\hline & 1,5 a 2,0 & 5 YR & $(5 / 8)$ & $(6 / 6)$ & $\begin{array}{c}\text { Vermelho } \\
\text { amarelado }\end{array}$ & $\begin{array}{c}\text { Amarelo } \\
\text { avermelhado }\end{array}$ \\
\hline & 2,0 a 2,5 & 5 YR & $(5 / 8)$ & $(6 / 6)$ & $\begin{array}{c}\text { Vermelho } \\
\text { amarelado }\end{array}$ & $\begin{array}{c}\text { Amarelo } \\
\text { avermelhado }\end{array}$ \\
\hline & 2,5 a 3,0 & 5 YR & $(5 / 8)$ & $(6 / 8)$ & $\begin{array}{c}\text { Vermelho } \\
\text { amarelado }\end{array}$ & $\begin{array}{c}\text { Amarelo } \\
\text { avermelhado }\end{array}$ \\
\hline & 3,0 a 3,5 & 5 YR & $(5 / 8)$ & $(6 / 8)$ & $\begin{array}{c}\text { Vermelho } \\
\text { amarelado }\end{array}$ & $\begin{array}{c}\text { Amarelo } \\
\text { avermelhado }\end{array}$ \\
\hline & 3,5 a 4,0 & 5 YR & $(6 / 8)$ & $-(6 / 8)$ & $\begin{array}{c}\text { Amarelo } \\
\text { avermelhado }\end{array}$ & $\begin{array}{c}\text { Amarelo } \\
\text { avermelhado }\end{array}$ \\
\hline & 4,0 a 4,5 & 5 YR & $(7 / 6)$ & $(8 / 4)$ & $\begin{array}{c}\text { Amarelo } \\
\text { avermelhado }\end{array}$ & rosado \\
\hline
\end{tabular}


Tabela A16 - Matiz, valores de croma, e cor perfil P42.

\begin{tabular}{|c|c|c|c|c|c|c|}
\hline Perfil & Profundidade & Matiz & $\begin{array}{c}\text { Valor/Croma } \\
\text { (úmido) }\end{array}$ & $\begin{array}{c}\text { Valor/Croma } \\
\text { (seco) }\end{array}$ & Cor umida & Cor seca \\
\hline \multirow[t]{7}{*}{$\mathbf{P 4 2}$} & & $10 \mathrm{YR}$ & & & & \\
\hline & 0,0 a 0,5 & $10 Y R$ & $(5 / 8)$ & $(5 / 6)$ & $\begin{array}{c}\text { Bruno } \\
\text { amarelado }\end{array}$ & $\begin{array}{c}\text { Bruno } \\
\text { amarehdo }\end{array}$ \\
\hline & 0,5 a 1,0 & $10 Y R$ & $(6 / 8)$ & $(5 / 8)$ & $\begin{array}{l}\text { Amarelo } \\
\text { brunado }\end{array}$ & $\begin{array}{c}\text { Bruno } \\
\text { amarelado }\end{array}$ \\
\hline & 1,0 a 1,5 & $10 \mathrm{YR}$ & (7/8) & $(6 / 8)$ & Amarelo & $\begin{array}{l}\text { Amarelo } \\
\text { brunado }\end{array}$ \\
\hline & 1,5 a 2,0 & $10 \mathrm{YR}$ & $(7 / 8)$ & $(7 / 6)$ & Amarelo & Amarelo \\
\hline & 2,0 a 2,5 & $10 \mathrm{YR}$ & $(7 / 8)$ & $(8 / 4)$ & amarelo & $\begin{array}{c}\text { Bruno muito } \\
\text { claro } \\
\text { acinzentado }\end{array}$ \\
\hline & 2,5 a 3,0 & $10 \mathrm{YR}$ & $(8 / 4)$ & $(8 / 4)$ & $\begin{array}{c}\text { Bruno muito } \\
\text { claro } \\
\text { acinzentado }\end{array}$ & $\begin{array}{c}\text { Bruno muito } \\
\text { claro } \\
\text { acinzentado }\end{array}$ \\
\hline
\end{tabular}

Tabela A17 - Matiz, valores de croma, e cor perfil P43.

\begin{tabular}{|c|c|c|c|c|c|c|}
\hline Perfil & Profundidade & Matiz & $\begin{array}{c}\text { Valor/Croma } \\
\text { (úmido) }\end{array}$ & $\begin{array}{c}\text { Valor/Croma } \\
\text { (seco) }\end{array}$ & Cor umida & Cor seca \\
\hline P43 & & $10 \mathrm{YR}$ & & & & \\
\hline & 0,0 a 0,5 & $10 \mathrm{YR}$ & $(5 / 6)$ & $(5 / 4)$ & $\begin{array}{c}\text { Bruno } \\
\text { amarelado }\end{array}$ & $\begin{array}{c}\text { Bruno } \\
\text { amarelado }\end{array}$ \\
\hline & 0,5 a 1,0 & $10 \mathrm{YR}$ & $(6 / 8)$ & $(6 / 6)$ & $\begin{array}{c}\text { Amarelo } \\
\text { brunado }\end{array}$ & $\begin{array}{c}\text { Amarelo } \\
\text { brunado }\end{array}$ \\
\hline & 1,0 a 1,5 & $10 \mathrm{YR}$ & $(6 / 8)$ & $(6 / 6)$ & $\begin{array}{c}\text { Amarelo } \\
\text { brunado }\end{array}$ & $\begin{array}{c}\text { Amarelo } \\
\text { brunado }\end{array}$ \\
\hline & 1,5 a 2,0 & $10 \mathrm{YR}$ & $(7 / 8)$ & $(7 / 6)$ & amarelo & amarelo \\
\hline & 2,0 a 2,5 & $10 \mathrm{YR}$ & $(7 / 6)$ & $(6 / 8)$ & Amarelo & $\begin{array}{c}\text { Amarelo } \\
\text { brunado }\end{array}$ \\
\hline & 2,5 a 3,0 & $10 \mathrm{YR}$ & $(7 / 6)$ & $(6 / 8)$ & amarelo & $\begin{array}{c}\text { Amarelo } \\
\text { brunado }\end{array}$ \\
\hline
\end{tabular}

Tabela A18 - Matiz, valores de croma, e cor perfil P51.

\begin{tabular}{|c|c|c|c|c|c|c|}
\hline Perfil & Profundidade & Matiz & $\begin{array}{c}\text { Valor/Croma } \\
\text { (úmido) }\end{array}$ & $\begin{array}{c}\text { Valor/Croma } \\
\text { (seco) }\end{array}$ & Cor umida & Cor seca \\
\hline P51 & 0,0 a 0,5 & 5 YR & $(5 / 6)$ & $(6 / 6)$ & Bruno claro & Bruno claro \\
\hline & 0,5 a 1,0 & 5 YR & $(6 / 6)$ & $(6 / 8)$ & Bruno claro & $\begin{array}{c}\text { Amarelo } \\
\text { avermelhado }\end{array}$ \\
\hline & 1,0 a 1,5 & 5 YR & $(6 / 6)$ & $6 / 8)$ & $\begin{array}{c}\text { Amarelo } \\
\text { avermelhado }\end{array}$ & $\begin{array}{c}\text { Amarelo } \\
\text { avermelhado }\end{array}$ \\
\hline & 1,5 a 2,0 & 5 YR & $(6 / 6)$ & $(6 / 6)$ & $\begin{array}{c}\text { Amarelo } \\
\text { avermelhado }\end{array}$ & $\begin{array}{c}\text { Amarelo } \\
\text { avermelhado }\end{array}$ \\
\hline & 2,0 a 2,5 & 5 YR & $(5 / 8)$ & $(5 / 6)$ & $\begin{array}{c}\text { Vermelho } \\
\text { amarelado }\end{array}$ & $\begin{array}{c}\text { Vermelho } \\
\text { amarelado }\end{array}$ \\
\hline & 2,5 a 3,0 & 5 YR & $(5 / 8)$ & $(5 / 6)$ & $\begin{array}{c}\text { Vermelho } \\
\text { amarelado }\end{array}$ & $\begin{array}{c}\text { Vermelho } \\
\text { amarelado }\end{array}$ \\
\hline & 3,0 a 3,5 & 5 YR & $(6 / 6)$ & $(5 / 8)$ & $\begin{array}{c}\text { Amarelo } \\
\text { avermelhado }\end{array}$ & $\begin{array}{c}\text { Vermelho } \\
\text { amarelado }\end{array}$ \\
\hline & 3,5 a 4,0 & 5 YR & $(6 / 6)$ & $(6 / 8)$ & $\begin{array}{c}\text { Amarelo } \\
\text { avermelhado }\end{array}$ & $\begin{array}{c}\text { Amarelo } \\
\text { avermelhado }\end{array}$ \\
\hline & 4,0 a 4,5 & 5 YR & $(6 / 6)$ & $(6 / 8)$ & $\begin{array}{c}\text { Amarelo } \\
\text { avermelhado }\end{array}$ & $\begin{array}{c}\text { Amarelo } \\
\text { avermelhado }\end{array}$ \\
\hline & 4,5 a 5,0 & 5 YR & $(6 / 6)$ & $(6 / 8)$ & $\begin{array}{c}\text { Amarelo } \\
\text { avermelhado }\end{array}$ & $\begin{array}{c}\text { Amarelo } \\
\text { avermelhado }\end{array}$ \\
\hline
\end{tabular}


Tabela A19 - Matiz, valores de croma, e cor perfil P52.

\begin{tabular}{|c|c|c|c|c|c|c|}
\hline Perfil & Profundidade & Matiz & $\begin{array}{c}\text { Valor/Croma } \\
\text { (úmido) }\end{array}$ & $\begin{array}{c}\text { Valor/Croma } \\
\text { (seco) }\end{array}$ & Cor umida & Cor seca \\
\hline \multirow[t]{11}{*}{$\overline{\text { P52 }}$} & & $10 \mathrm{YR}$ & & & & \\
\hline & 0,0 a 0,5 & $10 \mathrm{YR}$ & $(4 / 6)$ & $(4 / 6)$ & $\begin{array}{c}\text { bruno } \\
\text { amarelado }\end{array}$ & $\begin{array}{c}\text { Bruno } \\
\text { amarelado }\end{array}$ \\
\hline & 0,5 a 1,0 & $10 \mathrm{YR}$ & $(5 / 8)$ & $(5 / 8)$ & $\begin{array}{c}\text { Bruno } \\
\text { amarelado }\end{array}$ & $\begin{array}{c}\text { Bruno } \\
\text { amarelado }\end{array}$ \\
\hline & 1,0 a 1,5 & $10 \mathrm{YR}$ & $(6 / 6)$ & $(6 / 6)$ & $\begin{array}{l}\text { Amarelo } \\
\text { brunado }\end{array}$ & $\begin{array}{l}\text { Amarelo } \\
\text { brunado }\end{array}$ \\
\hline & 1,5 a 2,0 & $10 \mathrm{YR}$ & $(6 / 6)$ & $(6 / 6)$ & $\begin{array}{l}\text { Amarelo } \\
\text { brunado }\end{array}$ & $\begin{array}{l}\text { Amarelo } \\
\text { brunado }\end{array}$ \\
\hline & 2,0 a 2,5 & $10 \mathrm{YR}$ & $(8 / 4)$ & $(8 / 4)$ & $\begin{array}{c}\text { Bruno muito } \\
\text { claro } \\
\text { /acizentado }\end{array}$ & $\begin{array}{l}\text { Bruno muito } \\
\text { claro } \\
\text { /acizentado }\end{array}$ \\
\hline & 2,5 a 3,0 & $10 \mathrm{YR}$ & $(8 / 4)$ & $(8 / 4)$ & $\begin{array}{c}\text { Bruno muito } \\
\text { claro } \\
\text { /acizentado }\end{array}$ & $\begin{array}{l}\text { Bruno muito } \\
\text { claro } \\
\text { /acizentado }\end{array}$ \\
\hline & 3,0 a 3,5 & $10 \mathrm{YR}$ & $(8 / 4)$ & $(8 / 4)$ & $\begin{array}{c}\text { Bruno muito } \\
\text { claro } \\
\text { /acizentado }\end{array}$ & $\begin{array}{l}\text { Bruno muito } \\
\text { claro } \\
\text { /acizentado }\end{array}$ \\
\hline & 3,5 a 4,0 & $10 \mathrm{YR}$ & $(8 / 4)$ & $(8 / 4)$ & $\begin{array}{c}\text { Bruno muito } \\
\text { claro } \\
\text { /acizentado }\end{array}$ & $\begin{array}{l}\text { Bruno muito } \\
\text { claro } \\
\text { /acizentado }\end{array}$ \\
\hline & 4,0 a 4,5 & $10 \mathrm{YR}$ & $(8 / 4)$ & $(8 / 4)$ & $\begin{array}{c}\text { Bruno muito } \\
\text { claro } \\
\text { /acizentado }\end{array}$ & $\begin{array}{c}\text { Bruno muito } \\
\text { claro } \\
\text { /acizentado }\end{array}$ \\
\hline & 4,5 a 5,0 & $10 \mathrm{YR}$ & $(8 / 4)$ & $(8 / 4)$ & $\begin{array}{c}\text { Bruno muito } \\
\text { claro } \\
\text { /acizentado }\end{array}$ & $\begin{array}{c}\text { Bruno muito } \\
\text { claro } \\
\text { /acizentado }\end{array}$ \\
\hline
\end{tabular}

Tabela A20 - Matiz, valores de croma, e cor perfil P53.

\begin{tabular}{|c|c|c|c|c|c|c|}
\hline Perfil & Profundidade & Matiz & $\begin{array}{c}\text { Valor/Croma } \\
\text { (úmido) }\end{array}$ & $\begin{array}{c}\text { Valor/Croma } \\
\text { (seco) }\end{array}$ & Cor úmida & Cor seca \\
\hline \multirow[t]{10}{*}{ P53 } & & $10 \mathrm{YR}$ & & & & \\
\hline & 0,0 a 0,5 & $10 \mathrm{YR}$ & $(4 / 6)$ & $(5 / 6)$ & $\begin{array}{c}\text { Bruno } \\
\text { amarelado }\end{array}$ & $\begin{array}{c}\text { Bruno } \\
\text { amarelado }\end{array}$ \\
\hline & 0,5 a 1,0 & 10YR & $(6 / 8)$ & $(6 / 8)$ & $\begin{array}{l}\text { Amarelo } \\
\text { brunado }\end{array}$ & $\begin{array}{l}\text { Amarelo } \\
\text { brunado }\end{array}$ \\
\hline & 1,0 a 1,5 & 10YR & $(6 / 6)$ & $(7 / 6)$ & $\begin{array}{l}\text { Amarelo } \\
\text { brunado }\end{array}$ & Amarelo \\
\hline & $1,5 \mathrm{a} \mathrm{2,0}$ & 10YR & $(7 / 8)$ & $(8 / 6)$ & amarelo & Amarelo \\
\hline & 2,0 a 2,5 & 10YR & $(8 / 6)$ & $(8 / 4)$ & amarelo & $\begin{array}{c}\text { Bruno muito } \\
\text { claro } \\
\text { acinzentado }\end{array}$ \\
\hline & 2,5 a 3,0 & 10YR & $(8 / 6)$ & $(8 / 4)$ & amarelo & $\begin{array}{c}\text { Bruno muito } \\
\text { claro } \\
\text { acinzentado }\end{array}$ \\
\hline & 3,0 a 3,5 & 10YR & $(8 / 4)$ & $(8 / 4)$ & $\begin{array}{c}\text { Bruno muito } \\
\text { claro } \\
\text { acinzentado }\end{array}$ & $\begin{array}{c}\text { Bruno muito } \\
\text { claro } \\
\text { acinzentado }\end{array}$ \\
\hline & 3,5 a 4,0 & 10YR & $(8 / 4)$ & $(8 / 4)$ & $\begin{array}{c}\text { Bruno muito } \\
\text { claro } \\
\text { acinzentado }\end{array}$ & $\begin{array}{c}\text { Bruno muito } \\
\text { claro } \\
\text { acinzentado }\end{array}$ \\
\hline & 4,0 a 4,5 & 10YR & $(8 / 4)$ & $(8 / 4)$ & $\begin{array}{c}\text { Bruno muito } \\
\text { claro } \\
\text { acinzentado }\end{array}$ & $\begin{array}{c}\text { Bruno muito } \\
\text { claro } \\
\text { acinzentado }\end{array}$ \\
\hline
\end{tabular}




\section{ANEXO B}

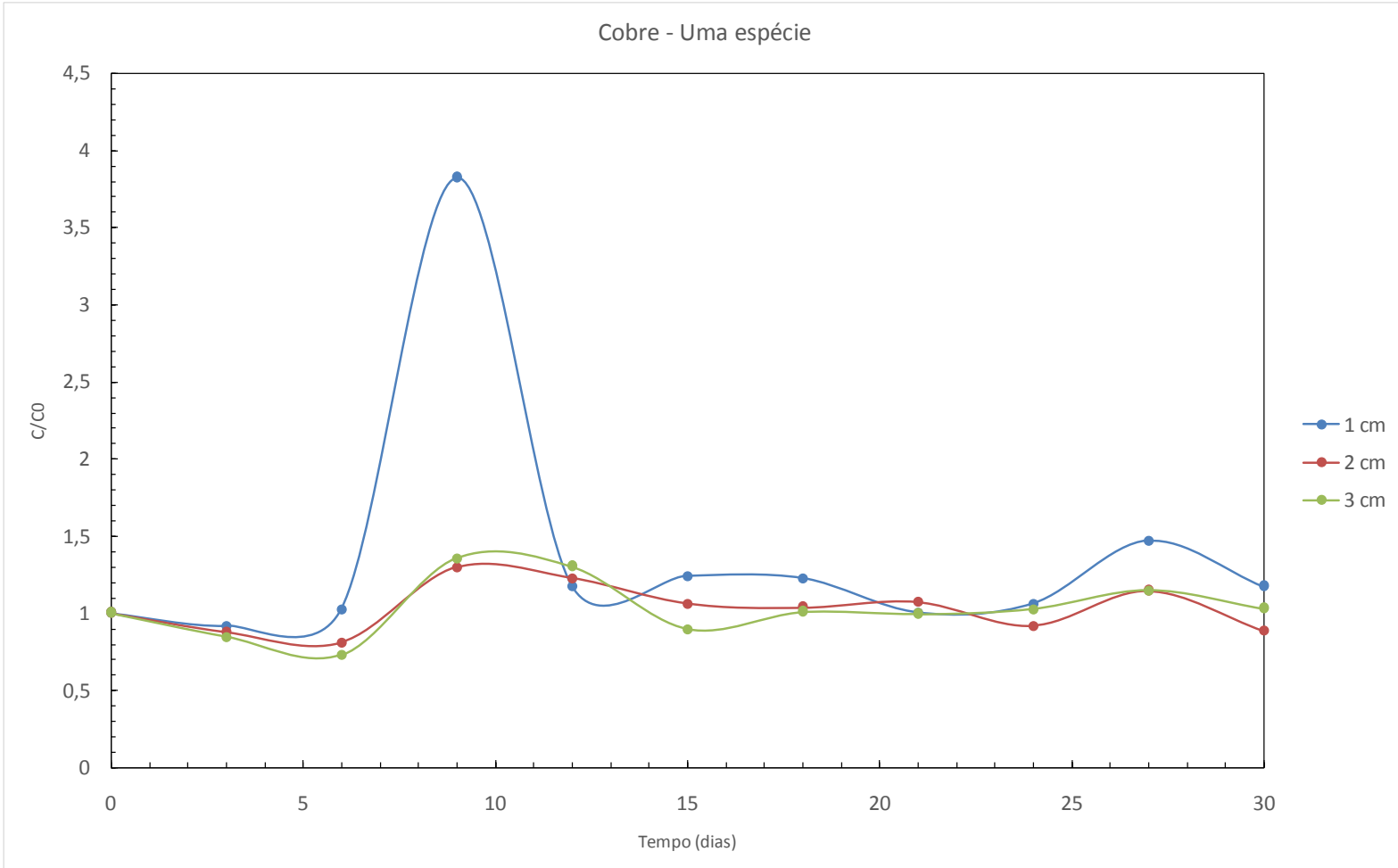

Figura B1 - Comportamento do cobre no corpo de prova (não saturado).

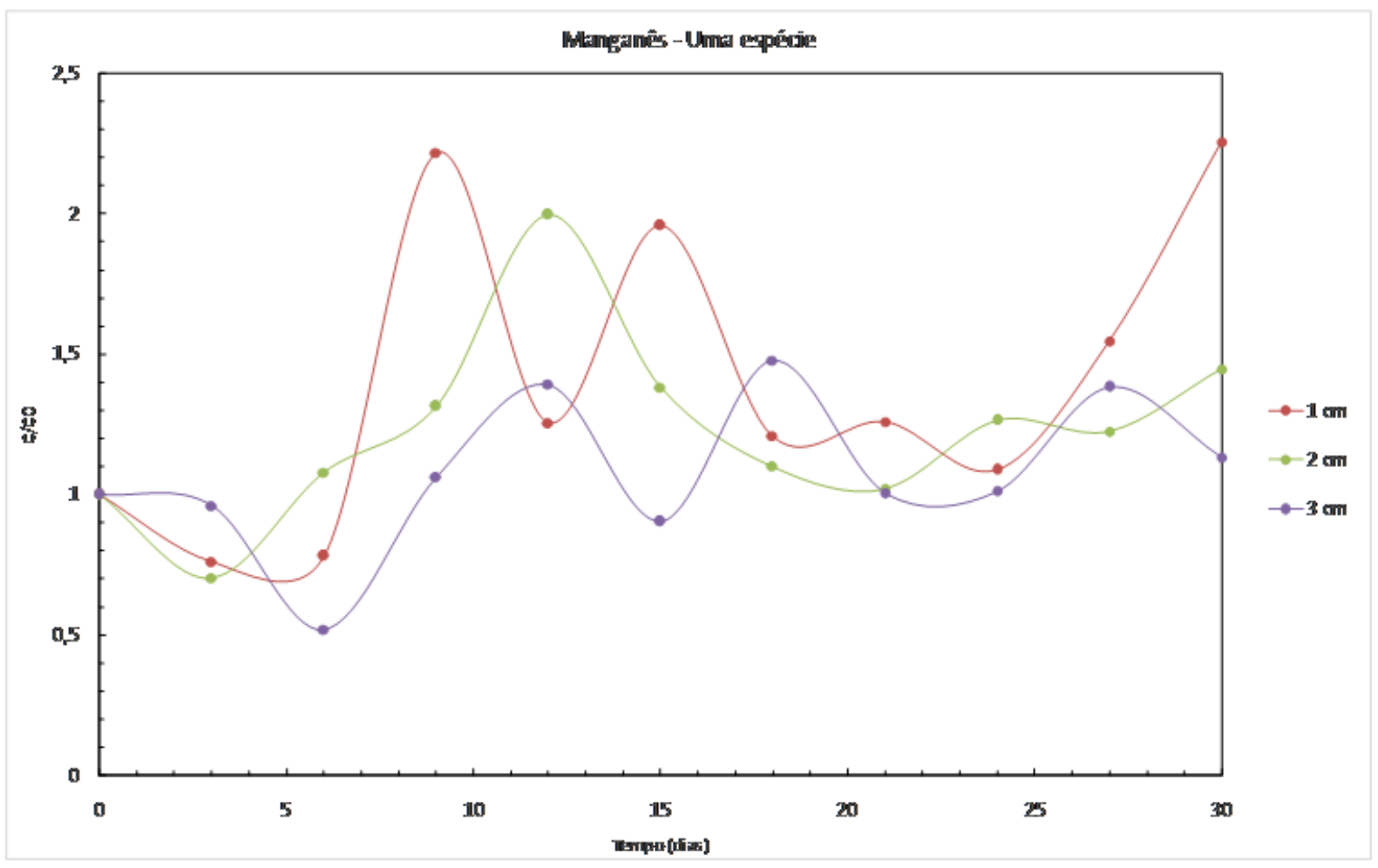

Figura B2 - Comportamento do manganês no corpo de prova (não saturado). 


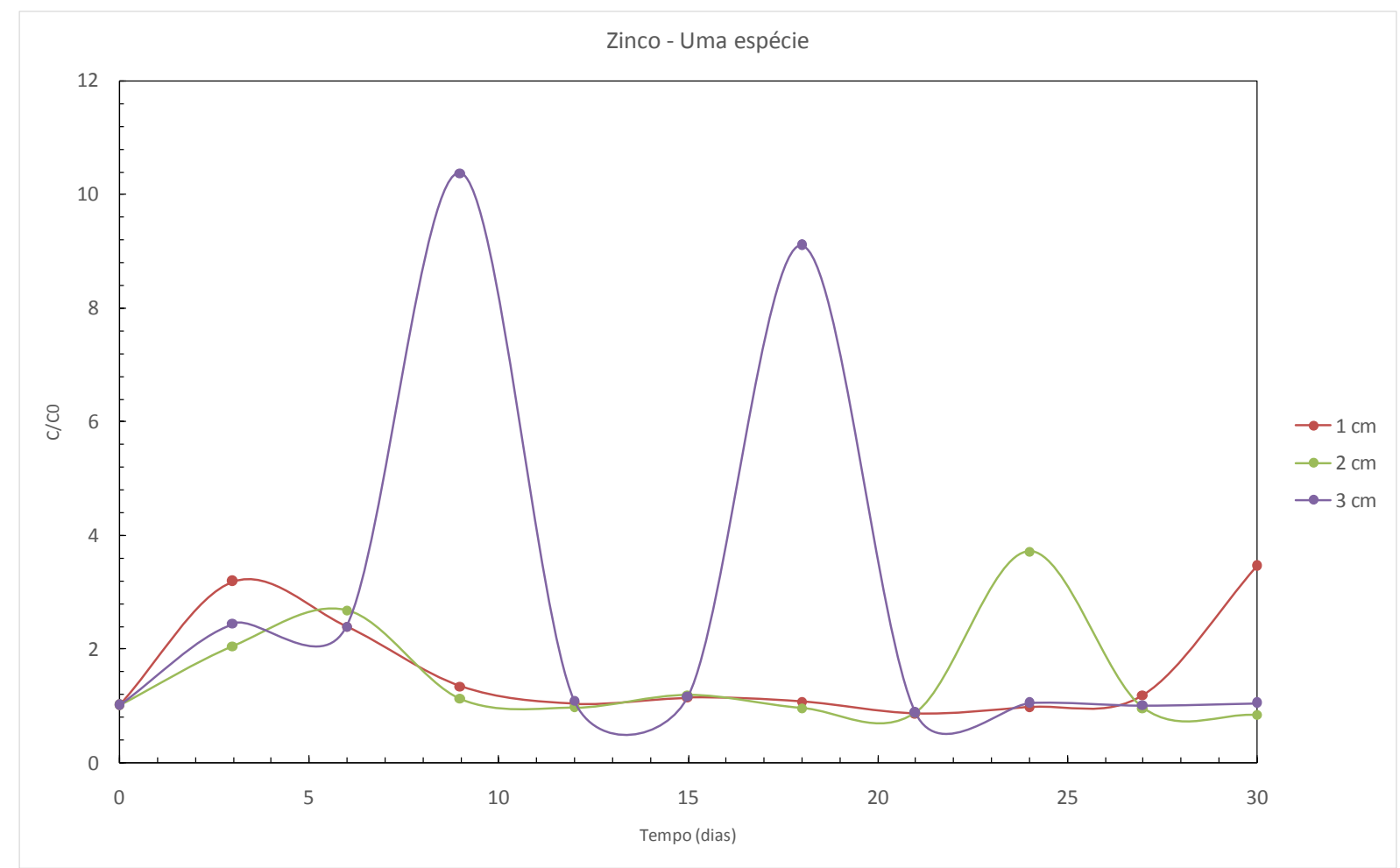

Figura B3 - Comportamento do zinco no corpo de prova (não saturado).

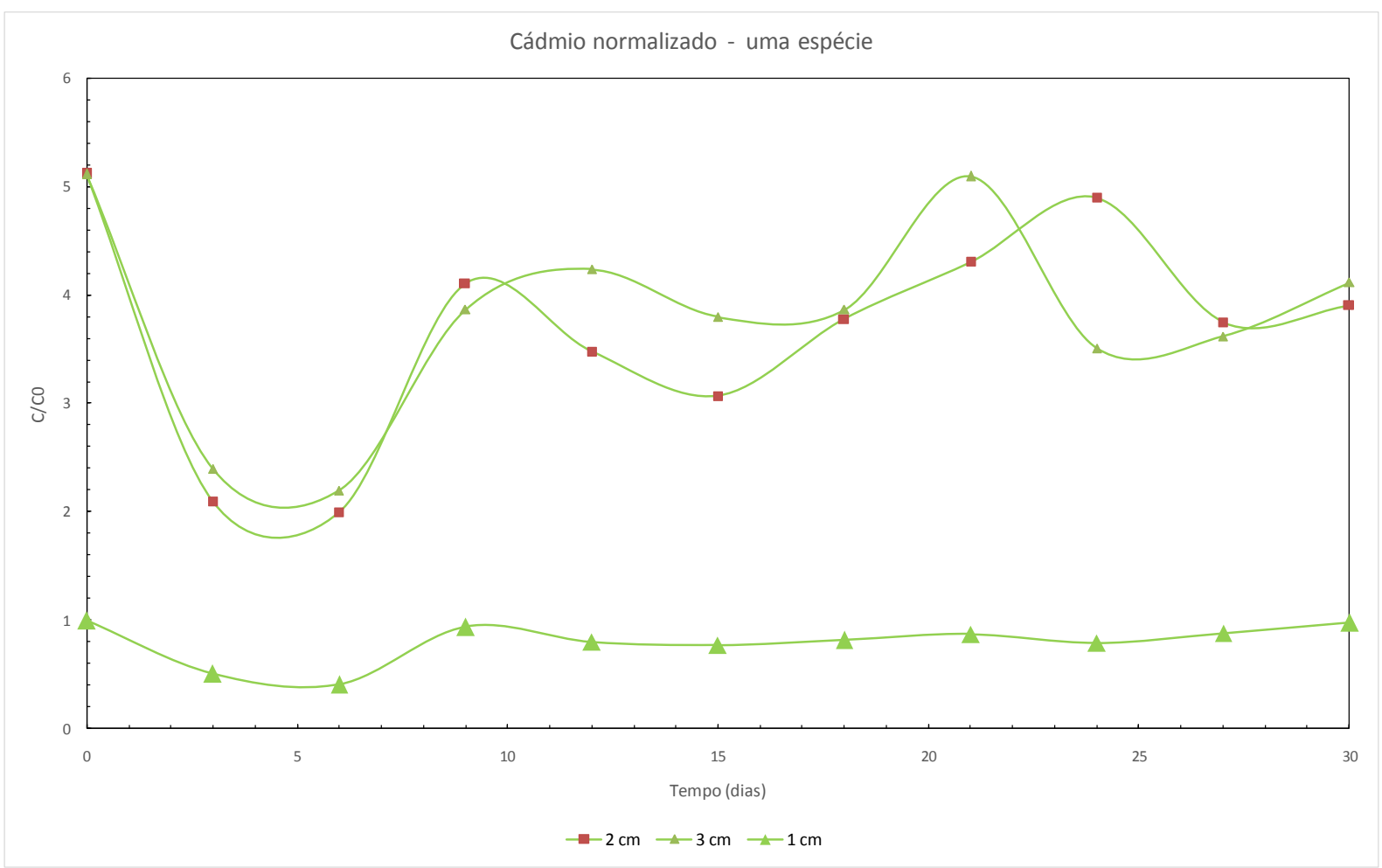

Figura B4 - Comportamento do cádmio no corpo de prova (não saturado). 


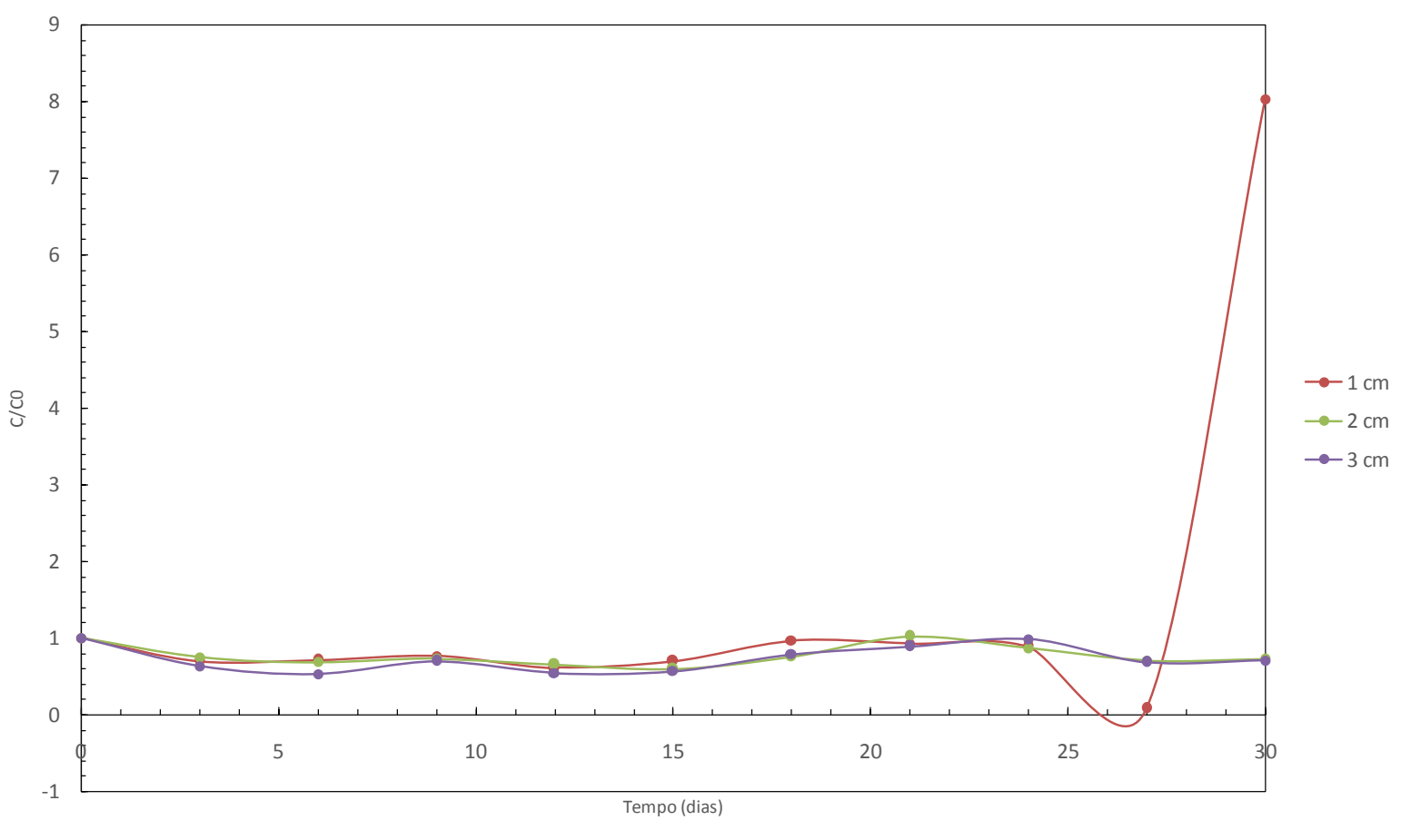

Figura B5 - Comportamento do níquel no corpo de prova (não saturado).

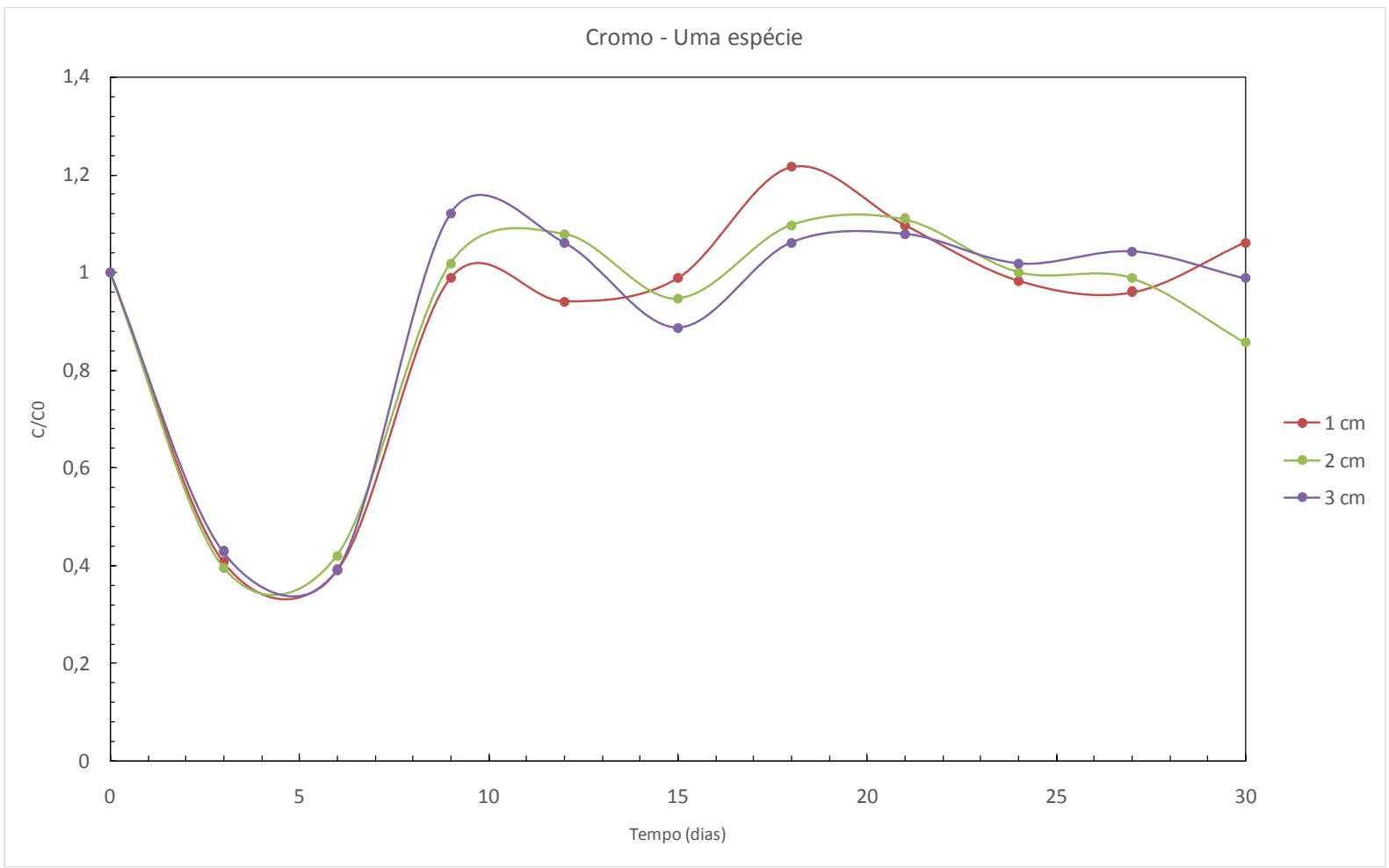

Figura B6 - Comportamento do cromo no corpo de prova (não saturado). 


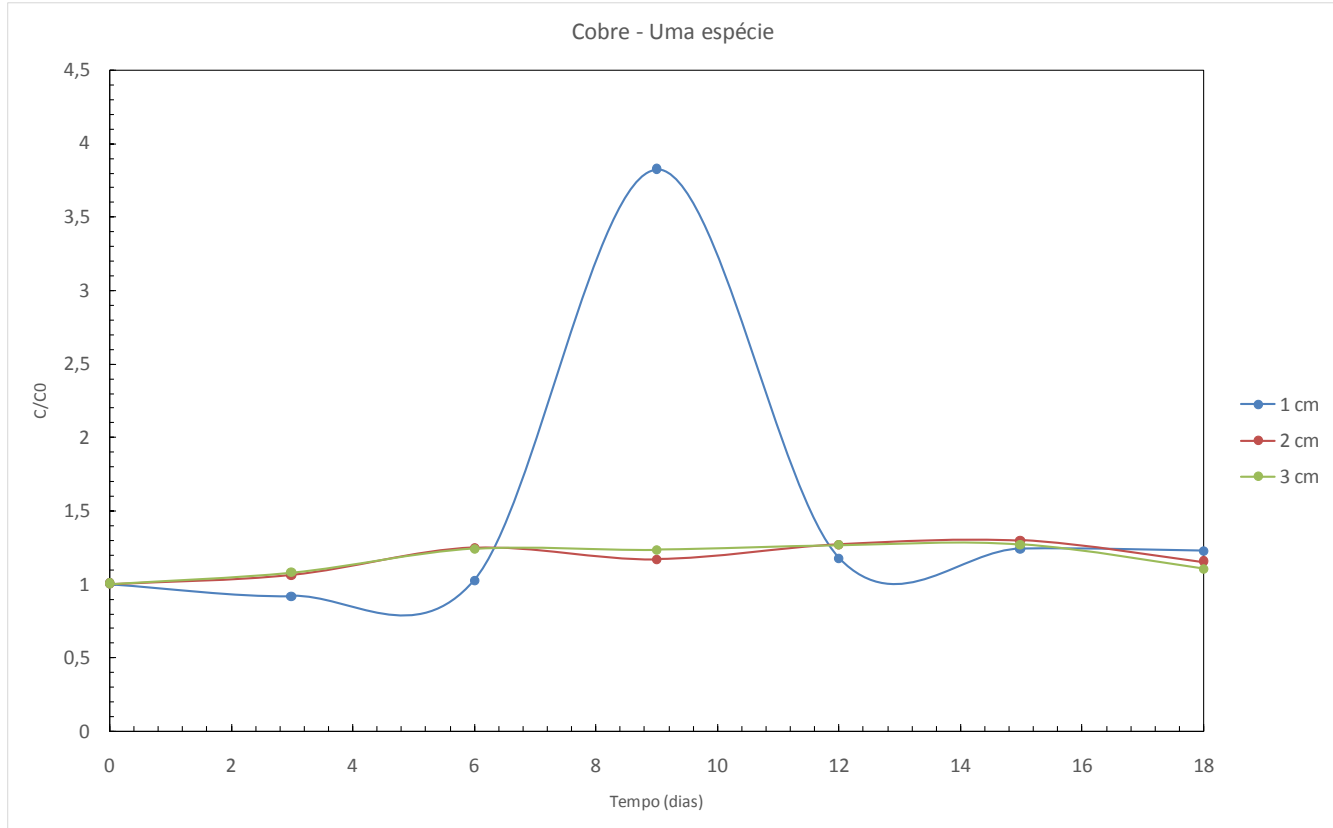

Figura B7 - Comportamento do cobre no corpo de prova (saturado).

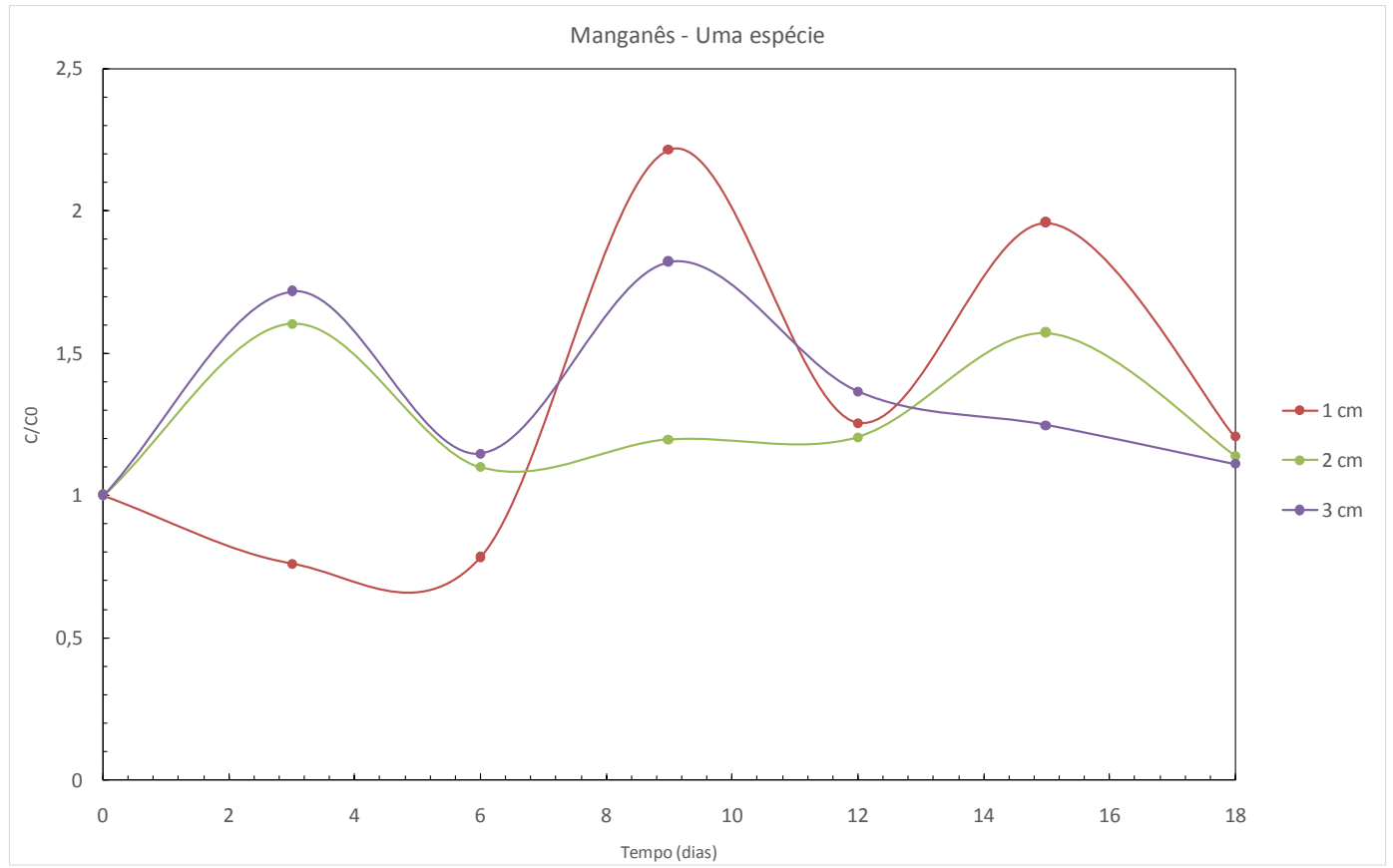

Figura B8 - Comportamento do manganês no corpo de prova (saturado). 


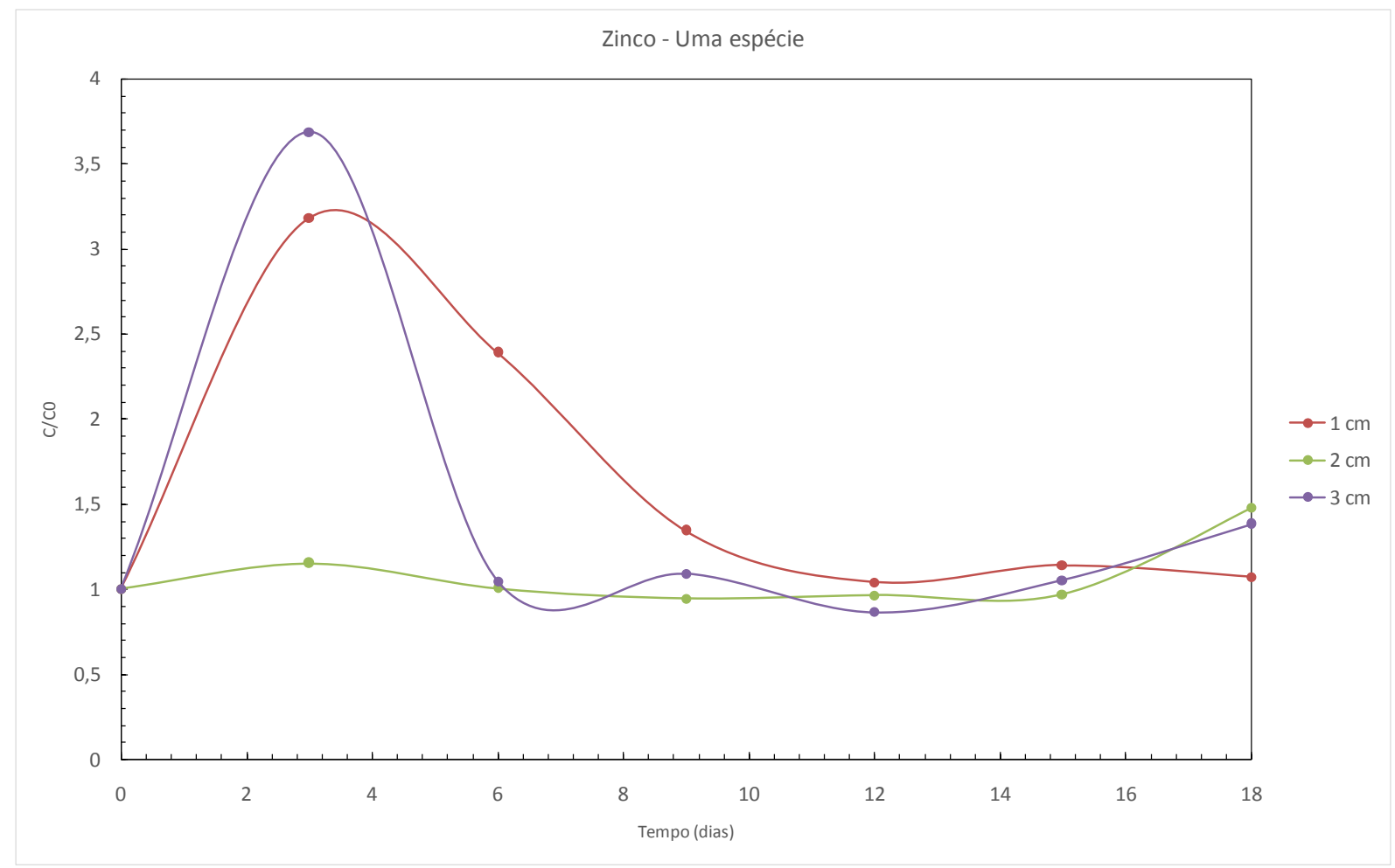

Figura B9 - Comportamento do zinco no corpo de prova (saturado).

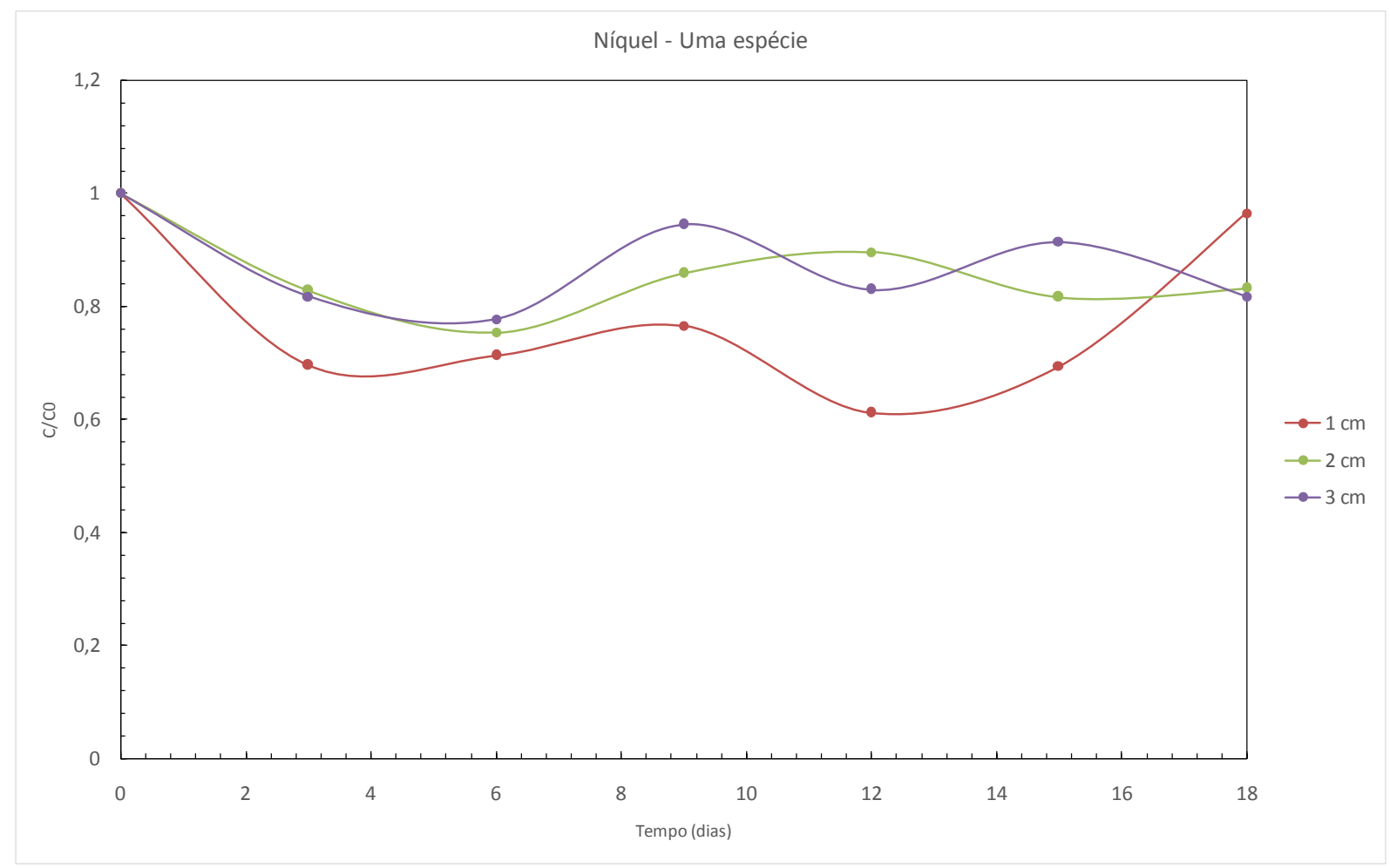

Figura B10 - Comportamento do níquel no corpo de prova (saturado). 


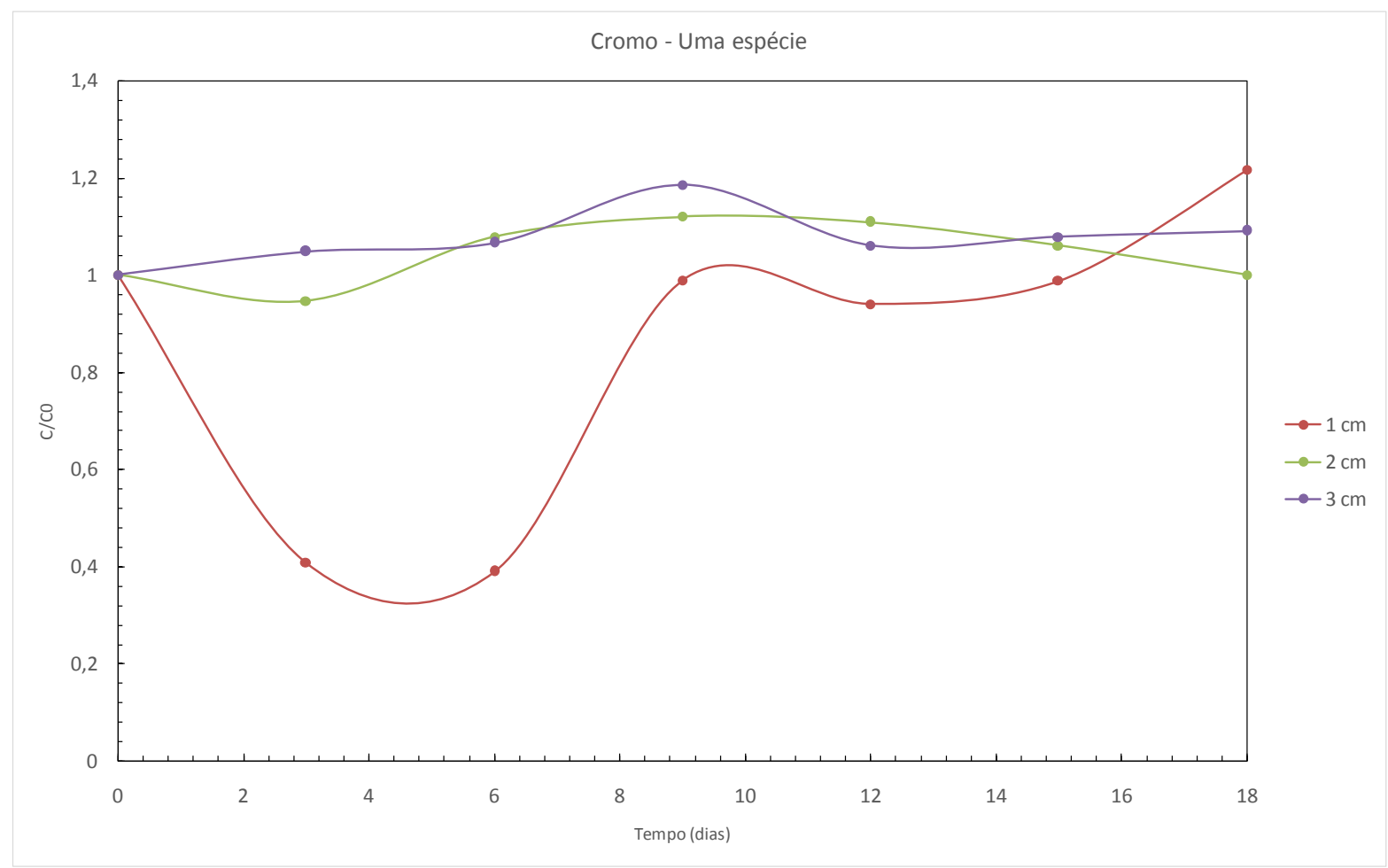

Figura B11 - Comportamento do cromo no corpo de prova (saturado)

\section{ANEXO C}

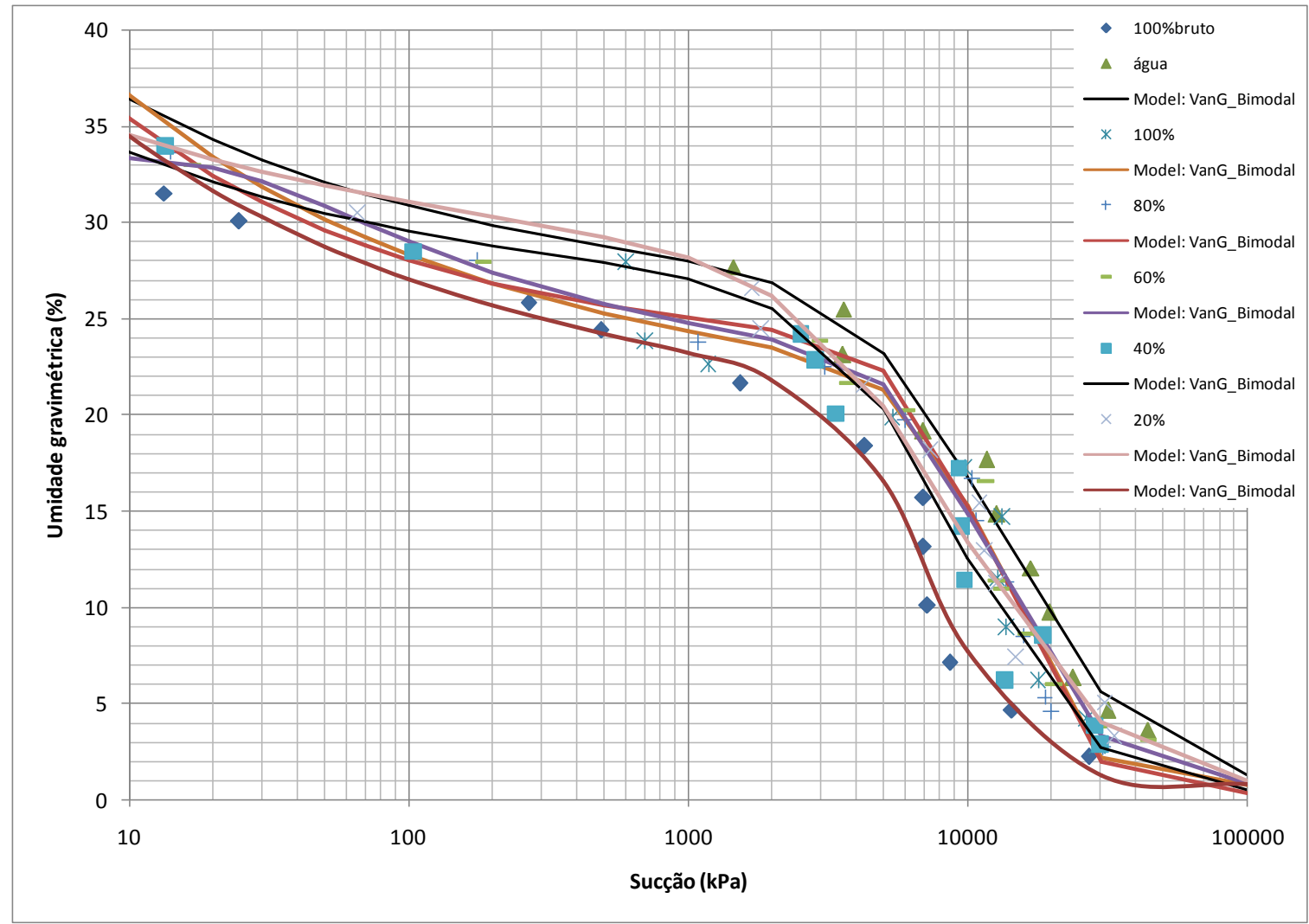

Figura C1 - Curvas características contaminante sem cal. 


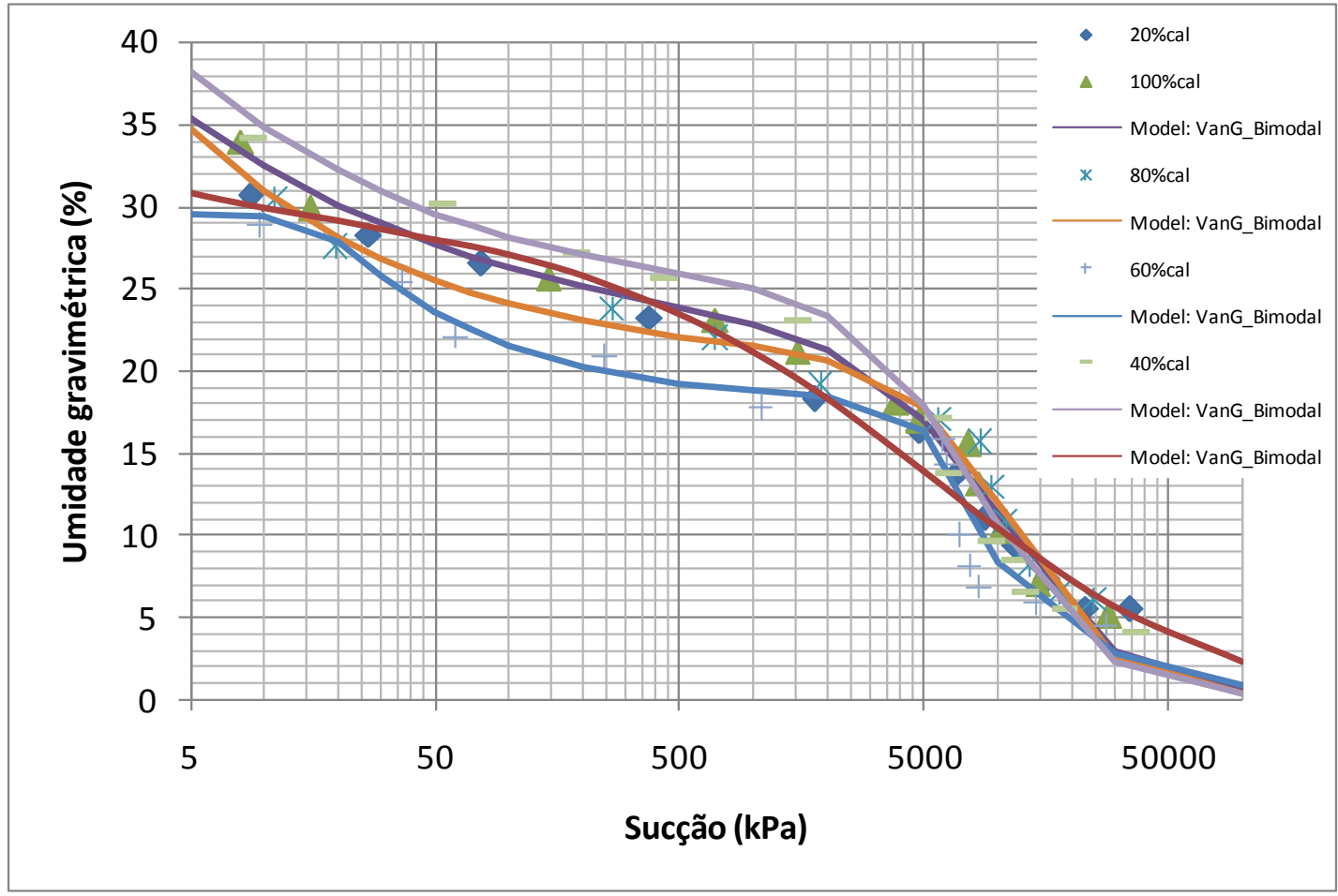

Figura C2 - Curvas características contaminante com cal. 